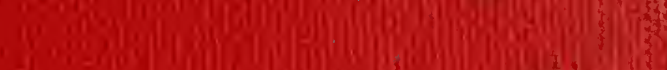
-

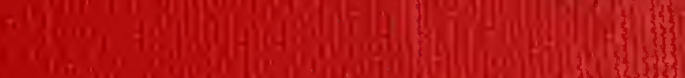
90. giln.

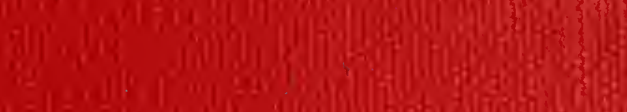
Wer.

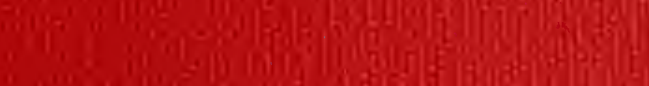

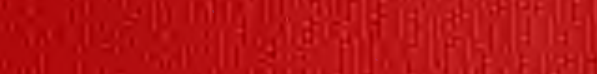
(1) I-5.

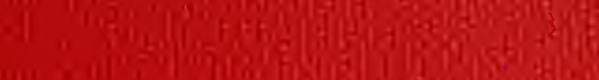
ina 3. iog

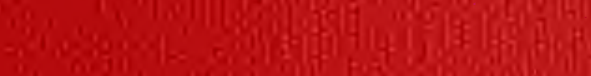

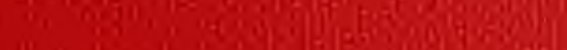
I5 y. E. M.

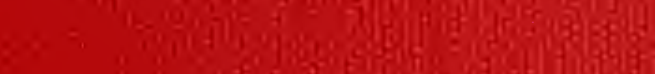

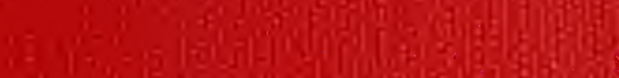

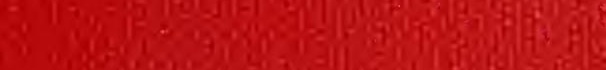

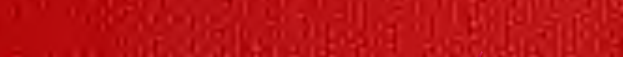

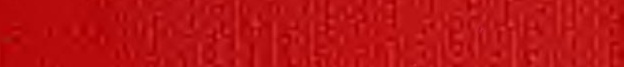

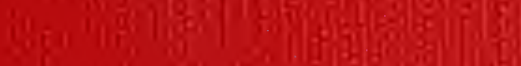

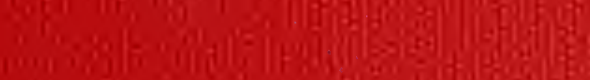

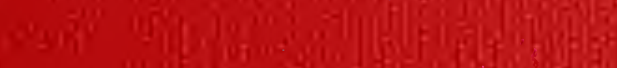

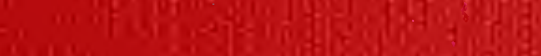

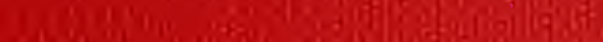

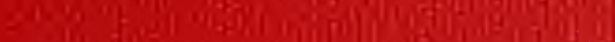

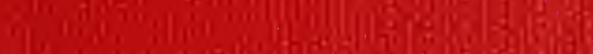

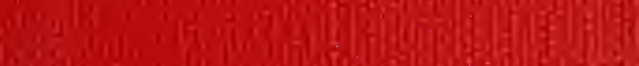

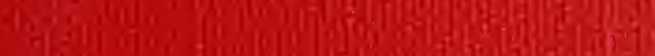
75:

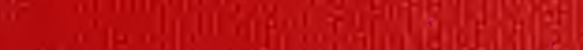

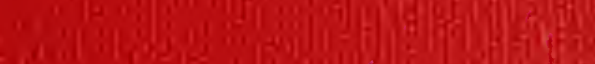
Yilon. A

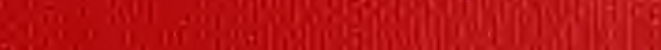
Fyo. III '

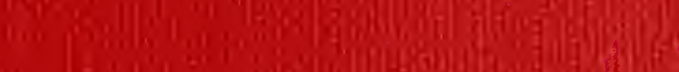
(- ㄴำ wat

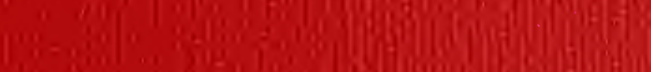

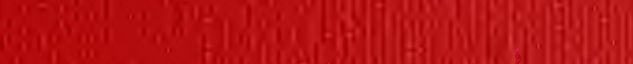

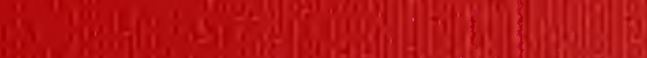

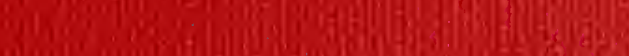

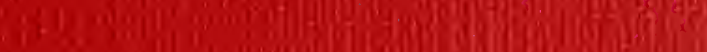




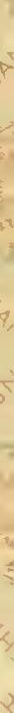

(i)

$$
\text { 1.20 }
$$

,

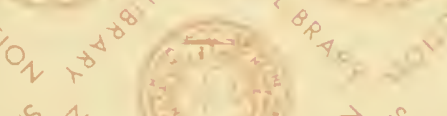
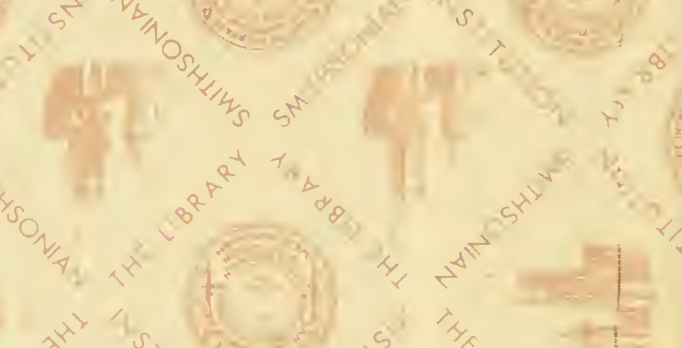

1 o $_{1}$

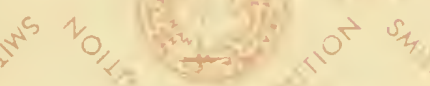

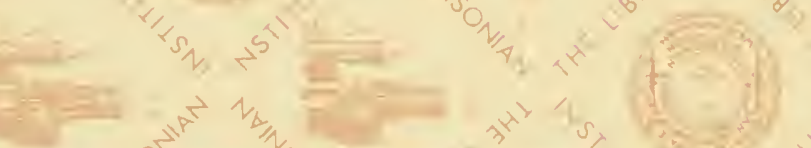

10

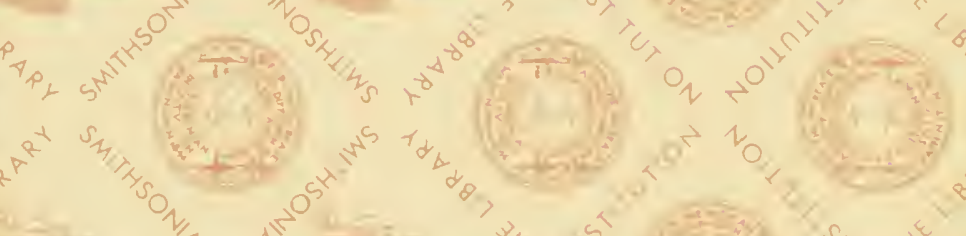

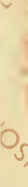

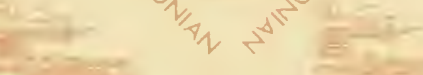

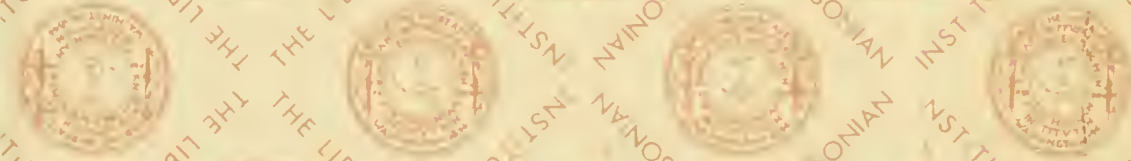

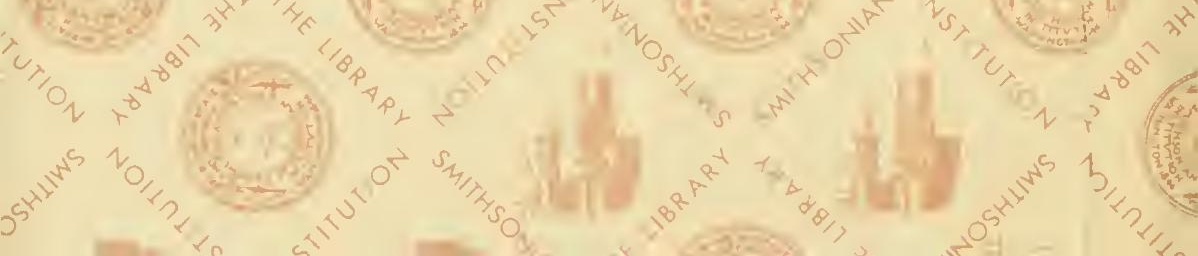








\section{INJURIOUS INSECTS}

OF THE

ORCHARD, VINEYARD,

FIELD, GARDEN, CONSERTATORY,

HOUSEHOLD, STOREHOUSE, DOMESTIC ANIMALS, ETC,

WITH

REMEDIES FOR THEIR EATERIIINATION

BI MATTHEW (?)KE,

LATE CHIEF EAECUTIVE HORTHCLTURAL OFFICER OF CALIFUIIA

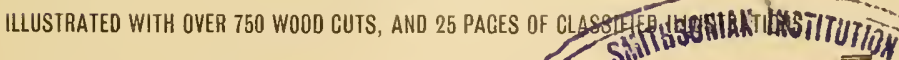
88425

* hü21 1931

NATIONAL INUSEU

S ACRA IIENTO:

II. S. CROCKER \& CO., PRINTERS ANH STATIUNERS.

1883. 


\section{PTrs, PIlary E. Sregory,}

OF SACRAMENTO, CALIFORNA,

As $A$ TOKEX OF SIYCFRE RFGARD, AND ACKNUWLEDGMIXT FOR KIXD ASSISTANCE IN PLACING ME IN A

MANCEACTCIING BL'SINESS IN 1874, WHICII LED TO MY

IXVESTIRATHONS IX ECOXOMIC EXTOMOLUGY,

THIS BUOK is

IESPFCTFLLY DEICATED BY 'THE

A CTHIHR.

Eintered according to Act of Congress, in the year $18 s 3$, B) MATTHЕW COONL, In the oflice of the Librarian of Congress, at Washington. 
This book is designed for the use of orchardists, vineyardists, farmers, and others interested in the subjects treated. It is designed to convey practical information concerning some of the species of insects injurious to the industries of cultivators of the soil, and those interested in earth produce generally.

It has been my aim to free the volume, so far as was possible, from technical terms, and I have retained the technical or scientific names of insects only to aid the reader in reference to seientific works.

It must not be assumed that there has been any intention to present this work as a seientific treatise, and I may be pardoned for supplementing the statement by the information, that I have never laid claim whatever to scientific education. $\mathrm{My}$ advantages were limited in youth to a common school system, and since that period I have, from time to time, pursued the study of economic entomology, as opportunity allowed, up to the year 1874 . Since that date I have been enabled to engage in extended practical investigations into the realm which hefore I had knowledge of only by reading.

I was led to the field of experiment and investigation through my business. In 1874 I engaged in the manufacture, in the City of Sacramento, of fruit boxes. The next year the codlin moth appeared in some orchards, and the fruit of the country was threatened. Naturally, its injury would affect my business, and thus I was drawn to a consideration of means to protect it. I therefore entered upon the field of investigation, as I found the text-books and treatises did not afford the clesired information-at least such as I was enabled to find in the literature of the subject.

In 1878 I began to give the result of my inquiries to the public through the columns of the daily and the reekly press. Very few persons in this state, especially of those who should have manifested the deepest interest at that time, paid any attention to economic entomology. In time, however, through the assistance of the Sacramento RECORD-UNION and the PACIFIC Rural Press, and some other journals, and the discussions 
('ngaged in at the meetings of the State Herticultural soriety. the public was hrought to a degree of appreciation of the rlangers threatening the fruit interests, and as a result, protective legislation was had in Mareh, $18 s 1$.

In comnection with the investigations marle, the results of which appear in this rolume, I deem it not out of plares to state that I have heen engaged in mechanical pursuits mearly forty years. I became interested in the fruit box business as a manufacturer, through findneial assistance extended me by

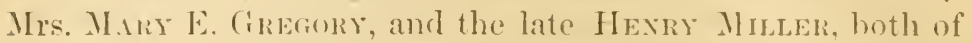
sacramento. To the former, as a token of sincere ackmowlederment, this rolume is respectfully dedicaterl.

It is due that I should acknowledge my spejal indebtedness to P'rofissor ('Hardes I. Riney. Entomologist of the Enited States Department of Igrienlture. for his kindness in affording me the use of his valuable reports and works, and also for his identitication of specimens sent to him for that purpose firm time to time.

To Professor Cromis Tirouas, late State Entomologist of Inlinois, and at present commecterl with the smithsonian lnstitution at Washington, D. (C., for the use of his valuable rolumes of reports, I am much indehted.

To P'rofessor J. H. Constock, late Entomologist of the Inited States bepartment of Igrieulture, and at present Professor of Entomology in Cornell Lniversity, at Ithasa, New lork, my thanks alle due for favors extended.

To ny repected friend. Professor C. H. Dwaserse of the State Eniversity, at Berkeley, Califumia, my sincere thanks are due for his kindly assistance and his many favors to me during the period I have been engaged 11 wou this work.

I desire also to acknowledge the kind favors of R. li. BuwEks, Esre, of Woolland, california, extruled huring my inrestigation of graperine and other inseret pests.

I have frecely consulted, in the preparation of the volume

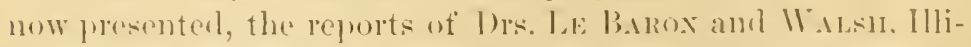

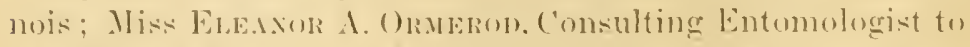
the Royal Agricultural Society of England; of lors. Fiten

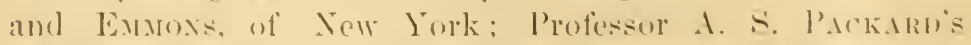

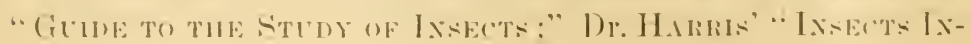


JURIOLS TO IEGETATION;" Professor SAUNDERs' recent work, "Ixsecta Ixjurious to Frutts;" Figuier's "Ixsect World ;" "The Caxadias Extomologist," and the "Bulletiss of The Uniten States Extomological Commision."

In the preparation of this book I have been placed under special obligations to D. W. Conullut, Esq., late Assistant State Entomologist of Illinois, who has been assiduous in his labors for the last four months, in preparing manuscript, reading proof, and assisting me in my labors connected with the issuance of the volume.

In the matter of illustrations, some of those presented have been copied from previous works of this character, and due credit has been given in another place.

I should be doing an injustice to my own sense of propriety, if I submitted these pages to the eriticism of the reader without acknowledging the courtesy of my publishers, H. S. Crocker \& Co., of sacramento, at whose establishment the typographic work has been done; and also if I failed to add that the binding in which the volume appears, was the work of a fellow mechanic of sacramento, Fraxk Foster, Esq., the pioneer bookbinder of the city. Very much is due to the skill, patience, and care of O. H. TuBbs, foreman for Crocker \& Co., for the freedom of the book from errors, and for its neatness of appearance.

This volume presents to the reader the results of my investigations during the eight years last past. Two years of that time I had the honor to fill the position of Chief Executive Horticultural Officer of this State, a fact that it is deemed proper to state, that the reader may be fully informed of the opportunities enjoyed for the preparation of the work now offered him.

$1 \mathrm{am}$ much indebted to the fruit-growers of California, and to the cultivators of the soil generally throughout the State, for their cordial assistance in my work; and I feel it no more than right to close this page by saying that to the press of the State which first enabled me to araken the people to the danger threatening them from insect pests, and has since giren me free use of its columns, not only ux thanks are due, but those of all the citizens of California.

II. C.

SACranexto, Cal., September, 1883. 


\section{ACKNOIVLEDGMENTS.}

The electrotypes of the following Figures were purehased from Prof. C. V. Riley : 14, 25, 29, 30, 33-39, 43-45, 52-60, 63, 68, 72, 77, 85, 86, 90, 91. 103, 105, 109, 120), 121, 146, 148-15i3, 159-175, 180, 181, 183, 187-193, $195^{1}, 2,196,198,200,205-213,215,216,218,219,232,261-266,269,271-281$, 285-289, 290-293, 298-309, 312-333, 338, 339, 359, 360, 365 and 368.

'The folluwing were purchased from Lippincott of Co., of Philadelphia: 31, 69-71, 88 89, 104, 147, 197, 199, 201 and 214.

Electrotypes of Figures 11-13, 51, 96, 97, 138 and 155, were purchased of Dr. A. S. Packard, Jr.

'The following were copied from Dr. Fitch's Reports : 73, 74, 114, 204, 259-263, 268, 273-27.), 284, 336, 337, 356 and 357.

Figrures 26-29, 116-119, were eopied from Riley's Reports.

Figures 156, 202, 2013, 233, 254, 347, 351, 363, 364 and 369, were copied from Packard's "Ginide to the Study" of Inseets."

'The following are from Harris' "Insects Injurious to Tegetation :" $67,108,113,157,227,229,234,244,245,25.5$ and 294.

'The following were eopied from Fignier's "Insect World :" 87, 121$127,194,195,348,349,361$ and 362 .

Figures 256, 2i\%, 267, 292, 284, 334 iut 340, were copied from Miss Ormerod's "Manual of Injurious Tusects."

The following are from the U. S. Agr. Reports : 40-42, 82-\$1, 277-280, 297, 341-343, 366, 367, :370.

Figures 350 and 352 were copied from the report of the Ontario Entomological Society.

Figure 293 is from Dr. Le Baron's Fourth Illinois Report, and Figure 8 was copied from the Mass. Agr. Report.

Figure 253 is from the "Scientifie American Supplement."

The following were kindly lomed me by the "Pacitic Rural Press:" $80,122,128,132-137,140,141,154.186,226,235,237 \mathrm{t}, 237^{1}, 241,242$, $218-252$.

To Mr. C. Muller, 135 Montgomery St., San Franeiseo, I am iulebted for the use of the electrotypes of Figures ? and 10.

The remaining ents are oricrinal, and were made expressly for this work. Of these, Figmes :32, 40, 41, 42. 51a, 64. 65, 66, 7i, 76, 78, 82, 83, $84,92,93.94,95,106,107,110,111,112,115,127,1.66,179,182,184,185,220$, 221, 231), 231, 246, 277, 27 $, 279,280,297,310,341.342,343,353,351,355$, 355, 370, 371 and 37:2, were drawn and (mgraved lyy Mr. Buchi, of Messrs. M. Sehmint of Co, of Siu l'ranciseo. 'These were received too late to be inserted in the text, and so are given on Plates 1-4. Sereral of the remaining figures were (lawn and engraved by Mr. R. Thilip, of this eity, and by Mr. T. Craig and Mr. Patten, 659 Clay St.. San Franeiseo.

In orler to assist frnit.growers and whers in readily identifying insects, twenty-five mages of elassified figures are given. 


\section{CONTENTS.}

Preface..................

PAGE.

3

Sentiments of an enterprising Fruit-grower............

History of Legislation to prevent the spread of Injurious Insects................

Progress of the warfare against Insect Pests, from Jan. 1, 1879, to April 1, 1883........... 2

Disinfection of Return Packages versus Free Packages.. 24

Quarantine ..............28

Danger of importing Injurious Insects from foreign conntries 30

Danger of spreading Insect Pests by the transportation of infested fruit and nursery stock................ 30

Notes on Experimental Work.. 31

Alkaline Washes as Insecticides and Fertilizers............ 33

Thorough application of Remedies................ 34

Pumps and Nozzles for Spraying Trees............... 37

DeLong's Moth Trap......... 39 Structure and Growth of Plants 43 Entomology should be made a permanent Study in the Public Schools.............. 48

Economic Entomology....... 50

Mildew or Seab on the Foliage and Fruit of Apple and Pear Trees.................. 51

Birds; Beneficial and Injurions 52 Insects Infesting the-

Alfalfa...............287

Almond...............231

Apple............... 55
PAGE.

Insects Infesting the-

Apricot.................. 132

Asparagus . . . . . . . . . . . 336

Azalea ................254

Barley ................ 287

Bean ...................334

Blackberry..............214

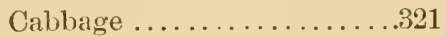

Carrot..................337

Cherry ..................... 136

Chestunt ..............233

Clover...................287

Conservatory ............263

Corn..................290

Cottou ................297

Cottonwood.............214

Cucimber.............302

Currant................216

Elm...................245

Eucalyptus ............238

Fig ................. 167

Filbert...............237

Flower Garden.............261

Gooseberry ............... .225

Grape.................. 168

Hop... . . . . . . . . . . . . . 269

Juniper ... . . . . . . . . . . 251

Lemon . . . . . . . . . . . . . . 153

Lettnce..................331

Lime... . . . . . . . . . . . 153

Locust.................239

Melon..................301

Nectarine ................145

Oak .....................216

Oleander.................255

Olive.................. 147

Onion .................... 330

Orange................. 153

Parsley ................ 337 


\begin{tabular}{|c|c|}
\hline P.so & Inserts Infesting the \\
\hline arsnip................337 & 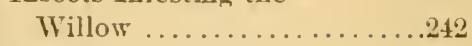 \\
\hline Pea..................3332 & Wheat .............. \\
\hline Peach............... & Household and storehouse pests 338 \\
\hline Pear....................112 & Inseets infesting Domestic Ani- \\
\hline Persimmon .......... & mals ..................349 \\
\hline Pie Plant............ & s infesting the Apiary . . 361 \\
\hline Pine $\ldots \ldots \ldots \ldots \ldots \ldots$ & Iiscellaneous Insects.... \\
\hline Plum ............. & What are they, Friends or Ene- \\
\hline Poplar.............. & $\operatorname{mies} . \ldots \ldots \ldots$ \\
\hline Potato................306 & Remedies............. \\
\hline Prune.............. & Conclusion..... \\
\hline Pumpkin............ & Explanations of Plates 1 and 2,425 \\
\hline Quince .............. & Explanations of Plates 3 and \\
\hline Radish .............. & $4 \ldots \ldots \ldots \ldots \ldots \ldots \ldots+29,430$ \\
\hline Raspberry........... & Plates of Classified Illustra- \\
\hline Red Bay............. & tions......... \\
\hline Rhubarb........... & Beetles.............. \\
\hline Rose.............. & Bot-Hies . . . . . . . . . . . . . \\
\hline Rye .............. & True Bugs............. \\
\hline Squash............. & Plant-lice...... \\
\hline Strawberry ........... & ies... . . . . . . . . . . . \\
\hline eet Potato........ & illars, Grubs, etc... \\
\hline ceo........... & Buttertlies :md Moths........447 \\
\hline 'Tomato ........... & Index to Seiantific Names.....457 \\
\hline Turnip. ............ & Index to Common Names......465 \\
\hline Walnut ........... & \\
\hline
\end{tabular}




\section{NTROD UCTORY.}

\section{CHAP'TER I.}

The Sentiments of an Enterprising Fruit Grower.

The following is quoted from an address by A. T. Hatch, Esq., of Cordelia, Solano County, California, before the Committee of Agriculture of the Senate, at the State Capitol, January 13,1883 :

"Onr watchword must ever be onward and upward, and falter not, although difficulties apparently insurmountable arise; he who will, may overcome them. The enterprising fruit growers of California are filled with a spirit that no power on earth can curb. It falters not at misfortune's door, or any obstacle to success, but boldly advances and removes them all; at least, it has been so, and nust ever be. The time was when our glorious climate, fruitful soil, and exemption from all diseases and pests, made our Golden State the wonder of all who were conversant of its fruits and flowers. Now, alas! the spoiler's hand is felt-a change has come orer the spirit of our dream. It seems as though all that is detrimental to the fruit interest is here, or coming, making eternal vigilance the price of success in this, the industry of the State. The time has come when every one who by this occupation would thrive, will find ceaseless use for head and hand; even then, the fittest only can survive. Who will supinely sit and see misfortune spoil the result of years of toil, while others gird on their armor with energies stimulated by the presence of the forces arrayed against them on every hand?"

\section{CHAPTER II.}

History of Legislation to Prevent the Spread of Injurious Inseets.

As California is the first of the United States, and it may be said of any part of the world, that has attempted to prevent 
the spread of injurious insects of the orchard, etc., by legislation; and as fruit growers in distant parts of the world are watching our success, it may be well to place on the record what has been accomplished in the space of thirty months, or, from October, 1880, to $A$ pril 1. 1883.

During 1879 and 1880 , the subject of the spread of the codlin moth and other injurious insects of the orchard was discussed in the newspapers of this State, and at the meetings of the State Horticultural Society ; and these discussions resulted in the above society, at its Oetober meeting, 1850, appointing a committec, consisting of Professor C. H. Dwinelle, of Alameda County; Dr. Behr, of San Franciseo; A. T. Hatch, of Solano County; W. H. Jessup, of Alameda; and Matthew Cooke, of Sacramento, to prepare a bill for the protection of the horticultural industries of the State, to be presented to the Legislature, which would meet in the month of December following.

The committee met at the office of the Hon. J. N. Young, at Sacramento, early in the month of November, and a bill was prepared, which, in due time, was presented in the Assembly by Mr. Young. About the same time a bill was presented in the Senate by Senator Baker, of Santa Clara. These bills were referred to a joint committee of the Senate and Assembly. The chairman of this committee called a meeting, and the fruit growers were represented by A. T. Hatch, W. H. Jessup, and the late James B. Saul, and others; as the bills presented for the protection of horticulture conflicted somewhat with each other, and also with another bill (viticultural) before the Legislature, the committee recommended that a new bill be presented. I new bill was prepared, and on its being brought before the Senate was passed to a second reading, but amended to such an extent that it was thought best to have it withdrawn. Later in the session, the Hon. William Johnston, of Sacramento County, then Vice-President of the Senate, had the viticultural bill, which had passed the Assembly, amended in the fenate by adting Section 8. The viticultural law, as enacted, reads as follows: 


\section{AN ACT}

To define and enlarge the duties and powers of the Board of State Viticultural Commissioners, and to authorize the appointment of certain officers, and to protect the interests of horticulture and viticulture.

\section{[Approved March 4, 1881.]}

\section{The People of the State of California, represented in Senate and Assembly, do enact as follows:}

Section 1. The Board of State Viticultural Commissioners, in addition to the duties and powers provided for by the Act entitled "An Act for the promotion of viticultural industries of the State," approved April 15, 1880, shall, in respect to diseases of grape vines and vine pests, constitute a Board of Health. It shall, in addition to laboratory work, cause practical experiments to be made to determine or demonstrate the utility of known and new remedies against such diseases and pests.

SEc. 2. The Board shall elect of their own number, or appoint from without their number, a competent person to serve as Chief Executive Viticultural Officer, who shall perform also the duties of Viticultural Health Officer, under direction of said Board, and subject to removal from such office at any time by the Board.

SEc. 3. The Viticultural Health Officer shall have power, subject to the approval of the Board, to prevent the spread of vine diseases and vine pests, by declaring and enforcing rules and regulations in the nature of quarantine, to govern the manner of, restrain, or prohibit the importation into the State, and the distribution and disposal within the State, of all vines, vine cuttings, debris of vineyards, empty fruit boxes, or other material, on, or by which the contagion of vine diseases and germs of vine pests may be introduced into the State, or transported from place to place within the State; to declare and enforce regulations approved by the Board for the disinfection of vines, vine cuttings, vineyard debris, empty fruit boxes, and other suspected material dangerous to vineyards, while in transit, or about to be distributed, or transported into, or within the State; to classify the vineyards and viticultural regions of the State, according to the degree of health, or vine disease prevailing therein, and to change the same as circumstances may require to be done, subjecting each class to such varying rules and regulations, respecting the introduction or transpor- 
tation of vines, vine euttings, and other material liable to spread contagion of disease among vines, as may, in the opinion of the Board, become necessary and expedient for the preservation of vineyards. Such rules and regulations shall be cireulated in printed form by the Board among the vine growers and frut lealers of the state, shall be published at loast thirty days in two daily newspapers of general circulation in the state, not of the sime eity or county, and shall be posterl in a conspicuons place at the county seat of calch county affected by their provisions.

Sisc. 4. The Viticultural Health oflicer mar appoint locial resident Inspectors in any and all of the viticultural regions of the State. whose duties shall be to report to him conceming the health of grapevines, the progress of vine diseases and pests, and all violations of the rules and regulations of the Board; to certify to the proper disinfection of vines, vine cuttings, empty fruit boxes, and other transportable articles required by the Board to be disinfected before transportation, or while in transit, or after delivery at any point of destination: the methorls of disinfection to be determined and approved by the Health officer and the Board; to seize upon and destroy all vines, vine cuttings, debris of vineyards, empty fruit boxes, and other material liable to spread contagion, which may be found in transit, or delivered after transportation, not eertified to as required by the Board; movided, that the same may he exempt from such destruction if the cost of disinfection by such Inspector shall be provided for by the owner or agent in charge thereof, as may be prescribed for such cases of negligence, carelessness, or violation of quarantine rules, and to keep a record of all proceedings as such Inspectors; prorided, that there shall be no compensation for such scrvices of inspection, excepting a fee, not to exceed one dollar for each certificate of disinfection, in ease of compliance with yuarantine regulations, and not to exceed five dollars for each certiticate of disinfection after seizure for non-compliance; frerided, lumerer, such inspection may be employed at the uption of the owners of property recpuring disinfection to disinferet the same. All vines, or other articles alssolutely prohibited of importation or transportation, may be promptly destroyed by any lnspector discovering the sime transported or in transit, in violation of regulations, and the cost of such scizure, together with a fee of ten dollars, shall be paid to such Inspertor out of any fine that may be collected from the party or parties cruilty of such violation. Willful violation of the quarantine regulations of the Board shall be considered a misdemeanor, and punishable by a fine of not less than twentyfive nor nore than one hundired dollars. Whenever required 
for the eonvenience of vine or fruit growers, or fruit dealers, a resident Inspector shall be appointed upon petition of any three neighboring vine or fruit growers, or dealers in grapes, to reside in their vieinity, if not already provided for ; and there shall be not less than two Inspectors appointed for each county which is subjected to such quarantine regulations, and they shall each be subject to removal at the will of the Viticultural Health Officer, if ineompetent, or if they fail to perform their duties, or are umeasonably distasteful to vine growers and grape dealers.

SEC. 5. It shall be also the duty of the Chief Executive Viticultural Officer to personally visit, examine, and report upon the several viticultural regions of the State; to prepare documents for publieation, as required by the Board, relating to any and all branches of viticultural industry, including treatises for the instruetion of the publie; to supervise the preparation of reports for publication, and especially report upon the practibility and means of cradicating diseases from vineyards, and to superintend experiments with known and new remedies.

SEc. 6. All printing heretofore ordered by the Board shall be paid for out of the appropriations heretofore made for its use. All printing required hereafter shall be done by the State Printer.

SEc. 7. The salary of the Chief Exeeutive Vitieultural Officer shall be fixed by the Board, not to exceed one hundred and fifty dollars per month, for services while engaged as sueh offieer, and his actual traveling expenses shall be allowed, not to exceed five hundred dollars per annum.

SEc. 8. The Board of State Viticultural Commissioners shall also appoint an officer, who shall be especially qualified, by practical experience in hortieulture, for the duties of his office, to perform similar duties respecting the protection of fruit and fruit trees as are provided for in this Act in referenee to grapevines, with like powers; and the salary and traveling expenses of such offieer shall be fixed by the said Board, at the same amounts provided for in the ease of the Chief Executive Viticultural Offieer; and the said Board shall have power to establish such quarantine rules and regulations as are required for the protection of fruit and fruit trees fron the spread of insect pests.

SEC. 9. There is hereby appropriated for the uses of the Board of State Viticultural Commissioners, as set forth in this Aet, and in the Act providing for its organization, out of any moneys in the State treasury not otherwise appropriated, the sum of ten thousand dollars for the year commencing July first, eighteen hundred and eighty-one, and ten thousand dol- 
lars for the year commencing July first, eighteen hundred and eighty-two; and the State Controller will draw his warrants upon the State Treasurer in favor of the Treasurer of the said Board for the said sums, or any part thereof, when they become available. upon proper demand being mate for the same by sairl Board; frocided, that no claim shall be paid out of said appropriation until the same shall have heen presented to and approverl by the State Board of Examiners.

SEc. 10. This Act shall take effeet and be in force from and after its passage.

Assemblyman Reynolds, of Santa Clara, introduced the following bill. which passed hoth houses and was approved by the (iovernor March 14, 18s1:

\section{AN ACT}

To protect and promote the horticultural interests of the State.

\section{The People of the State of California represented in Senate and Assembly, do enrict as follors:}

SECTIOA 1. Whenever a petition is presented to the Board of Supervisors of any county, and signed by five or more person: who are resident freebolders and possessors of an orchard, or both, stating that certain or all orchards, or nurseries, or trees of any variety, are infested with scale bug, codlin motl, or other insects that are destructive to trees, and praying that a commission be appointed by them, whose duty it shall be to supervise their destruction, as hereinafter provided, the Board of Supervisors shall, within twenty dars thereafter, select thres commissioners for the county, to be known as a County Board of Horticultural Commissioners. The Board of supervisors may fill any vacaney that may occur in said commission by death, resignation, or otherwise, and appoint one Commissioner each vrar, one month or thereabouts previous to the expiration of the term of office of any memher of said commission. The said ('ommissioners shall serve for a period of three rears from the date of their appointment, except the Commissioners first appointed, one of whom shall serve for one rear, one of whom shall serve for two years, and one of whom shall serve for three rears, from the date of appointment. The Commissoners first appointed shall themselves decide, by lot, or otherwise, who shall serve for one year, who two years, and who three rears, and shall notify the Board of supervisors of the result of their ehoire.

SEa. ‥ It shall be the duty of the county Board of Hor- 
ticultural Commissioners in each county, whenever they shall be informed by complaint of any person residing in such county, that an orchard, or nursery, or trees, or any fruit packing house, storeroom, saleroom, or any other place in their jurisdiction, is infested with scale bug, codlin moth, red spider, or other noxious insects liable to spread contagion dangerous to the trees or fruit of complainant, or their eggs or larvæ, injurious to fruit or fruit trees, they shall cause an inspection to be made of the said premises, and if found infected they shall notify the owner or owners, or the person or persons in charge or possession of said trees or places, as aforesaid, that the same are infested with said insects, or any of them, or their eggs or larvæ, and shall require such person or persons to disinfect the same within a certain time to be specified. If, within such specified time, such disinfection has not been accomplished, the said person or persons shall be required to make application of such treatment for the purpose of destroying them as said Commissioners shall prescribe. Said notices may be served upon the person or persons owning or having charge or possession of such infested trees, or places, or articles as aforesaid, by any Commissioner, or by any person deputed by the said Commissioners for that purpose, or they may be served in the same manner as a summons in a civil action. If the owner or owners, or the person or persons in charge or possession of any orchard, or nursery, or trees, or places, or articles, infested with said insects, or any of them, or their larvæ or eggs, after having been notified as ahove to make application of treatment as directed, shall fail, neglect, or refuse so to do, he or they shall be deemed guilty of maintaining a public nuisance, and any such orchards, nurseries, trees, or places, or articles thus infested, shall be adjudged and the same is hereby declared a public nuisance, and may be proceeded against as such. If found guilty, the Court shall direct the aforesaid County Board of Horticultural Commissioners to abate the nuisance. The expenses thus incurred shall be a lien upon the real property of the defendant.

SEc. 3. Said County Board of Horticultural Commissioners shall have power to divide the county into districts, and to appoint a local Inspector for each of said districts. The duties of such local Inspectors shall be prescribed by said County Board.

SEc. 4. It shall be the duty of said County Board of Commissioners to keep a record of their official doings, and to make a report to the Board of State Viticultural Commissioners on or before the first day of November of each year, who shall incorporate the same in their annual reports.

SEc. 5. It shall be the duty of the Commissioners at large, 
appointed by the Board of State Viticultural Commissioners for such purpose, to recommend, consult, and act with the county Board of Commissioners in their respective counties. as to the most eflicacious treatment to he adopted for the retermination of the aforesaid insects, or larva, or egess thereof, and to attend to such other duties as may be necessary to arecomplish or carry out the full intent and meaning of this Art.

SEx. 6. Each County Commissioner and local Inspector maly be paid five dollars for each day actually engaged in the jerformanee of his duties under this. Act, payable out of the eomenty treasury of his county ; provided, that no more shall be paid for such services than shall be determined hy resolution of the Board of Supervisors of the county for services actually amel necessarily rendered.

SEe. 7. Each of said Commissioners may select one or more persons, without pay, to assist him in the discharge of his duties, as he may deem necessary.

SEC. S. If any County Boarl of Commissioners, after haying recoiver complaint in writing, as provider for in section two of this Act, shall fail to pertorm the duties of their ofliee, as repuired by this Act, they may be removed from oflice by the Board of supervisors, and the vacancy thus formed shail be filled in the same manner as providerl for in this tet.

SEx. 9. Nothing in this Aet shall be construed so as to affecet vinyards or their produets.

SEe. 10. 'This let shall take effect immediately.

The appointment of a Chief Hortirultural officer and the (nforement of quarantine rules, ete, heing given to the state Board of Viticultural Commissioners, they appointed a state Boarel of Horticultural Commissioners to recommenel a competent person for Horticultural Officer, and also such rexulations, ete., as were necessary for the protection of horticultural industries.

The Buard consisted of C. H. Dwinelle, Alameda County ; Elwool c'oopere, Santa Barbara County; Mlbert s. White, san Bornardino (ounty; Dr. Chapin, Santa Clara County; A. Cadwell, Somoma County; W. W. Smith, Solano County ; Felix Gillett, Nevadal C'ounty; W. B. West, San Joaquin County; E. J. Wicksom, Jr., Alameda C'unty; M. T. Brewer, Sacramento County: Matthew Cooké, Sarramento County.

* Mr. Charles H. Shinn was a member of the Board for one year, but resimed on accomnt of his leaving the State, and Mr. Wickson was a)pointed his successor. 
The State Board of Horticulture met quarterly. At first there was a laxity of action by the fruit growers in regard to petitioning for County Commissioners; however, in eight months sixteen comnties had appointed Boards, and in twelve months twenty-one counties, in all, had appointed Boards, namely :

Sacramento, Yolo, Solano, Santa Barbara, El Dorado, San Bernardino, Santa Clara, Santa Cruz, San Joaquin, Amador, Contra Costa, Nevada, Placer, San Diego, Alameda, Los Angeles, San Benito, Fresno, Marin, Kern, and Butte (leaving only six of what may be termed fruit growing counties that had not asked for Commissioners).

The State Board of Horticulture did not think it advisable to enforce quarantine regulations in 1881, They therefore had prepared, by the Chief Horticultural Officer, "A Treatise on the Injurious Insects of Califormia, and Remedies for their Extermination." Ten thousand copies of this book were distributed. A State Convention of Fruit Growers was held at Sacramento, in December, 1881. Quarantine regulations were issued, to be enforced after January 1, 1882, as follows:

\section{HORTICULTURAI, QUARANTINE RULES.}

To all whom it may concern: Be it known that I, Matthew Cooke, Chief Execntive Horticultural and Health Officer of the Board of State Viticultural Commissioners, being duly authorized and instructed by said Board, do cleclare the following quarantine rules and regulations for the protection of the horticultural interests of the State, and due notice thereof is hereby given as provided by law, to wit, thirty days of publication in two daily newspapers of general circulation in the State, and by posting notices in all counties to be affected by these rules. All parties concerned therein are required to conform thereto, subject to penalties provided for by law, for any infraction or evasion of said rules and regulations :

Quarantine Rules and Regulations for the protection of fruit and fivit trees

From inseet pests, namely, insects injurious to fruit and fruit trees, anthorized and approved by the State Board of Viticultural Commissioners of California. In pursuance of an Act entitled "An Act to define and enlarge the duties and powers 
of the Board of State Viticultural Commissioners, and to authorize the appointment of certain officers, and to protect the interests of Horticulture and Viticulture." approved March 4. 18s1, the C'hief Executive Horticultural and Health Officer may approint local resident Inspectors in any and all of the fruit-growing regions of the state, whose duties shall be as provider in soction IV of an Act entitled "An Act to define and enlarge the duties and powers of the Board of State riticultural Commissioners. and to authorize the appointment of certain officers, and to protect the interests of Horticulture and Vitirulture," jrovided that therr shall br no compensation for such servicer rof inspection excepting a fee, not to exceed one dollar for each certificate of rlisinfection, in case of compliance with quarantine regulations. and not to exceed five dollars for each certificat of disinfection after seizure for non-compliance ; providerl, however, such in-pection may be employerl at the option of the owners of property requiring disinfection, to disinferet the same. And also sairl local resident Inspectors will be entitled to such other fees as are provided for in cases of conviction and seizure:-

1. All tree or plant cuttings, graft: or scions, plants or trees of any kind, infested by any insect or insects, or the germs thereof, namely their eggs. larre, or pupse, that are known to be injurious to fruit or fruit trees. and liable to syread contagion; or any tree or plant cuttings, grafts, scions, plants, or trees of any kind, grown or planted in any county or district within the state of California, in which trees or plants, in orchards, nurseries, or places, are known to be infested by any insect or insects, or the germs thereof, namely, their eggs, larve, or pupe. known to be injurious to fruit or fruit trees, and liable to spread contagion, are hereby required to be disinfected before removal for rlistribution or transportation from any urchard, nursery, or place where said tree or plant, cuttings, grafts or sciuns, plants, or trees of any kind are grown, or offererl for sale or gift, as hereinafter providerl.

2. All tree or plant cuttings, grafts, or scions. plants. or trees of any kind, importerl or brought into this sitate from any foreign country, or from any of the Enited States or Territories, are hereby required to be clisinfected immediately after their arrival in this state. and before heing offered for sale or removed for distribution or transportation, as hereinafter rescribed; provided, that if on examination of any such importations by a local resirlent Inspector. or the Chief Executive Horticultural officer, a bill of health is certified to by such examining officer, then disinfection will be unnecessary.

3. Fruit of any kind. infested by any species of scale insect or scale in-ects; ir the germs thereof, namely, their egg:; larvæ 
or pupæ, known to be injurious to fruit and fruit trees, and liable to spread contagion, is hereby required to be disinfected, as hereinafter provided, before remoral off premises where grown, for the purpose of sale, gift, distribution, or transportation.

4. Fruit of any kind, infested by any insect or insects, or the germs thereof, namely, their eggs, larve, or pupæ, known to be injurious to fruit or fruit trees, and liable to spread contagion, imported or brought into this State from any foreign country, or from any of the United States or Territories, are hereby prohibited from being offered for sale, gift, distribution, or transportation.

5. Fruit of any kind infested by the insect known as codlin moth, or its larvæ or pupæ, is hereby prohibited from being kept in bulk, or in packages or boxes of any kind, in any orchard, storeroom, salesroom, or place, or heing dried for food, or any other purposes, or being removed for sale, gift, distribution or transportation.

6. Fruit boxes, packages, or baskets, used for shipping fruit to any destination, are hereły required to be disinfected, as hereinafter provided, previous to their leing returned to any orchard, storeroom, salesroom, or place to be used for storage, shipping or any other purpose.

7. Transportable material of any kind, infested by any insect or insects, or the germs thereof, namely, their eggs, larve, or pupæ, known to be injurious to fruit or fruit trees, and liable to spread contagion, is hereby prohibited from being offered for sale, gift, distribution, or transportation.

8. Tree or plant cuttings, grafts, scions, plants, or trees of any kind, may be disinfected by dipping in a solution composed of not less than one pound (1 lib.) of commercial concentrated lye to each and every two (2) gallons of water used as such disinfectant, or in any other manner satisfactory to the Chief Executive Horticultural and Health Officer.

9. Empty fruit boxes, packages, or baskets, may be disinfected by dipping in boiling water, and allowed to remain in said boiling water not less than two minutes; said boiling water used as such disinfectant to contain, in solution, not less than one pound (1 lb.) of commercial potash, or threefourths $\left(\frac{3}{4}\right)$ of one pound $(1 \mathrm{lb}$.) of concentrated lye, to each and every twenty gallons of water, or in any other manner satisfactory to the Chief Executive Horticultural and Health Officer.

10. Fruit on deciduous and citrus trees infested by any species of scale insect or scale insects, or the germs thereof, namely, their eggs, larræ, or pupa, may be disinfected before removal from the tree, or from the premises where grown, by washing or thoroughly spraying said fruit with a solution 
composed of one pound ( $1 \mathrm{lb}$.) of whale oil soap and onefourth of one pound of flour of sulphur to each and every one

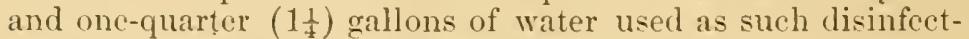
ant, or in any other manner satisfactory to the Chicf Executive Horticultural and Health Offieer.

11. Owners of fruit of any kind grown in any orehard, nursery, or place in which trees or plants are known to be infested with any insect or insects, or the germs thereof, namely, their eggs, larve, or pupx, known to be injurious to fruit or fruit trees, and liable to spread contagion, and all persons in possession thereof, or offering for sale, gift, distribution, or transportation, are hereby required to proeure a certificate of disinfection before removal for sale, gift, distribution, or transportation.

12. Any tree or plant cuttings, scions, plants, or trees of any kind, empty fruit boxes, fruit packages, or fruit baskets, or transferable material of any kind, offered for sale, gift, ilistribution, or transportation, in violation of the quarantine rules and regulations for the protection of fruit and fruit trees, approved by the Board of State Viticultural Commissioners, may be seized by the Chief Executive Horticultural and Health Officer, or by any of the local resident Inspectors appointed by him; said seizure to be the taking possession thereof, and holding for disinfection, or for an order of condemnation by a Court of eompetent juriseliction.

13. Any person violating the above quarantine rules and regulations shall be decmed guilty of a misdemeanor, and upon conviction thereof shall be punishable by a fine of not less than twenty-five nor more than one hundred dollars.

\section{MatTinew Cooke,}

Chief Executive Horticultural and Health Officer. Sacramento, November 12, $18 S 1$.

(For proceedings in Court in relation to quarantine rules, see Chapter IV.)

At the Fruit Growers' Convention, held at San Jose on the fourteenth, fifteenth, and sixteenth of November, 1ss:, the following committee was appointed to prepare such bills as were considered constitutional, and required for the protection of the horticultural industries:

Wal. J. Tuska, San Francisco; L. M. Holt, San Bernardino County; F. C. De Long. Marin County; s. M. Leib, Santa Clara County; Dr. Chapin, Santa Clara County ; Hon. J. H. M. Townsend, saunta ('lara County: (r. M. Gray, Butte County: 
A. T. Hatch, Solano County; Hon. Wm. Johnston, Sacramento County; Matthew Cooke, Sacramento County.

The committee met at San Jose, December 27, 1882. Subsequent to this meeting two bills were prepared by one of the committee-Wal. J. Tuska, Esq., attorney-at-law, San Francisco-one bill creating a Board of Horticultural Commissioners, and the other to prevent the spread of insect pests, etc. These bills were presented to the Legislature as Senate Bills Nos. 2 and 3, by Senator Cox, of Sacramento County, and Assembly Bills Nos. 31 and 32, by Assemblyman Hollister, of San Luis Obispo County.

The bills were amended in the Senate. The work of amending to suit the views of Senators was done by Senator Whitney, of Alameda. The bills as amended passed the Senate. In the meantime the Assembly had passed the bill creating a Board of Horticulture, and appropriating for its expense seven thousand five hundred dollars $(\$ 7,500)$ per annum, the Senate bill only allowing five thousand dollars $(\$ 5,000)$ per annum. The Assembly then took action on Senate Bills Nos. 2 and 3, and both were passed. The bill creating a Board of HorticultureSenate Bill No. 3-as passed by both houses, was approved by the Governor. Senate Bill No. 2, to prevent the spread of insect pests, etc., after passing both houses, was mislaid or stolen, so that it was not presented to the Governor for his approval. In connection with the passage of the bills referred to, I met with the greatest courtesy from the members of the Assembly and Senate from the time the bills were introduced until they were passed.

On the twenty-seventh of March, 1853, I called upon Governor Stoneman in relation to the appointment of a Board of Horticultural Commissioners. He expressed a desire to appoint only competent persons, irrespective of political consideration. If this promise was fulfilled it is well. 


\section{CHAPTER III.}

Progress of the Warfare Against Insect Pests from January 1, 1879, to April 1, 1883.

Previous to January 1, 1879, the codlin moth, orster-shell bark louse, San Jose scale insect, and black seale on deciduous fruit trees, and the soft orange seale, black scale, and red scale on citrus trees, were found to be sprearling rapidly in some fruit growing distriets. Excepting a few individuals, but little nutice was taken of their presence. In 1899 some individual eflorts were made to save the crops, which were successful. But, notwithstanding the great interests at stake, not one fruit grower out of every five hundred attempted to make any effort to prevent the spread of these enemies of their industry. Some fruit growers ridiculed the idea of any serious results occurring from the presence of such minute creatures; others seemed satisfied that the pests would disappear as they came, without any eftort of the fruit growers.

On the 29 th of October, 1579 , I visited an orchard seriously infested by San Jose scale (A. perniciosus). I recommended the owner to spray his trees with an alkaline solution. On the morning of the 30th he met the gentleman who accompanied me to his orchard, and sail the idea of washing trees was only a hobby. Had he done, as advised, in November, 1579, what he afterwards lid in the spring of 1852 , he could have saved one half of his crrcharel, which had to be dug out.

In 1880 matters hecame so serious in some localities that efforts were made to destroy the pests. Such a difference of opinion existerl as to the proper remedies to be employed, that a great deal of the work clone did not produce very farorable results, thus learing the matter in a more hopeless condition that in 1879 .

The securing of legislation for the protection of the horticultural interests of the State, in the Winter of 1880 and 1881 (the laws passed taking effect on March 14,15s1), brought the subject of insect pest prominently before the fruit-growers. The results of the work done in 18\$1, 1582, and in the spring of 1883 , may be stated as follows: 
1. It has been fully demonstrated that the insect pests can be exterminated in orchards at a profit to the owner of from one hundred to five hundred per cent on the amount expended for remedies thoroughly applied.

2. Remedies of undoubted utility have been discovered, that can be readily and thoroughly applied with the improved facilities that the necessity of the times brought forth.

3. We have become better acquainted with the natural history of the injurious and beneficial insects of California, and standard works on economic entomology can be readily procured by those wishing to get them.

4. In some of the districts that were seriously infested confidence has been restored, and land has increased in value from one hundred to two hundred per cent.

5. That the work became popular may be shown by the correspondence, etc., of the Chief Executive Horticultural Officer, of which the following is a sample:

From April 5, 1881, to April 5, 1883 :-

Number of letters, postal cards, and packages received, 5,581 Number of packages and letters containing specimens of insects, etc., - $\quad$ - $\quad$ - $\quad$ - $\quad$ - $\quad$ -

Number of visitors at the office on business connected with insect pests,

The information derived from the experience of the two years' work will not only benefit the fruit-growers of California, but those of our sister States, and also of foreign countries. For instance, at a recent meeting of the Royal Agricultural Society of South Australia, Frazer S. Crawford, Esq., of Adelaide, read a paper entitled, "California Legislation Against Insect Pests," etc., which concluded as follows:

"In conclusion, let me again point out the importance of carefully watching this California experiment. If we find, in spite of this expense and trouble the Californians are willing to put themselves to, that these pests do not decrease, or that the results bear no comparison to the cost of the means employed, it would be folly to follow their example. If, on the other hand, their vineyards and orchards yearly become more prolific and free from insect and other plagues, while our orchards are being destroyed with fungoid pests, our vine- 
vards deteriorated with odium, our orange, olive and other trees ruined by scale insects, we may conclude that our American cousins are reaping the benefit of their wise legislation, and that the sooner we follow their example the better, remembering the truth of the old proverb: 'Providence helps those who help themselves.'"

For the benefit of all interested in the warfare against inseet pests, positive assurance ean be given of the benefits to be derived from legislation against the spread of insect pests, etc.; but success call only be achieved under certain welldefined conditions, as follows:

First-The appointment of a Commission, each member of which is required to have a thorough experience of the best established methods used in preventing the spread of and in exterminating the insect pests, and sustained in the performance of their duties by well-considered laws.

Second-Adequate compensation to seeure competent officers.

Third-The appointment of officers to execute the laws of the State and such regulations as are made by the Commission; said officers to be in all respects competent to perform the cluties required, especially being thoroughly acquainted with the science of entomology.

A Commission and officers appointed under such conditions cannot fail to benefit the state tenfold the amount expended.

\section{CHAPTER IV.}

\section{Disinfection of Return Packages versus Free Packages.}

During the months of April, May, and June, 18s:, there arose considerable discussion amongst the fruit growers who were selling their fruit in local markets, as to the ntility of disinfecting packages in which fruit was shipped to market before the packages were reshipped to the orchards for further use, as required by the quarantine rules, ete. Had the settlement of the question been left entirely to the frnit growers, the matter would have been amicably arranged, and successful 
progress made in preventing the spread of the codlin moth and peach moth. Unfortunately for those directly interested (the fruit growers), an issue was marle by the non-producers (i. e. buyers and (lealers of fruit), under the cloak of friendship) for the fruit-growers, but in reality for personal gain, and for forcing the fruit-growers $t o$ use the so-called free lackage. The time may be stated about the first of June, 1882. Icest any doubt should exist that such was the intention of the opposition to the disinfection of packages, the following letter now in my possession, from a very extensive buyer of fruit in San Francisco to a member of the State Board of Viticultural Commission, will perhaps be sufficient proof:

\section{San Francisco, January 3, 1882.}

DEAR SIR: The box factories tell me they are making a larger quantity of peach baskets than ever before. Now, this is very bad, because the Fruit Growers' Convention, through the proper committee, particularly recommended the abolition of baskets and the substitution of boxes; and furthermore, the basket is as bad a package as can possibly be found for disseminating pests. Why cannot the fruit grower help himself in this matter? Nothing will do him good if he does not. You can show this to Mr. Cooke, if you think best. Will you get the sample of free packages into shape and put them on show here, somewhere, and oblige,

$$
\text { Yours, Etc., }
$$

[The above reveals the secret of the opposition to disinfection of packages.]

The State Board of Viticultural Commissioners had framed the quarantine rules, so as to give an opportunity to those who preferred the use of the return packages, to do so. The following circular was issued explaining the reason:

\section{To the fruit growers of California, and all whom it may con- cern:-}

I take the liberty of calling your attention to the necessity of disinfecting empty fruit packages before being returned from market to the orchards, as required by the Quarantine Rules and Regulations for the protection of Horticulture.

Rule 6. Fruit boxes, packages, or baskets, used for shipping fruit to any destination, are hereby required to be disin- 
feeted, as herinafter provided, previous to their being returned to any oreharel. storepoum, salestoom, or plawe to be used for storage, shipping, or any other pmpose.

Rule 9. Empty thuit boxes, packages, or baskets, may be disinfected ly dipjing in boiling water, and allowed to remain in sabl hoiling water mot less than two minutes ; said builing water userl as sueh disinfectant to contain, in solution, not less

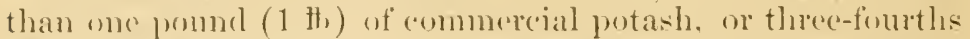
$\left(\frac{3}{4}\right)$ of one pound (1 th) of eoncentrated lye to a ach and erery twenty gallons of water, or in any other manner satisfactory to the Chice Exoeutive Horticultural and Health ofticer.

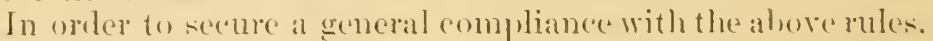
arrangenents will be marle at San Francisco, Saeramento, Sam Jose, stocktom, and other places, where fruit is shippeed to a market or for storage; and local Inspertors appointerl who will disinferet such parkages, if required by the owners thereof: or the owners of empty packages, or their agents. may disinfert them, subject to inspretion.

In answer to inquiries, the following questions may be askerl:

Are those recpuirments appressive on the fruit growers who wish to semil frut to market? I answer. they are not, for the following reasoms:

1. There are several counties which may be termesl fruit growing counties, such as Somoma, Napa, Yuba, Tuolumne. Calaveras, and others. where the fruit growers have failed in having a county Board of IIorticultural Commissoners appointed therefore there is not any organization in any of the above and some other eomties, with which I ean consult in relation to matters in which the fruit grower's are interested.

2. The commisionols in several counties have been retarderl in their work ly the requirements of the law, that comblatint must be made before they an make an inspertion

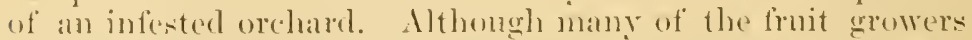

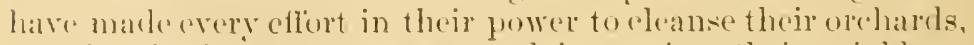
ret they hesitate to enter a eomplant against their meghbor : thereforr, in a large number of ureharels, the pests have been allowed to spreal as heretofore. Anel it is only by a creneral anfereement of the (Quarantine liules that any grod results can

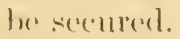

$\therefore$ I large number of orehards are rented, leaserl. wr owned

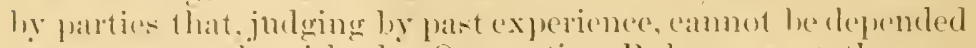
upon to comply with the Qualantine linkes, except they are compelled to dis so.

4. It would reepuire at least three hundred and tifty (350) local Inspertors threnghent the State, to have the work of disinferting (mipty fruit hoxes or packinges, at the orehard, steam- 
boat landings, and railroad stations, done as effectually as by the clisinfecting at markets, etc., as required.

5. The local Inspectors, if appointed, are allowed fees by law, and would be a heary expense on the fruit growers.

6. The rapid spread of codlin moth, to at least thirty counties in this State, since its first appearance in one orchard in 1874 , can chiefly be attributed to the use of the return packages; therefore, the disinfection of all return packages is a necessity.

7. There is a difference of opinion among fruit growers as to the style of package that should be usech in sending fiut to market. Some growers recommend and have adopted the socalled free package, and others use the so-called return package.

8. The clisinfection of the packages gives an opportunity of using the return packages at a nominal cost.

9. Stores, commission houses, and places where apples, pears, and quinces were stored or sold last season, are generally infested by the larra, pupe, or imago (perferet insert) of the rorllin moth, and are liable to be taken from such places in return parkages to orchards at this season of the year.

10. The disinfection of return packages at the place where the fruit is sent to market (or for storage) is not only the most effective method for the prevention of the spreal of insect pests, but is by far the most economical for the fruit growers.

Маттнеш CoOkE,

Chief Executive Horticultural Officer.

The opposition brought the question of constitutionality of the law into the courts; pending a decision, the enforcement of the quarantine rules was abandoned, and the pests not only allowed to spread as heretofore, but the free package system was not generally adopted. (In January, 1883, a decision of the Supreme Court declared that the Legislature, in giving the State Board of Viticultural Commissioners the right to declare what would constitute a misdemeanor, gave the Bond legislative power, and was therefore unconstitutional.)

After mature investigation, I can find no reason to change my opinion in regard to the prevention of the spread of fruit pests ; that the best, safest, and cheapest methorl is the general and thorough disinfection of all packages used in shipping fruit.

The non-producer and free package adrocate asserts (hypothetically, of course, ) that the cost of disinfecting one load of boxes and baskets sent from his store-containing thres hun- 
dred boxes and three hundred baskets, belonging to thirty owners-would he nearly thirty-five dollars, or as follows:

Disinfection of 300 bexes, at 1 cent, $\quad$ - $\quad$ - $\quad$ - $\$ 300$ Disinfection of 300 baskets, at $\frac{1}{2}$ cent, - $\quad-\quad-\quad$ - 150

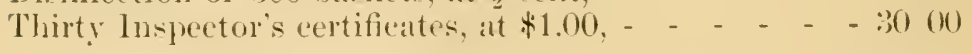

Hypothetical total, - $-\ldots+\ldots 3450$

The actual cost would have been :

Disinfection of 300 boxes at 1 cent, - - - - - $\$$-300 Disinfection of 300 baskets, at $\frac{1}{2}$ eent, - - - - 1 . 01 Certificate of Inspector (tree),

Total cost of hypothetical load of return packages. $4+5(1$ Again (ompare figures:

300 boxes, each containing 30 pounds of fruit, - $-9,000 \mathrm{lbs}$ 300 biskets, each comtaining 25 promels of firte - - $7,500 \mathrm{lbs}$

$16,500 \mathrm{ths}$

Total cost of disinfection so that they could be used again for shipping purposes, $\$ 4.50$.

Free patckages, to earry 16,500 pounds of fruit to market5.50 packages, 30 pounds each, 16,500 ; cost of 550 packagres, at $6 \frac{1}{4}$ cents each, cheapest style, 43.5 .75 . Thus showing a clear gain to the fruit grower of $x^{2} 1.25$. less return freight, in faror "if the plan of thisinfection.

\section{C'HAPTER V'.}

\section{Quarantine.}

In a warfare for the extermination of the inseret pests of the orelatels, otce quarantine laws are a neessity. The collin moth, peach moth, and other speeces of pests are spreat hy the shipment of infected fruits. The scale insect and woolly aphis have been and are being continually spread on nursery stock. 
From past experience I have concluded that it is an impossibility to secure any general law that will be aeceptable to the fruit growers, nurserymen and speculators combined. It is, unfortunately, an established fact that a majority of fruit growers, or persons growing fruit, prefer taking the chanees of allowing pests to spread rather than to disinfeet their packages when returned from market. The proof of this is heyond question. At this date I do not know of twenty persons in this State who are taking this preeaution. Nursery stock infested by the seale insect and woolly aphis is sent broadcast through the State, and what are the results?

A planted two thousand Bartlett pear trees in 1880; in the Fall of 1881 he discovered that they were infested by the San Jose seale; in the Spring of 1882 he cut them off at the ground as a sure prevention of their spread on the 10,000 trees adjoining, and grafted them. By thorough application of remedies he has the trees eleaned, but lost two years use of his ground.

B bought, in 1852, Bartlett pear trees for two acres; in the Spring of $188: 3$ he discovered that they were infested hy the San Jose seale. For the protection of the balance of his orchard property, the trees, after being planted one year, were dug out and burned.

C, in 1SS1, sent to a distant portion of the State for pear trees, to escape any ehances of getting infested trees; unfortunately the nursery-man had purchased the trees in an infested distriet. In $1 S S 3$, the trees planted two years ago are found to be seriously infested by the so-called San .Jose scale (A prerniciosus).

$\mathrm{D}, \mathrm{E}$ and $\mathrm{F}$ have had the same experience in buying and planting young apple trees, the roots of which were infested by the woolly aphis.

The true remedy of these evils is, let every owner of fruit trees, etc., liable to be infested by insect pests, make himself or herself thoroughly acquainted with the appearance and natural history of injurious insects; then constitute a home quarantine board, of one or more, for the purpose of preventing the importation of inseet pests on the premises. 


\section{CHAPTER VI.}

Danger of Importing Injurious Insects from Foreign Countries.

Dailers in fruit at San Franeiseo often hare (onnsignments of lemons and oranges arrive by steamships and sailing ress(els from Taluiti, from Australia, and also from European ports.

In some calrgoes the fruit is serionsly infested by scale inserets. Australia sends us the red seale (A. anrentii), and Australia, Talhiti, and Europe send the leaf and fruit scale ) 1. ritricola). The latter has not been fomml, so far as I an alware. in any orcharel on this coast.

1 shipment of apples reeeived lately from New Zealand was infesterl by the greedy scale (A. mpror). These species of scale inserets generally arrive in a healthy condition. The greedy. seale and resl seale are buth well locaterl here. C'are should be taken that the $A$. eitricola be not allowerl to spread. Remember, "ctemal vigilance is the price of fruit."

\section{CHAPTER VII.}

Danger of Spreading Insect Pests by the Transportation of Infested Fruit and Nursery Stock.

It would be superthous to give any extended repetition of the dangers which threaten husbandmen hy having infested fruits, nursery stock, seceds, ote., brought upon his premises, as the danger is fully described in other ehapters of this work. The following instances are given for the purpose of further "alling the attention of those living in distriets not yet infested :

The Novate Ranch orehard is isolated from any other orchard from which it eould become infested: the pests were hrought in return patekages, and to this date (.July, 1ss:i), the

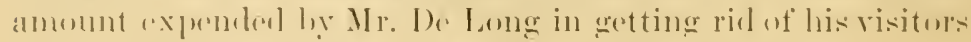

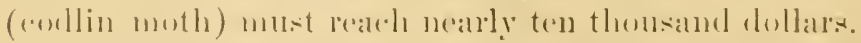

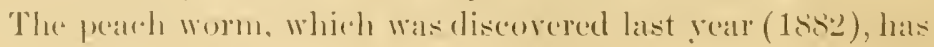


been found in isolated orchards this year, so that undoubtedly they were brought in return packages.

The discovery made in various sections of the eountry this Spring (1853), of the presenee in young orehards of the San Jose seale (A. perniciosus) is sufficient proof that the nursery stock was infested when bought.

The presence of the codlin moth in an isolated apple orehard in San Diego County, can readily be aceounted for by the owner carrying home his groceries in empty apple boxes that were shipped to San Diego with infested fruit.

The presence of the red seale (A. aurantii) in some orchards in Southern California is attributed to the importation of two or three young trees from Australia.

The presence of the cottony cushion scale (I. purchasi) can be charged to importation.

The codlin moth was brought in an importation of five barrels of apples from States east of the Roeky Mountains, about 1873. The grain weevil (C. granaria) and other injurious species of the weevil family (curculionidx) can readily be spread in grain and plant seeds.

\section{CHAPTER VIII.}

\section{Notes on Experimental Work.}

It is not only a duty, but a necessity, that every eultivator of the soil, irrespective of the line of industry in which he is engaged, if his premises are infested or likely to be infested by insect pests, that he should use his utmost efforts in experimental work to find the best and cheapest methods for their extermination, or for preventing their spread at least. In the course of such experimental work, should he think he had made an important discovery, he should be guided by the following rules:

1. It is well worth the care of any one who wishes to be sure-as every one should-of conferring a benefit upon his fellows rather than risk doing them an injury, to delay the expression of results of experiments until the correctness of their results are tested by repeated trials. 
2. Before advising your neighbor to adopt a certain course or remerly, be sure by repeated investigations that you are possessed of a fact, not a fancy. Experiments, to be convineing, require that they be subjected to well defined, clearly peraeived comblitions.

3. In reporting results of experinents, it should be remenbered that "it is the weakest link that determines the strength of the chain."

One of the obstacles with which the enterprising fruit grower has to contend in attempting to prevent the spread of insect pests, is the reliance their neighbors place in remedies which they have not sufficiently tested hefore adopting them. For instance: A's neighbor, Mr. B, has decided to clean his orehard to prevent the ravages of the codlin moth, and as a business principle makes an estimate of the cost, which will probably be from fifteen to twenty dollars per are, according to the size of the trees. About this time he notiers an article: in his newspaper: "No more use for pumps, sprays, nozzles, and solutions. By placing a branch of an eucalyptus tree in your apple and pear trees, the collin moth will not attack the fruit." Mr. B adopts the cheap remedy without further investigation. liesult: the collin moth is not rlestroyed, and $A$ 's orchard is placed in danger. Mr. C, who has been advised to use wide-mouthed bottles, with sweetened water, ete. tries the experiment and pronomnees it a success, having captureel hy aretual count nearly five hundred moths in one night. The suceess is annomeed, and others are induced to give up the application of all other remedies, and they are sulecesful in (alpturing a large number of moths. Query-Are they codlin moths? In one case, where fom humberl and righty-three mothe were captured, in an orchard as badly infested by the codlin moth as any that can be found in this state, not a corllin moth was found in the whole number. In another case, where loeomotive head-lights were used in an orehard at night and surrounded by devices for capturing moths, such as pans of sweetmed water, rum and molasses, eoal oil, ete., of the immonse number of nothe raptured, less than one fourth of one per exent were collin moths, or one in every four hundred. Mr. li rallere at my oflice a few days ago, and stated that he 
was capturing imnense numbers of the codlin moth in rlishes and bottles of sweetened water, in his orchard. On being shown a codlin moth, natural size, he discovered his mistake, and remarked that the moths which he was capturing, the body of each was over an inch in length and about as thick as a lead peneil. Serious consequences have happened by the application of highly recommended solutions for destroying scale insects, such as tree wash-a cheap production marle of coal oil, which proved an excellent insecticide, lut unfortunately those who recommended it did not wait to find out the effect on the trees. That it contained some pernicious qualities which destroyed the tree on which it was used was discovered in three or four months after application. Only use well known remedies if you wish to be successful.

\section{CHAPTER IX.}

\section{Alkaline Washes as Insecticides and Fertilizers.}

Since the passage of the laws in March, 1881, for the protection of the horticultural industries of this State, a large amount of money has been expended in purchasing solutions, and the necessary labor of applying the same for the purpose of exterminating insect pests. In nuany cases the result of the work did not meet the expectation of the fruit grower, and in consequence of being disappointed a premature verdict was given against the utility of the solution recommended. The question never oecurred: "Did I get the best material, or was the proper application made?" The object of this chapter is to explain how such failures have occurred.

No. 1. A proposes to wash his orchard trees with concen-. trated lye so that it will destroy insect pests, anrl at the same time invigorate his trees. He calls on a wholesale morchant (who knows nothing of the material required) and states what he wishes to purchase. A potash is offered at a very low price, but warranted equal to any in the market, if bought in quantities of a ton, more or less. An orler is given, and the socalled potash delivered at five and a quarter cents per pound, 
instead of nine or nine and a half cents per pound, the price of the proper article. The work of application is commenced, and it is only after the work has been eompleted that the fruit grower learns that the article he had bought for potash was a poor quality of canstic sorlas.

No. 2- wishes to serure one ton of whale oil soap. He goes to a salp fartory and purchases the amount requirerl, but after application be ascertains that whale oil soap proper is the resilue presipitater in bleaching whale oil, in which the fatty matter of the oil is saponified by liquid potassat, and can only he purchased at the hleaching works; also that the whale oil soap he bought was marle from a low grate of whale oil in the same manner as soft sottp, and instead of the saponifing matter being all potash, the greater part was caustic soda. In such eases the best results cammot be obtained; perhaps one or two cents per pound are sared, but the same amount of labor was required that would have applied the proper wash.

\section{CHAPTER X.}

\section{Thorough Application of Remedies.}

"I consider a creat deal of my suceess in exterminating scale insects was due to the thorough application of the remedies used." - Elwood Cooper.

I do not wish to be consillered an alarmist. but I state, frankly, that from this tine forth, any fruit grower in this state (expedally in infested rlistriets) who wishes the produce of his orehart to be choice and marketable, will he compelled to expend numere and labor to protect bis erop from the ratyages of inseret pests, and the following rules should be strictly arlhereed to :

1. P'rocure the lust quality of such articles as are required for insecticides and fertilizers.

2. If you are not a jurlege of the article, secure the assistallee of some person who is.

:B. Be stre that the formula for making any solution is meperly prepared, hefore application to the tree. 
4. Use only the best mechanical appliances, such as pumps, nozzles, etc.

5. Make thorough application in every respect the basis upon which the work must be done.

The following cases are related from personal observation:

1. A was advised to serape his trees, put on bands, sew them, ete., and was given full information how to proceed to prevent the spread of the codlin moth.

Application.-He contracted to get his trees scraped for three cents each-about forty prer cent of what it should have cost; bands were placed on the trees, and during the four months succeeding the fifteenth of May, they were partly examined twice, instead of every seventh day.

Result.-The crop of apples and pears was destroyed, as heretofore. The remedies recommended were denounced by $\mathrm{A}$ as worthless. The failure and loss of time and money were caused by the negligent manner in which the work was done.

2. B has an orchard infested by the scale insect, and is recommended to wash his trees with a solution of one pound of concentrated lye to each gallon of water used. He substituted two and a half gallons of water to each pound of the lye.

Result.-The scale insect was not destroyed. B was indignant, and denounced the remedies recommended as an imposition, but failed to state that he used two and a half gallons of water instead of one gallon to each pound of lye usedlabor and money lost by not making application as directed.

3. C was advised to use the concentrated lye solution, and not to use coal oil of any kind. Howerer, by advice of his neighbor, he used a wash nuade of a low grade of coal oil.

Result.-It proved an excellent insecticide, hut killed the trees.

4. D's orchard was infested by the San Jose scale (A. perniciosus). He procured material, the best to be found in the market, and commenced a thorough warfare against the pests. He succeeded adnirably in his work, hut husiness matters caused his absence for three or four days from the orehard. On his return he found some of his trees scorched by the application. On investigation he found that the liquid was taken 
from the casks without stirring; therefore, the trees washed from the liquill taken from the hottom of the casks stood an application ahout three times as strong as necessary; however, they came out all right. 'The mistake was rectified, and the experience noted for future use.

REstrt-D's thomugh application was successul in every respect. It cost him $\$ 900$, hut his orchard is clear of san Jose scale.

E owns an orehatrl containing seven thousand trees, for

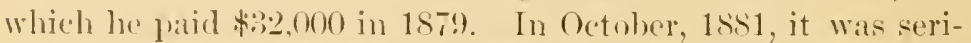
maly infested ly the san Jose seale. In November he bought seren tons of concentrated lye, and commenced work. About new-year his neighbor comrlemmed his work as being so thorough it killed all his trees. He wote me what he had done. I arbised him to "go on as he hed been doing," and in a few days after visited his orehard. The work was eompleterl as commeneerl. I visited the orehard on the thirty-first day of Ilareh following (1SS1); every tree was in b]oom, and but few of the scale inserts in al healthy condition. I asked the owner at what value he estimated the result of his perseverane and thorougl, work. He answered: "Last Octoler, I would have sold the orelatel, beges and all, for w15,000. At a cost of a little orer" $\$ 1,200$. I have conquered the bugs. Now, sile yom cammot buy it for $\$$ to, 000 , and you cam so intorm your friends."

Moral.-Follow E's example.

Firstelass material to make the solution and thorough application will destroy the seale insect without fail.

Do the work as recommended, thoroughly, and the bugs must go. 


\section{CHAPTER XI.}

\section{Pumps and Nozzles for Spraying Trees.}

Experience has taught us that the most effective remedies for the extermination of inseets injurious to fruit and fruit

Fig. 1. trees, especially those belonging to the Coccidue,

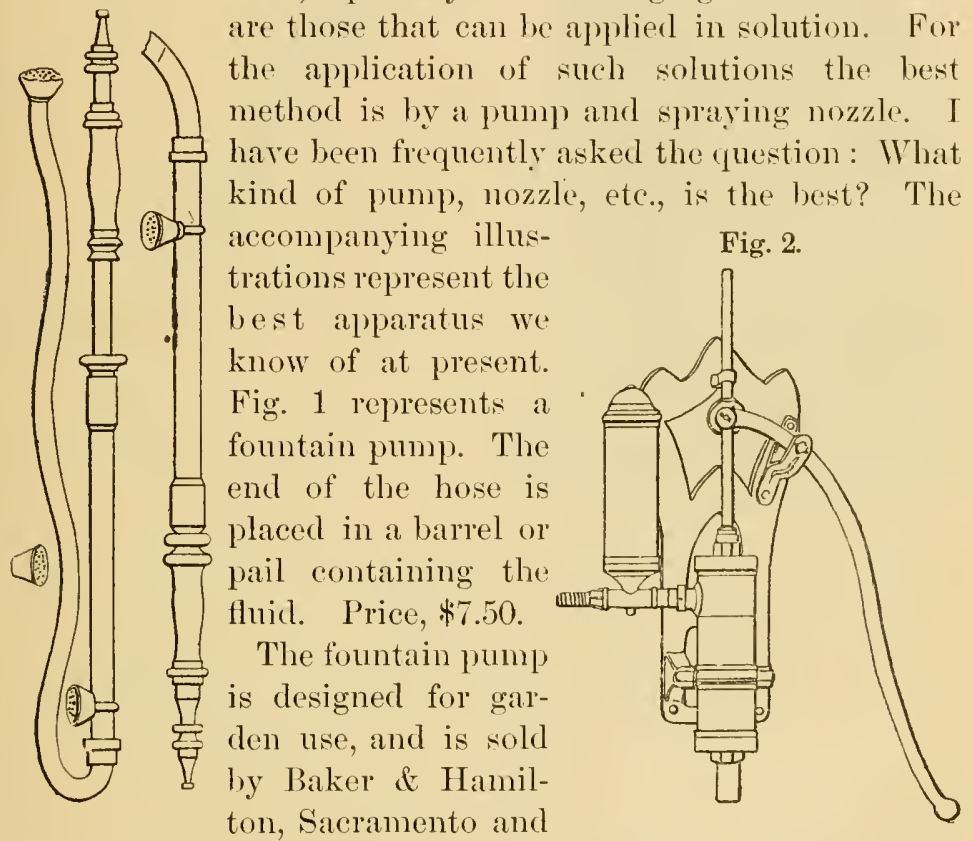

San Francisco; and by H. P. Gregory \& Co., San Franciseo.

Fig. 2 represents a pump, known as the "Croukd Pump," manufactured by H. P. Gregory \& Co., Nos. 2 and 4 California Street, San Francisco. A large number of these pumps are now in use, and give excellent satisfaction, as the working parts are made to resist the ehemical action of the disinfectants used.

Price of pump, $-\$ 1700$

Price, complete, with twenty-five feet of hose, suction, strainer, and spraying nozzle, - $\quad$ - $\quad$ - $\quad-2300$ Or, with fifty feet of hose, dunble discharge, and two spraying nozzles, 
Fig. :) is an illustration of a new improved pump, manufactured by H. P. (iregory of ('o., of san Francisco. This is

Fig. 3.

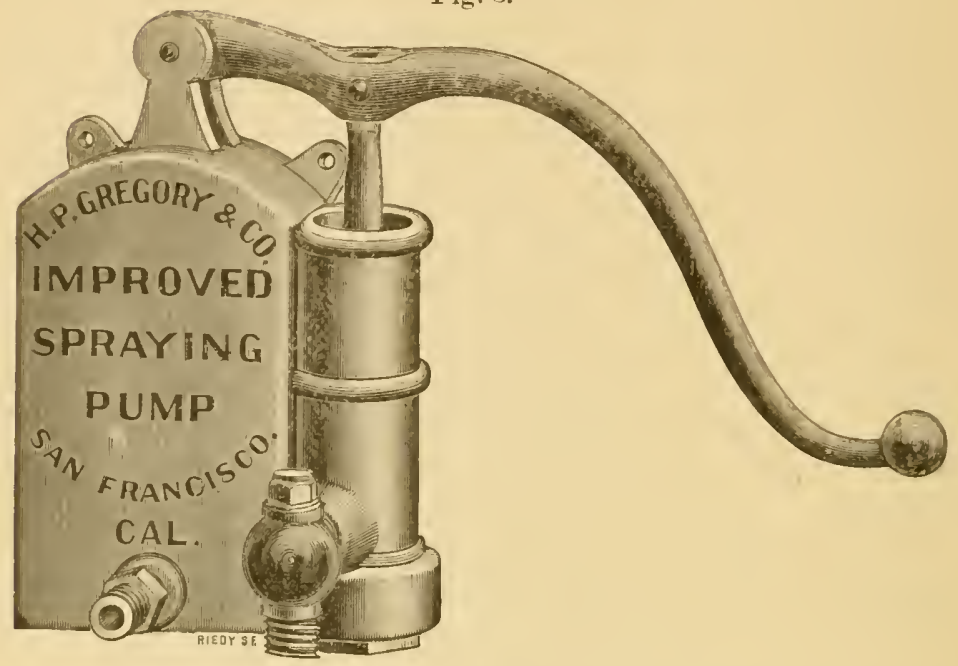

(o)tainly the best poum for spraying trees that has been offered for sale. It is stronger made than most pmmps thus giving more power. There are only two joints where it would be possible for the liquid to leak out, and these. if poperly screwed up, are perfectly tight. The air ehamber is very large in poportion to the size of the pump, therehy wiving an "xceerlingly steady sum. The cylinders are lined with brass, and the valves ale made of the same metal as the horly of the punp, inclueling the hamble. The outer parts are galvanized. thus preventing them from rusting, so that it will presorve the same neat alpearimee that it has when mew.

This pump was designed ly H. I'. Cregory, of the abore firm, and is cortainly a great imporement. 
Fig. 4.

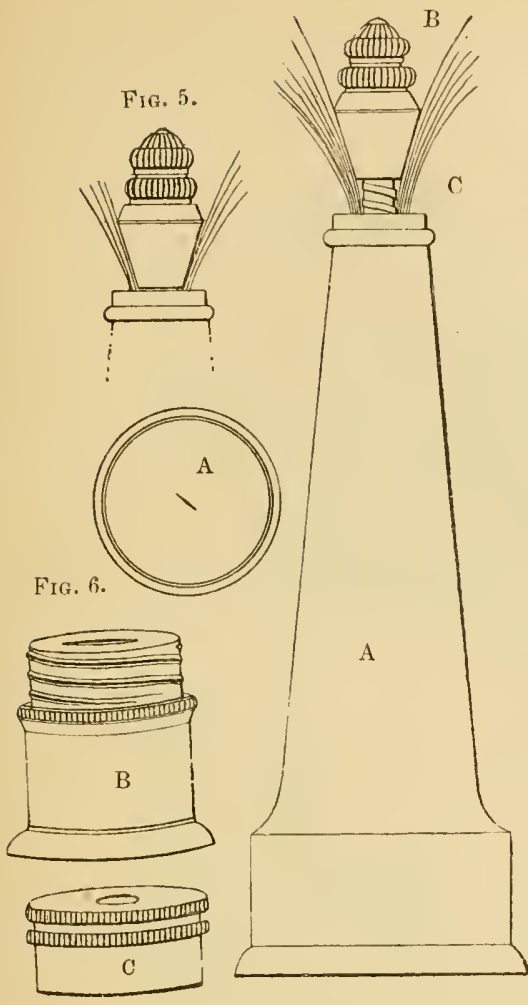

Of the spray nozzles in use, the most practical is a nozzle made by ITesley Fanning, No. 279 st. John Street, San Jose, and is known as the "Merrigot Nozzle." (Fig. 6.) A is a diaphragm, with a small opening in the center of any required size. This is placed on the piece $B$, on top of serew; the cap' ('is then screwed on, and the nozzle is complete.

Writh a force pump this throws a very fine spray over the tree.

A full set of diaphragms are sent with each nozzle.

Figs. 4 and 5 represents the Niagara Lawn Sprinkler.

\section{CHAP'TER XII.}

\section{DeLong's Moth-trap.}

The apple house (Fig. 7 ) at the Novato Ranch, in Marin County, California, owned by Mr. DeLong, is a three story building about one liundred feet long by serenty feet wide; the lower story is built of stone twelve feet high, the second story of brick fourteen feet high, and the third or upper story is in the form of a hip-roof, and is about twonty feet from the floor to the ridgepole. 
Mr. DeLong made this experiment of trapping the codlin moth, earried to his premises in return paekages. The following if takin from the report of the Fruit Growers' Convention at San Jose, Norember. 158.2:

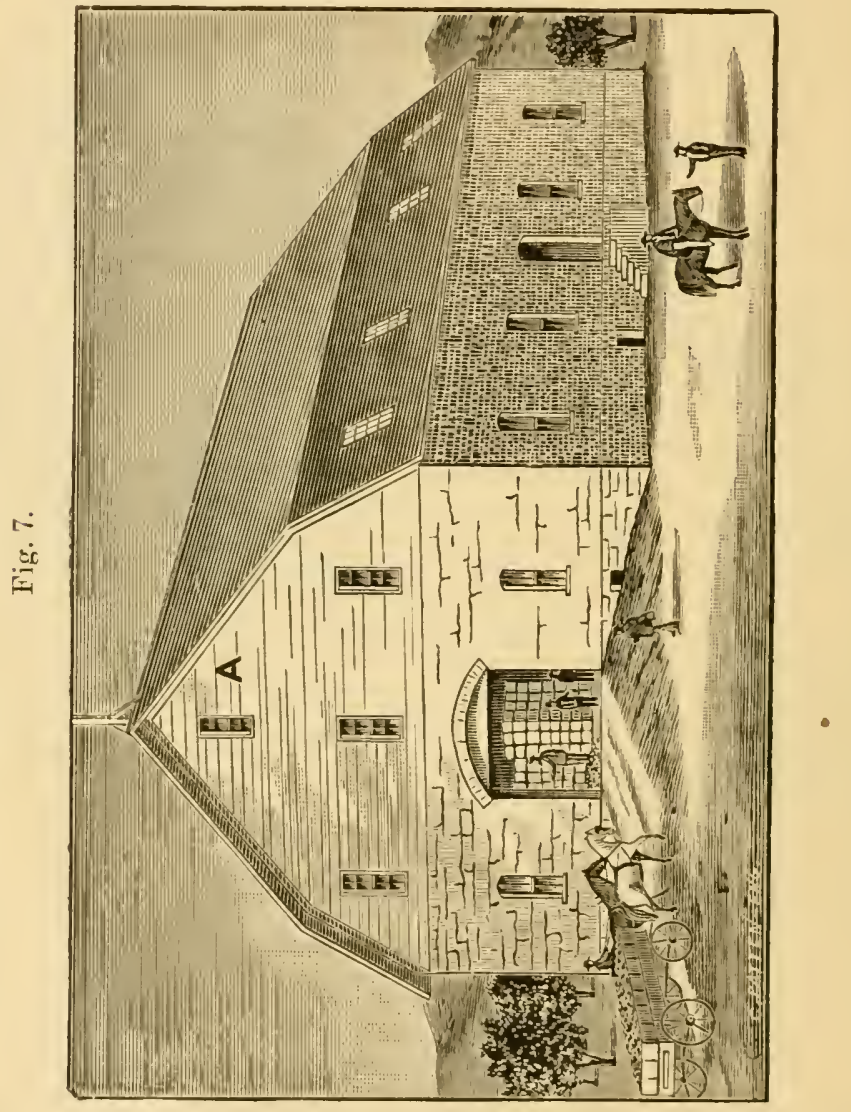

Mr. Cooke-"I call your attention to one matter in reference to an orehard, of 250 aceses, in Marin County, where there are $: 31,000$ trees subject to the attacks of the codin moth-the Sovato lianch. In June, 1SS1, I risited the ranch and, srreatly to the dismay of Mr. DeLong, I found the pupa of a collin moth. When I told him, he said: "No sir, we have nome here.' I replied: 'Mr. DeLong, there it is on this tree.' Now I would like to call for his experience since June, 1S\$1."

Ilr. Bebong- . All I cam saly is that I did not know that we 
had one in the year 1879 ; we had none in the year 1880 ; we had none in the year 1881 until he discovered it, as he says, in the chrysalis form. That year we gathered our fruit and carried it into the apple-house, and I saw very little of it on the fruit. The apples did not seem to be much affected, but the suggestion was male to me by Mr. Cooke, the following Spring, that I had better scald all of my boxes. I asked him whether they had gotten out of these boxes into the cracks of the floor in the building, and how would it do if I should close this building up by putting mosquito netting over the windows, so that there would be no possible chance for the moths to get out. He agreed with me that it would be a good idea, and I did so. Having done that, I thought I would like to know the result of it. I nailed all the doors up so that it woukd be perfectly impossible for anything to get in and out without my knowing it, and I locked the door and took one of my men and put him in possession of the key. He commenced finding some of the moths about the middle of April and killed them, and up to the 27 th of May, kept a ruming account; after that date he kept a daily aecount; he found that he had killed 15,627 up to the 27 thi of October. As the account is called for I will read it; it will give an idea. As the days grew longer and warner the moths increased; as they grew colder the moths diminished. This is the account of the moths themselves, not the pupæ.

DESTRUC'PION OF CODLIN MOTH IN FRUIT-HOUSE.

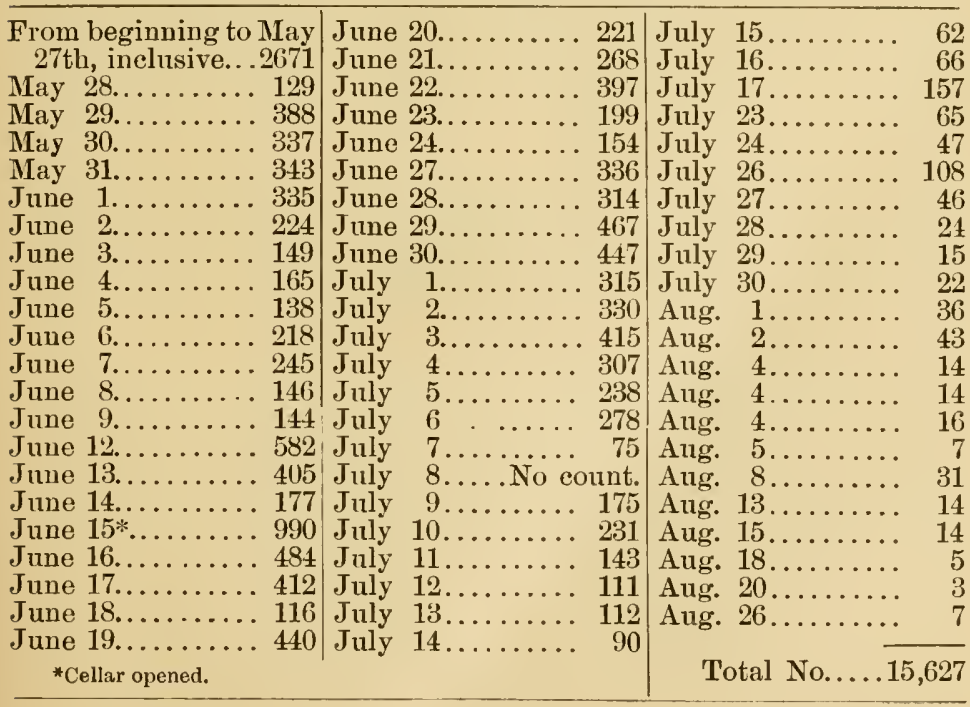


"I have kept ten or eleven men working eontinuously in the orchard all through the season. Nine of them going orer the trees and pulling off' all the fruit they could find that was infesterl with these worms, and others were picking then up and rarrying them in. The means that I used to rlestroy them was to put them in a large boiler and boil them up, not trusting to the hoge or anything else to eat them: and I came to the eomelusion that that was the surest way of exterminating them.

"I have carried that out until the apples got large, and they are now in the house. What the result will be, I don't know. I have worked the hands very offectually. killing some days thousanrls of larvae. I never krept an alecurate aceomnt."

Mr. Cooke-"How mamy" dir the bats rat?"

Mr. Dedeng-" That is al question I do not know anything alhout. I ront know that I ean grive any further icleas. We were working under the mode Dr. Chapin spoke of, which I think is most rffectual.'

Mr. Cooke-"I merely wanterl to call the attention of the (on)rention to the facts: when Mr. DeLang rovererl all of the winrows on the inside of the three story alple house (the uppere story is formed with a high roof, and he had to keep the mossquito har over both ends), he inelosed probalily five hundred (500) bats. Wr know that a bat lives on inserets, anrl it is reptain that the hats lived on the eoctlin moth, and of these

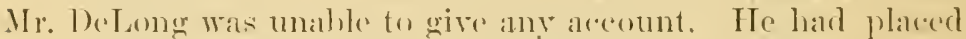

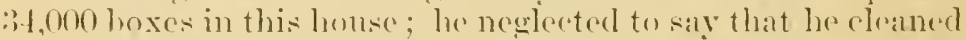
the boxes before they were put inte the trap, and he got ten or twelve larve in some of these hoxes. He got over 15,000 moths, the laresest eapture ever marle in this line of warfare. for his Summer's work.

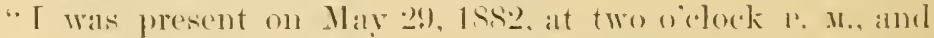
on the rovering of the top winkow, markesl A, on Fig. $\bar{~}$ one hundred and ten mothe were aptatured. Extended notios is thus giren in eommentation of Mr. DoLong's pratetical work from the 15 th of April to August 26 th."

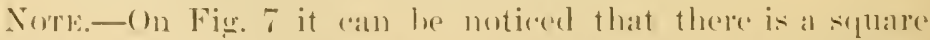
cornice on arable of building: the lats could only get inter this cornice from inside: the cosering of mosquito ball kept them on the top flowr, and as they alppeared woll fed cluring the ronfinement of four months and a half. it is presumed that

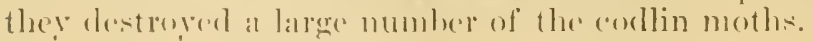




\section{CHAPTER XIII.}

\section{Structure and Growth of Plants.}

1 great amount of damage has occurred in some fruit growing districts of this State by the applieations of solutions, ete., as insecticides (i. e. a low grade of coal oil), which contained properties that were detrimental to plant-life. By examining Fig. 8, the outer bark is found to be represented by letter F, the green layer by letter ( $r$, the inner bark by letter $H$, and the ambium layer by the letter I. As the cambium layer is stated in the following deseription to be the seat of life of the plant, it may be readily nnderstood in what nimner a solution containing pernicious properties injures the tree when applied to the onter hark, viz. : by penetrating the outer bark, the green layer, and inner bark, thus reaching and destroying the cambium hayer (or seat of life of the tree).

On the contrary, if proper solutions, such as are recommended in this work, are applied, they destroy inseet life, and by penetrating the outer layers reach the cambium layer, and by means of the fertilization properties which they contain, invigorate the tree.

[The following extracts are taken from a paper by Colonel W. S. Clark, President of the Massachusetts Agricultural College.-Mass. Rep., 1873-4]:

"Every seed and every young plant consists wholly of cellular tissue, but with the development of leaves is combined the growth of fibro-vaseular tissue."

"The first vessels to appear in the plantlet are arranged in a cirele around a column of tissue, which rentains loose and soft, and atter the first season dries up and dies. This is called the pith, and seems essential to the life of every woody stem and branch during its infancy, although its special function is mknown. Between the vesscls around the pith may be seen the rays of cellular tissue, which ultimately becone hard and firm, and which unite in bonds, never broken except by some external force, the inside of the stem with the inside of the hark. These rays make up the woof and have much to rlo with the distinetive peculiarities of different sorts of timber."

"Immertiately outside the vessels inclosing the pith grows a layer of woody fiber, upon which, in a more or lesis developed 
state, aceording to season, is a layer of organizable material. (alled cambium, which may be regarded as the seat of life of the plant."

"Investigation seems to demonstrate that the camlium layer is the seat of life, and that wheneser the direct communieation between the root and the foliage is cut off' in this layer during one entire season of growth, the whole plant perishes. It has also been determined ly experiment that if sev(ral rings of bark he removerl from a growing shorit in such a mamner that on one of the isolaterl sections of hark there be no leaf, while leaves remain on others above and helow this, then the ladess section will fail to make any growth in any part. Nll other sections, if furnished with one or more healthy leavers. will inerease in thickness by the formation of new leaves, of woud and bark. This seems to prove that the material for growth is elaborated by the leares, and is transmitted only through the cambium, and has no power of penetrating the tissues of the wood."

"The peculiar vital and organie power of the rambium is remarkably illustrated in the structure and growth of grafter trees. Every person is aware that pear trees are grown upon quince roots, and that they often bear finer fruit than when cultivated as standards. This is douldtess owing to the filct that quinee roots, heing diminutive, furnish less water to the leaves, which thus claborate a richer sap, and produce more perfectly developed wood and fruit."

"The aprieot may le grafted on the plum, and the peach on the apricot, and the almond on the peach; and thus we may frodue a tree with flum roots and almond leares. The wood, however, of the stem will eonsist of four distinct valrieties, though formed from one continuous cambium layer. Below the almond wood and hark we shall have perfect peath wood and hark, then perfect aprient wood and hark, and at the bottom perfect plum wood and bark. In this emrions instance we see the intimate correspondence hetween the hatk amel the leaf: for if we should remove the almomel loranehes we might camse the sereral sorts of wood to develop hads and leafy twigs, each of its own kind. Each section of the rompound stem has its seat of life in the cambium, and the eambium of each remoduces rells of its own spereses out of a common mutrient fluid. Thus there is seen to he a tlow of sap upware in the wool, and a flow of organizahle material. escential to the lifo of the plant, proceeding from the leat to the root, theomerh the lark and the rambium laver. From this perfereted sily the growth of the season is formerl, amel

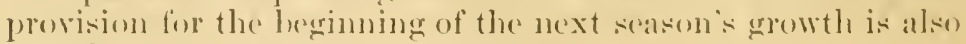
stored "1p, commonly in the root." 
"Next to the cambium, and united to the wood by the rays from the pith, is the bark, consisting of thrce layers."

"The inner, or fibrous layer, is formed by hast cells and firm cellular tissue. Surrounding the inner bark is a layer of cellular tissue in which the rays from the pith terminate, and which is named the green layer, because it often exhibits this color in young shoots, and then performs the same function with the green tissues of the leaf. Outside of all this is the corky layer, consisting of dry, deal, cellular tissue, and developed annually from the green layer. This is not usually of much thickness, or consequence, but sometimes, as in the cork oak of Spain, it becomes an important article of commerce."

"The growth of our trees goes on in the cambium layer, from which is produced annually a layer of wood and a layer of bark, each formed of longitudinal fibro-vascular tissue and horizontal cellular tissue."

"As the trunk expands, the onter bark cracks and falls off, as in the shag-bark hickory, or distends and envelops it with a somewhat smooth covering, as in the beech and birch. In these latter cases the annual cortical layers are quite thin, and the outer layer very gradually wastes away. under the influence of winds and storms. In the cork oak the outer layer is specially thickened, and if removed every eighth year, mat be obtained in stout, elastic sheets, which would crack and fall to the ground in the process of time if not harvested. The structure of the root is not unlike that of the stem, except that the pith is usually wanting, as well as the green layer of the bark, which could not be formed nor be of any use in the dark earth where the root makes its home."

Fig. S represents a section, both vertical and horizontal, of a branch of sugar maple, two years old, as it appears in December. The portion included in the lines marked $A$ is of the first year's growth; those marked B indicate the wood of the sccond year; while those marked C include the three layers of the bark. D represents the pith of loose cellular tissue; E the pith rays of silver grain of hard cellular tissue connecting the pith with the green or middle layer of bark, which also consists wholly of cellular tissue. F marks the outer or corky layer of the bark, which is composed of dry, dead cells, which are formed of consecutive layers from the outer portion of the living green layer; $G$ is the green layer of cellular tissue. H shows the liber or inner bark, made up of cellular tissue penetrated by 
long bast cells, arranged parallel with the axis of growth. I represents the place of the eambium or wrowing layer of organizable material which deseends from the leaves hetween the liber and the sap-wood during the period of growth. $K$ is

Fig. 8.

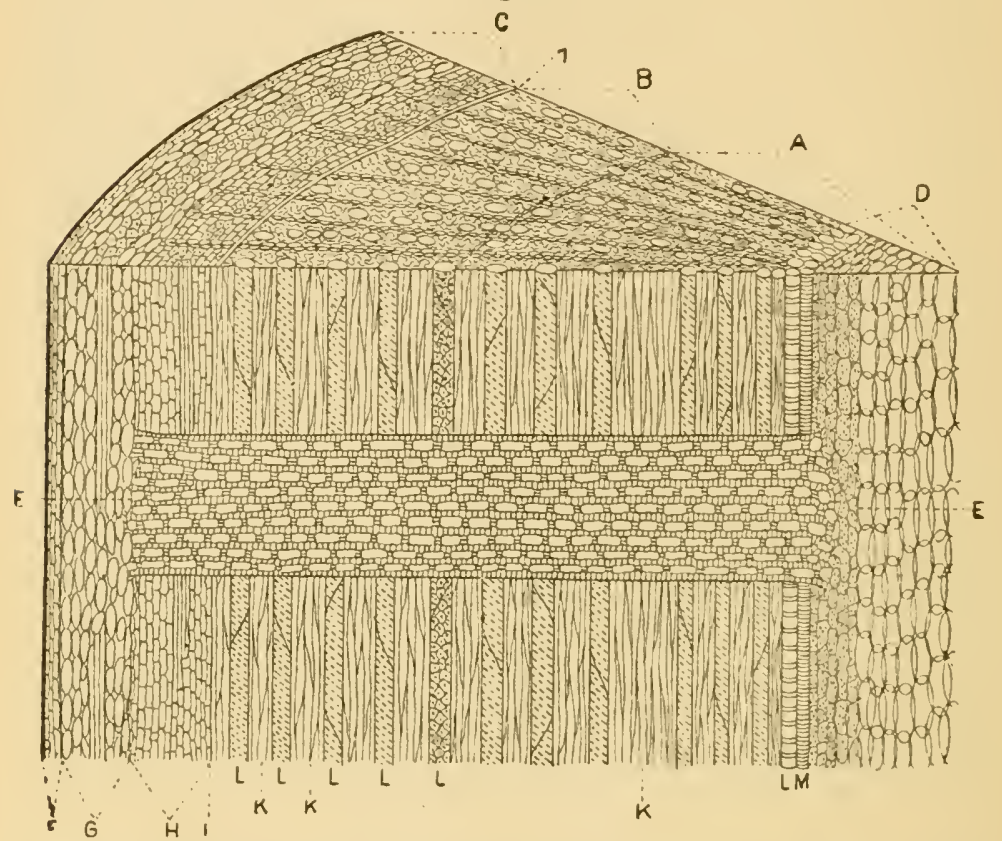

woody tibre, which gives strength to the stem, and through which the crude sap rises. I indicates the ressels or ducts, with varous markings, such as lots, ringrs, and spirals, which are formed most abundantly in the fipring, and usually antain no fluid. They conver gases and alyueous vapors, and it may be that a large proportion of all the water aserenting from the roots to the leares passes through them as a vapor. It is the bayere of spiral ressels or ducts which always incluse the pith, and in the youmg shoot extend into the leaves and unite them to the pith during its life, which ceases with the first season.

"This part of the plant develops an ammal layer of wood ancl bark, with rays of cellukar tissue like the stem. The num- 
ber and extent of root branches in the soil depend numeh upon its fertility and adiuptation to the plant."

"As the vigor of regretable growth depends chictly on the action of the roots, the importance of thoromgh tillage is apparent."

"The striking peculiarity in the structure of the root is the absorbent power of the young rootlets, which are either covered with a thick, spongy layer of cellular tissue, or furnished, as is commonly the case, with exceeding minute but innumerable hairs, which penetrate the erevices of the earth in every direction in search of food. The extreme tips of the rootlets, about one sixth of an inch in length, are not clothed with hairs, nor capable of alosorption, but serve as entering wedges for the advancing root, which lengthens only near the extremity."

"The bark of the larger roots becomes thick and impervious, like that of the trunk and its older lomeles, and the immer portion of the wood, both above and below ground, gradually solidifies, and becomes unfitted for the fiee transmission of fluids. It is then called heartworl, in distinction from the sapwood, through which fluids are transmitted freely. The farther any layer of wood or bark is removed from the living cambium the less ritality does it retain, and consequently the less useful is it in the economy of the plant."

"The leaf has been said, with some propricty, to be an extension of the bark, and consists of a framework of fibrovalscular tissue forming the stalk and reins, with al double layer of loose cellular tissue cosered with a distinct epidermir or skin. The ressels in the leaf stalk and the reins, which are its branches, are also in two layers, the upper connecting the leaf with the vessels surrounding the pith, which are called spiral on account of their peculiar markings, and the lower which are united to the cambium layer through the tissue of the inner bark."

"The distinctive features of the leaf is the presence of stomata or breathing pores, which are usually more numerous on the under side. These stomata are furnished with openings, so construeted as to close in rery dry air, and open in that which is moist, but they always remain shut, except under the stimulus of light. As the chief function of the rootlets is to alsorb the liquid food of the plant from the earth, so it is the special work of the stomata to transpire the surplus water of the crucle sap, which has heen employed as a carricr of food from one extrennity of the countless series of cells which build up the plant, to the other, in some cases a distance of five humched feet, through imperforate membranes, and against the force of gravitation." 


\section{CHAPTER NIV.}

\section{Entomology should be made a Permanent Study in the Public Schools.}

That many orehards, rineyards, etce, in this State, are infester ly insect pests is an assertion that eamnot be suecessfully contradicted. How can this evil be remolied? So long as each fruit grower considers himself a competent authority as to the necessity of axtirpating from his premises such insects as are known to be injurious. and cradicating such discases as imprair the vilue of the fruit crop, and decides to deternine for loinself the comblitions upon which he will interfere with their spread for the protection of his own property or that of his neighbor's, there ean he no miformity of antion, by which the evil ean be thoroughly eracticated, until a general agreement of all parties interested in the fruit growing industry ain be perfected.

The dissemination of such information as will give a thorough understamling of what is required, will require time. As the fruit growers of California are scattered over a large range of territory, and, as stated above, each individual having his own theory to eling hy, any advice oflered that is not in aceordanee with such a course as he has determined to adhere to, is looked upon as a milignant interference with his private affitirs.

There are sources of power by which the obstacles mentioned will be overeome, to wit: The Puble axd Private fenooss, eombined with the intelleet of Young America and the tearling in the family circle.

The query may be reasonably mate by persons who have griven liut little attention to the teachings of entomology: Why is it neesessary to introduce the study of eeomomie entomelogy into the public sehools at the present time? In answer to this inquiry, it is stated in the first part of this chapter that there is a confliet of opinion existing among fruit-growers, ete.; whose industries are threatened ly the invasion of insect pests. Howerer, it is a matter of $1001 \mathrm{mmom}$ agreement of those prersons who hate eonsidered the subject, that it is only by a mites warfare, or hy united action, that the insect pests can lex exterminated. 
Therefore, under present circumstances, it is absolutely necessary that the enterprising husbandman should be fully acquainted with the teachings of the seience of entomology, or in other words, with the natural history and habits of the insect pests which destroy his property.

Another inquiry may be made: Why has the sturly of this science been neglected? Until within the last few years the orchards in this State were free from codlin moth and scale insects; the vineyards were free from phylloxera, vine moths and flea beetles; the vegetable garden from cabbage worms and cabbage bugs; the granaries and storehouses from the grain weevil, ete; therefore our educators introduced such studios as they thought best for the requirement of the times. Besides, there were obstacles in the way of introducing this science not easily overeome, viz: the text books relating to entomology were generally written in technical or scientific language, with which the masses of the pupils attending the public schools were unacquainted. In many cases mechanical accessions have to be employed, such as the pocket lens and microseope to detect the presence of these creatures, they being amongst the minutest works of creation, and scemingly endowed with an instinct to avoid the enquiring eye of man. Again, the student who attempted to make insect life a study was treated as a mere trifler and a dabbler in childish pursuits. It may therefore be readily imagined why the study of this seience has been neglected in the past.

In order to promulgate information in relation to the natural history, etc., of injurious insects, it must not be treated as a matter of only local importance. The damage done to property by injurious insects is not eonfined to any one locality, but extends from the valleys to the hillsiles and mountain tops, from the northern line of the State to the sonthem line, and from the Sierras westward to the sea; so that the promulgation of information in relation to their natural history and habits must necessarily be general.

This requirement can only be attained by introducing the study of economic entomology into the public schools, and by discussing its teachings in the family circle.

Among the results that will follow, the husbandman will 
thoroughly understand the natural history and habits of those parasites that prey upon his industry, and can therefore make a successul warfare for their extermination, having a complete knowledge of low and when to strike the blow for victory.

\section{C'HAP'TER XY.}

Economic Entomology.

Hortirulturists and all other persons engaged in cultivating the soil slowld make the study of insects (espereially those known to be injurious to fruit and fruit trees, grain, vecgetatables, ete.), a part of their every dily work. It is as necessary for them to molerstand the natural history and haloits of such prists of the orchards, etr., as it is to understand how to plant, prume, ete.

Some fruit-growers think that for such practical insestigattion of inseret life, a scientifie knowledge of the anatomy and physiology of these creatures is indispensable. Such, however. is not the ease. It requires some apparatus (which cam be procured at a nominal expense), a little patience, and an interest in the subject investigated, to learn practioally what they have depended on others to fumish.

The following apparatus is necersary : tions to Ml: C. Muller, optician, No. 19:5 Montgomery street, san Franciseo, for illustrations of this (hapter.) Fig. 9 represents a one-inch focus watchmakers' glass; price, from 75 rente to $\$ 1.25$ each. Fig. 10 repre-

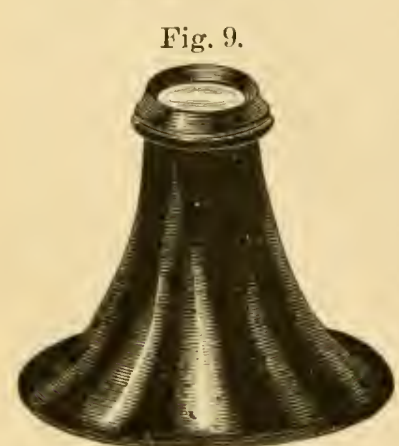
sents a small microseope; price, from $\$ 10$ to $\$ 20$. Such instruments have suflicient power for any practical investigation requiled on the farm orits surroundFig. 10.

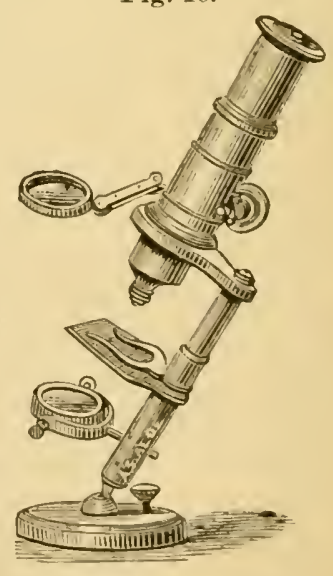
ings: One dozen erlass slides, albout $\$ 1.00$; me duzen glats 
covers, about 75 cents; Canada Balsam, 25 cents. A neat and useful outfit can be had for $\$ 15.00$, at C. Muller's, 135 Montgomery Street, San Francisco. Should the fruit grower be unable to give half an hour of his time each day for such investigations, the ladies and ehildren of the household should be trained to make observations that, when compared with those of others, such information will be oltained as will repay them for their time and labor. When the life history and habits of any of these insects is learned to such an extent as to be faniliar with the metamorphoses (changes) as larva, pupa (chrysalis), inago (perfeet insect), the fruit grower can then go to work intelligently to exterminate them. By following the above recommendations, the result gained will be replacing theoretical by practical information.

\section{CHAPTER XVI.}

Mildew or Seab on the Foliage and Fruit of Apple and Pear Trees.

\section{(Fusicladium dentritirum.-F. K. I.)}

For a number of years past the presence of what is commonly called mildew has been detected on the leaves of the apple and pear trees, but so far as the leaves are concerned, more abundant on the former. When the apple tree is attacked by this fungus early in the season, the young fruit is generally destroyed, and the leaves attacked hardly ever come to perfection, as they appear to dry up and crumble to pieces. On the pear leaf it is in the form of a brownish bloteh.

When the attack is first noticed on the young pears, it is in the form of an irregular brownish spot on the skin; this dark spot or seab, as it is commonly called, does not penetrate into the fruit to a great extent, but destroys the skin and forms a hard surface, thus preventing the growth of the fruit on and immediately around the place attarked; consequently when the skin of the young fruit is attacked in one or more places, when it is full grown the surface is not uniform, and the market value is thus decreased. That the fungus spores which cause this fungus, or mildew, on the leaves and fruit of apple 
and pear trees in the spring is on the trees from one season to another, I think is beyond question.

There is also a species of fungus that attack the aprieot, griving it a speekled alplearance and elestroying its market value. It is also notieed on the peach, nectarine and prune this season, 1 S.8\%

To destroy mildew, fungus, ete, on fruit and foliage of aprieot, ]each, prune, nectarine and almond, use Pemerlies No. 5 or 7 . one pound of the mixture to each one gallon of water.

()n apple, pear and quinee, use Remedy No. 6, one pound to

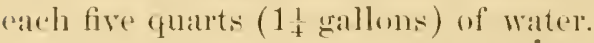

Note.-The above remedies should he applied by spraying the fruit and foliage as soon as the fruit is well set from the blosom, of about the size of a small marble. The spraying should be repeated in two weeks.

\section{CHAPTER XY'TI.}

\section{Birds-Beneficial and Injurious.}

It would be a rery diffieult task for any person to aseertain what hirks are injurious and which are heneficial. I do not think there is any birl that is wholly injurious, because those which are usually regarded as being injurious, such as the robin, hackhird, ete., are partially beneficial, sinee they sometimes feed upon injurions inserets. And it would be about as ditheult to name a himl that is wholly benefieial ; the swallows are usually regarefed as leneficial birels, and yet it is evirlent that they destroy more lenefieial inserets than injurious ones, sine the former are mostly on the wing in the daytine, while the latter fly chictly at night. The night-hawk and the whippoorwill ane about the only hirds that ean be regarded as being wholly lemeficial.

But, as any hird that foeds upon any part of our cultivated plants, slurulse or treess. or in any manner injures or destroys these animals which minister to omr wants, is msually regatled as bring injurjous, l will endearor to classify our more common lives inte there chasses: the beneficial, the injurious, and 
the doubtful. The first class will contain those bircls which feed almost exclusively upon insects or small animals, and which are not known to injure fruits, grain, or anything of any value to us. The secomd class will contain those which feed principally upon fruits or grain, or which are known to eause extensive injury to some of the useful products of the soil, without making adequate return for their destruetiveness by destroying noxions insects. In the third alass will be placed those birds which sometimes depredate upon the useful products of the soil, or upon our domestic animals (including fowls and bees), and which also feer largely upon insects ; so that it is doubtful as to whether we are to regard them as being beneficial or injurious.

\section{BENEFICIAL BIRDS.}

Bluebirds, pewees, tlycatchers (exeept the beebird), swallows, martins, wrens, chickarlee, vireos or greenlets, tanagers or redbirds, ground-robins, cuckoos, humming-lirds, warlolers, night-hawks, whippoorwills, mearlow-larks, shrikes, butcherbirds, road-runners, vultures, turkey buzzards, gulls, plovers and snipes.

The meadow-larks and plovers, and perhaps a few other birds in this list, sometimes feed upon seeds, but only to a limited extent, their food consisting ahmost exclusively of insects; the shrikes and road-runners feed upon insects, snakes, small lizards, ete., and the former sometimes destroy small birds; gulls feed upon insects, frogs crayfish, ete.

\section{INJURIOUS BIRDS.}

House-finches or red-headed linnets, cedar-birds or waxwings, orioles, doves, wild geese and ducks. These are about the only birds that are considered as being very injurious, and even these partly atone for their injuries hy feeding upon inseets. The linnets sometimes orasion considerable ramage by feeding upon the buds of fruit trees. (Early in spring use Remedies Nos. 5; 6 , or 7 , one pound to each gallon of water used, and the birds will not eat the bucks.) The eedar-birds and orioles feed upon fruit and berries, and the latter also feed 
upon green peas; the doves feed mostly upon grain, while the wild geese and ducks are sometimes very injurious to growing grain.

DOLBTFUL, BIRDS.

Thrushes, robins, atbirck, blackbirds, bechirds, finches, sparrows, blucjays, magpies, crows, hawks, owls, quails, woodpeckers, and mocking-birds.

As stated above, these hirls occasionally feed upon some of the useful products of the soil, or upon domestic animals, harmyard fowls, or hees, while they also feed upon injurious insects or other pests; and it is a matter of considerable doubt as to whether their good rleers do not counter-balance their evil ones. 'The thrushes, robins, catbirds, quats and woodpeckers sometines feed upon fruits; the blacklirds, crows, bluejays and wompeckers oreasionally feed upon com; the sparows feed principally upon seeds, while the finches feed upon seeds and buds; the beehirds are sometimes quite destructive to bees, but also feed largely upon other insects. 


\section{INSECTS INFESTING THE APPLE TREE.}

CHAP.

The Woolly Aphis (Schizoneuna lanigera)..18 The Oyster-shell Bark-Louse (Asqidiotus

conchiformis) ....................19

The San Jose Scale (Asqridiotus quernicio-

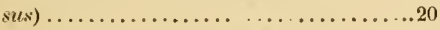

The Greedy Scale (Aspidiotus r(ty)ax).....21

The Round-headed Apple-tree Borer ( $\mathrm{Sa}$ perda cundida $) . . . \ldots \ldots \ldots \ldots \ldots \ldots . . .22$

The Flat-headed Apple-tree Borer (Chrysobothris femoratu) . . . . . . . . . . . . 23

The Apple-twig Borer (Bostrichus bicaudatus $)$.......................

The Prickly-hark Beetle (Leqfostylus aful-

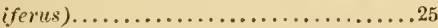

The Gray Bark-eating Weevil (Thricolepis

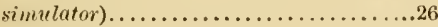

The Buffalo Tree-hopper (Ceresa bubalus) .27

The Harvest-fly (Cicata)..............28

Canker Worms...................29

The Fall Canker Worm (Anisoyteryx pome-

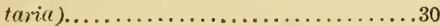

The Yellow Canker Wom (Hibernia tili(rin $) \ldots \ldots \ldots \ldots \ldots \ldots \ldots \ldots \ldots \ldots \ldots$

The Spring Canker Worn (Anisopteryx remata).........................

DeLong's Caterpillar (Clisiocamqra constricta $\ldots \ldots \ldots \ldots \ldots \ldots \ldots \ldots \ldots \ldots \ldots \ldots$

The Orchard Tent Caterpillar (Clisiocampa Americana $) . . . \ldots \ldots \ldots \ldots \ldots . . . \ldots 34$

The Forest Tent Caterpillar (Clisiocampa

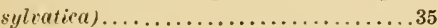

The Fall Web Worm (IIyphantria textor)..36 The Tussock Moth (Orygia leucostigma)...37 The Yellow-necked Caterpillar (Datana minist $(t) \ldots \ldots \ldots \ldots \ldots \ldots \ldots \ldots . \ldots \ldots$

The Red-humped Caterpillar (Notodonta concinna) ........................... . .

The Greater Leaf-roller (Loxotaenia roscl$\operatorname{ccan}(t)$
The Apple-leaf Crumpler (Phycita mobul ). 41 The Bud Worm (Penthina oeulana)......42 The Many Dotted Caterpillar (Brachytiemia

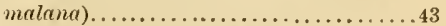
The Turnus Butterfly (Papilio turnus).....44 The Apple Buculatrix (Buceulatrix gromifoliella $) . \ldots \ldots \ldots \ldots \ldots \ldots \ldots \ldots \ldots . \ldots \ldots$ The Apple-tree Aphis (Aghis mali)......46 The Apple-leaf Aphis (Aphis walifolice). . . 47 The Ten-lined Leaf-eater (Polyghylla 10.

lineata $\ldots \ldots \ldots \ldots \ldots \ldots \ldots \ldots \ldots . \ldots 48$ The Goldsmith Beetle 1 Cotalyra lanigera)...49) The Robust Leaf Beetle (Serica malida)... . 50 The Codlin Moth (Carpoerysa pomonella)..51 The Apple Maggot (Tryyreta qomonelln)....52 The Apple Curculio (Anthonomus quadrigibbus) ....................... 53

The Earwig (Forficula auricularia),......54

The following insects are also injurious to the apple tree, but, as they are more destructive to other trees, they will be trcated of in another part of this work:

The Broad-necked Prionus (Prionus laticollis).

The Branch and Twig Burrower (Polycaon confcretus).

The Pear-tree Scolytus (Scolytus pyri).

The Snowy Tree-cricket (Oecanthus niveus). The White-lined Sphinx (Deileplizla lineata). The Angular-winged Katydid (Microcentrum retinervis).

The Rose Chafer (Macrodactylus subspinosus).

The Plum Curculio (Conotrachelus nenrephar).

The Plum Moth (Semasia pruniana).

The Red Spider (Tetranychus telarius). 


\section{CHAPTER IVIH.}

\section{The Woolly Aphis.}

\section{(Schizoneura lunigera-Hausman).}

Syxoxys-Aphis lanigera-Hausman. Coceus mali-Bingley. Eriosome mali (Leach, M. ...)—Samoulle. Myzoxylus mali-Blot. Schizonence lunigera-Hartig. I'emphigus pyri - Fitch. Aphis (Schizonena) lanigera-Ratz. Eriosoma lanigera-Ruricola.

Order, Hemptera ; Sub-order, Homortera ; Family, drHomis.

[Living in hollows on the trunk or limbs of apple trees, a sulall plant-lonse, which is more or less covered with a white, cottony matter.]

The presence of this insect can readily be detected from the appearance of the tree infested; the branches appear knotty, the wood dry, hard, and little, and the general appearance is that of over-age and decay. Its distribution may be said to he general in this state on apple trees, and it is very generally distributed on apple nursery stock. The opinions of writers liffer as to whether the insect found on the roots, and those on the trumk and limbs, are the same species, some contending that they are similar, and that those on the trumk and branches go to the roots and hibernate during the winter, or deposit their exgs for the next season's lrood, while others rontend that they are distinet species. For the present purpose it is suflicient to know that one or more species infest our trees. The climate of (alifornia may be farorable to their hibernating throughout the winter season on the trunks and limbs, as I have fomm them in ereviees of the hark throughout the winter season, and at the same time finding them on the roots. To destroy these insects effertually they must be attacked on the roots, and on the trunk and branches at the same time. 
Fig. 11.
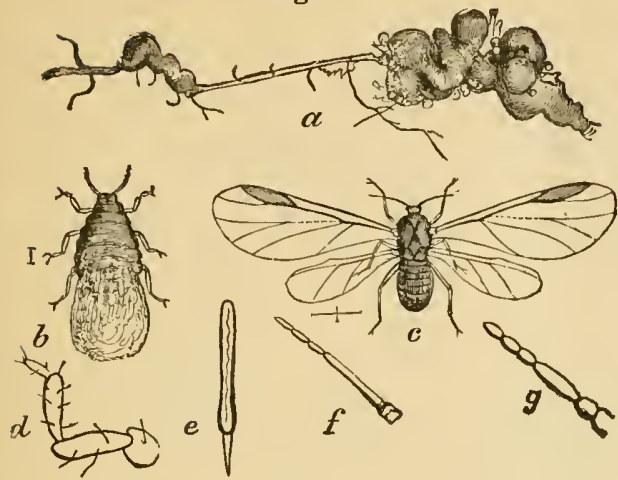

Fig. 11.- W o o lly Aphis; $a$, an infested root; $b$, the larvacolor, brown; $c$, winged adult-colors, black and yellow; $d$, its leg; $e$, its beak; $f$, its antenne; $g$, antennæ of the larva $(b)$-all higly magnified.

The woolly aphis (Fig. 11) is of a dark russet-brown color, with the abdomen covered with a white down, of a cottony appearance. It is said by some writers that it can only live on the apple tree. I have found it on the pear tree, and on pear nursery stock; also, one colony on a cherry tree; and in each case they scemed to thrive well above ground. This insect is only to be found on the roots, branches, limbs, and trunks of the trees; it does not infest the leaves.

When the woolly aphis begins to spread, it appears in blotches on the trees, of a white cottony appearance, which, if rubbed with the finger, will produce a blood-colored fluid.

Renedies.-For destroying wolly aphis on roots of trees, No. $39 \mathrm{or}$ No. 40. These remedies should be applied early in the Fall season, so that the rains will carry the solution to the roots. No. 40 or 41 may be used, but No. 39 or 40 are preferal)le.

For destroying wolly aphis on the trunk of the tree, use No. 43, when the tree is dormant. (Spray).

For destroying wolly aphis on limbs and branches, when the tree is in leaf, use No. 6, one pound of mixture to each five quarts (1 $\frac{1}{4}$ gallons) of water used; or, No. 51. (Spray.)

For destroying wolly aphis on roots of nursery stock (young apple trees), use No. 42; or, No. 5 or 7, one pound of mixture to each gallon of water used. 


\section{CHAPTER XIX.}

Oyster Shell Bark-louse, or Common Apple Scale Insect.

\section{(Aspidiotus Conchiformis-(imelin.)}

Srowrus-Mytilaspis pomicorticis-Riley. Aspidiotus pomorum-Bouche. Iytilaspis pomorum-Bouche. Aspidiotus jugnes-mealus-Rob.

$\left.\begin{array}{l}\text { Order, Hemptera; } \\ \text { Sub-order, Homoptera ; }\end{array}\right\}$ Family, Coccide.

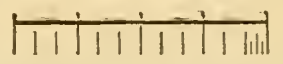

[The measurements of inseets in this work are given in inches and lines. The above cut represents one inch divided into lines and fractions thereof.]

[A slender, slightly-curved scale insect, infesting deciduous fruit trees.]

This speeles of scale insect wan be found in orehards in nearly all the ecentral counties of California, and is very destructive to apple trees, and also infests the pear and other deciduous fruit trees.

Fig. 12.

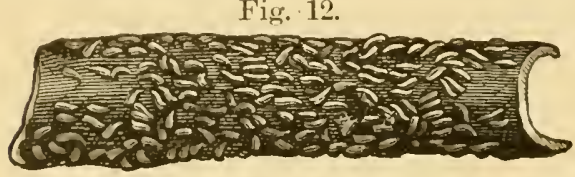

Fig. 12.-A piece of bark infested ly Oyster Shall Bark-lice-color: of scales, brown, yellow and gray.

This species an be readily distinguished from the other species of scale inserts that infest the apple tree and deseribed elsewhere in this work. The seale of the female is long and narrow, and more or less curved, and widened at the posterior end ; it measures from one line to one and one quarter lines in length. (color-Dark yollowish-hrown; exuvir, amberyollow.

The scale of the male is smaller than that of the female. and nearly straight; it is not so clark in color, and has a mottled alpeatrance.

\section{X.TTLRA, HISTORS.}

The cerge found under the female seale number from thirtyfive to seventy-fire: the young are hateherl about the tenth of 
May, and, so far as known at present, there is only one brood in each year. Larva length, one seventicth of an inch; color, pale yellow; form, ovoid; antenna, seven jointed, two anal setx. In a few days after it is hatched the larva fixes itself on the wood, leaves or fruit, and perfects its change, or metamorphosis, as shown in Fig. 13.

Fig. 13.
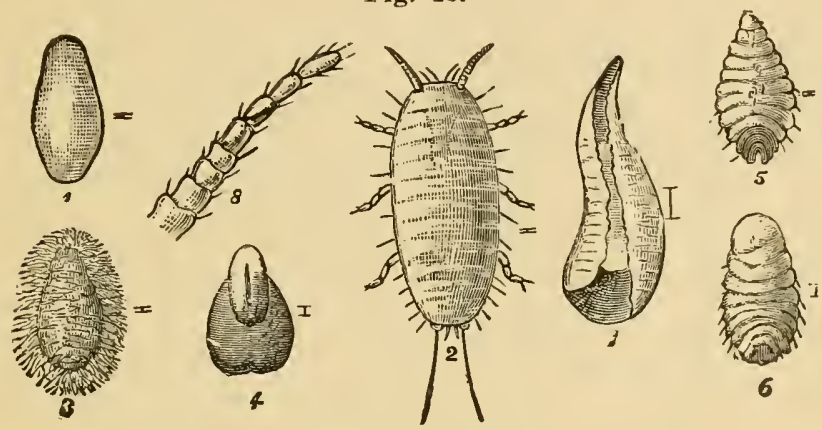

Fig. 13.-Oyster Shell Bark-louse, highly magnified. 1, the egg-color, white or yellowish; 2 , the newly hatched larvacolor, yellow; 3, the larva after becoming fixed; 4 , the scale after the second plate is formed; 7 , fully formed scale, ventral view; 5 , ventral view of larva; 6 , adult female-color, pale yellow ; 8 , antenna of the larva $(2)$.

The male (perfect) insect is winged, as shown in Fig. 14.

Fig. 14.

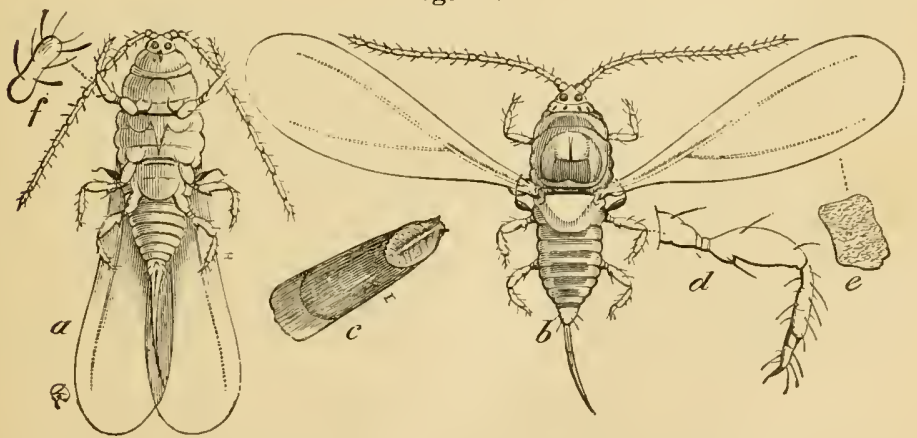

Fig. 14.-Oyster Shell Bark-louse (male), highly magnified; $a$, ventral view of winged male-color, gray; $f$, a joint of his 
antenna more highly magnified; r, a male scale-colors, yellow and brown; $b$, a winged male, with wings expanded-color, gray; $d$. one of his legs, more highly magnified: $e$, upper surface of the wing, more highly magnified.

It has been found very difficult to destroy this species, as the seale or shell is fastened very securely to the wood, ete.: but late experiments have proven that the pest can be erarlicated.

Rexedes. - When the tree is dormant, use No. 18-one pound of the mixture to each gallon of water used. (Spray.)

When the larve are hatched and the tree is in leaf, use No.

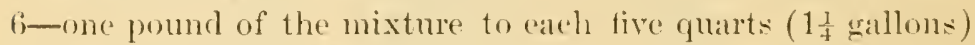
of water used; or, No. 5 or 7 -one pound to each gallon of water used. (Spray.)

\section{CHAPTER NX.}

The San Jose Scale. (Cal.)

\section{(Aspidiotus perniciosus.-Comstoek.)}

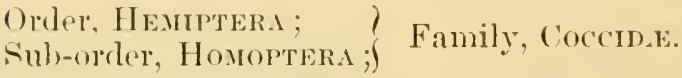

[A small, near]y eircular, and flattened seale inseet infesting decichous fruit trees.]

Ahout the year 1873 , this species of seale-insect appearerl in Sim Jose, Santa C'lara County; at least, in that year it was the first noticed by fruit-shippers as infesting the fruit.

From that time mntil $1 \$ 80$ it spread raprelly, and but little cefort was mate to exterminate it. In the Wintre of 1859 and 1880, some practical experiments were male which produced such results as encouraged those who had cutered upon the work to make further eflorts. In the Winter of 1851 and 15.52 . extensive work was done throughout the infested districts, and in many cases with excellent suecess. Unfortunately, in a number of eases. solutions were applied, such as a low grade of eoal oil that was in the market under the name of tier wash, which sold at about fourteren cents per gallon: and another 
under the name of crude petroleum; these were recommended by those who had used them as excellent insectieides. However, in a few months it was discovered that these solutions contained pernicious properties which were destructive to plant-life, consequently a large number of trees were destroyed or killed. This dangerous insect has been introduced into many fruit growing districts on nursery stock, and is found in over twenty counties at the present time (August, 1583). Great progress has been made in perfecting remedies for the extermination of this pest, so that if the work is thoroughly done the orchardist need not fear this most dangerous of the aspidiotus scale insects.

The A. perniciosus infests all the deciduous fruit trees, exeepting, perhaps, the Black Tartarian Cherry; it has also been found on the currant bush, and on tomatoes grown in the vicinity of infested trees. It also infests the poplar, osage orange, wild cherry, encalyptus and other ornamental trees and shrubs.

\section{NATURAL HISTORY.}

The females of the family coceida, to which the genus aspidiotus belongs, are described by Westwood as follows: "That without referring to their singular habits we find some of then on arriving at their last state are not only wingless, but also footless and antennaless, and in which all appearance of annulose structure is lost-the creature, in fact, becoming an inert mass of animal matter-a slender seta arising from the breast and thrust into the stem, or leaf, or fruit on which the animal is fixed, being the only external appendage of the body."

Prof. Comstock, in speaking of the metamorphosis of the subfamily diaspina, to which the genus aspidiotus belongs, says that "members undergo a remarkable change at the time of the first molt, losing their legs and antemne, and thus beconing apparently less highly organized than in the larval state."

\section{DESCRIPTION.}

The scale of the female is cireular, and in color blackish gray, excepting the exuvize in the center, which is of a deep 
straw color ; sometimes it has a redelish hue: it measures from one line to one and a quarter lines in diameter. The scale of the male is oval in outline, and nearly black with the exuriat between the center and the anterior margin of the scale, but is darker in color, and more obseure than that of the female.

The fentale insect (Fig. 15), is primrose rellow, and sometimes oche rellow in color, and measures about half a line in dianeter. Each female prorluces from thirty-five to fifty eggs:

[Fig. 15._-Sin Jose Scale, insect (adult frmale)

Fig. 15.

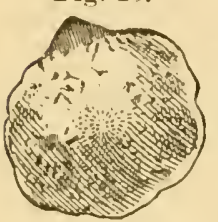
enlauged.]

[Fig. 16.-Larva of san Jose scale,enlargerl, rentral riew.]

The larva (Fig. 16), are rellowish, form oval, antenn: six jointed, two anal seta. length ahout one seventy-fifth $(1-75)$ of an inch. The larva creeps around for two or Fig. 16.

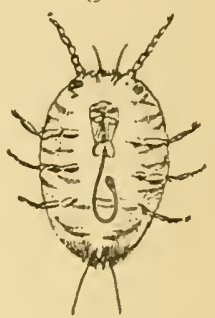
three days then finding a suitable place it fistens itself to the wood (Fig. 17), leaf, or fruit (Fig. 18), and unclergoes its change, or metamorphosix.

[Fig. 17.--Portion of a Fig. 17. Jramch infested by sam

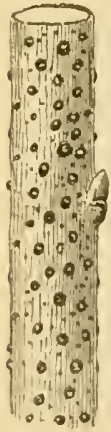
Jose Scales.]

[Fig. 18.- -1 pear infested by sam Jose Scales.]

The male insect (Fig. 19). (perfect), is winged; wings nearly transparent-color, body light amber, with dark matrkings; antemne temjointed (hairy); posterior stylet nearly as long as the body. Pupa of male

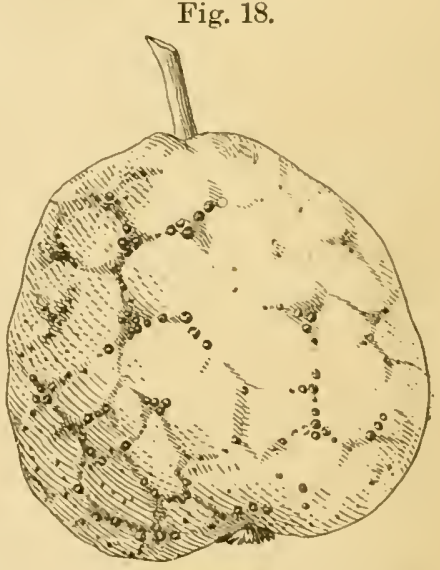
inseet (Fig. 20), fifteen days after the scale is formed; Fig. 21, thirty-five days after the scale is formed. The sting or bite of the femile insect produces a dark red mark on the wood or fruit. 


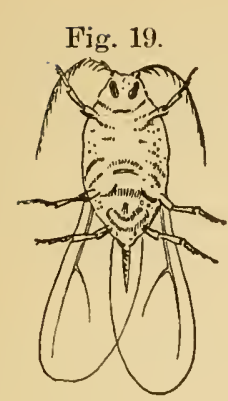

Fig. 20.

Fig. 21.
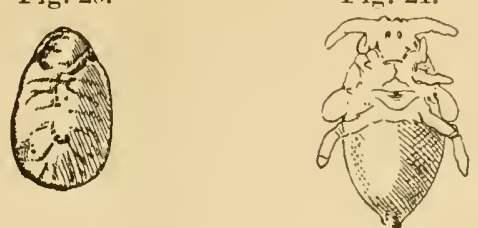

[Fig. 19.-San Jose Scale, insect (arlult male) enlarged.]

Fig. 20.-Pupa of San Jose S'rale, insect enlarged.

Fig. 21.-San Jose Scale, insect (male pupa) enlargerl.

This species produces three broods each year; the first may be expected about the time that cherries begin to color, the second in July, and the third in October.

Remedes.-When the tree is dormant, use No. 11, No. 12. Or No. 13-seven pounds of the mixture to each eight gallons of water. (The latter is preferable.) (Spray.)

When the tree is in leaf use No. 6-one pound of mixture to each five quarts of water (or $1 \frac{1}{4}$ gallons) - or No. 5 , or No. 7 .

Cautron.-Beware of mineral oils.

\section{CHAPTER XXI.}

The Greedy Scale Insect. (Cal.)

(Aspidiotus rapax-Comstock.)

$\left.\begin{array}{l}\text { Order, Hemiptera; } \\ \text { Sub-order, Hoyoptera; }\end{array}\right\}$ Family, Coccid 2.

[Infesting apple, pear, quince, peach, plum, apricot, alnond, and olive trees; also, acacia, willow, enealyptus, loeust, and other ornamental and forest trees.]

This species was given the specific name rapa.x, or Greedy Scale, by Prof. J. H. Comstock, in 18s1, on account of the great number of plants upon which it subsists. I found it on the fruit trees at Santa Cruz, in May, 1881, and wrote of it under the common name, Santa Cruz Scale, but have since found that it is generally distributed throughout the fruit dis- 
triets of California. It infests the wood (limbs and branches), foliage, and fruit of deciduous trees, including the peach, apricot, plum, ahnond, quince, and fig, and especially the apple, pear, and olive. In some cases apples and pears were so infested with this seale as to destroy their market value. The acacia, willow, eucalyptus, locust, ete., are also its food plants.

\section{NATLRAL HISTORY.}

Fig. 2.2 represents a portion of a branch infested by Gireedy Scales; at the left are two of the scales, enlarged-colors, gray or rellowish, and brown.

The seale of the female is nearly cireular, or slightly oval; yellowish in rolor when it covers a living, mature insect, but is generally a light gray. The full-grown specimons measure nearly one line in diamster, and its form is more eomex than the other species of aspidiotus described in this work; the cxurie is between the center and one side, or edge, of the scale. Eugrs, ovatecolor, yellow.

Fig. 22.

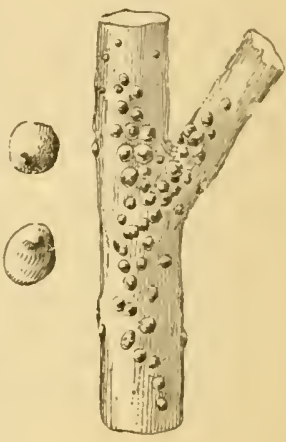

Fig. 23.

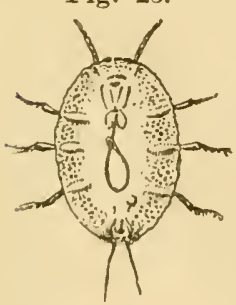

[Fig. 23.-Larva of Grecty Scale, enlarged; ventral view.]

[Fig. 24.-Female Greedy Scale Insect, cnlarged.]

Larva (Fig. 23)-color, yellow; length, one-eightieth of an inch; antemus, six-jointed; two anal setie.

Female full grown (Fig. 24) is circular in formcolor, rellow, with clear or nearly tramsparent Fig. 24.

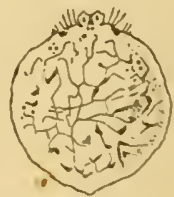
blotches. She deposits from thirty-five to eighty egogs.

Male (perfect) inseet, winged. (I have not been ahle to proeure a perfect specimen.) There are probably two broods each year, as I have found the egges in Maly and August.

Use remedies as described for Sam Jose Scale (A. perniciosus), Chap. XX. 


\section{CHAPTER XXII.}

The Round-headed Apple-tree Borer.

$$
\begin{gathered}
\text { (Saperda candida-Fabricius.) } \\
\text { Syroxy.-Saperda bivittata-Say. }
\end{gathered}
$$

Order, Coleoptera; Family, Cerambrcide.

\section{1|11|ा|ा|}

[The measurements of insects in this work are given in inches and lines. The above cut represents one inch divided into lines and fractions thereof.]

[Boring into the trunks of apple, pear,. quince, and sintilar trees, a nearly cylindrical, yellowish-white, footless grub, which is finally changed into a beetle of a brownish color, having two white stripes on its back].

The greater number of injurious insects live exposed upon the plants which they attack; but there are several kinds which live concealed from view in the stems or branches of various kinds of plants, shrubs, and trees, and thus hidrlen from view, they carry on their silent work of destruction. Prominent among this latter class is the round-headed apple-tree borer, which is found over the greater part of the United States.
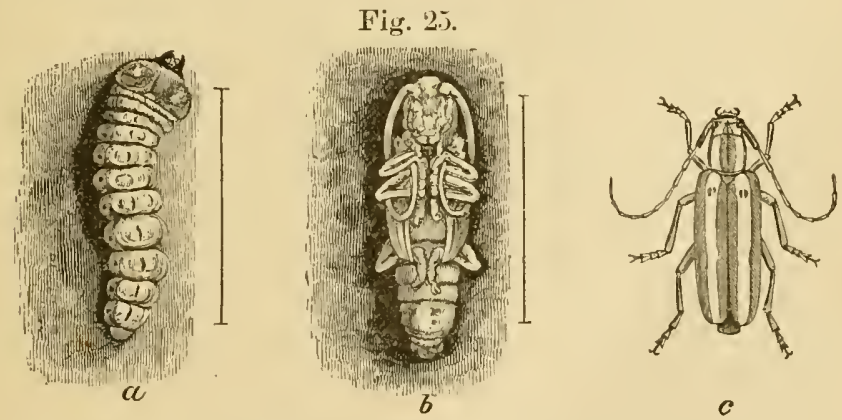

[Fig. 25.-Round-headed Apple-tree Borer; "the larracolor, yellowish-white; $b$, the pupa-color, yellowish-white; $c$, the beetle-colors, brown and white.]

The beetles, or perfect insect (Fig. 25c) first make their appearance a few weeks after the apple tree has put forth its 
leaves. They soon pair, and in the course of a few days the females deposit their egrs. This operation consumes considerable time, so that about three months elapse before all of the beetles have finished depositing their eggrs.

The latter are commonly deposited in the crevices of the bark, and usually near the surface of the ground. but sometimes they are placed in the axil of the lower branches, or the place where the branches start out from the trunk. In about a fortnight, from each of these eggs is hatched a minute, footless grub of a whitish color, with a rellowish head. These grubs eat their way obliquely downward through the bark, and for the first year of their lives they live upon the inner bark or sapwood, forming flat, shallow cavities. In their passage through the bark they push their excrements and refuse through the opening of their burrow, and being of a glutinous nature, it collects around the mouth of the burrow in a small mass, which, being usually of an orange color, is readily detected by the experienced eye. The following season the borer enlarges its burrow, pushing its castings out of the openings of its burrow in pellets, resembling in shape a grain of oats, but larger. These are commonly found in pairs, lying parallel, with their points toward the tree.

During this, the last Summer and Fall of their lives, they do their prineipal danalge by widening their burrows on every side, destroying the alburnum deposited the year before, and often the layer under it. If there is only one in a tree at this age, and the tree is not more than one inch and a half in diameter, the borer usually kills it by girdling entirely around it, exeept about one fourth of an inch, on one side. One borer in a large tree does not materially injure it, but generally in such trees there are from two to five, and they girdle all around to within one fourth of an inch of each other's hurrow, and thus kill the tree.

The borer or larva (Fig. 25a) during the last Fall of its life, cats voraciously until cold weather sets in, when it carefully hothses itself away until the following spring. As soon as the weather becomes mild, it begins to cut a cylindrieal burrow from three to six lines long, usually up the trunk of the tree, but sometimes direstly through it. ending it just under the 
outside bark, leaving the bark about the thickness of writing paper; it then draws back about an inch, places some coarse ehips before and behind it, and soon assumes the pupa form. (Fig. 25b). After remaining in this state for from two to six weeks, it is changed to a beetle, which soon afterwards gnaws a hole through the bark that covers the end of its burrow, and thus effects its escape. The head of this grub is small, horny, and brown; the first ring or segment is much larger than the others; the next two are very short, as are also the eleventh and twelfth; the rings, from the fourth to the tenth, inclusive, are each furnished on the upper side with two fleshy warts, which are situated close together, and are destitute of the rasplike teeth which are usually found on the grubs of the other kinds of borers; no appearance of legs can be seen, even with a magnifying glass of high power. When fully grown, it measures about one inch in length.

The beetle, or perfect insect, measures from six to nine lines, or one half to three fourths of an inch in length, and is of a einnamon-brown color, marked with two white stripes, which extend from the head to the tips of the wing-cases; the face, antennx, and legs are white, the antennx being nearly as long as the body.

Reuedy.-Use No. 37.

\section{CHAPTER XXIII.}

The Flat-headed Apple-tree Borer. (Cal.)

(Chrysobothris femorata-Fabricius.)

Order, Coleoptera; Family, Buprestime.

[Boring into the trunks of apple, pear, peach, and similar trees; a pale, yellowish, footless grub, having the forepart of the body greatly widened and flattened; finally transforming into a greenish-black or bronze colored beetle, which is copper-colored on the under side.]

While the round-headed apple-tree borer, S. bivitata (Fig. 25), usually infests healthy, growing trees, the present species seems to prefer those which are more or less diseased, in such 
places where the bark is hruised, sunburned or dearl, on which account it is not to be so much dreaded as the romnd-headed species.

The flat-headed apple-tree borer first makes its appearance in the month of April or May, soon after which it deposits its tergs; these are usually deposited in crevices or beneath the loose bark, several of them being not unfrequently found together. They are of an ovoidal shape, pale yellow, irregularly ribbed, wih one end Hattened. The young larva hatehed from these gnaw their way through the bark until they reach the green cambium layer, and gradually extend their broad and flattened channels beneath the bark. At length, when they have grown stronger and their jaws firmer, they bore into the more solid wood of the tree, working upwarl until about to undergo their transformations, when they cut a bassage to the outside. leaving a thin (overing at the surface through which the heetle (Fig. 26) afterwards forees its way. It is supposed to pass through its rarious thanges with inthe course of one rear. The grub or larra (Fig. 27 ) of the borer measures nearly nine lines or three fourths of an inch in length, when full grown, and is of a pale rellow color; it is antirely destitute of feet, and the second segment is rery broad and fattened, by which charaeter this grub may at onee be distinguished from that of the roundheaded borer (Fig. 2.5u). The beetle measures about six lines, or one half an inch in length, and is of a dark, dull, greenish color with a strong, colpery luster, which is deepest on the forehead and at the tip of the wing eases; the head is sunken up to the eyes in the thorax. On each wing-atse are two irregular impressed spots, which are generally of a deeper green or eoppery color than the surrounding surface, and sometimes appearing touble. The under side and limbs are of abrilliant eopper color. The pertion of the ahdomen corered by the wing cases is a light, bluc-green. 
Fig. 26.-Flat-headed Apple-tree Borer-color, dark gray or dull greenish.

Fig. 26.

Fig. 27.

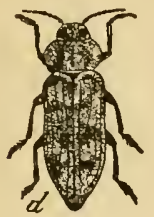

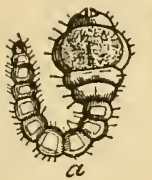

Fig. 28.

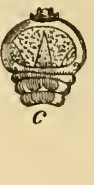

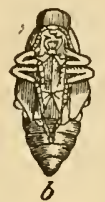

Fig. 27-Larva of Flat-headed Apple-tree Borer; $a$, the larra; $c$, the underside of the head and forepart of the bodycolor, white.

Fig. 28.-Pupa of Flat-headed Apple-tree Borer-color, white. ReMedr.-Use No. 37.

\section{CHAPTER XXIV.}

The Apple-twig Borer.

(Bostrichus bircendatus.-say.)

Srvoxy-Amphiceres (Bostrichus) bicaudatus.

Order, Coleoptera; Family, Ptrande.

[Living in grapevines, a small, whitish, nearly cylindrical, grub, which is thickest anteriorly ; finally transforming into a brown beetle which burrows in the twigs of the apple, pear and peach trees.]

The natural history of this insect has never been rlearly traced. Dr. Shimer states that he bred it from the larva found burrowing out the central pith of a graperine, while other authors contend that it spends its larval stage in some forest tree, and that the beetle forms a burrow into the grapevines, apple-twigs (Fig. 29), ete., merely for the purpose of getting

Fig. 29.

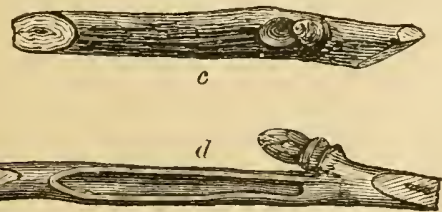

a sheltered place in which to pass the Winter.

Fig. 29.-Twigs showing burrows of apple-twig borer ; (; the entrance; $d$, the burrow eut open. 
The beetles (Fig. 30) are found in their burrows from early Fall till late in the following Spring. 'They measure from four to five lines, or ahout three eighths of an inch in length; are of a dark brown color, the thorax nearly black, and the anterior half is covered with spine-like points; at the apex of each

Fig. 30 .

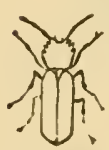
of the wing-corcrs of the male is a little horn

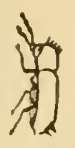
from which the species derives the specific nane: bicaudatus, or two-tailed.

Fig. 30.-Apple-twig Borer; back view and side view-color, brown.

Remedes.-If seriously infested, when the tree is dormant, use Nos. 11 and 12-one pound to each gallon of water userl. (Spray.) In the Spring when the tree is in leaf, use No. 5 or 7-one pound to each gallon of water used. This will prevent the insect from boring into the tree. Also, prune as directer in $\mathrm{N}_{0}, 2 \mathrm{2}$.

\section{CHAP'TER XXV.}

\section{The Prickly Bark Beetle.}

\section{(Leptnstylus aculiferus.-Say.)}

Orler, Coleoptera; Family, Cerambretid z.

Living under the bark of apple trees, small, whitish, footless grubs, similar in appearance to the young apple tree borers, occurring sometimes in multitudes, forming long, narrow, winding burrows upon the outer surface of the wood, these burrows becoming broader as the worm increases in size; finally transforming into a rather short and thick brownish gray beetle (Fig. 31) with small prickle-like points upon its wing-covers, and hack of their middle is a white curved, or $V^{r}$-shaped band, Fig. 31. with a hlack streak on its hind alge; length from three to four lines, or about one third of an inch. The perfect insect appearing the last of August. Fitch.

Fig. 31.-Prickly Bark Beetle-colors gray and blarke.

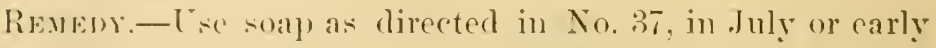
in August. 


\section{CHAPTER XXVI.}

\section{The Gray Bark Eating Weevil. (Cal.)}

(Thricolepis simulator.-Horn.)

Order, Coleoptera; Family, Curculionide.

[A small, light grayish snout heetle, feerting upon the bark of the small branches or twigs of apple trees early in the Spring.]

Early last Spring (1883), specimens were received from fruit growing districts located at least one hundred and fifty miles apart, of a small, light grayish colored weevil, reported as eating the bark and buds of apple trees.

This beetle (Fig. 32, Plate 1,) measures from one and one half to one and three fourth lines in length; the color is grayish brown, but is covered with fine white scales, giving it a light grayish color. The larva probably feed on the roots of plants, but as this species is only reported this spring its natural history is not known to me.

Resedies.-Early in the Spring spray trees infested the previous year with No. 5 or 7 ; repeat in two weeks. This will prevent the beetle from eating the bark.

\section{CHAPTER XXYII.}

The Buffalo Tree-hopper.

(Ceresa bubalus._Fabricius.)

Order, Hemiptera ;
Sub-order, Homoptera $;$$;$ Family, Membracide.

[Living upon the twigs of the apple, peach, apricot, almond and plum trees; a green leaf-hopper, shaped something like a beechnut, with two short spines jutting out horizontally from each side of the anterior end, having some resemblance to the horns of a bull or buffalo.] 
These insects obtain their nomishment by puncturing the twigs with their beaks and imbibing the sap.

Fig. 33.

Fig. 33.-Buffalo Tree-hopper-color, green ;

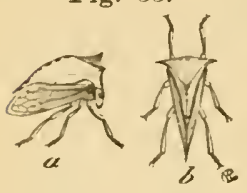
u, side view; b, lack view.

Fig. 31.
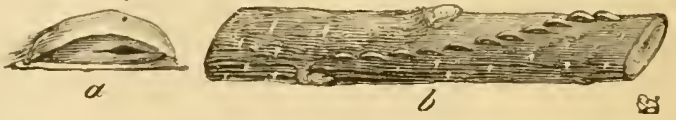

Fig. 3t.-Eggs of Buflalo Tree-holper; a. an egg, highly magnified; b, egegs natural size in a twig.

Fig. 35.
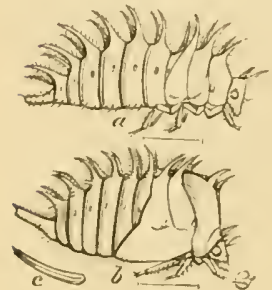

Fig. 35.-Larra and pupa of Buffalo Treehopper, enlarged ; u, the larva-color brownish; b, the juy a-color greenish ; $c$, the ovipositor of the adult female, magnified.

From specimens of this insect (Fig. 33), and branches rontaininge exors (Fig. :34), rereived from several places in this State, and also from the state of Nevada, I am inclined to think that from oight to twelve egges are laid in cach puncture.

The young (Fig, 3. i) luatch in May.

REMEDEs.-No. 28 and No. 25.

\section{('HAPTER XXVHI.}

The Cicada, or Harvest Fly.

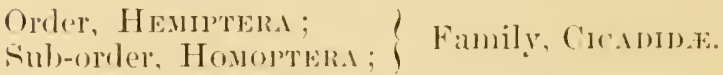

[Making small shits in the moler side of the lower hanches of the apple, "herry, and similar trees, and deprositing therein a row of pearl-white eggs; a laree, four-winged ty the body marked with greenish.]

These insects are nsually of a large size, their wings expanding from two to three inches. The males have a curious drum-like arangement on each side of the body, hehind the wings. It consists of comvex instruments of fine parrelunent, 
which are acted upon by small muscles; when these muscles contract and relax, which they do with great rapidity, the drum-heads are alternately tightened and loosened, producing a rattling noise, like that caused by a succession of quick pressures upon a convex piece of tin-plate. The body of the female is provided with a piercer, with which she makes numerous small slits in the under sicle of the branches (Fig. $36 d$,) of various shrubs and trees. The branches thus mutilated usually die back to the place where the slit nearest the trunk occure, and are frequently broken off by the wind.

Fig. 36.-Seventeen-year Locusts, pupa and eggs; $a$, the pupa-color, yellowish brown; $b$, the cast pupaskin ; $d$, a punctured twig, containing eggs ; $e$, two of the eggs removed from the twig-color, yellowish ; $c$, the adult, or perfect insect-colors, blackish, and dull orange.

Fig. 36 .
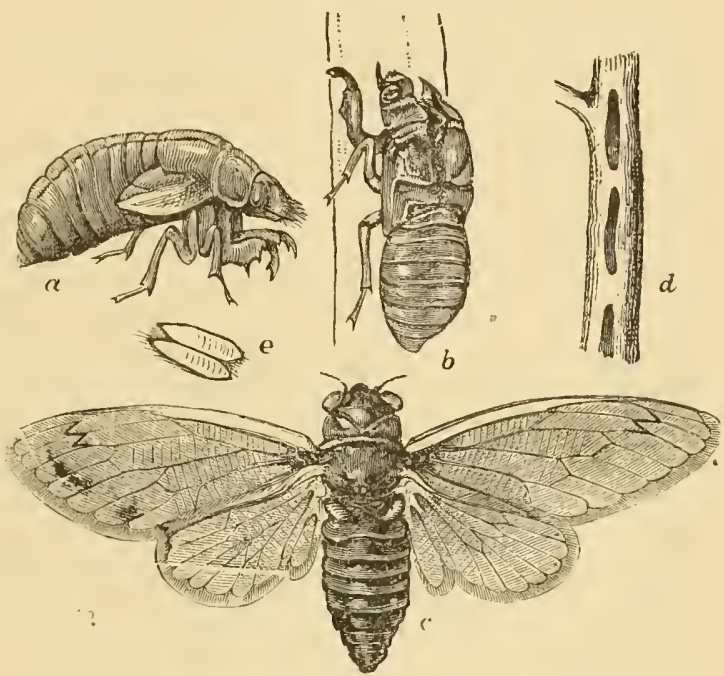

As soon as hatched, the young grub enters the earth, but this is as far as its history is known with any degree of certainty, except that when about to be changed into a perfect insect it comes out of the earth and ascends a plant (Fig. 36b), to which it attaches itself firmly by means of its hooked claws. In a short time the skin on its back splits open and the included insect issues in its perfect or winged form.

Some kinds are known to live for thirteen and even seventeen years in the larva state. They do not pass through a quiet pupa state as butterflies and many other insects are 
known to do, but remain active from the time they issue from the eggs (Fig. 36e) until they die of old age, or some other cause.

A small species of Cicada is found in California, infesting apple trees. The larva is about one inch in length, when full grown; the pupa is from seven to ten lines in length; and only finding a skeleton of the perfect inseet, a correct description ean not be given. Its natural history and habits are evidently the same as the C. septemdccim, excepting the time it takes to mature the perfect insect, which at present can not be stated reliably. They were found at Dutch Flat, in Placer County, and are probably the Cicadr noveboracensis.

Since writing the above, I am informed that a specimen has been taken at Anaheim, Los Angeles County.

Remedes.-No. 25 and No. 28.

\section{CHAPTER XXIX.}

\section{Canker Worms. (Cal.)}

Order, Lepidoptera ; Family, Phalanide.

[Feerling upon the leaves of the apple, cherry, and various other trees; yellowish or dark colored span-worm, provided with ten or twelve legs].

There are three specious of span-worms (geometers), which are commonly called "Canker Worms." (The Spring Canker Worm, Chapter XXXII. Anisopteryx vernata-Peck; Paleacrita remata-Riley); the Fall Canker Worm, ('hapter XXX. Anisopteryx pometaria-Harris; Anisopteryx autumataPackarel); and the Yellow Canker Worm (Chapter XXXI. Hibernia tiliaria-Harris). The females of these species are wingless.

\section{NATURAL IISTORY.}

The eggs are deposited on the trees by the female moth. A. pometariu and $I$. tiliaria deposit their eggs in the latter part of December, and in .January; these are hatched about the time the apple tree has put forth its leaves. 
The young caterpillars commence to feed on the new foliage, and in four or five weeks they attain their full growth; they then descend to the ground, which they enter to a depth of several inches; here each caterpillar forms a small cell, in which to pass the pupa stage. The $A$. vernata deposits her eggs early in the Spring; the caterpillars attain their growth in four or five weeks, and then enter the ground to pass the pupa state.

Use remedies as directed in Chapter XXXII-No. 10 or No. 89. (See note, Remedy No. 10).

\section{CHAPTER XXX.}

\section{Fall Canker Worm.}

\section{(Anisopteryx pometaria-Harris ; Anisopteryx autumnata- Packard.)}

Fig. 37.-Fall Canker Worm; e, cluster of eggs; a, side view of one of the eggs, enlarged; $b$, view of upper end of same, enlarged ; $f$, the wormcolor, olive-green, with brown stripe and white lines; $c$, side view of a segment of its body, enlarged; $d$, back view of Fig. 37. the same enlarged; $g$, female pupa-color, brown; $h$, tip of same enlarged.

The caterpillar of this species (Fig. $37 f$ ) is about one inch in length, and is provided with twelve legs--the pair on the eighth segment are very short; color, body pale greenish, marked on the back with a brown stripe (Fig. 37d), and with three white lines on each side of the body (Fig. 37c); below the spiracles is a brownish line, and below this a white line; the under, or ventral parts, are of a pale flesh color; head, brown; larva, when newly hatched, pale olive-green; head and cervical-shield pale. 
Pups,-On entering the ground the caterpillar spins a cocoon composed of silk, interwoven with particles of earth; in this cocoon it changes to a pupra (Fig. 37g and Fig. 3S) in four or fire weeks. and in this state it remains until the Fall.

Fig. 38 .

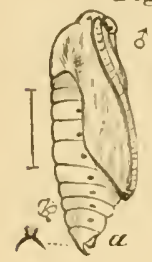

Fig. 35.-Pupe of Fall Canker Worms,

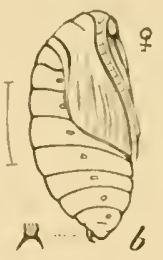
enlarged; $a$, the male; $b$, female-color; brown; at the left of each is shown the anal projection, as seen from below, enlarged.

IMAGO, OR PERFECT INSECT.

Toward the latter part of December: or early in January, the perfect insects (Fig. 39, $a$ and $b$ ). energe from the ground : the wingless females (Fig 39b) climb up the trees and lodge upon the branches, where they deposit their eggs in batches of from seventy-five to two hundred (Fig. $3 \overline{7})$; they are placed side by side in regular rows, and can be readily recogniized as belonging to this species, as they are flat upon the top, and marked with a brown ring or circle (Fig. 37, $a$ and $b$ ). The egges are generally deposited close to the bud, or in a crotch or indent of some kind.

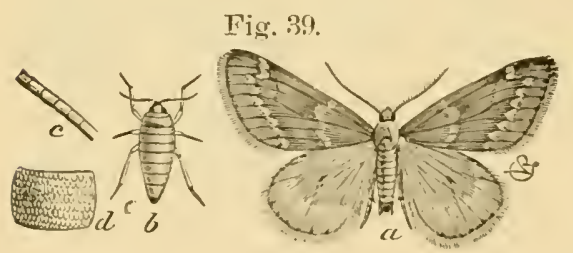

Fig. 39.-Fall Cankerworm Moth:; $a$, the male moth-eolor, brownish-gray ; $b$, the female moth - color, dark ash-gray ; $c$, several joints of her antennæ, enlarged; d, a segment of her body, enlarged.

Female Moth (Fig. 396)—color, dark ash-gray : body and legs smooth, and of a uniform color; antemne over fifty jointed.

Iale (Fig. :39u-color, brownish gray-sometines darker; the fore-wings are crossed by two whitish bands: the outer band is suddenly bent inward near the fore edge of the wing, forming a pale, quadrate spot: in some these bands are wanting, but in such cases the pale spot is nearly always present; expands one ineh and three lines.

Rementer-No. 9:2. No. 10. or No. 59. (stee Remedy No. 10.) 


\section{CHAPTER XXXI.}

The Yellow Canker Worm. (Cal.)

(Hibernia tiliaria-Harris.)

The caterpillar (Fig. 40, Plate 1 ) of this species is about one inch and three lines in length, and is provided with ten legs. Color-body yellow, marked on the back with ten black lines, which sometimes impart a bluish tinge to the ground color; under or ventral parts, yellowish-white; head, yellowishbrown.

PupA.-On entering the ground the caterpillar forms a cell, which it lines with a few silken threads, thus forming a cocoon. In from ten to fourteen days it changes to a pupa, in which state it remains until the following Fall.

\section{IMAGO, OR PERFECT INSECT.}

Female Moth (Fig. 41, Plate 1)-Color, whitish, dotted with black, and marked with two rows of black spots, and with a row of smaller black spots on each side of the body; the legs are ringed with black and white; the body is about half an inch (six lines) in length. The eggs are deposited in crevices and beneath the loose bark. Male moth (Fig. 42, Plate 1), fore-wings yellowish, dotted with brown, and crossed by two wavy brown lines, the line nearest the body being often indistinct. In the space between these lines there is usually a brown dot, placed nearest the front edge of the wing. The hind wings are pale-yellowish, with usually a brown dot near the center of each; expands about one inch and nine lines.

Use remedies as directed in Chapter XXXII-No. 10 or No. 89. (See note, Remedy No. 10). 


\section{CHAPTER XXXII.}

Spring Canker Worm.

(Anisopteryx vernata-Peck. Paleacrita vernata-Riley.)

The caterpillar of this species (Fig. 43a) is nearly one inch in length, and is provided with ten legs. Color-body greenish, marked on each side with four whitish lines (Fig. 43c), the two lowest further apart than the others; head mottled and pale on the top, and marked on the top with two pale transverse lines. The larva, when young, is dark green or brown, the head black.

Fig. 43.

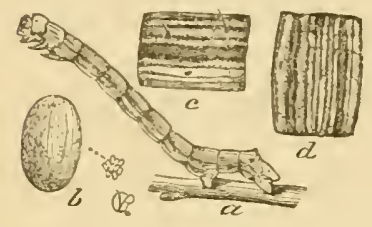

Fig. 43._Spring Canker Worm; a the worm-color, olive-green with paler stripes: $c$, a side riew, and $d$ a back view of one segment of its body, enlarged; $b$, an egg. enlarged; a small cluster of the natural size to the right.

PePA.-On entering the ground the caterpillar

Fig.44. forms a cell which it lines with a very few silken

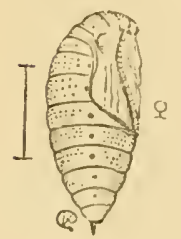
threads, thus forming a cocoon; in a few days it changes to the pulpa state (Fig. 44) in which it remains until the following Spring.

Fig. 44.-Female pupa of Spring Canker Worm enlarged-color, brown.

\section{IMAGO, OR PERFECT IISECT}

Female moth (Fig. 456) - color, pale gray, marked on the back with a black stripe, which is sometimes divided in the center by a whitish line or a row of whitish dots; legs ringed with black and gray; length of body, from four to six lines.

Fig. 45 .

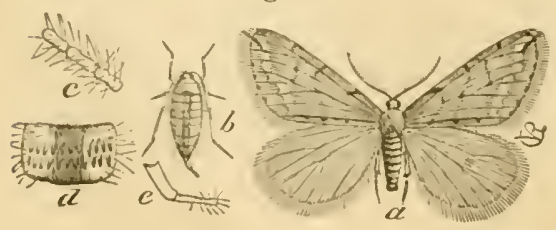

Fig. 45.-Spring Canker Worm Moth; a, the malc moth-color, brownish-gray ; $b$, fomale moth -color, pale-gray, a darker stripe on the back ; 'c, three joints of her 
antenna, enlarged ; $d$, one of her abdominal segments, enlarged; $e$, her ovipositor, enlarged.

The eggs (Fig. 43b) are deposited in irregular masses and secreted; they are elliptie-ovoid in form and can be readily distinguished from the eggs of the other species by the delieate shell being irregularly punctured.

Male (Fig. 45a)—color, brownish-gray; the fore-wings are crossed by three jagged, dark eolored lines, which are most distinct where they eross the larger reins, and at the front edge of the wing, where they divide the wing into four parts of nearly equal width; near the outer edge the wings are erossed by a pale, jagged band, which terminates at the apex, at which place there is a dark dash. Expands one inch and three lines.

Renedies.-As directed in Nos. 22, 10 or 89. (See note, Remedy No. 10.)

\section{CHAPTER XXXIII.}

DeLong's Caterpillar. (Cal.)

(Clisiocampa constricta.-Stretch.)

Order, Lepidoptera; Family, Bombycide.

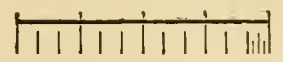

[The measurements of insects in this work are gilen in inches and lines. The above cut rep. resents one inch divided into lines and fractions thereof.]

[Living upon apple and plum trees; a striped, slightly hairy, sixteen-legged caterpillar.]

The eommon name, DeLong's Caterpillar, is given this species, as previous to 1883 it was only found, in this State, at the Novato orehard, of which Mr. DeLong is the proprietor. In the early part of the month of May, 1881, the eaterpillars of this moth infested the apple and plum trees in such numbers as to threaten the destruction of the entire crop of twenty thousand of the former and five hundred of the latter. The eaterpillar (similar to Fig. 55) is one inch and nine lines in length, nearly three lines in diameter, and is full grown by the twelfth day of May. The body is sparingly clothed with soft and short hair, rather thicker and longer on the sides than 
elsewhere. The head is dark brown on each side, and dark brown above, leaving an inverted $\mathrm{Y}$ mark in the middle and front, and haring much the appearance of a goblet, as one looks from above. The frontal mark is jet black, edged with a white stripe across and over the mouth parts and on each side of the inverted $Y$. The gromnd color of the upper part of the body is evidently light blue, with a dorsal row of oral orange spots, one on each segment; two sub-dorsal orange lines; also, two lateral orange lines. Between the sub-dorsal lines is a number of erinkled black and orange lines; between the sub-dorsal and lateral lines the space is blue, slightly variegated with fine orange and black lines intermingled. The lower part of the body and feet are dusky blue, with erinkled, orange and black irregular lines, and an amber-colored ring around base of pro-legs. The caterpillars do not make a tent or web, although they live in colonies on the tree.

Fig. 46.-Cocoon spun by eaterpillar of DeLong's Moth-color, yellowish.

The caterpillars spin their cocoons (Fig. 46) in folded leares (Fig. 47) of the trees on which they feed, and on fences and buildFig. 46.

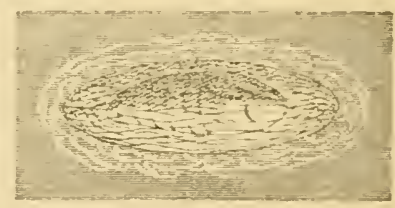
ings in the vicinity of trees which they have stripped of foliage.

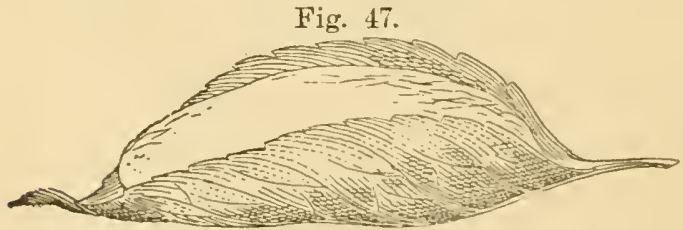

Fig. 47.-Folded leaf containing cocooon of DeLong's Moth.

P U PA. - Pupa elongate, posteriorly attenuated. inclosed in a loose silken web, suffused with fine yellow powder. The moth appears in about sixteen days, or about the twenty-eighth of May; is reddish brown, with two transwerse rust-brown nearly straight parallel lines on the fore-wings. 
Fig. 48.-DeLong's Moth (male)-colors, light and dark brown.

Male (Fig. 48) antennæ, short, curved, moderately bipectinated in both sexes, the pectinations gradually decreasing in length to the apex, and shortest in the females; thorax, robust; pilose, (hairy);

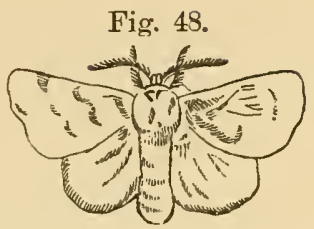
abdomen, elongate-robust in female, and tufted in both; femur (thigh) and tibia (shin) hairy. The male insect expands one inch and three lines, the female one inch and six to'seven lines. The female is lighter in color than the male.

Fig. 49.

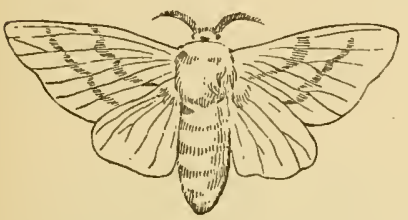

Fig. 49.-DeLong's Moth (female)-colors, light and dark brown.

The female moth (Fig. 49) lays her eggs-two to three hundred in number-in rows around the new growth of wood (Fig. 50),

and covers them with an apparent water-proof substance to protect them through the Winter season.

Fig. 50.-Eggs of DeLong's Fig. 50. Moth-color, reddish brown.

About the time the leaves are unfolding in the Spring, the

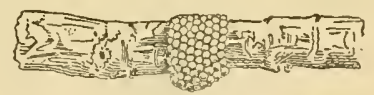
young hatch and feed on the foliage and young fruit. Mr. DeLong had a block of two thousand apple trees completely stripped of fruit and foliage by these caterpillars.

\section{METHOD ADOPTED BY MR. DE LONG FOR DESTROYING THE CATERPILLARS.}

He placed a band of butter-cloth, about four inches wide, covered with tallow, on the trees about two feet above the ground. He discovered that the caterpillars could form bridges over the tallow, especially at night. Orer the tallow he placed soft lard, which proved effective. Men with brooms swept the caterpillars off the trunks, limbs, and branches of the trees. The caterpillars attempted to ascend the trees again, but would not cross the greased band. On every tree they gathered in such immense numbers between the bands 
and the ground, that they were easily destroyed by the use of clubs. By these means the crop of twenty thousand trees was secured from their rarages, although the orchard was not entirely cleaned.

FATHERING TIE EGGS.

In the month of January, 1ss2, men were employed to pick the rings of eggs deposited on the branches, and succeeded in collecting eges which would have prodnced sixty millions of eaterpillars. The cost of collecting the eggs was one dollar and fifty cents per ounce. One ounce of the rings represented one hundred and fifty thousand eggs.

\section{NATURAL REMEDIES.}

In 1SS1, many cocoons were found infested by the larva of a Tachina fly (Fig. 51).

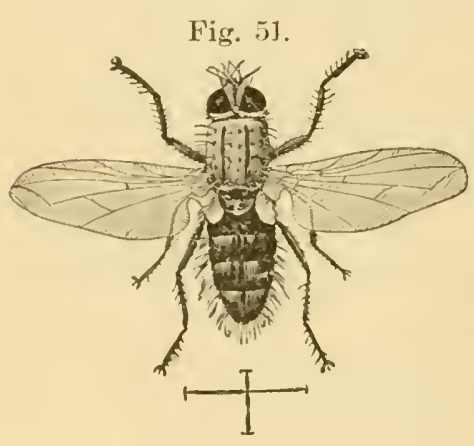

Fig. 51.-Tachina Fly ( $\mathrm{Ta}-$ china doryphora)—colors, gray and black.

In 188:- a small fly belonging to the Braconimx (Fig. 51 a, Plate 1), a sub-family of the Icheumonidie, made its appearance and destroyed the eaterpillars hatehed from the eggs that escaperl the eggr gatherers. At the present writing (May, 1853), Mr. DeLong eannot find any of the caterpillars of this species in his orehard. The full description of the work done in this case is given to prove what can be clone in destroying insect pests. Mr. DeLong's apple erop produces al revenue of thirty thensand dollars annually. Rather than to allow the caterpillars to destroy his arop, he exterminated them at a cost of about two thousand dollars.

Reports say that this species has been found this season in one of the Bay countic's.

Revedies-As described above. Sec Nos. 23 and 29. 


\section{CHAPTER XXXIV.}

\section{Orchard Tent Caterpillar. (Cal.)}

\section{(Clisiocampa Americana.-Harris.)}

Order, Lepidoptera ; Family, Bombrcidж.

[Living on apple, cherry and oak trees; a striped sixteenlegged caterpillar, sparingly clothed with hairs on the sides of the body.]

This insect infests apple trees, and is also found on cherry trees. Its presence can be easily detected by the web-like nests found on trees which they infest, and from which the insect derives its common name-Tent Caterpillar.

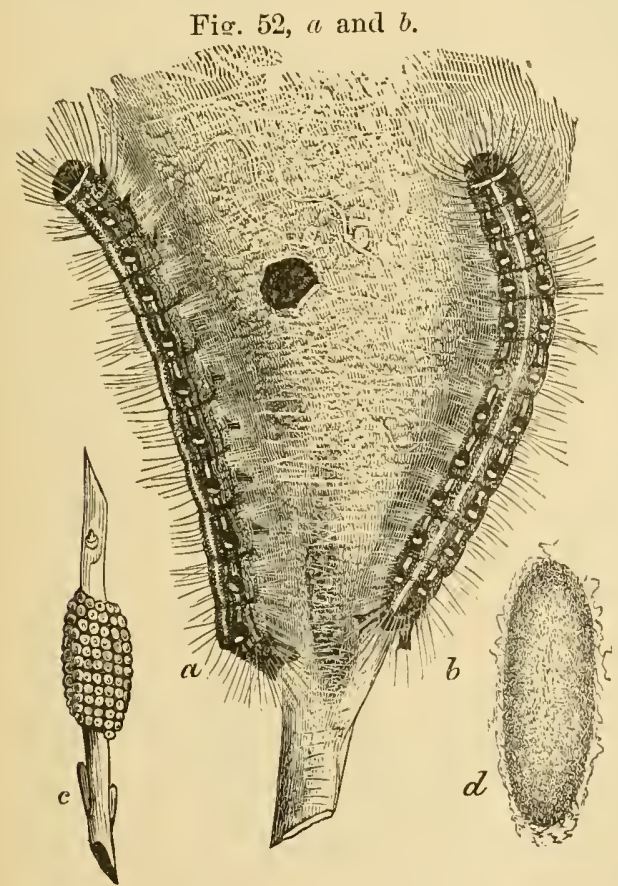

Fig. 52.-Or chard Te n t Caterpillar; $a$ and $b$, the caterpillars-colors, black, yellow, white and blue ; $c$, the eggs (poor figure; Fig. 54 is more accurate); $d$, the cocoon--color, yellowish white.

The caterpillar (Fig. 52 , $a$ and $b$, ) is abont two inches in length, and nearly three lines in diameter; head black, frontal mark inverted $Y$, same as DeLong's caterpillar (Clisiocampa constricta); ground color of back apparently brownish-black.

A dorsal line of a yellowish-white color extends the whole length of the insect, on each side of which, on a yellowish or orange ground, are black crinkled lines, which on the sides 
form a black lateral line, or when the caterpillar is stretched appears as a large black spot on the side of each segment; in the center of these spots is a small bluish mark; below this is a yellow (orange) line, and lower are five crinkled lines, yellow and black. Ventral parts a dark, dusky color; on one of the posterior segments is a small blackish wart. The body is clother with soft short hairs, rather thicker on the sides than on the back and rentral parts. When full grown it spins a cocoon (Fig. 52d), in which it undergoes its transformations.

PupA.-The pupa state is from fourteen to sixteen days.

MOTH.

Fig. 53.

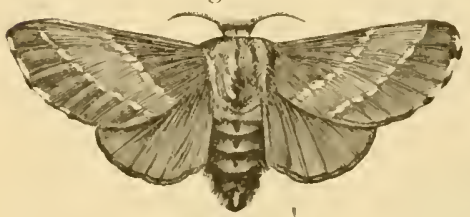

Fig. 54.

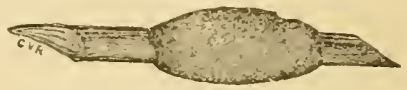

Fig. 5t.--Eggs of Orchard Tent Caterpillar-color, brown.

Fig. 53.-Fentale Moth of Orchard Tent Caterpillar-(sometimes called the American Lackey Moth)-colors, yellowish or reddish-brown and white.

The moth (Fig. 5:3) rliffers but little in appearance from the $C$. constrictr; the color is somewhat lighter; the lines on the fore-wings are more oblique, and the apex shorter. In some specimens the band between the lines of the fore-ring are dark, or of the same color as the base and apex ; in others it is rery light, or what may be termed a rlirty whe. The perfect insects appear about the latter part of May. They deposit their eggs (Fig. it) on the branches on which they feed, and cover them with a secretion to protect them in the Winter season. The young caterpillars hateh about the time the leares open. This speries can be exterminated ly picking off and destroying the bunches of egge before the tree leaves out, and by picking off and destroving tents when made; or the latter may be burned with their occupants, at such hours of the day as the eaterpillars are at rest. A torch made of rags bound upon a pole and saturated with kerosene is a useful weapon for this kind of warfare.

Remedies as above described. Also, see Nos, 23, 29 and 31. 


\section{CHAPTER XXXV.}

\section{The Forest Tent Caterpillar. (Cal.)}

(Clisiocampa sylvatica.-Harris.)

\section{Order, Lepidoptera ; Family, Bombicide.}

[Feeding upon the leaves of the apple, oak, cherry, and various other trees, a bluish, slightly hairy caterpillar, sprinkled all over with black dots, and with a row of oval or diamondshaped white spots on the back.]

When young, these caterpillars live in communities under a web which is spun against the trunk of one of the larger branches of the tree, but as they grow older they disperse and live singly, unprotected by a web.

Fig. 55.

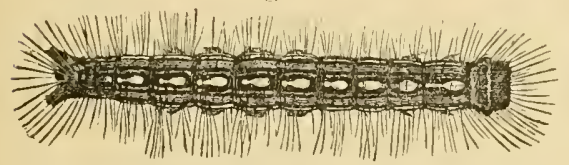

Fig. 55.-Forest Tent Caterpillar-colors, bluishgray, white and yellow.

When fully grown (Fig. 5.5) ther measure about one inch and six lines in length; they then seek some sheltered place in which to spin their cocoons, which are filled with a yellow, mealy powder.

The moths apjear early in June; their forewings are of a grayish color, crossed by two parallel brown lines, the whole space between them sometimes being of the same dark brown color; the male moth expands about an inch and three lines, while the female expands about an inch and nine lines.

Fig. 56.

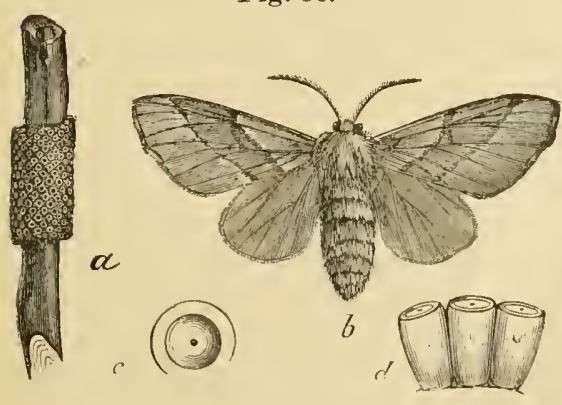

Fig. 56.--Moth and eggs of Forest Tent Caterpillar: , the eggs-color, brown; c, an egg highly magnified, top view; $d$, three eggs highly magnified, side view ; $b$, the female moth-color, brownish-yellow.

The female (Fig. 56b, ) deposits her eggs in rings 
around the small twigs (Fig. 56a), and these do not hatch out until the following spring.

The rings of eggs are similar in appearance to those of DeLong's moth, C. constricta, excepting that the eggs of the former are somewhat larger.

Renedies-Destroy web or tent as described in Chapter XXXIV. (Orchard Tent Caterpillar.) Also, as in Nos. 23 and 29 .

\section{CHAPTER XXXVI.}

The Fall Web Worm. (Cal.)

(Hyphantria textor.-Harris.)

Order, Lepidoptera; Family, Bombycide.

[Living under a web on apple, hickory, walnut and other trees, and feeding upon the upper surface of the leaves; sixteen legged caterpillars of a yellow and black color, their bodies sparsely covered with whitish or brownish hairs.]

"This insect passes the Winter in the pupa state, and the moth emerges during the month of May. The female deposits her eggs in a cluster on a leaf, generally near the outer end of a branch. Each worm or caterpillar (Fig. 57a) begins spinning the moment it is hatched, and by their united efforts they soon cover the leaf with a web, under which they feed in companies, derouring only the pulpy portion of the

Fig. 57.
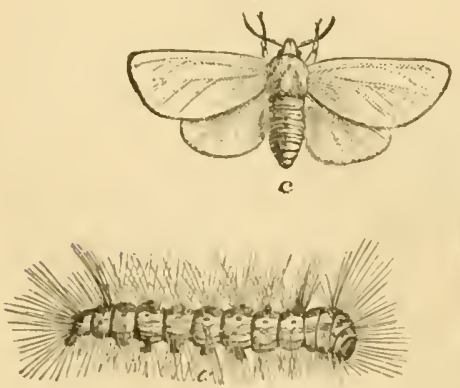
leaf. As they increase in size they extend their web, but alway remain and feed underneath it." -Riley.

Fig. 57.-F a ll $\mathrm{Web}$ Worm; a, the wormcolors, gray, black and yellow; $b$, the pupacolor brown; $c$, the moth -color, white.

"The web sometimes reaches a length of fully seven feet."- 
La Baron. The young worms are of a pale yellow color, with black heads. When fully grown they are a trifle over an inch long; of a yellowish or bluish-gray color, the back usually black; the body is sparingly clothed with whitish, reddish or mouse-colored hairs, which grow in clusters from warts which are usually yellowish-brown, or the two rows on the back are frequently black, or reddish-brown marked with black. When fully grown these caterpillars descend to the ground, which they enter, and form small cells in which to pass the pupa state (Fig. 57b). They spend the Winter in this latter state, and the moths (Fig. 57c), which issue the following Spring, expand about an inch and three lines and are of a pure white color and without spots, except on the legs. "The proper time to destroy these caterpillars is while they are young; at such time the branch containing the nest can be removed and its contents easily destroyed."-Riler.

ReMedy.-Use No. 97.

\section{CHAPTER IXXVII.}

\section{The Tussock Moth. (Cal.)}

(Orgyia leucostigma-Abbot and Snith.)

Order, Lepidoptera; Family, Bombycide.

[Feeding upon the leaves of the apple and various other trees; a black and yellow caterpillar having large bunches and plumes of hair on its body.]

The pretty catcrpillar of this moth (Fig. 58) is found on the apple, pear, plum and horse-chestnut; also on the walnut and oak, and perennials in the flower garden, especially the rose.

Fig. 58. - Caterpillar of Tussock Moth-- colors, yellow and black, or brown; hair white, the pencils blackish.

When full grown it measures from one

Fig. 58.

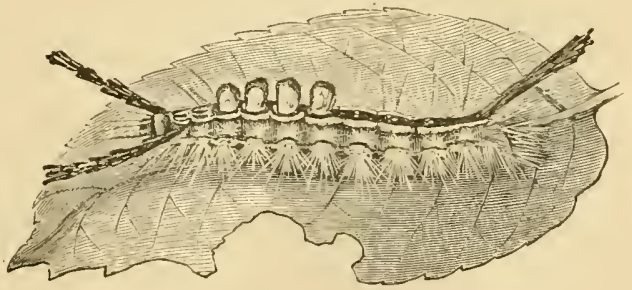
inch and three lines to one inch and six lines in length. Color, 
cream-yellow, a black dorsal stripe extending the whole length of posterior of the third segment; next to the dorsal stripe is a yellowish line, then a greenish-blue stripe on which is sometimes a black line; stigmatal line black, and below this is a yellow line. On dursal section of segments 4, 5, 6 and 7 , is a wide tussock of whitish hair; on each sicle of the segments next to the head, and on the dorsal part of the eleventh segment, is a pencil of long black hairs, which are knobbed at the apex; on top of segments nine and ten is a small red wart; rentral parts yellowish-white, tinged with blue. Head reddish-brown or dark red; cervical-shichl red.

Pup..-Pupa of male (Fig. 59d) elongate, posteriorly attenuated, inclosed in a coarse silky cocoon. Pupa of female (Fig. $59 c$ ), orate in form.

Fig. 59.
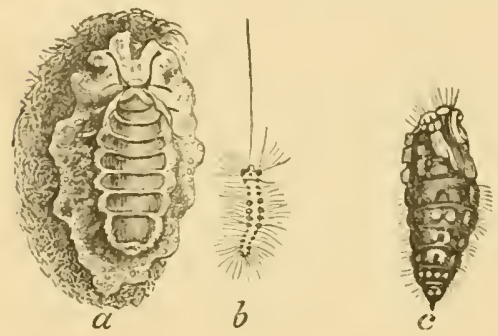

Fig. 59.--Tussock M oth, Caterpillar and Pupa; $a$, the female moth on her cocoon - color of

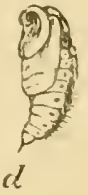
former, whitish or gray; of the latter, gray or yellowish; $b$, a young caterpil. lar; $c$, the female pupa-color, brown or gray; $d$, the male pupa-color, brown. Imago.-The male insect (Fig. 60) is ashen-gray; the foreFig. 60

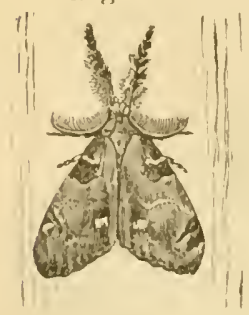
wings are crossed by wary bands of a darker color; on each wing is a small white crescent near the inner angle; antennæ pectinated; expands one inch.

Fig. 60. - Male Tussock Moth-color, ashen-gray.

The female (Fig. $59 a$ and 61) is wingless-color, brownish; form oval, and is from four to five lines in length. Antenne small. The eggs (Fig. 62) are generally deposited and fastened on the outside of the cocoon. 
Fig. 61.-Female Tussock

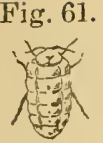

Moth-color, gray.

Fig. 62.-Eggs of Tussock Moth on the cocoon-color, eggs white, cocoon pale yellow.

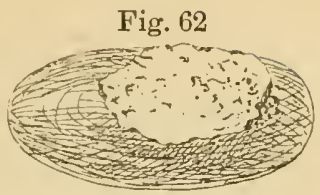

RENEDY-L'Se No. 30.

\section{CHAPTER XXXVIII.}

The Yellow-necked Caterpillar.

\section{(Datana ministra-Drury).}

Srnoxy-Pygxra ministra.

Order, Lejidoptera: Family, Bombrome.

[Feeding in communities upon the leares of the apple, walnut, ete., a black or reddish brown caterpillar, which is usually marked with five yellow lines on each side of the body.]

Fig. 63.

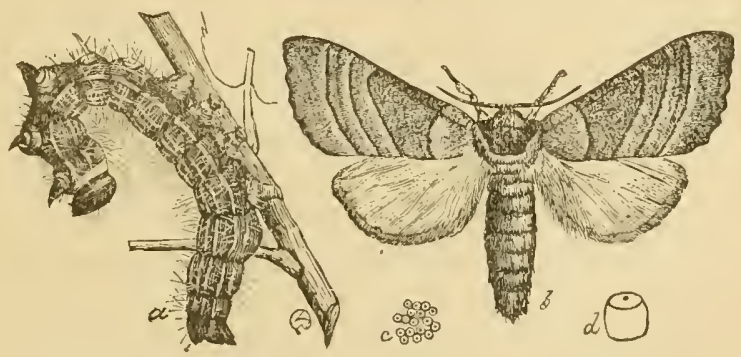

Fig. 63.-Yellow-necked Caterpillar, Moth, and Eggs ; $\boldsymbol{a}$, the caterpillar-colors, black and white; $b$, the moth--colors, brown and yellowish ; e, the eggs-color, white; $d$, an egg magnified.

These caterpillars usually live in communities, and when at rest have a habit of holding both extremeties of the body upwards. (See a, Fig. 63). They differ widely in their colorings, according to the kind of tree they infest. Those which feed 
upon the leares of the apple tree are usually of a black color, the top of the first segment yellow, and there are five yellowish lines on each sifle of the body, while those infesting the black walnut are destitute of the yellow stripes, and the top of the first segment is black; in both of these varicties the head is black.

When fully grown (Fig. ( $6: 3$ ) they measure about two inches in length; they then descend to the ground. which they enter a short distance, where each one forms a cell in which to pass the pupa state, which continues throughout the Winter. Only one brood is usually produced earh rear.

The wings of the moth (Fig. (iob)) expand nearly two inches, and are of a reddish brown abler, crossed br four transverse lines of a darker brown; the hind wings are of a lighter color, and are ummarkel. The moths from the caterpillars wheh infest the black walnut, are more of a smoky brown color. Owing to the fact that these caterpillars congregate in large companies upon a single branch, the latter can be easily removed from the tree, and the caterpillars can then easily be destroyed.

Reneur.-Üse No. 97.

\section{C'HAPTER NXXIX.}

The Red-humped Caterpillar. (Cal.)

\section{(Notudonta conrinne-Simith.)}

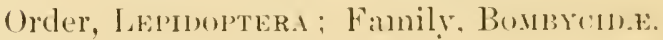

Feerting in communities upon the leases of the cherry, apple, plum, and pear: a striped aterpillar, having two rows of black spines along the batek j.

These raterpillars live in large companies, and when at rest they elevate the hind part of the body. They alle of a reclelish color, and arestriped lengthwise with rellow and white lines; on the fourth segment is a coral-red lump, on which are four black spines; scattered orer the body are numerous black spines or points, those on the back the largest; head, coral-red. When 
fully grown (Fig. 64, Plate 1) they measure about one inch and three lines in length; they then leave the trees and conceal themselves beneath the fallen leaves, etc., where each one spins a whitish, parchment-like cocoon (Fig. 65, Plate 1); they remain in this cocoon a long time before changing to pupa, the moths not issuing until the following Summer. Specimens in breeding cages changed to pupa in February, and emerged from pupa March 20, 1883. As these specimens were collecter the previous September, it is possible the Notodonta may be double-brooded.

The fore-wings of the moth (Fig. 66, Plate 1) expand from one inch to one inch and three lines; are of a brownish color along the hind margin, with the rest of the wing grayish, and marked with dark brown and whitish; the hind wings of the male are brownish, or dirty white, with a brown spot at the hind angle; those of the female are dusky brown. This insect is known to oceur in large numbers in some portions of this State.

Remedies.-No. 97 and No. 20.

\section{CHAPTER XL.}

The Greater Leaf-roller. (Cal.)

(Loxotania rosaceana.-Harris.)

Order, Lepidoptera; Family, Tortricide.

[Living in a rolled leaf on the apple, cherry, rose, etc.; a greenish worm with a black or brownish head.]

The larva brings the two opposite edges of a leaf nearly together, and holds them in this position by means of a great many silken threads; in this case, or nest, it remains during the greater part of the time, coming forth only to feed. It feeds upon the leaf which forms its nest, and after eating itself out of a habitation it repairs to another leaf and constructs a similar shelter. In this way it proceeds until reaching its full growth, when it lines the interior of its case with a fine layer of silk, and soon afterwards assumes the pupa form. The full 
grown larva measures nearly an inch in length, is of a green color, sometimes tinged with yellow; the head is rellowishbrown, with the regions of the jaws black, or entirely black in the young. Sometimes the upper part of the face is tinged with brown; on top of the first segment is a black spot tinged . with green next the head, or in its place is a simi-circular black line.

Fig. 67.-Greater Leaf-roller - colors, light and dark brown.

The fore-wings of the moth (Fig. 67) expand about one inch, are much arched at the midrle of the front edge, and curve in an opposite direction near the tip ; they are

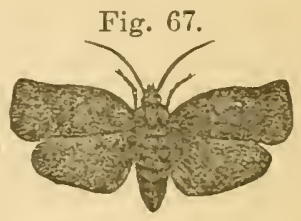
of a light brown color, crossed by dark brown lines and bands. The hind wings are yellowish, with the part next the body blackish. Dr. Emmons (N. Y. Rep., 1S54), states that this insect passes the Winter in the egrg state, and is to be found in small elusters on the bark of trees infested the previous year.

In California there are several species found, which, if they do not belong to the genus loxotania, are closely allied to it. The young eaterpillars appear early in the season, and make their nest under the blosiom leaf, or petal, of the apricot, when the fruit is not larger than a garden pea, and feed upon the skin or epidermis of the fruit on which they lodge. As the fruit becomes larger and the insect gains in strength, it bores into the fruit, destroying the pulp or mesocarp, and in many instances eat part of the pit or stone.

Rementes.-When the tree is dormant wash or spray thoroughly with No. 53, to destroy any egrs deposited on the tree. All infested leaves and fruit slould be picked off and destroyed. See No. 24. 


\section{CHAPTER XLI.}

The Apple Leaf Crumpler.

(Phycita nebulo.-Walsh.)

Synoryar-Acrobasis nebulo.

Order, Lepidoptera; Family, Pyralide.

Living in a curved, black, silken tube (Fig. 68a), on apple and plum trees, a reddish-brown worm, having a roughened head. (Fig. 68c.)

Fig. 68.-A p ple Leaf Crumpler; $c$, the hearl and fore part of the caterpillar's body en larged-color, brown; $d$, the moth, enlarged-colors, gray and brown; $a$, a case in which the caterpillar lives, with the fore part of the latter's body protruding from the opening in the larger end; $b$, several cases fastened together-color, black.

When fully grown this worm measures nearly six lines in length; it then closes the opening of the Fig. 68.

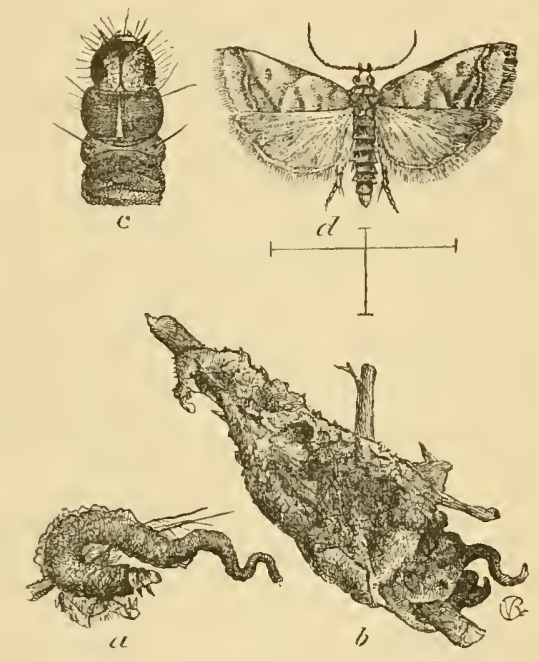
silken tube in which it lives, and soon afterward assumes the pupa form. The moth (Fig. 68d,) issues during, the Summer season, and the worms or larve which are produced from the eggs she deposits pass the Winter inside of their silken tubes (Fig. 68b), there being but one brood produced in one year. It has the habit of fastening dead leaves to the outside of its case, which makes its presence very conspicuous during the Winter season. In order to lessen the ravages of this insect, it is only necessary to collect the silken tubes containing the larvie and burn them. This can best be accomplished in the Winter season after the leaves have fallen from the trees, at which time the cases of this insect may be readily discovered. 


\section{CHAPTER XIII.}

The Bud Worm.

\section{(Penthina oculana.-Harris.) \\ Srvoxym.-Sipilonota oculane.}

Order, Lepidoptera ; Family, Tortrictde.

[Fastening together and devouring the leaves of the opening buds of apple trees; a small, brownish eaterpillar.]

Although of small size, these worms sometimes occalsion a great deal of damage by devouring the buds. They mally attain their full growth by the mirldle of Summer, when they prepare to assume the pupa form hy lining their retreat with a layer of silken threads.

Fig. 69.-Bud-worm and IIoth: lower figure, the worm-color, pale brownish; upper figure, the moth-colors, ash-gray and whitish.

These worms (Fig. 69) or caterpillars are of at pale or dull brownish color, with the head and Fig. 69.

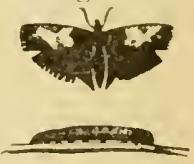
top of the first segment shining brown : and there is a clark brown spot on the top of the eighth segment, which appears to be under the skin. The moths (Fig. (is), which appear in June or July, have the head and thorax dark ash color: the forewings are of the same color at each end, and gralyish-white in the middle, mottled with dark gray: there are two little eyelike spots on each one, near the tip, consisting of four little black marks placed close together in a row; the sccond eyespot is near the immer hind angle, and consists of three hlack dots arranged in the form of a triangle, sometimes with a black dot in the middle; the hind-wings are dusky hrown. The fore-wings expand from six to seven lines.

Remenes.Use No. 65, and "ut out infested branches. See No. 27 . 


\section{CHAPTER XIIII.}

\section{The Many-dotted Caterpillar.}

\section{(Brachytrnia malana.-Fitch.)}

\section{SyNonym.-Nolophana malana.}

Order, Lepidoptera; Family, Noctudde.

[Eating the leaves of the apple, cherry, and peach tree; a naked, sixteen-legged caterpillar, of a green color, dotted with white, and marked with fine whitish lines.]

"These caterpillars live exposed upon the leaves of several different kinds of trees. When fully grown they measure an inch in length; they then roll up a leaf, and inside of this roll they spin a thin cocoon. Two broods are usually produced in a vear, the last broor passing the Winter in the pupa state. The fore-wings of the moth expand about one inch, and are of an ashen-gray color, crossed by three zigzag black lines, which are connected in various places by black dashes.

"For the destruction of these worms it has been recommended to place blankets beneath the trees and jar the worms off, when they may then be casily destroyed. As the last brood remains in the pupa state within the leaves, by raking these into winrows in the Winter and then burning them, the greater number of these pests will be destroyed."-[Condensed from Fitch.

\section{CHAPTER XLIV.}

\section{The Turnus Butterfly. (Cal.)}

\section{(Papilio turnus.-Linnæus.)}

Order, Lepidopteri: Family, Papilionide.

[Feeding upon the leaves of the apple and cherry tree; a bluish-green, sixteen-legged worm, having an eye-like spot on each side of the third segment.]

This caterpillar spins a fine web upon the upper surface of a leaf, drawing the edges of the leaf slightly upwards; when 
not feeding, it rests upon the upper side of this wob. The young caterpillar is of a black or brownish color, marked with flesll color or white.

Fir. 70.--Caterpillar Fig. 70. of 'Turnus Butterfly-colors, green, yellow, and black.

When fully grown (Fig. 70), it measures

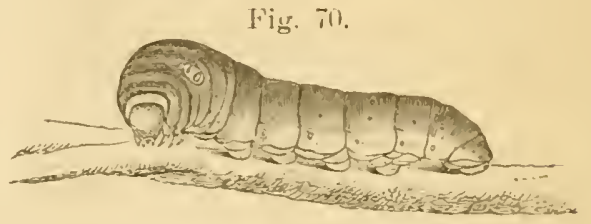
from one inch and six lines to two inches in length, and is of a bluish-green color; on each side of the third segment is a black spot, centered with blue and surrounded by a yellow ring, and this by a hlack one; on top of the fourth segment is a transverse vellowish ridge, in front of which is a row of four blue dots; on top of the last segment is a transverse yellowish ridge; hear, pinkish-brown. When about to pupate, this caterpillar suspends itself hy the hind-feet and a transwerse band of silken threads which is passed around the forepart of the body. It assmmes the chryalis form in the lutumm, and the butterfly does not issue until the following sipring.

Fig. 71.

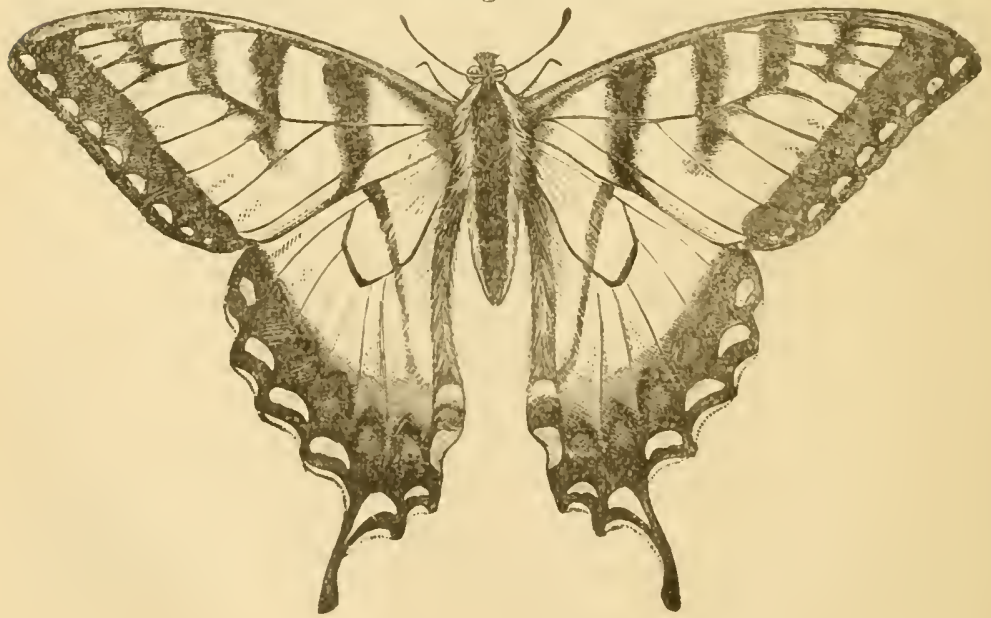

Fig. 71.-Turnus Butterfly-colors, yellow, blick and orange. 
This is one of the largest buttertlies (Fig. 71) found in this State. The wings expand from four inches and six lines to five inches, and are of a pale yellow color, with a broad, black outer margin marked with yellow sputs; the fore-wings are marked with four black bands, the one nearest the body extending across the hind-wings; the latter are tailed, and have an orange-colored spot near the hind angle.

Remedr.-Use No. 14.

\section{CHAPTER XLV.}

The Apple Buceulatrix. (Cal.)

(Bucculatric pomifoliella-Clemens).

Order, Lepidoptera; Family, Tineide.

[Feeding ipon the leaves of the apple tree, a small, dark, yellowish-green, sixteen-legged worm, nearly six lines long; spinning against the bark an elongate, dirty-white, ribbed [ocoon].

This larva assumes the pupa form within its encoon (Fig. $72 a$ and $b]$, and before the moth issues, the pula works itself part way out of the cocoon. Several broods are probably produced in one year; the last brood passes the Winter in their cocoons.

Fig. 72.-Apple Bucculatrix ; $a$, the cocoons on a twig-color', dirty white ; b, one of the cocoons, enlarged; c, the moth enlargedcolor, gray and brown.

The perfeet moth (Fig. 72c) is a dirty white or gray color, marked with brown, as in the figure.

Fig. 72.

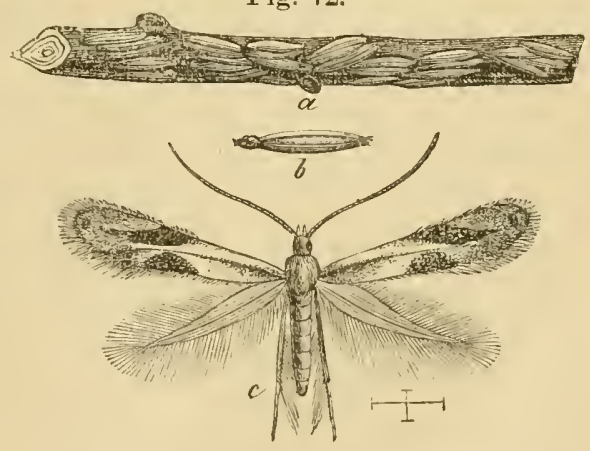

REMEDY.- When the tree is domant, spray or wash thoroughly the parts infested with No. 13--one pound to each gallon of water used. 


\section{CIHAPTER XIYT.}

\section{The Apple-tree Aphis. (Cal.)}

\section{(Aphis mali.-Fabricius.)}

\section{$\left.\begin{array}{l}\text { Order, Hemitera; } \\ \text { Sulb-order, Homortera ; }\end{array}\right\}$ Family, APHIDIde.}

[Living on the leaves or twigs of alple trees: small green, or grreen and black, plant lice.]

This plant louse, as its name indicates, is frequently found on the alple tree. It may he easily detected by the hlack appearance of the ends of the sueculent twigs and leatres. caused hy a honey-dew emitted by this inseret and others robedy related to it. (Fee Aphis malifolin; ('hap) t7.)

Fig. 73.

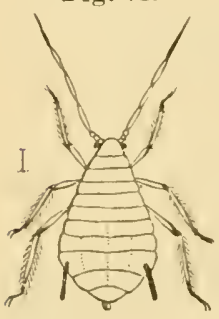

Fig. 73.-Apple-tree Aphis (voung), enlarged-color, wreen.

The winglesindividuals (Fig. 73) are small, erreen lice, and ran be found in great number. on the under side of the leares and tender twigs. They measure about one line in length, and are often aceompanied hy winged individuals. As the Winter season alpproaches. the egge are laid on the bramehes and twigs, and can be easily seen with a lens. Shout the time the leaves begin to open in the spring, these egge hateh, and the roung lice fasten themselves to the tender leaves and extract the silp.

Figr. Tt.-Apple-tree Iphis, enlarged-colors, black and green.

In about ten days after hatehing the lice reach maturity (Fig. T.t) and rommenee griving birth to living roume. In the course of from fifteen to trent! days after reaclung mat urity. they die. The roungr, atter realehing wa a t urity, become parents.

Fig. 74 .

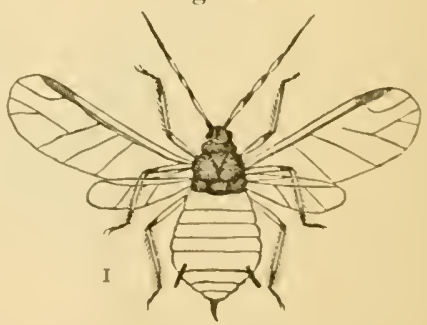
and it is generally eonceded by naturalists that in the summer season they reateh maturity in five or six dars. Therefore. 
it can be easily seen that their increase surpasses computation. This species is spreading rapidly in the vicinity of Sacramento. Trees infested emit a very disagreeable smell. Mr. Haywards, writing of this pest from British Columbia, says: "After night, in passing along the road I can tell an infested tree." In cases where trees are badly infested they produce a smell similar to that of decayed fish. I have noticed in handling infested branches that this loathsome smell remains on the hands.

Leaves infested by these plant lice eurl or curve backwards until a roll is formed, thus furnishing the insects with shelter from the rays of the sun, or from rains, or dews, and makes it difficult to destroy the insects by spraving the trees.

During the Summer they are found grouped together on the leaves in all stages of their growth, and of various colors. The mature insects (Fig. 74.) are of a yellowish-green, and when half grown pale-yellowish, and when born the color is nearly white. In Autumn the color changes in many cases, either from the change in temperature or change in nourishment.

REMEDIEs-When the tree is dormant, spray thoroughly with No. 13; one pound of the mixture to each gallon of water used. When the leaves begin to expand, if the lice are present, spray thoroughly with No. 64 or No. 65 , and repeat if necessary.

\section{CHAPTER XLVII.}

\section{The Apple Leaf Aphis. (Cal.)}

\section{(Aphis malifolin-Fitch.)}

$\left.\begin{array}{l}\text { Order, Hemiptera; } \\ \text { Sub-order, Hemoptera } ;\end{array}\right\}$ Family, ApHidida.

[Living upon the leaves of the apple tree, a small, blackish plant-louse.]

This species infests the leaves of the apple tree, and in their habits they are similar to and are often mistaken for the apple 
tree aphis (Aphis mali), though they are larger, and generally of a rlarker color. The winged insect of this species differ from the $A$. mali in being larger, and the thorax and abromen are black; there is also a slight difference in the renation of the wings.

These insects emit a honey dew, which gives the leaves and branches an appearance similar to that caused by the appletree aphis (A. mali).

Rementes-To be used as described in Chapter XLVI for the apple-tree aphis.

\section{CHAPTER XLVIII. \\ The Ten-lined Leaf Eater. (Cal.) \\ (Polyphylla decemlineata-Say.)}

Order, Coleortera: Family, Scarabeide.

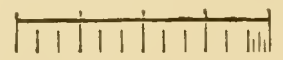

[The ineasurcments of insects in this work are given in inches and lines. The above cut represents one inch divided into lincs and fractions thereof.]

[Feeding upon the leaves of the apple and other fruit trees, a large, grayish-brown bectle, marked with white lines; or, feeding upon the roots of grass, a large, white, six-legged larva or worm ].

The perfect beetle (Plate 1, Fig. 74, male; Fig. 75, female) measures from an inch to an inch and three lines, and is of a redrlish hrown color, covered with short yellowish hairs, which give it a grayish appearance; the thorax is marked with three white stripes, and on each wing-cover are three white stripes, and two or three less distinct whitish lines.

The habits and transformations of this species are similar to those of the common May beetle.

REMEdY.-Use No. 38. 


\section{CHAPTER LIX.}

The Goldsmith Beetle. (Cal.)

(Cotalpa lanigera-Linnæus.)

Order, Coleoptera; Family, Scarabeide.

[Feeding upon the leaves of the apple, pear, and various other trees, a broad beetle of a rich yellow color, the top of the head and thorax having the appearance of burnished gold.]

Fig. 77.-Croldsmith Beetle-color, rich metallic yellow.

This beetle (Fig. 77 ) measures about an inch in length. 'The female deposits her eggs in the ground, and these hatch into white, six-legged grubs which closely resemble those commonly known as white grubs; they feed upon the roots of various plants, and in this way are sometimes very injurious to strawberry patches. They spend sev-

Fig. 77.

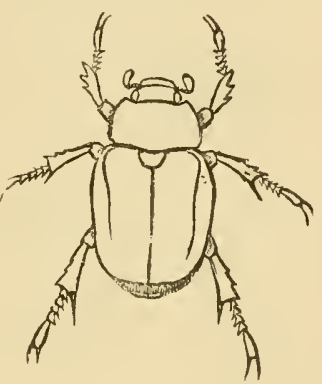

eral years in this their larval stage, and finally assume the pupa form in the Fall, and are changed to beetles in the following Spring.

Reyedy.-Use No. 38.

\section{CHAPTER L.}

The Robust Leaf Beetle. (Cal.)

(Serica valida-Harold.)

Synonym.-S. robusta-Leconte.

Order, Coleoptera; Family, Scarabeide.

[A reddish-chestnut colored beetle, feeding upon the leaves of the apple, apricot, plum, and prune trees].

This beetle (Fig. 78, Plate 1 ) has been reported damaging the foliage of apple, apricot, plum, and prune trees. 
They feed on the foliage at night and hide themselves in the ground and dark places in the day time; recent reports state that in some sections they have damaged the foliage of young trees.

Desrription.-Length, four and one quarter lines; form, elongate orate, narrowing toward the head; color, redrlishchestnut, but grows darker with age; antenne, lanellate.

The larva of this species I have not found, but it probably lives in the ground, feeding upon the roots of grasses, etc., near the roots of the trees on which the perfect insect feeds.

Reneny.-L'se Yo. 38.

\section{CHAPTER LI.}

The Codlin Moth, or Apple Worm. (Cal.)

\section{(Carpocapsa pomonella.-Limn.)}

Order, Lepidopteri; Family, TORTRICide.

[Living in apples, ete., a whitish, sixteen-legged worm.]

It is generally conceded that this insect was imported into this state in shipments of apples received from states east of the Rocky ILountains, and placed on exhibition at the State Fair in or about the year $18 \%:$. Its first appearance in an orcharl in the vicinity of Sacramento was in the Spring of 1874. Since that date it has sprearl rapidly, and can be found at the present time infesting orchards in thirty-four counties.

The moth belongs to the family Tortrieidel, and is known to naturalists as Carpocapsa pomonella (the codlin or apple moth). It passes the Winter in the larva state, and in some instunces in the chrysalis form. The larva can be found hibernating uncler the loose bark, in erotches or indents, or in cracks in the hark of the trees infested the previous year, or in the erevices of wood, or woodwork of rooms, or places where fruit infested by the larva was stored or packed, and in empty packages in which fruit was shipped or gathered. It is often found hibernating on bark of trees, from one to six inches below the surface of the ground, especially if the tree has 
smooth bark. In one case, where four hundred apple trees were dug up, the larræ were found in large numbers in the roots of such trees as were decayed at or above the surface of the ground.

Fig. 79.— $a$, nest of larva as it appear's on inside of bark when taken off tree-color, drab; b, pupa or chrysalis-color, dark amber; $c$, appearance of larva when cover is removed from Winter nests - color, body yellowishwhite, head dark brown; $d$, appearance of bottom of Winter nest on bark

Fig. 79.
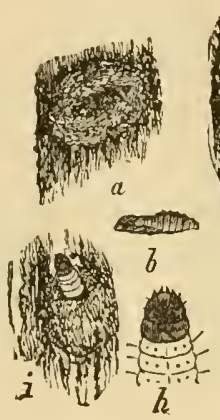

when larva is remored in the following spring; e, a position the larva takes when looking for a tree or place to make its nest when ready to assume the pupa or ehrysalis form. [Note: when the larve are full grown and ready to assume the pupa or chrysalis form, the color is light pink]. $f$, the moth, at rest carries its wings like a steep roof; $y$, moth with winge spread, length of body five lines, spread of wings nearly nine lines-color, body and legs rich bronzed light clrab, fore-wings mottled with gray and drab, with dark copper bar across hind margin on which is a golden ocsellated patch near inner angle, hind-wings plain drab a little darker than body (the moth after depositing eggs has assumed a light drab color on fore-wings, and copper bar changes to a very light color, scarcely perceptible, caused probably from flying among the branches and leaves); h, head of larva as seen through a glass magnifying nine times; $i$, in this figure it was intended to represent the pupa or chrysalis case protruding through nest prior to moth leaving it, but represented as larva to show better. [Note: the figure would be correct if the chrysalis (b) was represented instead of larra $(c)$; the figures $a, \dot{b}, c, d, e$, and $f$, are natural size; $y$ is a little larger than natural size; $h$, as described]. See, also, Fig. so. 
Fig. So.-Codlin Moth; $a$, an infsted apple; $b$, the place where the larva entered the same: $e$, the larracolor, whitish; $h$, hearl and fore part of the body of the same-back riew, enlarged; $i$, the eocoon-color. Whitisle; "l, the pupa-color, brown : g, the muth-color's. light, dark gray and brown.

If the syring is warm and farorable, the larve are realy to assume the jupa or chrysalis form by

Fị. 80.

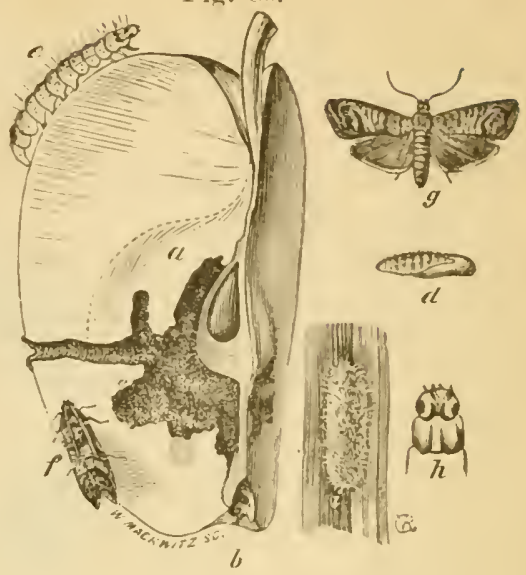
the fifteenth of April. The cluration of the pupa or chrysalis state depends on external circumstanees; if warm spring weather, the perfect insect may appear in trom fiftecn to twenty dars, and may be prolonged to twenty or thirty days. The spring of 1581 has proven an exception. I found Madalene pears on the sixteenth of May in which the larre had matured and left: also, on May seventh found a pear with larva about eight days old. (This is about eighteen days carlier than usual.) On the seventh of April, 1853. I found an cmpty pupa case from which the moth had escaped.

\section{FIRST APPEARANCE OF TIIE MOTII.}

The moth generally appears from April 25 th to the fifteenth of May-a few in favorable locations by April fifteenth. The time at which the egges arrive at maturity apparently coincides with the ends or terminations of the pupa or chrysalis state, so that the sexes are rearly to mitr soon after transformation. The moths prorlueed by the hibernating larve deposit their eggs in the blossom end (or calyx) of the fruit, generally; possibly because they camnot puneture the epiclermis (or skin) of the roung fruit. Later broods deposit their eggs on any part of the fruit. The eggs are attached to the fruit by a pasty substance. It is rare to find more than one exger on any apple, pear, or quince, or more than one larva. The larra is hatched 
in from seven to ten days, and begins to eat eagerly and burrow toward the core.

Fig. 81.-A, blossom end or calyx of apple, and where larva is supposed to enter the fruit; B represents an empty space where carpellary ovarium or shell containing the seeds was located before the entrance of the larva; $\mathrm{C}$ represents the burrow made by the larva through the pericarp by which it Fig. 81 .

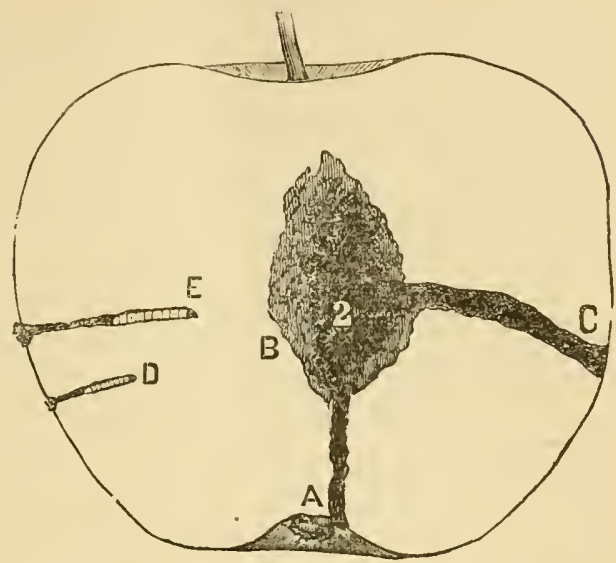
escapes from the fruit when it is ready to assume the pupa or chrysalis form; D, appearance of larva in burrow when six days old; E, appearance of larva in burrows when ten days old.

The larva when hatehed can searcely be seen with the unaided eye; at six days it measures nearly one quarter of an inch in length, is about as thick as a fine silk thread, and shows first signs of exerement at burrows (D Fig. 81) ; at ten days three eighths of an inch, and about as thick as a number twenty wire (E Fig. S1). It has burrowed by this time about three fourths of the distance to the core (B Fig. 81). At twenty days nearly full grown (c, Fig. 79), and often as large (e, Fig. 79).

When the larva is ready to assume the pupa or chrysalis form, it leaves the fruit by gnawing a hole through the pericarp (C Fig. 81). Nature has supplied it with a spinneret, the opening apparently in the lower lip, from which issues a viscid fluid in a fine stream and hardens into silk on contact with the air. By this means it lowers itself to the ground or intervening branches. If it reaches the ground, it immediately crawls toward the tree, and on its journey can often be 
seen, as at $c$ Fig. 79. On reaching the tree it searches for a nesting place under the loose bark, in the erotches, or in any earity it can find. If it comes in contact with a branch when leaving the fruit, it generally crawls toward the crotehes, or until it reaches a hiding place. If the place seleeted is under the loose bark, it commences building an oval-shaped wall about one sixteenth of an inch high. composed of silk from the spinneret, and sometimes mixed with pieces gnawed off the bark. A silken cover is then put on the nest by using the spinneret; the whole completed in twenty-four hours. If in the erevice of the bark, the nest is made in different shapes. It is noticealule in the linter nest that the top, sides, and hottom are washed with the fluid from the spinneret, making the nest water proof to a great extent.

The moth remains in the pupa or chryalis form about nine days in our usual May and June weather ; a little longer if the weather is eool. At the proper time the pupa ease is burst open, and the perfect moth appears. (Fig. T0, $f^{\prime}$ and $y$.)

PROBALILE RATE OF INCREASE OF TIESE MOTHS.

Each female lays from two hundred to two hundred and tifty eggs. Taking two hundred as the lowest number. twelve female moths in one orchard would produce two thousand four hundred caterpillars. If one half of these were females, they would produee two humdred and forty thousand. In proportion the third generation would reach twenty-four millions, supposing that no untinely deaths took place. Most of the hooks on this subject speak of the coullin moth as groing thromgh but one generation in a year. This may be true in colder rlimates and shorter seasons than ours, but in parts of our farurerl state there is no question that two or three generatiuns or broods are common. From personal observations l know that the rule for the saramento Valley is three hrouds atch rear. In $1 \mathrm{~S} S 1$, on areount of the early appearance of the first moths, as noted alhore, we had four broods. These farts explain the exeeptional importance of this insect in Califormial.

I have in my possession a vial containing eighty-tive eggs, deposited by one codlin moth. I have read statements by 
fruit-growers that they have seen the codlin moth flying in large numbers. In my investigations I have not seen more than two at any one time. The moth will live in a glass vial seven days. The female moths deposit their eggs within forty-eight hours-these are deposited at night. The egg cannot be seen plainly by the unaided eye.

The best time to see the moths at work is at the dawn of day in the months of June and July. Part of the carly fruit falle prematurely when attacked by the larva; but little of the late fruit falls until the larvi escape.

The theory that the moth always deposits the egg on the fruit blossom, and that it remains there until the fruit has grown to natural size, is a mistake.

IOW TO PROCURE SPECIMENS OF THE MOTH.

When you find the larva, if it is on the loose bark, remove the piece of bark or wood to which it is attached, place it in a small vial, and if in the Summer time, inside of ten days you will have a genuine specimen of the moth $(f$ and $g$, Fig. 79). Fruit-growers can get important information concerning the natural history and habits of the insect pests by experiments of this kind. Every fruit-grower should unite in the crusade against this pest. "In union there is strength."

Since writing the above, or on August S, 1883, I bought a box of bellthower apples which was offered for sale in market. With few exceptions each apple contained two larre of the corllin moth, and in nearly every apple infested by the later broods the egg had been deposited near the stem. This is the first instance that furnished me actual proof that the later broods would deposit their eggs in fruit that had been infested by the earlier lroods of the season. In the absence of the sceds of the apple, eaten by the larva of the carlier broods, the larra of the later brood seemed to burrow (or honeycomb) the pericarp in all directions. The larve in the apples containing more than one specimen were apparently of different ages.

From invostigation it is probable that there are more than one species of codlin moth infesting fruit in this State; but I am not prepared to report at present writing. 
That the codlin moth infests the peach and aprieot, I hare abundant proof by rearing moths from both kinds of fruit.

Revedies.-For trees, No. 69; return packages (see Chap. IV), No. 70; packages stored from previous year, No. 71 ; storerooms, salc-rooms, etc., No. 72 ; debris accumulating from preparing fruit for drying, No. 15.

\section{CHAPTER LII.}

The Apple Maggot.

\section{(Trypeta pomonella.-Walsh.)}

Order, Diptera; Family, Trypetide.

[Eating the pulp of apples, causing them to decay, a white, footless maggot which, when fully grown, enters the earth and is finally transformed into a black and white two-winged fly.]

This maggot (Fig. S2, Plate 1,) may be easily distinguished from the larva of the codlin moth by being entirely destitute of legs. It also differs from the latter in its mode of operating, for while the larra of the corllin moth works for the most part in the core of the apple and ricinity, this maggot runs its burrows in all directions through the pulp; it also differs from the larva of the apple curculio (Fig. 556), which, like itself, is also destitute of legs, by apparently having the hind end of the body obliquely cut off, the curculio larva having this part rounded.

The apple maggot usually appears rather late in the Summer, and after reaching its full size-about three lines in length-it deserts the fruit and enters the earth. where it forms a small cell in which to undergo its transformations. It assumes the pupa form (Fig. S3, Plate 1,) in the Autumn, and is not changed to a fly until the following Summer.

The body of the fly (Fig. S4, Plate 1) measures three and a half or four lines (or from one fifth to one fourth of an inch) in length, and is of a black color, the thorax marked with four whitish lines, and with a white dot next to the abdomen; the latter is marked with three or four whitish transrerse 
lines. The wings, which are only two in number, are transparent, and marked with four black cross bands, which are more or less united with each other. The only remedy seems to be to gather the infested apples before the maggots have deserted them, and make such use of them as will destroy the maggots. This insect, so far as is reliably known, has not yet been found in California, but from descriptions given of the decay of late varieties of apples in 1882, it is thought necessary to give the above description. (See U. S. Agr. Rep. for 1SS1.)

Reuedies.-Should this insect appear, it can be kept off the fruit by spraying, in July and August, with Nos. 5 or 7, but probably No. 4 would be better.

\section{CHAPTER LIII.}

The Apple Cureulio. (Cal.)

\section{(Anthonomus quadrigibbus-Say.)}

Order, Coleoptera; Family, Curculionide.

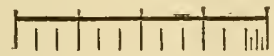

[The measurements of insects in this work are given in inches and lines. The above cut represents one inch divided into lines and fractions thereof.]

[Living in apples, pears, and quinces; a curved, footless grub of a white color, marked with bluish-black; assuming the pupa form within the fruit, and finally producing a rustybrown snout-beetle, having three pale lines on the thorax, and four humps on the wing-cases.]

The female curculio punctures the apple with her long snout, and after widening the puncture at the bottom, she deposits therein a single egg, from which is hatched a footless grub (Fig. S5b) which burrows still deeper into the fruit, and feeds upon the latter in the vicinity of the core. After attaining its full growth, it forms a small cell, with a burrow leading from it to the outside of the apple, and in this cell it soon casts off its skin and enters upon the pupa stage (Fig. $85 a$ ), from which the perfect beetle is evolved in the course of a few weeks. 
Fig. 85 .

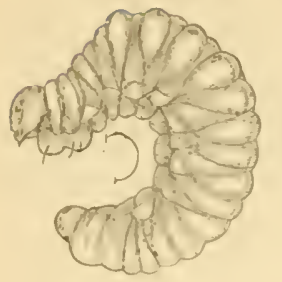

6

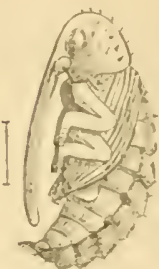

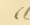

Fig. 85.-Larva and Pupa of Apple Curculio, enlarged; u, the pura; b, the larvaculor of each, whitc.

The full grown larva measures a little moler five lines, or one third of an inch in length, and usually lies in a curver position; it is of a

white color, sparsely covered with wrinkles, the spaces letween which are bluish-black, of which color is the line on the back.

The perfect heetle (Fig. sibi) measures from one and one half to two lines in length, and is of a dull reddish color, marked on the thorax with three indistinet whitish lines: on the hind part of the wing-cases are four prominent humps, and the snout is mearly as"long as the body.

Fig. S6.-Aprole Curculio; $a$. natural size; $b$, enlarged, side view: r, enlareel, back viewcolors, brown and gray.

The perfect insert issues from the pupa state early in September, and passes the Winter in al semi-torpid state. It intests apples, pears, quinces, thornapples or haws, and crabFig. 86.

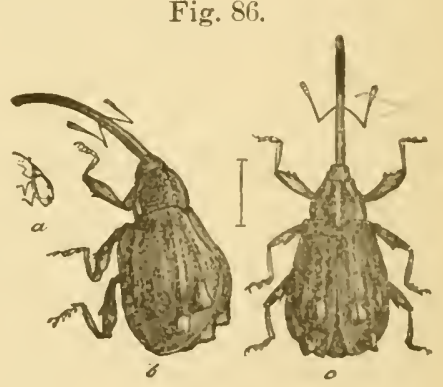
alplules.

l'revious to last Fall (1852), when apples were found with a single empty lurrow, ants and some other inserts were credited with capturing the larva of the collin moth before maturity, hut the presenee of this insect being detected. axplains the true liarts in many of the rases mentionerl.

likmentes. - see note at ent of No. 6\%. In the spring use No. ז. or No. fi, or No. T. 


\section{CHAPTER LIV.}

The Earwig. (Cal.)

\section{(Forficula auricularia-Linnæus.)}

\section{Order, Orthoptera ; Family, Forficularide.}

[Feeding upon the flowers of various plants, and also upon fruits. A brownish or black six-legged insect, having a forceps-like appendage at the hind end of the body.]

The female Earwig deposits her eggs beneath stones, etc., and-what is rery unusual among insects-she broods over them like a hen until they are hatched out, and afterwards manifests the most lively interest for the safety of her young. The latter (Fig. S7, left) closely resembles the arhults, but are entirely destitute of wings. (Pupa, Fig. ST, middle).

Fig. 87.
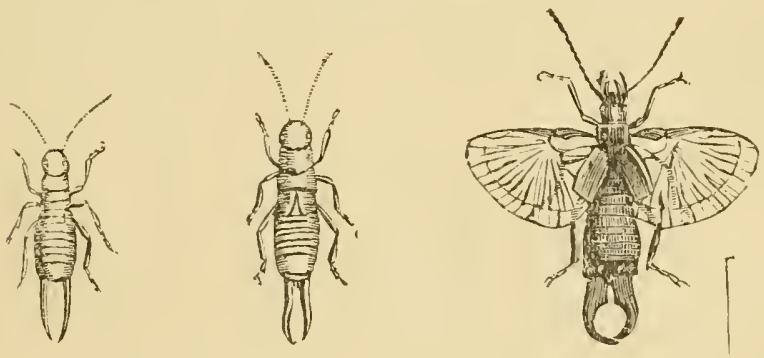

Fig. 87.-Earwigs, enlarged-color, brown; at the left, the larva; in the middle, the pupa; at the right, the perfect insect, with its wings expanded.

In the adults (Fig. 87 , right) the wing-cases are very short, and the wings, when not in use, are folder in a very complex manner, and concealed beneath them. Although these insects have been reported as crawling into the ears of certain persons, yet no authentic instance of this kind is on record. These insects are sometimes quite destructive to various kinds of fruit, especially such as have been injured by some other insects. 


\section{INSECTS INFESTING THE PEAR TREE.}

The Oyster-formed seale (Diangis ontre.

furmis $\ldots \ldots \ldots \ldots \ldots \ldots \ldots \ldots \ldots 5$

The Pear-tree Sicale (Lecanium pyri).....56

The Pear-tree Borer (_Egevia qyym)......57

The Pear-tree Seolytus (Sicolytus gyyri) . . . .58 8

The Branch and Twig-burrower (Polycaon

confertuxp.........................59

The Pcar-tree Psylla (I'sylla yyri).......60 60

The Pear Slug (Sclandria cerasz)........61

The l'ear-leaf Caterpillar (Nematus) . . . . 62

The Thrips.....................63

The following insects also infesi the pear tree:

The Woolly Aphis (Schizoneura langera).

'The Oyster-shell Bark-Louse (Asyidiotus con-

cliformis).
The Greedy Scale (Aryidiotus rapax).

The Round-headed Apple-tree Borer (Saper da candida).

The Flat-headed Apple-tree Borer (Chrysobothrix femorata).

The Apple-twig Borer (Eostrichus bicanda. tus).

The Red-humped Caterpillar (Folodonta con. rinna).

The Goldsmith Beetle (Cotalya lanigera).

The Red Spider (Tetranychus telarizs).

The lellow Mite.

The Codlin Moth (Carpocajisa yomonella).

The Plum Cureulio (Conotrahelus nemughar).

The Alple Curculio (Anthunomus quadrigib. bus).

The Qquince Curculio (Conotrachclus cratogi).

The Green Fruit-beetle (Gymnetis nilida).

\section{CHAPTER LV.}

The Oyster-formed Scale of the Pear and Apple. (Cal.)

(Diaspis ustier formis-Curtis.)

Srionvis-Aspidiotus ostreiromis-Ruricola. Aspidiotus circularis-Fiteh.

Order, Hemptera; $; \nmid$ Fanily, Coccrde.
Sub-ortler, Homorters;

[A small, cireular scale insect, infesting pear trees].

In the Inited States Agricultural Rejort, 1Sso, Professor J. H. Comstock writos of this speedes as follows:

"This is a common species on the pear and apple in England. Slthough l lo not know of its oeeurrenee in the lnited States, it will be strange if it is not found here." 
I received the following, dated-

$$
\text { "Ithacd, N. Y., March 3, } 1882 .
$$

"Your letter and specimens duly received. Without doubt you are right. The scale is Diaspis ostrexformis. This is very important, as it is the first instance of which I know of this species in this country. Strong measures should be taken to crush it out before it gains a foothold," etc.

\section{"J. H. Coмstock."}

This species is found on pear and apple trees in the vicinity of Sacramento; it is not known what length of time the trees have been infested, but serious damage has been done. In many cases the bark is destroyed.

\section{NATURAL ${ }^{\tau}$ HISTORY.}

The scale of the female insect is nearly circular, or a broad oval, and measures about three fourths of a line in diametercolor, ashy-gray; exuviæ in the center, or nearly so, yellowish-brown; the inside of the scale and the venter is snowy white.

The scale of the male is elongated. The eggs are pinkishred and ovate. The female insect is of a reddish-purple color, and in form is somewhat elongated. There are at least two broods each year, as I have found the eggs early in May, and also in the latter part of July. The male insect is winged, and is described by Curtis as being of a bright ochreous color, with a black band on the thorax.

REuEdiEs. - When the tree is dormant, a thorough spraying with No.13-one pound of mixture to each gallon of water used. Summer wash, Nos. 5 or 7 . Where trees are seriously infested, when dormant No. 44 may be used as a spray, but followed by No. 13 in about twenty-four hours. 


\section{CHAPTER LVI.}

The Pear Tree Scale. (Cal.)

(Lecunium pyri._Schrank.)

Srxorya-Coccus pyri.-Schrank.

$\left.\begin{array}{l}\text { Order, Hemiptera; } \\ \text { Sub-order, Howoptera } ;\end{array}\right\}$ Family, Coccida.

[A light brown scale inscet or bark louse, about half the size of a pea, infesting the pear trees.]

This species of scale insect can be found in several of the fruit-growing districts of this State, and is injurious to the trees infested by it. It is only found on the pear, so far as known at present.

\section{NATIRAL IISTORY.}

The insect is hemispherical, and is about the size of half a pea. It is of a bright hrown color, and oval in form; the upper surface slightly indented. Its longest diameter is from one and one half to two lines; the width from one line to one and one half lines. Specimens sent me were received early in June, at which date the young were hatching out. The egrgs are oval, and of a dirty white color; number produced by each female, from fifty to one hundred; length. one eighty third of an inch; color, brownish-white; antenna and anal setre present. In passing through the stages from the larva state to the mature insect, at first the color is greenish-yellow, but changes at the approach of maturity to a chestnut-brown, then to a bright lrown.

After the eggs are cleposited the insect dies; then the scale or outer covering is blackish. It is probable that there is only one brood in each year. (See Black Scale.)

Fig. $87 \frac{1}{2}$. Portion of a branch infested by Pear-tree seales; at the right are two of the scales-color, brown.

REMEDEs.-When the tree is dormant, spray thoroughly with Nos. 11 or 12. Or in summer, No. 4, or No. 5 , or No. 7 . For Summer wash the latter are preferable, as the sulphur is an enemy to fungi.

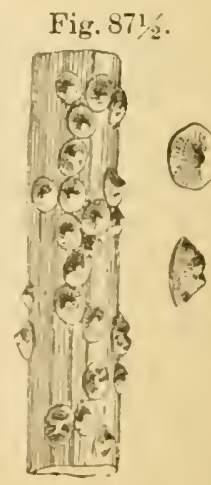




\section{CHAPTER LVII.}

The Pear Tree Borer. (Cal.)

\section{(Egeria pyri.-Harris.)}

Order, Lepidoptera ; Family, Egeridæ.

[Boring into the trunks of the pear tree, a pale-yellow, sixteen legged larva.]

This borer has about the same habits as the peach tree borer, but, as far as known, never infests any other kind of tree than the pear.

The perfect insect (Fig. 85-moth) usually issues Fig. 88. from the pupa state in July. The wings expand about eight lines; they are transparent, but bordered and veined with purplish black, and across the tips of the front wings is a broad, dark band, show-

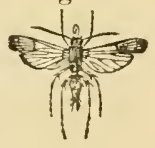
ing a coppery reflection; the upper side of the body is purplish-black, with the edges of the collar and of the shoulder tufts, three bands across the abdomen, and the tuft at the posterior end of a golden-yellow; the under side of the body is mostly of this color.

Remedi.-Use No. 37 .

\section{CHAPTER IVIII.}

The Pear-tree Scolytus.

(Scolytus pyri-Peck.)

Order, Coleoptera; Family, Scolytide.

[Boring into the branches of apple, pear, apricot, and plum trees; a small, footless grub, finally transforming within its burrow into a dark-brown beetle.]

The egg from which this grub hatches is deposited in the latter part of the Summer, and is usually placed at the base of a bud; as soon as hatched, the grub gnaws its way into the branch and works around the central part, usually following 
the course of the central part of the branch. By this means the vessels which convey the ascenrling sap is cut off, and that part of the branch above the place where the insect is located, withers and soon beromes dead word.

The larva assumes the pupa form in its burrow, and the perfect insect appears early in Summer.

The perfect beetle (Fig. 89) measures about one and one quarter lines, or a tenth of an inch, in length, and is of a deep uniform brown color.

Fig. 89. - Pear-tree Scolytus, natural size and en- Fig. 89. larged-color. brown or black.

For the destruction of this insect, it has been recommended to cut off and burn the infested limbs. This should be done earlier than the month of April, otherwise the beetles will have completed their trans-

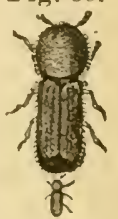
formations and made their eseape.

I have not found this insect in this State, but from specimens of branches sent me for examination, there can be no doubt of the presence of this beetle, or a closely allied species.

Revedy.-Prune, as above described, and use No. 37 on the branches as soon as the beetle appears, which is in the latter part of July. The branches, etc., may be sprayed with No. 4 , or Nos. 5 or 7.

\section{CHAPTER LIX.}

The Branch and Twig Burrower. (Cal.)

\section{(Polycaon confertus.-Leconte.)}

Order, Colvoptera: Family, Ptixide.

[An elongate pitch-colored bectle, about half an inch in length, burrowing into the branches and twigs of the apple, pear, cherry, almond, apricot, peach and olive trees, and also into grape canes.]

In June, 1s\&1, Mrs. E. R. Thurber, of Vacaville, sent me some olive branches (Fig. 92, Plate 1) which were infested by this beetle. In the Fall of 1851, grape cuttings (Fig. 93, Plate 1) were sent me from Sonoma County, with a beetle, which 
proved to be this species, burrowing into the pith. In 1882, I received apple, pear, cherry, almond, apricot, peach, and olive branches, all of which were infested by this beetle. I also visited one pear orchard, and one orchard in which olives are grown, and found some trees damaged to a serious extent. The nature of the damage done by this beetle, is the burrowing into the branch and eating the center or pith. (Fig. 94, Plate 1.) The place selected to commence operations is generally in the axil of a bud, or small branch. The burrows made are invariably downwards, and measure from six lines to one inch in depth, and from two to three lines in diameter. A pear branch, thirty inches long, contained eleven of these burrows.

The damage done the trees is caused by their burrows being filled with water by the Winter rains, causing the branches to decay, and also by the branches burrowed breaking off.

The natural history of this beetle (Fig. 95, Plate 1) has not been fully studied, but it is supposed the eggs are deposited and the larvæ live in forest trees.

The perfect insect, both male and female, burrow into the branches of the fruit trees, but the eggs or larvæ have not been found in any of the varieties which they infest. This Spring, 1883 , serious damage has been done by this species to trees planted last year.

Remedies.-Use No. 27, and early in the Spring spray with Nos. 4, 5, or 7 .

\section{CHAPTER LX.}

The Pear-tree Psylla. (Cal.)

(Psylla pyri.-Linnæus.)

Order, Hemiptera ;

Sub-order, Homoptera; $\}$ Family, Aphidide.

[Living in communities upon and puncturing the twigs of the pear tree; a small, yellowish or greenish louse.]

These insects possess the power of leaping, and hence in some localities are known by the name of flea-lice. They 
obtain their nourishment by puncturing the twigs with their heaks and imbibing the sap. The larre. or young, are of a dullorange color, and are obtuse behind. (Pupa, Fig. 90). The perfect or winged insects (Fig. 91) are a little orer a line long to the tip of the closed wings; the eyes are large and prominent; the head and thorax are of a brownish-orange color, and the abdomen is greenish; the wings are transparent. I have found this species in one orchard only, and not sufficiently numerous to do much damage to the trees infested.

Fig. 90.

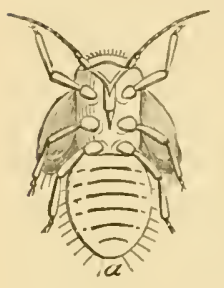

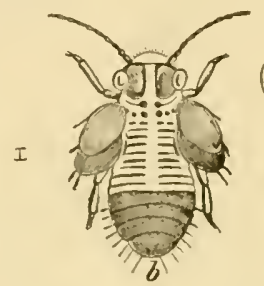

Fig. 91.

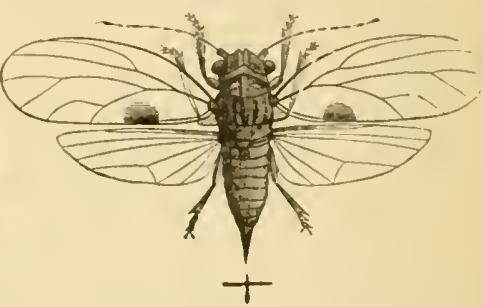

Fig. 90.-Pupa of Pear-tree Psrlla, highly magnified-colors, orange-red and black; $a$, rentral view; b, back riew.

Fig. 91.-Pear-tree Psylla, enlarged-colors, orange-red and black.

Revedies.-Trees, infested the previous year should, when dormant, be thoroughly sprayed with No: 13-five pounds of mixture to six gallons of water. In April, spray with Nos. $\overline{5}$ or 7 . Repeat the spraying in two weeks, if necessary.

\section{CHAPTER LXI.}

The Pear Slug.

(Selandria cerasi-Peck.)

Urder, Hrimoptera; Family, Texturenisin.

[A small twenty-footed caterpillar. coveres] with a sticky olive-colored slime, infesting the foliage of the pear and cherry trees.]

The specific name, cerasi, given to this saw-fly, places this 
insect as a pest of the cherry tree, but in this state it does most injury to the pear; therefore, it is placed in the list of pear insects.

The pear slug is found in many orchards in Central California; it feeds upon the foliage of the pear, the cherry, and the plum tree, but only eats the epidermis off of the upper sicle of the leares, leaving the framework and under surface untouched.

"The trees attacked by them are forced to throw out new leaves during the heat of the Summer at the end of the twigs and branches that still remain alive; and this unseasonable foliage, which should not have appeared until the next Spring, exhausts the vigor of the trees and euts off the prospect of fruit."-Harris.

The egg is deposited in a cut made in the leaf, by the sawlike apparatus or ovipositor of the female. Nineteen eggs have been found deposited in one leaf.

The larra (Fig. 96) is hatched from the egg in two days, and feeds upon the leaves, as described above; it attains its full growth in from twenty to twenty-five days. During the time it is feeding it exudes an olive-colored slimy substance, which covers the body and gives it the appearance of a tadpole. When it ceases eating it casts its skin and shimy coat, and appears with a clean, yellowish skin; the divisions of the segments of the body are plainly seen; it then descends to the earth and crawls beneath the surface, from one to four inches, and forms a cocoon, where it undergoes its metamorphoses or chainges; in about fifteen days the perfect insect (Fig. 97) appears.
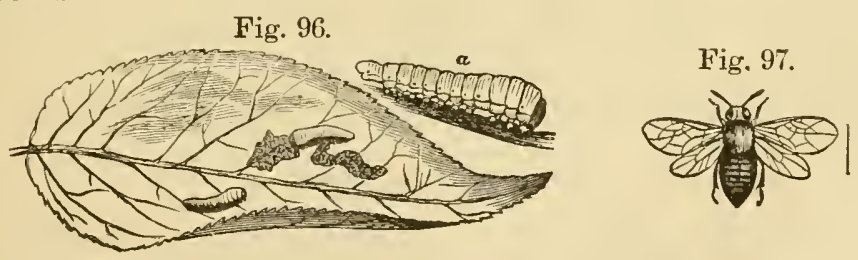

Fig. 96.-Pear Slug; an infested leaf on which are two slugs ; above it is one of the slugs, enlarged-color, olive-brown.

Fig. 97.-Pear-Slug Saw-fly, enlarged--color, black.

The first brood appears late in April, or early in May; the 
second, early in July. When the larvæ of the second brood are full grom they enter the earth, and remain unchanged until the following Spring. Harris says, referring to the first brood:

"It seems that all of them, however, do not finish their transformations at this time; some are found to remain in the ground unchanged till the following year, so that if all the slug: of the last hateh in any one year should happen to be destroyed, enough from a former brood would still remain in the earth to continue the species."

There are apparenty but two broods in each year.

Larva length, five and one half lines. Perfect insect, body. shining black, nearly three and one half lines long; expanse of wings, six lines; wings transparent; lower part of fore anterior legs, dirty-white.

Renedies.-Use No. 61 and No. 63.

\section{CHAPTER LXII.}

\section{The Pear-leaf Caterpillar. (Cal.)}

\section{(Nematus Sp?)}

Order, Hriexoptera; Family, Texthredinide.

[A small twenty-footed caterpillar, feeding upon the foliage of the pear tree.]

Considerable damage has been done to pear trees in the Sacramento Valley by a small green caterpillar (of a saw-fly) eating the leaves. In some orchards the varieties of pear trees which were the first to put forth their leaves were seriously infested, and not only injuring the erop of fruit on the trees by destroying the foliage, but also the crop of the next year.

\section{NATLRAL HISTORY.}

About the time the leares begin to appear, the eggs are deposited in a small slit or opening made by the oripositor of the female $f y$ in the surface of the leaf. These are hatched in about ten days. 
The young caterpillar (Fig. 9S) commences to feed by eating a short track, apparently under the surface of the leaf; it eventually makes an opening in which it feeds until one fourth grown, or six days old; it then leaves this opening and commences feeding on the edge of the leaf, and as there are often from one to eight on a leaf, they move from one leaf to another until full grown, which is in about twenty-two days from the time they were hatched. When the larva, or caterpiller, ceases to eat, it descends to the earth and crawls below the surface and makes a tough, dark-brown oval cocoon. In this cocoon it hibernates, in the larval state, until the next Spring. Caterpillar (larva); length, six lines; color, green; head, yellowish-green ; eyes, black; twenty legs.

Fig. 98.

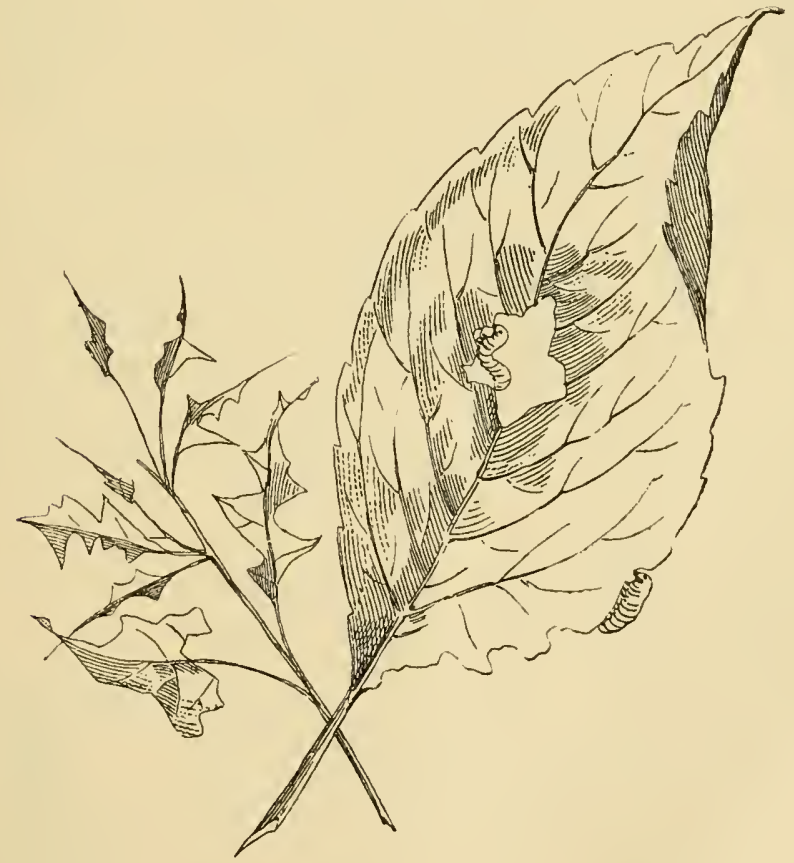

Fig. 9s.-Pear leaf, caterpillar and work. 
Fig. 99.-P'ear-leaf sall-lly-rolors, black and rellow.

Perfect insect ( Fig. 99)-length of body, three and three fourths lines; expanse of wings, about seven lines; color, head and thorax black, aldomen yellowish, with a black transverse band on the dorsal half of each segment; wings transparent, with a brownish hue.

There is, apparently, only one brood each rear.

Fig. 99.

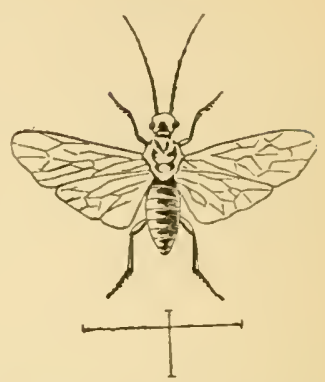

REnEDIEs-As soon as the larve appear, spray as directed in No. 61, or 65; also, see No. 62.

\section{C'HAPTEL LAIII.}

The Thrips.

Order, HeMtetera;

Sub-order, Heteroptera ;

Family, Thripide.

[Feeding upon the upper surface of the leaves of the pear, peach, ete., minute black or yellow six-legged insects.]

Last year, $185 \%$, the owners of a great number of orehards complained that the leaves of the pear, peach, and plum trees were attacked by some insect or disease which caused them to wither and fall off. On examination they were found to be infested by a species of Thrips not heretofore noticed on fruit trees in this sitate.

The leaves infested by these insects appeared marked all over their surface with minute black lots, either caused by the bite of these minute insects or were their excrements. Many of the loranches, especially on the lower part of the tree, were denuded of their foliage.

Fig. 100.-Larva of Thrips-colors, bright and dark yellow.

The larva (Fig. 100) of this species of Thrips is one twenty-sixth of an inch in length; colur, primrose-yellow, with narrow

Fig. 100.

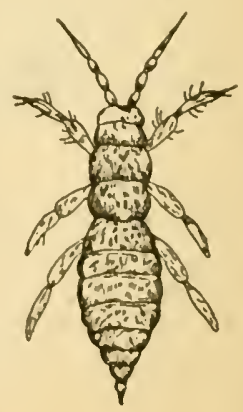


transverse orange-colored markings. (Fig. 100, highly magnified.)

The pupa (Fig. 101) is one twenty-fifth of an inch in length; about the same color as the larva, only the transverse markings are not so clear. The legs and antennie are obscured by a film, the wings are in a sheath (see Fig. 101, magnified), and the insect moves more sluggishly than when in the larva state.

Fig. 101.

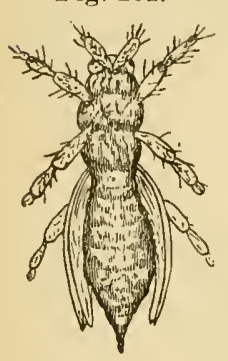

Fig. 101.-Pupa of Thrips-col- Fig. 102. or, yellow.

Fig. 102.-Thrips-color, black.

The perfect insect (Fig. 102) is one twenty-second of an inch in length; body black; wings black, bordered with a silvery fringe; there is a yellowish transverse bar aeross the base of the wings.

REMEDIES.-As soon as the thrips are noticed on the foliage,

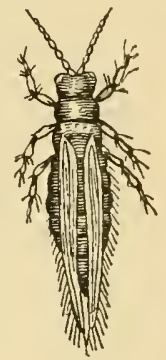
spray thoroughly with No. 4, or No. 5, or No. 7 ; repeat spraying if necessary. 


\section{INSECTS INFESTING THE QUINCE.}

CuAP. The Round-headed Apple-tree Borcr (Saperda candida).

The Red Spider (Tetranychus telarius).

The Codlin Moth (Caryocapsa pomonella).

The Plum Curculio (Conotrachelus nenuphar).

The Apple Curculio (Anthonomiss quadrigib. bus).

The Negro Bug (Corimelcena pulicaria).

\section{CHAPTER LAIY.}

The Quince Scale.

\section{(Aspidiotus 'yduniz'-Comstock.)}

Order, HeMrtera ;

Sub-order, Homoptera; $\{$ Family, COCCIDA.

[A species of scale insect found on the quince in Florida.] Prof. Comstock reports this species in Florida, and states in appearance the scale is indistinguishable from that of the greedy scale-(A. rapax).

Remedies.-Same as for San Jose Scale (A. perniciosus), Chap. XX.

\section{CHAP'TER LXY.}

The Quince Curculio. (Cal.)

(Conotrachelus crateyi-Walsh.)

Order, Coleoptena; Family, Curculaorida.

[Living in quinces and pears, a whitish, footless grub, about four lines long, with a distinct tuberele on either side of each segment, and a reddish-brown head; usually, but not always, deserting the fruit and entering the earth to pupate.] 
The female curculio punctures the fruit and deposits an egg therein. This hatches out in a few days, and the grub works, for the most part, near the surface of the fruit, never, as far as known, entering the core. It acquires its full growth in about a month after leaving the egg, and then usually, but not always, deserts the fruit and burrows two or three inches into the earth. Here it forms a small cell, in which it remains unchanged until the following Spring, no matter whether it left the fruit as early as the first of August or as late as the first of October. In April of the following year, the larva assumes the pupa form, from which the beetle issues in the course of a week or two.

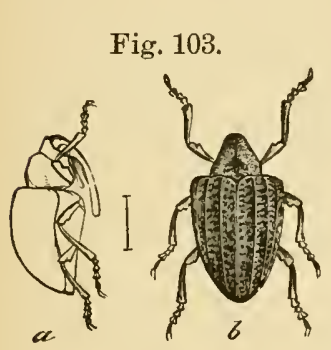

Fig. 103.-Quince Curculio, enlarged; $a$, sicle view: $b$, back view-color, ashgray.

The beetle (Fig. 103) is about two lines long, of an ashen-gray color, mottled with pale-yellow, dusky and whitish, and at the base of the thorax is a somewhat triangular dusky spot. The body is broadest at the shoulders, and the wing cases are destitute of humps. The snout is longer than the thorax and is bent beneath the breast.

I have found but two specimens of this species, and these were found in 1882 .

REMEDIES.-In the latter part of April, spray the foliage and fruit thoroughly with Nos. 5 or 7 . Repeat in two weeks if necessary. 


\section{INSECTS INFESTING THE PEACH TREE.}

CHAP.

The Peach-tree Borer (Aegeria exitiosa)...66 The Peach Jloth (Anaria lineatella).....67 The Peach Leaf-roller (Crasia quersicana) . .68 The Peach Aphis (Myzux qureica).........69 The Indian Cetonia (Cetomia ind $\alpha) \ldots \ldots \ldots 70$ The Green Fruit-beetle (Gigmnetis nitida)..71

The following insects also infest the P'each tree :

The San , lose Scale (Asyidiotus gremiciosus). The Grcedy scale (Asyridiotus rograx).

The Flat-headed Apple-tree Borer (Chrysobothris femorata).

The Cherry-tree Borer (Dicerca divaricata).
The Apple-twig Borer (Bostichus brauda(iivi).

The Branch and Twig burrower f'wlycam confertux).

The Snowy Tree (ricket (Oecanthus niveus). The Buffalo Tree-holper (Coresa bubalus).

The Many-dotted Caterpillar (Brachytania malara).

The Almond Aplis (Aydic amygdali).

The Red Spider (Tctramychus telarius).

The Yellow Mite.

The Codliu Moth (Caryoragia gromomella).

The Plum Cureulio (Comotrachelus nemuyhar). The Thrips.

\section{CHAPTER LAVI.}

\section{The Peach Tree Borer}

\section{(Ageria exitionat-say.)}

Order, Lepmoptera; Family, Aegeride.

[Boring into the trunks of peach, plum, cherry and similar trees, a pale yellow sixteen-legged larva.]

The peach trer borer is widely distributed over the greater part of the Gnited states. and wherever found it is one of the most pernicions enemies of the peach tree.

The arg from which this horer hatehes is deposited in the latter fart of summer upon the trunk of the tree, usually near the rocts, but sometimes at the hase of one of the lower limbs.

As som ans hatchor, the young borre hegins to eat its way lownwarl through the bark and sapwood, continning its rourse in this direction until the following spring, when it turns alsont and direets its course upward. before pupating. it forms a coconn composed of its chips and castings, mised 
with gum. The perfect insect issues during the latter part of July, or during the month of August. The presence of this borer may easily be detected by the mass of thick gum mixed with the castings of the larva, which accumulates around the opening of its burrow. It usually works in that part of the tree which is at or just beneath the surface of the ground, although it oceasionally occurs in the crotehes, or upon some other part of the tree.

Fig. 104.-Peach Tree Borer-color, yellowish.

The full grown larva (Fig. 104) measures from six to eight lines in length, and

Fig. 104.

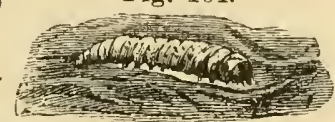
is pale yellow, and provided with sixteen legs; the head is reddish, marked with black.

Fig. 105.-Peach Tree Borer (moths)-colors, steel blue and yellow; 1 , the female moth; 2 , the male moth.

The perfect insects into which these borers are

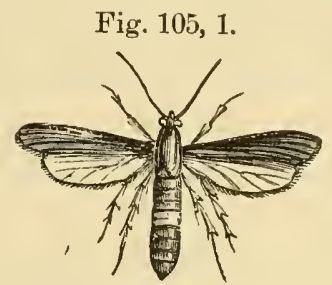
Fig. 105, 2. finally transformed somewhat resemble wasps, being provided with four nearly transparent wings. The female (Fig. 105, 1,) differs so much from the male (Fig. 105, 2,) as to cause her to be mistaken for a distinct species. Her body is of a steel blue color, with a dark orange colored band across the middle of the abdomen; the fore wings expand about one inch and six lines, and are of a steel blue color ; the hind wings are transparent, but are veined and bordered with steel blue.

The male expands obout one inch; the wings are transparent, and are bordered and veined with steel blue; the forewings crossed beyond the middle by a band of the same color; the body is also steel blue, and the edges of the collar and shoulders tufts, as well as two rings on the abdomen, and the brush at the end are pale yellow.

Remedy.-Use No. 37 in July and August, or No. 98-the latter is preferable. 


\section{CHAPTER LXVII.}

\section{The Peach Moth. (Cal.)}

\section{(Anarsia lineatclla.-Zeller.)}

\section{Order, Lepinoptera; Family, Tixeid}

[A small reddish-pink larva, from four to five lines in length, horing into the fruit of the peach and apricot; also, into the buds and the new growth of the peach.]

In $15 S 2$ the larva (Fig. 106, Plate 1) of this species was found boring into peaches (Fig. 107, Plate 1) and apricots in several of the fruit-growing distriets of this State. The moth or perfeet insect is small; length, three lines; spread of wings, about six lines; color, dark-gray ; antenm gray, ringed with brown; wings gray, with brown streaks; hind wings, smokygray ; cilia, gray. Larva length, nearly four lines; color, reddish-pink; head, brownish-black.

I found a larva in a peach early in June, 1SS2. It left the fruit on the $13 \mathrm{th}$, and was changed to a pupa by the 16 th. On the 25th of June, the perfect moth appeared. The larva in apricots matured to perfect insect in about the same length of time. I have also found the larva of this moth in peach buds, also in the end of the new growth. In the latter it can be easily detected, as the new leaves present a withered appearance. The larva passes its transformations in the dehris in the crotches of the trees. or on the ground among fallen leaves, ete. I have found them more than half grown in the buds in Jannary, hut apparently in a semi-dormant state.

The variety found in the fruit of the aprieot and peach is lighter in color than that found in the buds and new growth. The perfect inseet (Fig. 106, Plate 1) that is reared from the fruit-eating larva, is lighter colored than those raised from the bud or new growth karra.

There are probably three broods each year. From the limited opportmities I have had tu investigate the natural history and habits of this pest, I am inclined to think that a part at least of the so-called sap disease, or gun ocozing from 
the buds is caused by the boring of the larva of $A$. lineatella, but will not say positively that such is the case. It is also reported as a destructive pest to the strawberry, by eating channels through the crown of the plant, and also burrowing into the runners.

Since writing the above, I have reared a number of the perfect insects. The larva leaves the fruit to pass its tranformations. When it selects a place it spins a few threads, then changes to pupa. It remains in the pupa state from seven to ten days, according to the temperature.

This season (1883), specimens of plums, prunes and nectarines have been received infested by the larva of this moth.

Peaches received in this city (Sacramento) in July last, had at least forty per cent. infested by this pest. The moth deposits the egg on the fruit, generally near the stem.

Revedies.-See No. 67, and use Nos. 5 or 7 as spray, For strawberries, see No. 68 .

\section{CHAPTER LXVIII.}

The Peach-leaf Roller. (Cal.)

(Crusia persicana.-Fitch.)

Srooxys.-Ptycholoma persicana.-Fitch.

Order, Lepidopteria ; Family, Tortricide.

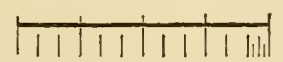

[The measurements of insects in this work are given in inches and lines. The above cut lepresents one inch divided into lines and fractious thereof.]

[Living singly in a nest of newly-expanded leaves on peach trees; a pale-green worm, with two white lines along the back, the head dull-yellowish.]

This leaf-roller assumes the pupa state in its nest. The fore-ivings of the perfect moth expand about eight lines, and are of a yellowish color, varied with black, and marked with white spots.

ReMedy.-Use No. 24. 


\section{CHAPTER LXIX.}

\section{The Peach Aphis. (Cal.)}

(Myzus persicx.—Sulzer.)

\section{$\left.\begin{array}{l}\text { Order, Hemiptera; } \\ \text { Sub-order, Homoptera } ;\end{array}\right\}$ Family, Aphiddiz.}

[Living on the underside of the leaves and on the new growth of peach, prune, and nectarine trees, causing the leares to eurl and thicken by puncturing them with their beaks and extracting the sap; small, black or reddish-brown plant-lice.]

The wingless females are rusty red; the winged females are black or greenish-brown.

The winged males are a bright yellow, with a transverse brown streak on the thorax, and a few streaks of the same rolor on the abdomen.

Remedies-When the tree is dormant, sluray with No. 11 or 12; when in leaf, use Nos. 4,5 , or $7-5$ or 7 preferable.

\section{CHAPTER LXX.}

\section{The Indian Cetonia.}

\section{(Cetonia inda.-Linnæus.)}

Srvorru.-Euryomia inda.

\section{Order, Coleoptera; Family, Cetonide.}

[Eating into peaches, pears, and grapes; a coppery-brown beetle, about six lines or half an inch long, sprinkled with brown dots, and thinly covered with yellowish hairs.]

Fig. 108.-Indian Cetonia-color, coppery-brown. Fig. 108.

The larral and pupa stages of this insect are unknown, but it probably lives in the ground during the larral state, feeding upon the roots of plants.

The beetles (Fig. 108) make their appearance in the Autumn and again in the Spring, passing the Winter in some sheltered situation. 


\section{CHAPTER LXXI.}

The Green Fruit-beetle. (Cal.)

\section{(Gymnetis nitida.-Linnæus.) Synonyu-Allorhina nitida.}

Order, Coleoptera; Family, Cetonide.

[Feeding upon ripe peaches, pears, plums, figs, and melons; a green beetle (Fig. 109c) measuring about one inch and two lines in length, having the wing-cases bordered with yellow; or feeding upon the roots of strawherry plants, ete, a whitish six-legged larva.] (Fig. 109a.)

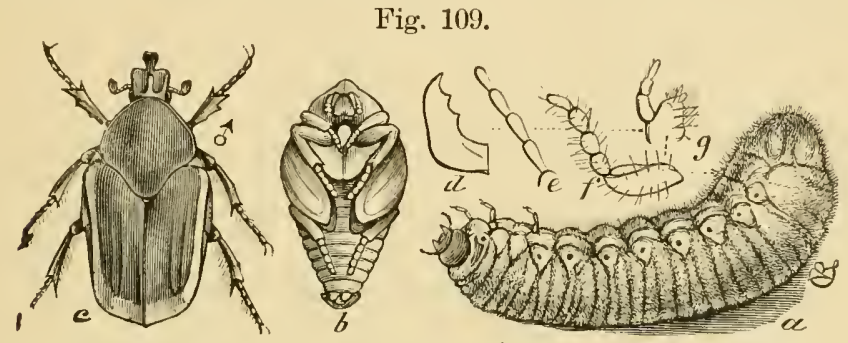

Fig. 109.-Green Fruit-beetle, Larva and Pupa; c, the male beetle-colors, green and yellow; $b$, the pupa-color, brown; $a$, the larva, or grub-color, whitish; $d$, its upper jaw, enlarged; $e$, its antennæ, enlarged; $f$, one of its legs, enlarged; $g$, its upper lip and palpus.

This species is very scarce in this State, as but few specimens have been found. It is plentiful in Arizona Territory, and is very destructive to peaches and melons. 


\section{INSECTS INFESTING THE APRICUT.}

CHAP.

The Red-bodied Saw Fly (Dolerus tejonicus).72 The Apricot Leaf-roller (Dichalia californiana $\ldots \ldots \ldots \ldots \ldots \ldots \ldots \ldots \ldots \ldots . \ldots \ldots$ The Striped Bud-beetle (Disonycha limhicollis).......................

The following insects also infest the Apricot : The Greedy Seale (Aspidiotus rapax). The Pear tree Scolytus (S:o'ytus pyri).
The Branch and Twig-burrower (Polycaon confertus).

The Peach IIoth (Anarsia lineatclla). The Robust Leaf Bectle (Serica valida). The Buffalo Tree-hopper (Ceresa bu'yalus). The Red Spider (Tetranychus telarius). The Plum Curculio (Conotrachelus nenuyhar) The San Jose Scale (Aspidiotus perniciosus). The Black Scale (Lecanium olere).

The Cottony Cushion Scale (Irerya purchasi).

\section{CHAPTER LXXII.}

The Red-bodied Saw Fly. (Cal.)

\section{(Dolerus tejonicus.-Norton.)}

\section{Order, Hymenoptera; Family, Texthredinide.}

[A four-winged saw-fly with dark wings and a recldish body, cating the leaves and shoots of young fruit trees.]

About the 1.5th of Mar. 1853, a young orchard planted in 1882, was attacked by this saw-fly (Fig. 110, Plate 1). The owner of the orchard writes on the $3 \mathrm{~d}$ of June: "The flies injured my trees very much by eating the leaves and young shoots off entirely; many of the trees have sent out new growths, but many have not, and appear as though they were killed."

The following is the description of this new pest: Head, black; antenne black. nine-jointed; thorax reddish, hinder portion and scutollum black: abdomen marked with black at the base; legs. black; wing: alouded with smoky oi blackish; the veins and rosta deep, black; length of body nearly half an inch: sprearl of wings, three fourths of one inch. 
At a later date, June 26, the orchardist writes: "They are now feeding on the weeds around the orchard."

Note.-This saw-fly, if not identical with the European saw-fly, Dosytheus lateritius-Klug., very closely resembles that species. The larval history of this insect is unknown to us at the present time.

ReMEDY.-Spraying the foliage with No. 5, or 7 , or 65 , will protect it from the ravages of this pest.

\section{CHAPTER IXXIII.}

The Apricot Leaf-roller.

(Cal.)

\section{(Dichoelia Californiana.-Walsingham.)}

\section{Order, Lepidoptera; Family, Tortricide.}

[A small caterpillar, living in a rolled leaf, and feeding upon the new leaves and growth of the apricot tree. It also feeds on the fruit after it sets forth from the bloom.]

This caterpillar appeared in several orchards in the Spring of 1882. In one instance it nearly destroyed the entire crop of apricots, by feeding upon the fruit. I did not succeed in rearing the moth last year, but this season I have been successful. It has attacked several orchards this Spring, 1883; in one case young trees planted last Spring from the dormant bud, were nearly denuded of their foliage by this pest. In other cases it has fed on the fruit. The caterpillar first attacks the fruit when about the size of a small marble-first fastening a leaf to it. At first it feeds upon the epidemis, or skin, but as the caterpillar grows larger it eats into the fruit. When not feeding, it returns to its nest. At other times it folds a leaf and feeds upon the new shoots and leaves near its nestin some cases nearly cutting off the former.

The body of the caterpillar (Fig. 111, Plate 1) is yellowishgreen, with a dorsal line of a darker shade; head and cervical shield brownish-black, with a pale space between them ; spiracles, ringed with brown; length, seven to eight lines.

The perfect insect (Fig. 111, Plate 1) emerged from the pupa 
case on the 6 th, 7 th, 11 th, and 12 th of June, after remaining in the pupa state ahout eleven days.

The moth is of a golden ochre-rellow color: the fore wings are crossed near the middle, by an oblique reddish-l,rown irregular band, on which are scattered some bluish scales; and there is a reddish-brown bar, tinged with yellow, across the outer end of the wings; hind wings, reddish-brown, marked with whitish on the front edge: legs, vellow; length, from front of head to apex of fore wings (when at rest), nearly four lines; spread of wings, about nine lines. There are two broods each year.

Rementes-As directed in No. 24. Spray early in May, with Nos. 5 or 7 , or 65.

\section{CHAPTER IAXIV.}

\section{The Striped Bud-beetle. (Cal.)}

\section{(Disonyche limbirollis.-Leconte.)}

Order, Colleoptera ; Family, C'Hryomeline.

[A five-striped beetle, similar in size and appearance to the striped cucumber beetle ( $D$. vittata), feeding upon the buds of apricot trees.]

This species has appeared in immense numbers in several localities, and many persons supposed it to be the striped cucumber beetle. It hibernates in the jerfect state (Fig. 112. Plate 1), and as soon as the warm weather begins it appears in the orchards and attacks the fruit-buds as soon as they begin to swell, seeming to have a preference for the aprieot. After their appearance in the early spring, at night and on cold disy, they gather together in large numbers. As many as one or two gallons have been found on one tree, fence, frame of windmill, etc., apparently in a semi-dormant conelition; but as soon as the weather became warm again they took to flight. This beetle is elongate-oval in shape; thorax, black, bordered with a narrow light-yellow margin; the wingcases are light yellow, marked with five lalack lines. The dif- 
ference between this species and the striped cucumber beetle can be readily distinguished. The larva probably lives in the roots of some kinds of plant.

Remedies.-Spray trees infested by this beetle with No. 5 , or 7 , or 65 . If the trees are seriously infested, by stirring or mixing one pound of buhach in fifteen gallons of the mixture, it will effectually destroy the beetle. When gathered in large numbers in one place, as described above, the solution, mixed with buhach, should be used.

\section{CHAPTER IXXIV!}

\section{The Twelve-spotted Diabrotica. (Cal.)}

\section{(Diabrotica 12-punctatu.-()]ivier.)}

Order, Coleoptera; Family, Chryomelide.

[Feeding upon the buds and leaves of various kinds of plants, and also upon ripe or nearly ripe fruit; a yellow beetls (Fig. $112 \frac{1}{2}$ ) about three lines long, the head black, and the wing-cases marked with twelve black spots.]

Fig. 1121/2.

The early stages of this beetle have never been traced out, but it probably lives in the gromel in the larval state, feeding upon the roots of plants.

Fig. 112 $\frac{1}{2}$ - - Twelve-spotted Diabrotica-colors, vellow and black.

Rementes.-The fruit in an orchard in this vicinity (Sacrimento) was attacked by these pests in the month of August, 188:. The owner sprayed the trees with a solution composed of six pounds of buhach steeped in one gallon of alcohol, then diluted with twenty gallons of water; this destroyed the posts very effectually. I have succeeded in driving them ofl of the trees by spraying the latter with Remedy No. 5 or 7 , one pound to each gallon of water used.

Note.--Since writing the article on the Horned Flower-beetle (page 259), 1 learn that these beetles sometimes burrow into ripe peaches, pears, and phums; and they are also eharged with gnawing off the green grapes and lelting them fall upon the ground.

When furnishing copy to the publisher, this Chapter was overlooked and not detected intil too late.-M. C. 


\section{INSECTS INFESTING THE CHERRY TREE.}

The Cherry-tree Borer (Dicera divaricata). 75 The Cherry Tortrix (Loxotania cerasicor.

ana $\ldots \ldots \ldots \ldots \ldots \ldots \ldots \ldots \ldots \ldots \ldots \ldots$

The Cherry Worm..................

The following inseets also infest the Cherry tree :

The Woolly Aphis (sithizoneura langera).

The Lemon-peel Seale (Aspidiolus nerii.)

The Peach-tree Borer (Egeria exitiowa.)

The Branch and Twig-burrower (Polycton confertus.)

The IIarvest-fly (Ciccidu.)

The Orchard Tent-caterpillar (Clisiocamya A mericana.)

The Forest Tent-caterpillar (Clisiocainqa syl vataca.)
The Red-humped Caterpillar (Notodonta con. cinna.)

The Canker Worms.

The Grenter Leaf-roller (Loxotania rosaceana.) The Many-dotted Caterpillay (Erachylania malana.)

The Turnus Butterfly (Payilio turnus.)

The Pear Slug (Selandria cerasi.)

The Red Spider (Tetranychus telurius).

The Yellow Mite.

The Rose Chafer (Macrodactylus subspinosus.) The Angular-winged Katydid (Microcentrum retineris.)

The Brown Strawberry-weevil (Listronotus neradicus.)

The Segro-bug (Corimclena pulicaria.)

The Plum Curculio (Conotrachelus nenuphar).

\section{CHAPTER LAXY.}

The Cherry-tree Borer. (Cal.)

$$
\text { (Dicerea diraricata-Say.) }
$$

Order, Coleoptera; Family, Buprestide.

[Boring beneath the bark of cherry and peach trees; a yellowish footless grub, having the second segment greatly widened and flattened.]

This borer closely resembles the flat-headed apple-tree borer in all its stages, as well as in its habits.

The perfect beetle (Fig. 113) is from eight to eleven lines

long, and is of a shining bronze or copper-color; the wing-cases are elongated, their tips separating quite widely from each other, and appearing as if broken squarely off at the apex.

Fig. 113.-Cherry-tree Borer-color, coppery-gray. REMEN:-U'se No. Ӟ7. 


\section{CHAPTER LXXVI.}

\section{The Cherry-tree Tortrix. (Cal.)}

\section{(Loxotrnia cerasivorana-Fitch.)}

Order, Lepinoptera ; Family, Tortrictod:

[Living on cherry trees, between two leaves, or in communities in a large nest formed by fastening the leaves and branches together with silken threads; a nearly naked, paleyellow eaterpillar, with the head and a spot on top of the fore and hind parts of the body, black.]

This caterpillar pupates within its nest, and a short time before the perfect moth issues, the pupa works itself part way out of the nest.

The moth (Fig. 114) expands from nine to thirteen lines, is of a pale ochre-yellow color, marked with pale leaden spots or bands; the hind wings, and the under side of all the wings are pale yellow.

Fig. 114.-Cherry Tortrix-colors, yellowish and brown.

Remedies. - When the tree is dormant, spray with No. 13-five pounds of the mixFig. 114. ture to six gallons of water; or, No. 11 or 12. As soon as the fruit sets well from blossom, use Nos. 5 and 7 .

\section{CHAPTER LXXVII.}

\section{The Cherry Worm. (Cal.)}

Order, Hyanoptera; Family, Tenthredinide.

[A small twenty-footed larva, eating into eherries.]

Speeimens of cherries infested by a small, twenty-footed larva, have been received from at least three localities, situated about thirty miles from each other.

The larva (Fig. 115, Plate 1), when full grown, measures about three lines in length; color-body yellowish-white, 
immaculate, anal shield a little darker than body; head small, round and pale-yellow; eyes black; twenty legs.

The egg is probably laid by the parent fly on the cherry when the latter is about the size of a pea; as soon as hatched the larva commences to feed upon the skin of the fruit and cats in toward the pit or stone. In the young fruit it eats into the pit, but when the cherry is more than half grown it seldom attacks the pit. When the larva is full grown it evidently leaves the fruit to prepare to go through its change (metamo)phosis) in the ground or elsewhere. The specimens were received too late in the season to learn the natural history of this pest ; and failing to rear the perfoct insect, it is only by analogy that its history can be referred to, therefore its having torenty legs: inclicates that it is the larva of a saw-fly, and as the full grown larra is only three lines in length, the perfect insect on Hy must be very small.

Remeny.-The natural history of this insect being unknown to me at present, I can only recommend the picking off of the trees all infested fruit and boiling it, or otherwise making such use of it as will destroy the insect which it contains. It would be benefieial to the tree to spraty it when dormant with No. 11 or 12. Or No. 13-five pounds to each six gallons of water used. 


\section{INSECTS INFESTING THE PLUM TREE.}

The Plum-tree Aphis (Aqli is qruni) .....78

The Plum Leaf-hopper (Bythosecrous clitel-

larius)

The Plum Cureulio (Conotrachelus nenushar.

...80

The Plum Gouger (Anthonomus pminicida).81

The Plum Moth (Semasia qminiane)... . . 82

The following insects also infest the Plum Tree :

The San Jose Scale (Aryidiotus querniciosus). The Greedy Scale (Aspilliotus rayax).

The Lemon-peel Seale, Asyridiotus nerii).
The Peach-tree Borer (Aegeria exitios $\alpha$ ). The Pear-tree Scolytus (Scolytus quyri). The Buffalo Tree-hopper (Ceresa bubalies). DeLong's Caterpillar (Clisiocamya constricta). The Tussock Moth (Orygia leueostigma). The Red-humped Caterpillar (Notodonta con(inno).

The Apple-leaf Crumpler (Phycita nebulo). The Red Spider (Tetranychus telarius). The lobust Leaf-Beetle (Sericu valida). The Green Fruit-Beetle (Gymmetis nitila). The Thrips.

The Peach Moth (Anaria lineatella.)

\section{CHAPTER IXXYIII.}

The Plum Tree Aphis. (Cal.)

(Aphis preni.-Koch.)

SYNonym.-A. prunifolia.-Fitch.

$\left.\begin{array}{l}\text { Order, Hemprera; } \\ \text { Sub-order, Homoptera }\end{array}\right\}$ Family, Amimme.

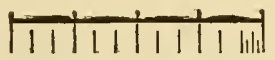

[The measurements of insects in this work are given in inches and lines. The ahove cut represents one inch divided into lines and fractions thereof.]

[ Jiving on the under side of the leaves of the plum, which they puncture with their beaks and extract the sap; small greenish plant-lice, usually marked with black.]

The wingless lice are greenish-white; or the head is black, the thorax green, with two transverse black lines, and the abdomen is green, dotted with black, and marked on the top with a large dark eolored spot. 
The winged lice have the head and thorax black, usually with a green ring around the neck; the abdomen is colored similar to that of the wingless lice, but is larker.

This species is very destructive to the plum and prune.

Remedies.-When the trees are in leatf, use No. 3 or 4 , or No. 5 or $\bar{~}$; when dormant, spray with No. 11 or 12 , as directed ; or No. 1:-five pounds to six gallons of water.

\section{CHAPTER LXXIX.}

The Plum Leaf-hopper.

\section{(Bythosenpus rlitellarius.-Say.)}

$\left.\begin{array}{l}\text { Order, Hennprena: } \\ \text { sub-order, Hunoptera ; }\end{array}\right\}$ Family. C'ecropide.e.

[Puncturing the fruit-stens of plums and extracting the sap; a small cylindrieal, slightly tapering leaf-hopper, about two and a lalf lines long; black or dark brown, with a bright, sulphur-yellow spot on the middle of its back and a pale yellow band in front of this ; the heal pale yellow, with two black dots on the forehead.-Fitch.]

REmidis.-When the tree is clormant, spray with No. 11 or 12, as directed; or with No. 13-five pounds to six gallons of water. For Summer wash, use Nos, :3, 4, 5 , or 7 ; those mixed with sulphur are preferable.

\section{CHAP'TER LXXX.}

The Plum Curculio.

\section{(Conotrachelus nemphar.-Herbst.)}

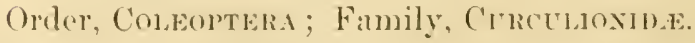

[Living in ]lums, cherries, peaches, pears, nectarines, aprieots, yuines and apples, a rellowish-white footless grub which undergoes its transformations in the earth.] 
This is undoubtedly the worst enemy with which the fruitgrower has to contend-in fact its operations have become so extensive that the raising of plums has become almost entirely abandoned in several sections of this country. This pest can be kept in check by following the proper course, but it requires constant watching; or, as Professor Riley remarks, "eternal vigilence is the price of fruit."

Fig. 116.-Plum, showing egg-puncture and crescent-mark of the plum Curculio; also, a curculio resting upon the plum.

The female curculio makes a small hole

Fig. 116.

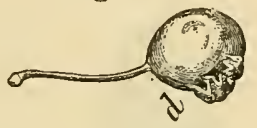
in the fruit (Fig. 116) with her snout, then turns around and deposits therein a single egg; after which she gnaws a crescent-shaped slit around and partially under the egg. This precaution is probably taken in order to prevent the fruit from growing over and thus destroying the egg. On account of this habit, the insect has been named the "Little Turk," the crescent being the national emblem of the Turkish Empire.

This crescent is a pretty sure indication that the fruit upon which it appears is infested with the curculio, although upon apples and similar fruits the growth of the fruit is so rapid as to obliterate the crescent in a short time. Each female is supposed to have a stock of from fifty to one hundred eggs, and to deposit from five to ten a day. While those which appear earlier begin this work by the middle of May, it is continued by others, which appear later, so that the period of egg-laying is extended to a perior of about two months.

Fig. 117.-Larva of Plum Curculio, Fig. 117. enlarged-color, yellowish-white.

The larva (Fig. 117) which hatches from the egg of the curculio is a small footless worm, somewhat resembling

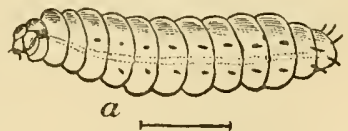
a maggot, except that it does not taper so much, and it has a distinct head. It is of a glossy yellowish-white color, but partakes more or less of the color of the flesh of the fruit it infests. There is a lighter line rumning along each sicle of the body, with a row of minute black bristles below, and a less distinct one above it. The under part is reddish-brown, and the head is yellowish or pale brown. When fully grown it 
measures abont five lines in length. As soon as it rearhes its full growth, the larva rleserts the fruit-which usually falls to the ground before ripening-and enters the earth to the depth of a few inches, where it forms a small cell in which to pass the pupa state (Fig. 11S). It remains in this state about three weeks when the change to the perfect state taks place.

Fig. 11s.-Pups of Plum Cureulio, enlargerlFig. 118. color, yellowish-white.

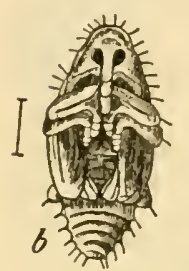

Fig. 119. - Plum C'urculio, enlarged-colors, brown, yellow, black and white.

The perfect beetle (Fig. 119) or atureulio is about two lines long.

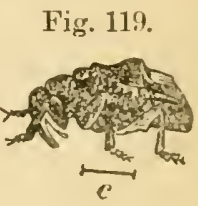
and is of a dark brown color, rarigated with white, rellow and black; the snout is rather longer than the thorax-the latter is uneven; the wingcases have two black tubercles on them, one on the millle of each near the suture; behind these is a houd band of dull rellow and white; the thighs have two small teeth on the under side.

This insect lives not only in the fruits mentioned at the head of this article, but also in the black knot infesting flum and chery trees. The perfort beetle feeds not only upon the fruit, but also upon the leave, and even the bark of newlyformed twigs does not esealje its attacks.

The number of broods which this insect produces in one vear is not definitely known, but most authors regard it as being singlo-broosled: the perfert beetles hibernating beneath pieces of wood, ete.. lying upon the ground.

I am not aware that this inseret has been foumcl in this State up to date; hut as we have reecered so many injurious inserts frem the East, it is not at all improbalnle that the plum cur(ulio will make its alpearance among us. The greatest eare should le taken to prevent its importation on nursery stoek from infested districts.

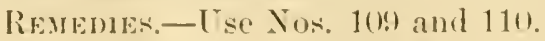




\section{CHAPTER LXXXI.}

\section{The Plum Gouger.}

\section{(Anthonomus prunicida-Walsh.) \\ Synonym.-Coccotorus scutellaris-Lee.}

Order, Coleoptera ; Family, Curculionide.

[Living in the pits of plums; a small milk-white footless grub with a yellowish-white head, passing through its transformations within the pit, and finally producing a brown snoutbeetle, having the thorax pale-yellow.]

This insect, as its name indicates, seems to confine its attacks wholly to the plum. The female gnaws a hole into the fruit and deposits an egg therein; as soon as hatched, the young larva makes its way directly to the pit or stone, which it enters and feeds upon the kernel; after attaining its full growth, it cuts a round hole through the shell of the pit-which is now quite hard-and having thus prepared a place of exit, it casts off its skin and appears in the pupa form, from which the perfect insect issues in the course of a few weeks.

The larva of this species can easily be distinguished from that of the plum curculio by having the under part of its body white, this part being reddish-brown in the eurculio.

The perfect insect (Fig. 120) is about one and a half lines long, exclusive of the snout, which is not much longer than the thorax; the latter is pale yellow, as are also the legs; the wing-cases are brown, with a dull grayish tint, and are destitute of tubercles.-Walsh and Riley.

Fig. 120.-Plum Gonger, enlarged-colors, yellow and grayish-brown.

In 1882 I received specimens of plums, in the pits of which was a small grub, but failed to rear the perfect insect, therefore cannot say if this species is found here.

Renedies.-Use Nos. 109 and 110.

Fig. 120.

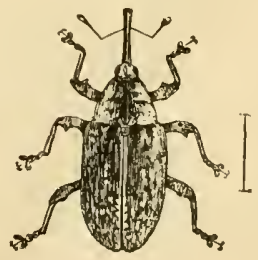




\section{CHAPTER IAXXII.}

\section{The Plum Moth.}

\section{(Somaxia pruniana-Walsh.)}

Order, Lepidoptera; Family, Tortricid...

[Living in plums, apples and crab-apples; a dingy white or brownish-yellow sixteen-legged worm, having a black head.]

It is not known with certainty whether this larva will attack sound fruit, or whether it only infests fruit which has been attacked by some other insect, but the latter is perhaps the (ase, and, if this riew is correct, then this insect cannot be regarded as being very injurious to the orchard. When fully grown, this worm measures about three lines in length; it then deserts the fruit and spins a dark colored cocoon, which is fastened to some neighboring object.

The perfect moth has the fore-wings black and variously marked with red, blue and white, the latter forming seven short streaks along the front edge of the wing; the hind wings are grayish next the body, shading into black at the tips. This insect was bred by Mr. Walsh from the plum; the black linot; a gall produced by plant-lice on an elm leaf: and a gall marle by a four-winged fly on an oak leaf, and I'rofossor Riley has lored it from the apple, crab-apple and haws.

This insect is deseribed in order that investigations may be marle by those who have plums infested by a small whitish larva. I have been umable to procure specimens, but I know of at least six localities in which plums are infested hy a 5 mal ('aterpillar. 


\section{INSECTS INFESTING THE PRUNE.}

The following insects infest the prune, but are treated of elsewhere in this work:

The Robust Leaf-beetle (Serica valida).

The Peach Aphis (Myzus grersiea).

The Peach Moth (Anarsia lineatella).

\section{Tree Cricket (0ecanthus).}

I have received twigs of prune trees containing eggs similar to that of the gray tree ericket (Oecanthus latipenuis-Fig. 121), but whether they belonged to this or to an allied species I am unable to say.

Fig. 121.-Eggs of (iray Tree Cricket; $a$, the wood remored showing the eggs; $b$, punctures containing the

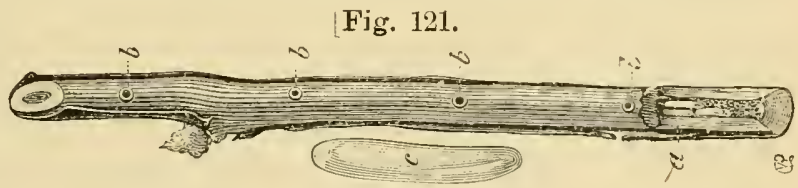
eggs; c, an egg highly magnified-color, white.

Remedies-Use Nos. 25 and 28.

\section{INSECTS INFESTING THE NECTARINE.}

The following insects infest the nectarine, but are treated of in another part of this work: 


\section{INSECTS INFESTING THE PERSIMMON TREE.}

The Persimmon Aphis (Aylis dioxynri)

Chap. 83

\section{CHAPTER LXXXIII.}

The Persimmon Aphis.

(Ahlis diospyri-Thomas.)

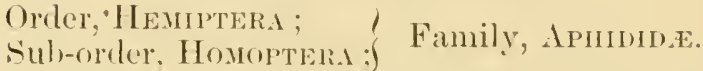

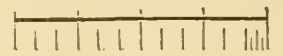

The measurements of insects in this work are given in inches and lines. The above cut rep. resents one inch divided into lines and fractions thrreof.

[living upon the leaves of persimmon trees, which they puncture with their heaks and imbibe the sap; small brown and black plant-lice.]

The wingless lice are purplish-bown; the head and thomax are dark; the abdomen lownish with the extremity black. The winged line are usually colored like the wingless onesProfessor Thomals.

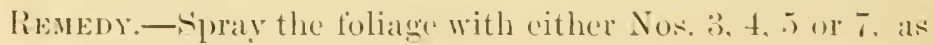
directed. 


\section{INSECTS INFESTING THE OLIVE.}

\begin{tabular}{|c|c|}
\hline The Black Scale (Lecanium olere). . . . . . .84 & $\begin{array}{l}\text { The following insects also infest the olive: } \\
\text { The Greedy Scale (Asqridiotus ray)ax). }\end{array}$ \\
\hline The Olive Worm (Dacus olere)............85 & $\begin{array}{l}\text { The Red Bay Scale (Asquidiotus grersece). } \\
\text { The Branch and Twig Burrower (I'olycaon } \\
\text { confertus). }\end{array}$ \\
\hline
\end{tabular}

\section{CHAPTER LXXXIY.}

The Black Scale. (Cal.)

(Lecanium olex.-Bernard.)

$\left.\begin{array}{l}\text { Order, Heniptera; } \\ \text { Sub-order, Honoptera } ;\end{array}\right\}$ Family, Coccine.

[A dark brown hemispherical scale insect, or bark-lonse. which infests all varieties of citrus trees, and nearly all varieties of deciduous fruit trees, and many shrubs, vines, etc.]

The black scale is more generally found in the orehards and gardens of California than any other species of the Coccidir.

It infests the orange, lemon, lime, olive (Fig. 122, 1,) apple, pear, peach, apricot, plum, prune, cherry and pomegranate trees. In the garden. it infests the honeysuckle, chrysanthemum, rose, oleander, and many other plants; and this, or a closely allied species, infests the forest trees. The presence of this species can be readily detected by the appearance on the branches, foliage and fruit of a black smut, known to scientists as Fumago salicina, and the cause of its production is a question upon which authorities differ. I am ronvincerl, from practical investigation, and also from information received from Mr. Alexander Craw, and Mr. Wolfskill, of Los Angeles, and the late A. B. Clark, of Orange, Los Angeles County, that the black smut is caused by a honeydew exuded by the females of the black scale insect, in the stage of their life 
between the time of the first formation of the calcareous secretion hy which the insect is covered, and their reaching maturity or becoming tixed to any part of the plant.

Fig. 122.

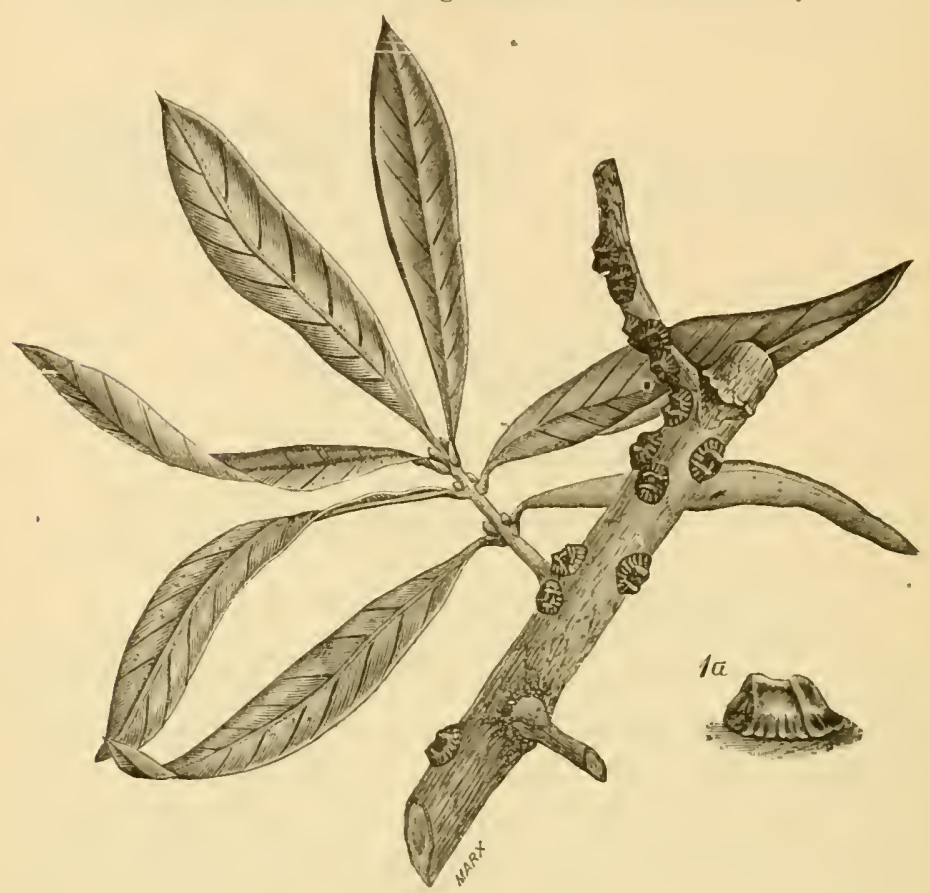

Fig. 12.2.-Black ficale; 1 , an infested twig; 1a, side riew of one of the seales, enkarged-color, dark brown.

In relation to this smut or fungus, Professor Barlow writes: "The result of our examination of the diseased orange and olive leaves is briefly as follows: The disease, although first attracting the aro by the presence of the black funcus, is not catused by it. lut rather by the attack of some insect which itself dejosits some gummy substance on the leaf and hark, or so wounds the tree as to rause some sticky exuclation on which the fungus aspecially thrives. It is not denied that the growth of the funcus gratly ageravates the trouble already existing ly encandes the leares thus preventing the action of the sunlight. Wre only saly that in soeking a remedy we are to 
look further back than the fungus itself, to the insect, or whatever it may be, which has made the luxuriant growth of the fungus possible."

The smut or fungus is found on the branches, foliage and fruit of orange, lemon, lime and olive trees infested by the black scale. I have also seen apricots and peaches, taken from trees infested by this insect, so thoroughly covered by this smut that it destroyed their market value for canning purposes.

\section{NATURAI، HISTORY.}

The black scale (Fig. 122, 1a,) when full grown is of a dark brown color, nearly hemispherical in form, but is slightly longer than broad; length, from two to two and a half lines; width, about two thirds of the length; height, one and one half lines; there are two ridges or bars across the body, apparently dividing it into three parts, the middle being the largest; a short ridge along the back joins the two cross ridges, forming lines resembling the letter $H$; the edge of the covering of the insect resting on the wood, foliage, etc., is margined, and has a grooved or fluted appearance nearly one half the height of the insect.

The eggs are oval in form; when first laid, whitish; before hatching, a reddish-yellow. From serenty-five to one hundred and seventy-five are deposited by each female of this speciès.

Fig. 123.-Larva of Black Scale, en-

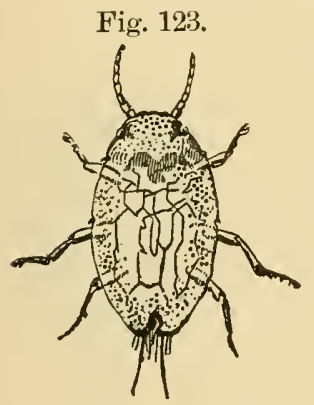
larged, back view-color, reddish-yellow.

The larva (Fig. 123) is one seventyfifth of an inch long; width, five eighths of length; form, oval; antenrix, six or seven jointed. From the time the secretion begins to form until the insect has reached maturity, it assumes different shades of color-first, greenish-brown; half grown, reddish-brown, and at maturity, dark brown.

It is cloubtful if there are more than one brood in each year ; the first brood are hatched, in this locality (Sacramento), about the first of $\mathrm{May}$, but do not attempt to leave from under 
the seale until the twelfth; yet it is very common to find the fomales of this species lepositing their eggs late in September, but whether they are of the spring brood I am not prepared to say.

In relation to the lengtl of time the lecaniums are capable of moring from one place to another, Mons. I'. Signoret writes: "Before pregnancy, they have the power to move, if necessary."

Revenrs:-Deciduous fruit trees: When the tree is dormant, suray with Nos. 11 or 12, as directed; or No. 13-fire pounds to six gallons of water. In Apring or Summer, when the young are hatched, spray thoroughly with Nos. 5 or 7 . (No. 4 may be used and prove very effective, but the solution containing sulphur is preferalule, as it destroys the black smut.) For citrus trees: (se No. 48), spray, ete., as directed in No. 49, and also as directed for olive trees. For olive trees: L'se same als for citrus trees; or No. 9, with one gallon of water added to every gallon of the solution. Example-Tothirty gallons of No.9, adel thirty gallons of water-sixty in all.

\section{CHAPTER LAXXY.}

\section{The Olive Worm.}

\section{(Dacus olex.)}

Order, Diptera; Family, Ortalin.e.

[Living in the olive berries (Figs. 126 and 127): small whitish footless magguts.] 
Fig. 126.

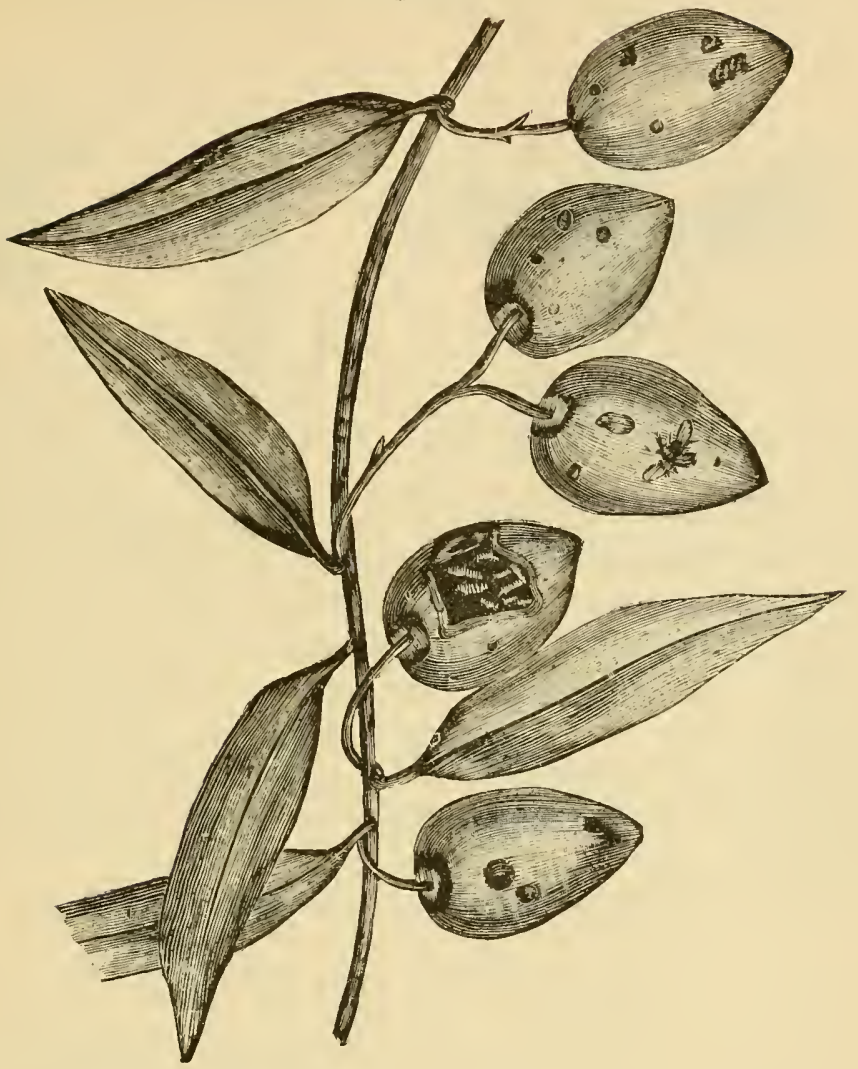

Fig. 127

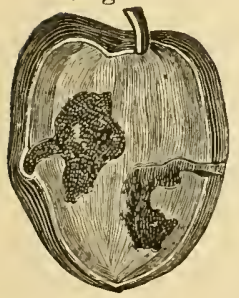

Fig. 126.-Olives infested by Olive Worms. Fig. 127.-An olive eut open, showing work of Olive Irorms.

This pest is not found in California, so far as I am aware, at present. The following is taken from Figuier's account of this insect :

The parent (Fig. 124), which deposits the eggs from which the maggots (Fig. 125, left,) are produced, is about one half the size of the common house-fly, and of an ashen-gray color; its head is orange-yellow, with two black spots on the upper part of the face; the eyes are green; the thorax is marked with four 
light yollow spots, and the abdomen is brownish, spotted with black on the sicles.

Fig. $12 t$.

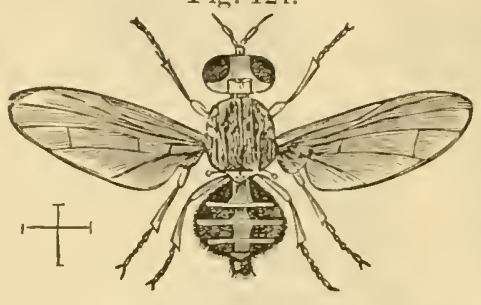

Fig. 125

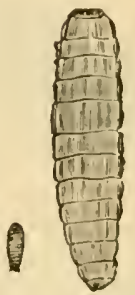

를

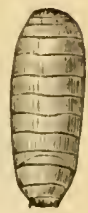

Fig. 124.-Olise Fly, enlarger-colors, gray, black and yellow.

Fig. 125.-Olive Worm and Pupa; at the left, the worm, natural size and enlarged-color, whitish; at the right, the pupa, natural size and enlarged--color, brown.

This lly punctures the skin of the olive and deposits therein a single egg; the maggot, which hatehes from this, burrows into the berry until reaching the stone, which it leaves untouched. Ifter attaining its full size, it forms a cell beneath the skin, and in this cell it assumes the pupa form (Fig. 125, right.)

Reven:--Spray with Nos. t, is or 7. 


\title{
A. N. Uaudei,
}

\section{Inseets Infesting Opange, Lemon and Lime Trees.}

The Red Scale (Aspidiotus aurantii) . . . . .8.86 The Red Scale of Florida (Aspidiotus ficus) 87 The Lemon-peel Seale (Aspidiotus nerii)...88 Pergande's Orange Scale (A*qudiotus per-

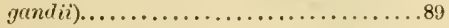

The Citrus Leaf and Fruit Scale (Asquidiotus citricola).

The Soft Orange Scale (Lecanium hesgreridum $) . . \ldots \ldots \ldots \ldots \ldots \ldots \ldots . . . . . .91$

The Cottony Cushion-scale (Ieerya qurchasi) 92
The following insects also infest Citrus trees:

The Black Scale (Lecanim olece).

The Filbert Scale (Lecanium hemisyhericum). The Common Healy-bug (Dactyloyius adonidum).

The Destructive Mealy-bug (Ductylopius destructor).

The Red Spider (Tetranychus telarius).

\section{CHAPTER LXXXVI.}

\author{
The Red Scale. (Cal.)
}

\section{(Aspidiotus aurantii-Maskell.)}

Syxoxym-Aspidiotus citrii-Comstock.

Order, Hemiptera;
Sub-order, Homoptera ; Family, Coccide.

IA cireular reddish scale insect, infesting the citrus trees, and has been found on grape vines and the foliage of walnut trees.]

The red scale (Fig. 12S) infests some of the citrus groves of Southern California, and orange trees in Sacramento and Marysille. It has also been found on grape vines and on the foliage of walnut trees, but I do not think that any damage will be done to these plants by this pest. As the walnut sheds its foliage ammually, the inseets are likely to be destroyed; and those which I have examined on the grape vines in the month of September, and which appeared to be in a healthy 
condition, were dead and shrunken when I examined the rines in the month of February following.

It is generally conceded that this species is an importation from Australia.

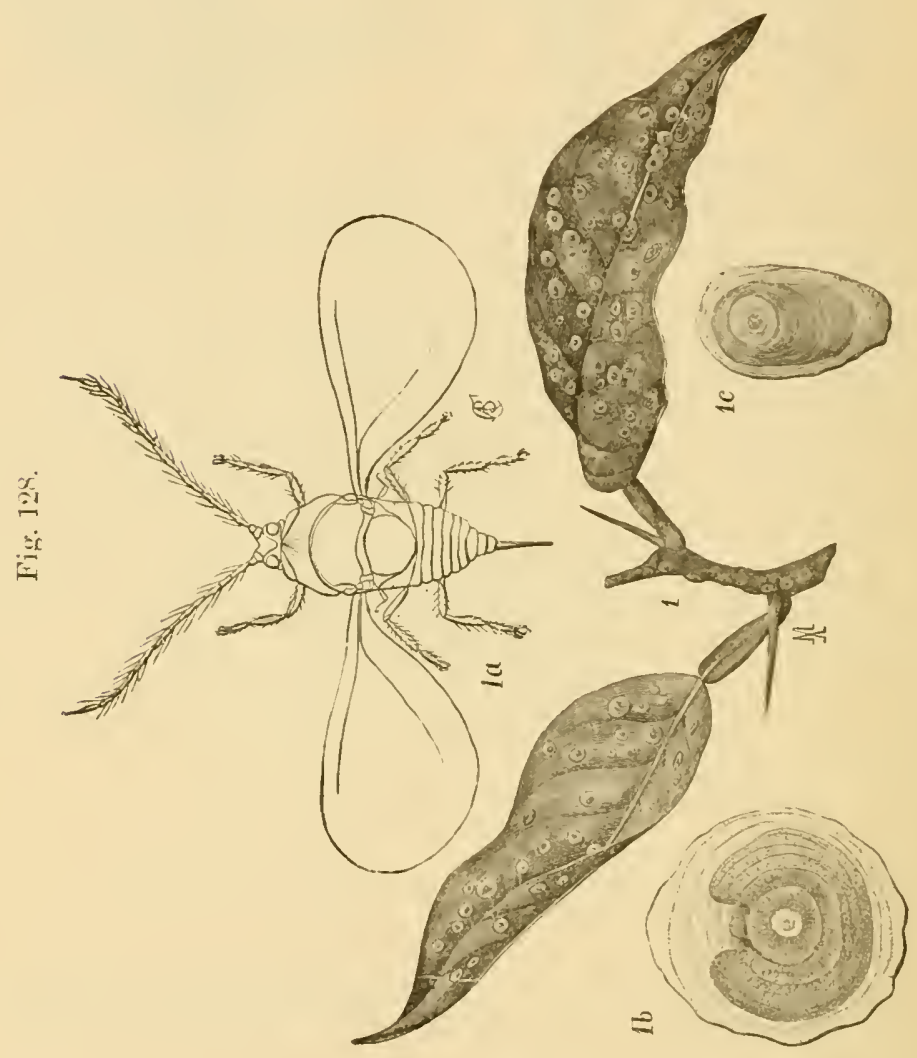

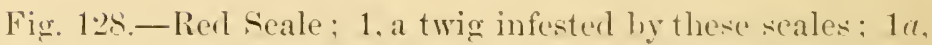
the male, highly magnified-rolors, rellow and hrown; 1 b, the female scale, greatly enlarged-color, gray, yellowishor hown ; 1e, the male seale greatly enlargerl-color, same as the female seale.

\section{XATURAl, HISTOLY.}

Female suale (Fig. 128, 1b), nearly transparent, circular, of a light-grayish color, and measmes from one line to one and 
one quarter lines in diameter ; exuviæ or cast skin in center. yellowish; second larval skin easily distinguished.

Male scale (Fig. 12S, 1r) a little darker in color and smaller than the female scale; form, elongated; exurix nearest the anterior end.

Eggs.-It is thought by some writers that the females of this species are viviparous. I have watched the female insect ovipositing, and immediately examined the egg or sack under a microscope, using a high power, and could not detect any appendages; however, in twenty-four hours I noticed the presence of antennie and legs. The insect produces from two to four of these eggs or sacks in twenty-four hours, and the number produced by each female is from twenty to forty-three; the latter is the highest number I have found.

In the month of September, 1882, I found a lemon at an orchard in Los Angeles County, on which the larve of thirtynime male scale insects had located around the stem of the fruit, and as there was only one matured seale on the lemon, this was evidently the number produced by one female. Iarva color, bright yellow; form, ovoid ; length, one eighticth of an inch; antemn, six-jointerl ; anal setx, present.

Female (Fig. 129)-color, light or primrose-yellow when the scale is formed, but as it reaches maturity it becomes a brownish-yellow. The formation of the body is such that under the scale, when examined with a lens. its appearance is that of a broken ring, but when ovipositing the posterior end of the abdomen extends beyond the circular line of the body. The color of the natural insect is shown through the nearly transparent scale from which it derives its common name-Red Scale.

Male (Fig. 128, 1a)-color of body, amberJiig. 129. yellow, with dark marking on thorax; eyes, black.

Fig. 129. - Fenale Red Scale Inseet, enlarged, ventral view-color, yellow.

The young larre can be found at all seasons of the year, and there are probably four or five broods in each year. 


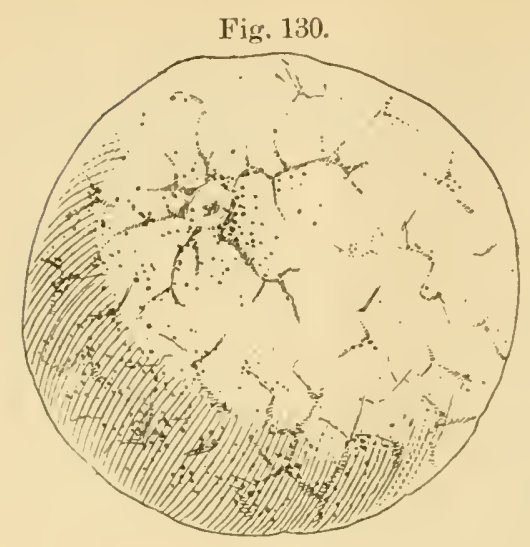

Jig. 131.

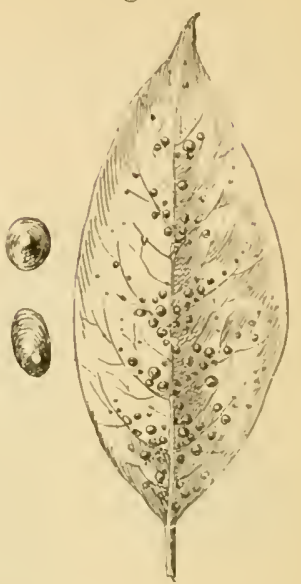

Fig. l:30.-Orange infested hy lied seale.

Fig. 131.-Leaf infested hy Red seale; two of the seales at the left, enlared-eolor, yellew of hrown; the upler one the fenale: the lower one the male.

This species intests the small loraluebes and foliage (Fig. $12 \mathrm{~s}, 1$ ) and fruit (Fig. 1:30), hut secms to juofer the fruit and foliatge. (Fig. 1:31.)

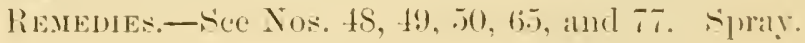

\section{CHAPTER IAXXYII.}

The Red Scale of Florida.

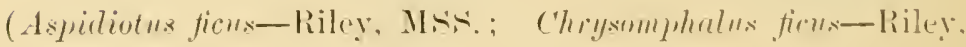
IIS- Ashmearl.)

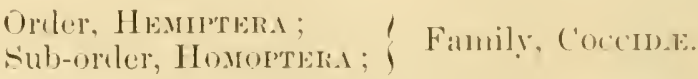

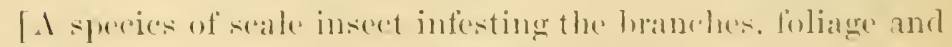
fruit of orange trees in Florada and the Fs lamel of ('uba. |

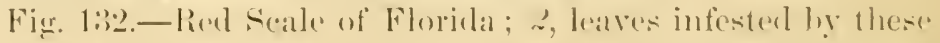

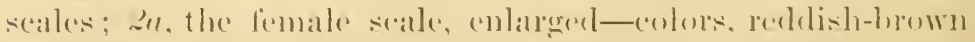

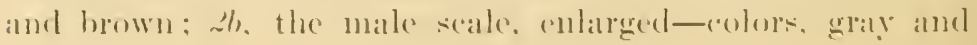


hrown: 2e, young larva, highly magnified-eolor, yellow ; $2 d$, 2f and sf the scales in different stages of formation.

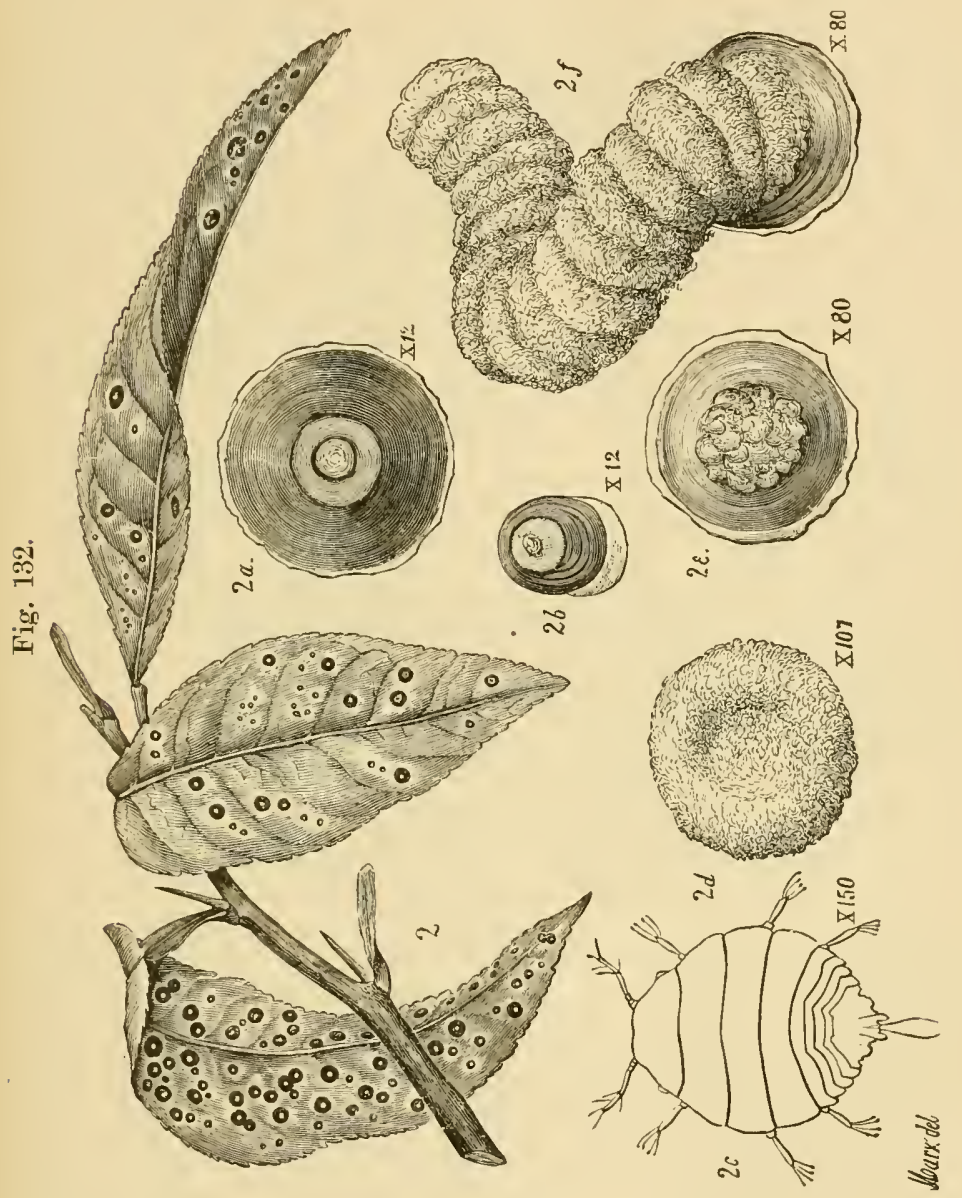

Professor Comstock describes this species as follows (Fig. 132): "Female Scale-Color, the part of the sale covering the sereond skin is a light redshish-brown; the remainder of the scale is much darker, varying from a dark redelish-brown to black, excepting the thin part of the margin, which is gray : exurice nearly central, whitish in fresh speciniens; form circular, one line in dianeter. Male Scale.--The scale of the male 
is about one fourth as large as that of the female; the pos-

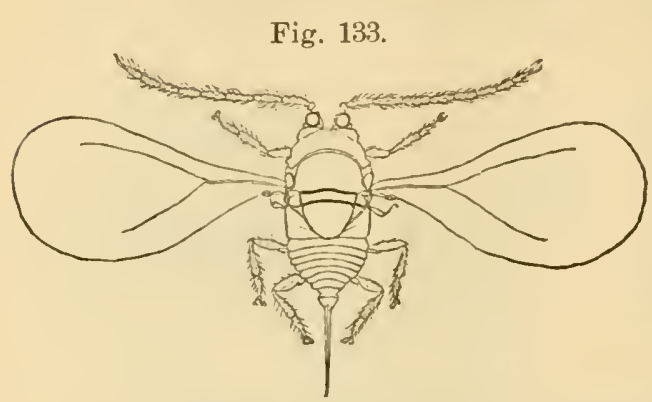
terior side is prolonged into a thin flap, which is gray in color (Male, Fig. 133). (See United States Agricultural Report, 1.880; and A s h mead in "Orange Insects," 1.SS0.)

Fig. 133-Red Scale of Florida (male, highly magnified)colors, yellow and brown.

Rexedes,- Nime as for red scale (1. aumntii). Nos. 48. $49,50,65,75$ or 44.

\section{CHAPTER LXXXYIII.}

\section{The Lemon-peel Scale. (Cal.)}

\section{(Aspidiotus nerii.-Bouche.)}

\section{$\left.\begin{array}{l}\text { Ojder, Hemiptera; } \\ \text { Sub-order, Homotera; }\end{array}\right\}$ Family, Coccina.}

[A whitish circular scale insect, infesting the lemon, plum, rherry and currant; also the oleander, acalcia, magnolia, etc.]

This speeies has been known to seientists as the "Oleander scale" (Fig. 1:5), from which it derives its specific name, nerii. Within the last four or five years it has been found on the lemon, plum, cherey and currant; also on the alcaleia, magnolia. ete. It seems to prefer the fruit of the lemon, and in many cases infests the skin or peel to such an extent as to redue its market value. California camnot claim a sole proprictary right to this pest, as lemons imported from Europe are often oflered for sale in our narket which are seriously infested liy 1. nerii.

Figg. 134-Lemon-peel scale; 1, leares and twigs infested by these scales: 10 , the male seale insect greatly magnified- 
colors, yellow and brown; $1 b$, scale of male greatly enlargedcolor, white; 1e, scale of female highly magnified-color, whitish or gray.

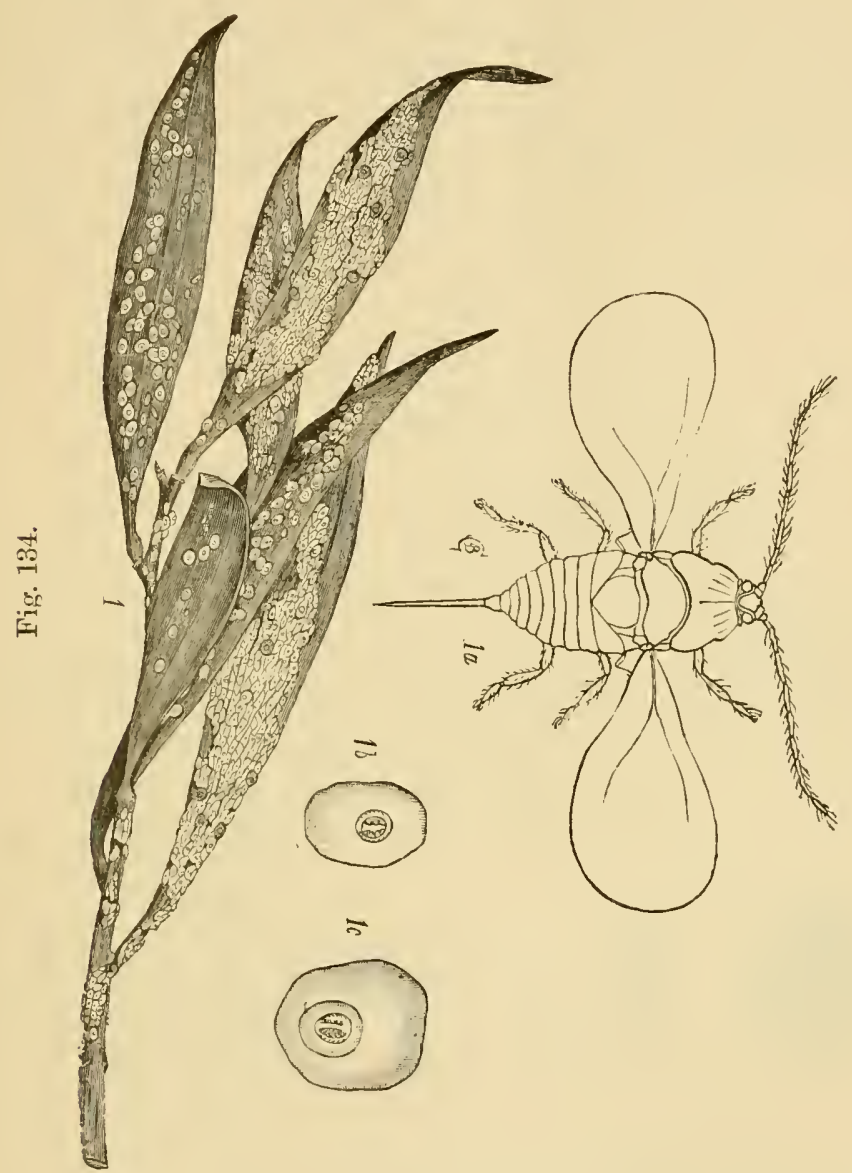

NATTRAL HISTORY.

The female scale (Fig. 1:4, 1c, ) is of a whitish color, and nearly cireular, measures one line in diameter; exuria or cast skin, yellowish, and near the center. Male scale (Fig. 134, 16,) white, smaller, and not as eircular as that of the fenale. Egg, light yellow. Larra, yellowish white ; length, one eighty 
fifth of an inch. Female, light vellow, with clarker blotehes; body, circular; abdoninal segments appear as a pointed projection at one part of the circle. Male insect (Fig. 1:3t, 1a.) winged; hody yellowish, with dark markings. The lemompeel soale insect closely resembles the red suale, and it is only by the difference in color that a person not thoroughly acyuainted with the respective species can distinguish them.

REMenes-UTe Nos, 48, 49, 50, 65, 77 or 4 .

\section{CHAP'TER IAXXIX.}

\section{Pergande's Orange Scale. (Cal.)}

\section{(P'relatorin pergandii.-C'omstock)}

$\left.\begin{array}{l}\text { Order, Hexiptera: } \\ \text { Sub-order, Honomena: }\end{array}\right\}$ Family, C'occine.

[A scale insect infesting the branches, foliage and fruit of (itrus trees. |

l have fomel this species on the orange tree in sacramento, but have not found it in any other part of the State.

Fig. 136.

Fig. 135.
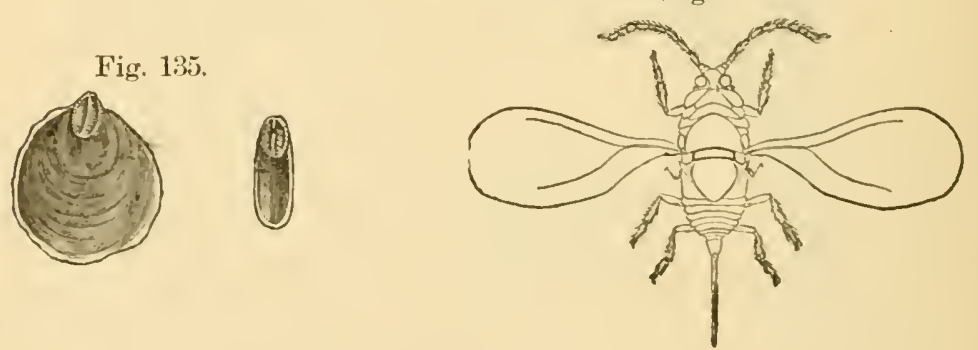

Fig. 135.-Pergande's ()range sieale; at the left. the female scale anlargerl-eolor, dirty erray ; at the right, the male sale "mlingexl-color, gray.

lijg. 1:36.-Pergande's Orange Seale; male, highly magnified-color; purplish.

The female soale (Fig. 19,5, left,) is somewhat elongated in form, but nearly ciremalu, the exurie at one side of the cen- 
ter-color, grayish; exuvice yellow, and genenally oval in shape.

Male scale (Fig. 135, right,). The scale of the male is elongated and narrow-color, dirty white; exuvia at the anterior end. Female-color, purplish, with posterior end of body yellowish, and is nearly as broad as long. Eggs-color purplish, elongated; from nine to twenty found under each female seale. Larva length, nearly one nineteenth of an inch-color purplish. Nale (Fig. 136)-color dark purplish.

Revedies.-Nos. 48, 49, 50, 65, 77 or 44.

\section{CIIAPTER XC.}

The Citrus Leaf and Fruit Seale.

(Mytiluspis citricolı-Packard.)

Srxorvu-Aspidiotus citricola-Packard.

$\left.\begin{array}{l}\text { Order, Hemiptera; } \\ \text { Sul-order, Howoptera } ;\end{array}\right\}$ Family, Coccide.

[An elongated slightly curved scale insect, infesting citrus trees.]

This species of scale insect has not been found on any of the citrus trees in this State, so far as I know, but it will be strange if it is not found in the near future. It is not a rare ocenrence to find it on oranges, etc., which are imported from Emope, Australia and Tahiti, and offered for sale on fruit stands throughout the State.

The scale of this species (Fig. 197, 10,16 ) is similar in form and appearance to that of the oyster shell bark-louse ( $M$. pomorum, Chap. XIX), exeepting that it may be a little wider at the posterior end. Length of female seale about one and onc half lines. The male scale (Fig. 137, 1c) is similar to other speeies of Mytilaspis in having a hinge-like joint, posterior to the middle of the scale, so that by lifting the posterior part u, the perfect insect (Fig. 138 1 ) can emerge. 


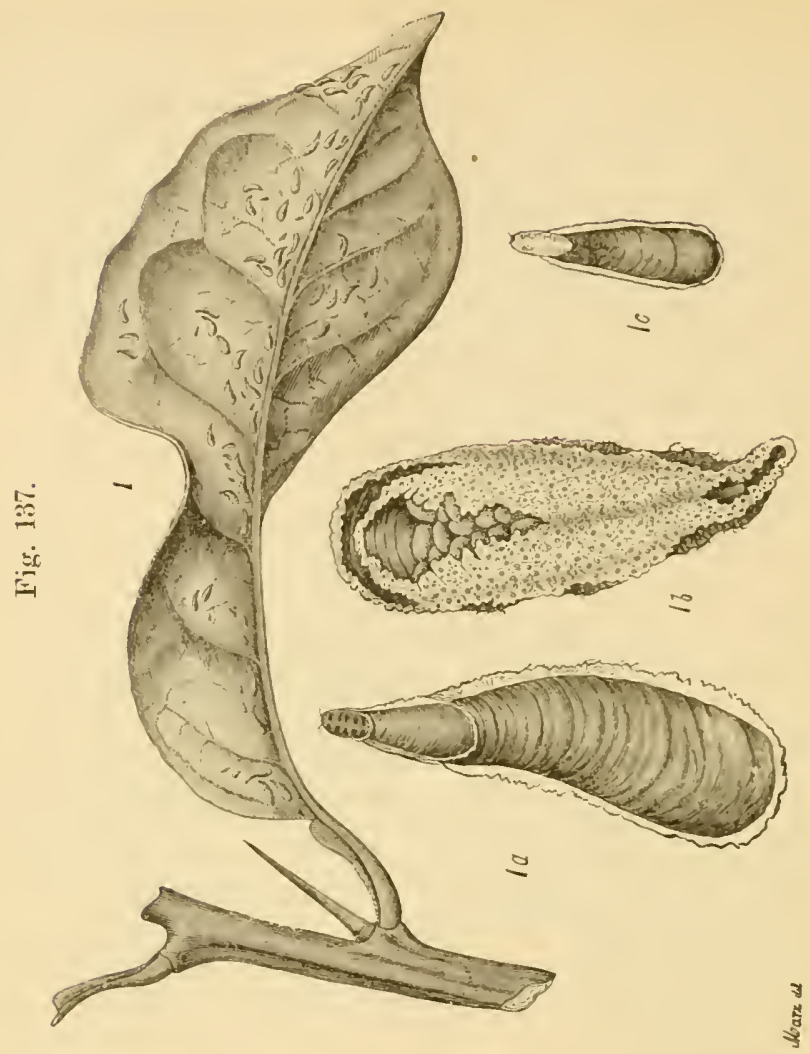

Fig. 1:37.-Citrus Leaf and Fruit Scale; 1 , a leaf infested by these scales: $l u$, the female seale greatly enlarged, back view -oolor, blown; 16 , the sime, rentral riew, showing equcolor of each, white; If, the male sale enlarged, back view(color, hrown.

Fig̣. 1:S.S.-Citrus Leaf and Fruit šale, enlaliged: $c$, the male seale-color, brown; ", the male seale insect-color, red; b, the larratecolor, rellowish.

Rementis-Nos. 4t, ts, 49, jo, (i.). and 7 .

Fig. 138.

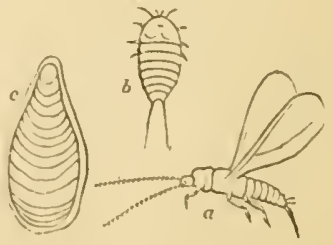


CHAPTER XCI.

The Soft Orange Scale. (Cal.)

\section{(Lecanium hesperidum.-Linnæus.)}

$\left.\begin{array}{l}\text { Order, Hemiptera; } \\ \text { Sub-order, Honoptera ; }\end{array}\right\}$ Family, Coccide.

[An oval flattened scale insect, infesting citrus trees, especially the orange.]

The soft orange scale is found in California in nearly every locality where citrus trees are grown; it infests the wood, foliage and fruit. This, or a closely allied species, is found on plants in hot-houses.

Fig. 139.

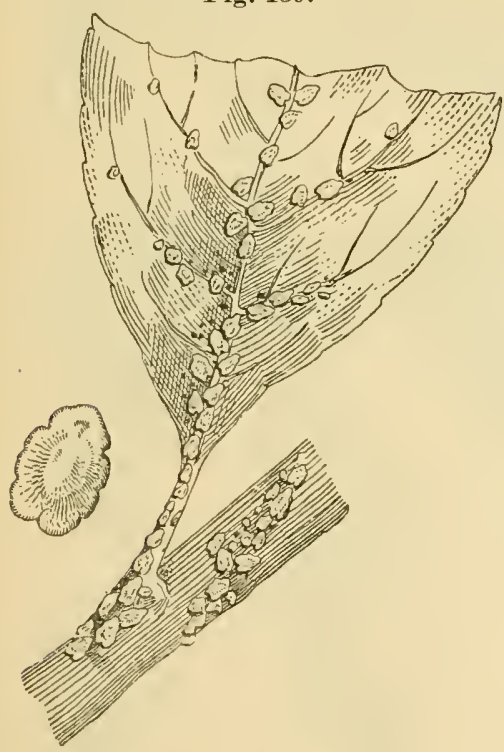

Fig. 139. -- Soft Orange Scales; at the left, one of the scales enlarged-color, yellowish.

In the Treatise on Injurious Insects, 1881, I described the male of this species as winged. Prof. Comstock, in his Entomological Report of 1880 , writes: "The male of this species has never been found, although it has been sturlied from the time of Linnæus down."

In September, 1880, I prepared a dry mounting of al specimen of Lecanium hesperidum for microscopic use at the State Fair of that year ; early in the week a small insect was noticed coming from under a specimen beneath the glass, and finally released itself. It proved to be a male scale insect. 
N.TTR.M. HISTHL.

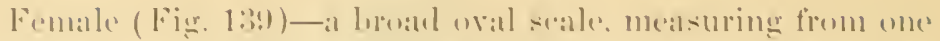

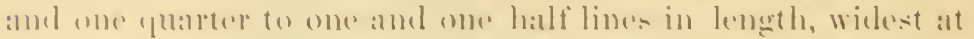

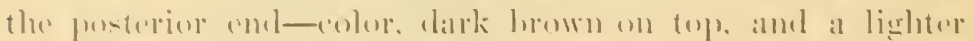
bown suremeling the margin. Two indentations on the

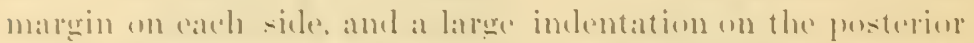
amel. It hals powers of lexemution similat to those of other

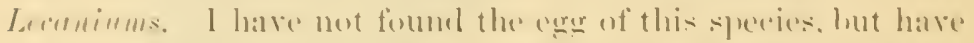

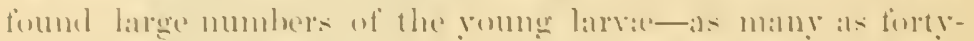

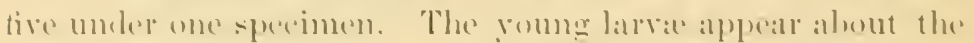

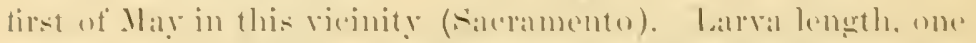

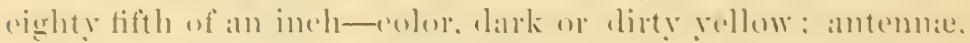

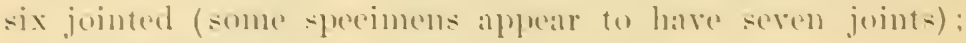
(wo allal setar.

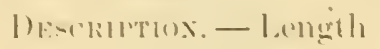
of herly, one serenty-sece(n)el of an inch: from firomt of head to apex of wint all imbh: pusteriur stylots. (m) forty-tifth of : 11 inch. of ond half the lemerth of lomly-enlor. lorly. immaneulate wollelem-

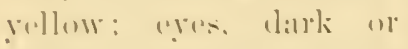
blak : antemma (from the ferulialu fustion in which

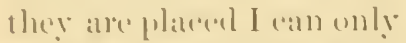

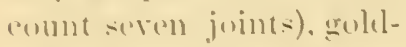
(2) yellow and haire : lewe. malilen-yollow.

A. it eliel met aterene with the deseription of any of the male stalle insects I haml reat of, or sperimens of males of

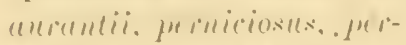

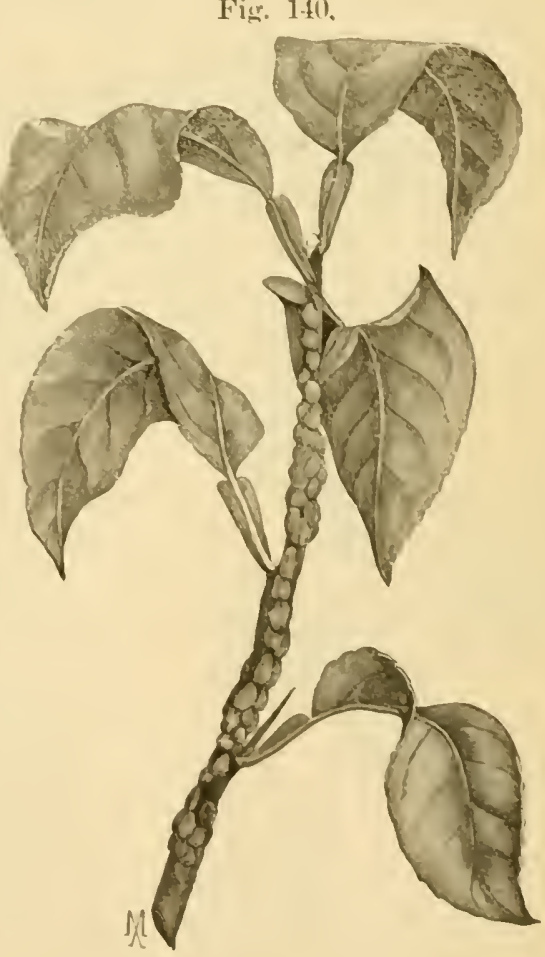

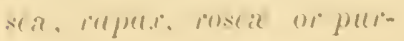

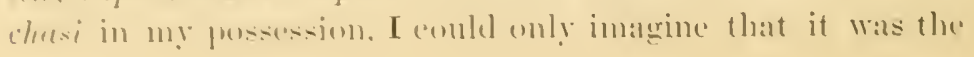


male of L. lexgeridum (be what it mas, it romers from unrler ther: L. liesperiflom sialos, and fortunately I preserverl the inountingr.

Fig. 1.10)._- Goft Orange: Seralo-_er)lor, l,rown.

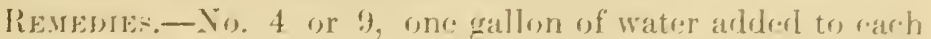

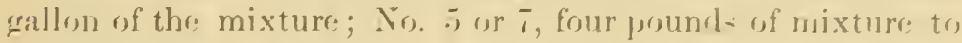
rach five gallons of watrer. Apply all the aboser at a trolsperature of one hundred and thirty degrees Fahrenheit. (Fyrag.)

\section{('HATTER XCII.}

The Cottony Cushion Scale. (Cal.)

(Ireryre purchusi.-Iaskell.)

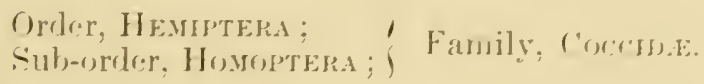

[A whiterushion-like srale insect. feerling upen citrus trees. derirluous fruit trees, forest trees, and on wornt varieties of rogetablos.]

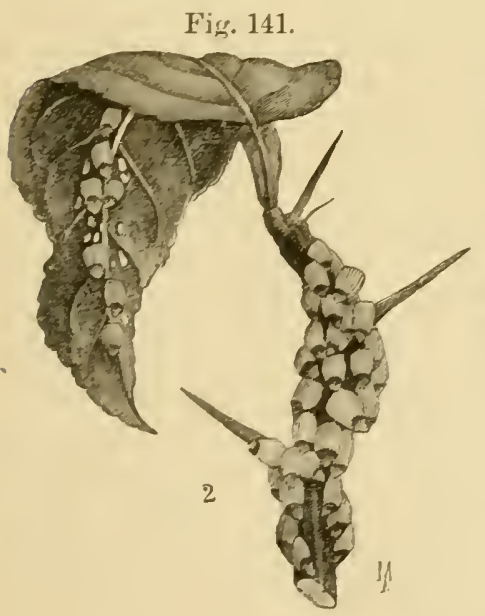

Firg. 141.- I'orFig. 142. tiron of a braneh infostred by Cottony Cushion sirales.

Fig. 142. - Cirt-

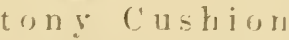
Scales, natural -ize-colors, rorange, red, whitish and pale fellowish.

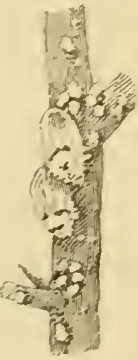

This species of serale insert (Figs. $1+1$ and 1+2) 1 eronsirler the most rlangrerous of any that infest. fruit and other trem in ('alifornial, as it may be-airt to fre a ceneneral frestur: it i- found on all varieties of eitrus trees, flecifluous fruit trees, on many varieties of ornamental trees, forest trees and shrubs: al $=0$ on 
some varieties of regetables. The apparent color of this scale insect at first sight is white, with a dark colored head. On examination, it is found that the part indicated by the dark color is the insert, and the white portion a hag or case spun by the insect to conceal her eggrs when deposited.

Figr. $14 \%$ - 'ottony Cushion sicale-color, yelluwish-white.

The females (Fix. 14:3), after ovipositing (the Fig. 143.

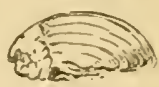
egrer case included), difter in size, some measuring six lines in length; but the general length is from three to four lines; width, one and one half to three lines, and slightly tapering toward the posterior end. Each female deposits from two hundred to five hundred eagrs. In one instance I counted seven hundred and three. The eggs are oblong-orate in form, and of a pale red color.

Fig. 14t.-Larva of Cottony Cushion Scalerolor, red.

Larva (Fig. 14t)-color, body red : antemnat six jointerl, clubled at the apex, on which are six long hairs-color, smoky black; legs, smoky black (the joints of the antemar and legs are

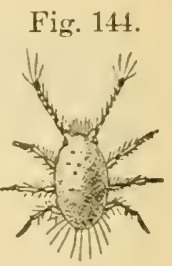
lighter in color than the balance); there are six long anal hairs; the margin of the hody and back is also clotted with hairs; length of body. one thirty fifth of an inch.

Fig. 145.-Female of Cottuny ('ushion

Fig. 145 .

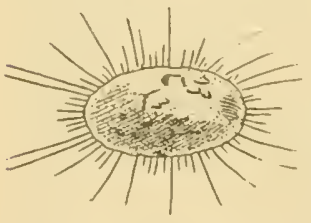
Scale Insect-color, reddish-brown.

Mature female (Fig. 145) before spinning egg-case. The female insect during her growth assumes a varicty of colors; principally yellowish-red, with irregular blotches of white, green and yellow. At full growth, and before spinning egar-case. she is oroid in form ; the hairs on the anal margin and sides are used as spinerets, exuding a cottony-like secretion of which the egg-case is formed. During her yrowth, and before beginning to spin her egg-case, the females exude a honeydew. which forms a black smut on the branches and foliage, as described in the chapter (nn the Black sicale.

Male insect (Fig. 146, Plate 3), winged-color, thorax and 
body dark brown, abdomen red; antennæ dark colored, with light brown hairs extending from each joint; wings brown, irridescent.

Revediss-Nos. 96, 44, 77 or 50-one part to twelve of water. If No. 50 is used, wash thoroughly with No. 5 or 7 after the leaves drop off. Simple remedies are of no avail in fighting this pest.

\section{INSECTS INFESTING THE FIG.}

The Green Fruit-beetle (Cymmetis nitida), and the Cottony Cushion-scale (I. purchasi) infest the fig, but are treated of in another part of this work. 


\section{INSECTS INFESTING THE GRAPE.}

The Grape-root Borer (. Egeria qulistiformix) 93 The Broad-neeked Prionus (Prionus lati. collis)........................

The Girape-root Louse (Phylloxera lasta-

trix)...................... 95

The Cottony Grape-scale (Leranium vitis). 06

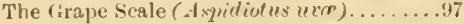

The Irecaving Wood Borer (Lyctus). . . . . .98

The Achcmon sphinx (Philanyelis ache-

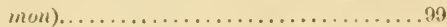

The Satellite Sphinx (Philamgelis satel-

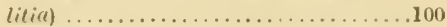

The Albott sphins (Thyreus tbbutti)....101

The llog Catcrpillar (Chorocamyie pamqinatrix) ...................... 102

The White-lined Sphinx (Deiteqtila limeata)103

The Bight-spotted Forester (.1lyyia w'tomaiulatat.......................104

The Beautiful Wood-nymuph (Evdryas yrat(u) .......................... 105

The Grape-vine Epimenis (I'sychomonylua

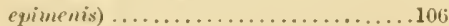

The American Proeris (I'rocris il mericanc) 107 The Grape-leaf Folder (Desmia marn. lalis) .............................. 108

The frape-vine l'ume (I'terowhorus qeriscelidactylus). .109 pe-vine Flea-beetle (/Ialtica chaly-

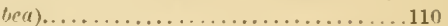

The Inıporteil Grape Flea-bectle (Adoxus vilix)............................. 111

The Rose Chafer (Wacrodarfylus subxyino.

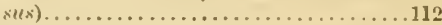

The Spotted l'elidnota (I'elidmote gnene. $t a t(t) \ldots \ldots \ldots \ldots \ldots \ldots \ldots \ldots . \ldots \ldots . \ldots \ldots 13$

The California Grape-vine Hopler (Erythroutevertomes) .................114 The Grape-vine Aphis (Siyhonowhore riti-

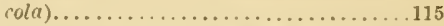
The lalse Chinch-bug (- Hyxius destructor) 116 The Vellow Jite....................117 The Angular-winged liatydid (Vicrrentmu retinertis).......................11s

The snowy Tree-cricket (lidanthus nireus) 119 The Grape Cureulio (Coliodes invequalis). .120 The Grape-seed Magrot ( $l_{\text {sonsma }}$ vitis)...121 The (irape-leaf Roller (Turtrix si) f... . . 122

The following insects also ufest the Grape: The Red sisale (Asyidiutus anrantii).

The Braneh and Twig.lurrower ( I'olycar confertux).

The Apple-twig Borer (Bostrichus bicaudatus). The Vellow Bear (Syilosomu Virginica).

\section{CHAP'TER CXIII.}

\section{The Grape-root Borer.}

\section{(. Eycria polistiformis.-Harris.)}

Order, Lepidoptera; Family, Egrmus.

[Feeding upon the hark and sapwood of the roots of the urapevine; a whitish sixtern-lexperl larval

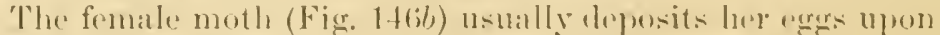
the vine close to the ground, and the young horer, as soom as 
issuing from the egg, begins to excavite a burrow through and just beneath the bark, proceeding directly to the roots, devouring the sapwood and leaving the heart untouched. When fully grown (Fig. 147) it measures about one inch and six lines in length. Before pupating, it forms an oval porl-like rocoon near the infested roots. The moth, or perfect insect, issues in July or early in August. Male insect (Fig. 146r )-The forewings of the moth expand a little over one inch, and are of a brownish-black eolor, with one or two nearly transparent spots at the base of each; the hind wings are transparent, with the veins and outer border brownish-black. The body is blark, and rariously marked with yellow; in some the basal part of the abdomen is black, with the remainder dull yellowish; in others the abdomen is whollyblack, with the exception of one or two yellow rings.-[Condensed from Riley.

Fig. 146.

Fig.

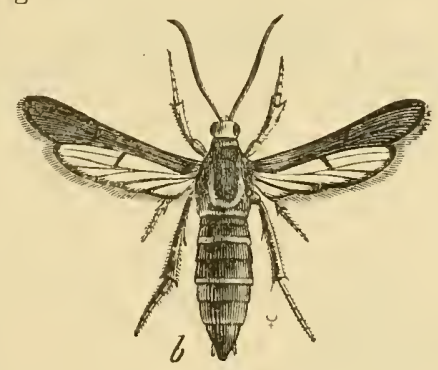

147.
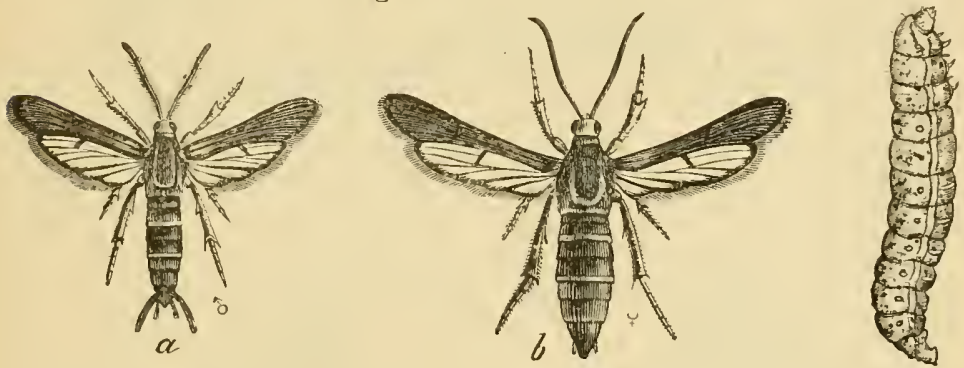

Fig. 146. - Grape-ront Borer Moths-eolors, dark brown and orange: $a$, the male moth; $b$, the female.

Fig. 147,-Grape-root Borer-color, yellowish.

Remedr.-Use No. 37 or 9S. The latter is preferable.

\section{CHAPTER CXIY.}

The Broad-necked Prionus. (Cal.)

$$
\text { (Prionns latirollis.-Drury.) }
$$

Order, Coleoptera; Family, Ceranbrécide.

[Living upon and usually hollowing ont the roots of apple trees, grape and hop rines; a large white nearly footless 
larsa or grub, having the first segment of its londy larger than any of the others.]

This larva (Fig. 14s) is of a creamy-white color, with a pale bluish line along the back: the first segment is as long or longer than the next three combined; the body tapers gradually from the third segment backward; the head is brown, and the legs are minute. It is supposed to pass three years in the larrat state. When fully grown it measures about three inches in length; it then reserts the roots and forms a smooth eavity in the earth, wherein to undergo its transformations. The perfort beetle alpears in about three week: after the change to the puna form (Fig. 149) has taken plate.

\section{Fig. 148.}

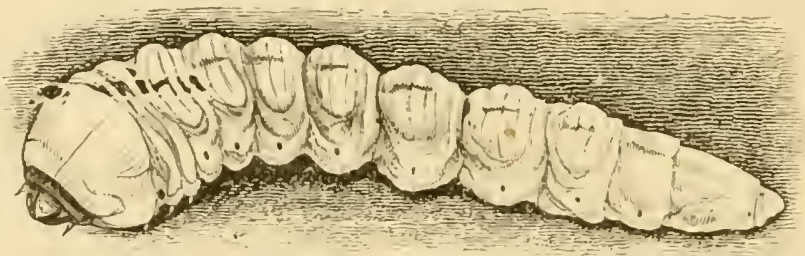

Fin. 14S-Latrat of Broatheckerl Prionus-color, rellowish-white.

Fig. 149.

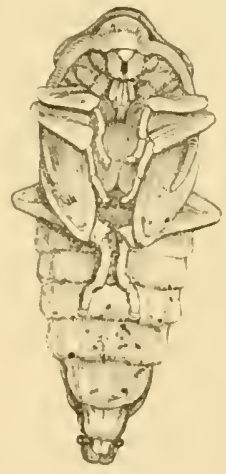

Fig. 150.

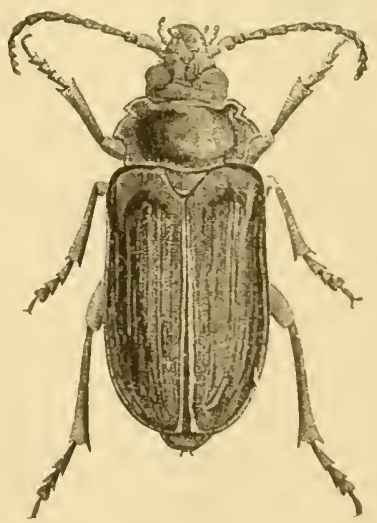

Fig. 14!--Pupa of Broatenecked Priomus-color, yellowishWhite.

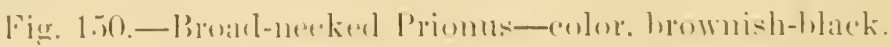


These heetles (Fig. 150) vary in length from a little wer an inch to an inch and eight lines, and are of a brownish black color; on each side of the thorax are three teeth, the middle one the most prominent.

There is another heetle very closely related to the above species, which, like the latter, also infest the roots of grape and hop vines in its larva state. This is known as the tilehomed prionus (Prionis imbricornis). It differs from the brual-necked species in having from sixtecn to ninetern joints in ear h antenna, whereas those of the broad-necked species have only twelve joints.

Remedr.-L'se No. 99.

\section{C'HAP'TEL C'TY'.}

The Grape-root Louse. (Cal.)

(Phyllowera instatric--Planchon.)

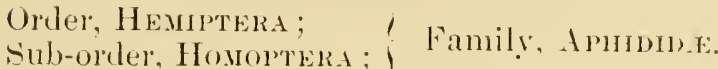

[A minute yellow louse, feecling upon the roots of the gral] vine.]

Fig. 151.
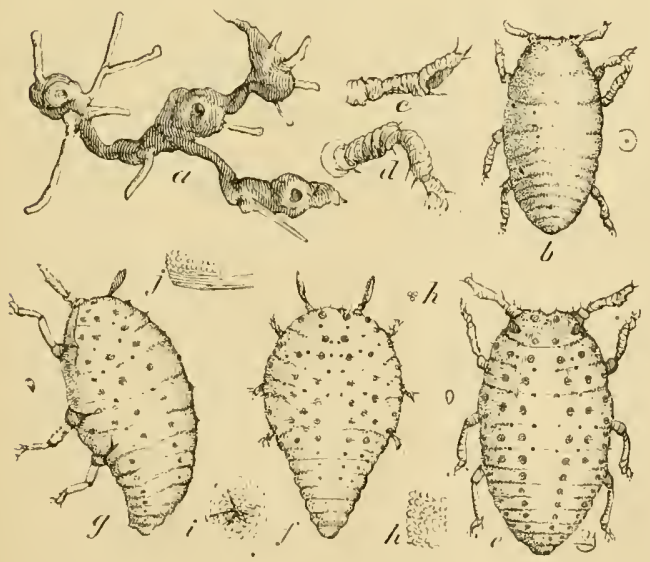

Fig. 151.-(ir:ale Root loonse (rootinhahiting forme); $a$, an infesterl root; b, hibernatinglonse enlargerl--eolol, rellow; c, its antemma enlarged $d$, one of its leger enlarged : e,t, and $y$, the lice enlaregedcolor, yelluw: i, a tubercle enlarged; le and i, granulations of the skin, enlarged: $k$, the simple eyes, enlargerl. I will not give an extended descrip- 
tion of this pest, nor an aceount of the ramage done to vinegrowers by its ratages, as the reports of the state Board of Viticultural Commissioners, the report of charles $A$. Wetmore, Chief Exerutive Vitioultural Officer; papers by Prof. E. IV. Hilgard and others, of this state. and Prof. C. I. Riley's Missouri Reports. have given full information of its natural history, halits, ete.

Unfortunately the presenee of the grape-root louse (Fig. 151) in some of the vineyards of this state is establisher beyomel a doubt, amb that a large acreage of vineyal property has been destroyed by the ravages of this pest many of the vine-growers ran offer sulsitantial rerifications.

Various opinions have been expresed as to how this insect spreacls from one rine-growing distriet to another. A asserts that the winged indiviluals fly from one vineyard to another, as other species of 1 phididax spread on their respertive food plants. B considers that the insect is splearl hy transporting from infested vineyards rooted vines and cuttings on which the Winter egg is deposited. (' claims that the grape-root louse was brought on his premises by hoxes returned from market in which grapes had heen shipped. D insists that he has not han any hoxes returued to his premises, that the cuttings he used were grown in his own vinegard, yet on al pateh of ground fire rods suluare the vines are infested by the I'hylloxem, although the latter are not foumd on his oldor vines from which the cuttings were taken. The opinions of $\mathrm{A}, \mathrm{B}$. C', and D, may individually or collectively be correct, and ats the pest has securesl a footholel on their premises, the query arises: "What can le done to save the infested vines?"

fince the first of Jannary, 1s\$o, I have risited several localities in which I found grape-vines infested by the crape-root louse, and in nearly every ase the appearanee of the vine indieaterl the presence of the pest. In conversation with the vincyard owners, in relation to the decaly of their vines, the following questions amd answers maly be talken as the result of such investigations:

Question-How many erops of grapes have pou taken oft of these vines: Answer (from different growers)-From ten to fiften (口) 
Q.-Were the vines pruned each year? A.-Yes.

Q.-What was done with the cuttings or prunings? A.Some of them were used for cuttings for planting, the balance were hauled off the ground and burned.

Q.-Has the ground been thoroughly cultivated each year? A.-I believe so.

Q.-And of course you gathered the crop of grapes each year? 1.-That is what I planted the rines for.

Q.- Have you at any time during the last eight years used any kind of fertilizers on your vineyard? A.-No.

Q.--How did the rield of the vines planted fourteen years ago or more, compare last year with those of four or five years ago? A.--Five years ago I had a much larger yield on the same vines.

Q.-Did you notice any difference in the yield of the crops of 1881 and 1882 of the rines planted, say seven year's ago? A.-The crops of 1882 were heavier; but that may be attributed to a favorable season, as much at least as to the increased age of the vine.

My reasons for asking questions as indicated above, were this: In 1880 I had formed an opinion that a remedy for the graperoot louse could be found by fertilization, and so stated at a meeting of the State Horticultural Society-that "The presence of the grape-root louse and the serious damage done by it to the rine might, to a great extent, be attributed to the weakly condition of the vine at the time it was attacked by the pest, and which was probably aused by the vine being deprived of some nutriment that it required, and which did not then exist in the soil in which it was growing." At that time some of the vine-growers took issue with me on that opinion. In the month of September following the meeting of the State Horticultural Society referred to, a meeting was held of the "Phylloxera Congress," at Paris. France, at which the President of the Congress, M. Henricy, expressed the following opinion: " The phylloxera were but the result of the long use and fatigue of the vine, and that they might get rid of them by restoring health and vigor to the soil and plant."

Fig. 152.-Grape-root Louse, highly magnified (the rootinhabiting form); $a$, a healthy root; $b$, a root on which the 
lice are working: $r$ a ront which they have deserted; $d, d, d$. d. the lice on large ronts: , the female pupa, hatk viewcolor. vellowish; $f$, the sillue. rentral view: !s the winged female, batek riew-rolur: yelluw: h, the same, rentral riew; i. her anteman, more highly magnifiod: j. side view of wingless fenale. laying eggs: $k$, a sertion of an infested root, whowing efriects of their work.

Fig. 152.
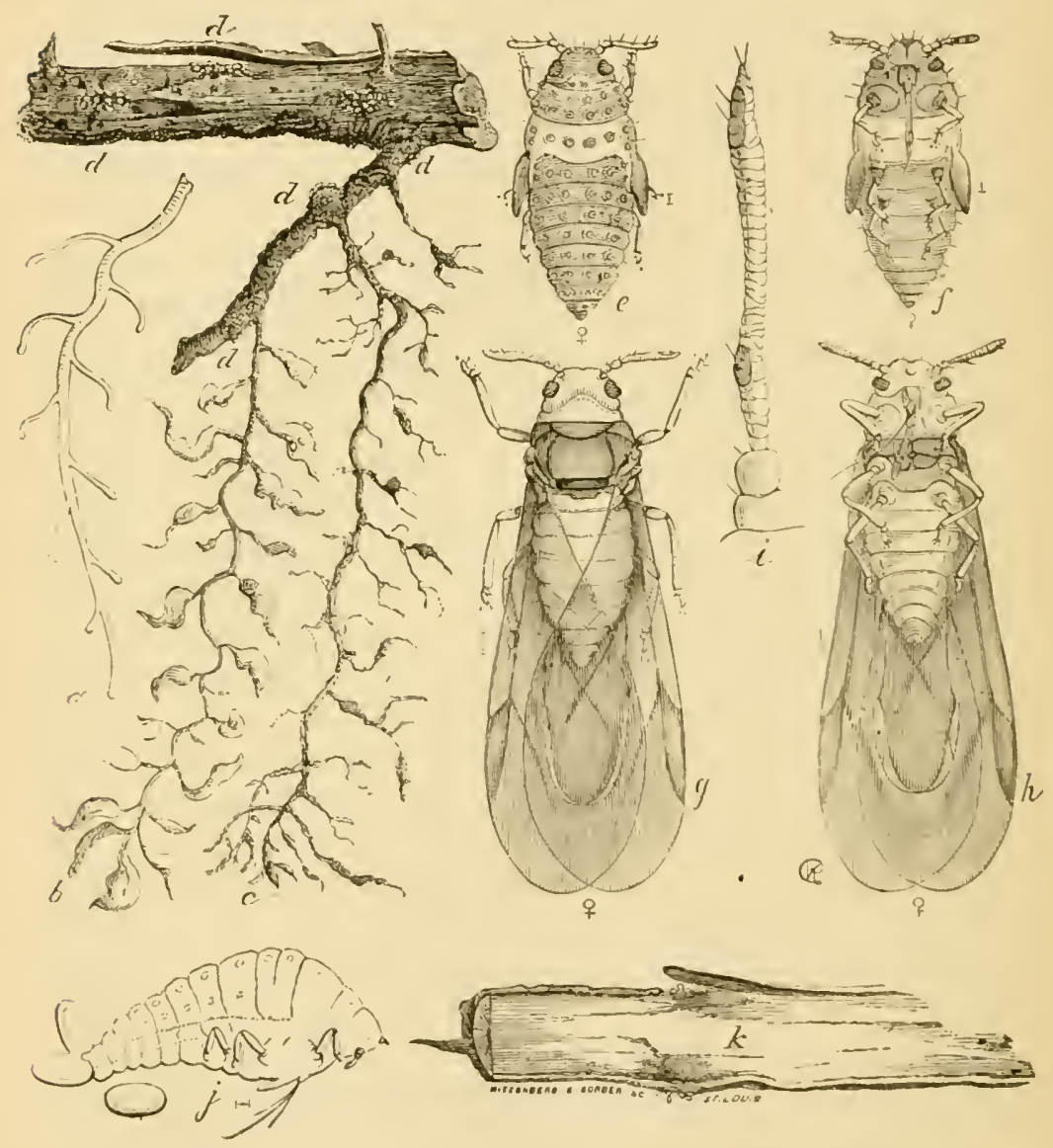

In disensing the merits of fertilization, vine-growers hate used the following argument: "If fertilizers are nsed to pro-

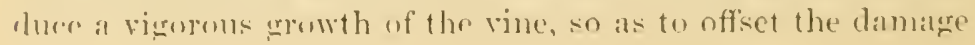


done by the attack of the grape-root lonse, the ralue of the grapes would be destroyed to a great extent for making fine wines."

Fig. 153.
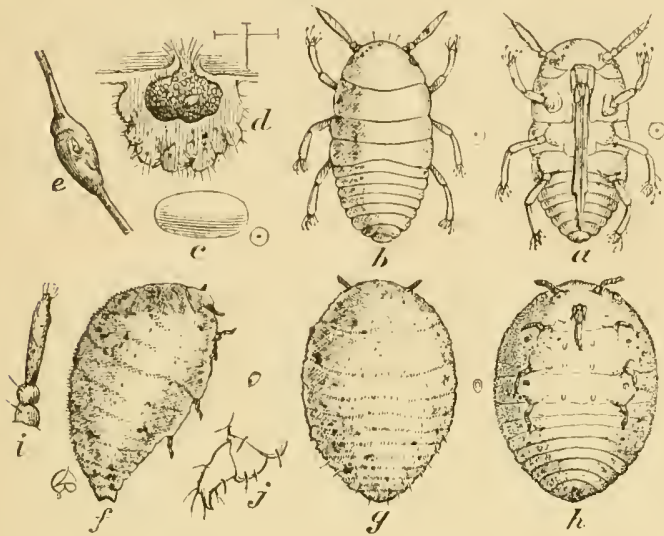

$\mathrm{Fig} .153$. (irape-root Lonse (ga 11 - inhaloiting form) ; $d$, a gall in the laat cut open ; e, a gall in the tendril ; $c$, an egg, highly magnitierl--color, pale yellow; b, back view of newly hatcherd louse, enlarged; a, ventral view of the same, enlarged - color,

rellow; $\dot{f}, y$, and $h$, adult female lion-side view, bark view, and rentral view, enlarged; $i$, an antenna-rolor, orange-yellow, greatly magnifier ; j, a foot, greatly magnifierl.

Tothis argmment I only answer: Taking into consideration the general richness of the lands yet to be planted in this State, the visitation of this pest may be considered a benefit rather than a misfortune to the vine-growers who grow grapes for wine-making purposes. In regard to grapes grown for table use and raisin making, the objection to the use of fertilizers is untenable, as I know a very extensive grower of these varieties who has been rery sucesstul in maturing heary arops of a choice puality by the use of fertilizers. A vinegrower residing within forty miles of sacramento had thirtynime acres, principally table grapes, which netted him a revenue of nearly six thousand dollars per year. The vines commenced to deeay to such an extent that thirty-four arres were dug ont and peach and apricot trees were planted in their place, and these are in full bearing at the present time-.June, 1853. It was ascertained afterwards, by examining some of the roots left in the ground, that the grape-ront louse was the canse of the deray of the vines. The fow ares remaining were found 
to be infested. Every alternate row was taken up. and fertilizers used. The improvement in the appearance and hearing of the vines in two years was such that the grower axpresed the opinion that had he known at the time his vines hegan to decay, what he has since leamed by practical experiments, he might have saved his thirty-four acres of vines dug ul, and also the loss of three or four years' arop.

Rementes-If the vines inferted are planterl close together. say less than ten feet between the rows, dig out arey third row, and use as a fertilizer No, 3.5.

\section{CHAP'TER ('XY'T,}

The Cottony Grape Scale. (Cal.)

$$
\text { (leceminn ritis._Fitch.) }
$$

SYxoxry-Coress ritis-Kirls.

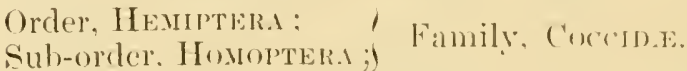

[Infesting the grape vine; a scale insect which exuder a white cottony-like secretion in which its egros are concealed.]

Fig. 155.
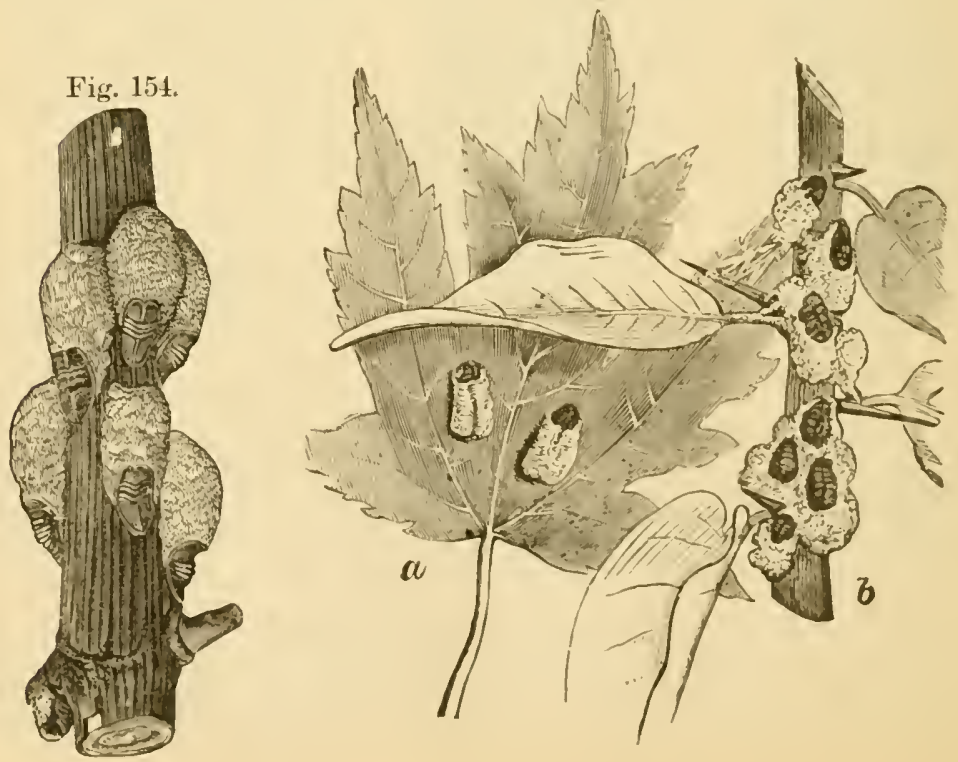
Fig. 154.-Cottony (rrape Scale-color of the scales, reddishbrown: of the cottony masses, white.

Fig. 15.5.-Cottony Maple Scale (Pulrinaria inmumoribilis,

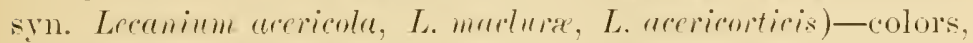
brown and white.

This species is closely allied to the Lefanium arericoln (Figs. 154 and 155), which infests the maple, and has been found in sereral parts of this state. It infests the foliage and hranches of the graperine.

\section{NATIRAL HISTORY.}

The female is oval in form, and measures about two lines in length; color, dark-hown; near the posterior end are ridges or carine, and the lines separating them are darker than the other parts; anal indentation similar to L. hexperidnm or soft orange scale. The eggs are white when first laid, hut change to a yellowish tinge before hatching; oval in form, and about one ninetieth of an inch in length.

In one of the eottony-like masses attached to a temale of this species, I have found nearly three hundred eggs. Larvacolor, yellowish-white; form, ovoid; length, one ninetieth of an inch. Similar in appearance to the larva of the soft orange scale, except in color.

Remeder.- When the vine is rlormant, use Nos. 14, 12, or 13, after scraping off the loose bark and burning it. In Summer use No. 4 , or No. 3 if No. 4 camnot be had.

\section{CHAPTER CXVII.}

The Grape Scale.

\section{(Arpillintus nis.-C'omstock.)}

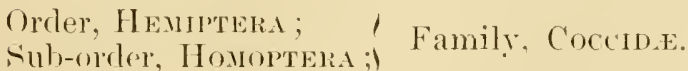

[A small circular scale, found on the trunk of the rine and wood left from growth of the previous year.]

I have only had one specimen of this species sent ne, which 
was found on importorl rines. P'rofessor Comstock reports it from Indiana, and describes it as infesting the lower part of the graperines from the sround to the shoots of the second rear's growth. In comparison with the red scale it is smaller, and the rolor is lighter, being a rellowish-hrown.

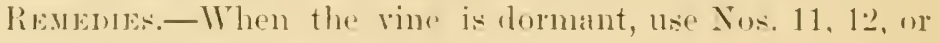
13. In s.mmmer use No. 1.

\section{('HAPTER NO'VITI.}

\section{Decaying Wood Borers. (Cal.)}

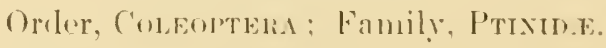

[Crmbe from thee to fire lines in length. found in levaying wroed of iruit trees and gralues-rines.]

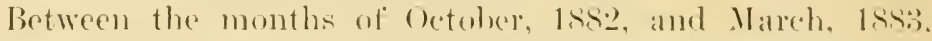
several spesimens of grubs were resedved that were fommel in decaying wool of fruit trees and grape-vines.

Fig. 15ti-Decaying Woud Borers (Bi-

Fig. 156.

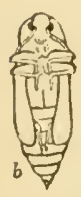

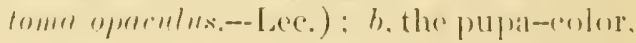
vellowish; ", the larva-rolor, white: in the midrlle. the beetle-ualor lirown. lives in rearl grape canes.

I kept the specimens of larve (Fig. 1.5tin) until they assumed the jula form (Fig. 1.566), but dirl not sueceed in rearing the prerfere inseret (Fig. 1.76), as the insects died when casting the gula skins; hemerer. they were sufliciently matured that they ermlet be identified as to tamnily and gemus. The specimens belonged to

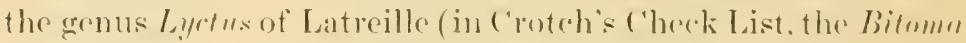

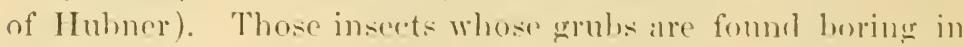
deeaved wour are not injurious to trees of a healthy growth.

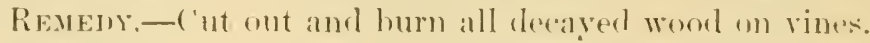




\section{('HAPTER NC'TX.}

The Achemon Sphinx. (Cal.)

(Philampetis achemon.-1)rury.)

Order, Lepidoptera: Family, Spmingide.

[Fceding upon the leaves of the graperine, a large green. yellowish or brown worm, with six narrow eream-colored spots on each side of the body. ]

Fig. 157,

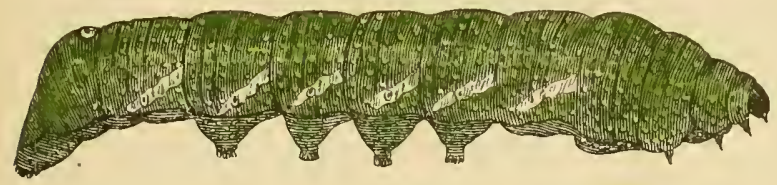

Fig. 157-('a terpillar "f $\mathrm{d}$ ( he he monsphinx - i. (1) lors, yellow and linown.

When fully srown (Fig. 15i) it measures about three inches and six lines in length: it then desirts the vine and enters the

Fig. 158.

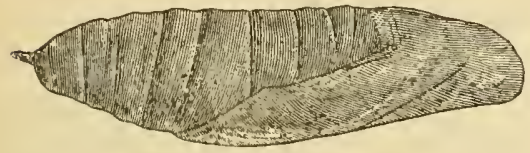
warth, where it forms a smooth rell in which to undergo its transformation. (Fig. 1.is.)

Fig. 15s.-Pupa of Achemon sphinx-color, brown.

The young worm is green, with a long slender horn on the hind end of the body: after casting its skin sereral times the horn disappears, and in its place is a polished black tuherele; the body is now a pale straw-color on the back, the sirles brown and marked with six narrow scalloped ream-colored spots.

The fore-wings of the moth (Fig. 15.) expand from three to four inches, ale of a dark olive-gray color, marked with three dark olive spots; the hasal part of the hind wings is roseate. followed by a dark stripe, next to which is the olive border. The body is fawn color, with two triangular olive rolored spots on the thorax. 
Fig. 1.59.-Achemon Sphinx-colors, gray, brown and pink.

Fig. 159.

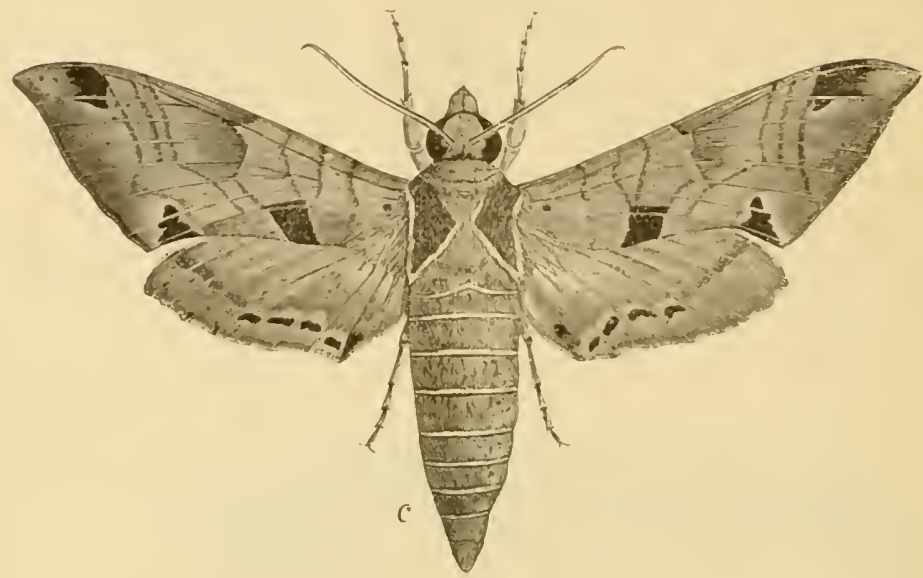

Reventes. - Nos. 14, 100 and 101. (See letter of Mr. Blower, \o. 93.$)$

\section{CHAPTER C.}

The Satellite Sphinx. (Cal.)

(Philampelis sutellitin.-Linn.)

Srxorym-P. pundurus--Hubner.

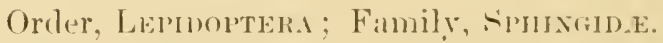

[Feeding upon the leaves of the graperine: a large brown worm. having five or six large ream-rolored spots on each sirle of the borly.]

The egr from which this worm hatehes is deposited singly upon a leat. When first hatched, and for some time afterwards, the worm is green, with a tinge of pink alonge the siles. and on the hime part of the boly is a long eurved horn. After the worm has ast its skin about there times. the hern rlisalpears, and in its place is a polisherl, black tuluerele: the color of the borly is now a rich relvety bown. with five or six aream-yellow spots upon each sile. When fully grown (Fig. 
$160)$ it measures three inches or more in length; it then enters the earth, and forms a smooth cell in which to undergo its transformations.

Fig. 160.

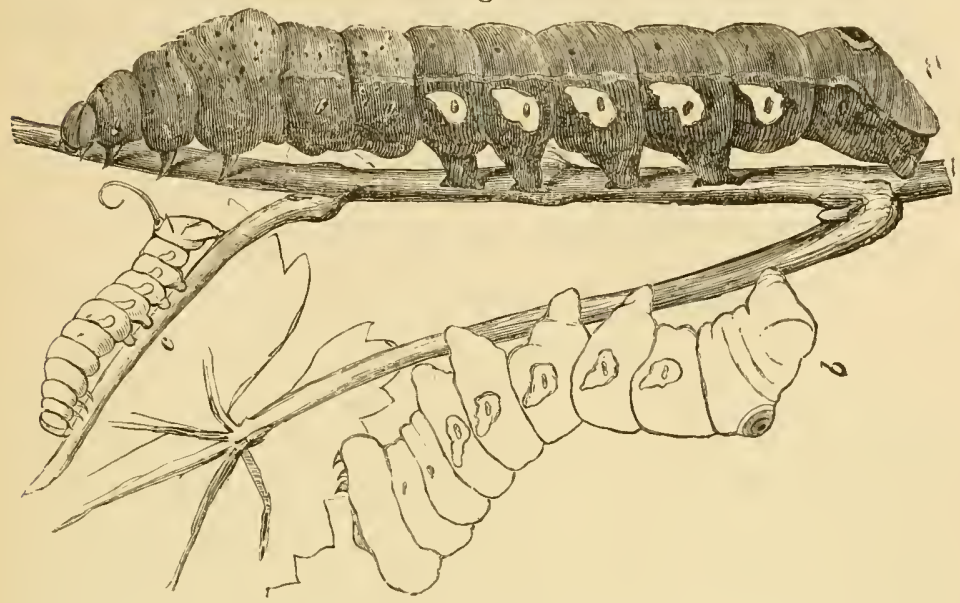

Fig. 160.-Caterpillars of Satellite Sphinx-colors, green or brownish and yellowish-white; $c$, the young caterpillar; $b$, the same nearly grown, at rest; $u$, the full grown caterpillar.

Fig. 161.

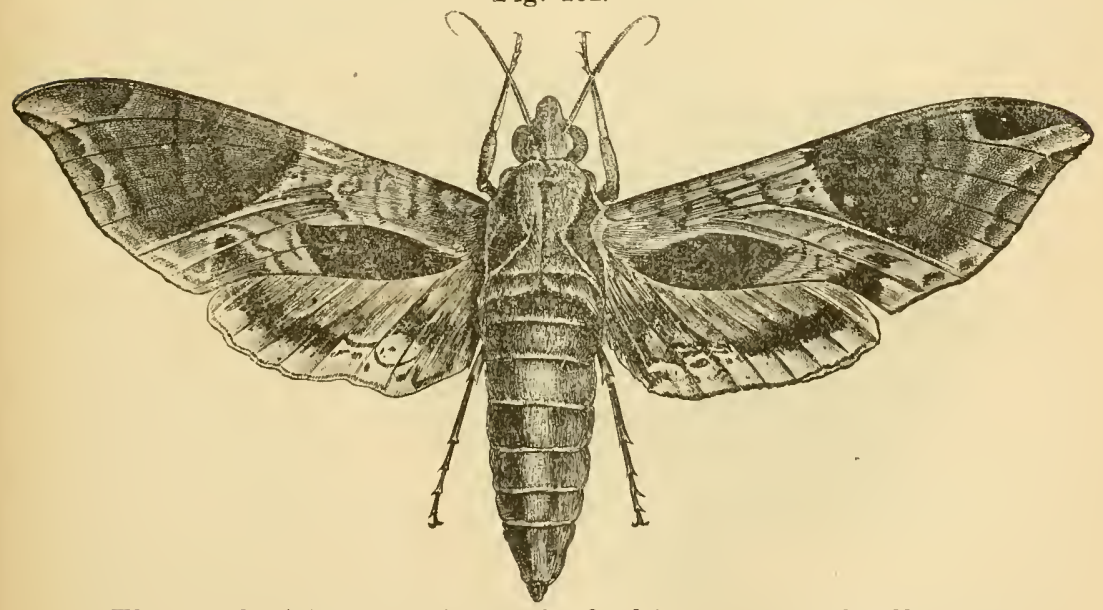

The moth (Fig. 161) into which this worm is finally transformed, expands from four to fire inches; the fore-wings are 
palde olive-gray, marked with rarker olive-green patches, me of which is at the tip, one near the outer hind angle, anel a thirel on the hind margin near the body.

Fig. 161.--Satellite Sphin $\mathrm{x}$-colors, gray and dark olive-green.

Renedies-Ľse Nus. 14. 100, and 101. (see R. B. Bluwers' letter. No. 33).

\section{('HAP'TER ('I.}

The Abbott Sphinx. (Cal.)

(Thyiens Ahbutii-swainson.)

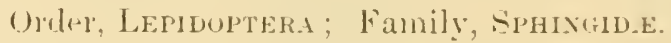

f Feeding upon the leaves of the graperine; a checkered gellowish and hrown worm. nearly three inches in length. hasing a polished black tuberele on the hinel part of the herly. I

The ground colur of this caterpillar (Fig. 16i2) is a dirty yelluwish, marked with nunerous transterse blatk lines and back-brown patches, forming a line along eatele siele of the borly. The hearl is slightly roughenert and rank, and is matked with a light streak, and there is another streak in the mildele, Wheh sometimes forms the letter X. When ahout to pupate, it deserts the vine ame spins a coroun leneath the leaves, ote.

Fig. 162.

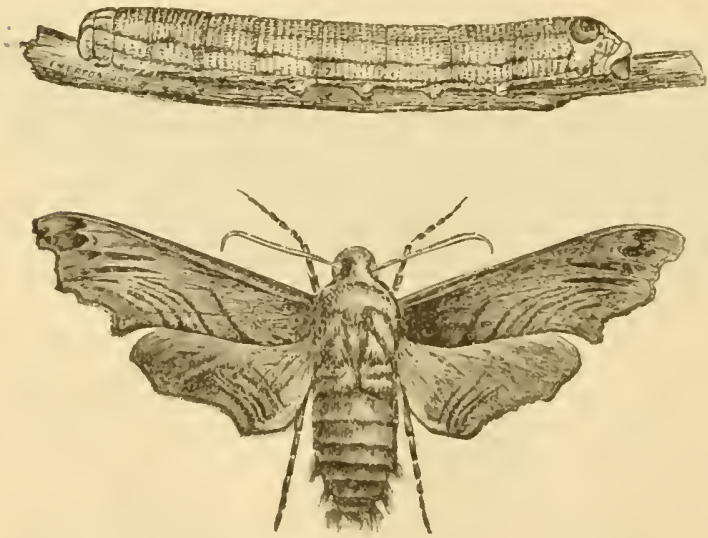

Fig. 16i2. Dhot simhinx;

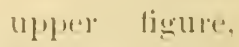
the raterpillatr - - coloris, yol-

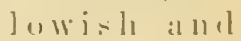
hiark: low( ) li $\dddot{2} u 1 \cdots, \quad 1$ l 12 meth-- (m) (2) I) and liale yellul.

The perfecet moth(Fig. $1\left(i_{-}\right)$ hais the outer arlege of the wings deeply stalloperl: the fore-wings atre dull 
grayish-brown, variegated with dark brown; the hind wings are pale yellow, with a dark brown hind border.

Remedies.-Use Nos. 14, 100, and 101.

\section{CHAPTER CII.}

The Hog Caterpillar.

(Charocampa pampinatrix-Abbott and Smith.) S'rvonya-Darapse myron.-Cramer.

Order, Lepinoptera; Family, Sphngide.

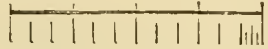

The measurements of insects in this work are given in mohes and lines. The above cut represents one inch dividel into lines and fractions thrreof.

[Feeding upon the leaves of the grape-vines; a brown or green worm, with a light stripe on each side of the body and a curved horn on the posterior end.]

The eggs of this species are perfectly round, of a uniform yellowish-green color, and are ghued, singly, to the underside of the leaves.

Fig. 163.-Hog Caterpillar--color, green and yellowish.

The full grown worm (Fig. 163) measures about one inch and six lines in length ; is of a pale green or brown color, marked with a rellow stripe on each side of the body, and Fig. 163.

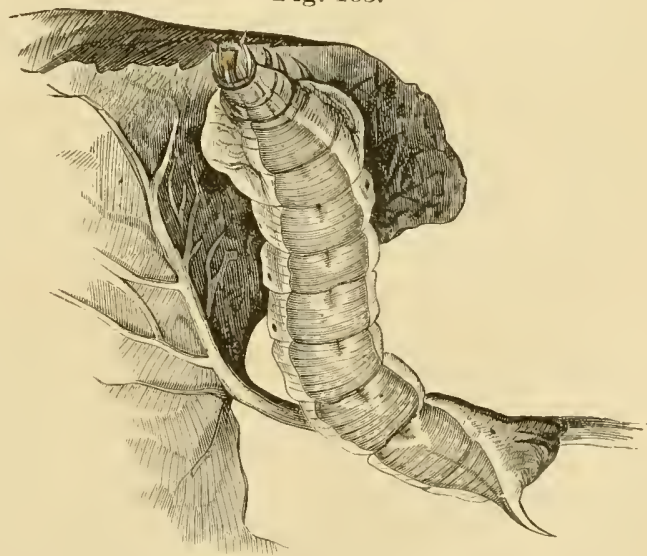

with a row of dark spots on the back. It receives its name of "Hog Caterpillar" from the forepurt of the body being greatly" 
swollen, thence tapering to the head, giving to this part a vague resemblamee to the head of a fat hog. "When about to

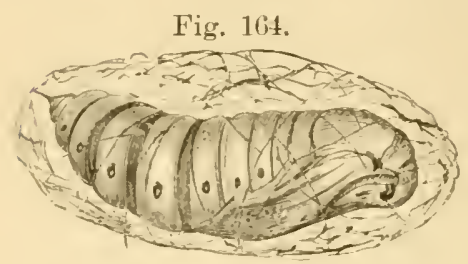
pupate it cleserts the rine and spins an imperfect ruroun beneath the leaves. etc. (Pupa, Fig. 1(it.)

Fig. 1lit. - 'upal of Hogr 'aterpillar in its rocoon- rolor. brown.

The perfect moth (Fig. 165) expands about two inches and three lines, and has the boty and fore-wings of a lilac wray

Fig. 165.

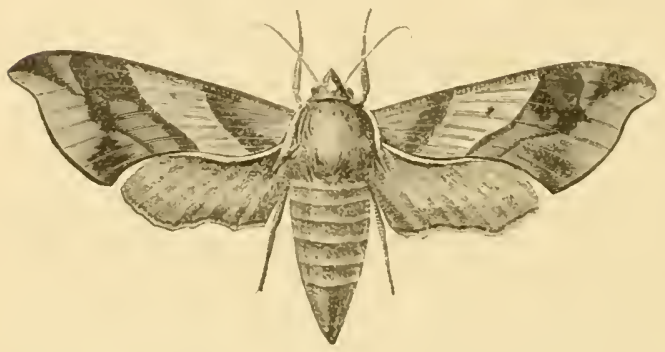
color. markext and shaded with olive green. while the hind wings are of a leep rust color, with a shate of gray near their inner angle.-liiley.

Fig. 16.5. - .11 oth of $\mathrm{Hog}$ ('aterpillar-colors, gray, olive-green and rust-red.

Use the same remedies as recommenderl for the Achemon sphinx-c'hapter c'XIX.

\section{CHAPTER C'III.}

The White-lined Sphinx.

(Cal.)

(Deilephiln linentu-Fahricius.)

Order, Lemuntena: Family, SpHorins.

[Fecding upon the leaves of the grape. apple, melon and turnip); a green or hromnish-black worm, having a horn upon the hinel end of the body. ] 
Fig. 166.

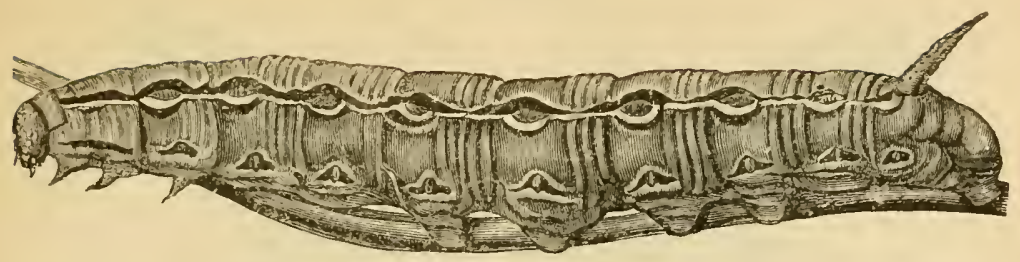

Fig. 166.-Caterpillar of White-lined Sphinx-colors, green and yellow.

This worm appears in two entirely different colorings; in the more common form (Fig. 166) it is yellowish-green, with a row of oval spots along each side of the back, which are usually connected by a yellow line; these spots consist of two eurved black spots enclosing a yellow and a crimson spot.

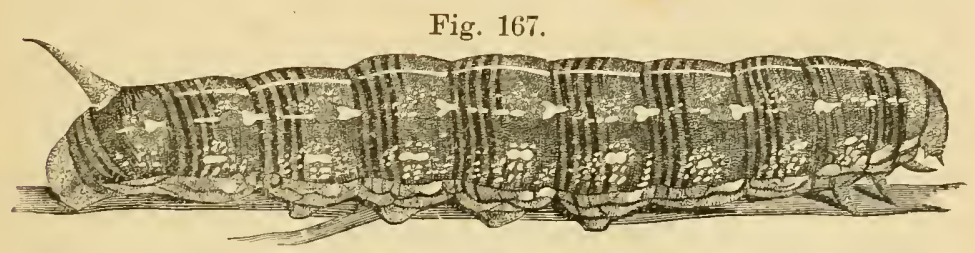

Fig. 167.-Caterpillar of W'hite-lined Sphinx--colors, black and yellow.

In the other form (Fig. 167) the body is black, usually. marked on the back with a yellow line, and with a number of yellow spots on each side of the body. When fully grown it measures from three to four inches in length; it then crecps beneath some leaves or other rubbish, sometimes cven entering the earth, and forms a smooth cell in which to undergo its transformations.

The fore-wings of the moth (Fig. 168) expand about three inches, are of a dark olive-green color, with a whitish line extending from the base to the tip of each wing; the hind wings are black, with a rose-colored band extending lengthwise through the midlle. This moth is quite common in this State. and may frequently be seen in the erening twilight hovering over the flowers like a humming-bird. 
Fig. 168.

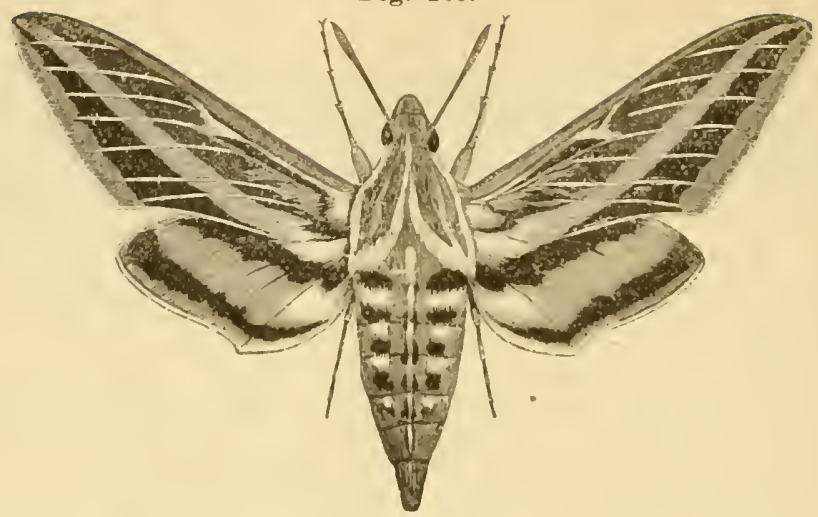

Fig. 16is.-- White-lined Sphinx-oolors, olise-ween, white. hlark and rosereolored.

Revbun:-Nos. 14, 100 and 101.

\section{CHAITER ('IV.}

The Eight-spotted Forester. (Cal.)

(slipria octomaculata-Fabricius.)

Order, Lendopteris; Family, \%ritevide.

Feerling upon the leaves of the graperine; allush-white worm. dotted with black, amo having on the midrle of each segment a luoal transwerse orange hamd, on each sicle of which an four lilack rings.]

Fig̣. 169.-Fight--spotted Forreter and ('atcrpillate: re the moth-o'olors. blue-lilark and rellow: ": the catempillan-(colwre, hluish-white, likck ams arange: b, one serment of its locly, enlarged.

This worm when fully growm (Fig. 16941) measmes onle inch and four lines in longth: it fupates within a slight roreon

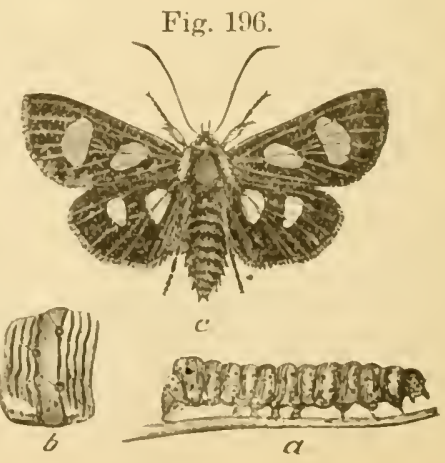


spun beneath some leares, or just beneath the surface of the ground. The fore-wings of the moth (Fig. 169e) are of a deep blue-black color, and each are marked with two light rellow spots; the hind wings are also blue-black, and are each marked with two white spots. The larve are found in the latter part of May. One specimen was received about May 27 th, and one on the 3d of :June, 1882; both specimens were nearly full grown.

Remedrs. - Where vines are seriously infested, spray with No. 5 or 7 , with an equal number of gallons of No. 9 added; also No. 101. The larva will creep under chips, ete. Iaid on the ground under the vine, to pupate, and can be gathered in the Autumn.

\section{CHAPTER CT.}

The Beautiful Wood Nymph.

(Eudryas gratu.-Fabricius.)

Order, Lepidoptera; Family, Zromainf.

[Feeding upon the leaves of the graperine; a bluish-white caterpillar dotted with black, and marked on the middle of each segment with a transverse orange band, on each side of which are three black rings.]

Fig. 170.--Caterpillar and eggs of the Beautiful Woor Nymph; a, the caterpillar-colors, bluish, black and orange; $b$, a segment of its body enlarged; $d$, back view of hump on eleventh segment enlargerl ; $c$, back view

Fig. 170.

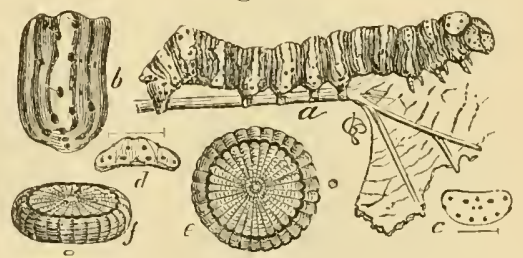

of the top of first segment enlarged; $f$, side view of an egg enlarged (natural size indicated beneath); $c$, an egg as seen from above enlarged (natural size indicated at the right)colors, yellowish and black.

The full grown larva (Fig. 170) measures about one inch and six lines in length; it then deserts the vines and burrows a 
short distance into a piece of soft wood, or enters the earth and forms a cell in which to pass the pupa state.

Fig. 171.

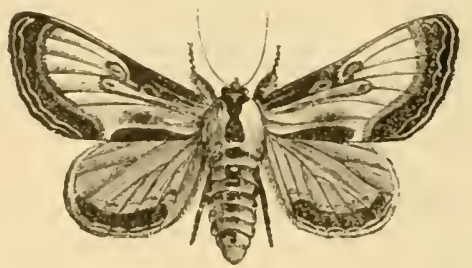

Fig. 171.-Beautiful Wood Nymph (female moth) - colors, white, yellow, hrown and olive-green.

The fore wings of the moth (Fig. 171) expand about one inch and six lines, and are of a white color, broadly bordered and marked with reddis-li-bown and olive-green; the hind wings are pale yellow, broadly marked with pale brown on the hind border.-liley.

I have not found this species in this. State. although moths of a similar description have been reporterl.

Rembriks-Come as recommended for the Eight-spotted Forester. Chapter CIV.

\section{CHAPTER CTI.}

The Grapevine Epimenis. (Cal.)

(Psychomorpha epimenis-Drury.)

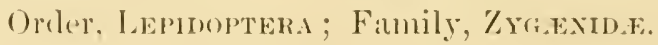

[Feeding upon the leaves of the graperine: a bluish-white (aterpillar, dotted with black and marked on each segment nitle four lilar.k rings.]

Fig. 172.-C'aterpillar of Cimperine Epinenis: a, the (aterpillar--oulors, white and black; b, segment of its body, rnlarged : ralck view of the Fig. 172.
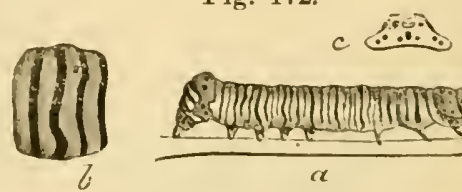
top of the ale venth signent, culargexl. This caterpillar (Fig. 172) lives in a solt of nest formed l,y fastening several leares together with silken threads. When fully grown, it measures about ome inch in length: it then deserts the vine and bores into wood or other sufficiently solt sulstander and forms a cell in which to undergo its transformations. 
Fig. 179. - (iraperine Epimenis (nale moth)-colors, black, white, and recl.

The fore-wings of the moth (Fig. 17:3) expand a little over an inch, are of a velvety black color, marked with blue; and a Fig. 173. little beyond the middle of each is a large yellowish spot, which on the hind wings is of a deep orange color. I have found the nest and caterpillar as described early in May, but failed to rear the perfect insect.

Remedies.-Use No. 24, and the same as recommended for the Eight-spotted Forester, Chap. CIV.

\section{CHAPTER ('VII.}

The American Procris.

\section{(Procris Amerirana.-Bois.)}

Order, Lepidoptera ; Family, Zrganinf.

[Feeding in companies upon the leaves of the grapevine: : small yellowish caterpillar, usually having small tufts of black hairs on the body.]

Fig. 174. - American Procris Caterpillars on a leaf-colors. yellow and black.

These caterpillars (Fig. 174) arrange themselves side by side, their heads all pointing in one direetion. When young, they eat only the surface of the leaves, but when they get stronger, they devour all the leaf excepting the larger veins.

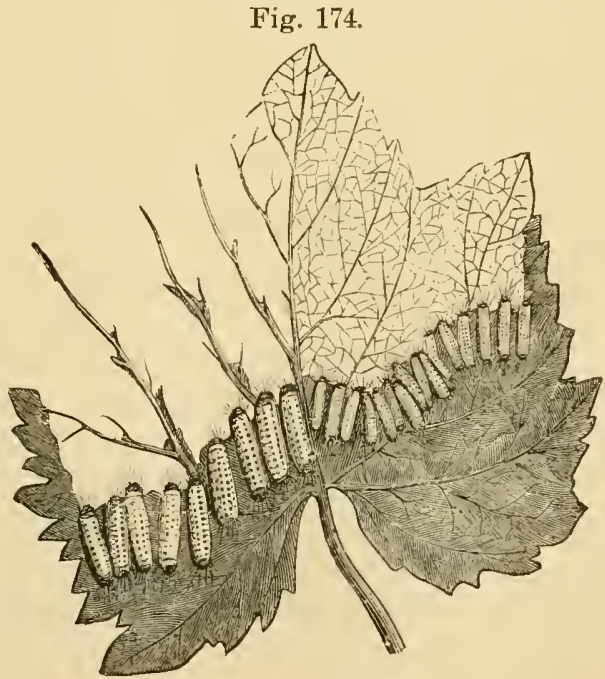


The full grown caterpillar (Fig, 175a) measures about six lines in length, is of a pale yellow, with a row of black prickly tufts on each segment: the first segment is black, with a rellow edge, and the head is brown. When about to pupate they desert the plants and spin in somesheltered place their tough, Hattened, whitish cocoons (Fig. 175c). The perfect moth (Fig. $175, r$ and $r$, expands a little under an inch. and is wholly black exeept the deep orange collatr. I have not found this species in this state, although its presence here has been reported. The above description is taken from liley"s second Missouri Report.

Fig. 175 .
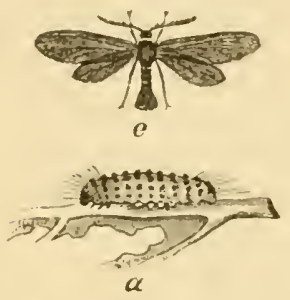
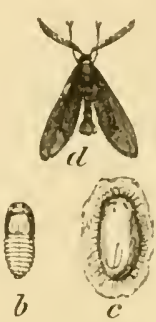

Fig. 175.-Anerican Procris; ', the moth, with its wings expanderl: d. the same, with its wings closed -colurs, hlack amel orange ; ", the caterpillar - colors, rellow and black: $b$, the pupat-color; hrown; i", the rocoun-color, whitish.

ReMedes-lise No. 5 or 7 . mixed with equal quantity of No. 9 ; on non-bearing or young vines. use No. 10 or No. 103.

\section{CHAP'TER ('V'III.}

\section{The Grape Leaf-folder.}

\section{(I)esmia macululis.-Westwood.)}

Order, Lepronters; Family. P'rratum.

[Living in a folded grape leaff; a pale-green larva or caterpillar, with a reddish-hrown head, marked with darker spots.]

When fully grown this larva (Fig. 176, 1,) measures about ten lines in length. It assumes the pupa form (Fig. 17ti, ú,) within its nest. At least two broods are produced in one year: the last brood spends the IVinter in the pupa or chrysalis state, and the moths issue during the month of May of the following vear. 
The perfect inseret or moth (Fig. 176, -4 and , j, is of a black color, the fore-wings markel with two white spots and the hind wings with only one white spot-but this is sometimes divided into two spots; all of the wings are bordered with white.

Fig. 176.
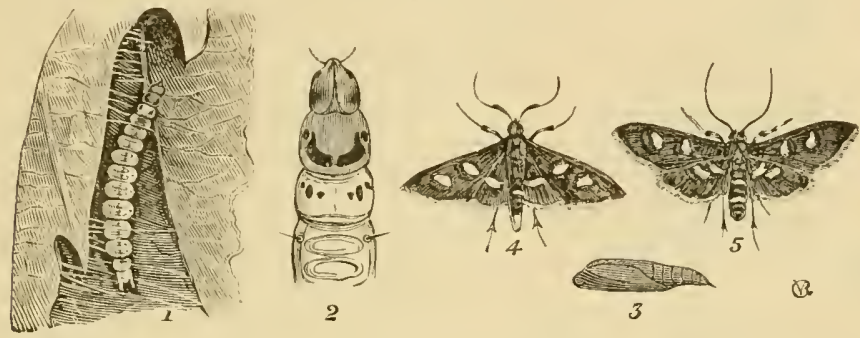

Fig. 176.-Cirape Leaf-folder ; 1 , the caterpillar-color, green or yellowish; 2, the head and fore part of its hody, rnlarged ; 3, the pupa-color, brown; \&, the male moth-colors. black and white; $\bar{j}$, the female moth-colors, black and white.

Remenr.-Une Xo. 24; where seriously infesterl use No. 5 or 7 , with an equal quantity of $\mathrm{No} .9$.

\section{CHAP'TER ('IX.}

\section{The Grapevine Plume. (Cal.)}

\section{(Pterophorus periscelielactylus.-Fitch.)}

Order, Lepidoptera ; Familỵ, Pterophoride.

[Living in a rolled grape leaf, upon which it feeds; a small pale greenish caterpillar, about six lines long, with numerons spreading clusters of whitish hairs.]

This caterpillar (Fig. 17Ta) usually fastens the opposite edges of a leaf together with silken threarls, but it sometimes fastens several leaves together, forming a large carity in which it resicles. When about to pupate-which is about the tenth of May-it suspends itself by the hind feet. The pupa (Fig. $17 i b)$ is angular, and the anterior end appears as if it had been obliquely cut off; on the middle of the back are two angular projections. 
Fig. 177.

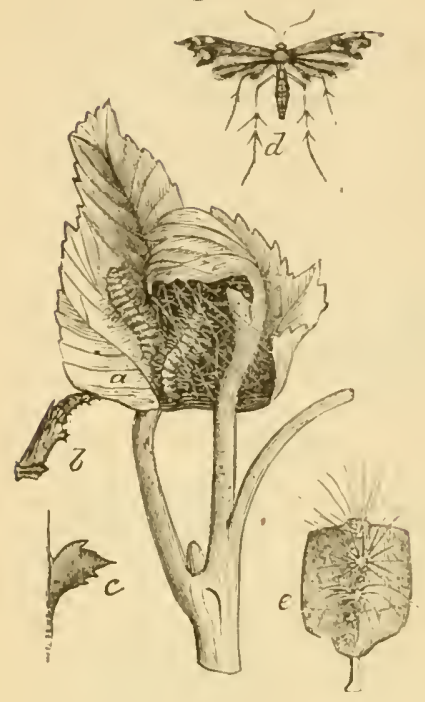

Fig. 17T.-Ciraperine Plume: $d$, the moth-colors, pale yellow, white, and brown; a, the aterpillars in their nests - color. greenish-yellow, with white hairs; $b$, the pupa-color, green or brown; $c$, one of the horns on the back of the pupa, enlarged; $c$, one of the leg-bearing segments of the larvia, enlinged.

The perfeet moth (Fig. 1Tid) exprands a little over nine lines, is of at tawny yellow colur, and ealch fore-wing is markerl with about five white spots; these wings: are cleft or cut nearly to the midale; the hind wings are cleft twice, the forward eleft reaching nearly to the middle, and the second cleft reaches nearly to the base of the wing; they are rusty brown at the base, with the remaining part tawny yellow. I have found the perfect insect; also, a rolled leaf on rines.

Rexedr-L'se No. 24. Spray in the latter part of April, or early in May, with No. 5 or 7 .

\section{CHAPTER CX.}

The Grapevine, or Steel-blue Flea-beetle. (Cal.)

$$
\text { (Haltica chalybea.-Dlliger.) }
$$

Order, Coleoptera; Family, C'hryomelid.e.

[Feeding upon the buds or leaves of the gralpe and willow; an elongate brownish six-legged larva, marked with black duts and with a black head; finally changing to a small blueblack beetle, about two lines in length.] 
Fig. 178.

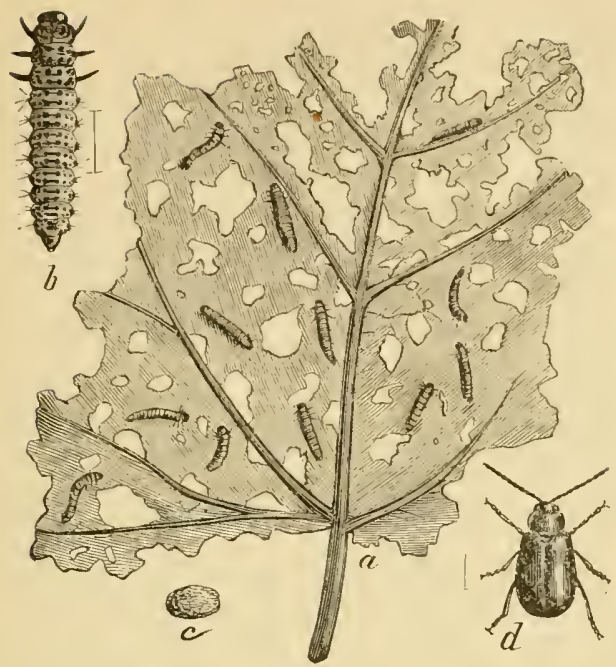

Fig. 178.- (irapevine Flea-beetle and Larve; $a$, several larræ on a leaf; $b$, a laria enlarged-colors, brown and black ; $c$, the cocoon; $d$, the beetle enlarged--color, steel-blue.

These beetles have the hind thighs greatly enlarged, which enables them to leap to a considerable distance, like a flea; it is from this peculiarity that they take the name of "flea-beetles." They spend the Winter in some sheltered situation, and come furth early in the following spring and feed upon the buds of graperines, usually hollowing them out. As soon as the leaves are expanded the females deposit their eggs upon them; in a few days the young are hatched, and immediately begin to feed upon the leaves. When fully grown (Fig. 178b) they descend to the ground, which they enter, and form small cells (Fig. 178c) in which to pass the pupa state. These insects are very destructive to grapevines, and every effort should be made to exterminate them.

Rexedies.-No. 19, 20, 21 or 102. On young non-bearing graperines, ete., use No. 103, or No. 10 may be used instead. 


\section{CHAPTER ('XI.}

The Imported Grape Flea-beetle. (Cal.)

$$
\text { (Adloris ritin-Limnarus.) }
$$

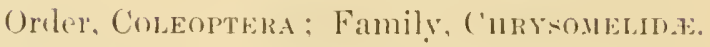

[A small dark-brown beethe, ferding upon the leaves of the grilpevine.]

This speeies was reported in 1552 , from at least six of the vine-growing districts, as elamaging the foliage of graperines, and is reported this spring (18si3) to be destroving the vines infesterl. 'This is an enemy of the grapevine, which must be eradicated. 'Their mode of attack on the vines is similar to that of the steel-blue or grape flea-beetle (Hultira chalybea), and they frefuently datuage young vines to sueh an extent that they die. One vineyard in this vicinity (Facranento) has been clamaged seriously this spring. The perfect insect (Fig. 179, Plate 3, ) is black, with a sub-metallic luster of a greenish hue, but after emerging from the pupa state is of a reddishbrown color. It is ovate and convex, and measures from two lines to two and one quarter lines in length; antenna, eleven jointed. This insert, although known to be widely destructive on the Pacific coast and in the memtainous regions of the Atlantir states, had not been reported as being very injurious in this state until 1882. In Europe it is well known as a dangerous enemy to the graperines, especially in France, where it is called ('. gribourier, and where much has been written in regarel to its destruetive habits.

Rementes - Nus. 19, 20, 21 and 102. On young non-bear ing grapevines Nos. 103 and 10 may be used. 


\section{CHAPTER CXII.}

\section{The Rose Chafer. (Cal.)}

(Macrodactylus subspinosus.-Fabr.)

Order, Coleoptera; Family, scarabeine.

[Feeding upon the leaves of the grape, rose, apple, cherry, ete.; a slender brownish-yellow beetle, about four lines long.]

This insect is a very general feeder, and at times beeomes very injurious. During its larva stage it hives in the ground, feeding upon the roots of various kinds of plants.

The eggs laid by each female are ahout thirty in number, and are deposited from one to four inches below the surface of the earth.

The larve lie upon their sides, their boties being curved so that the head and tail nearly meet each other. They are of a yellowish-white color, with the head pale reddish. They pass the Winter in their earthen cells, and assume the pupa form the following spring, there being but one annual brood.

Fig. 180. Fig. 180.-Pose Chafer-color, brownislryellow.

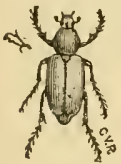

The beetles, or chafers (Fig. 1S0), as they are commonly called, measure about four lines in length; the thorax is produced into a small point on each side of the middle; the head and thorax are black, and the wing-cases brown, but the entire insect is colored with yellowish scales which give it a brownish-yellow appearance.

Remedies.-Nos. 19, 20, 21, 102; or No. 103 or No. 10 on non-bearing vines or plants. 


\section{('HAP'TEli ('XIII.}

The Spotted Pelidnota.

\section{(Pelidnota punctutu-Iimnzus.)}

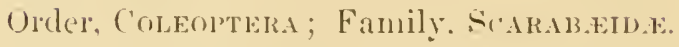

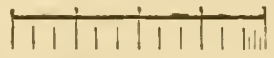

(The measurements of imects in this work ale gilen in julies and lines. The above cut rep. resents one inch divided juto lines and fiactions thereof.]

[Ferling upon the leares of the graje vine: a robust clayyellow heetle. about one inch long. markert with a black spot wn rach side of the thorax, and with three black spots on each wing-(u)

Fig. 1s1.-Sijutted Pelidnotal. Larva and P'upal; $c$, the heetle-colors, rellowish and blark ; $a$, the grub -color, white; $d$, the tip of its body ; $e$, one of its antennix, (enlargerl ; $f$, one of its legs, colitrged ; b, the pupa in its earthen cell-color, hrown.

'These beetles (Figr. $1 S 1 c)$ sometimes oc( $u{ }^{\circ}$ in destructive num-

Fig. 181.

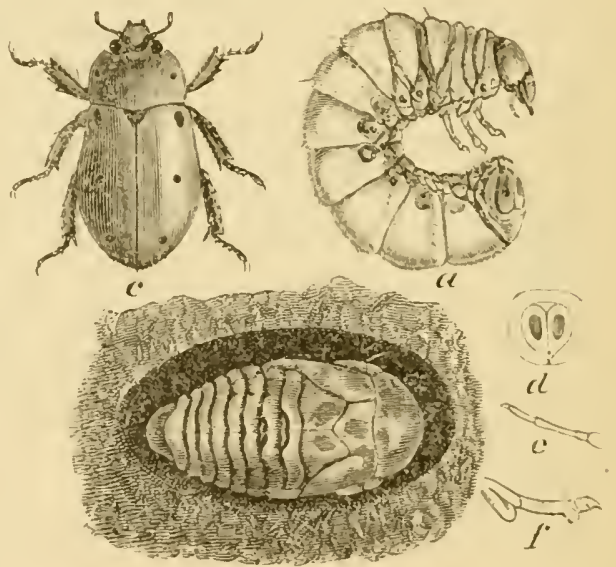

bers mpon the leaves of the cultivated grapevine, but only in limited localities.

The larve or grubs (Fig. 1Sla) closely resemble the white grubs, but differ in having a heart-shaped swelling at the hind end of the body.

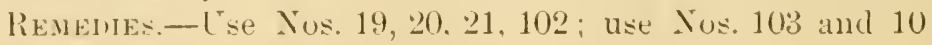
(ll nun-bearing trees and vines. 


\section{CHAPTER CXIY.}

\section{The California Grapevine Hopper. (Cal.)}

\section{(Erythromenra enmes.-Say.)}

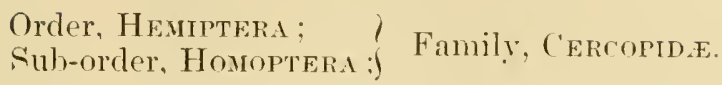

[Infesting the leaves of the graperine, which they puncture with their beaks and imbihe the sap, eausing the leaves to turn yellow prematurely; a vellowish-white vine hopper marked with orange-red.]

The perfect insects (Fig. 182, Plate 3,) are yellowish-white, with oblique confluent orange-red bands on the wing-cases, and a short oblique line on the middle of the outer margin of cach; on the thorax are nsually three red stripes, the middle one forked anteriorly and confluent with two red stripes on the rown of the head; length. about one line and a half. The scutellum is large, triangular and marked with three orange spots which form a triangle; the two anterior spots are sometimes black. At the outer fore-angle of the wing-ases is a black dot, and there is another black dot at the outer hind angle; the posterior tibia are densely spined, and there is a row of spines on the anterior tibix.

These inseets hibernate in the perfect state around the rines, etc.. and come forth in the following Spring and feed upon the new growth of regetation. The females deposit their eggs upon the leaves of the graperine as soon as the latter are expanderl. The young rine-hoppers closely resemble the adults in form. but are destitute of wings. They east their skins sereral times before arring at maturity, and these white cast off skins may frequently he found adhering to the leaves or seattered upon the ground beneath them. I have first observed the perfect insect in the month of July.

These insects puncture the leaves of the vine and extract the sap to such an extent as to cause the leaves to turn yellow prematurely, preventing the 'anes from rijening, and when the grapes, picked off of the invested rines, are used for shipping to the Eastern states they are liable to mildew.

Reventes.-Nos. 32 and 3:'). (See Nos. 19, 20, 21 and 103.) 


\section{CHAPTER CXV.}

The Grapevine Aphis.

(Siphonophorn viticoli.-Thomas.)

Oreler, Hamereri ;
Sub-order, Homoptera $;$ Family, Arhidida.

[Living upon the leaves and twigs of grapevines, which they puncture with their beaks and extract the sap; small brownish plant lice.]

The wingless females are lusky brown; the legs and honey tubes are hack; the latter are about one fourth as long as the body. The winged lice are colored similar to the wingless ones, but are darker.-Profersor Thomas.

Rismedes.- Use No. jor 7 : No. 4 will also be effectual, or No. lit.

\section{CHAPTER CXVI.}

The False Chinch Bug. (Cal.)

(Nysius destructor.-Say)

$\left.\begin{array}{l}\text { Order, Hemiptera; } \\ \text { Sub-order, Howoptera }\end{array}\right\}$ Family, Lrfreida.

[A small grayish-brown bug. feerling on the foliage of the graperine, etc.]

In 1,8.2 specimens of the larva and pupa (Fig. 1,83h) of this speeies were sent me, areompanied by a note stating that these insects were destroying the foliage of graperines (Fig. 18.3a), and in two or three weeks later specimens of the perfect insect were received. The first letter recoived with these specimens stated that vines on about five rods square of ground were attacked; ten days later nualy two atres were infested before the inserts were cheeked from spreading. 

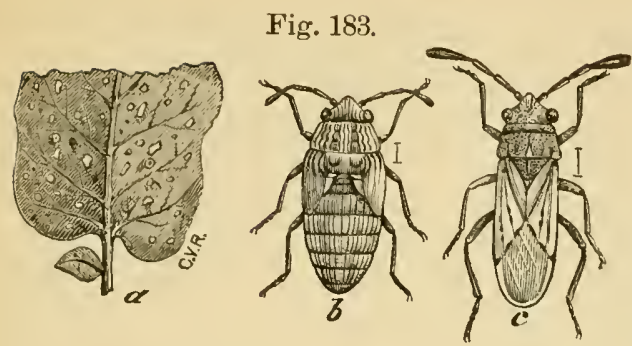

Fig. 183. - False Chinch Bug; a, a leaf, showing its work; $b$, a pupa-colors, dingy yellow, red, and hrown; $c$, the alult-colors. grayish-brown and black.

The perfect insect (Fig. 183r) is of a grayish-brown color; the wing covers (hemelytra) are nearly transprarent, and generally colorless; the legs are yellowish, inclining to brown; length, one and one half lines-in some specinens a little over. The pupa is nearly of the same color as the perfect insect, excepting that the longitudinal lines are brighter; in color, red and brown; wing-pads visible. The larra is of a brownish-yellow color.

This plant bug is reported as feeding on the potato, cabbage, etc., but has only been reported on grapevines in this state.

Rexedies.--Use Nos. 36 and 51 ; or No. 65. (See No. 20.)

\section{CHAPTER CXVH}

\section{The Yellow Mite. (Cal.)}

\section{(Tetranychus sp?)}

Class, Arachind ; Sub-class, Acarina; $\}$ Family, Trombidide.

[A small yellow mite infesting the branches and foliage of deciduous fruit trees, grapevines and nursery stock.]

As this species was only brought to notice last year (1S52), I cannot give any particulars as to its natural history. The color is immaculate primrose-yellow, excepting that the male (Fig. 1st, Plate 3,) has two bright minnte vermillion-red spots on the anterior portion of the hody (or on the shoulders). The female (Fig. 18.). Plate 3. ) is about one serentieth of an inch in length; form, orate; the male is smaller. 
They are very destructive to the foliage of fruit trees grapevines and nursery stock, and appear to spin more than the red mite. Mr. W. B. West, of Stockton, has found them on forest trees. Mr. Williams, of Fresno, repolts them on weeds growing on uncultivated land.

ReMedY.-Tse No. Bt.

\section{CHATTER CAVIII}

The Angular-winged Katydid. (Cal.)

(Hicrocentrum retineris-Bumeister.)

Order, Orthoptens; Family, Locustid.z.

[Feeding upon the leaves of the orange, apple, eherry and graperine: a large green grasshopper.]

The following areount of the manner in which this insect deposits her eggs is condensed from the excellent history of this speres given by l'rofessor Riley:

"Selecting a twig about the size of" a common goose-yuill. this provident mother prepores it for the reception of her exgs by biting and roughening the lark with her jaws for a distanee of two or three inches. When this operation is areomplisherl to her satisfaction, she eommenos at one enrl of the roughened portion of the twig and, after fretting it anew with her jaws and feeling it wore and over again with her palpi as if to assure herself that all is as it shoulel be, she rurls the ahdomen under until the lower edger of the rurved ovipositor is brought hetween the jaw and palji. ly which it is grateper and guiderl to the right position. It is then gently worked up and down for from four to six minutes, while a riseid fluid is given out apparently from the ovipesitor. Finally the exg gradually rises and adheres to the roughened bark; the insecet now rests for a few minutes, soon to resume hereflorts and repeat the like preformance in every particular, exeept that the egg is plateed to one sirle, and a little above the tirst." 
Fig. 186.

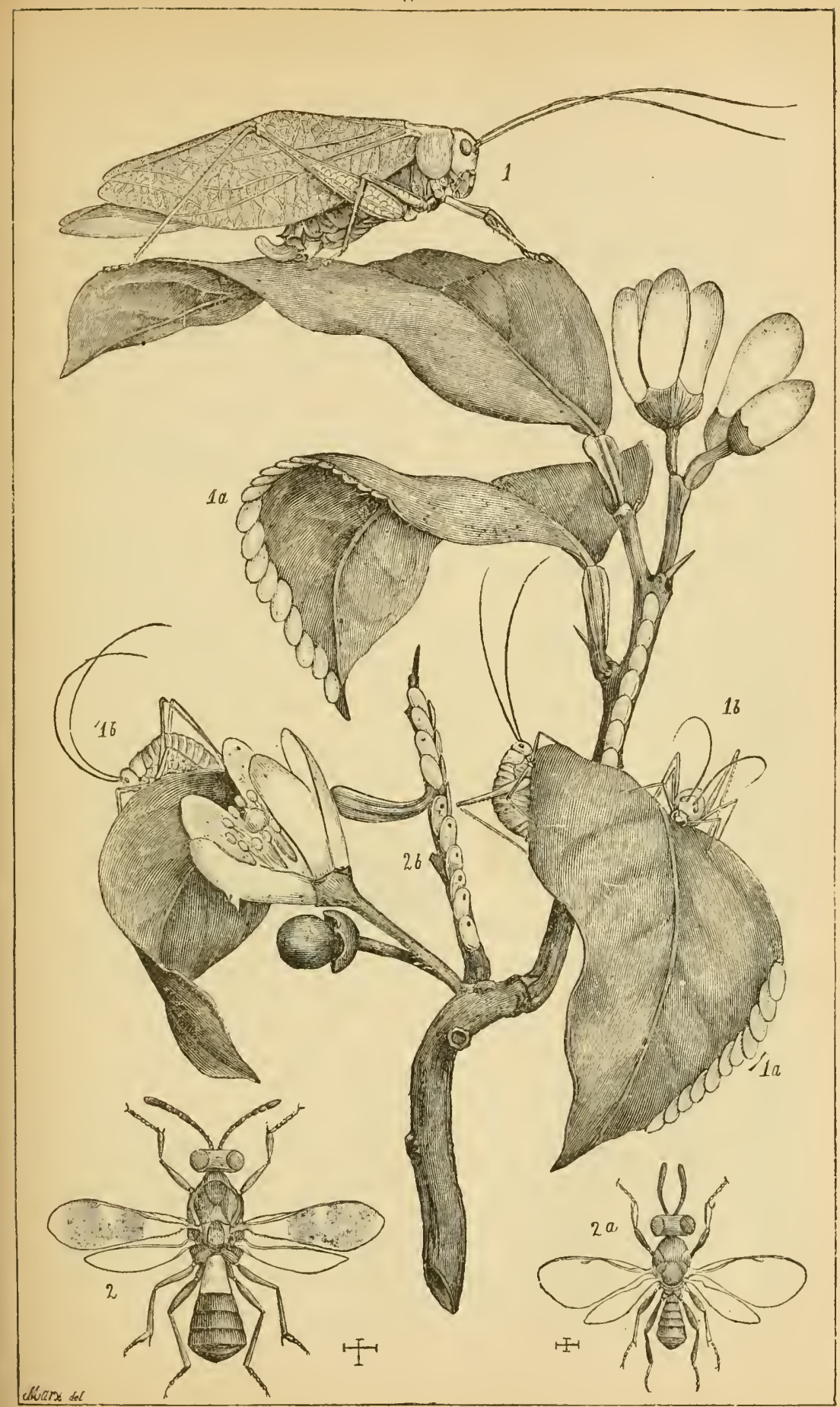


Fig. 1S6.-Angular-winged Katydid; 1, the adnlt-color, green; 1a, the eggs-color, brownish or slate color; 1b, the young-colors, green and yellow; 2 , an egg parasite (the Eupelurus mirabilis of $\mathrm{W}^{r}$ alsh) female, enlarged-colors, black and yellowish; $2 a$, the male, enlarged-color, metallic-green; 2l, eggs, showing holes from which these parasites had emerced.

The eggs overlap each other (Fig. $1 S 6,2 b$, at one end and are usually placed in two rows, side by side, but more rarely in a single row. The number of eggs laid at one time varies from two to thirty, and each female (Fin. 161, 1,) deposits about two hundred eggs. As soon as hatehed, the young grasshoppers (Fig. 186, 1l, 1b,) legein to feed "pon the pulpy part of the leaf. They do not pass through a yuict pupa state, as butterflies and many other insects are known to do, but continue active from the time they leare the egra until they die of old age or some other cause. Two broods are probably produced in one season, the egers of the last brood not hatehing until the following spring. Should this species ever become numerous, a great amount of damage would be done to the foliage of the trees or plants on which they feed.

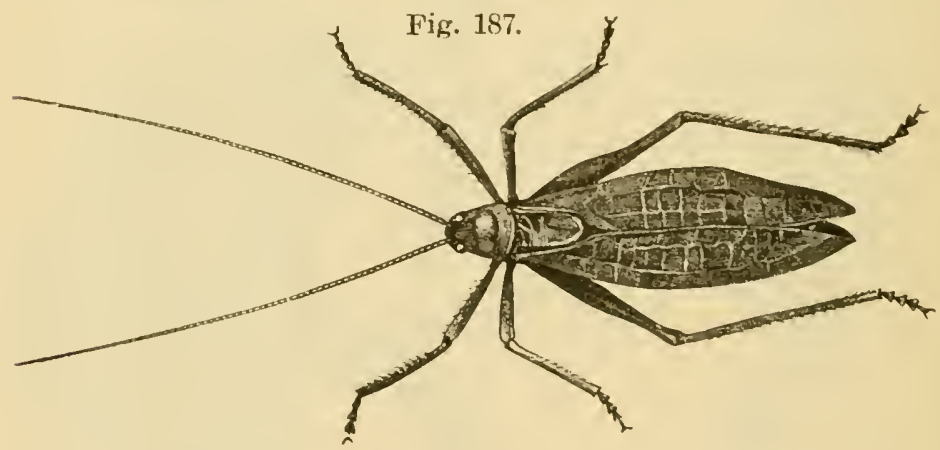

Fig. 187.-Katydid-color, green.

Nots.-The above insect is freipently mistaken for the true katydid (Patyphyllum concacum-Harris) which inhabits the casterm part of this comntry, but has not, so far as I am al ware. been found in this state. By complaring Fig. 1St with Fig. 1sti, 1 , the differenee between these two speeies is readily observible.

Rementes.-No. 1s; and also hy capturing and destroying the perfect insects. 


\section{CHAPTER CXIX.}

The Snowy Tree-cricket.

('Escenthus nitens.-Harris.)

()rder, ()nthoptena; Family, (ikYlande.

[Puncturing the tender twigs of the graperine, apple and peach trees, raspbery and blackberry bushes, and depositing her eggs therein ; a greenish-white cricket.]

Fig. 188.

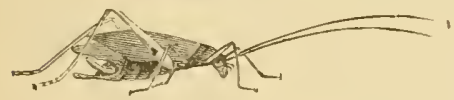

Fig. 188.--snowy Tree-cricket. female-color, greenish white.

In depositing her eggs, the female ericket (Fig. 1SR) first uses her jaws for the purpose of slightly tearing away the outer bark: the oripositur is next inserted into the twig, and an egg thrust into the puncture thus made.

Fig. 1s9.-Eggs of snowy Tree-cricket; $a$, the egg punctures in a twig: $b$, the egg: exposed-color, pale yellow; ', an eger highly magnified; $d$, upper end of the same, still more highly magnified.

These eggs (Fig. 189) are usually placed diagonally across the central pith. In this way the female proceeds until her stock of over two hundred eggs is exhausted. These punctures are frequently made within four lines of each other, and extend in an irregular row a distance of one foot and six lines or over.-Riley.

Fig. 190.

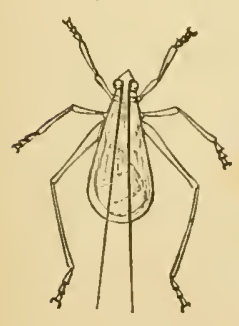

Fig. 190.- Snowy TreeFig. 189.

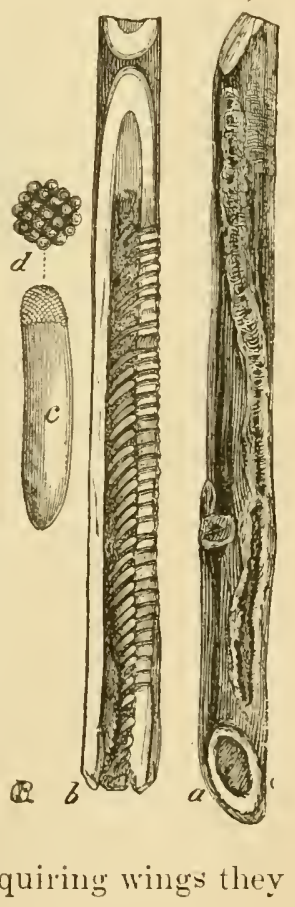
cricket, male-color, greenislı white.

When first hatched, the young cricket feeds upon plant-lice, egogs. etc., and has even been known to attack and levour one of its own kinched. After acquiring wings they 
sometimes do considerable mischief by gnawing off the stalks of green grapes, permitting the latter to fall to the ground. The eggs are usually deposited in the latter part of summer or early in the Autumn, and these do not hateh out until the following spring.

Resedy-L'-Le No. $2 S$.

\section{CHAPTER CXX.}

The Grape Curculio.

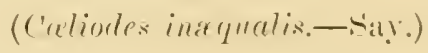

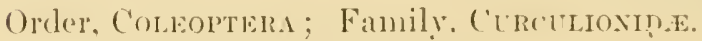

[Livine in arajese, a whitish or bluish footless grub about two lines long, with a brownish hearl: when fully grown deserting the fruit and entering the earth to pupate.]

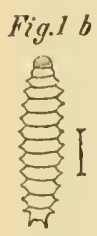

Fig. 191.

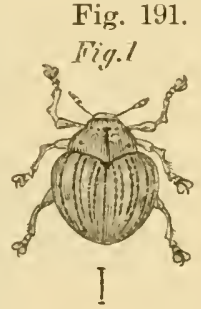

Fig. 191.- (riripe Cureulioenlared-color, gray is liblack: " w, we of its rigla tore legs; $b$, its larra-color, yellowisli-white.

The female eurlio (Fig. 191, 1, ) ex-

eavates a small earity in the grape (Fig. 192a), and then deposits therein a single egy of a bright yellow color. The grub (Figr. 191b) which hatehes from this egg feeds upon the pulp or Hesh of the grape, and rare!y upon the seeds. When fully grown (Fig. 1926) it is about two lines long, and each segment of its body luears on each side a larege fleshy. tuberele.

Fig. 192.-Crape Curculio; $a$, an infested grape; $b$, the larva enlargedcolor, white.

When about to assmure the pupa Fig. 192.

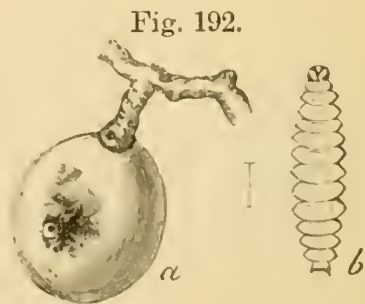
form the larva deserts the fruit, which sometines drops from 
the vines previous to this, and enters the earth to the depth of a few inches, where it forms a small cavity in which it shortly afterwards assumes the pupa form. The beetle issues in the Fall, and passes the Winter in some sheltered place. The perfect beetle is nearly hemispherical in outline, and of a black color, but is covered with short appressed scale-like white hairs, which give it a grayish tinge; the legs are reddish, and on the upper and outer edge of each fore and niddle shank (tibia) is a rectangular tooth. The body measures about one line in length. I have not found this species in this State.

\section{CHAP'TER ('XXI.}

\section{The Grape-seed Maggot. (Cal.)}

\section{(Isosoma vitis.-Saunders.)}

Order, Hymenoptera; Family, Chalcidide.

[Living within the seeds of grapes; a minute footless maggot.]

This maggot (Fig. 193) burrows into the grape while the covering of the seeds are still soft and tender; it makes its way directly to the seed, which it enters and feeds upon the kernel. It undergoes its transformations within the seed, and the fly, when about to issue, gnaws its way out.

Fig. 193. - Grape-seed Maggot-color, whitish.

The perfect fly is black, and the forewings expand about one line. Only one brood is usually produced in a year, and these pass the Winter in the larva state.

Mr. Charles A. Wetmore, ('hief Executive Viticultural Officer, called my attention to the larva found in the seed of the California wild grape, from which I bred the fly, and found it to be the Isosoma ritis. I do not know of any cultivated grape being infested by this pest, but close attention should be given to examinations lest it gains a foothold.

REveDies.-Should this pest spread to the cultivated varie- 
ties, all grapes should he picked off the vines at the end of the seasurt, and if not fit for any use, destroyed; also, all seed from wine presses, ete., should be destroyed.

\section{('HAT'TER ('XXII.}

\section{The Grape Leaf-roller. (Cal.)}

\section{(Tortivir sir?)}

Orler. Lephoptera: Fanily, Tortricidi:

[Living in a jolled grape luaf : a small greonish eaterpillar.] Last season (1852) specinens of wape leaver rolled up and fastened with silkenjthrads, as in Figrs 194 and 19\%, were

Fig. 194.

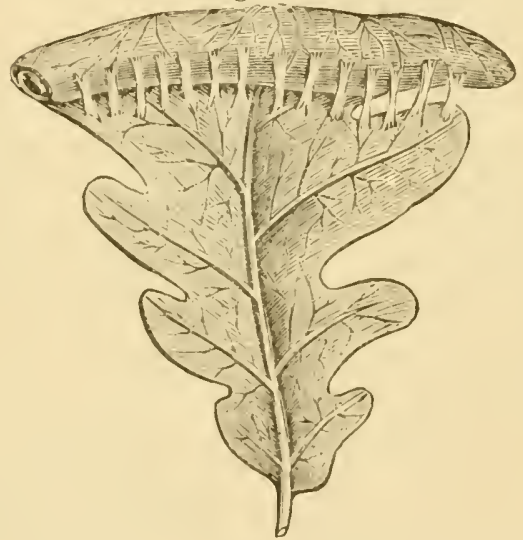

Fig. 195.

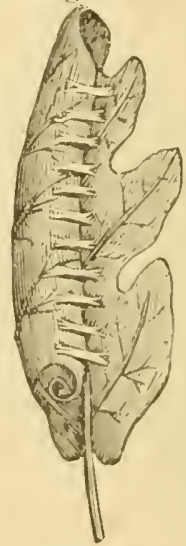

went no from Fresno ('omntr. Is I dirl not suceed in lineeding the perfect inreet, I am mahle to give the nande of the speries to which this leaf-roller belonge; but. judging fiom the

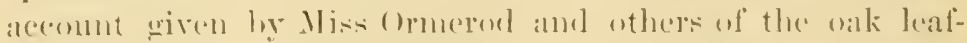

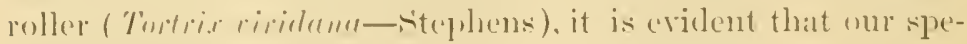

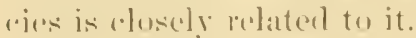

lis:mest:- - 


\section{CHAPTER CXXII 告.}

\section{The Red-shouldered Grapevine Borer.}

\section{(Sinoxylon basillare.-Say.)}

\section{Order, Coleoptera; Family, Ptinidiz.}

[Living in the canes of grapevines; a small yellowish sixleggerl larva or grub, finally changing into a black beetle which is usually marked with a red spot at the base of each wingcover.]

This grub (Fig. 195 $\frac{1}{2} a$ ) lives in the eanes of grapevines, boring the wood beneath the bark, and also the heart-wood, in various directions. It also lives in the trunks of apple, peach and hickory trees.

The pupa form (Fig. 195 $\frac{1}{2}$ l) is assumed in the burrow.

The beetle (Fig. 195 $\frac{1}{2} c$ ) measures about two and a half lines in length, is of a black color, and there is usually a large reddish spot at the base of each wing-eover; the thorax is armed with short spines in front, and the wing-cases are armed with several small teeth at the apex or tip.

Fig. 195 $\frac{1}{2}$. - Red-shoul-

Fig. 1951/2.
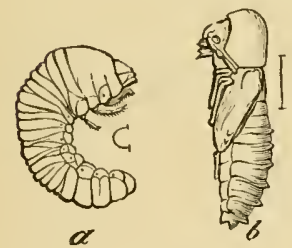

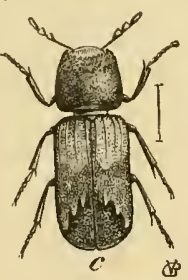

dered Grapevine Borer, enlarged ; $a$, the larva-color, yellowish; $b$, the pupacolor, yellowish ; $c$, th e beetle-color, b lack and reddish.

Remedies.-Use Nos. 26 and 27 . 


\section{INSECTS INFESTING THE RASPBERRI.}

CHAP.

CHAT.

The liaspherry-root Borer (.Eiferia rubi)..123 The Raspberry-root (:all-fly (Rhodites radi-

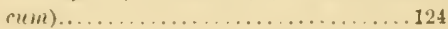
The Raspberry Borer (.Ijpilus ruficollis)...125 The lasplerry span-worm (Ay)lodes mebi-

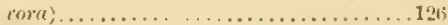

The Raspherry Leaf-roller (Exartemia grermundana $) . . . \ldots \ldots \ldots \ldots \ldots \ldots . \ldots . \ldots . \ldots 127$

The Raspberry $\Lambda_{p}$ his (Sighonophora rubi).12s
The Negro Bug (Corimelcena pulicuria) . 129

The following inseets also infest the Rasj. lerry :

The Rose Seale (Di(t)yis rosis').

The Blackherry Cane-horer (Oberea Iripunclatu).

The Sncwy Tree Crieket ( $Q$ scanthus niteus).

\section{CHAPTER ('XNIII.}

The Raspberry-root Borer. (Cal.)

\section{(Eegeria ruli--liile.}

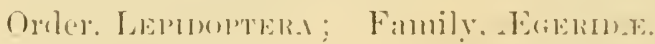

[Jiving in the stems and roots of raspluedry and blacklowry bushes; a palo yollow sixtern-leggedl larra.]

Fig. 196.
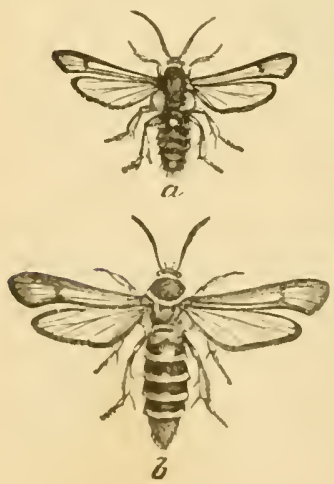

Fig. 196. - Raspluerry-pout Burer-

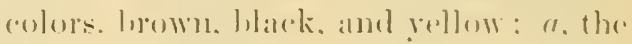
male moth: h, the femsile.

The perferet inseret (ris. 196i) (xplanels from ane inch to ance inch and threer lines, and is of a blarek eolore, marked with gray, as follows: A narrow ringr arement the neck, the hind thinel of the abrluminal sements: a low of tufte om the hack. and amether row along wath side of the aldemene hesides a lew strake (1) the thurax.

The egge from whith these burers hatch are dipugited upen 
the bushes at a distance of from four to six inches from the ground. As soon as hatched, the young borer enters the stem to the pith, and then directs its course downward to the roots, which it reaches at the approach of Winter. Here it remains until the following Spring, when it directs it course upward, burrowing out a different stem than the one by which it had entered the roots. After attaining its full growth it preprares a place of exit, and soon afterward assumes the pupa form.

I have only found one specimen of the larva of this species and have had specimens of roots sent me from which the borer had matured.

RemenY.-Use No. 37 in the latter part of June and early in July : or No, 5 or 7 .

\section{CHAPTER CXXIV.}

The Raspberry-root Gall-fly.

\section{(Rhodites rudirum.-Osten Sacken.)}

\section{Order, Hruenoptera ; Family, C'resipidz.}

[Living in a large swelling on the roots of raspherry bushes; small whitish footless grubs.]

If one of these galls were to be ent open, it would be found to be composed of a yellowish pithy substance, and scattered through it are a number of small cells, each containing a small white larva or grub. These soon change to pupæ, which in turn produce the perfect flies; and the latter gnaw their way out of the gall, leaving small holes to mark their places of exit.-Condensed from Saunders.

\section{CHAPTER CXXY.}

\section{The Raspberry Borer.}

\section{(Agrilus ruficollis.-Fabricius.)}

Order, Concopter. ; Family, Buprestida.

I Living in the stems of raspberry and blackberry. bushes, producing a gall-like swelling; a pale yellow footless grub. 
which is finally transformer into a slemkler blackish beetle, with the head and thorax of a brilliant copper color.]

The location of these burers in the canes may easily be eletected by the gall-like swelling in the canes; this swelling is about an inch long, and is very rough as eompared with the rest of the cane. ()ecasionally several larva will be found inhabiting the fame gall, thus lengthening the latter and causing it to assume a very irregular shape.

Fig.'197.--Raspherry Borer, enlarged; b, the larra-color, yellowish; $a$, the hind part of its body still nore enlarged; $c$, the beetle-colors, black and coppery-red.

When fully grown, the larva (Fig. 197b) measures about seven Fig. 197.

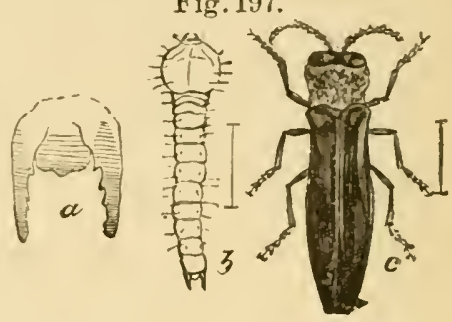
lines in length, and is of a yellowish-white color ; the first segment behind the head is greatly dilated on each side, and the last segment is armed with two clark brown horns, each with three teeth on the imner edge. It assumes the pupa form within the gall in $\Lambda$ pril or May, and the perfect beetle (Fig. 197c) issues in the eomre of a few weeks.

This speceies has been reported to me as infesting the blackberry in this State, Jut I have not seen any specinems.

Resedies-Use No. 27, 2S, 37, or 67.

\section{CHAPTER CXYT.}

The Raspberry Spanworm.

\section{(Aplodes rubirora.-Riley.)}

Order, Lemooptens ; Family, Phal.xim.t.

[Feeding upon the leaves and fruit of the raspherry and hackberry; a yellowish ten-legeded span-worm, thinly vovered with small spines, on which are nsually aflixed small picese of leaves.) 
Fig. 198.

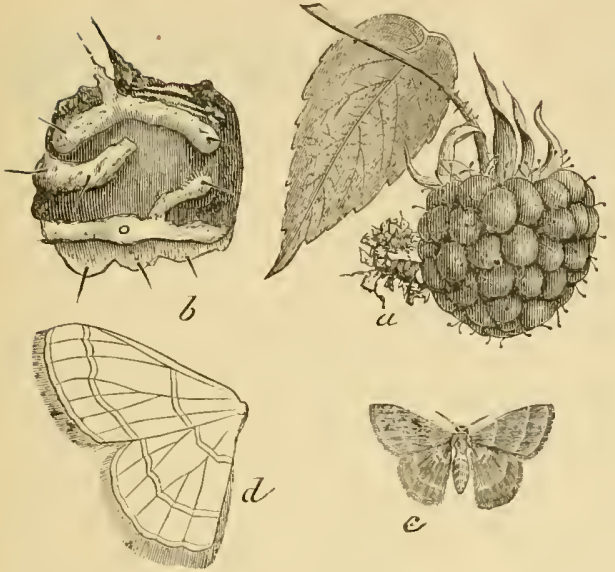

Fig. 19s. - Raspberry spanworm and Moth ; a, the worm-color. rellowishgraly ; b, a segment of its body greatly enlarged; $c$, the moth-solors, green and white; d. two of its wings enlarged.

Before pupating, this worm ( Fig.198a) spins a loose cocoon in which to undergo its transformations.

The perfect moth (Fig. 198c) expands about wix lines, and is of a delicate green color, and all of the wings are crossed by two eurved light colored lines.-Riley.

Revedies. When the caterpillars appear, spray with No. 83 or No. 85.

\section{C'HAPTER ('XNYII.}

The Raspberry Leaf-roller.

(Exartema permunduna.-Clemens.)

Sroxrar-Eeropsis pemundam.-Clemens.

(Moler, Lepmorerera; Family, Tortrictde.

[Living within a rolled leaf on raspberry, strawherry and various other plants; a greenish worm with a black head.]

Besides rolling up and derouring the leaves, this leaf-roller sometimes fastens several blusioms together with silken threads, afterwards feeding upon them. It has nearly the same halits as the (ireater Leaf-roller (Chaj,ter XL.) 
Fig. 199.-Raspberry Leaf-roller, natural size and enlarged-colors, yellowish or brownish.

The perfect moth (Fig. 199) has the fore-wings yellowish, raried with brown streaks and patches. The caterpillar appears alout the time the berry is in hloom. I have found the moth of this Fig. 199.

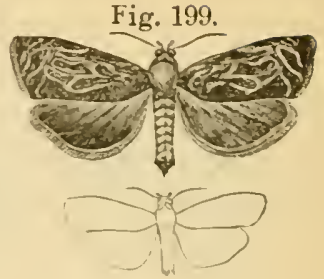
species, and also the nest of the larra, but have never found the larva.

Remedies-(See Remedies, Chapter XL.)

\section{CHAPTER CXXYIII.}

The Raspberry Aphis.

(Siphonophore rubi.-Kaltenbach.)

$\left.\begin{array}{l}\text { Order, Hemptera; } \\ \text { Sub-order, Homoptera }\end{array}\right\}$ Family, Aphidide.

[Living on the stems and leaves of blackberry and raspberry bushes. which they puncture with their heaks and extract the sap; small, ereenish plant-lice. I

The wingless and winged lice of this species are almost entirely of a greenish color.-Prot. Thomas.

ResienY-L'se $\mathrm{N}_{0}, 3,4,5$, or 7 .

\section{C'HAPTER C'XXIX.}

The Negro Bug.

(Corimelarne juliereriu.-(iermar.)

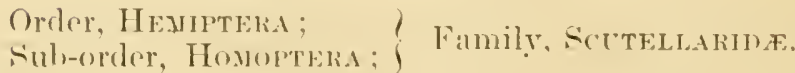

| Living "lpon the stems ame fruit of the strawhery, rasplecry, cherry, and ynince: a small black hug, with a white strije on each side of the wing-enters.] 
"These bugs puncture the young twigs and fruit and imbibe the sap; but the injury they oecasion in this direction is as nothing compared to the effect which their presence has upon the fruit, as they exhale an offensive oder which renders the fruit upon which they congregate wholly unfit to be eaten; besides this, their small size renders their detection very difficult, so that a person is likely to get one or more of them into his mouth, along with the fruit, without being aware of it."Riley.

Fig. 200.-Negro Bug, natural size and magnified-colors, black and white.

The young bugs closely resemble the adults (Fig. 200), but are of a more brownish eolor and are entirely destitute of wings.

Fig. 200.

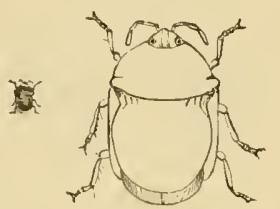

I have a speeimen found on the cherry that agrees with the above description, excepting stripes on the wing-case. It is probably a closely allied species, but I have found the genuine negro bug in Southern California, on purslane. 


\section{INSECTS INFESTING THE BLACKBERRY.}

CIIII)

The Blackluerry Cane-borer (Oberea triymertata) ...................... 130 The Blackberry Ajhis (Sigha mbifolii)... 131

The following inserts also infest the Blackiberry:

The liaspherry-root liorer (. Figria mbi).
The lasplucry Borer (Agrilus ruficullix).

The lina séale (Jia-yis rowa').

The snowy Tree Cricket (lidunthus niteus). Tha Red-humped Caterpillar (Notudundu enonrimnes).

The Raspluerry Span-wom (Ayllodes muluoru). The liaspluerry Aphis (sighonnyiliorce mubi).

\section{('HAY'TER ('XXX.}

\section{The Blackberry Cane-Borer.}

\section{(Oberee tripunetuta.-Fabricius.)}

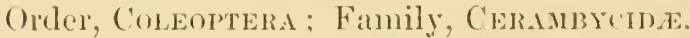

[Living within the stems of blackberry and rasploery bushes; a yellow footless grul, transforming into a slonder black longhorned beetle, having the top of the thorax yellowish, and usually marked with two or three hlack dot:.]

Fig. 201.-Blackluery ('anc-borer-color's, black and yellowish.

The prefect heetles (Fig. 201) appear in May or Jume. The female beetle, after gnawing two rings

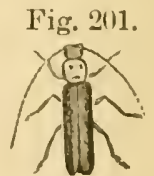
around the growing cane, punctures the latter between the griblled rings, and depesits therein a single egog; the grub which is produced from this arger hurrows into the rent ral pith. where it lives until reareling its full growth, when it forus a cell in its hurrow, and soon afterward assumes the fupal form: in due time the pupa is transformed into the perferet inseret, or beetle, which gnaw its way ont of the burrow.

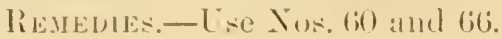




\section{CHAPTER CXXXI.}

\section{The Blackberry Aphis. (Cal.)}

\section{(Sipha mbifolii.-Thomas.)}

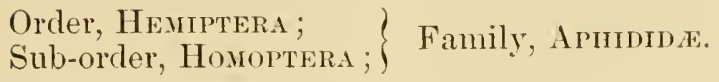

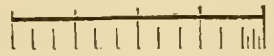

The measurements of insects in this work are given in mehes and lines. The above ent represents one inch divided into lines and fractions thereof.

[Living on the underside of the leaves of blackberry bushes, which they puncture with their beaks and extract the sap; small, black and green or pale green plant-lice.

The wingless lice are pale green, marked with a darker green, the head tinged with yellowish. The winged lice have the head and thorax black, and the abdomen colored as in the wingless lice.--Professor Thomas.

Remedies.-Use No. 4, 5, or 7; No. 3 will do if No. 4, 5, or 7 cannot be obtained. 


\section{INSECTS INFESTING THE CURRANT.}

The Curreut $\mathrm{CHAP}$. The Americun Cumant-horer (Potnocers suyernotatus) ..................... 133 The Currant Mite (Tyroglyyhus ribis). . . 134 The Imported Currant-worm (Kematus) ientricosus)....................... 135

The Native Currant-wom (I'ristophora grosivilariop).

The Currant Span-wom (Euritchia rele(aria).
The Progne Buttertly (Grayta yroyue) cilsis. The Currant Alhis (Ityzus ribis).

132

The following insects also infest the Currant :

The Rose Scale (Dianyis rosce).

The Lemon Peel Scale (Ayridiuhus nerii).

The Stalk Borer (Gortyna nitela.)

The Gooseberry Fruit-worm (f'emyelia gros rularia.)

\section{CHAPTER ('IXYII}

The Currant Borer. (Cal.)

(. Eyeria lipuliformix-Linn.)

Oreler, Lesidortera; Family, Egeride.

[Eating out the central pith of currant and goosebery bushes; a whitish sixteen-legrged worm.]

Among the numerous insect 'nemies of our small fruits. none are more widely distributed nor better known than the currant borers.

The eggs from which these borers (Fig. 202) hateh are deposited near the buds, only one egg usually being consignerl to a single plant. As soon as hatehed, the young borer penetrates the stem to the pith, which it devours, forming a burrow several inches in length in the interior of the stem. As it increases in size it enlarges the hole communieating with its burrow, so as to adnit of the more easy passage of its castings. which it pushes out of this opening. It reaches its full growth in the folluwing spring, and then measures a little over six lines in length. 
Fig. 202.-Currant Borer; upper figure, the larva-color, white; lower figure, the pupa-color, white.

When about to assume pupa form (Fig. 202) this borer takes up a position near the opening of its burrow, and closes the burrow above and below

rig. 202.
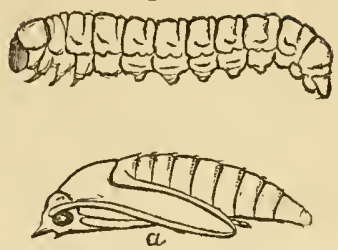
it with its castings, and then spins around its body a silken cocoon. Soon after completing this task the borer is changed to a pupa, from which the perfect insect is evolved in the course of a week or so. The latter usually makes its appearance in April or May, and soon afterward deposits its eggs.

The fore-wings of the perfect moth (Fig. 203) expand about ten lines; they are transparent, with the veins and margins black, and crossed near the middle with a black band; at the tip of each wing is usually a black spot, which is more or less tinged with copper color; the body is blue-black, with the edges of the collar and shoulder tuft, and three rings on the abdomen, golden yellow.

Fig. 203.-Currant Borer (moth)-colors, Fig. 203. blue-black and yellow.

Remedies.-Use Nos. 60 and 66 . In the latter part of April or early in May, spray with No. 5 or 7 ; use No. 3 or 4 if No. 5 or 7 cannot be obtained.

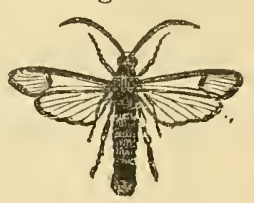

\section{CHAPTER CXXXIII.}

The American Currant-borer.

\section{(Psenocerus supernotatus.-Say.)}

Order, Coleoptera; Family, Cerambycidez.

[Living within the stems of currant bushes; a whitish footless larva with a brown head.]

"This larva feeds upon the pith until reaching its full growth, when it gnaws a hole to the bark; it then retreats to 
a short distance below it and forms a cell in which to undergo its transformations. It remains in its cell unchanged throughout the Winter, and is changed to a pupa in the following Spring, the beetle issuing in April.

Fig. 20t.-American Currant-borer, cnlarged-colors, brownish and white.

This beetle (Fig. 204) is a little over two lines long, and is of a black eolor, with the margins of the thorax and wing-covers pale brown. Near the middle of each wingcover is a crescent-shaped white spot, and a short distanee toward the base of the wingcover from this are two yellowish or ash-

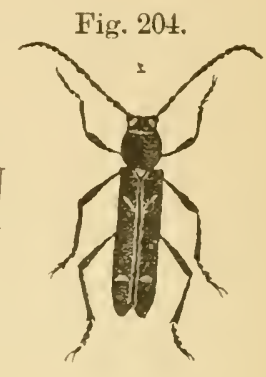
gray spots-Fitch.

Remedies-C - Tse Nos. 60 and 6 ti.

\section{CHAPTER CXXXIV.}

The Currant Mite.

\section{(Tyroglyphus ribris-Fiteh.)}

Class, Arachind; Family, dentme.

[Living in the burrows of the currant-borers; minute eight legged mites of a white color, and measuring scarcely one hundredth of an inch in length.]

In specimens of eurrant stocks infested by borer's sent me by Mr. Wr. H. Jessup, of Haywards, in September, 18so. he called my attention to nests of egos in the debris left by the borel from which hatehed mites. These are not true insects. but belong to the same class as the spiders, and are characterized by having in the adult state four pair of legs. whereas no insect in the perfect state has more than three pairs. They belong to the same family as the iteh-mites-minute creatures which live beneath the skin of man, produeing that luathsome disease conmenly known as the itch.

The habits and ceonomy of the currant mite have never 
been studied up, and hence it is impossible to say whether it should be regarded as a beneficial or as an injurious insect.

Another species belonging to the sane genus- the phylloxera mite, tyroglyphus phylloxer:-Planchon and Riley-feeds in the early part of its existence upon partly decomposed vegetable and animal matter, while later in life it preys upon the living phylloxere or grape-root liee; and so we may conelude that the currant mite is a friend and not a foe ; or at least that it is not destructive to living plants.

\section{CHAPTER CXXYY}

The Imported Currant-worm.

\section{( Vemutus rentricosus.-Klug.)}

\section{Order, Hymenoptera; Family, Tenturennid.}

[Feeding upon the leaves of eurant and gooseberry bushes; a naked green twenty-legged worm, marked with black spots.]

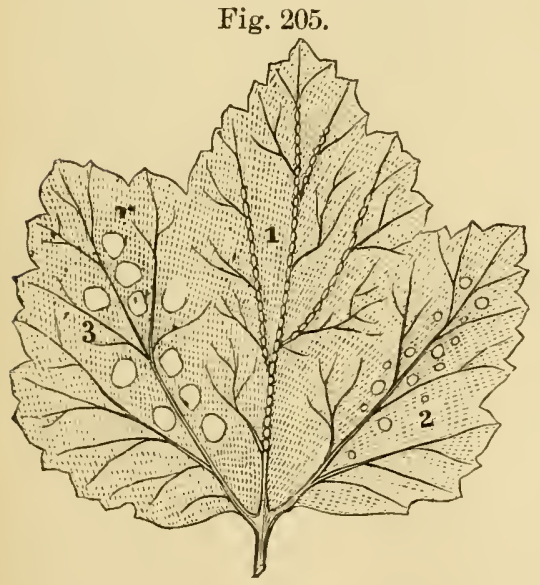

Fig. 205.-Eggs of Imported Currant saw-flies; 1 , the eggs; 2 and 3 , holes made in the leaf by the young worms.

The eggs (Fig. 205) from which these worms hateh are laid along the larger reins on the underside of a leaf. In the course of eight or ten days these hateh into pale worms, having a large whitish head with a black spot on each side. After casting the skin the color becomes green, and the body is marked with numerous polished black spots (Fig. 206); the head is also black. After 
the last molt the black spots disappear, and the head becomes greenish, with a dark spot on each side.

Fig. 206.-Iniported Currant Worms; $a, a$ and $a$, the worms of different sizes-colors, green and black; $b$, a segment of a worm's body enlarged.

When fully grown they measure about nine lines in length. They then desert the plants and hide themselves beneath the leaves, or enter the earth and spin their tough brownish coFig. 206.

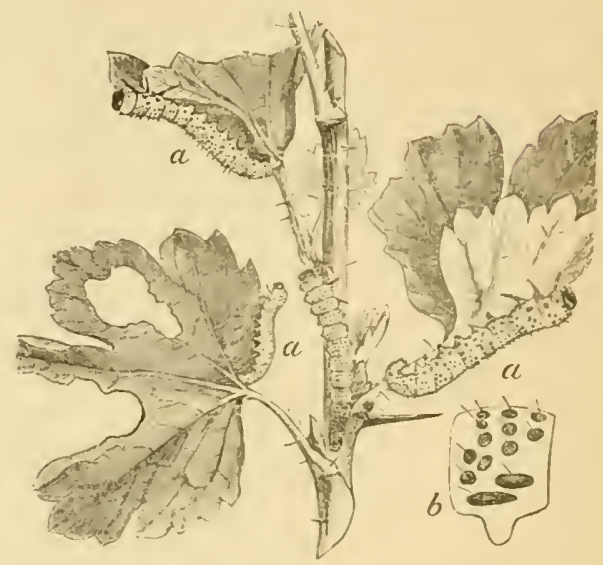
coons. At least two broods are produced in one season; the last brood passing the Winter in their cocoons.

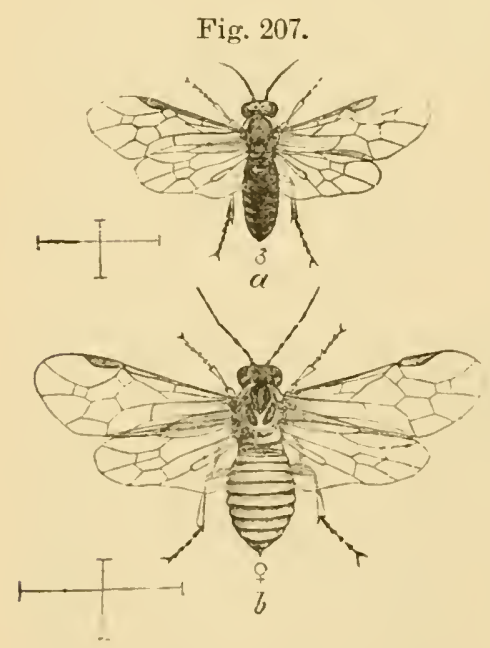

Fig. 207.- Imported Currant saw-flies-colors, yellow and black; $a$, the male enlarget: $b$, the female enlarged.

The female fly (Fig. 207b) is of a bright honey-yellowcolor, the top of the head and thorax marked with black; the wings expand about six lines, and are transparent with black veins.

The male fly (Fig. 207a) difer's so much from the female as to be easily mistaken for a distinct species. It is black, with the top of the thorax marked with yellow, and the tip and the under side of the abdomen are marked with yellow. 
Fig. 208.

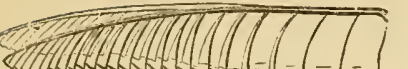

a

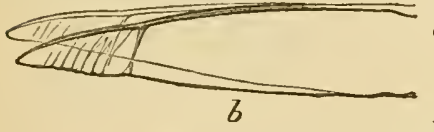

Fig. 208.-Ovipositors of Sawflies highly magnified; $a$, ovipositor of willow saw-fly (N. salispomum) ; b, ovipositor of imported currant saw-fly.

Renedies.-When the larva is noticed on the foliage, use No. 64 ,

No. 5 or No. 7 . See also No. 80.

\section{CHAPTER CXXXVI.}

The Native Currant Worm.

(Pristophora grossularix.-Walsh.)

Order, Hymenoptera; Family, Tenthiednide.

[Feeding upon the leaves of currant and gooseberry bushes; a naked green twenty-legged larva or worm.]

Fig. 209.

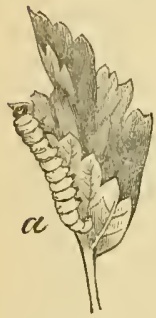

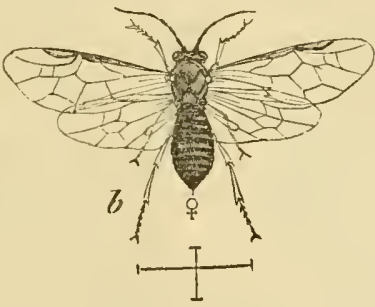

Fig. 209.-Native Currant Worm and Fly; $a$, the worm-eolor, green; $b$, the fly-colors, black and yellowish.

When fully grown (Fig. 209a) this worm measures about six lines in length; it then spins a tough cocoon in some sheltered place, usually among the leaves of the plant it infests.

Two broods are usually produced in one season, and the second brood are changed to flies (Fig. 2096) in the Fall. The latter deposit their eggs upon the twigs, and these eggs do not hatch until the following Spring.

The wings of the perfect fly expand from four to six lines; the body is black, and the thorax is marked with pale yellowish.--Riley, ninth Missouri Report.

ReMedies. - When the larve appear on the foliage, use No. 64, No. 5 or No. 7 . See also No. 80. 


\section{CHAPTER CXXXYII.}

The Currant Span-worm.

\section{(Eufitchia ribearia.-Fitch.)}

\section{Sranxy.-Abraras, or Ellopia ribearia.}

Order, Lepimoteka; Family, Phaldexidf.

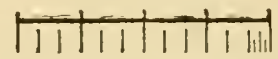

[The moasurements of insects in this work are given in inches and lines. The above cut rep. resents one inch divided into lines and fractions thereof.]

[Feeding upon the leaves of currant and gooseberry bushes; a whitish ten-legged span-worm, marked with yellow stripes and numerous black spots.]

Fig. 2010.-C C u r r a n t Span-worms and l'upar $a$ and $b$, the worms in different positions-colors, rellow and black; $c$, the pupat-color, brown.

This span-worm (Figr. 210, $a$ and $b$ ), when fully erown, measures a little orer an inch in length, is of a whitish color, spotted with black, a 11 d markel with a yellow stripe on the back and at similar one on earh sicle of the boxly: the muler side of the boety is also white, and has a yellow line in the middle. When

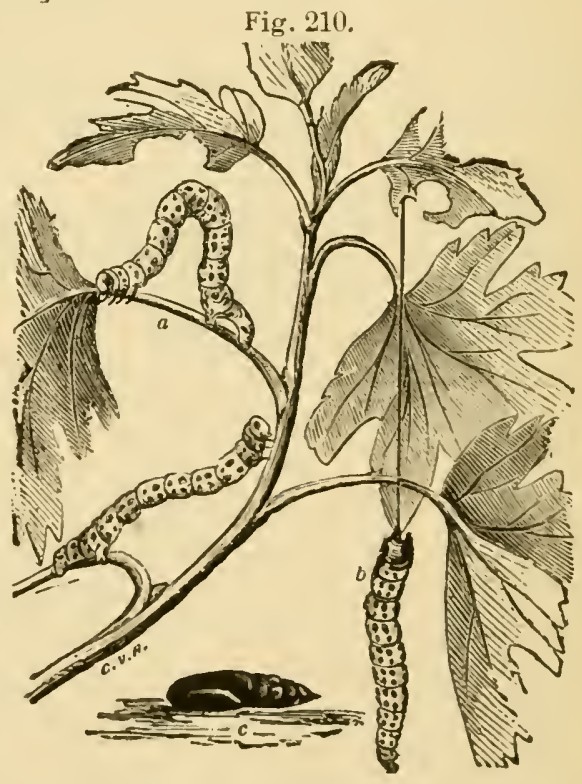
abrut to pupate. it deserts the hishes and ereeps beneath the fallen leares, ete., or enters the earth and forms a small exll in which to undergo its transformations. (Fig. 210i.) 
Fig. 211.

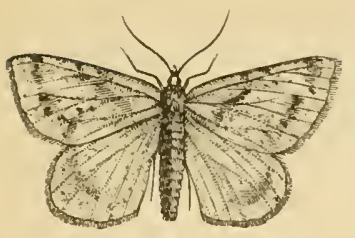

Fig. 211.--Currant Span-worm . Hoth (female)-colors, yellow and leaden.

The wings of the perfect moth (Fig. 211) expands about an inch, are of a pale yellowish color, marked with several dusky spots.

This moth appears in June or July, and deposits her eggs upon the stalks of the currant and gooseberry bushes; these eggs do not hatch until the following Spring, there being but one brood of these insects produced in one year.

Remedies.-When the larva appear on the foliage, use No. 64 or No. 5 , or No. 7 . See, also, No. 80 .

\section{CHAPTER CXXXVIII.}

\section{The Progne Butterfly. (Cal.)}

\section{(Grapta progne.-Fabricius.)}

Order, Lepidoptera ; Family, Nympinalide.

[Feeding upon the leaves of the currant and gooseberry bushes; a grayish sixteen-legged caterpillar, thinly covered with whitish spines tipped with black.]

When fully grown, this caterpillar measures about one inch and three lines in length; the body is marked with alternate l, lack and white bands, and on each side are two rows of yellow spots. When ahout to pupate, it suspends itself by the hind feet.

The pupa or chrysalis is pale brown, faintly clouded on the sides with olive-lrown, and the abdomen is broadly striped with the same color on the back and sides; across the middle of the back is a deep depression, on each side of which are two silvery spots.

The fore-wings of the butterfly expand about one inch and teu lines, are of a reddish-brown color, marked with black spots; the onter edges of the rings are scollopred; the under 
side of the wings is blackish-gray, paler at the tips, and on each hind wing is a silvery character, resembling the letter $\mathrm{L}$.

Remedies. - When the caterpillars appear on the foliage, use No. 64 , or No. 5 , or No. 7 . See No. 80.

\section{CHAP'TER CXXXIX.}

The Currant Aphis. (Cal.)

(Myzus ribis.-Linnæus.)

$\left.\begin{array}{l}\text { Order, Hemiptera; } \\ \text { Sub-order, Homoptera } ;\end{array}\right\}$ Family, Aphidide. .

[Living on the under side of the leaves of currant and gooseberry bushes, which they puncture with their beaks and extract the sap; small green or yellowish plant-lice.]-Thomas.

Remedies.-Use No. 64, or No. 5, or No. 7 ; Nos. 3 or 4 will give good results. 


\section{INSECTS INFESTING THE GOOSEBERRY.}

The Frosted Leaf-hopper (Fociloptera pmeinos $a)$..........................140

The Gooseberry Fruit Worm (Pempelia grosintarice).....................141 The Gooseberry Midge (Cecidomyia gros. sularice........................42

The following insects also infest the Gooseberry :
The Currant Borer (Egeriu tipuliformis).

The Imported Currant Worm (Nematus ven tricosucs).

The Native Currant Worm (Pristophora grossularice.)

The Currant Span Worm (Eufitchia ribearia). The Progne Butterfly (Grapta qrogne).

The Currant Aphis (Myzus ribus).

\section{CHAPTER CXL.}

The Frosted Leaf-hopper. (Cal.)

(Peciloptera pruinosa.-Say.)

$\left.\begin{array}{l}\text { Order, Hemiptera; } \\ \text { Sub-order, Homoptera ; }\end{array}\right\}$ Family, Fulgoride.

[Puncturing and sucking the juices of the leaves and tender shoots of gooseberry bushes and the rhubarb plant; a small four-winged moth-like insect of a rusky bluish color, covered with a white mealy powder.]

This insect (Fig. 212) neasures about four lines in length, and when at rest holds its wings slanting over the back like a steep roof.

Fig. 212.

Fig. 212.

Fig. 213.

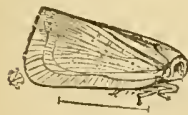
-Frosted Leaf - hopperenlarged-color, dull leaden or pale green.

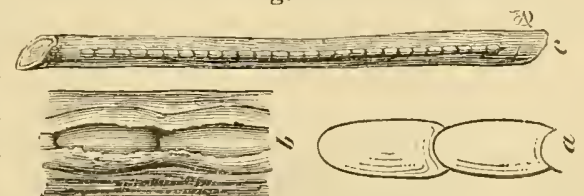

Fig. 213.-Eggs of Frosted Leaf-hopper; ", the eggs highly magnified-color, yellow; $b$, the same in the twig, highly magnified; $c$, the same in a twig, natural size. 
The female deposits her eggs: (Fig. 213) in acontinuous slit in a twig of a tree or shrub, placing them upon one side, end to ent. The young leaf-hopper is of the same general form as the adult, but is destitute of wings. It is covered with a cottony matter which enrelopes the entire body, excepting the heat.

I have found these insects on rhubarb in May.

Remenes.-Use No. 28, No. 5 or No. 7.

\section{CHAPTER CXLI.}

The Gooseberry Fruit-worm. (Cal.)

(Pempelin arossulurix.-Pactard.)

Grder, Lepidoptera: Fimily, Prealiua.

[Eating out the interior of currants and gooseberries; a pale green worm.]

Fig. 214.--Gooseberry Fruitworms-enlor, green.

The eaterpillar (Fig. 214) after eating out the interior of one herry will fasten a neighhoring one to it with silken threads, and in this way whole hunches of "urrants or gooseberrics are sometines webbed Fig. 214. together, and will have nothing left of them except the empty hulls. Ifter reaching its full growth this worm deserts the plants and entres the earth, where it forms a small cell in which to unelergo its transformations. Only one brood is prolueed in aseason, and these pass the Winter in the pupa state.

Fig. 215.

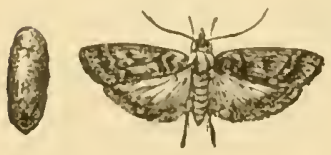

Fig. 215. - Gooseberry Fruit-worm Moth and cocoon; at the left the eocoon-color, grayish-lorown : at the right the moth-colur, gray.

The fore-wings of the perfect moth (Fir. 215) expand nearly an inch: are of a pale gray color, and malked with transverse white and 
dark lines. I have found the eaterpillar and pupa of this insect, but failed to raise the perfect moth.

Remeny.-Use No. 2s. Piek off and destroy all infested fruit, in addition to gathering the larra.

\section{CHAPTER CXLII.}

The Gooseberry Midge. (Cal.)

(Cecidomyia grossularix-Fiteh.)

Order, Drpterd; Family, Tipulines.

[Living in gooseberries, causing them to turn prematurely' red and to decay; a bright yellow fontless maggot.]

The mirlge which produce these maggots quite closely resembles a mosquito; it is only about one line to the end of the closed wings, and is of a pale yellow color, the eyes black, the legs yellow and dusky, and the wings are tramsparent and faintly tinged with dusky.

This midge or fly punctures the young goosoberies and deposits therein one or more eggs. The maggots latehed from these eggs are entirely destitute of feet, and are of a bright yellow color. They assume the pupa form within the berries; the latter usually berome prematurely red, and trop to the ground sometime previons to this.

The only remedy which suggests itself is to gather up and destroy the fallen fruit shortly after it falls, or bufore the maggots have completed their transformations and escaped.

Remedies as above, and when the frut is fully formed use No. 5 or 7 , and repeat in two weeks. 


\section{INSECTS INFESTING THE STRAWBERRY.}

The Strawberry Crown-borer (Analcis fraigarice $). \ldots \ldots \ldots \ldots \ldots \ldots \ldots \ldots \ldots$ The Brown Strawherry Weevil (Listronotus nevadivus).....................144 The Strawberry Worm (Emphytus macu-

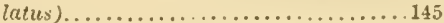

The Strawberry Leaf-roller (Anchylopera fragaria)
The following insects also infest the Strawberry:

Crane Flies i'Tipula).

The Peach Moth (Anarsia linearella).

The Negro Bug (Corimelena pulicaria).

The Raspherry Leaf-roller (Exartema permundana).

\section{CHAPTER CXLIII.}

The Strawberry Crown-borer.

\section{(Analcis fragarix-Riley.)}

Order, Coleoptera ; Family, Curculionid

[Living in the roots of strawberry p]ants; a whitish curved grub or larva, about two lines long, with the head yellow; finally changing into a chestnut-brown snout-beetle.]

Fig. 216.-Strawberry

Fig. 216.

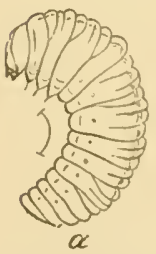

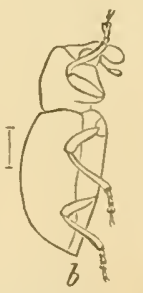
Crown-borer; $a$, the lar-

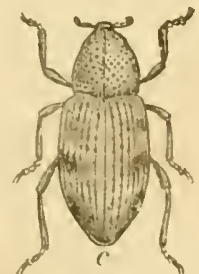
va, enlarged-color, white; $b$, the beetle, side view, enlarged; $c$, the same, back view, enlarged-color, chestnutbrown.

The egg from which this grub (Fig. 216a) hatches is probably laid upon the crown of the plant, and as soon as hatehed the grulb burrows downward into the pith. Here it remains until it has acquired its full growth, working in the thick, hulbous root: it undergoes 
its transformations to the pupa and perfect beetle state within the roots, and the beetle (Fig. 216c) makes its appearance above ground in the month of August.-Riley.

I have not found this species in this State, although I hesitate to say that it is not here. I have found grubs in strawberry plants which I supposed to belong to this species, but I did not succeed in rearing the perfect insect.

REMEDY.-Use No. 104.

\section{CHAPTER CXLIV.}

The Brown Strawberry Weevil. (Cal.)

\section{(Listronotus nevadicus.-LeConte.)}

Order, Coleoptera; Family, Curculionide.

[A small snout-beetle feeding on strawberry and cherry leaves, also eating into the crown of strawberry plants.]

This species was found, last Summer, eating the leaves and also the crown of the strawberry plants; it also eats cherry leaves. The fruit grower sending the specimens writes:

"I found this weevil on a strawberry patch; it eats the leaves, making them appear like lace work, and it also eats into the heart of the plant. I have also found it eating cherry leaves. In the daytime it hides in crevices in the bark of trees or in the ground under the strawberry plants; it is a night feeder."

This beetle (Fig. 127, Plate 3,) measures from two and a quarter to two and one half lines in length; is of a reddishbrown color, mottled with yellow, whitish or light markings on each sicle of the thorax and the outer base of the wingcases, also at the apex of the wing cases; inner edges of the latter bordered with black. From the fact that the larrw of this group of insects usually live on the roots of plants, it is probable that the larvæ of this species live in the roots of strawberry plants.

Resedy.-Use No. 105. 


\section{CHAPTER CXIN.}

The Strawberry Worm.

\section{(Eimpliytus marulatus-Nortou.)}

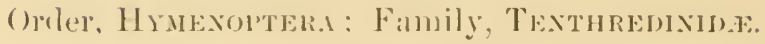

[Feerling upon the leares of strawberry p]ants; a naked dirty-yellowish wom, which is provided with twenty-two legs.]

The eggrs (Fig. 2018, ?.) from which these worms hateh are deposited in the stems of the plants; this operation is performed by the female fly hy means of a sam-like instrument with which all the flies ledonging to this fimnily are provided. Whan fully grown the woms (Fig. 218, f, ) measures about six lines in length; they then enter the earth and form small (eells in which to molergo their transformations. Two hroorls are usually produed in one seakon, and the last brood remain in their cells unchanged until the following spring.

Fig. 218.

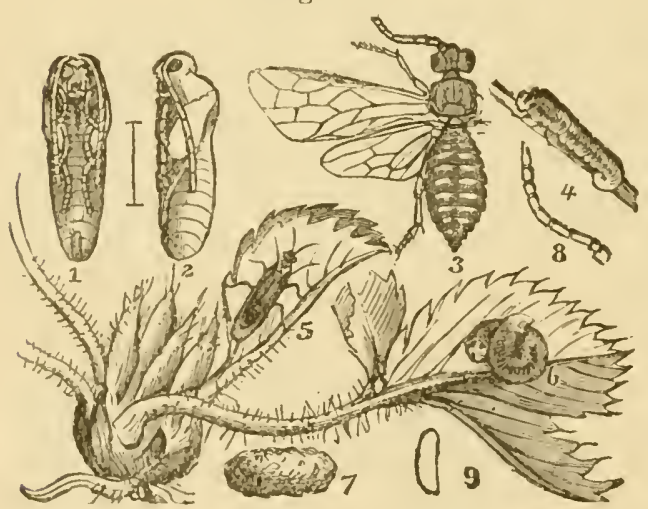

Fig. 21s.-Stratwberry $\|$ orm, Pupa, Fly, ete.; 1, the lupar enlarged, rentral view; $\therefore$ the salne, side viewcolor, green ishwhite: $\therefore$ the $11 \mathrm{y}$, mlarecel pthe winges (1) onsesidenot rep)-

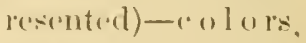
blark and dirty white; s', her an. tenuil, greatly enlargent: 5, the fly with its wings closerl ; b, the worm at rest; 4, the same extented-color, dirty yellow: $\tau$, the eocoun: 0 , the egg, magnitied-color, white.

The perferet tlies (Fig. 218,2 and $\bar{y}$ ) are deep black, with two rows of dirty white spote on the abdomen; the wings are 
transparent, and expand about six lines.-Riley's Ninth Missouri Report.

Renedr-If the plant is bearing fruit, use No. 19, or spray with No. 83 or 85 .

\section{CHAP'TER CXIAI.}

The Strawberry Leaf-roller.

\section{(Anchylopera fiayuria-Riley.)}

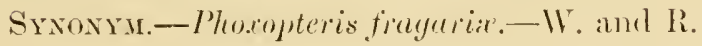

Order, Lemidoptera ; Family, Tortricma.

[Rolling up and feeding upon the leares of the strawbery; a yellowish or greenish brown caterpillar about four lines long, with a yellowish-brown head having a hlack spot on each side.]

This caterpillar (Fig 219a) feeds upon the upper surface of the leaf, giving the latter the appearance of having been scorched. It pmpates within its nest, and the moth (Fig. 219c) which issues a few weeks later has the head, thorax and forewings reddish-brown, the latter streaked and spotted with black and white. It expands about six lines.

Fig. 219.--Strawberry Leaf-roller ; $a$, the caterpillar-color, dull olivegreen; $b$, head and first four segments of its body, enlarged; $d$, two last segments of its

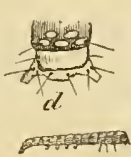

$\alpha$
Fig. 219.
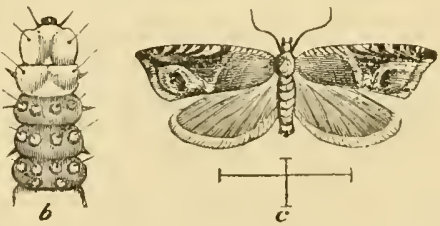

body, enlarged; $c$, the noth enlarged-colors, redclish-brown, black and white.

There are two broods of these leaf-rollers each season, the last brood passing the Winter in the pupa state.

I have found a small caterpillar on the strawberry leaves similar to that deseribed here, hut failed to rear the perfect insect, and therefore cannot say to what species it belonged.

Remedy.-Use No. 24. 


\title{
INSECTS INFLSTING THE IVALNUT TREE.
}

\author{
chap. \\ The Walnut Scale (Aspidiotus juglan:- \\ regia $) . . \ldots \ldots \ldots \ldots \ldots \ldots \ldots \ldots . \ldots \ldots$ \\ The following insects also infest the Walnut \\ tree : \\ The Red Scale (Aspidiotus aurantii). \\ The Yellow-necked caterpillar (Datuna min. \\ istra). \\ The Fall Web-worm (IIIy/hantril textor . \\ The Tussock Moth (Orygia leacostigmu).
}

\section{CHAPTER CXLVII.}

The Walnut Seale. (Cal.)

(Aspidiotus juglans-regix.-Comstock.)

$\left.\begin{array}{l}\text { Order, Hemiptera; } \\ \text { Sulb-order, Howoptera; }\end{array}\right\}$ Family, Coccida.

[A grayish-brown seale, infesting the walnut tree.]

Mr. Alexander Craw, of Los Angeles, sent me specimens of this scale in 1SS1. I have examined several trees infested by this species of scale, and find that they spread rapidly on the bark of the limbs and branches.

\section{NATLRAL IIISTORY.}

The female scale measures one line in diameter-color, grayish-brown; form-circular, or slightly elliptical; exurix or larval skin on one side of the center. giving the shell in some cases the appearance of a cockle shell. The scale of the male is similar in form to the male of the red seale, and is of the same color as the female scale, which is gravish-brown. The female is pale yellow, with golden colored spots; when matured she is of a rich amber color. This species infests the limbs and branches. I have a specimen of a limb over two inches in diameter, the bark of which is entirely corered by this pest.

Remedies.-Use No. 11, 12 or 13, when the tree is dormant; or No. 4 in Summer. 


\section{INSECTS INFESTING THE CHESTNUT TREE.}

\section{CHAPTER CXINIII.}

\section{The Brown Chestnut Bud Beetle. (Cal.)}

\section{(Pityophthorus pubipennis.-Leconte.)}

Order, Coleopters; Family. Scomstume.

[A small dark-brown beetle aating into the base of the buds of chestnut trees, especially the variety known as the Italian chestnut.]

Last" year (1S82), specimens were received of branches (Fig. 220 , Plate 3, ) of ehestnut trees, the buds of which were infested by a small beetle. The beetle (Fig. 221, Plate :3,) measured from three fourths of a line to one line in length, and is not half as wide as long-color, dark-brown; and as its specific name, pubipemis, indicates, the wing-cases are covered with a fine hairy-like down.

The perfect insect infests the bud at the base of the outer sicle, and eats into the heart, entirely destroying it, as only the outer shell remains. This beetle is probably a native speeies, as Dr. Leconte found it twenty years ago in this State, living under the bark of oak trees. It is also found feeding on the oaks in the ricinity where it is found feeding in the buds of chestnut trees. This species hibernates in the perfeet state, as I found the beetles in buds last Narch in a semi-dormant condition. I am not awatre that the larva have been found upon the ehestnut.

Reuedies.-Use No. 67, No. 11 or 12 ; or No. 13 -tive pounds of the mixture to each six gallons of water used. These solutions should be used when the tree is dormant. 


\section{INSECTS INFESTING THE ALNONI) TREE.}

CIIAI"

The Red Spider (Tetranyitus telarius)... .149 The Almond Aphis (Aghis amugdali) . . . 150

The following insectsalso infest the Alnond tree:
The Greedy seale (Asyoidistus' raquax).

The Branch and Twig-burrower (l'olycaon confertus).

The Buffalo Tree-hopper (Ceresa bubalus). The Vellow Mite.

\section{CHAP'TER ('XIIX.}

The Red Spider. (Cal.)

(Tetratiphus teluriux.-linn.)

('lass, Arachitda;
sub-rlass. Acarixa;

[A smal] red mite, infesting the trunk, limbs, and foliage of fruit trees and nursery stock, and also garden and hot-house plants.]

The red mite (Fig. 2.2.2), commonly called the "red spider," may be said to be a minersal pest of the orchird, gatrden and hot-house, and has been allowed to spread to an alarming extent in orchards in this State. Although a feeder on nearly all varieties of deciduous fruit trees. and also on ritrus trees, the almond secm to be the worst inferted hy this species.

Fig. 22.2.-Red spider, adult-colur, reddish. Fig. 222.

The perfect mites have eight legs; form, ovate; length, one sixtieth of an inch; color. various, sometimes brick-resl, rust-red, or greenish, dotted with red; head, rellowish.

The egr when first exposed is eolorless, but changes to a loright red; in form it is round, and measures one one-humbled-ind-fortieth of an inch in diameter.

I have no reason to change my opinion ex-

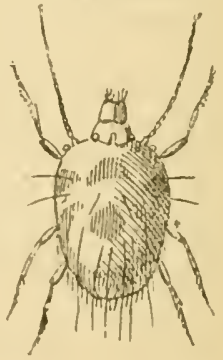
pressed in 1881, in my. "Inserts Injurious," etc, that the female 
does not cleposit the eggs, but at maturity fistens herself to the bark or leaf and dies; the covering is removed from the body by the males, exposing from fifteen to twenty whitish eggs. I have counted one hundred and twenty-seren female bodies fastemed hy the anterior part to the bark, and have also noticen the male insects remoring the skin of the dead females, and in this way exposing the eggs.

Fig. 223.

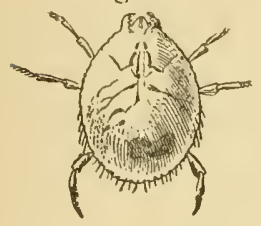

Fig. 22.3.-Larva of Red spirler, enlarged -color, bright red.

The young mite, when first hatched from the egg, has only six legs (Fig. 223); in at few days a film scems to cover the body, and from this emerges the perfect mite, having eight legs. (Fig. ‥2.2.)

The injury lone by this species is prineipally on the fruit buds, blossoms, and on the leares; they eat the epidermis or skin of the latter, and also corer them with a tine web, causing them to wither and fall off. The trunk, limbs and branches of trees seriously infested by this mite appear of a recllish color ; this is from being covered by a multitude of the eggs of these mites. (Fig. 2.24.)

Fig. 2.24.-Portion of a twig infested by Red Fig. 224. spiclers.

In some eases where not seriously infested, it has the appearance of being corered with iron rust.

When this species first attack a tree the mites are generally found around the bud and new foliage.

The red spider is also occasionally found on trees infested by scale insects.

Rimedr-Use No. : 4 .

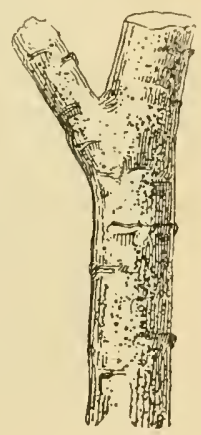




\section{('HAPTER CI.}

The Almond Aphis. (Cal.)

\section{(Aphis nmygdali.-Blanch.)}

$\left.\begin{array}{l}\text { Orrler. Hentrtera: } \\ \text { Sulb-orler, Honortera: }\end{array}\right\}$ Family, ApHidide.

[Living upon the under side of the leares of almond and peach trees, causing them to become crisp and wrinkled. by puncturing them with their heaks and extracting the sap; small green plant-lice.] (Fig. 225.)

Fig. 225 .

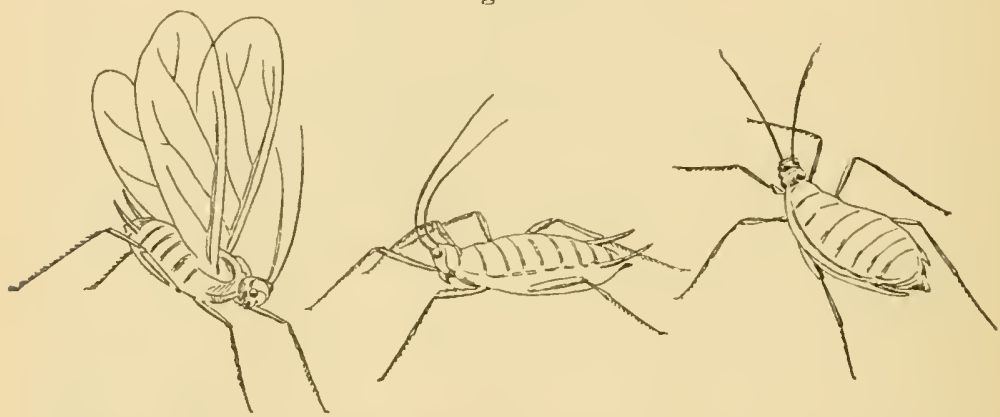

Fig. 225.-P']ant Iice (Ahis) highly magnifier-color, green.

Remedies-Use No.5 or 7 ; No. 3 or 4 will give good results if $\mathrm{No} .5$ ol 7 cannot be had. 


\section{INSECTS INFESTING THE FILBERT}

The Filbert Scale (Lecanium hemisyharicum).

.Chap. 151

\section{CHAPTER CLI.}

The Filbert Seale. (Cal.)

(Lecanium hemisphricum.-Targioni.)

$\left.\begin{array}{l}\text { Order, Hemiptera; } \\ \text { Sub-order, Homoptera } ;\end{array}\right\}$ Family, Coccide.

[A dark-brown hemispherical scale insect, or bark-louse, feeding upon the filloert and orange trees, and on the oleander and other ornamental trees.]

I take the liberty of designating this species as the "Filbert Scale" so as to distinguish it from the soft orange scale ( $L$. hesperirlum) on account of the similiarity of their techni(al names.

Fig. 226.-Filbert scale; 3 , leaves infested ly this scale; $3 a$, the adult female, enlarged-color, brown.

The filbert scale (Fig. $226,3 a$,$) when full grown is$ of a dark brown color,

- hemispherical in form, and measuring one and threequarters lines in length; width, one and a half lines; Fig. 226.

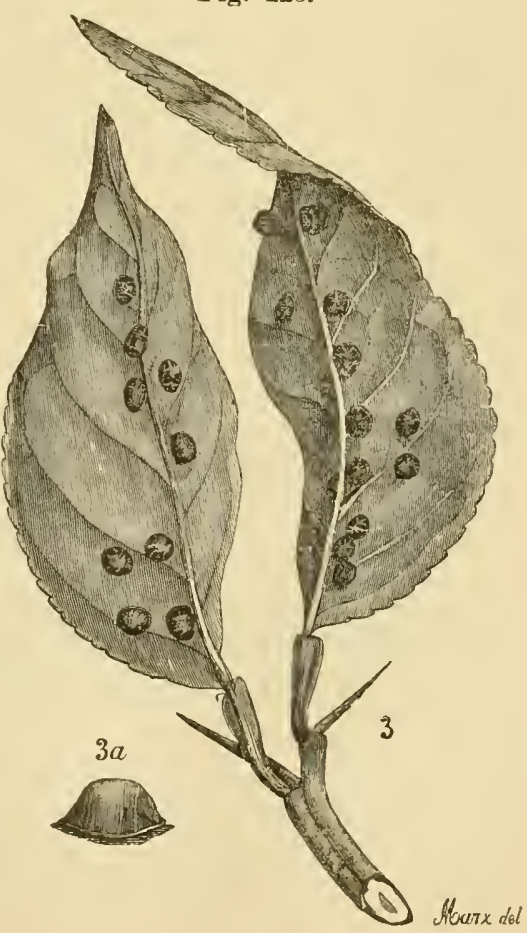


height, varying, but alhout one line. The size of the hranch on which the insect locates sometimes alters or changes its form; if the branch is small, the flattened edge of the insect will spread downward, elasping the branch or twig, thus giving the inseret an elongated and narrowed appearance, diflerent from those lecated on a flat surfize or leaf.

\section{NATERAL, IISTORY.}

Eggs-length, one eighty fifth of an inch: width, one half of the length; color, pinkish. From seventy to one humbed are laid by each female. Larva-color, reddish; length. ome seventy fifth of an inch; antennar, seren jointed : anal setre present.

The females of this species (Fig. 220, $3(1-c n l a r g e d)$, like other Lecanims. have the power of locomotion until they become fixed to the plant. When young they are of a redilish color, changing to a light hrown, and finally becoming a dark brown color when they reach maturity. They infest the filbert and orange, also the oleander and other ornandutal trees. They ean be reallily distinguisherl from the liarek seale (L. olea) by the absenee of the carina or ridere, forming the letter. $\mathrm{H}$ on the back.

Rexedes-Use the same as for the blatek scale on deciduous trees. (Chapter LXXXIY.)

\section{INSECTS WEESTING THE ETCALPTUS TREL.}

The following insects infest the Eucalyotus Trec, and are treated of in another part of this work: 


\section{INSECTS INFESTING THE LOCUST TREE.}

The Legged Locust Borer ( Tyleutus robinice)............................ 152

The Legless Locust Borer (Clutus robinire) 153
The following insects also infest the Locus t Tree:

The Greedy- Scale ( Aspidiotus rapax).

The Elm and Locust Sicale.

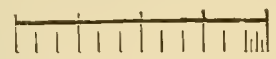

The measurements of insects in this work are given in unches and lines. The above cut represents one inch divided into lines and fractions thereof.

\section{CHAPTER CLII.}

The Locust Carpenter Moth, or the Legged Locust Borer.

\section{(Tyleutus robinix.-Peck.)}

Order, Lepidoptera; Family, Bonbrowis.

[Living in the trunks and larger limbs of locust, willow and oak trees; a greenish-white, sixteen legged worm.]

The common names giren to this borer, "Legged. etc.." are to distinguish it from the grul, of Clytus robinir, which also infests locust trees and is destitute of legs.

Fig. 227.

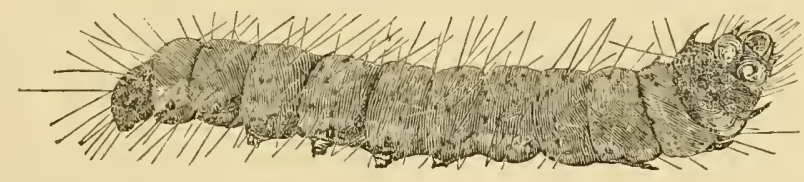

Fig. 227.-Legged Loeust Borer; the full grown caterpillar - color, greenish-white, with a tinge of pink or yellow.

This borer (Fig 22T) keeps its burrow open, and not packed full of woody fibres as many other borers are known to do. 
When about to pupate it spins a cocoon in the lower part of its burrow. and before the perfeet moth emerges the pupa works itself up to and partially out of the opening of its burrow, and while in this position the moth (Fig. 2.2S) makes its escape.

Fig. 2.28.-Locust Carpenter Moth (female)colors, gray and black.

The sexes differ wirlely formeateh other, both in size and color. The female is the largest, $\mathrm{ex}$ panding from Fig. 228.

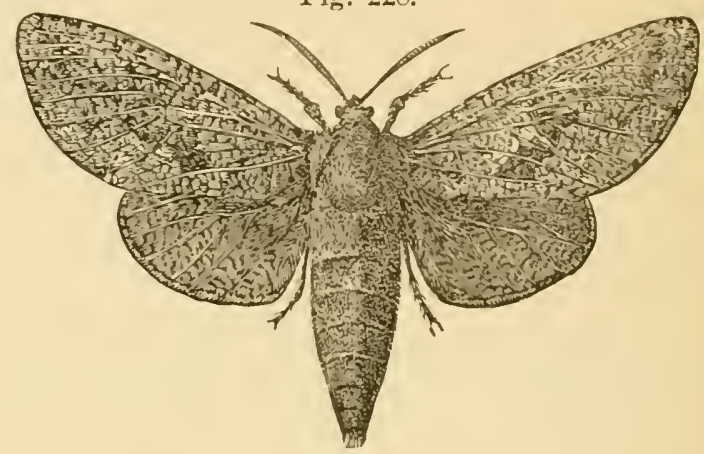
two inches to two inches and six lines; the wings are gray, dotted with black and marked with a network of blatek line's.

The male moth expands only ahout an inch and six lines; the wings are darker than those of the fenale, and there is a large yellow spot on each hind wing. This species is rery destructive to becust trees.

RevenY,-Use No. 37.

\section{('IIAT'TER ('LAII.}

The Legless Locust Borer. (Cal.)

$$
\text { (clytus robinial-Forster.) }
$$

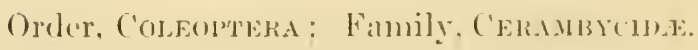

[Boring inte the trunks and bramehes of the locust tree; a nearly footless whitish grub, alout one inchloug and as thick is a gerotice-1[uill.]

When goung this borer lives in the silp-woud, but is it srows longer it hurrows into the solid wood, perforating it in very direction. It first it calsts its chips out of the opening 
of its burrow, which finally becomes packed full of the coarse and fibrous parts of the wood. It assumes the pupa form in its burrow, and the beetle issues late in July or early in August. Fig. 229. Fig. 229.-Legless Locust Borer (the beetle)colors, yellow and black.

This beetle (Fig. 229) is of a black color and is marked with several transverse and oblique yellow lines; it is sometimes very destructive to locust trees.

Revedr.-Use No. 37. 


\section{INSECTS INFESTING THE WILLOW.}

\begin{tabular}{|c|c|}
\hline $\begin{array}{l}\text { The Weeping Willow Borer (Sti(ty)teron ro- } \\
\qquad \text { bini( }) \ldots \ldots \ldots \ldots \ldots \ldots \ldots \ldots \ldots \ldots \ldots \ldots \ldots \ldots \ldots\end{array}$ & $\begin{array}{l}\text { The following insects also infest the Willow: } \\
\text { The Legged Locust Borer (Iyleutus robinip). }\end{array}$ \\
\hline The Willow Scale (Aspridiotus concexus)...155 & The fireedy scale (Aspidiotus ray)(ux). \\
\hline $\begin{array}{l}\text { The San Bermardino Willow Scale (Asyndi. } \\
\text { otus ortholobus)...................156 }\end{array}$ & The steel-blue Flea-beetle (IItica chalybea). \\
\hline
\end{tabular}

\section{CHAPTER ('LIV.}

\section{Weeping Willow Borer. (Cal.)}

\section{(Srityerron robinite-Edwards.)}

\section{Order, Lepmoptena; Family, Egeride.}

[A yellowish-white sixteen-legged larva, about one inch in length, boring into the wood of the weeping willow, locust and cottonwood.]

In September, 1S82. I was requested to examine al number of weeping willows planted for ornamental purposes near a resilence. I found them so infested by the larva (Fig. 230, Plate 3,) of a moth that I recommended they he cut down. whirh was immediately rlone. The wool of the stems was thoroughly burrowed. I found a number of larve, and one pupa. On the 30th of September the perfort insect emerged from the pupa. At the present time. Inne sthe one of the larva found is spinning a cocoon; it is evidently allout to umlergo its changes. The perfect insert (Fig. 2:31, Plate :3.) is ahout nine lines long; spread of wings, ahout one ineh and two lines; color, head dark-brown; palpi, dark-orange ; antennar, gellowish-red; thorax, dark brown, with a narrow yeliow marginal line around the upere surface: tirst segment of ablomen, dirk brown; second semment, yellow: third and fourth segnents, dark brown; all the sements posterior to the fourth 
are vellow; anal segment slightly tufted; fore-wings, brick red, with black veins; hind-wings clear, transparent, the inner edge bordered with a narrow brown band, yellow at the hase; legs yellowish red. Pupa-color, dark amber. Larvalength, one inch; color, pale yellowish; second segment, yellowish; head yellowish-red; mouth part dark brown; about six fine yellowish hairs on each segment, growing on as many wart-like spots; spiracles small, round, and of a light-brown color; true legs light-brown; pro-legs represented by eight rings of hooks. This species is found in localities one humdred and fifty miles apart. This species also infest the locust tree.

Note.-Since writing the ahove the perfect insect has emerged from the pupa of the above mentioned larva. It proved to be a specimen of the Sriapteron robinix of Edwards. (July 13.) Remedr.-Use No. 37.

\section{CHAPTER CLV.}

\section{The Willow Seale. (Cal.)}

\section{(Aspidiotus ronvern.-Comstock.)}

Order, Hemptera;
Sub-order, Homoptera ; Family, Coccinf.

\section{[ A species of scale insect infesting willows.]}

This species resembles the greedy seale (A. ropror) in appearance, and it is only by scientists that a distinction can be made. I think it heyond plestion that this species will spread on cultivated trees, especially the apple and pear.

Near the city of Los Angeles, the orchards of Mckinlay Brothers and Mr. Kinser were protected hy orer two miles of wind breaks marle by planting willows, which forned an cxeellent protection from the winds and supplied a large puantity of firewood amnually. Two years ago it was noticed that the fruit-alples and pears-was serionsly infested hy the d. coucexus. It was fomurl that the willows were also infested by the same speries. I advised the digring out of the willows, which 
was done, and the wind breaks replaced by planting encalyptus trees. Last year there was no scale on the fruit.

Reuedies.-Same as for San Jose scale, Chapter XX.

\section{CHAP'TER CIVI.}

The San Bernardino Willow Scale. (Cal.)

(Chionaspis orthololis.-('omstock.)

$\left.\begin{array}{l}\text { Order, Henipteka; } \\ \text { Sub-order, Homopteka; }\end{array}\right\}$ Family, Coccide.

[A srale insect found on the willows at San Bernardino, Cal.]

Prof. Comstock found this species on willows, and described it as follows: "Color white, about one line in length. The body of the female is dark purple; eggs dark purple. 'This species infests chiefly the bark of the small whip-like limbs which spring from the trunk of the trees."

Remedies.-Same as for San Jose scale, Chajter XX.

\section{INSECTS INEESTING THE POPLAR ANI) COT'TONWOODE-}

The following insects infest the poplar and cottonwood, and are treated of in another part of this work:

The San Jose Scale (Ayridiotus perniciosus). , The Legged Locust-Borer ( $\boldsymbol{X}$ yleutus robinia). 


\section{INSECTS INFESTING THE ELM.}

chap. The Semicolon Butterfly (Graqta interroga The Elm and Locust Scale.. ..........157 tionis), also infests the elm.

\section{CHAP'TER CLVII.}

The Elm and Locust Seale (Cal.)

\section{(Lecamium Sp?)}

$\left.\begin{array}{l}\text { Order, Hemiptera; } \\ \text { Sub-order, Honoptera ; }\end{array}\right\}$ Family, Coccide.

[A dark brown scale insect infesting the elm and locust trees.] Fig. 230.

Fig. 230.-Elm and Locust Scales-color, brownish-black.

This species is found on the eln trees, especially the cork elm, and also on the locust treesvarieties, honey locust and Chinese locust; they infest the branches (Fig. 230) and leaves.

The female scale is of a dark-brown color, ovate in form, and measures three lines in length, two and one quarter lines in width, and nearly two lines in height. This scale differs from the black scale (Chapter LXXXIV) and filbert scale, in the form being conical (Fig. 230).

Fig. 231.--Larva of Elm and Locust Seale enlarged-color, reddish-yellow.

Larva (Fig. 231)-length, one ninetieth of an inch; form, elongate-ovoid. Eggs-color yellowish-white, from two hundred to three hundred being produced by each female.

REMEDiEs.-Same as for black scale, ChapFig. 231.

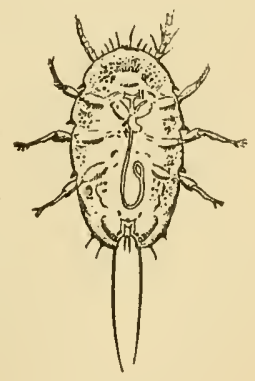
ter LXXXIV. 


\section{INSECTS INFESTING THE OAK.}

The Acorn Motls (IIolocera glandulella) .158

The following inseets also infest the oak:

The Legged Loeust Borer (Iyleums robinic).

The liorest Tent Caterpillar (Clisime'(my,a sylvalica).
The Fall Web Worns (IIy)huntria textur).

The Yellow-neved Caterpillar (Datuna muistiut.

The Tussock Joth (Orygia leverostignua).

C'IAPTEL ('LN'IH.

The Acorn Moth. (Cal.)

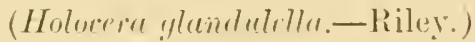

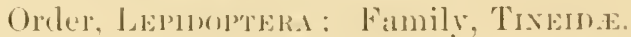

Lliving in anoms; a vellowish or grayish-white sixteenlegged caterpillar, from three to six lines long. f

This catripillar (Fig. 230 $(1)$ is supposed to infest only those acorns which have been infested by some other insect, such as the larva of a weevil. It assumes the pupa form in its burrow.

Fig. 2y?2. - Acorn Moth; $f$, the moth enlarged--color, asilgray, b, all allorm, showing hole where the caterpillar entered; ", the raterpillar in an ateorncolor, gravish-white;

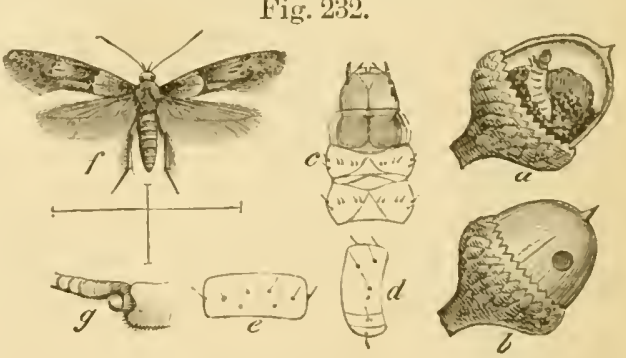
$e$, back view of a regment of its borly, anlargerl; 1 , sicle view of same, enlarged; $e$, top of the head and first three segrments of the caterpillar's hody, enlarged-color of head and first segment, lightit brown.

The fore-wings of the moth (Fig. 232 $f$ ) expand from six to nine lines, are of an ashen-gray color, matred near the midelle with two dark spots, and with a pale transierse stripe aleross the basal third of the wing. The moths issue during the Sum mer scason, or from $A$ pril to september.

Note-The above alecomnt of this insecet is given becallse several persons have insisted that it is the codlin moth. 


\section{INSECTS INFESTING THE PINE.}

The Pine Weevil (Fissoles stroli)........159 The Norfolk fsland Pine Seale (UhleriaP The Pales Weevil (Iylobius qules)........160

\section{CHAPTER CLIX.}

The Pine Weevil. (Cal.)

(Pissorles strohi-CPeck.)

Order, Coleopteisa; Family, Curculionida.

[Living in the terminal shoots of pine trees; a footless grub, which is finally changed into a brownish beetle, marked with two large whitish spots behind the middle of the wing-eases.]

Fig. 233.
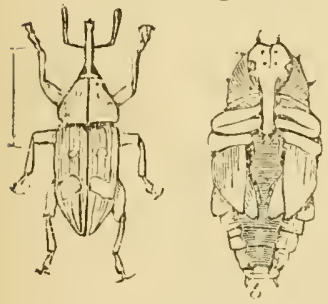

Fig. 2:33.-Pine Weevil, enlarged; at the left, the weevil -colors, brown and white; $b$, the pupa, ventral view-color, white; a, the larva-color, white, the head reddish.

The larva (Fig. 233a) or grubs of this weevil are sometimes rery injurious to pine trees, by destroying the terminal shoots; as many as forty have heen found in one shoot, which they had perforated in various directions. They assume the pupa form (Fig. 233b) within their burrows, first gnawing a passage to the outside for the egress of the perfect beetles (Fig. 233, left). In the vicinity of Sacramento these insects have peen found on pine trees that had been planted for ornamental purposes.

Renedies.-Nos. 26 and 27. 


\section{CHAPTER CLX.}

The Pales Weevil. (Cal.)

$$
\text { (Mylobins pules.-Herbst.) }
$$

Order, Coleoptera; Family, Cunculionid A.

[Living beneath the bark of the pine tree; a whitish footless grub, finally transforming into a dark brown or black snoutbeetle, about four lines long, and marked with numerous whitish spots.]

Before pupating the larva gnaws a passage to the outside of the bark, but leaves a thin covering to its burrow in which it assumes the pupa form.

Fig. 2:34.-Pales Ireevil-colors, black, brown and white.

In due time it is changed to a beetle (Fig. 234) which gnaws through the thin eovering of its burrow and makes its eseape. I have found the grub, pupa and perfect insect of this species in pine slabs shipped from the mountains, and have found a specimen having a similar appearance on pear trees.

Rexiedies-Use No. 26 or 27.

\section{C'IAI'TER C'LAI.}

The Norfolk Island Pine Scale. (Cal.)

\section{(lhlerin nianearia.-Comstock.)}

$\left.\begin{array}{l}\text { Order, Hemptera; } \\ \text { Sub-order, Howoptera ; }\end{array}\right\}$ Family, Coccide.

[Infesting the Norfolk Island pine tree; a white, nearly circular seale insect.]

This species is found only upon the Norfolk Island pine, and occurs in the Counties of Sacramento and Santa Barbara. 
Fig. 235.-Norfolk Island Pine Scale (Figs. 1 in 1h): 1, an infested twig; 1a, the male-colors, white and brown; 1 , the hind end of the borly of the male; 1e. hind end of the body of the female; $1 d$, the adult fomale-color, yellow; 1 , her antemna; $1 y$, her spinnerets; $1 f$, one of her legs: $1 c$, portion of the leg of a male; all highly magnified. Oak sealo (Rhizococus quercus) (Figs. 2 to $2 l)$ ) ; $\therefore$ an infested twigr ; 20 spimerets of a female, highly magnified; $2 b$, one of her legs, greatly enlarged.

The scales (Fig. 235, 1,) are nurly circular, white, and measure about two sixteenths of an inch in diameter. The larva (Fig. 236) is of a light amber color, and about one-hundredth of an inch long; it is provided with two long anal setre, and appears to be covered with very fine armor-like plates or seales.

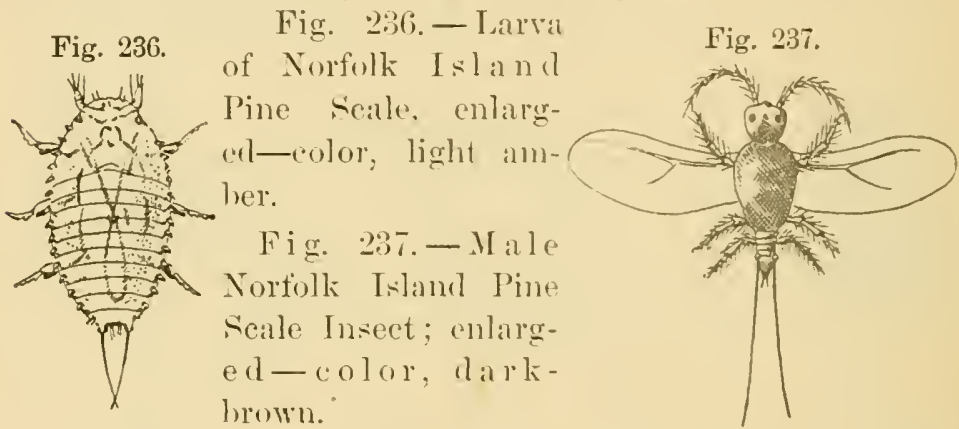

The adult female (Fig. 2:3, 1,7, is of a vellowish color.

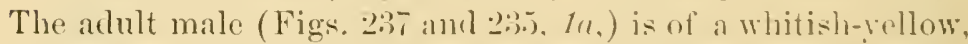
marked with dark hown; wings nearly transjarent; antenna ten jointed; two lomg filaments protrude from the amal segment, in the place of the anal stylet, which is fomml in some species described in this work.

"When the femald is rearly to lay her wows she exretes a coeoun-like covering to the bexly, (omplosed of white silken threads. The sac is dense like felt hut easily torn: it is epren on the midlle line of the ventral surfatere or very much more relieate on that part. It allieres to the tree retute firmly, remaining where exereted after the death of the inseret. Athe egers are latid, the boty of the fembale shrinks awaly, matiing room for them, and finally it becomms a very small pellet 
in the anterior end of the sac, the remainder of the space being filled with eggs. These are light yellow in color. When the male larva is ready to undergo his metamorphosis he sucretes a covering to his body resembling the sac excreted by the female, except that it is very much smaller, measuring only one five hundredth of an inch in length."-Comstock.

Remedies.-Use Nos. 4,5 and 7.

\section{INSECTS INFESTING THE JUNIPER}

The Juniper Scale (Diaspis carieli)....

\section{CHAPTER CIAXII. \\ The Juniper Seale. \\ (Diaspis carueli.-Comstock.)}

$\left.\begin{array}{l}\text { Order, Hemiptera; } \\ \text { Sub-order, Hovioptera }\end{array}\right\}$ Family, Coccide.

[A white scale insect infesting various species of juniper, and some other shrubs of the pine family.]

Professor Comstock describes this species as being very common in Washington, 1). C.

The seale of the female (Fig. $237 \frac{1}{4}, 2 n$,) is circular, snowywhite, with the exuria central or nearly so; diameter of scale, from one half to three fourths of a line. The females are of a yellow color, nearly circular in outline, but a little elongated posteriorly. 
Fig. $2371 / 4$.

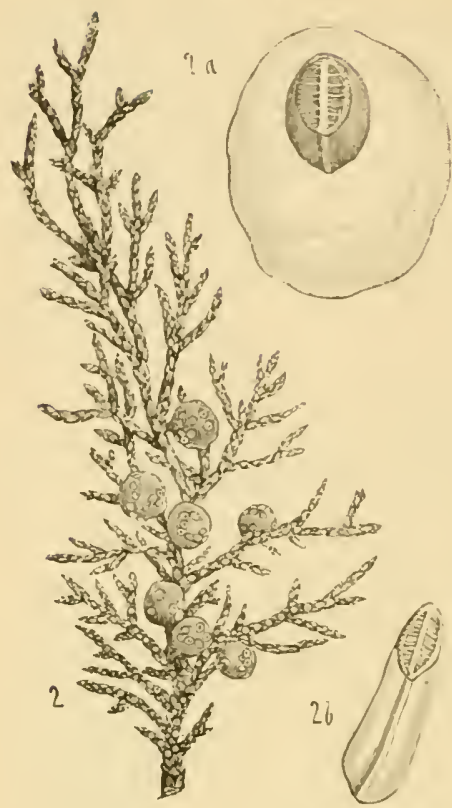

Fig 2371,2 .

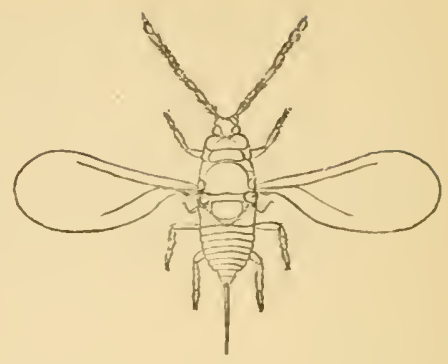

Fig. $2: 37_{4}^{1}$-Juniper Scale: 2, an infested branch: 2u, the female scale-color, phite; $2 b$, the male scale-color, white. fig. 20.7-Male Jumiper siale Insect, highly magnificed-culor. aringe-yellow.

ReMrdes-Use same as for the Red seale, Chaj. LXXXY. 


\section{INSECTS INFESTING THE RED BAY TREE.}

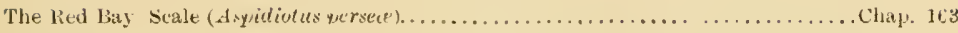

\section{CHAI'TER ('LAIII.}

The Red Bay Seale.

(Aspidiutes perace.-Ciomstock.)

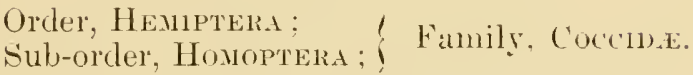

[A cireular scale infesting the foliage of the red bay tree, and also the olive tree.

The red bay scale insect infests the foliage of the red bay tree, and also the foliage of trees planted in the vicinity of trees infested by this species. I have also found this, or a closely allied species, on a priret hedge.

The scale of the female is circular, and from three fourths of a line to one line in diameter; the outer margin is dark reddish-brown with a yellowish tinge; the central part is a clarker brown; the exuria is nearly in the center, and forms a nipplelike prominenee.

Fig. 238.-Male Red Bay Scale Insect, enlarged, Fig. 238. ventral view-color, yellowish.

The male scale (Fig. 235) is of a dirty white color, elongated; the exuvice or larval skin nearly central, and of a golden-yellow color. The egges are yellowish, and of an elongate-oval shape; from twenty to thirty-five are deposited by each female. The larve are yellow.

The female is orange-yellow; form, similar to

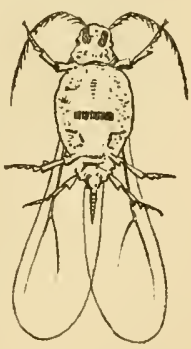
the red scale of Florida (A. ficus).

Renediss-Sime as for the red scale, chapter LXXXVI. 


\title{
INSECTS INEESTING TIIE AZALEA.
}

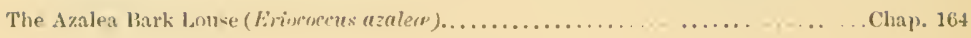

\author{
('HAT'TEL ?LAIS. \\ The Azalea Bark Louse. \\ (Erincoerens azulea.--('omsturek.)
}

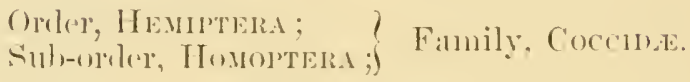

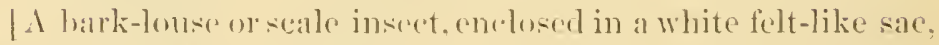
feeding on the azateat.]

This speries can lu readily distinguisherl from other species of sabe inserets or bark-lice described in this work. ly being enclosed in a felt-like sale. In form thesar or covering is hemispherical, but more pointerlat one ond than at the other, and snow-white in enlor.

The female insect is dark purplish in eolor ame wal in form, the posterior end being the narrowest: the enges and romme larve are of a redslish-pulphe or "almine color.

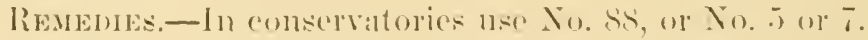




\section{INSECTS INFESTING THE OLEANDER.}

\begin{tabular}{|c|c|}
\hline The Oleander Aphis (Aqhis verii).........165 & $\begin{array}{l}\text { The Black Seale (Leccuium olem). } \\
\text { The Filbert scale (Lecunium hemisylericum). }\end{array}$ \\
\hline $\begin{array}{l}\text { The following insects also infest the Olean- } \\
\text { der: }\end{array}$ & The Lemon Peel Scale (Asyridiotus nerii) \\
\hline
\end{tabular}

\section{CHAPTER CLAY'}

The Oleander Aphis.

(Aphis nerii.-Fonseol.)

$\left.\begin{array}{l}\text { Order, Henfrtera; } \\ \text { Sub-order, Homoptera } ;\end{array}\right\}$ Family, Aphindod.

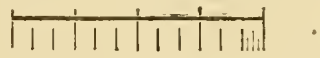

[The measurements of insects in this work are griven in inches and lines. The above cut tepresents one inch divided into lines and fractions thereof.]

[Living upon the leaves and tender twigs of the oleander, which they puncture with their beaks and extract the satp; small yellowish plant-lice, sometines marked with brown.]

The wingless lice are yellow. The winged lice are also yellow, having the thorax marked with brown.

Remenes.-No. 3 or No. 4 ; but No. 5 or No. 7 are preferable. No. (it. 


\section{INSECTS INEESTING TIE ROSE BLSH.}

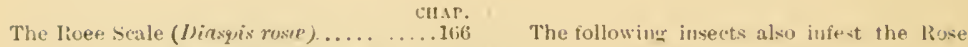

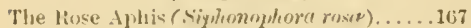

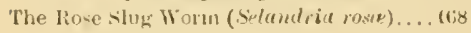

The Horned flower-heetle (Fotocks monhush:

The 'lussock Hoth (1)rygia leucostigma).

The (ireater Leaf roller (Luxutura rusucunu).

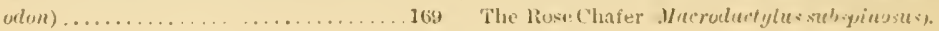

\section{('HAT'TER ('L N'l}

The Rose Scale, or White Seale. (Cal.)

(D)iaspis rosir._. Sandlunerg.)

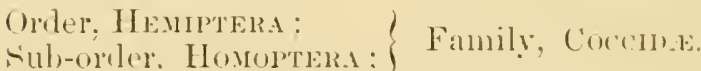

[A white scale-insect infesting the rose, rasploerry, b]ackberry, ("urrant, ete.]

The rose or white scale insect (Fig. -2:3!) infests sereral varieties of rose bushes, and also the lasplerry, blackberry, ('urrant, etc.

Fig. 239.

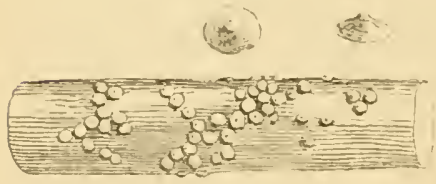

Fig. 2.39. - R ose Fig. 240. Srales-colerr, white: at. the top, alle two scales. mannitied, the one to the right being a sile view and the one to the left heing at top

vier. Fig. 2to.-Female Rose scale-inseret. enlarged.

Fomale (Figr. 240) form, elongated ; abdomen. distinctly scermented: color, dark red.

Male (Fiğ. 242), winged-color, light amber, with dark irrerular matkingrs; wings white, the veins slightly colored; anal stylet half the length of the body ; legs. yelluwish. 
Fig. 241

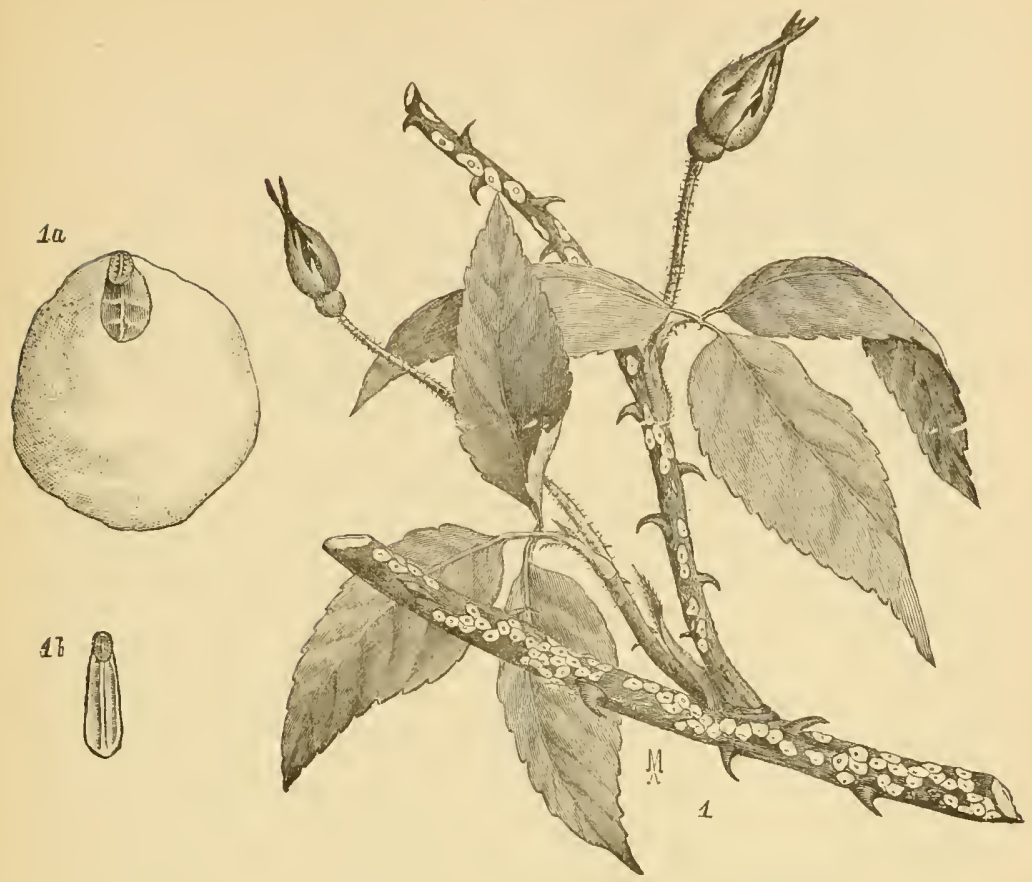

Fig. 241.-Lose sicale; 1, a portion of an infested bush; 1 a, the female scale, greatly enlargecl-color, white; 16 , the male scale, enlarged-color, white.

It is generally found on the stems and branches of the plants (Fig. 241) and its presence can be easily detected, as its color contrasts strongly with the color of the bark of the plant which it infests. I have recently received specimens of currant roots taken from below the surface of the ground which are covered by this species of scale-insect. QueryDoes this species infest the roots of plants? Will fruitgrowers please investigate?

The scale of the mile (Fig. 241, 16, ) is elongater and measures three fourths of a line in length; color, white; exurice near the anterior end.

Eggs-color, red; form, oval; lengtlı, one one-hundredth of an inch-from twenty to fifty under each scale.

Larva-length, one eighty-fifth of an inch, and about two 
thish as wirle; aolol, resldish; antemuar, six-jointerl; two anal setre, but very tine.

Fig. 242.-Rose Scale-jnsect (male, greatly (nlargerl) color, yellow.

The scale of the fermale insect (Fig. $2+1,1 a$,$) is circu-$ latr, or mearly $\mathrm{xa}$; color, snowy white; lengeth. from one line to one and one Fig. 242.

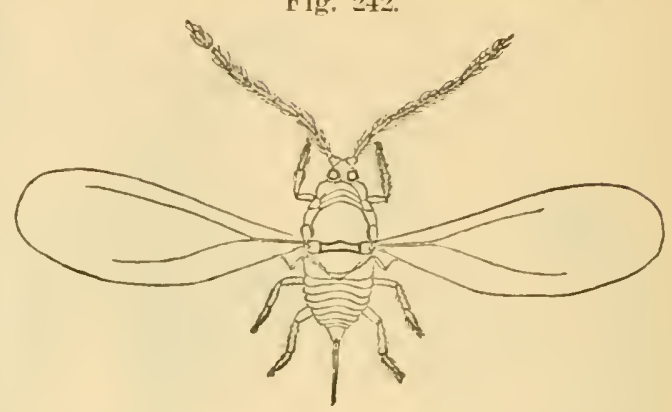
quarter lines; exurice or cast skin to one side of the renter. Remenis. - No. 3 or 4 ; but No. 5. 6. or 7 are preferiblale.

\section{C'HAP'TER ('LAVII.}

The Rose Aphis. (Cal.)

(Siphomphorel rosit.-Reammur.)

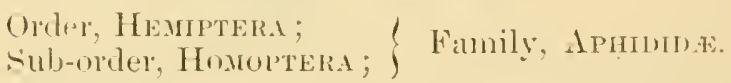

[Living on the stems and leaves of the losehush, which they puncture with their beaks and extract the sall: sulall green ol redish plant-lice, usually marked with black or brown.]

Fig. 243.

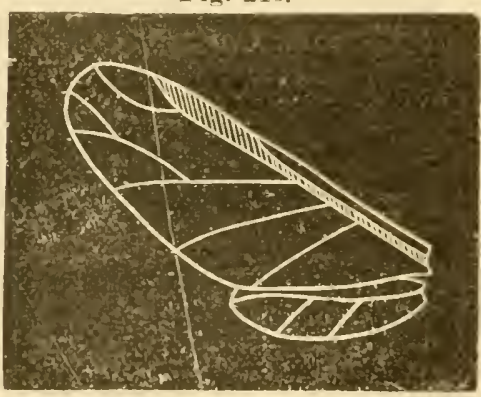

Fig. 2-43.- Wing of Aphis. showing renation.

The wingless lice are greeri in entor, excepting one villiety, which is redelish. The winged liee (Fig. 2-4:), wing.) are ereen, the head and tho-

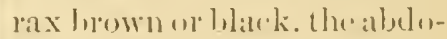
mell matreed with brown or hatek.

Rigmedes-Les No lit:

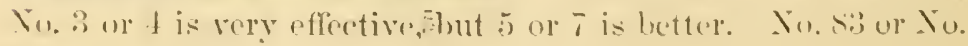
(i) ale exeellent. 


\section{CHAPTER CLNVIII.}

The Rose Slug-worm. (Cal.)

(Selaudive rosa'-Harris.)

Order, Hrminoptera ; Family, Texturedixide.

[Feeding upon the leaves of the rosebush; a naked green worm, provided with twenty-two legs.]

Fig. 24t.-Rose Slug-worm-color, green.

These slug-wolms (Fig. 2t4) eat only the upper surface of the leaves, leaving the remainder unFig. 244. touched, thus giving the leaves the appearance of having been scorched. These worms have the heat yellowish, with a black spot on each side, and on the edge of the first segment are two triple-pointed warts. When fully grown they desert the plants and burrow at short distance into the earth, where each one forms a small cell in which it spins a tough elliptical cocoon. Two broods are usually produced in one year, the last brood passing the Winter in their cocoons.

Fig. 245.

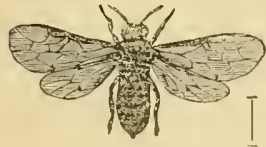

Fig. 245.-Rose Saw-fly-color, black.

The perfect fly (Fig. 245) has four smoky wings, which expand alout five lines: the body is of a uniform black color. The female tly deposits her eggs singly in pumetures marle in a leaf br means of a saw-like instrument with which her aldomen is armed.

Reventes-Lse No. 6t, 5,7 or 6 ; the latter is excellent, hut might mark the foliage.

\section{CHAPTER ('LAIX.}

The Horned Flower-beetle. (Cal.)

(Notorus monodon.-Fabricius.)

Order, Coleopters; Family, Axthicide.

[Feeding upon the petals of the garlen rose; a grayishbrown beetle, having a brown band across the middle of the 
wing-cases: two or more hrown spots at the base of the same, and an obscure hand at the tip: the thorax projects in the form of a long horn orer the hearl.]

This beetle (Figr. 24ti, l'late.:3,) meatsures about a line and a half in lenerth. Where it lives lluring its larvil stage is not known. but the perfect insect passes the 1 inter heneath pieces of wool, etc., that lie upon the erround.

Remedes_-Fray with No. 万, T or (it: or dust after sunset witl Jo. 1!. 


\section{INSECTS INFESTING THE FLOWER GARDEN.}

CHAP.

The Verbena Aphis (Siphonophere cerbeno) 170 The Carnation A phis (Rhopulosiphum dianthi) ..........................
The Tulip Aphis (Rhopalosiphwin tulign) 172 The Snowball Aphis (Aghis viburni)....173

\section{CHAP'TER CLAX.}

The Verbena Aphis. (Cal.) (Siphonophora Terlucue.-Thomas.)

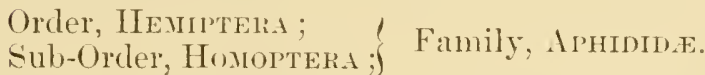

[Living upon the leares of the garden verhena, which they puncture with their beaks and imbile the sap; small green or yellowish plant-lice.-Thomas.]

Remedies-C - Ee No. 3 or t, one pound to ach two gallons of water used : or No. 8.3 or No. S..

\section{('HAP'TER ('LXNI.}

The Carnation Aphis. (Cal.)

\section{(Rhopalosiphum diunthi.-Schrank.)}

Order, Hemptera:
Sub-order, Homoptera ; Family, Aphidide.

[Living upon the stems and leaves of the carnation pink and German iry, which they puncture with their beaks and imbibe the sap: small green plant-lice. sometimes marked with black.

The wingless lice are yellowish-green, striped with darker 
green. The winged lice have the head and thorax black, the abdomen dark olive-green, with darker transverse lines.

Rementes.-Yo. ? or 4, one pound to each two gallons of water ured ; or No. s:i or No. s.i.

\section{C'HAP'TER CLAXII.}

The Tulip Aphis, (Cal.)

$$
\text { (Rhopalosiphum tulipre.-Fonscol.) }
$$

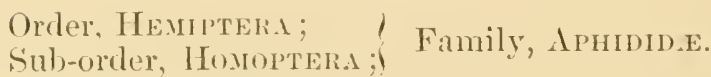

[Living upon the leaves and stems of the garden tuli], which they puncture with their beaks and imbibe the sap; small green plant-lice, sometimes marked with black.]

The wingless lice have the head and thoma blackish-green, the aldomen dark green, with darker transverse lines and a low of black dots along each side.

Reverdes-No. 3 or 4 , one pound to each two gallons of water used; or No. 8.: or No. S.5.

\section{('HAPTER CLAXIII.}

The Snowball Aphis. (Cal.)

$$
\text { (.1,his vilurmi-sicopoli.) }
$$

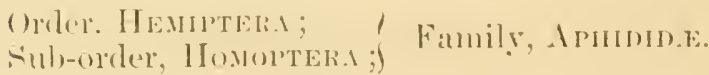

[living upom the leares and stems of the gardens smowbill ame the high-lush aranlerry, which they puncture with their beaks and inlibe the salp: small brown or halckish plantlier.-Thomas.

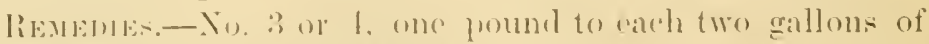

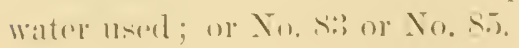




\section{INSECTS INFESTING THE CONSERVATORY.}

The Common Mealy-bug Dactylogius adomidum ) ....................... 174

The Destructive Mealy-bug (Dartyloyius destructor)
CHAP. The Mlealy-hug with long threads (Dactyloquius longifitis)..................... 176 Slugs or Snails................... 177

\section{CHAPTER CIXXIV.}

The Common Mealy-bug. (Cal.)

\section{(Dartylopius adonidum.-Linneus.)}

$\left.\begin{array}{l}\text { Order, Hzмmpteka; } \\ \text { Sub-order, Homopten ; }\end{array}\right\}$ Family, Coccida.

[Living upon various kinds of green-house plants and orange trees; a small scale-like inseet, more or less covered with a whitish, mealy powder.]

Fig. 247.--Female Mealy-bug, enlargedcolor, yellowish-white.

This species is commonly termed the mealy hug, as if there was only one species. It is sometimes very trouhlesome in hot-houses, conservatories, and also to some. kinds of garden plants. I have also received specimens of oranges which were infested by this, or a closely allied species. The

Fig. 247.

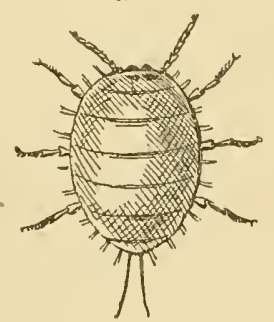
female (Fig. 247) measures from one line and a quarter to a line and a half in length; is of a whitish or yellowish rolor. with a hrown hand on the middle of the back, and is eorered with a mealy powder which is excreted through pores situ ated on various parts of the borly. In ardition to this there 
is a woolly horder around the edge of the body which is longest at the hind end of the body.

Fig. 248.
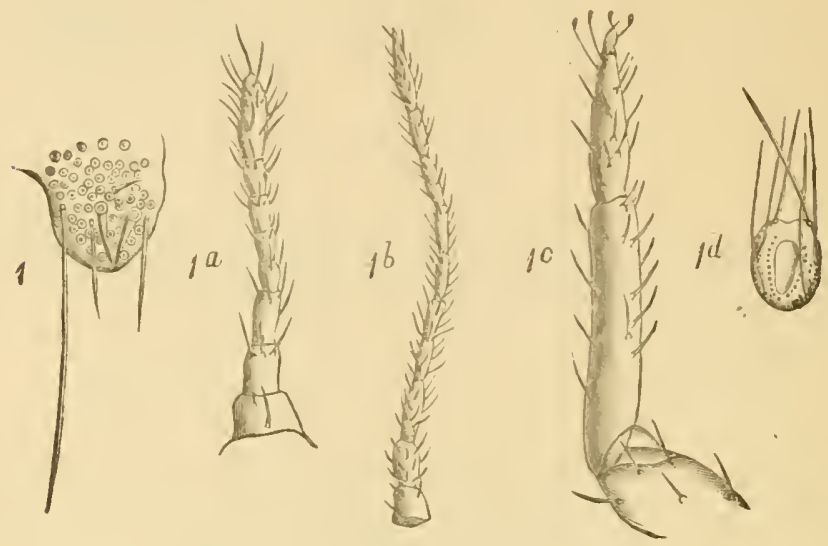

Fig. 24s.-('ommon Nlealy-long; 1, a lobe of hind end of the borly of the female: 11 , an antenna of the female; $1 b$, an antenna of the male; 1 r, a leg of the female: $1 / l$, anal ring of the female-all highly magnified.

The achult male is furnished with two wings, and is of a brownish color.

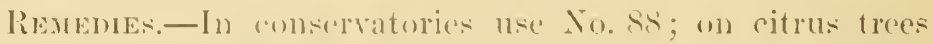
serionsly infested use No. on, and piek off all fruit; when the foliage and fruit are off, spray theroughly with No. 5o $\overline{7}$; this should be done before the growing season, when the trees will send out a new foliage.

\section{('H.MPTER ('IANY.}

The Destructive Mealy-bug.

(Dactylopins destiuctur.-('omstork.)

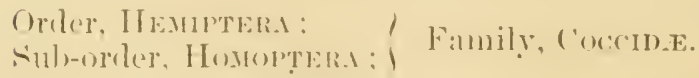

[Infesting green-house plants ame] urange trees; a small yellowish bug, thinly covered with a mealy powder. | 
Fig. 249.-Destructive Mealy-bug,

Fig. 249 . female, greatly enlarged--color, brownish-yellow.

This species is sometimes very destructive to orange trees, and also to green-house plants. The female (Fig. 249) is of a dull brownish-yellow color, very slightly covered with a mealy powder; length, nearly two lines.

Fig. 250.

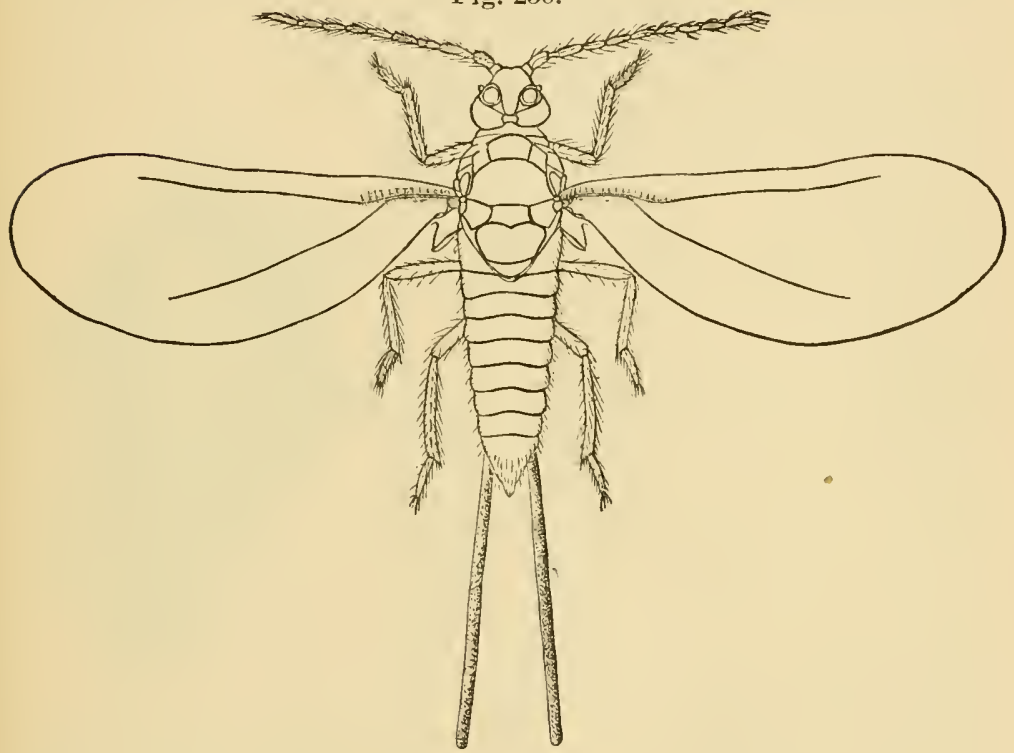

Fig. 250.-Destructive Nealy-bug, male, highly magnifiedcolor, light olive-brown.

The winged male (Fig. 250) is of a light olive-brown color, and is marked with olive bands. The female deposits her eggs in a cottony mass which is excreted from the hind part of her body. The eggs and young lungs are of a light yellow color.

Remenes.-Same as in Chapter CLAXIV. 


\section{CH.APTER CIANTI}

The Mealy-bug with Long Threads.

\section{(Dartyluprius lomgitilis.-Comstork.)}

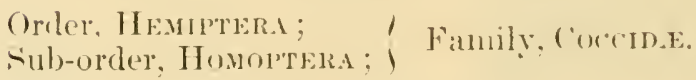

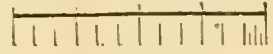

The measurements of insects in this work are riven in mches and lines. The ahove cut represents one inch divided into lines and fractions thereof.

[Infesting green-house plants; a small yellowish bue thinly covered with a whitish mealy powher.]

Fig. 2.51.--1 a a l $y-$ - lo ug with long threals. female, greatly enlarged-color, rellowish.

Professor comstock has deseribed amother kind of mealy-bug which l have not foumel in C'alifornia; the following is eomdensed from his original description of this insect: "The fenale (Fig. 251) is from two to two and a half lines long, and is of a pale-yellowish color, sparsely covered with a mealy powder. The wingerl male (Fier. 252) is of a light olive-hrown color. The female deposits egress, hut these

Fig. 251.

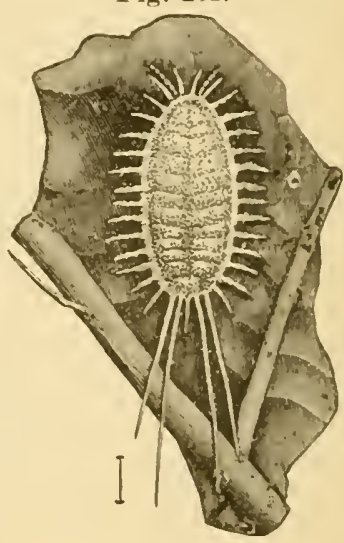
areso far developed that the young bug issues shortly after the eggr is laid. These insects are sometines quite destructive to green-house plants, especially to ferms." 
Fig. 252.

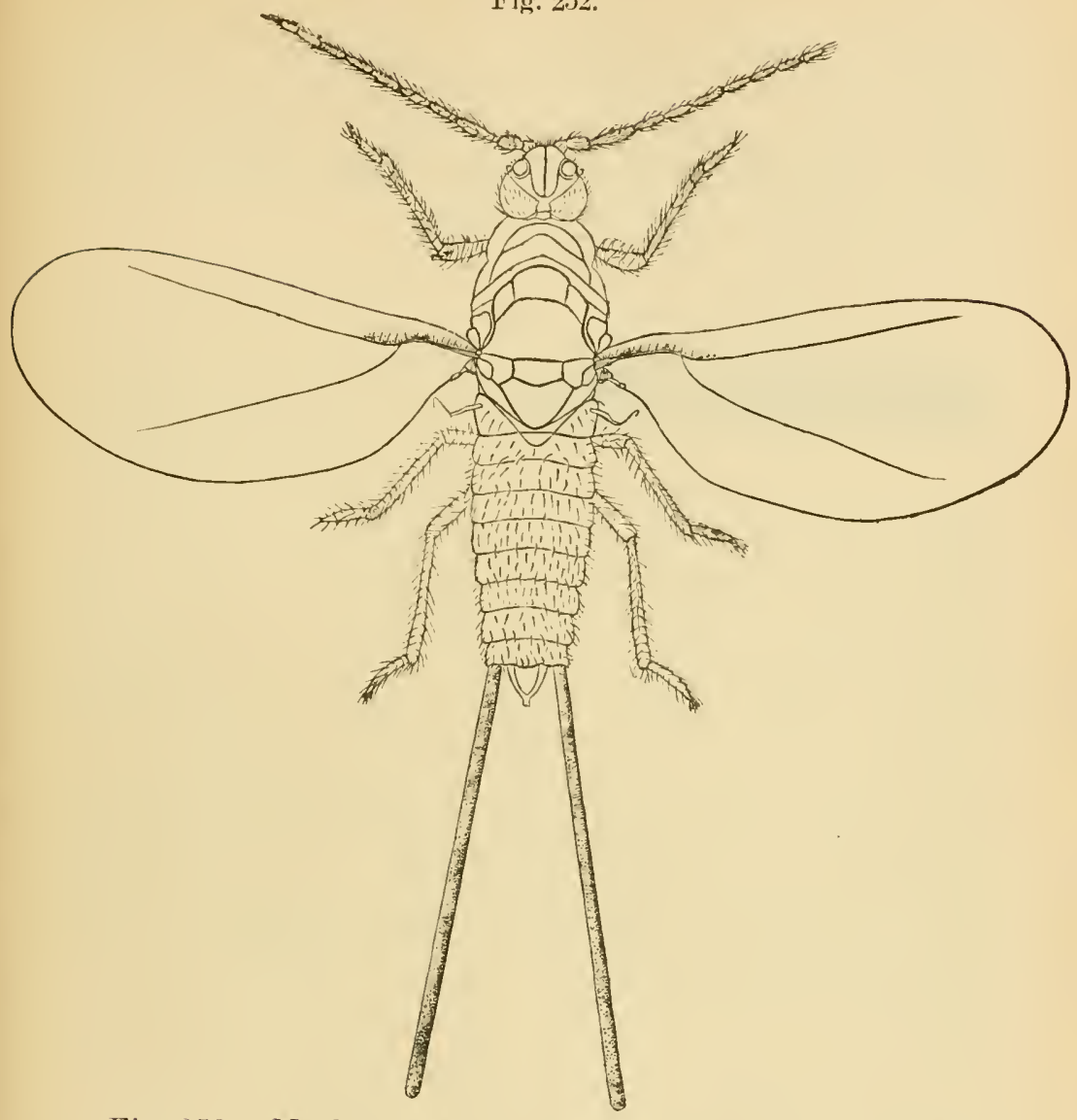

Fig. 252.-Mealy-bug with long threads; male, highly magnified-color, olive-brown.

Remedies.- Same as in Chapter CLAXV'1.

\section{CHAP'TER CLXYTII.}

\section{Slugs or Snails. (Cal.)}

$\left.\begin{array}{l}\text { Class, Gasteropoda; } \\ \text { Order, Pulnonata; }\end{array}\right\}$ Family, Helicide.

[A small gray or black slug, feeding at night on conservatory and garden plants.] 
Altheugh the slugs or snails do not belong to the same subkingrlom as insects do, Articulatu. but belong to the sub-kingfom Inolluserr. which romprise the soft-bodied animals of the shell-bearing and non-shell-bearing spereses yet the damage which some of the speres infliet on earden regetalshes and other probuctions of the garelenere, florist, ete., is suflicient to rause mention of these pests in this work.

Fig. 253.

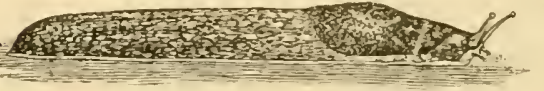

Fig. 25:.,_-slug-rolor, mp:

Thu most destruetive spereses that is fouml in the gandens. loot-homies and conservatories in this state is the suall gray slug, Lymar ayrestis (Fig. 2.53), and a dartior colored speries, problably the Lymar uter. These species may he designated ats the gray

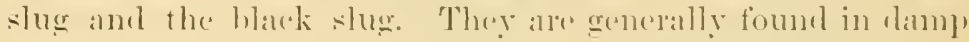

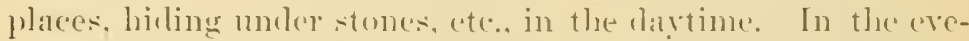
ning they rome from their hiding plares in search of fordel and as they are gregarions in their hathits, they often do great dian-

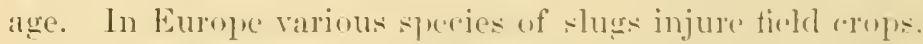

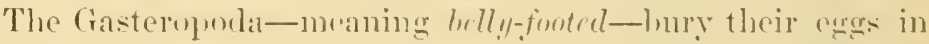

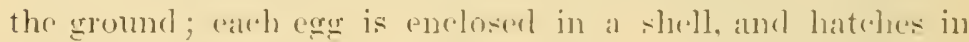
Alugust wr september. They hibernate through the and weather, and attain their full size the next spring.

Remetr-lise No. Si. 


\section{INSECTS INEESTING THE HOP PLANT.}

The Hopvine Plusia (Plusice balluea)..... 17s The Hoprine Snout-nsoth (II/] rena humuli) 179 The senicolon Butterfly (Gruptu interro. gationis) . . . . . . . . . . . . . . . . . 1s0 The Hop Aphis ('Thorodon humuli)....... 1s1
The following insects also infest the llop plant :

The Broad-necked Prionus (Primus laticollis) (ut-worms (Agrotis).

\section{CHAPTER CLAXVII.}

The Hopvine Plusia.

(Plusia balluca-m-(ieyer.)

Order, Leproptera; Family, Noctunde.

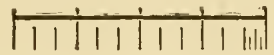

[The measurcments of insects in this work are given in inches and lines. The above cut represents one inch divided into lines and fractions thereof.]

[Feeding upon the leaves of the hopvine; a green, fourteenlegged eaterpillar, marked with white streaks; the head green, and destitute of black dots.]

This caterpillar arches up its back slightly when erawling. When fully grown it measures about one inch and three lines in length. It then trawls into some sheltered place and spins a thin cocoon. The fore-wings of the perfect moth expand about one inch and nine lines; they are almost entirely covered with metallie green scales, and are crossed by two oblique dark lines. The hind wings are dusky gray.

I lave not found this species in this state. The above account is taken from the Canadian Entomological Report for 1873 .

Remedes.-Spray thoroughly with No.5 or 7; or No. 64, which is preferable. Read No. 106 carefully. 


\section{CHAPTER CLAXIA.}

\section{The Hopvine Snout Moth.}

\section{(Hyроля humuli-Harris.)}

order, LennortekA; Family, P'rkande.

[Feeding u]our the leaves of the hopvine; a nakerl, green. fourteen-leggerl worm, lotted with black and marked with from two to four white stripes, and having the head dotted with black.]

Fig. 254. - Hopwine Sinout-moth; at the left, the moth-rolor: dusky-brown, graly and back; a, the pupacolor, brown; above the pupa. the caterpillarFig. 251.

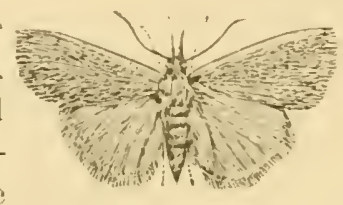
color, groen, with white and dark lines and blatk dots.

These caterpillars (Fig. 2.it) in walking areh up their backs like the span-worms. and when jarred from the leares they usually hang suspended hy a silken thread. They are rery sprightly, frequently leaping sidewise to a distance of sereral inches when touched. When fully grown they are about an inch long. They then desert the plants and seerete themselves beneath the fallen leares, etc., or enter the earth and form small cells in which to pass the pupartate (Fig. 2.5ta).

The perfect moth (Fig. 2.5t) expands aloout an inch and three lines. The fore-wings are of a dull hrownish color. marked with darker spots and eonl-hlack elevated points. The hind wings alde palc dusky hrown.

There are at least two brooks of these worms produced in ome season. and these are to be foumel fiom May to september. The manner in which these insects pass the Winter is not known; but the last brool of moths, which alpear in september or Uetober, probalbly libernate. and deposit their egge in the following spring. This species is reported as accurring in this state, but I have nererseren as specimen of either larra or perfece insect. 
Rementes.-Spray thoroughly with No.j or 7 ; or No. if which is preferable. Read No. 106 carefully.

\section{CHAPTER CLXXX.}

\section{The Semicolon Butterfly. (Cal.)}

\section{(Grapta interrogationis.-Fabricius.)}

\section{Order, lapidoptera; Family, Nrmphalid.t.}

[Feeding upon the leares of the hoprine; a browish caterpillar, nottled with rellow and covered with red or light colored spines tipped with black, or the spines wholly black.]

The fully grown caterpillar is abont one inch and six lines long; the head is reddish-brown, thinly covered with small prickles, and on the top are two branching spines. When about to pupate, it suspends itself by the hind feet.

The ehrysalis is ashy-brown, and the head is surmounted with two projections resembling ears; on the back of the thorax is a nose-like prominence, and on the back are a number of silvery spots.

Fig. 255.

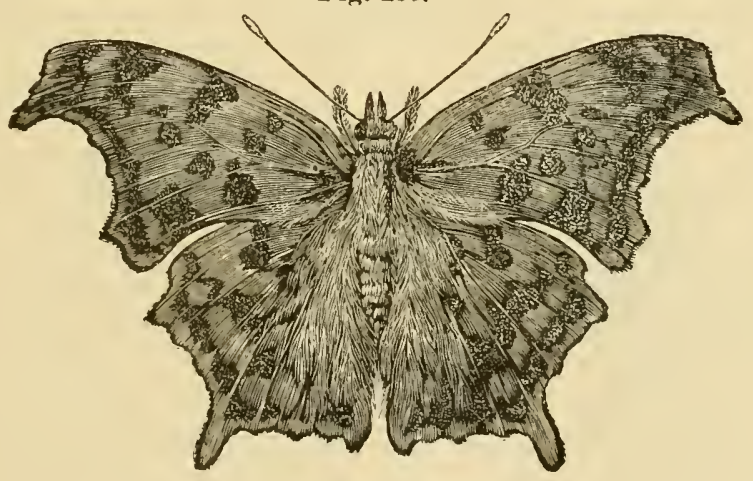

Fig. 255.-Semicolon Butterfly-colors, reddish-brown and black.

The butterfly (Fig. 255) which issues from this chrysalis has the outer margin of all the wings notcherl they are of a reddish-brown color, marked with black and dark brown spots, and with an outer brown border; in some the greater part of 
the hind wings are hlack. On the under side of each hind wing is a silvery character resembling a semicolon $(;)$. The fore-wings expand from two inches and six lines to two inches and nine lines.

likmedes.-Should the caterpillars appear on the vines, spraly thoroughly with No. 5 or 7 ; or No. 64 , which is preferal)le. Read No. 106 carefully.

\section{CHAPTER CIXXYI}

The Hop Aphis. (Cal.)

\section{(Phorodon humuli-Schrank.)}

$\left.\begin{array}{l}\text { Order, Hemptera; } \\ \text { Sub-order, Homoptera } ;\end{array}\right\}$ Family, Aphinm.z.

[Living upon hopvines, usually near the terminal end, which they puncture with their beaks and imbilse the sap; small yellowish-white or green plant-lice, sonetimes marked with black or brown.]

The wingless lice (Fig. 2.56. 3 and 4,) are yollowish-white or green.

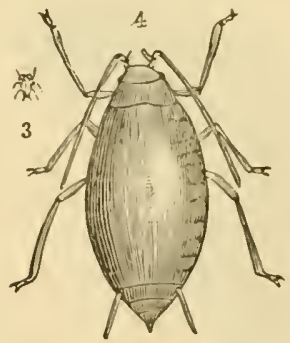

Fig. 256.

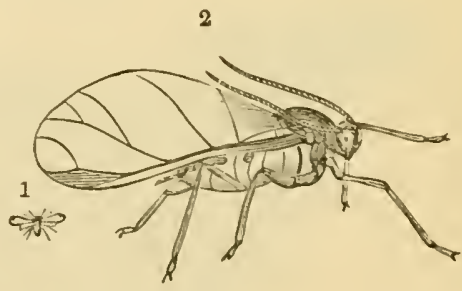

Fig. 256.-Hop Aphis; 4, a wingless aphis. onlarged ; 3 , the same, natural size-eolor, yellowish or green; "2, a winged aphis, enlarged; 1 , the same, natural size-colors, green, brown and black.

The winged lice (Fig. 2.56, 1 and 2,) are green, and the females have the heat brown or black, and the thorax and abdomen marked with dark hown or lilack.

REMEDHE-Use No. 5 or 7 ; or No. 64 , which is preferable. Real No. 106 carefully. 


\section{INSECTS INAESTING WHEAT.}

Crane Flies (Tipula)...............

The Hessian Fly (Cecidomyia destrutor)..183 The Joint Worm (Eurytoma tritici).......1S4 The Chinch Bug (Wiropues leveopterus) . . 185 The Grain Aphis (Ay)his arena).........186 The Army Worn (Leucania uniquencta)...187
The California Locust (Widiqoda atrox)....188 The Wheat Midge (Diylosis tritici). . . . . . 189

Wire Worms (Elaterida) also attack the roots of the Wheat plants.

\section{CHAPTER CLXXXII.}

\section{Crane Flies. (Cal.)}

Order, Dirtera; Family, Tipuline.

[Feeding upon the roots of barley, corn, turnips, stramberries, etc.; a grayish footless grub. having the hind end of the body apparently cut squarely off and provided with tubercles.]

Fig. 257.-Crane Fly ; 1, the larva or maggot-color, gray; 2 , the pupa-color, brown; 3 , the fly-color, brown; 4 , the $\operatorname{egg} \mathrm{s}$.

In England the larva (Fig. 257,1, ) of these flies are known by the name of "Leather Jackets," on account of their tough, leathery skins. In that country they are sometimes very destructive to various crops by feeding upon the roots; but I am not aware that they have ever been reported as being very injurious in this

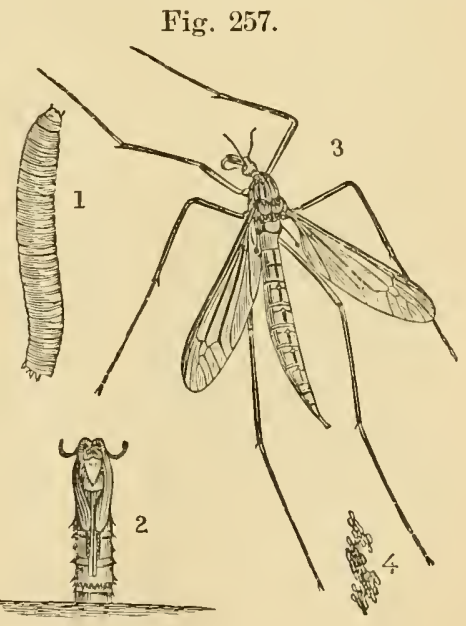
State, although quite a number of species are found here. 
Fig. 258.

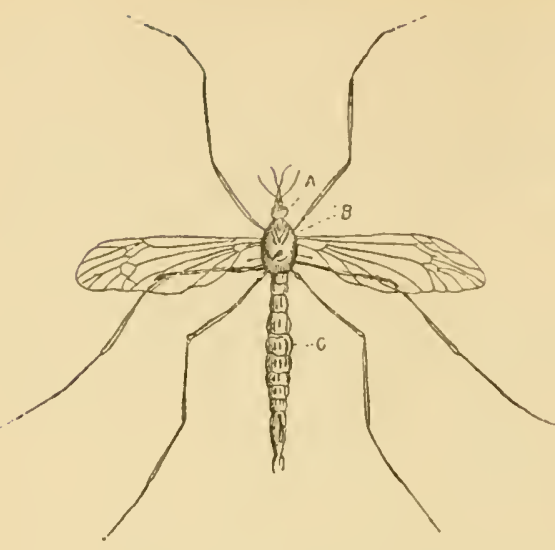

Fig. 2.5s.-Crane Flycolor, brown.

These long-legged twowinged flies (Figs. 25\%, 3 , and 2.5.), which somewhat resenble gigantic mosifuitnes, ale familiar to almost everybody, and known as the "Darldy Long-lers." The greater number of them live in decayed regetable matter, and ane henee not injurious to the agriculturist in this state, so

far as at present known. The pupa (Fig. 2.5. 2,) is somewhat cylindrical. and at the anterior end are two horn-like projections.

Remedes.-In gardens, use No. 5.5. 1. In fields. decp plowing, thorough drainage, and reaning the grounds. See No. 20, No. 32, A. B.. and No. 10k, 1 .

\section{('HAPTER ('IAXXIII.}

The Hessian Fly.

\section{(Ceriduminie destructor:- itay.)}

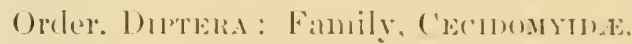

[hiving between the leaves and the stalk on the lower part of the wheat plant; an wal, relintrical, white, fleshy maggont. finally transforming into a hrownish two-winger fly:

Among the wheat pests clrearled in the Eastern States is the Hessian fly. I have not found this inseret in California. 
Fig. 259.-Female Hessian Fly, enlarged-color, black.

The Hessian fly (Fig. 259), named Cecidomyia destructor by Mr. Say, appeared in this country in 1776 , and the general opinion was that it was imported in the stores by the Hessian soldiers in the employ of the British Government, from which it derived the name of "Hessian Fly." There is probably no other species of the insect kingdom that has occasioned so much diseussion as to whether it is indigenons to this comntry. Sir John Banks, an English entomologist, reports to the British Government, in 175?, that no such insect could be found to exist in Germany. Its first appearance in this country was in 1776 , on Staten Island, and at Flatbush, on the western extremity of Long Island. Some writers state that it travels about seven miles each Summer. ITowever, Dr. Chapman discovered it in 1787 on the west side of the Alleghany Momntains, which would be about thirty miles each year, dating from staten Island in 1776. Wheat, rye, barley, and even timothy grass, were attacked by them; and so great was their ravages in the larva state that the cultivation of wheat was abandoned in many places where they had established themselves. It has been a subject of general discussion as to where the female deposits her eggs. Some claim on the young leares of the wheat, others on the grain before sowing; but the following opinion is evidently correct, as expressed by Dr. Chapman : "The Hessian fly lays her eggs in the small creases of the young leaves of the wheat." Mr. Havens states that the fly lays her eggs on the leaves. Mr. Herrick writes: "I have repeatedly, both in Autumn and in Spring, seen the Hessian fly in the act of depositing her eggs on wheat, and have also found that she selects for this purpose the leaves of the young plant. The eggs are laid in various numbers on the upper surface of the strip-shaped portion (or blade) of the leaf." Mr. Herrick also states that the number of eggs on a single leaf is 
often twenty or thirty. The exy is about one fiftieth of an inch in length, and it hatehes in less than fifteen clays.

Fig. 260.

Fig. 260.-Larva of Hessian Fly, enlarged-eolor, yellowish-white.

Fig. 261.-The sheath remored, showing thee hibernating larre or magrots of the Hessian Fly. They are now sainl to be in the flaresed state, from the resimblance they bear to those secels.

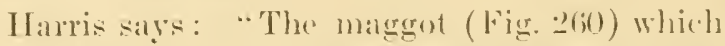

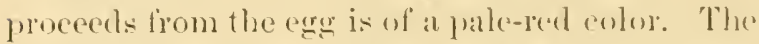
maggots erawl dewn the leatf and work their way

Fig. 261.

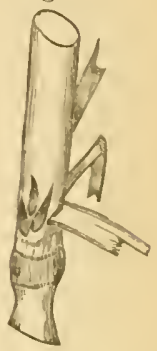
between it and the main stalk (Fig. 261), passing downward till they come to a point a little below the surface of the gromed, with the head towards the root of the plant. Having thus fixed themselves ujom the stalk they become stationary. and never move from the plane till their transformations are completed. They rlo not a at the stalk, neither do they penetrate within it, as some fersoms have supposed fut they lie lengthwise upon its surface, corered by the lower part of the leaves, and are nourished wholly by the salp, which they appear to take by suction. As they increase in size they grow plump and firm; they beeome embedeled in the side of the stem by pressure of their body upon the growing plant. (Fig. ․ $\left(i_{2}.\right)$

Fig. 262.

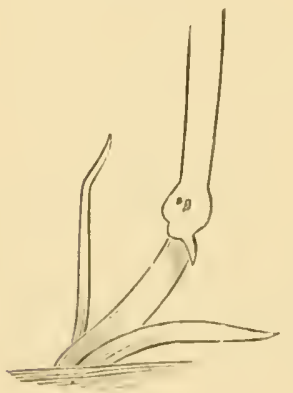
The magreot thus selekm destross the plant; but where two or three are fixed in this mamer around the stem they weaken and imporerish the plant and eause it to fall down or (o withed and dic." (rig. ö (6i, right.)

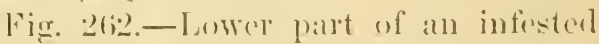
wheat plant, showing the swelling at the lower and of the sheath calued hy the larvie of the Hessian fly.

The magent reaches maturity in about forty days and measures about there twentiethes of an inch in lenerth. 
Fig. 263.--At the left, a healthy wheat plant: at the right, a plant infested by the maggots or larve of the Hessian fly.

The transformation of this species is different from some others in the pupa or chrysalis state, inasmuch as it first passes through what is termed ly naturalists the "flax-soerl" state. It assumes the pupa form only a few days before the perfect insert emerges.

This pest produces two broorls each year-one in the Spring and one in Autumn.

The perfect insect (Fig. 259) is described as follows: "Color, llack, exeept that the ab-

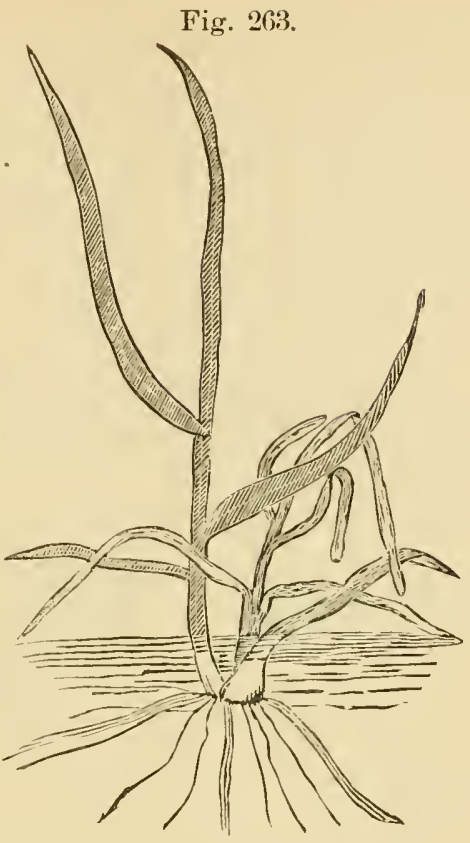
domen is more or less tawny, each ring being marked more or less with black; legs, pale-red or brownish, with black feet; wings, three-veined, ciliate or fringed. The length of thr insect is about one tenth of an inch, the expansion nearly one quarter of an inch." The insect belongs to the order diptera, or two-winged flies.

Dr. Cyrus Thomas, state Entomologist of Ilinois, writes as follows :

\section{"DOES THE IIESSLAN FLY EMIGRATE?}

"As regards the so-called emigration of this insect, we would express our disbelief in any such movement from place to place as is involved in the idea of the word smiyration. The history of the insect simply shows that it has steadily spread from its original point of introluction to new sections of the country as rapidly as they were settled and wheat became a staple article of production.

"It is periodically alumedant; most other noxious inscets are mole abundant some years than others, becoming abun- 
dant in some localities and scarce in others. It cannot, therefore, truly be said to migrate from one part of a State to another, or from one region to another."

Again, writing of the probable limits of the Hesian fly, Dr. Thomas says: "The question naturally arises whether this pest will ever infest the wheat regions of westem l)akota, Ifontanat, Utah, Colorado, amel the Pacifie states and Torritories? We believe (though not awate that such a statement may be haraded) that it was originally an inhabitant of ('entral and Southern Enrope. It lats become acchmated in the Eastern, Itlantir, and Viddle States, in the Valley of the Upper St. Lawrence, and in the Valley of the Miscissippi River; that it can thrive in the elevated iry Rocky Mountain plateau regions, and withstand the cool nights and dry hot atmosphere of the far west soems doubthul. At least. so slowly has it spread westward, so slight an anount of wheat or straw is transported westward (all produce of this kind geing eastward), that we doubt whether, during this edentury at least, it will extend west of Kansals and Minmesota, where it hats already hal a foothold for sererill years."

From what has been said of the IIessian fly, it is obvious that the wheat-growers of California camot be too careful in preventing the importation of this pest.

REMents- Should this pest appear in this state, a good preventative of its spreading would he the use of No. 56 or 20 .

\section{CH.IPTER ('LAXXIV.}

\section{The Joint Worm. (Cal.)}

\section{(Eurytome tritici.-Fitch.)}

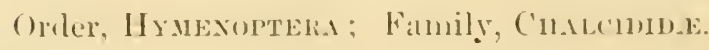

[Living in galls or swellings on the fower part of wheat plants; a footless pale yellow matgerot.]

The parent flies appear in the latter part of . April or begin-

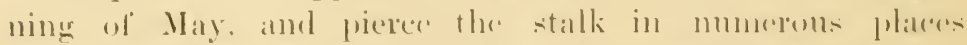
immediately above one of the joints, inserting an roge into 
each puncture. These eggrs soon hatch into minute footless, rellowish grubs, whose presence in the plant near the joint soon causes the latter to swell, forming a sort of gall which is of a hard, woody texture. These grubs remain in their cells in the center of the stalk all Winter, and are changed to thes in the following spring. 'The perfect insect (Fig. 26t) is wholly black with the exception of the front shanks (tibiae), which are pale yellow.

Fig. 264.-.Joint Worm Flies, enlarged - color, black; $a$, the female; $e$, her abdomen, still more enlarged; $c$, her antenna, highly magnified ; $b$, the male tly ; $f$, his abdomen ; d, his antenna.

An insect very closely related to the preceding infests rye in the sime manner as the latter infests wheat. This is known as the rye $\mathrm{H}_{\mathrm{y}}$ Fig. 264.

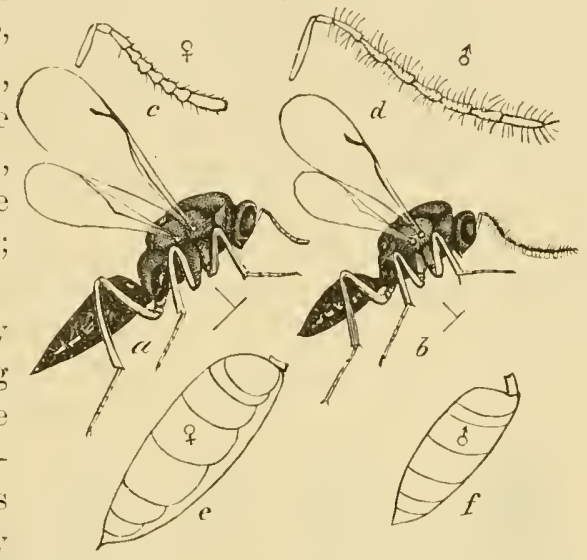
(Eurytoma seculis-Fitch). It is wholly black except the front and hind shanks (tiliae), which are pale yellow.

Two other species infest barley in the same manner as the above insect infests rye. There are the black-legged barley fly (Eurytoma hordei-Harris) - of a black color, with only the knees and feet pale yellow; and the yellow-legged barley fly (Eurytoma fluvipes-Fitch) —of a liack color, with all the legs pale yellow. Some anthors contend that the four species of flies described above are but rarieties of one species, which was first describerl by Dr. Harris moler the name of Eurytoma hordei.

Remenies - T'se Nos. 56 aud 20. 


\section{C'H.APTER CIAXYY.}

\section{The Chinch Bug.}

\section{(. Micropus leueoptems.-Sis.)}

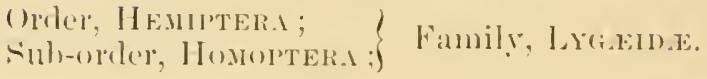

[Living "lpon the stalks of wheat, corn, oats, ete; a smal] black bug with white wings, which lie flat upon the back and have a blark spot on the outer edge of each; or a vellow, red or gray lugg entirely destitute of wings.]

The female deposits her eggs (Fig. 2(i5), a amel b,) in the groumel at the roots of the piants upon which her progeny are to feed. These egrgs are of a pale amber-white color, elongate oval, and one ond alppearsas if it har been eut sfluarely off and is smrmounted lyg four small rounded tubereles.

\section{Fig. 265.}
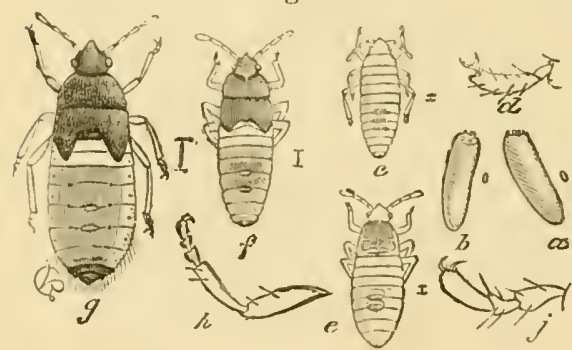

Fig. 26.5.-Chinch Bug Larvil, Pupa and Eggrs; !h the pupa

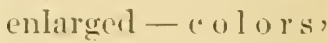
bromnish-black and gray ; c, e and $f$, the lanve in alforent stages of their growth-culors, yellow or red; 1 , one of their feet, enlargerl; $b$ and $a$, two egers, highly magnifiedcolor, whitish or pale brown; $h$, a leg of the alult, enlarged; $j$, the foot of the same, still more enlarged; $i$, the beal of the achult, highly magnified.

The young huge (Figr. 265, c and $c_{\text {, }}$ ) are variously markerl; some are yellow, with an orange stain upon each of the three larger aldominal segnents; others alle reddish, with the two hasal abrlominal serments jale or with a pale band alcross the mirldle; and still other's are of a dingy eraly. These insects obtain their menrishment by puncturing the plants with their healks and imbiling the salp; they hibernate in the jerfect or winged stage (Fig. 26(i). 
Fig. 266.-Chinch Bug, enlarged-colors, black and white.

I have had many specimens of inscets sent me, those forwarding them stating that they thought them to be the chinch bug, but so far I have not found a specimen of this species in this state.

REMEDIEs.- Should this pest appear in this State, it can be prevented from spreading by trenching, as recommended in No. 86 ; use in the trenches No. 81 or 85. If Fig. 266. No. 85 is dusted on the perpendicular side of the trench, and renewed every three or four hours, few of the insects entering the trench will survive. See Nos. 20 and 56 ; also No. 106, A, as recommender for cleaning hop fields.

\section{CHAPTER CLXXXVI.}

The Grain Aphis. (Cal.)

(Aphis arenx.-Fabricius.)

Syroxym.-Siphonophora revenæ.-Fabr.

$\left.\begin{array}{l}\text { Order, Hemiptera; } \\ \text { Sub-order, Homoptera ; }\end{array}\right\}$ Family, Apimdide.

[Living upon the stems, leaves, etc., of wheat, barley, etc.; small brown, green or yellow plant-lice, which puncture the plant with their beaks and extract the sap.]

Fig. 267.-Cira in Aphis; 1, the winged louse, enlarged (natural size indicated at 2 ) -colors, green, yellowish and black; ' a wingless louse, enlarged (natural size indicated at 4)-color, Fig. 267.

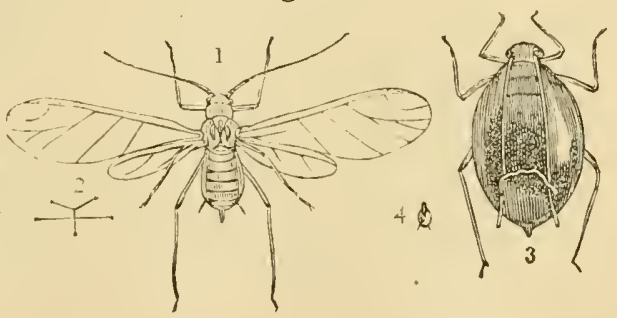
green, yellow or brown.

The wingless lice (Fig. 26\%, 3 and 4, ) are either dark brown 19 
or dark green, with a reddish band across the abdomen at the base of the honey tubes; the antennæ. knees and feet are black.

The winged female (Fig. 267, 1,) is either dark green or brown, with a row of black dots on each side of the body; the head and thorax are sometimes marked with black.

The present season, 188:), this species appeared in at least ten counties in this State, and in some instances did considerable damage to wheat, etc., but were prevented from sprearling by the late rain. which also gave such impetus to the growth of the infested grain that in many fields the damage is scarcely pererptible. On the 29 th and 30 th of $A$ pril, and on the 1 st, 2d and sil of May, unusual flights of the winged insects (Fig. 2(is) were noticed in this eity (Sacramento) but they disalpeared "ntirely with the advent of the rain of May 4, $185 \%$.

Fig. 268.--Grain Aphis (winged female, e. 1 lar ged (a) - colors,

Fig. 268.

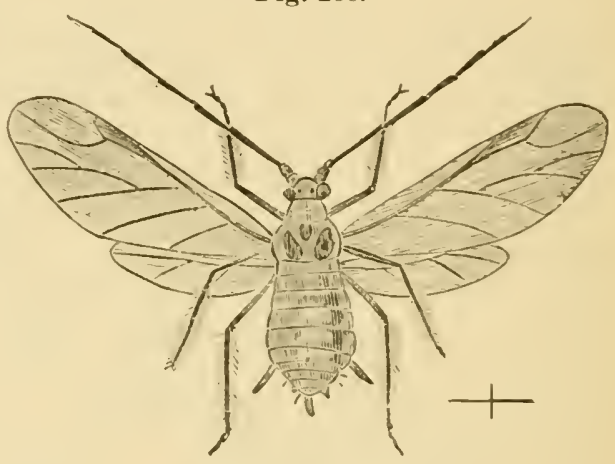
green, yellowish and black.

Remedtes.-Use Nos. 56 and 20.

\section{CHAPTER CLXXXVII.}

The Army Worm.

\section{(Leucania unipuncte--Haworth.)}

Order, Lepidoptena; Family, Noctum.z.

[Migrating in large armies and feeding upon the leaves of various kinds of grain and grass; a naked caterpillar having sixteen legrs, the boly marked with lines of dusky, hlack, white and yellow. !

This insert plays two roles-one as a cut worm. living con- 
cealed during the daytime and coming forth at night to feed, and the other as an army worm (Fig. 269) migrating from one field to another and devouring everything hefore it. It is in this latter capacity that this insect has figured the most conspicuously.

Fig. 269.-Army Worm--

Fig. 269. colors, dusky, black, white and yellow.

When fully grown it measures a little over one inch in length, is of a dingy velvety black color, with a white line

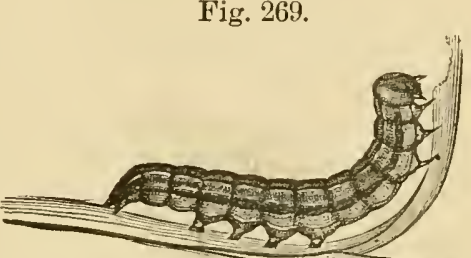
on the back and four light lines on each side of the body, the two uppermost lines white, the two lower ones yellow; the head is rellowish, and marked in front with two curved blackish lines.

Fig. 270.

Fig. 270.-Pupa of Army $\mathrm{W}^{\gamma}$ orm-color, brown. The caterpillars of this species which act as cut worms, attain a larger size than those which migrate from one place to another, and their colors are more obscure. Three broods or more are produced in one season, the last brood hibernating as partially grown worms. Before pupating they enter the earth and form small cells. (Pupa, Fig. 270.)

Fig. 271.

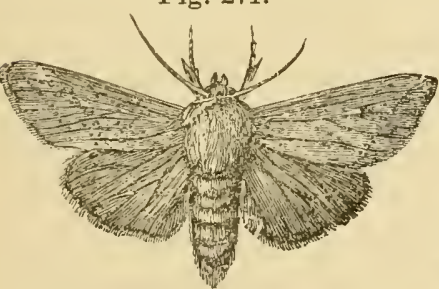

Fig. 271.-Army Worm Moth; color of fore-wings, light reddishbrown.

The fore-wings of the perfect moth (Fig. 271) expands about one inch and nine lines, are of a light redrish-brown color, dotted with black, and marked near the center with a black dot, from which they derive the specific unipuncta or one-dotted. The hind wings are smoky or blackish.

Remedy.-Use No. 86. 


\section{CHAPTER CTAXXTIII.}

The California Locust, or Grasshopper.

(Edipoda atrox.-Scudder.)

Order, Othoptera; Family, ACRIDIDA.

[Feeding upon nearly every kind of grain and grass and also the leaves of trees and nearly every speries of plant: a six-legged locust, or grasshopper.]

This insect is closely relaterl to the elestructive Rock Mountain locust-Caloptenus sprems-which is found from the sierras to the midlde of the State of Iowa, but has never leen reported as occurring west of the sierras. The California loeust has at times appeared in immense swarms in various parts of this state, but has been esperaslly destructive in the Sierra Valley. They sometimes $\| y$ in immense swams. hiling the sun from view for hours at a time. Their usual time of appearance is during the months of June and July. Their' flight is usually from the northeast to the southwest.

This insect measures from nine to fifteen lines to the tips of the wing-covers; general anlor, a dull brown, varicel with darker brown; the checks and a spot on cach sick of the thorax are yellow; along the inner or upper edge of earle wingease is a yellow line: along the opposite exte of the wing are from one to three dark brown spets, the one nearest the bake the largest, the others small. and sometimes obsolede: there are several other spots of the same color on the disk of rateh wing-cover; the hind wings are transparent: the hind femerap (thighs) are brown or yellow msually, lut not always. marked on the outside with two obliyue dark hrewn spots; the hind tibix (shins) are yellowish.

Fig. 272.-Egegs of a I.ocust. wh (imashopper-color, yellow.

The female locust deposits here e.gens in masses in holes excavated in the eitrth (Fig. 272) by the aid of four homy plates Fig. 272.

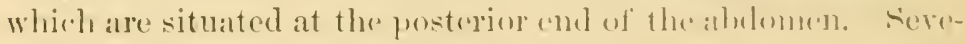

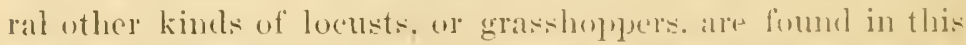
state, but they have ahout the same hahits as the abose speeeics, with this exception: that they have newer heen known to 
occur in such destructive numbers, or to migrate from one place to another, as the California locusts are known to do.

Revedy.-Mr. R. B. Blowers has been suceessful in destroying locusts, or grasshoppers, in his clover and alfalfa fields that were seriously infested, by using an arrangement constructed as follows: He had a pan constructed of sheet iron, ten feet long and three feet wide, turned up a few inches on the sides and ends; this was strengthened by pieces of two by two inch Oregon pine. A board ten feet long, two feet wide and half an inch thick is used on the back of the pan, and fastened with braces. A light runner is placed under each end and in the middle, raising the pan about one inch from the ground. Ropes are attached to each of the front corners, and to these a horse is hitehed. Coal tar to the depth of from half an inch to one inch is placed in the pan. A boy is then placed on the horse's back, and drives backward and forward

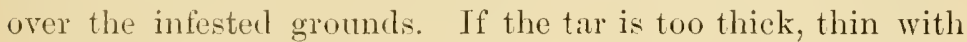
petroleum. The dear bodies of the insects can be taken out of the liquid with a rake or some other implement.

\section{CHAPTER CLXXXIX.}

The Wheat Midge.

(Diplosis tritici-Kirby.)

Order, Dipters; Family, Cectnomyide.

[Living in the heads of wheat; an orange-yellow footless maggot.]

Fig. 203.- Wheat Midge and Larva; at the left the larva, or maggot, natural size; in the middle the same, highly magnified-color, orange; at the right the $\mathrm{fly}$, or midge, with its wings closed-colur, orange.

As we have never met with this insect in this State, we take the following condensed account from

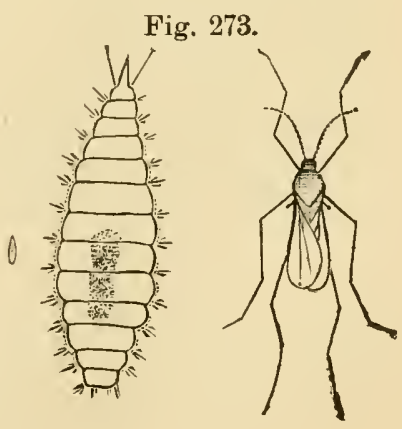
Packard's "Guide to the Study of Insects." 
"When the wheat is in blossom the females lay their eggs within the chaffy scales of the flowers, in clusters of from two to fifteen or nore. In eight or ten days the eggs disclose the transparent maggot, which, with age, becomes orange-colored,

Fig. 274. and when fully grown (Fig. 273) measures about

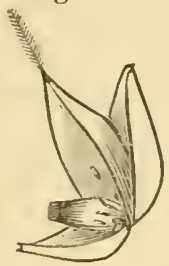
one line and a half long.

[Fig. 274.-A green kemel of wheat infested by the larva, or maggots of the wheat midgecolor of larva, orange.]

"They crowd around the germ of the wheat (Fig. 2i4), which by pressure beromes shriveled and aborted. At the end of July. and in the beginning of August, the maggots beeome full fed, and in a few days cast their skins; shortly after this-and sometimes before it - they descend to the ground. which they enter to the depth of about an inch; here each one spins around its body a minute silken cocoon. They remain in their cocoons unchanged during the Winter, and are changed to pupe the following June.

[Fig. 275.-W'heat Midge,female, enlarged and natural size-color, bright orange.]

"When the perfect fly is about to issue, the pupa works its way to the surface ; this usually oce eurs in June or July. The fly (Fig. 273 and 275) is of an orangeryellow color, with long slemrlex leges and two transparent wings: the antemne of the female are

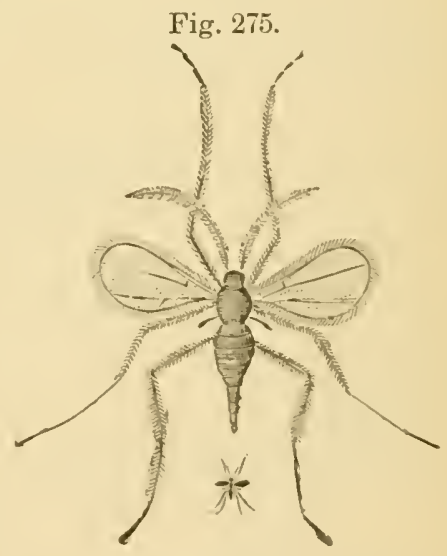
twelve-jointerl, while those of the male are twenty-four jointed."

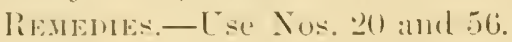




\section{INSECTS INFESTING BARLEY.}

The following insects infest barley, but are treated of elsewhere in this work:

The Crane Flies (Tiqula).

The Black-legged Barley Fly (Eurytoma hordei).

The Yellow-legged Barley Fly (Lubtomu flaviqus).

The Grain Aphis (Aqhis utena).

\section{INSECTS INFESTING RYE.}

The Rye Fly (Eurytoma secalis) (See article on The Joint-worm, (Chapter CLXXXIV.)

\section{INSECTS INFESTING CLUVER AND ALFALFA.}

The Clover-root Borer (Hylastes trifolii)...190 The clover-stem Borer (Languria mozar-

di).............................

The (lover-hay Worm (Asopiu ciostalis)....192
The following insects also attack Clover and Alfalfa :

The Crane Flies (Tiqula).

The California Locust (Uilizoda atrox).

CHAP'TER CLC.

The Clover-root Borer. (Hylastes trifolii.-Muller.)

Oreler, Colentelia; Family, Scolytue.

LLiving in the roots of cluver; a whitish six-legged grub, about one and a half lines long, with the head yellow, finally changing into a reddish-brown slightly hairy beetle.]

These insects usually reach maturity in October, and the 
beetles hibernate in their burrows. In the following spring they come forth from their. Winter quarters, and the female, when about to deposit her eggs. first gnaws a large eavity in the crown of the roots, and then deposits therein from four to six pale whitish elliptical eggs, which hatch in about a week. The young larva begins to bore downward into the root. passing between the outerskin and the heart. When fully grown, it assumes the pupa form in the bottom of its hurrow, and the perfect beetle issues in the course of a week or so.

I have found a grub in roots of alfallit, but did not succeed in rearing the perfect insect.

\section{CHAPTER ('XO'T.}

\section{The Clover-stem Borer. (Cal.)}

(Lrenguriu mosardi.-Latreille.)

Order, Colenptera: Family, Erotyudaz.

[Living within the stems of clover (lig. 276, Plate :, ) ; yellow six legged larvat about three lines long, with two eurvel spines at the hind end of the body; finally changing into at blue-lilack beetle, having the thorax yellowish-reel.]

The fomale beetle first gnaws a hold into the stem and then deposits therein a single egge (Fig. 27T. Ilate :3.) of a yellowish color. romded at eatch end and somewhat curvel. The yommg larva (Fig. 2-2s, Plate 3,) burrows lownward. consuming the central substance of the stem to al distance of six or eight inches. It assumes the pupa form (Fig. 27-7. Plate 3.) in the lower end of its burrow, and the beetle (Fig. 280. l'late :3.) wheh issues in the Autmom, desints its hurrow and, at the approale of eold weather, secks some sheltered plane in which to pass the Winter. I have found this. or al clusely allied species, in alfalfa.

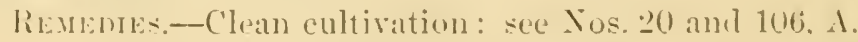




\section{CHAPTER CXCII.}

The Clover-hay Worm.

\section{(Asopie rostulis._Fabricius.)}

Order, Lepidoptera; Family, Prralinde.

[Living in silken tubes in elover-hay; an olive-brown or dull white sixteen legged-caterpillar.]

When fully grown these caterpillars (Fig. 281, 1 and 2,) measure about nine lines in length, and shortly afterward assume the pupa form (Fig. 281, 4,). There are probably two broods in one season, and the last brood passes the Winter in the larva state. In Europe the perfect moth (Fig. 281, 5 and 6, is known as the "golden fringe;" it is of a liliaceous or purplish eolor with a silky gloss; the front wings are tinged with gray and marked on the front edge with two large, bright, golden-yellow spots, which are narrowed behind into a slender line that extends across the wing; the hind wings are lighter than the front ones and are crossed by two light straw-colored lines; all of the wings are margined with deep orange; expands about ten lines.

Fig. 281. - Clover-hay Worm ; 1, lack view of one of the worms ; 2 , side view of the same (both suspended by silken threads) - color, brownish; $\gamma$, a worm in its silken tube; 4 , the pupa -color, honey-yellow; the cocoon-color, whitish; 5 , the moth with its wings expanded; 6 , the Fig. 281.

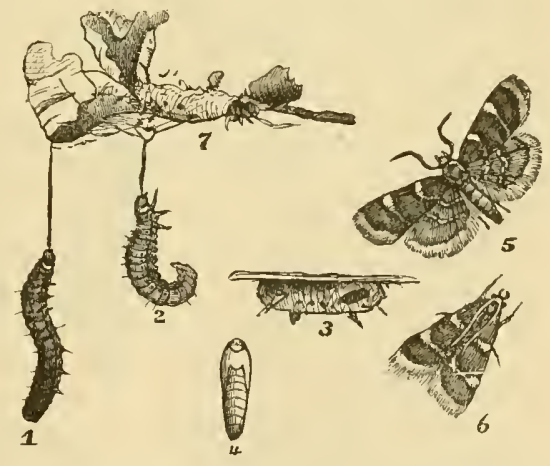
same with its wings closed-colors, grayish purple and yellow.

The larve or caterpillars of this moth are sometimes very destructive to clover-hay, especially to that which las stood in the stack for several years. They are most abundant in the bottom of the stack, where the infested hay will frequently be found to be webbed together by the silken tubes which they spin for a habitation in which to dwell. 


\section{INSECTS INFESTING CORN.}

The Wire Worm ... ................. 193

Cut Worms (Ayrotes)................ 194

The White Grub (Luchno:terna yueveina).195

The Corn Worm (Helinthis armigera).... 196

The Corn Aphis $(.1 y)$ is maidis $) . . . \ldots \ldots . .197$
The following insects also infest Corn: Crane Flies ('Tiyula).

The Stalk Borer (Fortyna nitelu).

The Chineh bug (.Mirroyses lencoyterar). The Army llorm (Leteanil uniyuneta). The Yellow Bear (Syjilosoma zirginica). The Califoruia Locust (Gdijodu utrox).

\section{CHAPTER CACHI.}

The Wire Worm.

Order, Coleopteka; Family, Elateride.

[Feeding upon the roots of wheat, vats, corn, potatoes, and many other plants; a nearly cylindrical reddish or yellowishbrown six-legged larra or worm.]

Fig. 282. - Wireworms and snapping-beetles ; 3, Elater obscurus, enlarged (natural size: indicated at 4)-color, black or brown; 2, E. lineatus, enlarged (llatural size inclicated at 1$)-$ color, grayish-brown, with darker lines; $5, E$. Fig. 252.

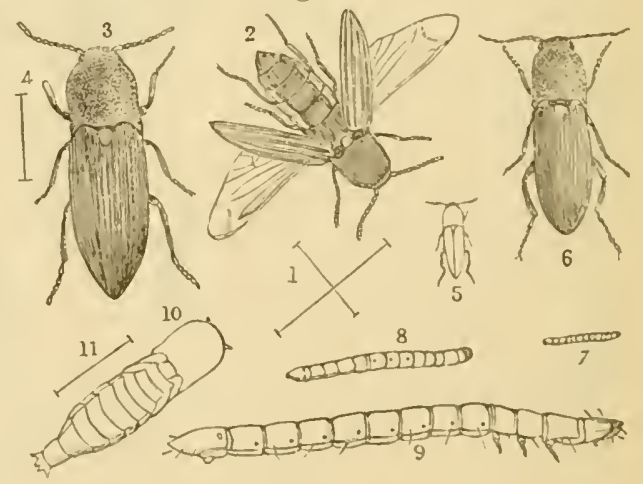
sputator, natural size;

6 , the same enlarged-color, blackish; 10 , the pupa of a wireworm, enlarged-color, yellowish; S, the larva of Li. lincates, natural size; 9, the same enlarged-color, yellowish: 7, a wire- 
worm, natural size. All of these are natives of the Easterm continent.

This is the larva of a beetle known as the "snapping beetle," "skipjack," etc. (Fig. 282, 2, 3, 5, and 6). They derive this name from the method they adopt to attain an upright posture when they happen to fall upon their backs. Being unable to turn over, they make a sudden jerk or spring, accompanied by a clicking noise; hence the name.

The larra (Fig. 282, 7, S, and 9, ) has six legs, two beneath cach of the three first segments, and a tubercle under the last segment of the abdomen, which it uses as a pro-leg.

It is an undecided question among naturalists as to the length of time these insects remain in the larva state; some say two years; others, as high as five; however, it is generally conceded to be about three years, which, like many other beetles of long larval lives, have an opportunity of doing immense injury to erops, etc.

Fig. 283. - Wire-worm-color, yellowish-brown.

Mr. Curtis writes: "Wherever

Fig. 283.

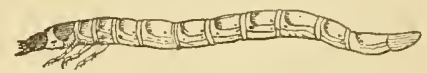
grasses will grow, the wire-worm (Fig. 2S3) may be found." Dr. Fitch writes: "They abound alike on the roots of the coarsest sedges, and on other wild grasses, on the borders of marshes and on those of the most delicate pasture." They do great damage to crops, especially corn, but can be found feeding upon the roots of barley, cabbage, wheat. rye, potatoes, asparagus, carrots, oats, etc, of the field, and dahlias, pinks, carnations, etc., of the garden. A great many remedies have been published for destroying those pests, but are generally inapplicable to field crops.

Fig. 254. - Milli pectes or Thousandlegged Worms-color, brownish or yellowish.

Note. - The millipedes, centipedes, or t ho u s a nd-legged worms (Fig. 284), are sometimes mistaken

Fig. 284.

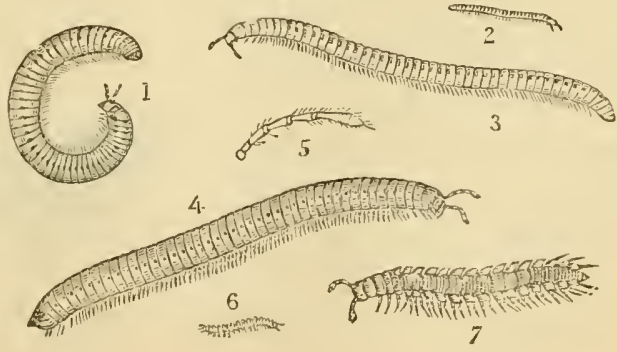


for wire-worms. They can easily le distinguished from the latter by laving onc or more pairs of legs to each segment of the body, whereas the true wire-worms have a pair of legs attached to the first three segments only. the remaining segments being destitute of legs; (ompure Figs. 2S:3 and 2\$4. On roots of trees, use Remedy No. 59 ; on roots of cereals, ete., No. $55, \mathrm{~A}$.

ReMenY.-Use No. 55.

\section{C'HAPTER ('NCIT. \\ Cut-worms. (Cal.)}

Order, Lephoretera: Family. Noctrow.

[Feeding upon the roots of corn, melons. cabbages. etc.. usually severing the plants; or ascending fruit trees. graperrines. rosebushes, etc.. and levouring the buds; a naled. grasy looking sixteen-legged caterpillar or worm.]

Fig. 285.

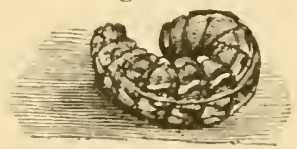

Fig. 286.

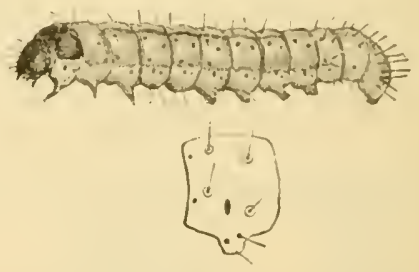

Fig. 20.5.-W-narked ('ut-wom (Ayrotis clandestina)color, ash-gray and black or brown.

Figr. 2sti.CGlassy ('nt-worm (Hadena derastator); the lower figure represents me of the middle sexments of its body enlarged-eolor, pale green.

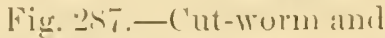
Moth (Mamestree renigera): at the left the moth (knuwn ats the Figure os Minor Moth)-color, dark gray; at the right the worm Fig. 287.
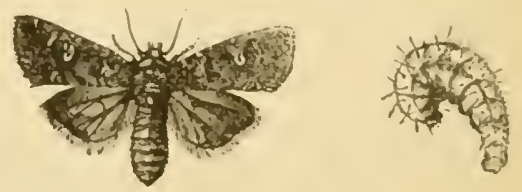
(callerl the White Bristly ('ut-worm) -color. yellowish gray. 
These worms (Figs. 285, 286 and 287) are very destructive to young plants of various kinds; their usual mode of procedure is to cut the young plants off and drag them into their burrows, there to devour them at their leisure. Others ascend various kinds of trees and shrubs and feed upon their leaves.

Fig. 288.

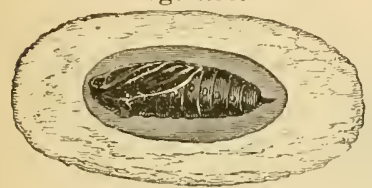

Fig. 288.-Pupa of Cut-worm in its earthen cell-color, brown.

They come forth to feed mostly in the night, remaining in their hurrows during the daytime. When about to pupate they form smooth cells (Fig. $288)$ in which to undergo their transformations.

Fig. 289.-Gothic Dart Joth (Agrotis subgothica, the parent of the Dingy (nt-worm)-colors, gray, yellow and white.

The perfect moths (Figs. 289 and 287 ) are usually of an ashengray color, rariously marked with

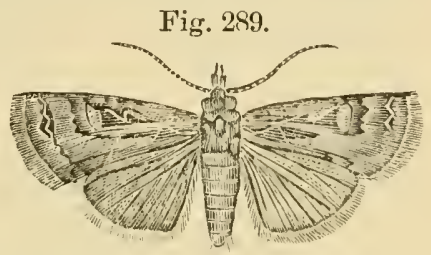
dusky or black; their hind wings are mostly whitish or smoky.

Remedy.-Use No. 73.

\section{CHAPTER CXCV.}

The White Grub. (Cal.)

(Lachosterna quercina.-Knoch.)

Order, Coleoptera; Family, Scarabaide.

[Feeding u]on the roots of corn, potatoes, strawberry plants, nursery stock and various kinds of grasses; a white eurved six-legged grub; or feeding upon the leaves of the apple and other trees; a robust reddish-brown beetle.]

Th e beetle (Fig. 290, 3 and 4,) which deposits the eggs from which these grubs (Fig. $290, \stackrel{2}{2}$ ) hatch, is commonly known as the "May-beetle," or "June-hug." It is from eight lines to nearly an inch long, of a nearly uniform chestnut-l,rown color, and the breast is covered with yellowish hairs. 


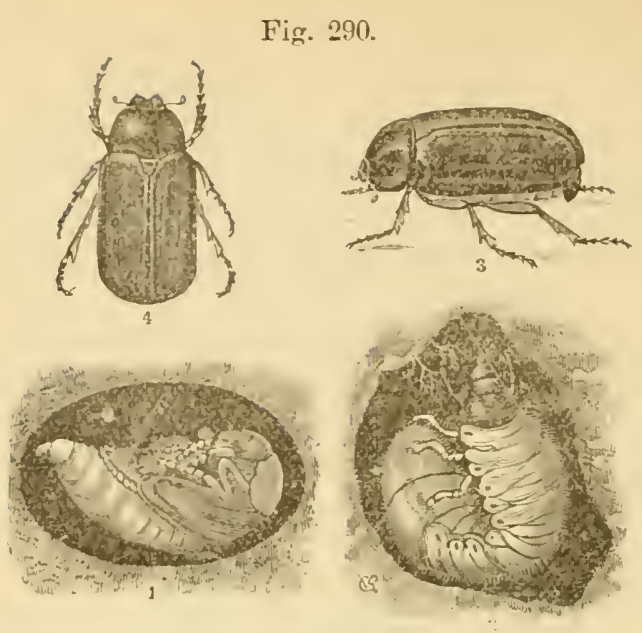

Fig. 290. -White Grub; 4, the beetle. back view; 3, the same, side viewcolor, e hestnutbrown; 1 , the pupa in its cell--color, yellowish-white; 2 , the grub in its hurrow in the earth-color. white, with the head brown.

The eggrs are laid in the eartls, and these soon hatch into small, whitish six-legged gruls, with brownish heads. When at rest they lie upon one sicle, the hody being curved so as to bring the head and tail nearly in contact. They feerl upon the roots of rarious kinds of plants, and are supposed to spend two or three rears in this, their larval stage.

When abont to pupate they form smooth oval cells in the earth (Fig. 290, 1.) in which to undergo their transformations. The perfect insects feed upon the leaves of the apple, cherry, and various other fruit and ornamental trees.

Remedi:-Use No. 107 .

\section{CIIAPTER CXCVI.}

The Corn-worm, or Boll-worm. (Cal.)

(Heliethis armigers.-Huhner.)

nrer. Lephoptera: Family Nomtuns.

[Living in threars of corn and fecding unon the kernels. or burrowing into the bolls of enton: a green or brownish sixtecn-legered worm. marked with darlier strijes. ]

The hody of this caterpillar (Fig. 291") is slarsely covered with polished black elevated dots, and the head is brown. 
When fully grown it measures about one inch and six lines in length. It sometimes assumes the pupa form in its burrow, but usually descends to the ground, which it enters and forms a smooth cell (Fig. 291d) in which to undergo its transformations.

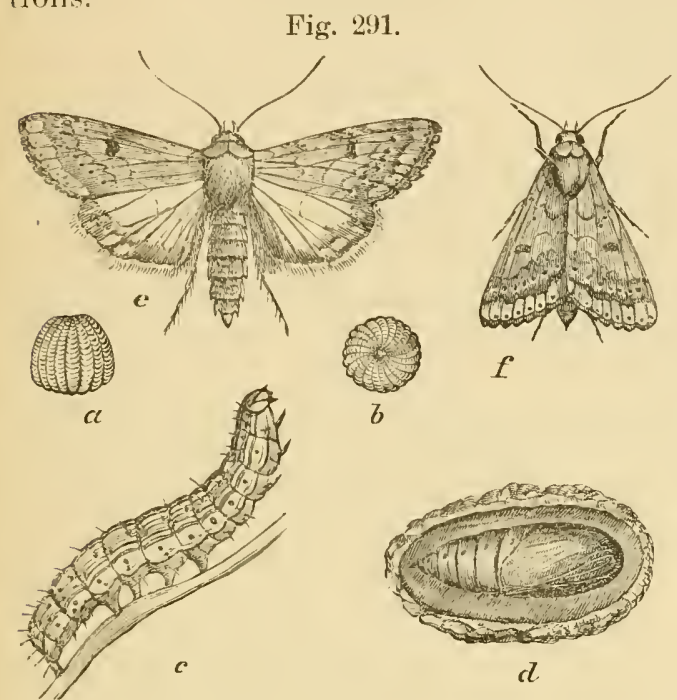

Fig. 291.-Cornworm; $\quad c$, the w o r m-colors, green and hrown; d, the pupa in its ce 11 - c o lor, bro $\mathrm{rn}$; $e$, the moth with wings exponded; $f$, the same, with wings c lose d-color, pale yellow tinged with olive-green; $a$, an egg, side view, highly magnified; $b$, the same, top view.

The fore-wings of the perfect moth (Fig. 291, e and $f$, ) expand about one inch and six lines, are of a pale yellowish color, sometimes tingerl with olive-green and reddish markings. Near the center of each wing is a blackish spot, and near the outer margin is a dusky spot, The hind wings are paler, with a blackish outer border, and containing a light colored spot in the center.

The caterpillar of this moth will bite human flesh. A case occurred in the city of Sacramento, where the arm of a baby was attacked by one of these worms until it bled freely; and several other cases have been reported.

Renenies-Use No. 5 or 7 ; spray the ears of corn to prevent the moth from depositing eggs on them. 


\section{CHAPTER CXCYII.}

The Corn Aphis.

\section{(Aphis mailis.-Fitch.)}

$\left.\begin{array}{l}\text { Order, Hemiptera; } \\ \text { Sub-order. Honortena ; }\end{array}\right\}$ Family, APHidide.

[Living on the roots, stalks, or ears of corn, which they puncture with their beaks and imlibe the sap; a small greenish plant-louse, marked with dusky or black.]

The wingless lice are apple green throughout, excepting the front of the head, which is dark. The antenne are brownish and the honey tubes are black.

The winged lice have the head and thorax shining black, the abdomen greenish-yellow marked along the sides with black dots.

Remedi:- Utse No. $10 S$.

\section{INSECTS INFESTING TUBACCO.}

The Tobacen Wrom (Macrosila Carolina) infests Tobaceo, and is treated of in another part of this work. 


\section{INSECTS INEESTING COTTON.}

culap. | The Corn Worm (Heliothas armi fera) also at

The Cotton Worm (Aletiu aryillacea), ...198 tacks Cotton.

\section{CHAPTER CXCYIII.}

The Cotton Worm.

(Aletia argillurea.-Hubner.)

Order, Lepidortera: Family, Noctuide.

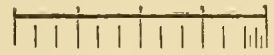

[The measurements of insects in this work are given in inches and lines. The above cut represents one inch divided into lines and fractions thereof.]

[Feeding upon the leaves of the cotton plant; a pale greenish caterpillar, dotted with black and marked with yellow stripes.]

Fig. 292.

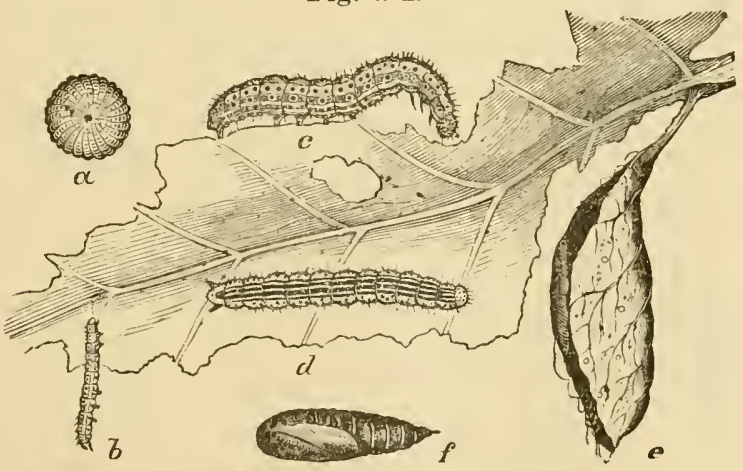

Fig. 29.2-Cotton Worm: a, the egrg, magnified-eolor, green; $b, c$ and $d$, worms of different sizes-color, green, with 20 
lighter lines; if the pupa-color. Jorown: c. a rollerl leaf, in which the worm assumes the pula form.

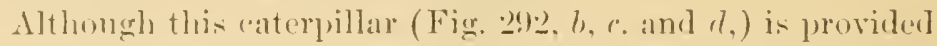
with a full complenent of sixteren legs yet in walking it is ohliges to areh up its lucly, somewhat as the span-norms do. This is due to the fact that the front pair of legs leneatl the midelle of the borly areso murle shortenerl as to be of no use to the caterpillar. When about to pupate it rolls a leat aromel

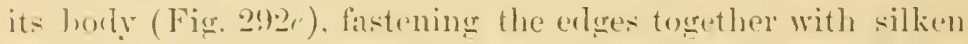
threads; it then lines the interior with a later of silk, anel

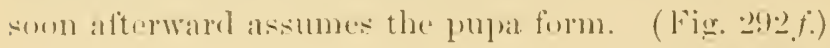

Fig. 293.

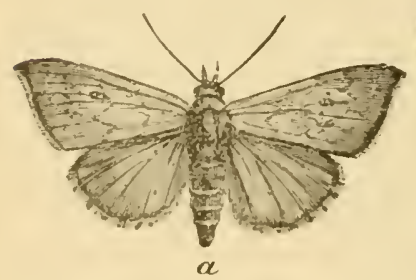

Fing. 29:?:-ciottonworm 11 oth s; a, with wings expandal; l, with wing: rlused - color, rellowish. with lilac lines.

The perfect moth (Fig. 293) has the fore-sings of a nearly miform reddish-brown color, with a dark spot. centeres with two pale ones, near the center of each wing. The head and thorax are also redelish-brown. while the hincl wings ares smoky hown.

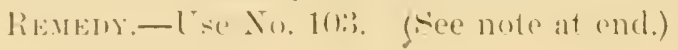




\section{INSECTS INEESTING THE SQUASH.}

The squash-vine Borer (.tigeriu curvubitop)199. The squash Buy (Coreus tristix) ..... . . . 200

The following insects also infest the syuash: The striped Cueumber-beetle (Diabrotio viltata)
The Cucumber Aphis (Siyhonophort ren'th vit( $\boldsymbol{\theta})$.

The Pickle Worm (Pharelluru nitidulis).

The Itelon Worn (Phucellura hyalinitulis).

\section{CHAPTEL ('XC'IA.}

The Squash Vine Borer. (Cal.)

\section{(Egeria cucurbitix-Harris.)}

Oriler, Leprdoptena; Family, Erikmo..

[Living in squash and punplin rines near thr roots: a whitish sixteen-legrged larva about one inch long.]

Fig. 294.

Fig. 294.-Giquash-vine Borer-colors, white and brown.

The egge from which these horers (Fig. 29.4) hatch are deposited on the rines near the roots. and as soon as hateherl the young borers penetrate the stems and devour the pith, frequently occasioning the death of the vines. They reach their full growth in Autumn, and usually enter the earth and construct a sort of cocoon in which to pass their transformations; sometimes, however, they pass through their transformations within their burrows. They pass the Winter in the pupa state, and are changed to perfect moths in the following Spring.

Fig. 295.-Squash-vine Borer (the moth) -colors, black, olive and orange.

The perfect insect or moth (Fig. 295) has blue-black fore-wings, which expand from one inch to one inch and six lines; the hind wings are wholly transparent; the abdomen is deep orange, marked with black.

Fig. 295.

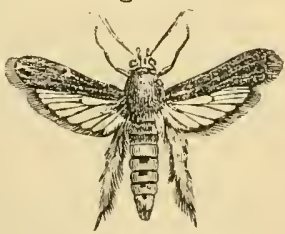

Remedies. - Spray with No. 5 or 7 , or No. 68 or 104 . (See note at end of No.98.) 


\title{
CHAPTER CC.
}

\section{The Squash Bug. (Cal.)}

\section{(Coreus tristis-DeGeer.)}

\begin{abstract}
()rier. IIEMTrtend; Sul-(i)

f Family, Conisidas,
\end{abstract}

[Living upon the leaves and fruit of the syuash and pumpkin vines; a rusty-black elongated hug whirh punctures the plants with its heak amel inubibes the salp.l

Fig. 29)(i.-Sumash Bug-oolors blackish Fig. 296. brown :met dirty rellow.

The perfect or winged bugs (Fig. 296i) pass the Winter in some sheltered situation; they are about seven lines longr, of a dirty rellow "olor beneath and black alore, the projecting edges of the abdomen spotted with pale yellow; the wing-covers are rusty black, with the thin ororlapping ends black.

The females lay their uggs on the underside of the leaves, to which they fasten them with a gummy substance.

The young are of a wray color, and as they increase in size and by molting their skins, they change to a dull rellow color. The leaves on which the younder fert soon wither and become dry and wrinkled; the hugs then change to fresh leaves and in this mamer the vine is eventually destroyed.

The stuash buge ean be fomet in all stages of its growth throughout the summer seatom. It hibernates around fences, (revices of walls, among weeds, and in other sheltered places. In Janmary. 1ss.e, I found on pine trees, which were covered with iry. immense numbers of squash bugs in all stages of their existence-larrat, pula and imago.

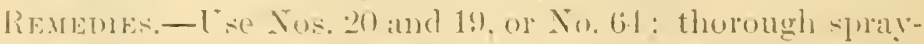
ind with the latter (No. (it)), one pound of the soap to each gallon of watter, then adding the buhach, as described, will be effectual. Sere also No. 114. 


\section{INSECTS INFESTING THE PUNIPKIN.}

The following insects infest the pumpkin, and are treated of in another part of this work:

The Squash-vine Borer (. Fiferia cucurbitic). The striper Cucumber Beetle (Diabrotica rittuta).
The Squash-hug (Coreus tristis).

The Cucumber Aphis (Siphomoltora cucurbiter).

\section{INSECTS INEESTING THE MELON.}

Cfrap. The Striped Cucumber Beetle (Diabrotica rittat $($ ).

The Nelon Worm (Phacellura hyalinitatis).20I

The Cucumber Fiea Beetle (Iraltica cucumerix).

The folloning insects also infest the Melon: The Green Fruit Beetle ('xymnetis nitilla). Cut Worms.

The Pickle Worm (I'harellure nitidalis .

\section{CHAPTER C'I.}

The Melon Worm. (Cal.)

(Phacellura hyalinitalis.-Linnæus.)

Order, Lepidoptera; Family, Prralıide.

[Eating large holes in cucumbers, melons and pumpkins, and also feeding upon the leares of these plants; a yellowish green sixteen-legged worm.]

The worms which occur upon the leaves (Fig. 297, Plate 4,) usually web up the latter with silken threads. When fully 
grown they measure about an inch and thres lines in length; they then spin their cocoons among the leaves, and soon afterwards assume the pupa form. The last broor pass the Winter in the pupas state.

The perfect moth (Fig. 297 , Plate-1,) expands about an inch, is of a pearly white color with a hlack stripe along the front olge of the fore-wings, and a similar stripe along the outer elge of all the wings.

Remburs.-Use Nos. 20 and 14 ; spray thoroughly with No. 51 or 6.5 .

\section{INECTS INFESTING THE CUCUNBER}

The striped Cueumber-beetle (Diabrotich vittatu)

The Cuember Flea-beetle (II ullira curu-

merix)
The Cucumber A phis (Siyhonophora rucur-

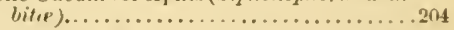
The Pickle Worm (Mharellura milidnlia)..205 The Melon Worm (Phacellura hyalinitalis), also infests the Cucumber.

\section{('HAP'TER' ('C'It.}

The Striped Cucumber-beetle. (Cal.)

(Dirbotice rittata-Dlivier.)

sivory-lialerned rittatu.

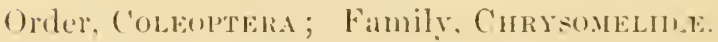

[Living in the stems of encumber, melon and squash vines: a slender whitish six-legged grub, about four lines long. with a brownish-lolack head, and a spot of the same color on the last segment ; finally ahanging into a reflowish leaf-eating leectle (Fig. ests) about three lines long, and having twe black dents on the thorax and three hlark stripes on the wing-cases.] 
Fig. 298. Fig. 29S.--Striped Cu-

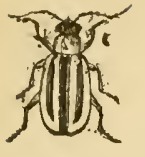
cumber-beetle-eolors, yellow and black.

Fig. 299.-Larva of the

Striped Cucumber-bectle, enlarged ; 1 , back view ; 2 , side view -color, yellowish-white.

In early Summer the grubs (Fig. 299) of this species are sumetimes found in the stems of young cuemmber vines, near the roots. They bore the stems in various directions, and after attaining their full size they desert the plants and form small cells Fig. 299.

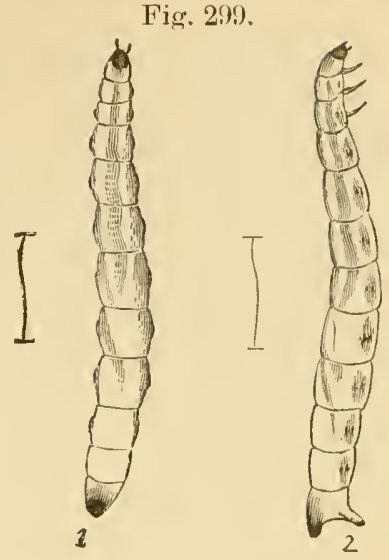
in the earth, in which to pass the pupa state.

Remplor. Use No. 111.

\section{CHAP'TER CCIII.}

The Cucumber Flea-beetle. (Cal.)

(Haltica cucumeris-Harris.)

Siroxym-Epitrix cucumeris.-Harris.

Orler, Coleoptera; Family, Chrsomentem.

[Fceding upon the leares of the eucumber, melon, potato, ete.; a small black heetle.]

Fig. 300.-Cucumber Flea-bectle, enlarged-color, Fig. 300. black.

This bectle (Fig. 300) is less than a line long, and the antennat and legs are yellowish, exrept the hind thighs, which are black and greatly swollen, enabling the insect to leap to a consideralile distance. The larve, or young, are supposed to live in the leaves of various kinds of plants, and to enter the earth to pupate. 
The perfort beetles pass the Winter in some sheltered place. These beetles attack the seed-leaves of cucumber plants as soon as they appear above the ground, thereby destroying them. They also attack tomatoes, potatoes: etc.. and injure the plants by eating holes in the leaves-the injury to the plant being in proportion to the extent of surface of the leaves destronyed.

Renedr-Use No. 111.

\section{CHAP'TER CCIY.}

The Cucumber Aphis. (Cal.)

(Siphomophore rucuilitx.-Midldeton.)

\section{$\left.\begin{array}{l}\text { Order, Heinterid } \\ \text { Sul-order. Howortera; }\end{array}\right\}$ Family, ApIIDIDA.}

[Living on the under sides of the leaves of cucumber, squash and pumplin vines, which they puncture with their beaks and imbibe the sap; small green plant-lice. sometimes marked with hrown.]

The wingless lice are green, with a few darker markings. The winged lice are green, the hearl yellowish, the eyes brown and the thorax usually brownish.

Rement:-Use No. 111.

\section{CHAPTER C CV'.}

The Pickle Worm. (Cal.)

\section{(Pharellura nitidalis-C'ramer.)}

Order, Lepinoptera; Family, Prraline.

[Boring cylindrica] holes into cucumbers, melons, and syuashes: a pale greenish-yellow worm, with a reddish head.] 
Fig. 301.-Pickle Worm; j, an infested cucumber; a, the worm-color, yellowish or green; c,one of the middle

Fig. 301.
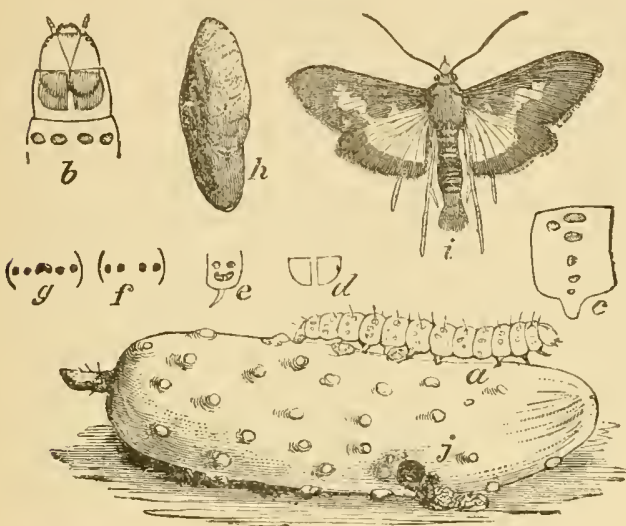

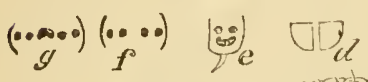

segments of its hody, enlarged; $d$ : the lorny plate on the top of the first segment, called the rerrical shield; e, arrangement of black spots on one side of the first seguent; $f$, shows arrangement of black spots on top of the second and third segments ; $g$, arrangement of black spots on top of the last seguent; $b$, the head and fore part of the caterpillar's body, enlarged, back view; $h$, the cocoon-color, white; $i$, the male moth-color, yellowish-brown and dull golden yellow.

When fully grown this worm (Fig. 301a) is about an inch Iong; it then crawls beneath the leaves, etc., which lie upon the ground, and spins a slight whitish cocoon (Fig. 301h). The last brood passes the Winter in the pupa state.

The perfect moth (Fig. 301i) expands about one inch and three lines. The fore-wings are of a vellowish-brown color' with a purplish reflection, and near the middle of the hind edge is an irregular semi-transparent dull golden-yellow spot. The hind wings are of the same brownish color, with their inner two thirds semi-transparent and rlull golden-yellow.

Renedres.-No. 20 ; spray fruit and foliage with No. 5 or 7. to prevent moth from depositing its eggs. 


\section{INSECTS MFESTING THE POTATO.}

The Potato-stalk Weevil (Burirtius trino. fulus).........................20

The stalk Borer (Gortmma nitela)........ 2017

The Colorado Potato licetle (Diryylima $10-$ lineat $a)$.....................

The Three-linerl Potato Beetle (Lema tril-

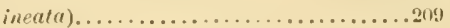

The A-h-colored Blister Beetle (Cantharis:

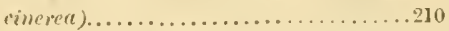

The Striped blister Beetle (Cantharis vittala).

The small Potato Bcetle, No. 1, (Eivitrix subcrinita $) \ldots \ldots \ldots \ldots \ldots \ldots \ldots \ldots \ldots \ldots \ldots \ldots 212$
The simall Potato Reetle, No. 2, (Ey)itrix hirtipennis) ...................213

The Potato Moth ................ 214

The following insects also infut the potato: The White Grub (Lachnosterna guerina) wire Worms.

The Tomato Worm (Varionsiln Camlina).

The Cucumber Flea Beetle (Lultica cucuneriv).

\section{CHAPTER ('CII.}

\section{The Potato-stalk Weevil. (Cal.)}

\section{(Berilins trinotulus.-Say.)}

Order, Colmoptera; Family, Curcluionida.

I Jiving within the stalks of potatoes; a whitish footless larva, about three lines long: funally transforming into a hush-gray snout-beetle, which is marked at the hase of the thorax with thee black lots.l

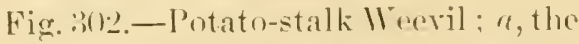

Fig. 302. larva enlarged--color, white: b, the pupa in its burrow, enlarged-color, yellowish white.

The female weeril makes a slit in the stalk he means of hej snout, and then deposits a singre egge therein. 'The lan

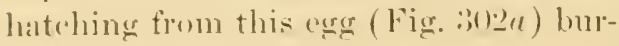

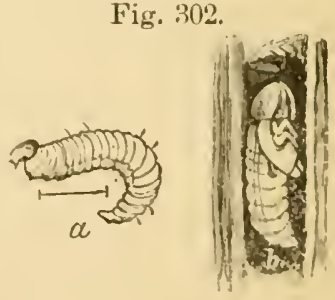
rows lownward into the stalk, sometines extending its hur- 
row even into the roots. It assumes the pupa form (Fig. $302 b)$ in its burrow, and the perfect beetle issues in the latter part of the Summer or late in the Fall, and passes the Winter in some sheltered situation.

Fig. 30:3.-- Potato-stalk Weevil--color, huish- Fig.303. black.

This weevil (Fig. 303) is about two lines long, of an elongate-oval form, and is of a bluish-black color, with three black dots at the base of the thorax, the midrle dot being situated upon the sumall wedge-shaped piece technically caller the scutel.

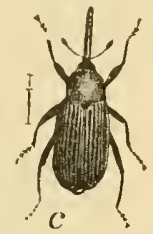

In the southern part of this State these insects are quite frequently met with upon the Jamestown weed (Datura stramonium), in the stems of -which they breerl.

Rened - -Use No. 25.

\section{CHAP'TER C'CII.}

The Stalk Borer. (Cal.)

\section{(Gortyna nitcla.-(iuenee.)}

\section{Order, Lepidopteki; Family, Noeteride.}

[Burrowing into the stalks of corn, potatoes, tomatoes, currant-bushes. cte.; a lownish sixteen-leggerl worm marked with white stripes.]

Fig. 304 - - it a l k Borer: 1, the mothcolor, gray; 2, the e a te rp il lar-colors. white and brown.

This borer (Fig. $304,2$,$) when fully$ grown neasures about

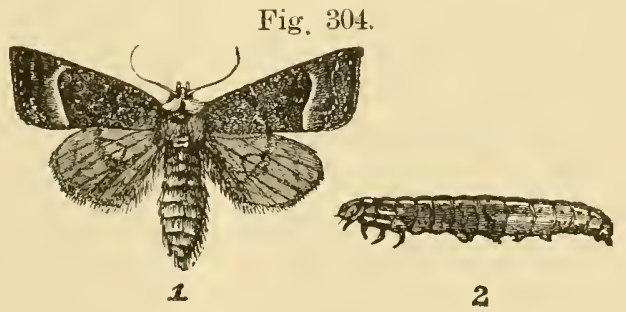
one inch and three lines in length, is of a rerldish-brown color, marker on the hack with three white lines, the two lowest ones interruptert on the segments from the fourth to the seventh, inchsive; the underpart of these segments is redtish-brown, 
while this part of the remaining scgments is greenish-white : the head is ycllowish-brown, wsually with a dark dash upon each sicle. It sometimes assumes the pupa form within its burrow, lut it usually enters the carth, where it forms a eell in which to undergo its transformations. The fore-wings of the moth (Fig. 3()4, 1,) expand from an inch and one line to an inch and six lines: they are of a mouse gray color, tinged with lilac, and finally sprinkled ower with bright yellow scales; toward the outer edge they are crosserl by a vellow line. These borers appear from April to August. there heing but one annual hrood; the moths are supposed either to hibernate, or to deposit their eggs in the Fall. these not hatehing until the following spring; the first supposition is probably the correct one. Remeny.-Use No. 25.

\section{C'HAPTER ('CVIII.}

\section{The Colorado Potato Beetle.}

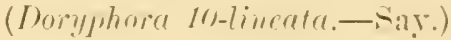

Order, Coleopetra: Family, Chrysomedre.e.

FFeeding upon the leaves of the potato and tomato: a sixlegged rellowish grub about six lines long. and marked with two rows of black dots along each side of the body, with the heart and legs also black; finally transforming into a robust yellowish beetle, having a hlack spot on the head, the thorax covered with dots and short streaks of black, and the wingrases markerl with ten hack lines.]

The egge of this species (Fig. 30.) a) are deposited in small clusters upom the leares. and hateh out in the course of about one work. After attaining their full growth the larra (Fig. 30.5h) enter the earth and form small cells in which to undergo their transformations. Sereral hroods are produced in one year, the las hrood passing the Winter in the pupa state (Fig. : is.ir).

Fig. :31.-Colorado Potate Bectle: a. a, the eggs-color, yellow; $b, b, b$, the larra in diflerent stages of its growthcolors, yellow and hlack: $r$, the pupi-color, yellow: $d$, $d$, the beetle-colors, yellow and hlack: $c$, one of the wing-ases. enlarged; $f$, one of the hind legs. enlarged. 
Fig. 305.

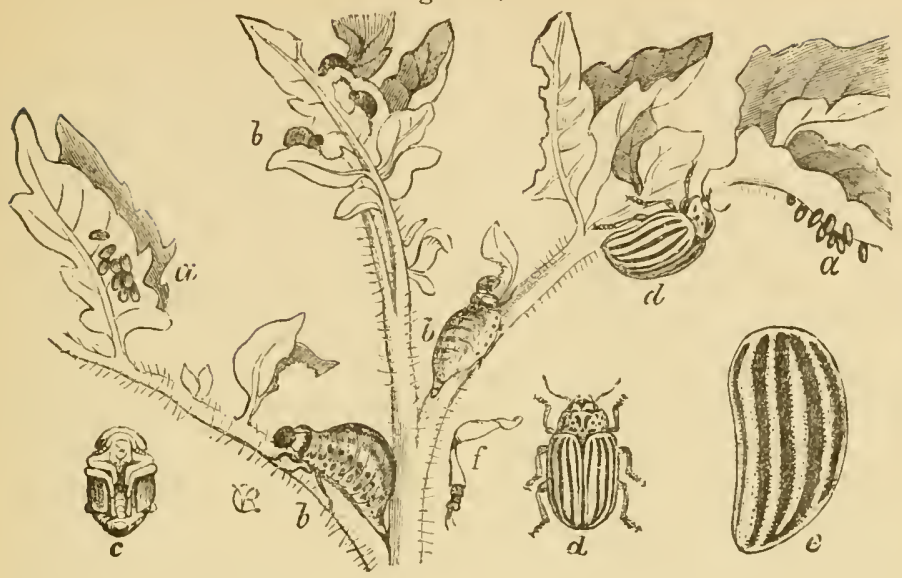

Remenes.-No. 10: ; spray thoroughly with liquid solution (see note at end of No. 103); good results hare been obtained by hand picking, ete. (See No. 112). For further description of remedies, see Professor Riley's Seventh Missouri Report, pages 1 to 19 .

\section{CHAPTER CCIX.}

The Three-lined Potato Beetle. (Cal.)

$$
\text { (Lema trilineatu-Olivier.) }
$$

Order, Coleoptera; Family, Chryouielide.

[Feeding upon the leaves of the potato; a six-legged sluglike larva, which is finally changed into a yellowish beetle, having two black dots on the thorax and three black stripes on the wing-cases.]

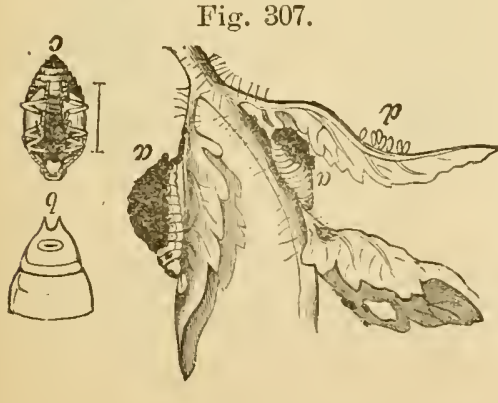

Fig. 307.-Lar- Fig. 306. va, Pupa and Eggs of Threelined Potato Beetle -; $a, a$, the larra-color, yellow;

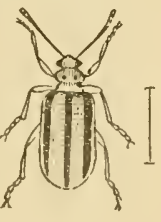
$b$, the tip of its body, enlarged; c, the pupa, enlarged -color, yellow; $d$, the eggs -color, yellow. 


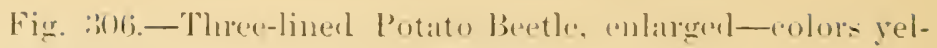
low and back.

The parent lecetle (Fig. :306) deposits her egers (Fig. :30-d) in patches of from half a dozen to a do\%(n, ustally placing them on the underside of the laters: they ane somewhat oral in shape and of a golelen-yellow color. They hateh in ahout two weeks, and the larve (Fig. $3(1)$ a) reacls their full growth in a few weeks anel then chater the earth and form small cells: in which to pass the pupar state (Fig. 3010). Sereral hromb atre produced in one seatson, and the perferet buetles patso the

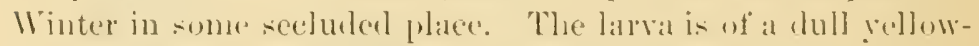
ish color, with a blark head: it has the halhit of eovering its latek with its own exrements. This insect is rery common in the southern part of the state.

libundes-lise same as in Chapter c'CIII.

\section{CHAPTER CCA.}

The Ash-colored Blister-beetle. (Cal.)

(Cuntharis cinereu.-Fibricius.)

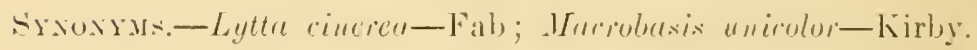

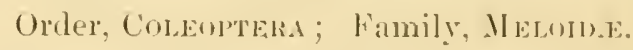

In elongate ash-colored heetle, about six lines long, fereling upon the laraes of potatoes, atc. ]

Fig. $315 .-A \leqslant h_{1}-$ (allowed libister-beetle; "1, the beetle, enlarged - eolor, ash-gray ; d, its antemma, enlargedon the lett, that of the nuale; on the right, that of the Fig. 308. female; l, the black variety (murima), enlarget-color, blarek; r, its antemua. enlanged-on the left, that of the female; on the right, that of the male. 
This species has done serious injury to the potato erop in one county in this state. It appears in the perfect state (Fig. $308)$ and attacks the potato ly feeding upon the leaves. Parties sending specimens to me could not give any particulars concerning the natural history of this inseet. Is the specimens sent me were from portions of the state infested by grasshoppers and crickets, it may be that this species in the larva state feeds upon the egres of these pests.

Professor Riley gives the natural history of this species, in substance as follows: The female lays her eggs in the nests of such locusts or grasshoppers as deposit their eggs in the ground. The larve produced from these eggs are of an elongate form and provided with six legs. They at once begin to feed upon the locust eggs, and at the approach of Winter they east their skins and appear in an entirely different form, known as the semi-pupa. In the true pupa form the next change results in the exclusion of the perfect insect; but in the present case, as soon as the skin is cast. the insect appears again in the larval form. The semi-pupa differs from the true pupa in laeking the wing and leg-sheatlss, but, like it, is incapable of moving about. It is of a pale yellow color. slightly curved, and beneath the fore part of the body are six short tubercles, which seem to rejresent the legs. In the following spring it casts its skin and again appears in the larval form. Its body is now much curved, the head nearly coming in contact with the tail. After attaining its full size it assumes the pupa form, from which the perfect beetle issues in the course of a few weeks.

1 have not fount it in any locality not infested by grasshoppers, so it may be a friend as well as a foe.

Remeny.-- Use No. 103-liquid solution preferable-and No. 112. 


\section{CHAPTEL ('C'Al.}

The Striped Blister-beetle. (Cal.)

(cantharis rittulu-Fabricus.)

Sravisu. - Lyttu, or Epicaulu i ittutu.

Order. Colmortema; Fimily, IIElom.e.

Fig. 309. [Fecting upon the leaves of the potato; an

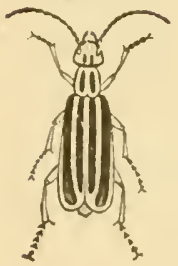
elongate yellowish betle (Fig. 309). about six lines long, matreel with two black spots on the head. two black stripes on the thorax. and two black stripes on each wing-case-the outer stripe the widest, and sometimes divided inte two stripes by a yellow line.]

Fig. 30\%._-Strijed Blister Beetle-colurs, dull yelluw and black.

The habits and natural history of this species are the sime as those of the ash-colored blister-beetle-Chapter C'X.

Revedies-C - se No. 10:3-liquid solution preferable-and No. 112.

\section{CHAPTER CCXII. \\ Small Potato Beetle.-No. 1. (Cal.) (Epitrix subcrinitu.-Leconte.)}

Order, Coleopters; Family, ('hrimomelide:

[A small metallic colored beetle. feeding on the leaves of the potato.

This species appeared early in August. 1852. on one side of a field of putatoes which contained three acres. and by the 20 th had infested the whole field, entirely destroying the foliage.

The perfect insect (Fig. 310, I'late 4, ) is vial in form, of at greenish-black color with a slight sub-metallic luster : antennat, ten-jointed: legs. pale brown; posterior thighs, stout ; length. 
about one and one half lines. The leaves attacked by these pests were filled with holes similar in appearance to grapevine leaves attacked by the grapevine flea-beetle (Haltica chalybea.) Should they appear this season, I will endeavor to learn something of their natural history.

Renedr-C Use No. 103-liquid solution preferable.

\section{CHAPTER CCXIII.}

\section{Small Potato Beetle.--No. 2. (Cal.)}

$$
\text { (Epitric hirtipennis.Mels.) }
$$

Order, Coleopteki; Family, ('nRyomfande.

[A small reddish-colored beetle feeding on the leaves of potatoes.]

This species was found in company with the preedingEpitrix subcrinitu-feeding on the leares of potatoes, but was not so numerous as the latter. The perfect insect is reddish in color, with indistinct black markings ; antennx, ten-jointed; legs, pale brown; length of insect, abont one and a half lines. Remedr-C Tse No. 10:3-liquid solution preferable.

\section{CHAPTER CCXIV.}

The Potato Moth. (Cal.)

$$
\text { ( relechin sp?) }
$$

Order, Lepidoptera; Family, Tinein.e.

[A small whitish caterpillar a little over six lines in length, the head and true legs black; feeding upon potatoes.]

In 1881 and 's2 specimens of potatoes were received infested by the larre of a small moth. Length of larva, about six lines; color, yellowish-white; head and cervical shield black, with a whitish space between them; true legs, black. (Similar to larva, Fig. 111, Plate 1.) 


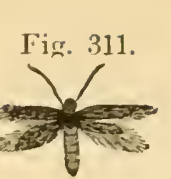

Fig. 311.-Potato Moth-color, ash-gray.

The moth (Fig. 311) is of an ash-gray color: length of borly, abrut four lines; spread of wings, seven to eight lines; fore-wings dark ash-gray, ciliatrel: hind wings lighter in color, and also riliaterl. The motlis appear about the first of July, and reposit their eggo in potatoes after the latter are gathered from the ground and placed in lieaps or in sacks. The following letter was receivel from a gentleman who has suffered from this pest :

"Yours at hand, and in reply I will say that the larva does not attark the potatoes in the gromor, hut it is after they are taken from the ground (dug) and placed in bulk that the moth rlepesits her eggs on the potatoes. chperially on those on the top of the heaps. Siomr arre infesterl to such an extent as to appear like a honeycemb. Last yoar (1si-2) the moths appeared about the first of July, and were present in all stages of their existence until the first of February, 1ss:). When I notired them first in 1 ssi, the potaters on top of the heaps were seriomsly infested. I "ewered the entire heaps with old sacks; as soom as the lara were full grown they left the potatoes and marle their cocoms on the mulel side of the sacks, in which to pass their transformation. When the sacks were taken off there was not a slace the size of a silver dollar but had one or more eocoons attached. In oreler to prevent its further spread I have burned the sacks, straw eorerings and sherls, and removed the storing place to a distant part of my place."

This pest is rejorterl from Fig. : $311 \frac{1}{2}$. three counties. There are criJinty two or three broukls ach rear. To provent this pest from injuring the crop) of potaters after they are gathered, the potatoes should bo covered with rarth, or placed in what is called

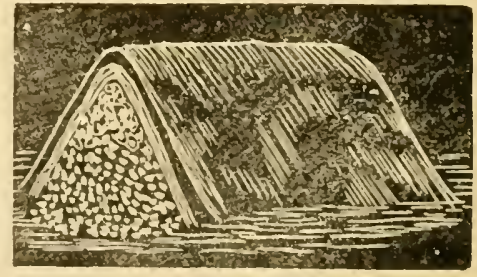
a pit, in England, which is marle ly piling the protatoes in a heap and putting a covering of

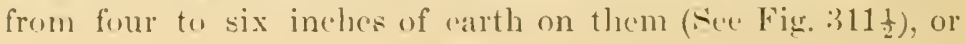


hy covering the heap with old sacks, etc., and placing on the top a light covering of earth. In all cases the storing place should be as far as possible from localities already infested. Sprinkling slackerl lime on the heaps will prevent the moths from depositing their eggs on the part covered by the lime.

\section{INSECTS INFESTING THE SWEET POTATO.}

Tortoise Beetles.

The Golden Tortoise Beetle (Cusxidu au-

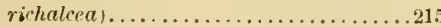

The Mottled Tortoise Beetle (Cas'vida gut. tata)
The Two-striped Tortoise Beetle (Cassida buvittata)....................215 The Black-legged Tortoise Beetle (Cassida

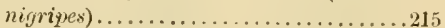

\section{CHAPTER CCXV.}

\section{Tortoise Beetles.}

Order, Coleoptera; Family, Ciryoumlide.

[Feeding upon the leaves of the sweet potato; a flattened larva, having a row of spines along each side of the body; finally transforming into flattened tortoise-shaped beetles.]

Fig. 312.

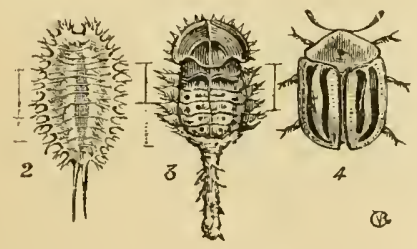

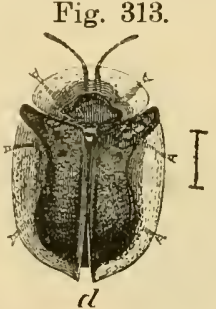

Fig. 312.-Two-striped Tortoise Beetle, larva and pupa; 2, the larva, enlarged-color, dirty white; 3 , the pupa, enlarged -color, brownish; 4, the beetle, enlarged-colors, yellow and black. 
In this country there are no less than four different kinds of tortoise bectles which are known to infest the sweet potato; they are more or less hemispherical in form, and the head is concealed beneath a thin, transparent extension of the front erlge of the thorax.

Fig. :13.-Nottled Tortoise Bectle. ('nlarged-color, hack.

The two-striped tortoise beetle (C'ussidu bivittata-Say: Fig. 312,4, ) is marked with two black strijes on each wing-case. In the three following species, the wing-ases alre unmarked.

The mottled tortoise beetle ('crsida ! futtuta-()]ivier: Fig. 313,) has the shoulders blackish to the extreme outer exlge of the wing-ease. In the renaining two speries the thin, transparent outer edge of the wing-ais's and thorax is mmarked.

Fig. 314.

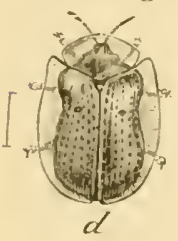

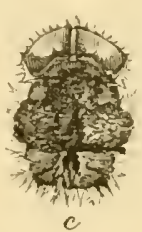

Fig. :31. - Golden Turtuise Besetle and I'upa: "l, the beetlecolor: yellow; ce, the pupa-color, brown.

Fig. :315. - Eger of ciolden Tortolise Beethe, enlarered-oolor, dirty white.

The galden tortoise beetle (crssside anrichalcea-Fabricius; Fig. $314 d$, ) is of a deep yellowish color, usually dotted with black. or

Fig. 315.

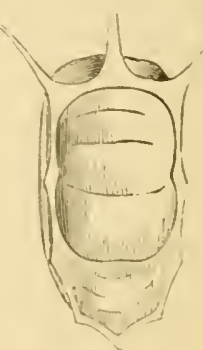
it is of a transparent golelen color, shining like a drop of liquid gold. It measures about two lines in length.

This is the only tortoise heetle that is known to oceur in this state, and is frepuently mot with on wild morning glories.

Fig. 316.

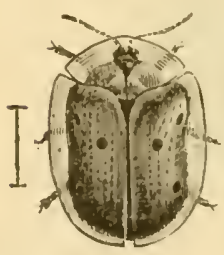

Fig. :316.-Black-legred Tortoise Beetlecolor, yelluwish.

The black-lewged tortoise beetle (Cassida nigripes-()livier; Fig. :316) elosely resembles the last, but is larger, measuring nearly four lines in length. It also differs in having the logs: hack, and rach wing-case is marked with three black dots. The larvie of these tortoise beetles are elongate-oval in outline. erreatly flattened, and have a row of spines on each side of the body and two larere spines, which are situated at the hind end of the boty ; there are usu- 
ally held over the batek and the excrements of the larvat ane sometimes collected upon them.

The larva of the two-striped tortoise beetle (Fig. 312, 2, ) is of a dirty, or yellowish white color. It differs from the other three mentioned below by not collecting its excrements upon its anal spines.

Fig. 317.

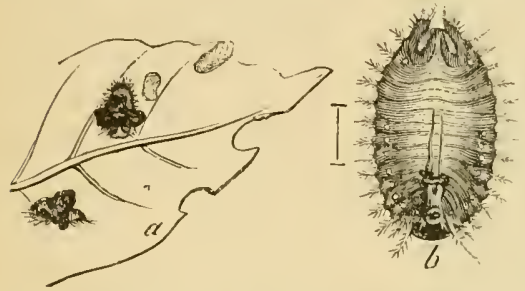

Fig. 318.

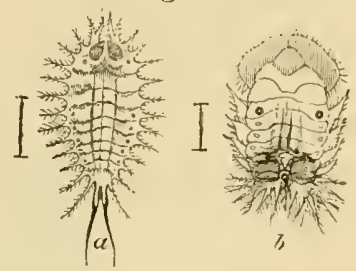

Fig. 317.-Larra of Golden 'Tortoise Bectle; ", several larve on a leaf; b, a larva, enlarger-color, dark brown.

Fig. 31S.-Larva and pupa of Mottled Tortoise Beetle; ", the larva, enlarged-color, green; $b$, the pupa, enlarged-color, green.

The larva of the golden tortoise beetle (Fig. :317) is of a clark brown color, with a pale shade upon the back.

That of the mottled tortoise beetle (Fig. $318 a$ ) is of a greenish color, while the larva of the black-legged tortoise beetle (Fig. 319, a and $b$,) is of a pale straw color, marked with clusky spots, the spines tipperl with hlack.

\section{Fig. 319.}
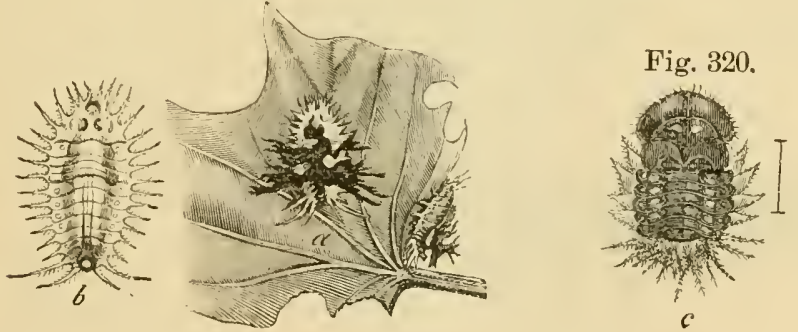

Fig. 319.-Larva of Black-legged Tortoise Beetle; b, the larva, enlargecl-color, yellow; a, two larvat on al leaf.

Fig. 320.-Pupa of Black-legged Tortoise Beetle, enlargedcolor, brown. 
When fully grown these larrs attach themselves to some ubject by the hind part of the body and soon cast off their skins, which are worked backward and allowed to remain, enveloping the hind part of the pupa. (Figs. 320 ), 318b, $314 c$ and $312, \dot{3}$, . The pupe somewhat resemble the perfect beethes, hut differ by being destitute of the hard wing-cases, and also in having a row of spines along each side of the body.

RenenY.- Cse No 113; if seriously inferted, use No. 103.

\title{
INSECTS INEESTING THE TOMATO.
}

\begin{abstract}
CIIAY.
The Tomato IForn (Macrosilu Carolina). 216 The Tomato Aphis (Megrura solani).....21\%

The following insectsalso infest the Tounatu: The stalk borer (fiurtyua nitela).

The Colorado Potato-beetle (Iuryyhora 10. lineata).
\end{abstract}

\section{CHAPTER C CAVT.}

The Tomato and Tobacco Worm. (Cal.)

(Mucrosila ('urolinu-Linn; and M. J-macmlata-Haw.)

Order, Lephoptena; Family, Sphxame.

[Fererling upon the leares of tomato, potato, and tobarco plantr; a large green worm, having seren obligue white stripes on each side of the body, and a hom on the hime end.]

Fig. 321.

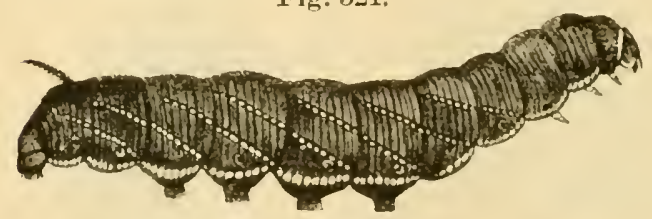

Fig. 322.

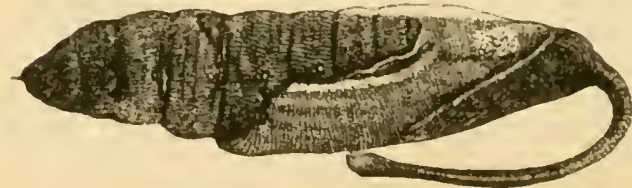

Fig. :321.--Potato or Tomato Wormcolors, egreen a 1 d white.

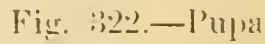
of Pentato or Tumate) 11 orm - coulor. lirown.

The ilbore t w o spexies rery closely resemble each oth- 


\section{INSECTS INFESTING THE TOMATO.}

er in all of their stages. The full grown worm (Fig. 321) measures from three to five inches in lengh. When about to pupate, it enter's the earth and forms a smooth cell ir which to mudergo its transformations.

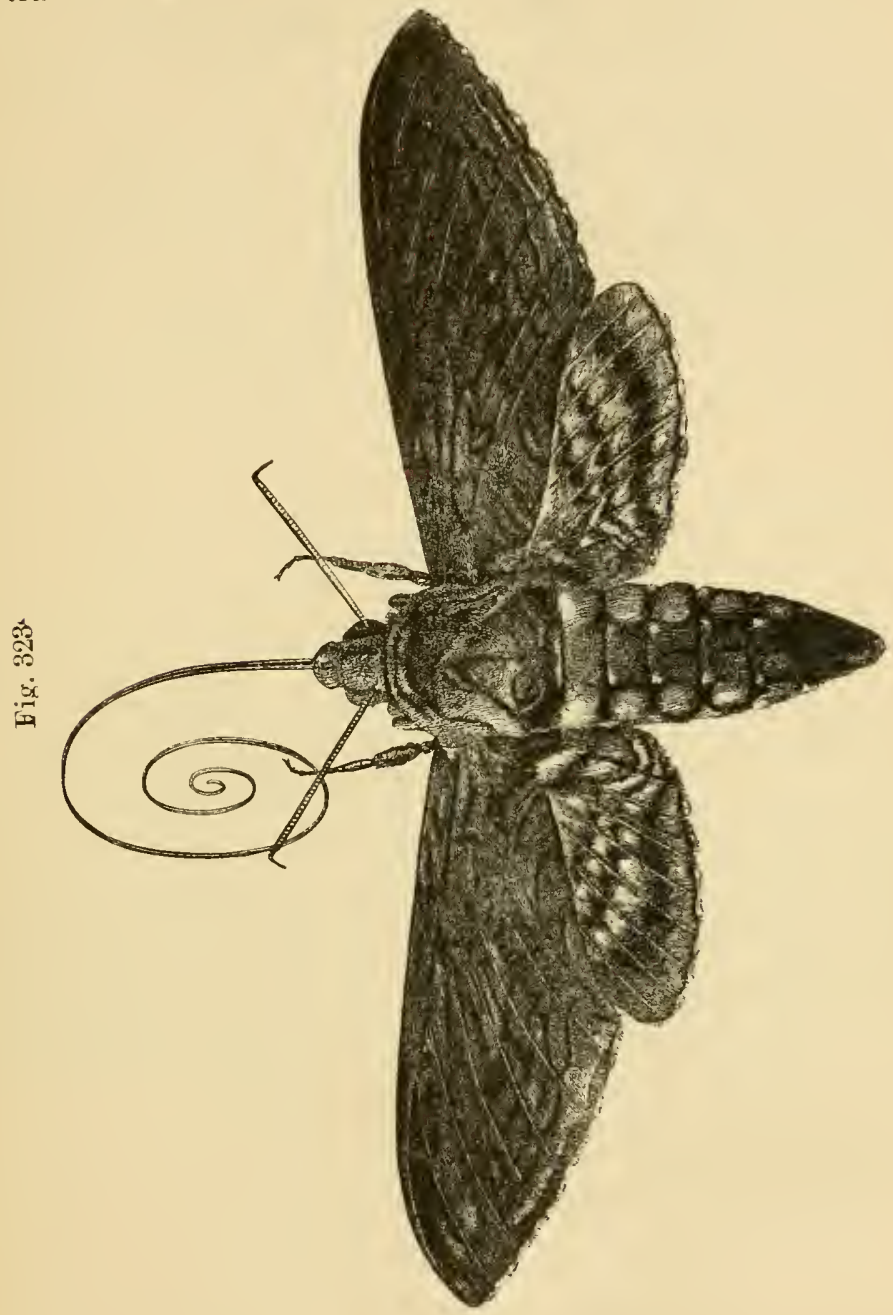

Fig. 328. -Putato Worm Moth or Fire-spotted Sphinx-colors, gray, black, and yellow. 
The pupa (Fig. 322) is rlark hrown, and is fumished with a long tongue-case, which curves around from the forward end, its outer extremity resting upon the breast of the pupa, somewhat resembling the handle of a piteher.

The perfect insects (Fig. 323) are commonly called "hawkmoths," from a habit they have of hovering over flowers in the evening while partaking of the nectar by means of their long proboseis. Their fore-wings expand from four to five inches: and are of a grayish color; the abdomen has a row of orange spots, surrouncled by lilack. on each side.

RexkDes-Use Nos. 14, 100, and 101. All chrysalids (pupa) dug up or plowerl up should be destroyed.

\section{CHAPTER CCAVII.}

\section{The Tomato Aphis. (Cal.)}

\section{(.Megonia sulani.-Thomas.)}

$\left.\begin{array}{l}\text { Order, Hentotera; } \\ \text { sub-order, Honomtena; }\end{array}\right\}$ Family. ArHidide.

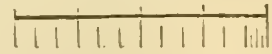

The measurements of insects in this work are given in mches and lines. The above eut represents one inch divided into lines and fractions thereof.

[Living upon the leaves and stems of tomato plants, which they puncture with their beaks and imbile the sap ; small greenish plant-lice, sometimes marked with yellow or brown.]

The wingless lice are pale green, with a lark erreen stripe alonge the bark; head whitish, the eyes brown.

The winged lice are greenish, the thorax black or marked with lilack or brown.

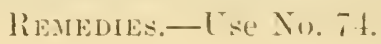




\section{INSECTS INFESTING THE CABBAGE.}

The Cabbage Maggot (Anthomyia brassi-

cae............................. 218

The Southern Cabbage Buttenfly (Pieris protodice ........................219

The Imported Cabbage Worm (Pieris

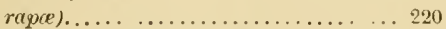

The Cabbage Plusia (Plusia brasice)....2:1

The Yellow Bear Caterpillar (Syilosoma Jirginica) . . . . . . . . . . . . . 222
The Harlequin Cabbage Bug i Strachia his-

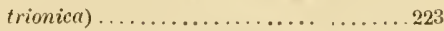

The Cabbage Aphis (Aphis brassicce). ...224

The following insects also infest the Cabbage :

Cut Worms (Ayrotis).

The Striped Flea Beetle (Ifultica ittata).

\section{CHAPTER CCXYIII.}

The Cabbage Maggot.

\section{(Anthomyia bressicap.-Bouche.)}

Order, Diptera ; Family, Muscide.

[Boring into the roots of the cabbage, turnip and rutabaga; a white maggot having a flattened hind end margined around with minute teeth.]

These maggots and the flies into which they are finally transformed so closely resemble the onion maggot and fly, and their habits are so similar, that the account given of the latter will apply equally well to the present species.

RemenY.-Use No. 113.

\section{CHAPTER CCXIX.}

The Southern Cabbage Worm. (Cal.) ,

(Pieris protodice. Bois Lec.)

Order, Lepinoptera; Family, Pieride.

[Feeding upon the cabbage and mustard; a sixteen-legged greenish or bluish worm, dotted with black and marked with from four to six yellow stripes.] 
Fig. :324.-Sioutherm Cabbage Wrorm and Pupal- $a$, the wormcolors, greenish-blue: and yellow; $b$, the pupa-color, gray.

The full grown worm (Fig. :20tu) measures alout one inch and three lines long. When

Fig. 324.

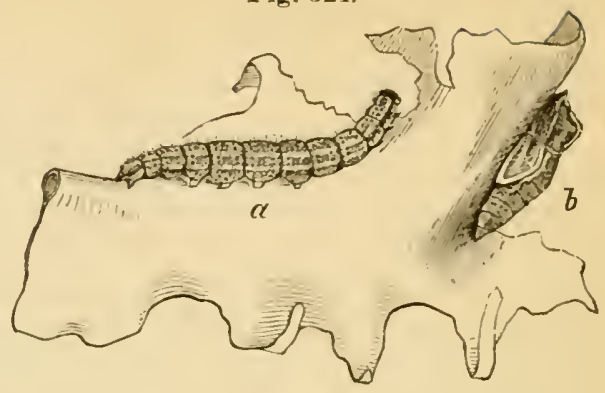
about to pupate it suspends itself ly the hind legs and a transierse loop of silken thread passed around the fore part of the body. The pupa (Fig. 32-4b) is grayish-bown,

Fig. 325.

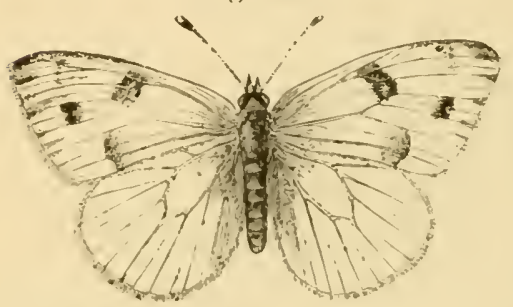
dotted with black; the lead terminates in a conical prominenee, and there is quite at large prominenceon the back of the thorax: it is alouut cight lines in length.

Fig. 325.5-Southern ('al)bage Buttertly male-colors, white and black.

Fig. 3:6-Southem C'abbage Butterfly, fenale-colors, white and black.

The wings of the buttertly (Figs. 325 and :326) expand about two incher, and are white, the fore omer marked with about eight blackish spots. and the hind wings sometines have a border of triatn@ular slate-colored rifots with a rigr-zalg wlateFig. 326.

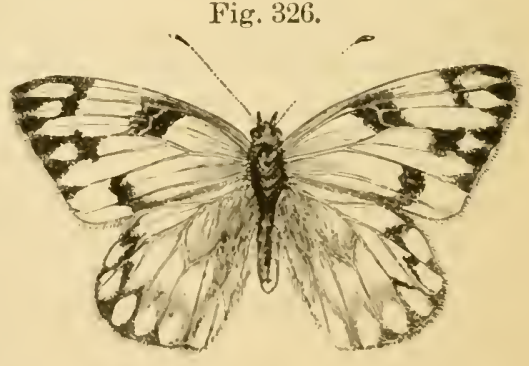
colored lime inside of them.

Risabules.-Siray once eateh week early in the season with No. $\bar{j}$ or $\bar{T}$; and should the callerpillars alpear, use No. 83 or 85 , or 6t; the latter is preferable. (See also No. 114.) 


\section{CHAPTEP CCXY.}

The Imported Cabbage Worm.

$$
\text { (Pieris rupr-Linneus.) }
$$

Order, Lepidoptera; Family, Pieride.

[Feeding upon the cabbage, etc.; a green sixteen-legged worm dotted with black, and marked on the back with a yellow line, and with a row of yellow spots on each side of the body.]

Fig. 327.

Fig. 327.-Imported Cabbage Worm and

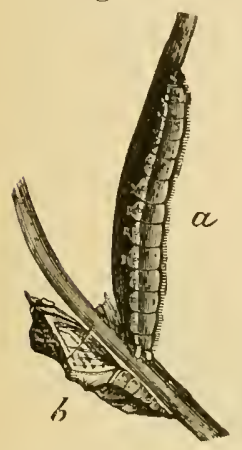

Fig. 32S.-Imported Cabbage Butterfly, male-colors, white and hlack.

The perfect insect, or hutterfly (Figs. 320's and 329) expands about one inch amel nine lines, and is white or, rellowish-white, with the fore-wings tipped with black

Fig. 329.

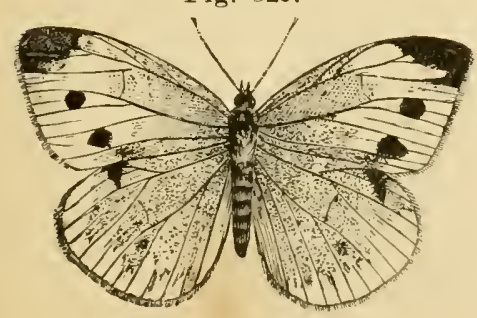

Fig. 328.

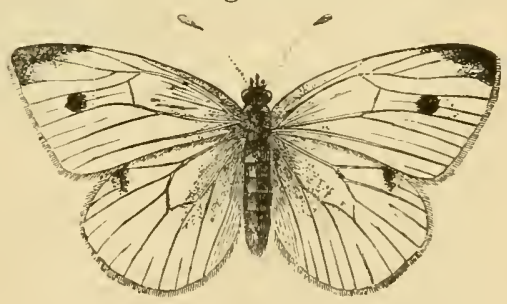

and marked with from one to three black spots; the hind wings have a blackish spot on the front margin.

Fig. 329. - Inuprted Cabbage Butterfly, female-colors, white and black.

Rementes.-Silne as in Chapter ('CXIX. 


\section{CHAP'TER C'CXXI.}

The Cabbage Plusia. (Cal.)

\section{(Ilusia biassirar.-Riley.)}

Urcler. Lepidoptera; Family. Nortudi.

[Feeding upon cabbages and lettuce: al naked green twelvelegged worm, lotted with white and marked with white lines.]

This caterpillat (Fig. 830a) arches up its back slightly when walking; it is of a rellowish-green color, sparsely dotted with white, and matked on the back with a dark line, on each side of which are three whitish lines; the heal is green, and is marked on each side with five black evelets, which are scarcely noticeable with the naked eye.

Fig. :3:30.-C a bbage Plusia; $a$, the caterpillatr-ecolor, green with white lines: b. the pupa in its rocoun-color, hrown: a. the moth - -oolor, grilyishbrown.

When about to pupate it spins a thin whitish reneom (Fig. :3:3(16) in some sheltered place, frequently among the

Fig. 330 .

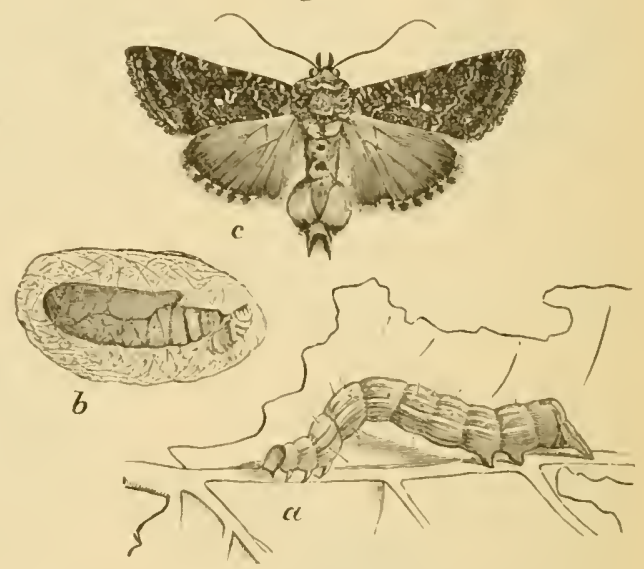
leaves of the plant it infests. The perfect moth (Fig. :33)r) expands from an inch and three lines to an ineh and six lines: the fore-wings are dusky gray, inelining to hrown, raliogated with light grayish-brown. and near the midelle of ealeh is a small oval spot and a somemhat l shalperl silvery mark. These insects may be found during the greater part of the year, there bering at least three browls produced in one season; the last brenel hibernating as half grown worns.

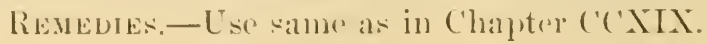




\section{CHAPTER CCXXII.}

The Yellow Bear, Caterpillar.

\section{(spilusoma Tirginica-Fabricius.)}

\section{Order. Leprnoptera; Family, Bombrom.e.}

[Feeding upon the leaves of the pea, bean, beet, aabbage, grape, etc.; a hairy aterpillar of a yellowish-gray or greenish-white color, marked with from two to four lines, usually of a dark color, and covered with white, yellow or redelish lairs.]

Fig. 331.-- Yellow Fig. 331.

Bear; ", the caterpillar--colors, white or gray, the hairs white or yellow; b, the pupa-color, hrown; $c$, the moth -color, white with black dots.

This caterpillar (Fig. 331a) varies greatly in its colors and markings; the

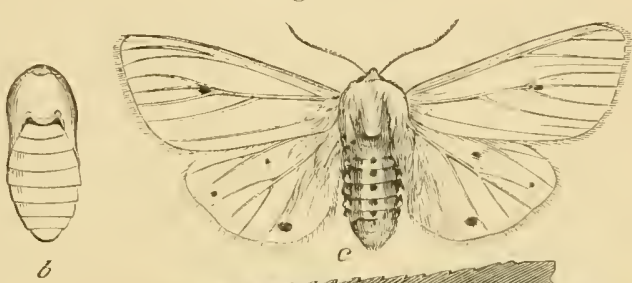
young caterpillar is of a greenish-white color, with three white lines on the back: the more mature ones are pale yellow or rlark gray, with two dark colored lines on the back, and sometimes there is a yellowish line low down on each side of the body. The hair is in spreading clusters, and is either white, yellow, reddish-brown, or the base is brown with the tips black. When fully grown it measures about one inch and six lines in length; it then ereeps into some sheltered place and spins a thin cocoon, intermixed with the hairs with which the body was covered.

The perfect moth (Fig. $331 c$ ) is commonly known as the "white miller," and is of a pure white color, usually marked with a few black dots. The fore-wings expand from an inch and six lines to nearly two inches. The caterpillar of this moth can be found from the 20 th of April to the 1 st of Oetoher. 
Revedr.-Should these caterpillars appear in large numbers, see No. 14.

\section{('HAPTER RCIXIII.}

The Harlequin Cabbage-bug. (Cal.)

\section{(Simerhia histrionim.-Hahn.)}

$\left.\begin{array}{l}\text { Order, Hewiterd; } \\ \text { Sub-order, Homortera; }\end{array}\right\}$ Family. Scrtelelerid.e.

[Living upon cahbages, rarlishes, turnips, ete. : a wingless greenish bug. markert with black, or a wingerl lug, marked with lilue-lilack and orange.]

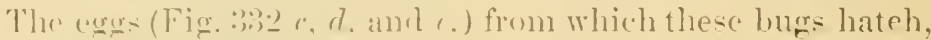

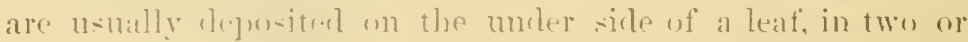

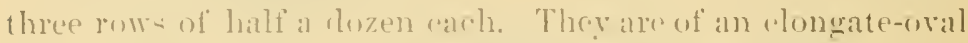

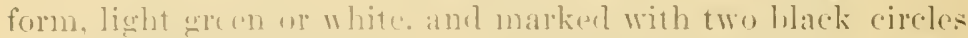
and a black dot. the latter placerl almore the lower eirele (Fig.

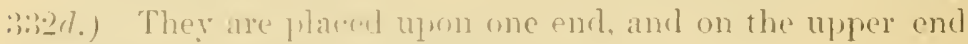

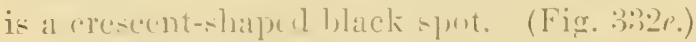

The perfect insert- (Fig. 3:3:3) are alonut five lines long by three line- hroat, and prettily markenl with blue-black and pulished orange. They pass the Winter in some sheltered place. ['nlike most other plant-bugs, they do not give forth a disagrecable odor when crushert.

l. ig. 332.
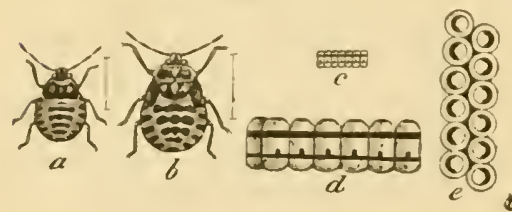

Fig. 333.
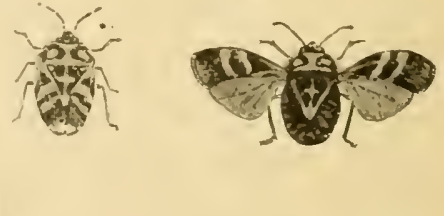

Fig. 3:3. - Lava. Pupa and liggs of Harlequin Cahbagebug: a, the larva. enlarerel-colors, pale erreen and hlack: $h$. the jupa. enlarged-rulors. greonish or yellow and lilack; $d$. side view of egras, enlargerl-enlors, white and black; $c$, the same. natural size: $e$, the rergs as seen from alowe. conlarged.

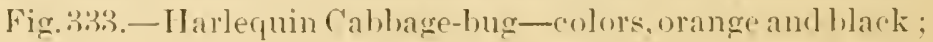


at the left, the bug, with its wings elosed; at the right, the same, with its wings expanded.

This species spread to such an extent in Sacramento County as to prevent the growing of cabluages.

ReMedies.-Nos. 20, 106r and 36. If the cabbages, ete, are serionsly infested by this cablage-bug, use No. 64, or 83 , or 85 , of double the strength recommended.

\section{CHAPTER CCXXIV.}

The Cabbage Aphis. (Cal.)

(Aphis brassicar.-Linnacus.)

Order, Hemiptera ;
Sub-order, Homoptera ; Family, Aphidide.

[Living upon the leaves of the cabbage, which they puncture with their beaks and extract the sap; small greenish-ycllow plant lice, sometimes marked with black and covered with a bluish-white powder.]

Fig. 334.-C ('abhage Aphis; 1, the wingerl louse, natural size; 2 , the same, enlargedcolors, greenish-yellow and black; 3 , the wingless female, natural size; 4 , the same, en- 1 larged-color, green or yellowish.

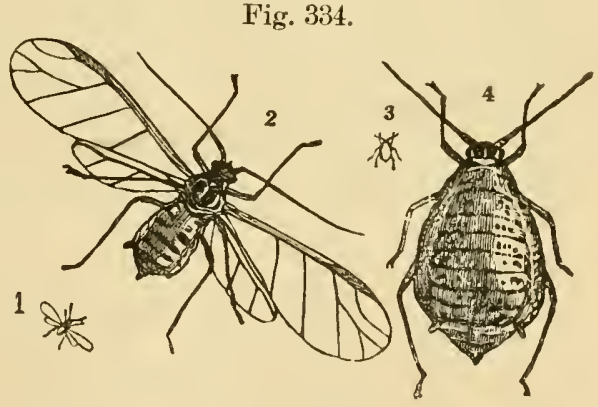

The wingless lice (Fig. 334, 4,) are of a pale pea green or greenish-yellow color. The winged lice (Fig. 334, 2,) are green or greenish-yellow, with the hearl black and a row of rlots along each side of the abrlomen of the same color.--Professor Thomas.

This species of plant-louse is the most injurious that the market gardener has to contend with.

RemenY.U - No $\mathrm{N}$. 4 . 


\section{INSICTS INEESTING THE RADISH.}

CHAP.

The Radich Ilaggot (Anthomyia ray)humi).225 The striped Flea-beetie (IIaltica villata)..226
The Harlequin Cabloge Bug (Strachin histrionic(t) also attacks the Radish.

\section{C'HAPTER C'MAY}

The Radish Maggot.

$$
\text { (Anthomyiu iophenui-Harris.) }
$$

Order, Drptera; Fantyily, Mlorid.e.

[Boring into the roots of the radish; a white foothess maggot, its blunt posterior end matrgined with minute tecth. of which the lower two are the largest and are notehed at the tips.]

These maggots so closely resemble the onion maggots in all their stages, that the account given of the latter will apply equally well to the present species.

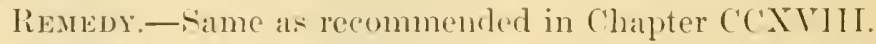

\section{CHAPTER CCXXVI.}

The Striped Flea-beetle. (Cal.)

(IIaltica rittrutu.-Fabricius.)

Syxoxy.-Haltica striolata.

Order, Coleneter. : Fimily, Cursomeline.

[Feeding upon thw leaves of turnips, radishes, cabbages, ete. ; a small liack heetle, having a yellowish way stripe on each wing caso.] 
Fig. 335.-Striped Flea-beetle, (nlarged-colors, Fig. 335. black and yellow.

These beetles (Fig. 335) have the hind thighs greatly enlarged, which enables them to leap to some distance, like a flea, hence the name "flea-beetle." The larva or young live in the ground and feed upon the roots of various plants. When fully grown they form small cells in the earth, wherein to undergo their transformations. They are minute slender whitish grubs, provided with six legs and having the head light brown.

RENEDiEs.-Should the beetles appear in large number's, use $\mathrm{No} .64$, double strength; spraty thoroughly, as often as the beetles appear; or Nos. 5 and 7 are effective. See also Nos. 20 and $106, \mathrm{~A}$.

\section{INSECTS INFESTING THE TURNIP.}

The following insects infest the Turnip, and are treated of in another part of this work:

The Wire Worm.

Crane Flies (Tipulu).

The Striped Flea-beetle (Ifaltica vittuta).
The White-lined sphinx (Deileyhala lineata). The Harlequin Cabbage Bug (Struchia histrionicte). 


\section{MSECTS INIESTING THE: ONION.}

The Onion Magrot (Anthrmyia ceyserum).

Chaj. 227

\section{C'HAPTER ('XXYI]}

\section{The Onion Maggot. (Cal.)}

\section{(. Inthemyin cepnrem.-Dimmats.)}

Orier, Drerens; Family, Mrside.

[Boring inte the bulb of the miom, causing it to wilt and deraly ; a white footless magrout, which tapers at one end, the opposite end appearing as if oblinuely ent off, and marked near the mildle with two elevated eye-like brown dots.]

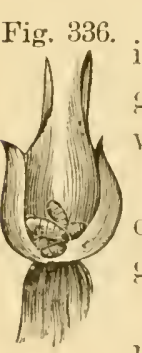

Fig. 3:36.-An Onion

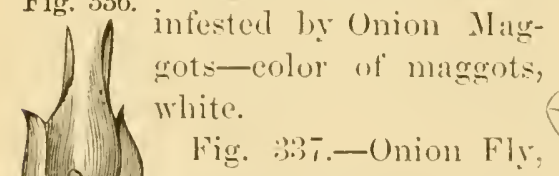
cnlirged-roblors, abhywray and black.

When fully grown theses magrgots sometimes as. sume the pupa form in a earity which they have gnawed in the

Fig. 337.

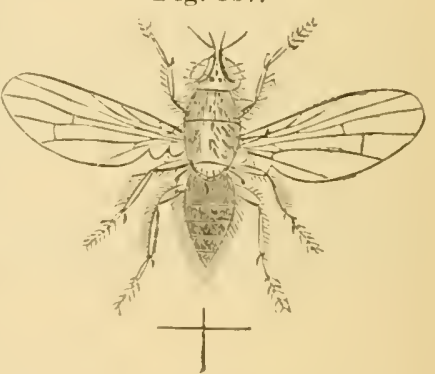
onion (Fig. :3:(j), lut they usually burrow at short distance into the earth and form a small cenll fhere the rhange to the pulat state takes place, and the perfect fly issues in the course of a week or so. This Hy (Fig. 3.97 ) rlosely resemlles the rommon house-fly, but is more slender; it is of an ashen-gray color: the fare is silvery, with a rusty blate stripe between the eyes, and there is wsully a black stripe or row of blate spots along the back.

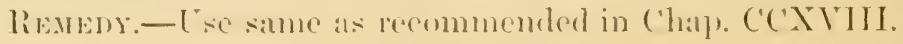




\section{INSECTS INFESTING LETTUCE.}

The Lettuce Aphis (Siqhonophorte latu('e)
The Cabbage Hlusia (f'lusiu brassice.) Alro, attacks Lettuce.

\section{CHAPTER CCXYYTIT.}

The Lettuce Aphis.

\section{(siphonuphoir larturie?)}

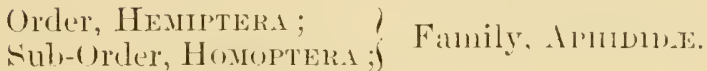

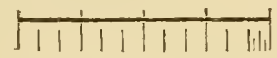

[The measurements of insects in this work are given in inches and lines. The above eut tepresents one inch divided into lines and iractions thereot.]

[living upon the laares of the garden lettuce, which they puncture with their heaks and imbibe the sap; small green plant-lice, usually marked with black or brown.]

The wingless lice are green or brown, usually marked with black dots.

The winged lice are green, the head and thorax sometimes black or brown.

Rexedes. - Spraty with No.:3 or No. tor use No. 83 or No. 85. 


\section{INSECTS INFESTING THE PEA.}

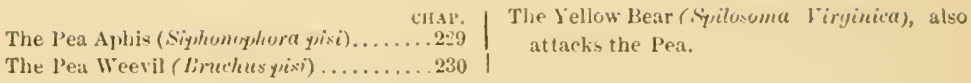

\section{CHAPTER ('XXIX'}

The Pea Aphis. (Cal.)

\section{(siphonophroe pisi-Kaltenhath.)}

\section{$\left.\begin{array}{l}\text { Order, Hemiptera; } \\ \text { sub-order. Honertera }\end{array}\right\}$ Family, ArHmin.e.}

[Living upon the stems, pods and leaves of the pea, which they puncture with their beaks and imbibe the salp: small green plant-liee, sometimes marked with yollow.]

The wingless lice are green, with the eyes liack.

The wingerl lice are green, the thorax brown or yellow, the eyes libak or hrown; the antemne are longer than the body. Rexlente-Use No. :; or No. t, or No. s: or No. Si.

\section{CHAPTER CCAXX.}

The Pea Weevil. (Cal.)

\section{(Brurlus pisi.-Limneus.)}

Grder. Coleortera; Family, Brtenda.

Lliving in peas; a small footless, deep yellow grub, with a black head, finally transforming into a small gray snout-beetle, which is striped with black and white.]

The fomale weevil deposits her egges upon the young pods; 
the larva (Fig. 338c), as soon as hatched, burrows through the pod and into a pea. Here it remains until it becomes fully grown, feeding upon the interior of the pea. When about to pupate, it gnaws a round hole under the shell of the pea, leaving the latter untouched. It assumes the pupa form (Fig. $338 d$ ) in the Autumn, and is changed to a beetle (Fig. 338b) during the Winter or early in the following Spring. The beetle gnaws a hole in the shell of the pea, through which it makes its escape, although it not infrequently remains in the pea until the latter is planted. During all this time it seldom injures the germ of the pea. so that peas infested by it will grow with ahnost as much certainty as those not infested.

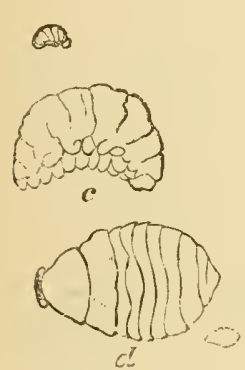

Fig. 338.

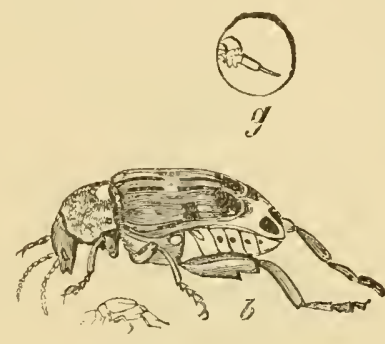

Fig. 338. - P e a IVeevil; $r$, the larva, side view. enlargerl (natural size indicated above) 一 color, yellowish ; $d$, the pupa, back view, enlarged (natural size indicated below and to the right-color, yellowish; $b$, the weevil, enlarged (natural size indicated below) -color, rusty-black and white; $g$, an infesterl pea.

The beetle, or weevil, is about two lines long, and is of a grayish color, the wing-cases being marked with alternate stripes of gray and black, and behind the middle of each is an olblique white stripe. The exposed tip of the abdomen is covered with a whitish down, and is marked with two black spots placed near the center.

Since writing the alove, I have met a gentleman from a section of this State where the pea weevil is doing considerable damage. He expressed his belief that the pea weevil was produded by "spontaneous generation," as he had never seen the beetle in his field when the crop was growing. The existence of the weevil in the perfect state is of short duration, and as it probably works only at night, this would account for its not being seen.

Rextedy.-Use No. 115. 


\title{
INSECTS INEESTING THE BEAN.
}

\author{
Cl1 1 r. The fcllowing insects also attack the Bean: \\ The Bean IFecrll (Bruches fahip).......231 The Ish-eolored Bli-ter-heetle (Cantharis \\ The bean djuis (Aybis ruarivis)........232 \\ cincren.) \\ The lellow Bear (Syritasma Virginith.)
}

\section{('HAP'TER C'CXXY.}

The Bean Weevil. (Cal.)

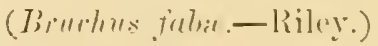

Srxoxy-Bruchus obsolctus-_-say.

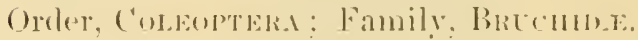

[Living in beans; suall foutless grmuls, finally transtorming into grayish-lume bertles.]

The temale weevil deposits hee egers upon the yomeng pods,

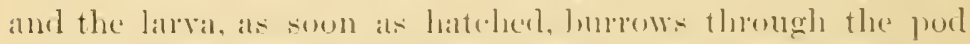
amd enters the beam (Fig. teen larros have heen amoted in on bean (liiley). When fully grown they gnaw a passige to the hull or shell, aml are soom elatuged to pulat: the transformation to the perferet state sometimes takes plater in the Fall, but usually not until the following sipring.

Fìr. 339.
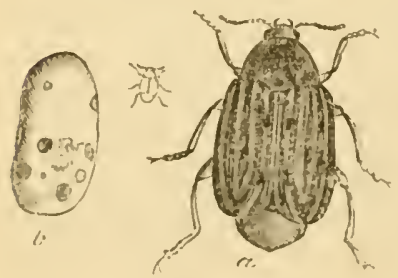

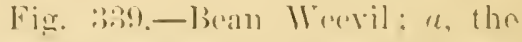
werevil enlarged, the sumall firture at the left leeing the natural sizecolos, brownish-gray: l, a lu:an infested by the larval of this weevil.

Tlu perfect worvil (Fig. 339911 ) is of a Trownish-gray rolor, amel measures about one line in length.

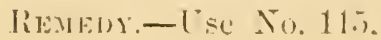




\section{CHAPTER CCXXXII.}

The Bean Aphis. (Cal.) .

(Aphis rumicis-Linneus.)

$\left.\begin{array}{l}\text { Order, Hemiptera; } \\ \text { Sub-order, Honoptera }\end{array}\right\}$ Family, ApHnnd).

[Living upon the leaves and stalks of the bean, which they puncture with their beaks and imbibe the sap; small blackish plant lice.]

Fig. $340 .-B$ e a $n$

Fig. 310.
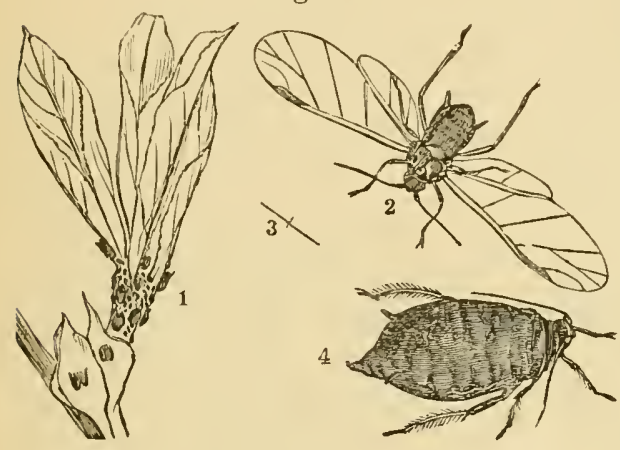

The winged females (Fig. 340, 2,) are wholly black. In England this species is called the "Collier," "Black Dolphin," "Black Fly," ete.

"The bean aphis sometimes appears in such vast numbers as to smother the beans, making them look as if they were coated with soot. The attacks are begun by a few wingless females establishing themselves near the top of the bean-shoots, where they produce living young. These in their turn are soon able to produce another living generation and so on and on, till the increase is numerous and from the numbers of the 'black fly' and the sticky juices flowing from the punctures which they have made with their suckers, the plant becomes a mere dirty infested mass, with a few infested leaves sticking out from amongst the plant-lice."-Miss Ormerod.

Remedy- - Use No. 116. 


\title{
INSECTS INFESTING ASPARAGUS.
}

The Asparagus Bcetle (Crioceris a.sparagi). . .

Chap. 233

\author{
CHAPTER C'NXXII. \\ The Asparagus Beetle. \\ (crioreris usparayi-Linnasus.)

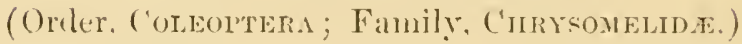

LFeeding upon the leaves of asparagus; a robust. ash-gray six-legged larva, about three lines long, with a row of hlack dots along each side of the horly. the head and two spots on the first segment also black.]

This beetle (Fig. 341, Plate t,) measures alout three lines in length; its thorax is reddish and usually marked with black; the wing-cases are pale-yellowish, marked with blue-hlack as in the tigure.

The perfect beetles pass the Winter in some sheltered situation and cone forth early in the following fummer to deposit their wow. These are placed um the stalks of the asparagus (Fig. 3t.), Plate 4 ) and somewhat resemble in form a grain of wheat, but are much smaller and are of a blackish-buwn ("olor. After the larvar (Fig. $34: 3$, llat 4 , ) attain their full size. they desert the plants and enter the earth. where areh one forms a small (eell in which to undergo its transformations.

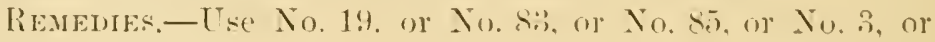
$\therefore 1.4$.

\section{INSECTS INFESTING RHLBARB, UR PIE PLANT.}

The following insects infest the lihularl plant, and are treated of in another part of this work: 


\section{INSECTS INFESTING PARSLEY. CARROTS ANI)} PARSNIPS.

The Parsley Worm (Papilin asterias......... Chapp. 234

\section{CHAPTER COXXXIV.}

The Parsley Worm.

(Papitio asterirs.-Fabricius.)

Order, Lepinntera ; Family, Papilinnides.

[Feeding upon the leaves and hlossoms of parsley, carrots, parsnips, etc.: a whitish or greenish-yellow sixteen-legged worm. banded with black and marked with black and yellow spots.]

Fig. 34t.-Parsley Worm-colFig. 344. ors, greenish-yellow and black.

When fully grown, this worm (Fig. 344 ) is about one inch and

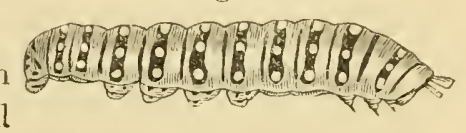
six lines long. Before assuming the pupa form it suspends itself by the hind feet and a transverse loop of silken threads passed around the fore part of the body.

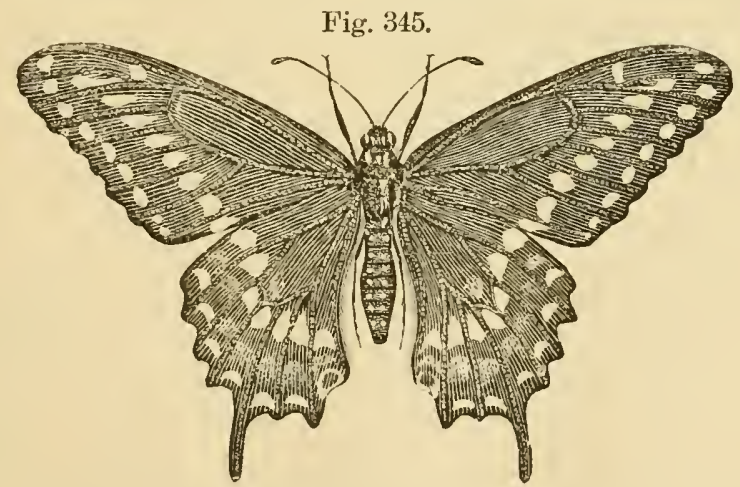

Fig. 345.-Asterias Butterfly-colors, black, blue and yellow. 
The pupa varies in color from pale green to yellowish. or ash-gray; at the anterior end are two ear-like projections, and there is a smaller projection on the back of the thorax.

The lunterfly (Fig. 345) expands from three inches and six lines to four inches, is of a black color, with two rows of rellow spots near the outer edge of the wings; the hind wings are tailed, and are marked with several blue spots, while ahove the angle near each tail is an orange spot centered witl black. Resedes-Same as recommended in Chapter ('CXIX.

\section{HOUSEHOLD AND STORLHOLISE PISTS.}

CII 1 ?

The Clothes Joth i Timea flarifromtella)...235 The Carpet lieetle (Anthrous serophu-

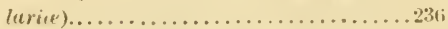

The Cockroach (ilafta germuenra)....... 2337

The Ilospuito $($ Culv $x) \ldots \ldots \ldots \ldots \ldots \ldots . .238$

The Uried Fruit $\mathrm{l}$ oth....... . . . . . . . 289
The (rain Weevil (Calundra yranuriu). .240 The Angoumons Grain Moth ('ireleckin

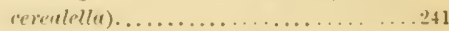

The Bran and Flour Bugs (Sileremes ymad.

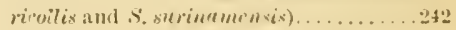
The Raw-hide liectle (Dormestes lardurius).24:3

\section{CHAPTER COXYAY}

The Clothes Moth. (Cal.)

\section{(Tinen Harifontrlla.-Limmas.)}

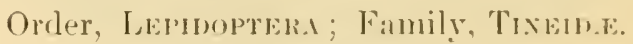

| Living in silken tubes on arpets, woolen gruods, ete. ; a small, pale, sixtern-legred worm.]

Fig. : Bfli-C'lothes Moth-color, light bult:

The perferet inseet (Fig. 34 (i) is a small moth or miller, of a miform light bufr color: the wings an a Fig. ö4tj. long and narrow, with the most deliente fringe of silken hairs. 
Fig. 347.

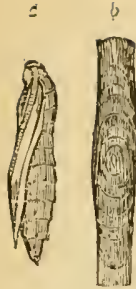

Fig. 347.-Catrpillar, Pupa, and Case of the Clothes Moth; a, the caterpillar-color, whitish; $b$, its case: $c$, the puparolor, brown; all enlarged.

This moth deposits her eggs in carpets, woolen goorls, furs, et.e. As soon as hatcher the young larva (Fig $347 a$ ) immediately hegins to construct for itself a nearly cylindrical tube (Fig. $347 \mathrm{~h}$ ), formed by fastening the gnawed pieces of the cloth together with silken threads. In this tube the larva lives, and instead of clragging its habitation over the hairs, etc., it first cuts these off, thus doing more injury than if it merry fed upon the cloth, fur, ets. When fully grown. the caterpillar eloses both ends of the tube and soon assumes the pupa form (Fig. $347 c$ ), from which the perfect moth issues in the course of a few weoks.

Fig. 348.-Larva and Cases of the carpet Moth.

closely relaterl to the abore species is the carpet moth, or woolen moth (Tinece tapetzelln-Limn), whose larra also lives in a silken tube (Fig. ? +4 s) and is sometimes very rlestruetive to carpets, ete.

Fig. 349.-Carpet Nothcolors, hlack, yellowish-white and gray.

Fig. 349.

The perfert moth (Fig. 349) is blackish at the base of the forr-wings. the remainder being yellowish-white; the hind wings are dark-gray, and the head is white.

Reventes.-No. S2, 90 and 117. 


\section{CHAPTER CCXXXVI.}

\section{The Carpet Beetle. (Cal.)}

\section{- (Anthrenus scrophularix.-Tinn.)}

Order, Coleopters: Family, Dermestins.

[Living beneath, and eating large holes in the carpet; a small hairy brownish larva or worm. ]

This larva (Fig. $350 a$ ), when fully grown, measures a little over three lines in length, and is of a brownish color, the sutures of the segments whitish. On various parts of the body are tufts of hair - that at the hind end the longest, and frequently as long as the borly itself. When about to puprate, it crawls into some sheltered place; here it remains perfectly quiet, and is changed to a jupa (Fig. $350 \mathrm{c}$ ) within the old larral-skin. A short time before the perfect beetle energes the larval-skin is rent on the hack, disclosing the included pupa ; soon after this takes place, the skin of the pupa is also ront on the back, giving us a glimpse of the partially inclosed bectle.

Fig. 350 .
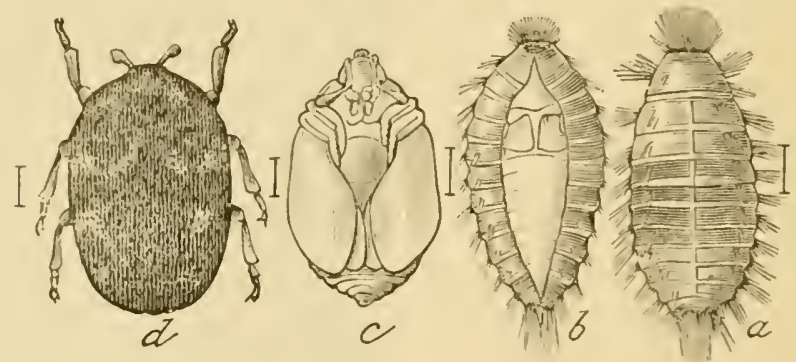

Fig. 3.00.-Carpet Beetle, cularged: d, the beetle-colors, black, white, and scarlet; $c$, the pupa-color, rellowish: b, the same, in the old larva skin: a, the larva-rolors, dark and light brown.

The beetle (Fig. 3.jod) crawls out of its anvironment in the course of a day or so. It is only about one and a half lines long hy one line broal. Its color's are black, white and scarlet, the latter forming a line along the misldle of the back.

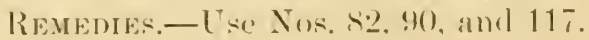

Note- This beetle frequents fluwers, and wan then be destroyed by using No.s1. 


\section{CHAPTER CCXXXVII.}

The Cockroach. (Cal.)

\section{(Blatta yermanica.-Linnæus.)}

Order, Orthoptera ; Family, Blattarida.

[Infesting houses, and feeding upon eloth, etc.; a flattened reddish-brown six-legged inseet.]

The female cockroach lays her eggs in a reddish-brown elongated capsule or pod, each capsule containing about thirty eggs. The young cockroach closely resembles the adult, but is entirely destitute of wings, although in the adult female the wings are greatly aborted, and are sometimes reduced to short wing-pads.

These inseets are nocturnal in their habits, remaining hidden during the daytime and coming forth at night to feed. Although they are sometimes rery troublesome, yet they partially atone for their ill-doings by ridding the house of bedbugs and similar vermin, which they devour.

. Revedy.-Use No. 121.

\section{CHAPTER C'CXXXVII.}

The Mosquito. (Cal.)

$$
(\text { Culpex sp?) }
$$

Order, Diptera ; Family, Culicide.

[A small two-winged blood-thirsty insect, sometimes very troublesome to both man and beast.]

It is only the females of this species which manifest the blood-thirsty propensity; the males are perfectly harmless. The eggs are laid in masses upon the water-usually in some stagnant pool. The young larva (Fig. 351), as soon as hatched, makes its way to the bottom of the pool, where it acts as a scavenger, by feeding upon the dead and putrefying vegetation. It rises occasionally to the surface for air, which it inhales through a tube situated near the tail. In the course 
of a fortught it attains it full grewth, and sono afterwads ats:mmes the jull:a firm.

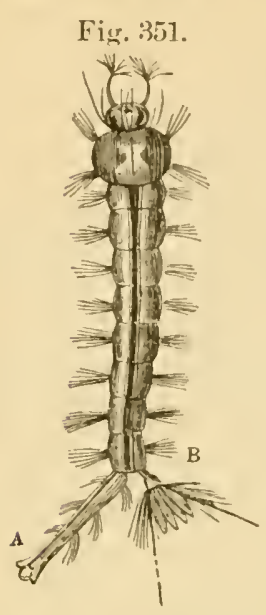

Fig.:3ij]-1,illlil of Mosifuitu,

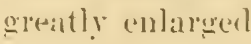
-rolor. whitisls.

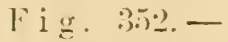
Male Mosipuito. highlymagnified - (*olor, brown.

The pupa remains near the surfirce of the

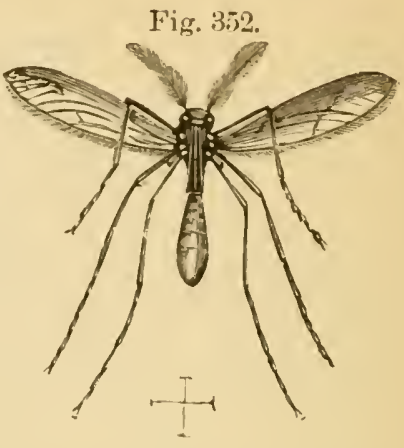
water, and has the power of wiggling about. In a tew days it is aluanged into the perfect insect, or mosquito (Fig. 3.5.). The latter is ton well known in Calitornia to repuire further description.

Remedes-C'se Nos. 82. 117 and 11 S.

Note.-Care shomld he taken to jrevent stagnant water being kepte allowed to rematin near the family residenece, ats it is in such places the mosquitoes deposit their eggrs. and the foung pass their lives as larvat and pupece

\section{CHAPTER C'C'ISTIS.}

\section{The Dried Fruit Moth. (Cal.)}

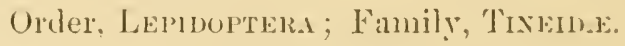

[A small latrva, feeding upon dried fruit, ete.]

The small larrie commonly known as "dried fruit worms." are a great amnoyance to these who dry fruits, and to raisinmakers; and also to the merelants and dealers handling dried fruits and raisins which are not properly protected against these insect pests.

The natural history of these insects is not known to nue further that a to follows: 
They hibernate in the larva state, the larva spimning a light cocoon in the eavity of the fruit, ete., upon which it has fed. Early in Spring they change to pupe, and in about fifteen days the perfect insect emerges. The eggs are laid on the fruit while in the course of drying, especially such as is dried by sun heat; but often in fruit while it is getting ready to be packed, or after packing, if the package is not moth-proof.

Fruit in sacks has not any protection, as the moth can deposit the egg through the eloth. If the fruit is packed in boxes, and the hoxes have not close joints, the moth deposits the eggs in the seams, and the larva as soon as hatched makes its way to the fruit in the package.

In Jimnary last (188:3), I received a small box filled with pits and decayed parings of apricots and peaches, which were infested by the larve of these moths-the person sending them making the inquiry: "Are they the larve of the collin moth?"

In September, 1881, a choice lot of dried plums, pears and peaches were exhibited at the State Fair, neatly packed in thirty pound boxes with glass covers (the fruit was dried by artificial heat). It was placed on exhibition in a fruit store until the following spring. In one of these packages of plums under the glass I found seventy-three moths which had emerged from chysalids in the fruit.

At present I have specimens of what appear to be two different species, but they may be merely varieties of one species. The larva measures from five to eight lines in length, is of a bright yellow color, and tapers slightly toward each end; stomata, faintly bordered with brown; head deeply notched above, yellowish-brown; cervical shield yellowish-brown. The larva is slender, and from its tapering form can be readily distinguished from the larva of the codlin moth.

Perfect insect. No. 1 (Fig. 353, Plate 4); length of body, nearly four lines; spread of wings, nine lines; color, head and thorax dark reddish-brown; fore-wings, inner third yellowish-white (forming a bar across base of wings when at rest), balance of wing to apex dark brown, with two oblique blackish stripes and blackish dots, the darker parts sprinkled with whitish scales; cilia, ash-brown; hind wings, silvery white; cilia, darker than the wings. 
No. 2 (Fig. 3j4, Plate 4); length, four lines; spread of wings, ten lines; color, head and thorax rark ash; fore-wings, mottled dark ash with a wary blackish line across about one third the length of the wing from the base; a second blackish line reaching half way across, nearly equilistant between the tirst blackish line and the apex: hind wings, silvery-white; cilia, a purer white than the wing.

ReMedies.-Use Nus. 15, 16, 17 and 1s.

\section{CHAP'TER CC'XL.}

\section{The Grain Weevil. (Cal.)}

\section{(Culundru granaria.-Linn.)}

\section{(Order, Coleortena; Family. CrRclionide.)}

[Living in the kernels of wheat; a reddish-brown weeril.] This species of weevil is very destrurtive to grain, espeeially in store-hoteses and mills in Californial, and although small, is a rery formidable pest. The female makes a hole in the kernel, or grain of wheat, with her beak and deposits therein a single egg. The larva which is produced from this egrg lives upon the farinaceous part of the grain, leaving only the hull. When full grown it is nearly one line in length, and changes inter a pupa within the hull in which it has lived. It remains: in the pupal state about nine days, when the predect beetle (Fig. 35.), Plate t,) alpears and guaws its way out of the grain. This pest devours the inside palls of the grain. not only in the larva but also in the perfect state. It is said that a single pair will purduce six thousand in five months; also, that fiom the time the exg is deposited until the perferet insect appears is about forty-tive days. It is clamed that at a temunerature of less than forty-five degrees (Falnr.) these inserts are incapable of multiplying their species, and in order to escinge the cold they hide themselves in the cracks of floors, walls. roofs, cete, and remain there until wamer weather. It is probable that as the temperature is wer sixty-five degrees for at leatst eight wonthe of the year in rentral (alifornia, that this may aceount 
in part for their rapid increase in this locality. I have before me now (January 2d, 1853, ) a sample of Tuscany wheat (crop of 1852 ) received in this city about the 15 th of November last, in a close-fitting paper box and apparently in perfect order. It was kept in an office where the temperature is generally above sixty-five degrees, for alout three weeks, or until about the 10th of December. On examination, it appears as if every kemel produced a weevil. I have kept them since that time and they still appear healthy. It is not by examining the surface of the grain heajs that the presence of this pest can be detected, but by examining at a depth of say four or more inches below the surface. By putting some of the grain in at vessel and then covering it with water, those kernels infested, or which the larva or perfect insect have eaten out, will float.

Since writing the abore, I have made some investigations, which are not yet complete, (August $27 \mathrm{th}, 1883$ ), but I have reason to think that the grain weevil (C.granaria) infests the wheat when growing in the field, and that the germ or egg is laid in the wheat (or, at least, in some of it.) before it reaches the granary.

On the 14th of August, 1883 , I found the male insects of the rice weevil (Calandra [Sitophilus] oryzx) in considerable numbers among the wheat weevils; and also found them pairing with the females of the latter.

Description of Rice Weeril: Nale not so large as wheat weevil, and has two red or yellowish-red spots on each wingcover.

Renedies.-No. 72 , No. 75 and No. 76, and careful selection of seed; general remerly for weevil, No. 11?. 


\section{CHAPTER C'CXLI,}

The Angoumois Grain Moth.

(riclechice reverella.-Limasus.)

Order, Laphopress: Family, Tramen.

[Living in grains of wheat and corn; a minute white larva.]

This post is rery destructive to stored wheat and com, especially to the former. It rats out the interior of the grain, - leaving mothing but the empty hull. It is said that a single erain furnishes sufleient food for a larva from the time it issues from the ego mitil it becomes fully grown. It assumes the pula form within the grain, or hull. The perfect moth (Fig. sigli) has the heat of at dull ochre color, the fore-wings pale shining ocher, with a grayish or brownish streale at the bate of ealeh wing; the hind wings are also grayish-ochre.

Fig. 356.

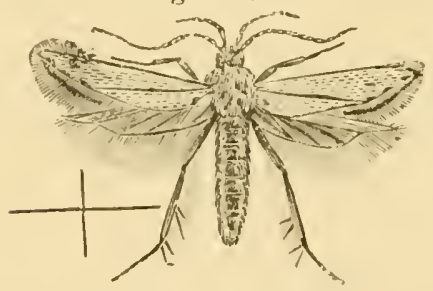

Fig. $35 \pi$.

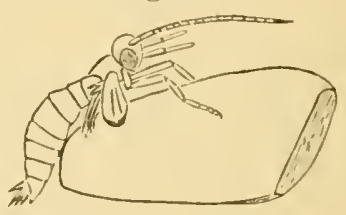

Fig. :; $; 6 .-$ Angommois frain Moth, tnlargerl--color, yellowish-bintur.

Fig. 357.-The Angommois (irain Moth just from the pupa.

Closely related to the alowe is the common grain moth (Tinen yrumella-Linn), sometimes called the "grain wolf." Its larvate differs from that of the Ingeumois moth hy fastening sereral grains togrether with silken threats and afterwards cating out the interior of each grain. The perfect moth is of a cramy-white color, with six hrown spots on each fore-wing.

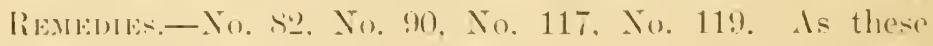
rimedies apply to destroying moths and beetles. and their larvor or ormb any of them may be applied in this ease that is matciciable. 


\section{CHAPTER ('XLII.}

\section{Bran and Flour Bugs. (Cal.)}

(Silcanus quadrivollis and s. surinumensis.)

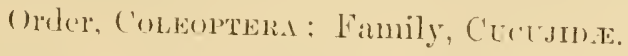

[Living in stored grain, brall, flour; sugar, etc.; small reddish slender beetle.]

These beetles are very small, none of them measuring over two lines in length. They are of a chestnut-brown eolor; quadricollis (Fig. 35s, Plate t,) as its name implies, has a nearly square thorax, while in surinamensis the thorax is rounded, and has several teeth on the outer edge.

In their larval state these insects usually live in the grains of wheat or corn, which they frequently hollow out until nothing but the hull remains. They assume the pupa state within the grains. Besides wheat and corn they are also found in bran, or middlings in flour, sugar, and in rarious other situations.

REnedY-Use No. 120. When in grains, same remedy as recommended in chapter C'CAL.

\section{CHAPTER C'C'XIIII.}

The Rawhide Beetle. (Cal.)

(Dermestes lardurius.-Linn.)

Order, Coleuptera; Family, Deruestid.e.

[A brown hairy lapar, feeding upon rawhides, funally changing into a blackish-brown beetle, with a whitish bar across the base of the wing-cases.]

The larva (Fig. 35!) a) of this species is found to be rery troublesome at certain sealsons of the year, in stores where hides are stored. It measures about nine lines in length, and is eovered with stiff hairs. When full grown it assumes the 
pupa form, and the perfect insect (Fig. 359c) emerges in about three weeks.

Fig. 359. - Rawhide Beetle and Fig. 359 .

Larra; a, the larva, enlarged-color, brown; l, one of its hairs, enlarged; $c$, the bectle, enlarged-colors, black and gray.

Description of Beetle: Shape, oblongr-oval ; color, dark-brown or blackish; on the base of the wing-cases is a broal whitish or buff-colored hand, on which are some brown or black spots; the under side of the body is blackish, anel covered with a whitish-colored powler or scales; length, four lines; wilth, alrout two lines. This iperes feeds also un baeon, hams, ete. ; and several other speceses which belong to the same family are very destructive to furs.

Reanem:-lise No. 91. 


\section{INSECTS INFESTING DOMESTIC ANIMALS.}

The Black Horse-Hy (Tubanus atratus) 244

The Horse Bot-fly (Oestrus equi) .........215

The $0 x$ Bot-fly (Oestrus bovis).............. 46
CHAP. The Sheep Bot-fly (Oestrus wis) .........247 The Scab Mite (P'soroyt is equi).........248 The Liver Fluke (Distoma hequaticum)....249

\section{CHAPTER CCXLIV.}

The Black Horse-fly. (Cal.)

(Tabanus atrates.-Fabricius.)

Order, Diptera ; Family, Tabanide.

[Biting and annoying horses, cattle and other animals; a large black two-winged fly, having the back of the thorax covered with a bluish-white powder, and the wings smoky dark brown or black.]

Fig. 360.-Black Horse-fly, La r va and l'upa; $a$, the larva-color, greenish-white; $b$, the pupa--color, brown; c, the fly-colors, black and bluishwhite.

The body of this fly (Fig. 360e) is about ten lines long, and the wings expand about two

Fig. 360.
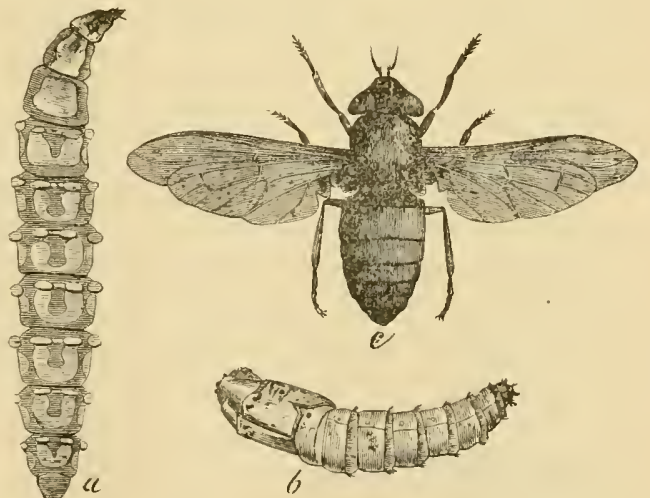
inches. Like the mosquito, it is only the females which attack animals; the males are destitute of mandibles, and 
live upon the sweets of flowers. The larva of this fly (Fig. 3(60u)lives in the vicinity of fresh water streams; they have heen fommel beneath subuerged stones in a small stream of rumning water, among floating pieces of wood, and on dry land less than a rod from a small permanent stream of water. It appears that a certain degree of moisture is necessary for thrif existence, althongh they are not strictly ayuatic. They feed upon snails, and problialy earth worms. These larve measures from une incle and nine lines to two inches and three lines in length, and ane nearly eylindrial. hut taper at wach end they are of a tramsparent greenish or yollowish

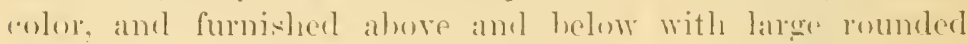
sponge-like tubereles which are extemeled or retrueted at the will of the insect. They reach their full si\% in mill-smmmer,

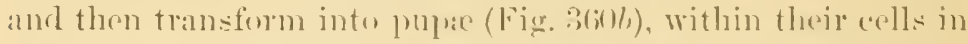
the earth. In the course of a reek or so they arre changerel inte prerfort Hies.

Sereral other herse-tlies oceur in this state; the one often-

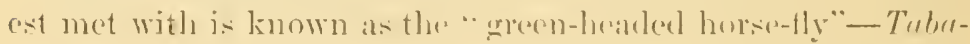

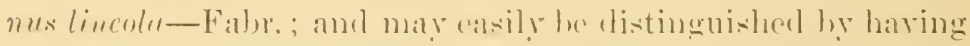
a whitish line on the bate of the aldomen: the hearl is usually green. It is a much smaller species tham the ahore.

\section{r'HAPTER C'NLY.}

The Horse Bot-fly.

(Hestims cqui.-Faloricius.)

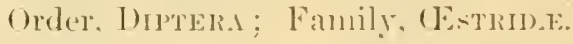

[Living in the stomath of the horre: a yellowishered or whitish grub, thinly corered with small bristles or spines.]

Fig. 361.

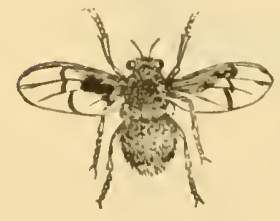

Fjo. Btis. - Horoce Bot-fly, male--reolors. grancish-yollow anul blark.

The agres from whirh these grubs hateh are

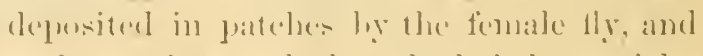
each exy is attached to the hatir hỵ a sticky Huid which is deposited with it. Ju a few weeks the grub batches. and is comvered to 
the mouth by the horse licking or biting the place where the egg has been deposited ; it then passes down the horse's throat with the food. After reaching the stomach, it attaches itself to the inner lining by means of two curved hooks with which the heat is provided. Here it remains until fully grown, when it lossens its hold and is carried onward and expelled with the excrements. Upron reaching the earth it at once buries itself, and soon contracts to a reddish-brown pupa, from which the perfect fly issues in the course of a few weeks.

Fig. 362.-Horse Bot-fly, female-colors, gray, black and yellow.

The perfeet fly (Figs. 361 and $36 \%$ ) is of a pale gellowish color, spotted with red, the thorax banded with black or red, and the wings, which are only two in number, are of a whitish color reflecting a golden tint, and are crossed by a dark band with two reddish spots at the tips.

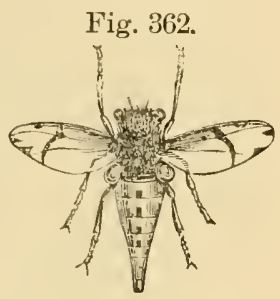

Figuier writes: "In fict, it is not in the egg state, but really" in that of the larva, that the horse, as we shall explain, takes into his stomach these parasitical guests to which nature has allotted so singular an abode. When lieking itself the horse carries them into his month, and afterward swallows them with his food, by which means they enter the stomach. It is a remarkable fact that is sometimes sen, other insects, as the Tabani. for instance, that by their repeated stinging eause the horse to lick himself and thus to receive his most cruel enemy. In the perilous journey they have to perform from the skin of the horse to his stomach, many of the larve of the Estrus, as may be supposed, are destroyed-ground by the teeth of the animal, or crushed by the alimentary substance."

Symptoms shown by a horse seriously infested by bots: He loes not eat heartily, and therefore loses flesh, and has a stiff and staggering walk, and to use a common phrase, appeal's "consumptive."

RenEDibs.-To prevent the eggs from reaching the horse's mouth, clean off' daily by scraping. There exists a vast difference of opinion in regard to remedies; some persons recommend drenching with oils and bleeding; others claim that 
the animal is benefited by the presenee of the bot. C'onsequently, I can only advise consulting a reterinary surgeon.

\section{CHAPTER C'NLVI.}

The 0x Bot-fly.

\section{(1Estrus boris.-l)e (iecr.)}

\section{Order, Diptera; Family, (Estridz:}

[Living in tumors on cattle; a whitish footless maggot.]

Fig. 3(i3.--Larral, or maggot of ox Bot-1fy-color, white.

Fig. 36t.-Ox Bot-lly, enlarged-colors, black, yellow and white.
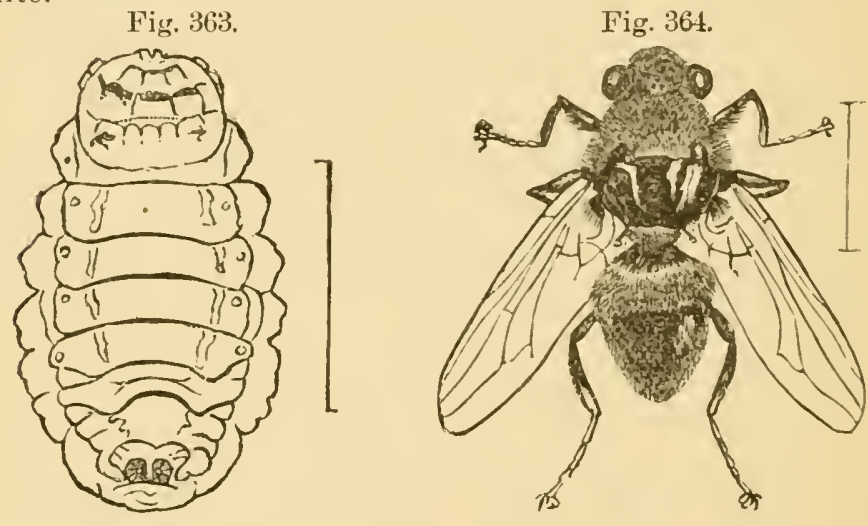

The parent fly deposits her egges upon the hacks of the cittle. or, according to some authors, she first punctures the skin, and then deposits therein a single egg; the first hrpothesis is the more reasonable one, and we nay suppose, with rery good

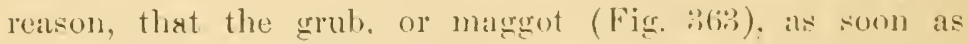
hatched, hurrows through the skin and takes up its ahode just beneath it, where its presence results in the formation of a tumor, in which the magrgot lives. After attaining its full size it descrts its former abiding place and falls to the ground, which it enters and soon contracts to a dark-brown pupa, from which the perfect $\mathrm{Hy}$ issues in the course of a few weeks. 
The perfect fly (Fig. 364) is of a black eolor, thickly covered with hairs except on the thorax, which is twice broadly banded with yellow and white; at the base of the ahdomen is a white or yellow band, and at the tip is a hand of reddish hairs. This species causes great annoranee to cattle in pastures. It is said that the buzzing noise made by the Hy terrifies work oxen to such an extent that they at times become unmanageable.

\section{HaRe, ol Jack RabBit.}

A species of (Estrus attacks the hare, or jack rabbit; the habits and natural history of this cestrus are probably similar to that of the estrus boris.

Renedr-The opening of the tumor may be enlarger with the point of a sharp linife, and the maggot extracted, or forced out; this can be done without much pain to the animal.

\section{CHAPTER CCXLVII.}

\section{The Sheep Bot-fly. \\ ('Estrus ovis.-Linnaus.)}

Order, Diptera; Family, (Estrid_.

[Living in the heacts of shee1; a whitish footless maggot.] It is thonght that the parent insects (Fig. 365, 1 and 2, ) are viviparons, and that the maggots (Fig. $365,4,5$ and 6 .) are brought forth alive, and are deposited in or near the nostrils of the sheep, up which they "rawl until reaching the frontal sinuses, where they attach themselves hy means of the hooks with which their hearks are provider. Here they remain until attainning their full size, when they loose their hold and make their way to the opening of the nostrils and then fall to the ground, which they enter, and soon contract to dark brown pupa (Fig. 365, 3,) from which the perfoct fly issues in a few weeks. 
Fig. 365.- Sheep Botfly; 1 , the fly with its wings elosed ; 2 , the simme witle its wings expanderl -color, ashen-brown; $\therefore$. the puna-color. brown: 4 and i; the maggot or grul-color, whitish; " the hearl; b, the anal plate; 6 , the young matggot; r, its spiractes or breathing pores.

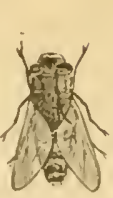

1
Fig. 365.

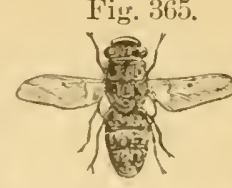

2

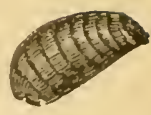

3

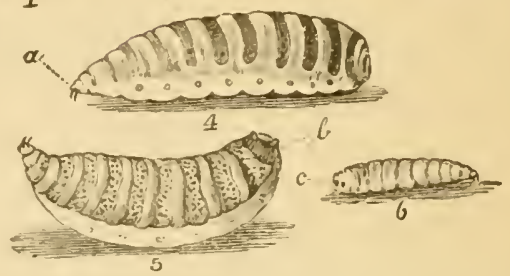

The fly (Figr. 36.5, 1 and 2.$)$ is of a dirty ash color, with four black lines on the therax, and the alwomen is swoted with back. The grubs or magrgots sometimes make their way even into the luain, and to their presenere is due the disease linown ats " grrul, in the hear."

Concerning this species. Fintujer writes as follows: "Eren at the sight of this insed the sheep fow the greatest terror. As som as one of them alpeats the flock beenmes disturherl; the sheepe that is attackerl shakes its head when it fects the fly on its nostril, and at the same time strikes the gromend violently with its forefeet. It then commenees to rum here and there, holding its nose near the eromel, smelling the grass, and looking about anxiously to sece if it is still pursuesl. It is to aroid the attacks of the Festrus that, during the hot days of summer. sheep lie lown with their nostrils huried in dusty ruts, or stand up with their heads lowered between their fore-legs and their noses nearly in emetact with the ground. When these poor heasts are in the open combery they are observed assembled with their nostrils against eatels other and rery near the gromel, so that those which oceny the outside are alone cxposud."

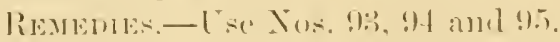

Note.-The abowe remedios hav been nsed, with excellent resuls hy Mesers Green and Trainer, of silcramento, at their farms in Placer (omnty. 


\section{CHAPTER CCXINIII.}

The Scab Mite.

\section{(Psoroptes equi.)}

$\left.\begin{array}{l}\text { Class, Aracuama: } \\ \text { Sulbelass, Acarixa; }\end{array}\right\}$ Family, Ararint.

The following is taken from the Seventeenth Illinois Report by Professor Cyrus Thomas:

"The scal mite of the shecp (Figs. 366 and 367 ), which is now believed to be the same speeies as that infusting the horse and ox, belongs to the family Acaride and sub-family Sarcoptina, which also contains the human itch mite, or mite that produce the disease in man known as the itch."

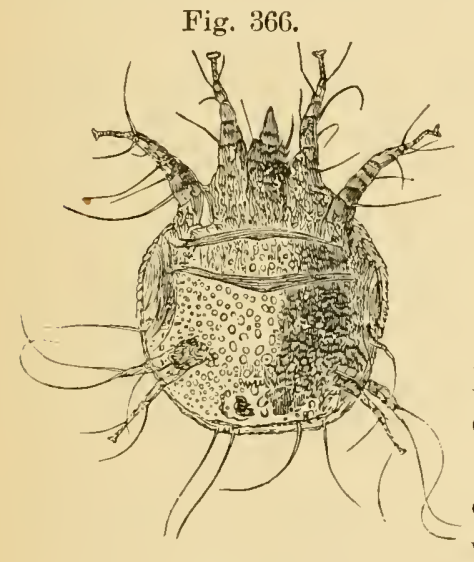

Fig. 366.
Fig. 367.

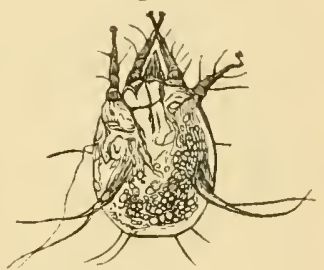

Fig. 366.-...cab) Mite (adult), highly magnified, ventral viewcolor, whitish.

Fig. 367._Seab Mite (young), enlarged, ventral view-color, whitish.

"The scab, as all are aware, is a skin disease analagous to the mange in the horse and itch in man, and, like these, is produced by a very small mite. It was, for a very long time, supposed that this mite was produced spontaneously by an unhealthy and unclean condition of the flocks, or from some insufficient or improper food, etc., and not from a preceding parent. Onr parasite has received various scientific names, according to the fancy or opinion of authors. but, as the further history of its elassification is umnecessary now, I will mention but two of these. 
" First-Dermatodectes oxis; sheep itch-mite of Gerlach, by whom it was considered as peculiar to sheep; but the most recent authority restores the name Psoroptes equi, horse itchmite of fervais, considering the speres infesting the horse, cattlc and sheep as identical. It is distinguished from the itch-mite of man (Sarcoptes scabei.-Latr.) by two or three important characters. The four anterior leges and two of the hind oncs, at least in the males of each species, are furnished with sucking disks placed on compraratively long pedicels or stems. In the itch-mite of man, als far as I can ascertain, these pedicels are only one-jointed. But the most important difference is that the mouth of the human itch-mite is furnished with seissor-like jaws or nippers with which they ean readily eut into the skin and form theig subentancous hurrows. The she'p mite is furnished with comparatively slender lancet-like mandibles, to the sirles of which the little palpi or mouth feelers are glued. thus forming a sort of tube, one part of which is capable of piercing. But while this peculiar form of the oral apparatus enables them to pieree and suck, it deprives them of the power of cutting, and hence, notwithstambling the general opinion to the contrary, they are not subeutaneons in their haljits and do not form true burrows, as the human itch-mite. It lays its egre on the surface of the skin, to which they arlhere by a gluey matter. The length of time these require to hatch in such situations is not positively known, but some placed in a bottle and kept to the warmth of the body hatched in fomteen days. The young, which are produced from these have only six legs, but after several changes of skin or monltings they arefuire cight. which is the normal number of this elass. With the little sucking disks of their feet they are enabled to cling firmly to the skin of the sheep. By piereing the skin with their lancet-like mandibles. irritation and a species of inflammation of the skin follows and an exmation takes plare which ultimately forms the scal, As stated by a writer on this subject: "Examination will disclose spots on the skin white and harl, the center markerl with yellow points of rxudation which adheres to the wool, matting the filues together. The wool may be firm on these spots and no seales are seen in this 
stage. Then the yellow moisture evaporates, giving place to a yellow scab which adheres firmly to the skin and wool.' Raw places appear at points which the animal can reach with its teeth and hind feet. The disease is aggravated in summer by the presence of the larve of the blow-fly, the maggot burrowing into the scab."

Remedr.-Use No. 92.

\section{CHAPTER CCXLIX.}

The Liver Fluke. (Cal.)

\section{(Distoma hepaticum.)}

The following is taken from the Seventeenth Illinois Report, by Professor Cyrus Thomas:

"Of the intestinal worms that attack sheep, we notice as the most important the Liver Fluke (Distoma hepaticum). This species belongs to the class Scolecida, order Tremolodu or' 'Suctorial wor'ms,' as given above, inhabits the gall-bladder or ducts of the liver' in sheep and, it is believed, causes the disease known as the 'rot.' It derives its common name from its resemblance in form to the flounder, of which 'fluke 'is a scotch and old English name. It is somewhat broad and flattened, of an elongate-orate form, somewhat pointed at each end and is usually nearly an inch long, often much less, but oceasionally more; its breadth at the widest part, which is toward the front, is about half its length. Its color is usually that of the organ in which it resides. It belongs to a very low type of beings, having neither eyes, true lespiratory organs, heart, or any other organ of special sense. The sexes are not even distinct and the alimentary canal does not even pass through the body, but dividing and sub-dividing, permeates all parts of it, distributing the imbibed nourishment, which needs little or no assimilation to adapt it to use in forming the materials of the body. It is proper to state, howerer, that Youatt and other writers on sheep distinetly aftirm that flukes have eyes and even figure them. But what possible use they have for these organs, in the situation they occupy, it is impossible to say; 
and moreover, withont nerves, of which there are but mere traces, these organs would be entirely useless, even if they were in the light. That they do possess eye-like spots at a certain stage of their life is true; but there is nothing to show that these are organs of sight or eyes in any true sense. What this anthor con-iders the heart and circulatory system is probably the watex vascular system, found in these and all other animals belonging to this elass, which is supposed hy many to represent the respiratory system in the higher grarles. He also suploses that the egrgs or spores, after being cast off, remain umereloped until taken into the stomach by the sheep with its food, which, as will be seen, is an error.

"The species belonging to this order vary considerably in their transformations and habits, some passing through a cyele of six forms, while others present only three or four. Some infest the liver or hepatic dnets of rertebrates; others infest the intestines of birds and hatrachians, the gills of fishes or paunch of ruminants, while others are found imbeddeel in the vitreous hmmour and lens of the eyes of certain fresh water tishes, such as the perch.

"The eycle of changes through which the liver Huke of the sheep passes has not been fully traced. but the life-history of Distoma militure, another species of the sime genus, which inhabits the intestines of water-birds, has been nearly completely traced and from it we may, with what we know of the life of the liver tluke, form a somewhat correct ideit of the history of its transfurnations.

"This speces as stated. in its perfect or mature state, resides in the intestines of certain water-birds. T'he wat or spore-like egge which it produces are few, some cight or ten in number. From each ege issues a ciliated larva, which still retains sonething of the character of an egg, although active. as there is an outer envelope in which is the real animal, or in which it derelopes, its history at this point of its life leing yet imperfectly known. From this eagr-like larvia procects the second larvia form, which is known as a Redia. Its mode ot development in this form is not fully known. It is now fouml attached usually to the body of some water-snail (Puludina), the cilia of the first larrat having now disappeaned. When the 
Rediu, or second lava form, has acquired its complete growth, it is somewhat of an arrow-head shape, consisting of a sac, within which is suspended a tubular bag containing colored masses, which Huxley supposes are alimentary. The head is represented by a kind of a crown, and near the other extremity are two lateral projections. In the body carity, external to the tabular sac, resicles now appear, which rapidly increase and assume the form of Cercuria, the name given to the third larval stage. The ledie now bursts and these new zooids escape. The multiplication at an intermediate and incomplete stage (before sexual characters have appeared) is rery remarkable and introduces to our view a strange feature in animal life.

"The Coraria resembles a peanut, with a slender tail at tached to one end; it also has lateral membraneous attachments, by means of which it swims after the manner of a tadpole. After swimming free for a certain length of time, it finally fixes itself upon and wsually bores its way into the body of a water-snail or some other mollusk. The tail then drops off and the body incloses itself in a cyst. The coronal hooklets of the perfect form now appear. It now remains quiescent, mable to develop further in its present situation, awaiting for some waterbird to swallow the mollusk in which it is imbedded. As soon as this is done and the cyst is set free in the alimentary canal of the bird, further development begins and the complete or Distoma form is assumed. The body elongates and narrows anteriorly, the suckers move nearer the head and the rircle of hooklets being complete, it attaches itself by these to the walls of the intestine. Such is the strange life history of this intestinal worm; and althomgh that of the liver fluke may vary in some respects, yet it is doubtless sinilar in a general sense.

"The following outline, given in my aldress before the Illinois Wool-growers Ascociation, September 20 . 187 7 . is probably substantially correct :

'They produce a kind of spore, or egg, but its subsequent progress, so far as it is at present known, presents one of those singular life histories occasionally met with in the lower order of animals. In some way, not rell unclerstood, this egg or germ spore makes its way to the external world; its history 
from this time until it is hatched is unknown, but moisture in some form is probahly urecssary to its development. It is next found in the body of some mollusk, as the smail, or some aquatic insect, where its form is so diflerent from that of its after-life that it was long comsidered as appertaining to an entirely different group of animals. From these, in some way not yet aseertained, it passes inte the sheep. It probubly escapes from the mollusk or insect to herluage in moist places, or water, and is taken into the stomach of the sheep with its food or hrink, and passes through the lanteals, and makes its way into the ducts of the liver.

'As sheep do not feed on mollusks as the water-birds do, it is diflicult to imagine how the cercaria, if it becomes eneysted in the body of the mollusk, makes its way into the stomach of the sheep. It is possible this may be explained in one of two ways. First, as has been stated above, the cercaria is for a time a free swimmer, and hence may be taken into the stomach when drinking, or attached to berlage in damp' places. Second, it has been ascertained by Van Benedin that some species of this group pass to the mature state directly from the redia stage without undergoing the intermediate or cerearia stage; as these are free they may be taken into the stomach in water or on damp herbage.

' $\Lambda$ s before stated, these internal parasites are supposed to be the cause of rot in sheep, though many persons are inclined to believe they are a ronsefuence rather than a rause of disease, But all appear to agree that this disease is comnecterl with the conclition of the soil, or the state of weather, moisture heing the element most likely to produre it. This correspomels exactly with the theory of its life history which I have presented, and indicates the best means of preventing it, to wit: Give them well-ilrained, open, airy pastures, and proper protection in clamp and miny seasons. It is nore probable the combition of sheep is often attributed to this disease, when it is due to other callses.." 


\section{INSECTS INFESTING THE APIARY.}

\section{CHAPTER CCL.}

The Bee Moth. (Cal.)

\section{(Galleria cerectna.-Fabricius.)}

Order, Lepidoptera; Family, Prrallide.

[Living in silken tubes in bee-lives, and feeding upon the wax and young bees; a small grayish worm.]

Fig. 368.

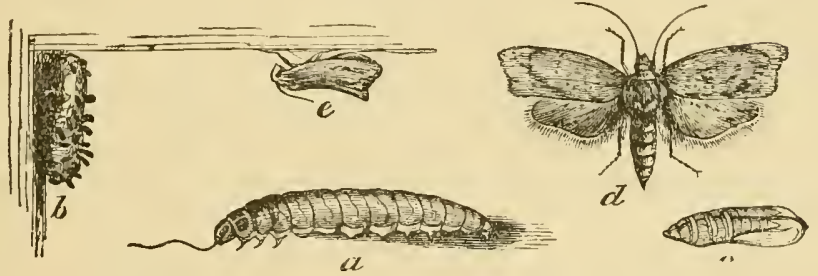

Fig. 368.-Bee Moth; a, the worm or caterpiliar-color, ash gray; $c$, the pupa-color, brown; $d$, the moth, with its wings expanded; $e$, the same, with its wings closed-colors, gray and brown; $b$, the cocoon-color, whitish.

This is by far the worst enemy with which the bee kecper has to contend. The female moth, if prevented from entering the hive, will deposit her eggs in cracks or any opening in the hives. As soon as hatehed, the young worm (Fig. 368a) enters the hive, and at once protects itself by spinning around its body a silken tube; as it increases in size it enlarges the tube, feeding the meanwhile upon the wax and young bees. When 
fully grown, it creeps into some corner of the hive, or into some other sheltered place, and spins a tough white cocoon (Fig. 3686), intermingled with its own black excrements. The perfect moth (Fig. 368, d and e,) has dusky gray forewings, which are scalloped at the outer end, and are sprinkled and dotted with brown.

Rruedi.-Une No. 122.

\section{MISCELLANEOUS INSECTS.}

\section{CHAPTER CCII.}

What are they, Friends or Enemies?

At various times during the last two years, I have received specinens of insects reported to be feeding upon fruits, and I refer to some of them as follows:

Fig. 369.-Larva of Lace-winged Fly-color, gray.

1st. Mr. Scott, residing near this city (Sacramento), brought me some ripe peaches in which were small insects, cating in holes made through the skin of the fruit. The holes were less than one line in cliameter, and from two to four lines in depth. By removing the insects from the holes in the fruit,

Fig. 369.

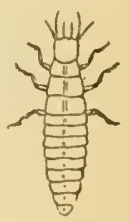
I found that the supposed new pest was the larva of a chrysope (Fig. 369) or lace-winged fly. That they were feeding upon the fruit is beyond question; but probably the opening had been made by a species of plant-bug, or by the striped (ncumber beetle ( $D$. irtutu), which infesterl the trees. I could not tind any plant-lice on the trees, therefore the larva of the Chrysopa may have entered the punctures made by some other insect to feed upon the fruit.

2d. I have also received specinens of a species of ladybird, said to attack cherries when ripe. It is the coccinella i-notuta var. C'aliformica. (Fig. Bio, I'late 4.) 
Description: Form, ovate; length, three lines; color, head black, with two white dots; thorax black, with a white mark on each anterior angle; wing-cases, light orange, with a minute white mark at each side of the seutellum.

In answer to inquiries made by me, Mr. A. P'. Crane, a prominent fruit grower at San Lorenzo, Alameda County, writes as follows, under date of June 12, 1883:

"DEAR SIR: Yours of the ninth instant eame to hand last evening. I send you specimens of lady-bird by this mail. They troubled our Black Tartarian Cherries some years ago. We allowed the fruit to become too ripe before picking, and the species I send you destroyed considerable. I have not noticed them to be so plentiful in three or four years past as they are this year (1883), but they are not doing any harm as yet that I can observe. Last Wednesday, while looking through our apple orchard. I found a large number of these lady-birds devouring the woolly aphis. This morning, in looking for these specimens whirh I send rou, I could not find any on the trees near the house, neither any aphis, but found the ladybirds on boxes containing cherrics. The lady-birds are often observed feeding upon ripe apricots, but some growers think that the striped or spotted Diabrotica first punctures the fruit before the lady-bird will tonch it. I believe the lady-birds will puncture and eat the fruit, if it is soft and ripe.

"A. P. Crane."

3il. Mr. Welty, whose orehard is located on the Sacramento River, a few miles below this city (Sacramento), brought me a specimen of a sand wasp, belonging to the genus Prioenemis. (Fig. 371, Plate 4.)

Description; Length, nearly one inch; color, body black, with bluish or greenish shades; wings, brick-red, with black tips.

Mr. Welty states that these insects have destroyed the crop of twelve peach trees (variety, "Alexander,") for two years in suecession-1851 and 1882. As soon as the fruit begins to get ripe, these pests attack it in such numbers as would destroy the entire crop if not picked before it is ripe. He also states that the other varieties of peaches are not attacked by this species. 
4th. Specimens of peach branches were brought me by Mr. I) ye, of Walnut Grove, in this county (Sacramento). On each hranch were three or four mud nests (Fig. 372, Plate 4,) each one containing a larva feeding upon a species of small spider placed in the nest by the parent insect. They were placed in boxes. The wasps did not mature entirely, hut nearly completed their ehanges. One of the nests produced a goldengreen fly, belonging to the Chrysididx $\rightarrow$ a beautiful specimen.

Description: Length of body, nearly four lines; color, ultramarine-blue; ovipositor, blackish; wings, hyaline (transparent).

I do not think that this insect is injurious to fruit.

5th. Bees.-A great difference of opinion cxists among fruitgrowers as to whether bees attack fruit and grapes. Some growers make positive assertion that they do attack fruit and grapes. while others are equally positive that they do not until the fruit or grapes are punctured by other insects, such as plant-bugs. wasps, ete.

In my investigations, I found an orehard and vineyard located at least two miles from any other orehard or vineyard. In this place are kept al large number of bee-hives. The owner informs me that his grapes are userl for making wines, and that the bees do not touch them until the picking of the grapes rommences; then they feud upon the broken berries and such as are attacked by other insects; also, that they do not attack the fruit until it is punetured by other insects. My informant gives this as the result of many years experience.

Fig. 373 .

Fig. 373.-Blapstinus lecontei; ventral and - clorsal views-color, black.

6th. In 1S5:2, Mr. R. B. Blowers, of Woodlant, sent me specimens of a small dark-colored beetle (Fig. 373 ), about one third of an inch in length, found in some vineyards near Woodland, feeding upon the leaves and young growth of graperines. I ascertained them to be Ilapstinus lecontei. This species had not been reported as being injurions heretofore. It belongs to the same family as the following species-Tenebrionidie. 
Fig. 374.-Eleodes quedricollis-color, black.

7th. Early in July, 188:, I received from J. W. Minturn, of Madera, Fresno County, specimens of a black beetle (Fig. 3it)-the Eleodes quadricollis of Leconte-about three fourths of an inch in length, reported to be feeding upon the foliage of grapevines. As this species is considered harmless, I doubted that the damage to grapevines was done by

Fig. 374.

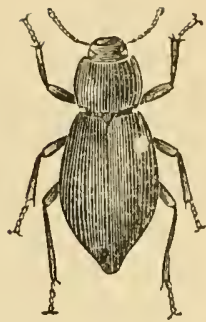
it, and wrote, asking that full investigation be made, to learn if the damage was not done by some other species of insect, and receiver the following answer, dated July 18th: "I have received your letter, and herewith return answer. As to those beetles eating the foliage of the vines, it is simply solved beyond any doubt, as far as I am concerned; and it is more than probable that a majority of men would be quite satisfied on this point, had they been up the greater part of ten nights and scen on each vine that they came to from two to a dozen of these beetles, besides thousands of them on the ground over an area of one hundred acres. If further proof is required, I think the destruction of thirty-five acres within the above naned time (there being no other insects, or rabbits, or squirrels to be found) would have the tendeney of convincing any person. They have also appeared in some alfalfa fields, and I am informed by a gentleman lately returned from the Tejon Pass, that there they are in such numbers that they have completely deroured every green thing. Those that passed over my vineyard were traveling from east to west.

"P.S. The gentleman above referred to tells me that the Mexicans over there say these beetles precele a very heary winter, and that they have been seen in the same numbers many times before."

In reply to further inquiries, the following letter was received, dated July 27 th :

"The beetles, as nearly as I can remember, first came about the 5th of July; within three days they had damaged some ten acres, and were evidently rapidly on the increase at this time. About the 8 th or 9 th inst. I discovered them at night. Until that time I had been at a loss to know what ras eating 
my rines, as I had a rabbit-proof fence around my field of 160 acres, which is looked after each day. Is fur as I know, they had not paired during the period that they were here, though during the day they seek the shade of clods of earth, holes in the checks, under some water gates that connect the checks, and in these places large numbers seem to congregate. For instance, this afternoon my brother turnerl up a couple of clork, each say four or five inches in diameter, and uncler them was at least sixty or serenty beetles. The greater part of the beetles have disapleared; whether they have lied or migrated I camnot be sure, but think the latter, for if they had died in such numbers I think I should have discovered them. In a slough that is used as a water chamnel there are pook of water somewhat stagnant, and at some of these I fomm thousands of dearl beetles-still not anything like enough to account for the disappearanee of the amy that was here."

I sent a specimen of this heetle to P'rof. Riley for determination, but he being alsent the specinen was refered to l'rut. E. A. Srhwarz, who replied as follows, under date of August ith :

"The tenelrionid you send, and which has destroyed thintyfive ateres of grapevines. is Eleodes puadrionllis-lene ; a very common species in the more northern part of your state. The species of that genus so numerous and ahundant in the region west of the liocky Mountains are all known te foed upon decaring regetable matter, and none have hitherto heen reported ats doing damage to cultivated plants. In fact your communication, if correct, would indicate a change of habit hitherto mprecedented in the history of ecomonic entomology : and unless further proof be hrought forth. I can hardly helieve that the suecies referred to is the real author of the damage to grapevines."

Sth. Ants-Fince the Spring of $1 \mathrm{~s} s$, oceasionally some fruit-growers would report that the ants were among the inseet friends of the fruit-growers. In 1site, the late Jannes B. Salul, of ()ak Shade (Orchard, Yolo County, wrote me that in his investigation he discovered that he was losing some larve of the corllin moth. and rould not areount for the less. The larve were taken from the apples and prears hefore they had 
attaekel the seed-bag, or core of the fruit. I visiterl the orchard, at his request, but could not fathom the mystery. A few wecks afterward Mr. Saul wrote me that he had detected the thief. That the larve were taken from the fruit by ants. I wrote him to write a letter on the discovery, and I would have it published; but the letter was not written before his sudden illness and death, which took place a short time afterward. In 1852, in eompany with Mr. C. W. Reed, of Washington, Yolo county, I witnessed the ants taking the larve of the corllin moth from pears; also carrying away larre placed on leaves. It is generally understoorl that the larve of the codlin wroth generally leaves the apple by eating a burrow in a different direction from the one by which it had entered the fruit. In noticing the absence of the larre without finding the burrow for its escape, was what caused the investigation by Mr. Saul. Since that time I have detected the presence of the apple curculio, which may aceount for some such holes in apples, since the curculio does not attack the seed. 


\section{REM EIIES.}

REMEDY NO. 1.

To mix sulphur with whale oil soap or home made soft soap:

Boil the sulphur in water for ten or fifteen minutes (if concentrated lye or other formulas are to be aldded they should be dissolved in water and added when the sulphur and water are boiled the required time, and allowed to hoil for five minutes); then add the suap.

Example.-To mix $10 \mathrm{lbs}$ of whale vil soap, 3 lbs of sulphur and $1 \mathrm{lb}$. of No. 11. or 12 , or 13 in 18 gallons of water. Boil say four gallons of water; then add the sulphur and boil ten or fifteen minutes (the lye compound, Nos. 11, 12 or 1:3, should be dissolved in one gallon of water), then add the lye and boil for five minutes. The soap is then added and allowed to boil five minutes. When the mixture is boiled together as directed, it may be plaeed in a barrel, thirteen gallons of water arlded, and it is then ready for use. It should be applied to the trees at a temperature of $130^{\circ}$ Fahrenheit.

All mixtures with sulphur should be made at least one reek before using; the longer it is kept the more fetid it becomes-therefore, the more cfficient.

REMLDY NO, 2.

C'oncentrated lye (Ameriean Lye C'o. brand). The following analysis is given ly Prof. Ililgard, of the state Lniversity of California: Caustic potash. S.3; caustic soda and some carbonate of soda. 91.7-100.0. Taking the eoncentrated lỵe as a basis, one pound of the alove brand dissolved in one grallon of water (tested by an alkalimeter for heary liquids) 
gives: density, 1074; alkalimeter, 10 . Cost per case of 48 lbs., $\$ 4.50$, or about $9 \frac{1}{3}$ cents per pound.

Cost of caustic soda (English), in drums, $5 \frac{1}{2}$ cents per pound; commercial potash, in drums, 9 cents per pound.

\section{Formula No. 1.}

One pound of caustic soda (Eng.)

Two ounces of commercial potash ( $\frac{1}{8}$ pound).

Dissolved in one gallon of water (tested with the alkalimeter, as above): (lensity, 1090 ; alkalimeter, 12.

This formula produces a solution of a higher density than the concentrated, lye at a cost of

$42 \frac{2}{3}$ pounds of caustic soda, at $5 \frac{1}{2}$ cts., $\$ 2.35$.

$5 \frac{1}{3}$ pounds of commercial potash, at 9 cts., .48-Total, $\$ 2.83$. (Less than six cents per pound.)

\section{Formula No. 2.}

One pound of caustic soda (Eng.)

Four ounces commercial potash ( $\frac{1}{4}$ pound).

Dissolved in one gallon of water (tested with alkalimeter as above) : density, 1094; alkalimeter, $12 \frac{1}{2}$.

$38 \frac{1}{2}$ pounds caustic soda (Eng.) at 5 cts., $\$ 2.12$.

$9 \frac{1}{2}$ pounds commercial potash, at 9 cts., $.85 \frac{1}{2}-\$ 2.97 \frac{1}{2}$. (Less than $6 \frac{1}{4}$ cts. per pound.)

This formula produces a solution of a higher density than either of the above, and is not only a superior insecticide, but a richer source of fertilization for the tree.

Note.-The data from the alkalimeter is merely given to show the difference in density as indicated by one instrument.

To dissolve the above material thoronghly the time required is about forty-eight hours; use boiling water. To make a certain quantity of No. 12, one ninth of the total weight of material required is potash and eight ninths caustic soda.

Example.-To make forty-five gallons of solution No. 12 (one pound to each gallon of water) it requires forty-five pounds of material (i. e., caustic soda and potash); $\frac{1}{9}$ of 45 pounds equals 5 pounds of potash; $\frac{8}{9}$ of 45 pounds equals 40 pounds, giving 5 pounds potash and 40 pounds caustic soda in 45 pounds of the mixture. 
To make 4.) pounds of No. 1:), one fifth of the total weight should be potash and four fifths caustic soda.

Example.- $\frac{1}{5}$ of t.5 pounds equals 9 pounds ; $\frac{4}{5}$ of 45 pounds equals 36 pounds, giving ! pounds of potash and 36 pounds of caustie soda in 45 pounds of the mixture.

As many fruit-growers are not acquainted with the use of the alkalinteter, and mistakes are liable to occur in the use of the alkaline solutions, I recommend the following simple test which will at least be a partial protection against the use of solutions of sufficient density to injure the tree. or, on the contrary, deficient in density to give the result required:

Fig. 375.

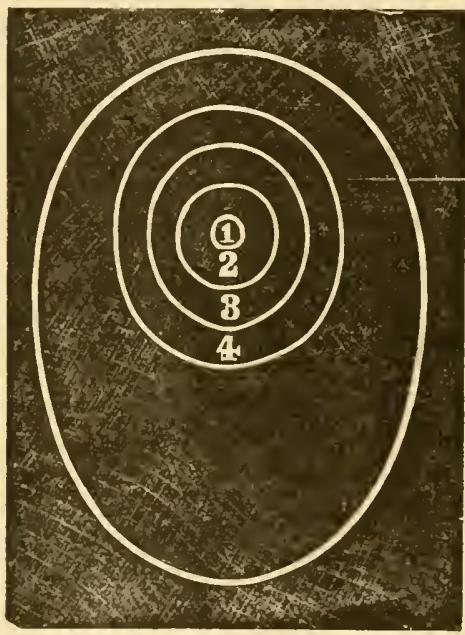

Fig. 375 represents an egre (hen's egg). The circular lines marked $1,2,3$ and $\&$ are intended to show galuges of density of the solutions.

In all cases the solution must be thoroughly stivited fiom the bottom of the vesset in erhich it is rlissolect. beforr testimy or treking ancely any portion of it to use on tireses, etr.

When the mixture is thoroughly dissolved, stir woll, and then test the density hy plaring in the solution the hen's egg. (In all tests of this

kind the egrg used should not be more than twenty-four hours laicl: and as near to a globular form as possible.) If the surface of the egg above the solution is more than the size of No. 4. the solution is too strong for use. This ean be reduced to $3 \frac{1}{2}$ by adding water. If the surface of the egg alove the solution is equal to No. $3 \frac{1}{2}$ it is just the right strength, and equal to Remedy No. 12. If the surface of the egg above the solution is the size of No. 23 , it is equal to liemedy No. 11. If the cag just floats or shows a speck above the solution the size of No. $1 \frac{1}{2}$, it is equal to one pound of liemedy No. 12 to $1 \frac{1}{4}$ galloms of water. In lye made from wood ashes the egg will just Hoat in a solution equal to one pound of lye to one and one quarter 
gallons of water. Space above water equal to $3 \frac{1}{2}$ represents one pound of lye to each gallon of water.

The above tests should be made with the solution at a temperature of $60^{\circ}$ Fahrenheit. Should any fruit grower wish to get an alkalimeter, I will have one that is properly adjusted forwarded to him on receipt of one dollar.

\section{REMEDY NO, 3.}

Home male soft soap, made with lye leached from wood ashes. One pound to each gallon of water used. Apply at a temperature of $130^{\circ} \mathrm{Fahr}$.

Note 1.-To mix with sulphur see No. 1.

NotE 2.-In making soft soap, if one ounce of glycerine is added to each gallon of soap, it will make an excellent inserticide.

\section{REIEDI' NO. 4.}

Whate oil soap (resirlue from bleaching whale oil and sold by Allyne \& White, Nos. 112 and 114 Front street, San Franciseo, in barrels, about $3 \frac{1}{2}$ cents or 4 cents per pound), one pound to each gallon of water used. Apply at a temperature of $130^{\circ}$ Falir.

Note.-See Chapter IX.

\section{REMEDY NO. 5.}

One pound of whale oil soap and $\frac{1}{3}$ of a pound of sulphur; mix as directed in Remedy No. 1. One pound of this mixture to each gallon of water used. Apply at a temperature of $130^{\circ}$ Fahr.

Note 1.-The weight of the soap and sulphur used in making this solution must be added together in computing the quantity of water required.

Note 2.-To procure genuine whale oil soap, see Remedy No. 4. 


\section{RENEIM NO. 6.}

One pound of whale vil soalp; one third of a pound of sulphur; one and one half ounces of Nos. 11 and 12; mix as deseribed in Remedy No. 1. One pound of this mixture to each gallon of water used, and apply at a temperature of $130^{\circ} \mathrm{Fahr}$.

see notes in No. $\overline{.}$.

\section{REMEDY NO. -}

One pound of the whale vil soap and sulphur mixture to each gallon of water used. (This mixture is manufactured and for sale by Allyne \& White, Nos. 112 and 114 Front street, SanFrancis co.) Apply at a temperature of $130^{\circ}$ Fahr.

\section{REMEDY NO. S.}

One pound of whale oil and parafline soap to two grallons of water. Spray thoroughly. (Manufactured and sold by Allyne di White, Nos. 112 and 114 Front street, San Francisco.)

Nore.-Paraffine can be substituted for coal oil in Remedy No. 4 ; see also No. 77 .

\section{REMEDY NO. Y.}

Boil thirty pounds of tobaceo leares in thirty gallons of water, and apply at a temperature of $130^{\circ}$ Fahr.

Note-Every fruit-grower should grow a small pateh of tobateco upon his premises. Mr. Ellwoud Cooper, of santa Barbara, grows all the tobaceo he requires for insecticiles. at al cost of about two eents per pound. Refuse tobaceo ean be bought at eigar manufactories, or nicotine of tohaceo at Leibes Bros. Nos. 14 and 16 Fremont street, near Market. San Francisco.

See Remedy No. 123. 


\section{REMEDY NO. 10.}

Boil six pounds of arsenic in sixty gallons of water (or one pound of arsenic to ten gallons of water) until the arsenic is dissolved; when ready to use, add ninety gallons of water, making one hundred and fifty gallons in all, or one pound of arsenic to twenty-five gallons of water. (Spray the foliage.) One or two pounds of potash dissolved and boiled in water before putting in the arsenie, will make the arsenic dissolve quicker. For every one pound of potash used, five gallons of water can be added.

Note.-In cases where trees or vines are seriously infested by canker-worms, beetles, etc., and the prospects of a crop ruined, use No. 10, or No. 89 . Thorough spraying will effectually destroy them. Care should be taken that this application should not be put on trees that the fruit is to be used for food in any way, as it is dangerous to those eating the fruit. Only use this remedy when all other means fail. See Remedies No. 22 and No. 123. Great care should be taken to keep children away from where this solution is prepared or used.

See Remedy No. 123.

\section{REMEDY NO. 11.}

One pound of American concentrated lye to each gallon of water used.

See Remedy No. 2.

\section{REMEDY NO. 12.}

One pound of caustic soda (Eng. brand) and two ounces of common potash.

Note.-The weight of caustic soda and potash used in making this solution must be added together in computing the quantity of water required.

See Remedy No. 2, directions for preparing solutions, and No. 123; or lye made from wool ashes; should be boiled until it will float a hen's egg when cool. If the surface of the shell 
above the liquid is of a larger size than a silver three cent piece, or ring No. 2, Fig. 37.5, reduce with water to that gauge; then add one quart of water for every three quarts of lyo; apply to trees when dormant. ('This equals No. 12).

\section{REMEDY NO. 13.}

One pound of caustic sorla (Eng. brind) and four ounces of commion potash. (See note No. 12.)

See Remedy No. 2, directions for preparing solutions, and No. 123.

\section{REMEDI NO. 14.}

[Remedy for cottony grape scale, No. 14 should be No.11.]

Where the eaterpillars infesting trees or vines are large (two and a half inches in length and upwarels) and do not live in colonies, they can readily be destroyed by cutting in two with a pair of seissors. This is preferable to hand-picking.

Sce Remedy No. 100 and No. 101.

\section{REMEDY NO. 15.}

All parings and other debris marle ly preparing apples, pears, ete, for drying, should be scalded or hurned so as to dertroy the larve they contain.

See Remedy No. 16.

REIEEDY NO. 16.

Early in Winter, destroy by burning or scalding, all peach pits, aprieot pits, ete. also the pearings, ete., left from drying fruit that has acemulated around the orchard and storehouses, as the larvir hilhernate in such material.

see Remedy No. 15. 


\section{REMEDT NO. 17.}

In store-rooms, packing-rooms, etc, infested by the driedfruit moths, put shelves across the windows and dust them over with buhach; renew the powder at least every second day, but better results will be obtained by renewing it daily.

\section{REMEDY NO. 18.}

For cleaning rlried fruit infested by the larve of the driedfruit moth, various methods are used; some place the fruit in ovens, others scald it. A practical plan user by extensive lealers, especially when the infested fruit is in sacks or boxes that are not moth-proof, is as follows: A rylinder about twelve feet in length, constructed of two circular ends eighteen inches in diameter, on which are nailed strips of wood twelve feet long, two inches wide and nearly one inch thick; between the strips an opening of about three eights of an inch is left (the openings at the lower end are large enough to let the fruit pass through). The cylinder is placed on a frame, one end of which is a few inches lower than the other end ; it rests on a central shaft, to one end of which is attached a crank, by which the cylinder is turned around. The fruit is placed in the cylinder through an opening at the higher end; by turning the eylinder the worms (larva) are shaken out of the fruit and fall through the openings between the slats. The exerements and webs of the worms is also cleaned off of the fruit. All larve taken out of fruit in this way should be destroyed by scalding, or otherwise.

\section{REMEDY NO. 19.}

Ten pounds of fine sulphur and one pound of buhach; mix thoroughly and apply with a sulphur duster after sunset. Or if the vines are not in bearing, and the attack is not of a serious nature, use No. 103, or No. 10, or No. 89. Read No. 123 carefully.

Note.-The sulphur, if applied with buhach, will prevent mildew. 


\section{REMEDY NO. 20.}

In orchards, vineyards, vegetable gardens, etc., grasses, weeds, and rubbish of every kind, including fallen leaves, should be carefully gathered off of the ground from around fences and buildings and burned early in the Fall, thus depriving the insects of a shelter wherein to hibernate; and the ground should be kept entirely clean of weeds, such as purslane, etc., in the Spring and Summer seasons. All grasses and weeds growing on the banks of sloughs, water ditches, ete., in or around orehards, vincyards, etc., should be burned, or otherwise destroyed.

See Remedy No. 32, A and B.

\section{REMEDY NO. 21.}

A smooth bark, free from moss, ete., on fruit trees, grapevines, ete, is an imperative necessity in a warfare against insect pests. This can be effected by scraping and llring alkaline washes, such as Nos. 11, 12 or 13 , when the tree is dormant; or Nos. 3, 4, 5, 6 or 7 in Summer. In all cases the scrapings should be burned.

Read Remedies Nos. 35, 123 and 124 carefully.

\section{REMEDY NO. 22.}

Early in the month of Oetober wrap a band of thick paper (the thickness of merlium lubilding paper), from six to (eight inches wide, around the base of the trunk of the tree close to the ground, and fasten by a piece of baling rope passed around about the center of the band: gather or mound the earth around the band below the rope. This is to prevent the wingless female from depositing her eggs on the tree, under or below the band. Take some roal tar and spread on the upper part of the hand, ahore the rope-two inches wide is sufficient. A little castor oil mixed in the tar will prevent it from hardening as rapidily as if only tar is used. The tar should 
be renewed every two or three lays, as it is necessaly to keep it moist to prevent the females from passing over it. Such of the females as will not go near the tar, and are prevented from getting to the tree under the band, will deposit their eggs on the hand. The bands should be kept on the trees until the apple trees begin to put forth their leaves, and should then he taken off and hurned, ropes inchuded.

Notw.-There are at least three species of canker worms in orchards at the present time, and as the natural history of all the species as regards dates of energing from the ground is not known, it is the safest plan to put on the bands early in the season. Should the caterpillars appear on the trees, spray thoroughly with No. 64 ; at the same time it would be well to experiment with Nos. 83 and 85.

See Nos. 10, S9 and 10\%. Read No. 123 carefully.

\section{REMEDY NO. 23.}

Put around the tree, about two feet from the ground, a band of cloth, such as muslin butter eloth; cover with tallow after it is placed on the tree, and put some lard over the tallow; the lard will keep soft and prevent caterpillars from passing over it. When the caterpillars are swept off the tree they will creep up the trunk again until they reach the greased band; they gather below the bancls in large numbers, and can then be destroyed by the use of clubs, etc.

See Chapter XXXIII. Read Remedies No. 35 and 124 carefully.

Note.-The caterpillars are swept off the branches with brooms.

\section{PENEDY NO. 24.}

A large number of varieties of decidnous fruit trees, vines and plants are liable to be infested by the caterpillars of various species of moths, commonly known as "leaf-rollers." An excellent remedy for preventing the spread of these pests is to pick off the rolled leares as soon as noticed, and destroy them 
by burning or wherwise. This can le profitably done on young trees and nursery stock. In some cases the insect fastens the leaf to the branches, and hibernates in them throughout the Winter. All such nests shonld be gathered off the trees in the Winter seasom, and bumerl.

Read Remedies Nos. 35 and 124 carefully.

\section{REMEDY N(). 2.).}

C'ut off' and hurn all branches showing punctures, swellings. ete., on rines, branches of trees. or stalks of any plant infested by larve, grubs, or beetles. This muning, combined with Remedy No. 20, will prevent the sprearl of varous species of insects.

See Remedies Nos. 26, 27, 60, fif and 67.

\section{REDEDT NO. 26 .}

Twig or loranch pruning. Twigs and branches of peach. aprieot, blackberry, raspberry, "urrant, ete., infested by the larve of moths or grubs of beetles boring into the new growth. cam be readily detected by their withered appearance, and should be cut off and burned or otherwise disposed of; in this mamer the larvie or gruls are destroyed.

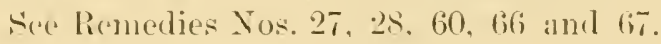

\section{RENEDY N().}

Branches and twigs of apple, apuricot, peach, pear and olive trese, graperines, ete. infesterl by the hurrowing hertles. or twig-horers, $I$. ennfertus and $B$. bicuedetur, should be ent oft and humed. Great care should be taken to capture the beetles. lomember, in these suecies it is the perfect inseet that attarks the trees.

see Remedies Nos. 25, 26, 28, 60, 66 and 6 . 


\section{REMEDY NO. 28.}

Branches and twigs of apple, ahnond, apricot, plume ote. infested by the eggs of the buftalo tree-hopper, or tree-crickets. or Cicadas, should be well cut out in pruning and the prunings burned, and while the tree is dormant, thoroughly spray with No. 12 or 13 -one pound to each gallon of water. In this manner many of the eggs will be destroyed. Early in July the branches should be sprayed with No. 5 or 7 , to prevent the female from depositing her eggs therein. No. 4 is also very effective.

See Remedies Nos. 25, 26, 27, 60, 66 and 67 .

\section{REMEDY NO. 29.}

The eggs of certain species of moths are laid in rings encircling the new growth or branches; in some species (as Fig. 54) they partly encircle the branch. These rings of eggrs are generally found on the branches of trees infested by the caterpillars of the moths the previous Spring.

To prevent the spread of such pests, immediately after the foliage has fallen off the trees the egg-rings should be collected and destroyed by pouring boiling water on them or by burning them. This work, if thoroughly done, will well repay the fruit-grower. (See (hapter XXXIII.) This also includes the eggs of the katy-did. (Chapter CXVIII.)

\section{REMEDT NO. 30.}

The egg-clusters of the tussock moth are generally found on the top of cocoons from which the wingless females emerged, and can readily be gathered and destroyed by burning, ete. The cocoons are found in the crotches and indents of trees infested by the caterpillars the previous Summer. 


\section{REMEDY NO. 31.}

The nests of the tent caterpillars may be destroved by holding a torch under them at a certinin time of day when the caterpillars are not feeding, and are gathered in their tent or nest; in this way the whole colony of caterpillars can be readily destroyerl. A torch such as is user in torehlight processions is excellent for this work.

See Remedy No. 29, and read Lo. 35 and No. 124.

\section{REMEDY NO. 32.}

For effective work the warfare against the graperine-hoppers should he commeneed early in the Fall season:

A.-By taking or scraping off all of the loose bark and thoroughly spraying the trunk of the vine with Remedy No. 51, or 6t, or 6.5; this will dislodge and destroy the insects and at the same time destroy the fungus spores on the vine. As soon as this work is done, a flock of sherp should be placed in the vineyard to eat the fallen leaves and keep (lown the growth of alfilaria and grasses upon which the insects, such as may escape. will feed on wam days. Cirasses and weeds around fences, ete, should be destroyed hy burning or otherwise.

B.-The vines should the reaned as rirected in section A. If sheep cannot be procured, the leares should be raked in rows between the vines, that the vine-hoplers may lodge in them. When the leaves are perfectly dry, apply fire to the rows in places not more than eight or ten feet apart. Before lighting the fires the vines should be jarred, and the vine-hoppers around them drove into the dry leares. This method is rery eflective.

See Remedies Nos, 20, 33: and 106, 1 .

\section{REMEDI NO. 3̈.}

Mr. R. B. Blowers, of Woodland, Yolo County, California. hats suereederl in conquering the vine-hoppers this season, and kindly furnishes me with the following information : 
"The mixture is as follows: In a fifty gallon barrel put thirty pounds of whale oil soap and fifteen pounds sulphur, and mix it up thoroughly. Then add water until the barrel is nearly full, and allow it to remain one day without anything else being done to it, except stirring it two or three times. The object of this is to allow the ingredients to he eompletely blended together, so as to form one homogeneous mixture. The next day take three pailfuls of this mixture and six of water, or in that proportion, until a barrel is filled containing forty or forty-five gallons. Then just previous to using add three cuarters of a pound of buhach, and mix it thoroughly. After the addition of the buhach it should to be applied immediately. The best mamer of conveying it to the vineyard is to place a barrel of it on a sled, so that it will not slop over. Apply this mixture to the vines with a fountain spray pump. Two men are necessary to do this successfully; one man with a spray pump on each side of the vine. The men should stand about six feet from the vine when making the application, and they should both apply the spray at the same moment. If they do not both make the application to the vine at the same moment, the insects may some of them escape on the upposite side of the vine from where the spray is applied. This is eertain to destroy ninety eight per cent of the insects of any and every variety that may trouble vines or fruits or flowers."

A few days later Mr. Blowers wrote me as follows:

"Woodhand, June 3d, 1883.

"Dkar Sir: The vine-hoppers were so plentiful this Spring that they destroyed many of the leaves on my vines before they were half-grown. Had I depended on my destroying the eggs and young hoppers, my entire crop would have been ruined. The cold weather being favorable, I commenced the work of spraying as I wrote you in my last. The buhach retained its power longer as the solution did not dry so rapidly, the vines being small. I did not get over my entire vineyard before the warm weather came, and I found it necessary to stop spraying, as the sun would burn the leaves.

"The balance I have given a heavy dose of powdered 
sulphur and huhach to kill the old hoppers, but sulphur effertually destrors the eggs; the buhach is death to the young hoppers. All insects yielded to the effect of the suray, the sphinx moth ( $P$. achemon) included. Yours, ete.

"R. B. BLOWERS.

"P. S.-The vinevard never looked better."

I prefer mixing the whale-oil soap and sulphur, as in Remerly No. 1.

\section{REMEDY NO. 34.}

An effective way of destroying red and yellow spirlers (or mites) is to spray the foliage of the tree or vine thoroughly with No. 5 or No. 7 , one pound to each five quarts, or one galllon and one yuarter of water used; add one gallon of Xo. ? to every dight gallons as soon as the mites appear on the leaves. The spraying should be repeated as often ats they alplear on the foliage.

In "ases where the tree or vine is bearing tender fruits, these jests can be prevented from spreading by thoroughly drenching the foliage with water.

Either of the ahove can be applied to nursery stodk infested lye red or yellow spiders (mites). When the tree is dormant use No. $s$ or $4 t$ on the ova, and follow in twenty-four hours with No. 13.

See Remedies No. 9 (in relation to tobaceo), and also No. 20.

\section{REMIE])Y N(), 3ร้.}

a.- 400 poumis of bone elust.

h. - io pounds of commercial potash.

(c- - T5 pounds of new lime (mslacked).

A.- Arlt to the potash just enough of water to liquify it (at first one half gallon to ten pounds of potash, then arld as reyuired for forty-eight hours).

B.- Tse just enough water to slack the line.

('- - Prepare enough of barrels or hins to hold the whole jej) jummls. 
D. - Spread the bone dust on the floor.

E.-Dampen the bone dust thoroughly with the liquid potash, but be careful not to wet any part of it so that it will calke (which spoils it); when thoroughly mixed, fill in barrels, etc., leaving ahout six inches on the top of each package to fill with the lime.

F.-Let it remain in the harrels for ten days, then spread it on the ground around the vines or trees, say four hundred pounds per acre.

The above material, prepared as above described, makes an excellent fertilizer. Where a large quantity is required, it can be prepared in large bins.

(i.- Use from 3.50 pounds to 500 pounds per acre, and even 1,000 pounds if the vines or trees are seriously infested.

H.-The combination of the potash and bone-dust produces ammonia, which is absorbed by the lime placed on top.

I.-Fruit trees that have been infested by scale insucts, woolly-aphis, ete., can be greatly improved by the use of this fertilizer.

\section{Wrod Ashes.}

J.-Fruit-growers residing in the vicinity of any town or (ity, or any place where wood ashes can be secured at a nominal cost, should collect every bushel available. The ashes should be thoroughly dampened and mixed with an equal quantity of bone-dust (bushel for bushel when dry), then placed about three feet deep in a bin, or enclosure of some kind, having the sides and bottom tight; spread on top from four to six inches of fresh slacked lime.

K.-If necessary, another layer of bone-dnst and ashes, and one of lime, may be placed on top of the first layers.

L.-Let it remain for three weeks, and an excellent fertilizer will be olstained.

II.-Apply on orehard or vineyurd grounds when thoroughly mixed.

Note.-In Sacramento several hundred bushels of ashes are wasted daily, which could be collected at a very trifling cost. Remember, the ashes should not be allowerl to get wet before being gathered, as it then becomes partly leached, thus impairing its value. 


\section{Stable dranure.}

As th the effect of stable manure, it may be approximated as regards its utility as a fertilizer for orehard or vineyard purposes. In some of the best authorities I find that one ton of stable manure contains ahout four pounds of phosphoric acid, eight to nine pounds of potash, and about eight pounds of nitrogen (ammonia and nitric acid). Stable manure for agricultural purpose is excellent, but for orehard or vincyard purposes it is reficient in restoring the ash constituents so much required by the trees. (See Remedy No. 124.)

I have briefly mentioned the available fertilizers, and the necessity of their application to many of the orchards and vineyards, especially those planted in California in what is termed the "early days."

To restore the producing power of exhausterl lands, to strengthen and increase the growth of young orrehards and vineyards that are backward in producing a good growth, to produce the highest rield from each and every acre planted.

Read No. 123 and No. 124.

\section{REMEDY NO. 36 .}

Early in the Spring, or as soon as the insects apperar on the plants or vines, place loose straw, hay, or wther like material, around or under plants or vines so that the insects can take shelter at nitht: in the morning before sumrise remove the material laid down and burn it.

I recommended this for the destruction of the filse whinch hug on grapurines. The vine owner reporterl sucerss. but he sprinkled some coal oil on some stral which he plased on the ground under the straw taken from around the vines, and in this way prevented the insects from escaping into the ground while the straw was burning, making the application a eomplete success.

Clean cultivation.- See No. 20 and No. 106, A.

Raad No. 35, No. 123, and No. 124. 


\section{REMEDY NO. 37 .}

In all cases for preventing the spread of borers in fruit, ornamental or forest trees, the coating of the trunk and larger limbs with soft soap, common bar soap, or whale oil soap and sulphur, will prevent the female from depositing her eggs on the parts thus treated. Two pounds of soap to each gallon of water used; apply with a brush.

Trees infested with the larva or grulss of borers, the burrows should be searched for, and when found a wire should be forced into the burrow, and in this way destroy the larva or grub.

Wounds or sunburned patches on the bark of trees should be dressed with some of the above soalps as soon as noticed.

Note.-Some persons cut out the grubs with a knife; such a method is not safe for the tree.

See No. 60, for borers in branches.

\section{REMEDY NO. 38.}

A.-Spread a sheet or eloth under the tree at night, when the beetles are feeding; by shaking the tree the beetles will fall off, and can then be gathered off of the sheet or eloth and destroyed. Some assert that early morning is the best time, as the beetles are not inclined so much to fly. See Remerly No. 102.

B.-For such beetles as feed upon the foliage in daytime, the spreading of the sheet under the tree and shaking should either be dlone after sumrise, or about noon. If the beetles in either instance are numerous, dipping the sheet in coal oil will destroy such beetles as may fall upon it.

\section{REMEDY NO. 39.}

Early in the Fall season dig a trench around the tree, uncovering the roots; in the trench put two or three shovelfuls of new lime if the tree is large, and less in proportion to smaller 
trues; add enough water to slack the lime, and cover up with earth. The Winter rains will convey the lime around the roots, and destroy the woolly aphis living upon them. Woorl ashes and lime mixed together make an excellent application applierl as above.

See Remerlies Nos. 40, 41, 42, 4:3, 45 and 58 .

\section{REILEY NO. 40.}

Early in the Fall season dig a trench around the tree and place in it drierl tohaceo leaver; wet the leaves with a solntion consisting of one pound of saltpetre, dissolverl in three gallons of water, and then cover the leaves with earth; the Winter rains will earry the tobaceo water around the roots and rlestroy the lice. Chimney soot makes an excellent mixture with the tobaces and saltpetre.

See Remedies No. 9, in relation to tobneco: Nos. 39. $41,42$. 48,45 and 5.5 . Read No, 47.

\section{REMEDY NO. $\$ 1$}

In a trench around the tree pour water heated to a temperature of 130 degrees, in which is dissolved one pound of No. 12 or 13 to earle gallon of water used. (Nos. 39 and fo are preferable to this.

It is relamed that hot water $\left.(s a y) 130^{\circ}\right)$ poured arromel the roots. produce good results, but my expreriments in using it did not warrant any recommendatiom.

See Remerly No. 98.

\section{RENEI)Y N(). 42.}

Two pounds of home made soft soap to one and one half gaflons of water poured around the roots of nursery stock (young apple trees), destroyed the woolly aphis, the earth being first reaned atway from the trees.

The roots of roung apple trees should he dipperl in one of the above solutions before planting.

siee No. ti and No. ist. 


\section{REMEI)Y NO. 43.}

Early in February the tree should be thoroughly serapert, and the crotehes and erevices eleaned out, and the limbs and trunk thoroughly washed with No. 44, and if the trees have been infested by the apple-leaf aphis (Aphis mulifolia), wash the branches also; then, in twenty-four hours, wash or spray with No. 11 or 12, using one gallon of water to each one pound in weight of the mixture, or No. 13, one pound to each five quarts of water used.

See also Remedy No. 77.

\section{REMEDY NO. 44.}

Dissolve two ounces of borax in four gallons of water ; the borax may be dissolved in two quarts of water, and then add enough water to make four gallons. To this add one quart of any kind of animal oil (i. e., lard oil, neatsfoot oil, ete, but whale oil is preferable), and one quart of coal oil; stir up properly, and it is ready for use. See heading No. Th. Paraffine may be used instead of coal oil, but only the best grades of either should be used. See Remedy No. 44. Read Remedy No. 47 .

\section{REMEDY NO. 45.}

Young apple trees with roots infested by woolly aphis, should be dug up and burnerl, as they will not mature healthy trees. If you find any swellings or knotty exerescenees on the roots of nursery trees, do not buy them. See Remedy No. 47 .

\section{REMEDY NO. 46.}

Young peach trees having swellings on the roots, will not mature healthy trees. If sueh are offered at any price, no matter how low, do not buy them. See Remedy No. 47. 


\section{REMEDY NO. 47.}

The greatest care should be taken in procuring nursery stock that is not infested by wolly aphis, leaf aphis, scale insects, etc. In all cases, before planting, deciduous fruit trees should be dipperl in No. 11 or 12-one pound of the mixture to each one gallon of water used; or No. 13-one pound to each $1 \frac{1}{4}$ gallons of water userl. exrepting the roots, which should be dipped in No.5 or i-one pounel to each one gallon of water used. See Remedy No. 45.

\section{REIEIY NO. 48.}

To prevent the spread of the black scale, soft orange seale, red scale, cottony cushion scale, etc., on citrus trees, the branches should be thinned out, to give free aceess to light :mel air, and also to sive an opportunity for thoroughly spraying. All prunings taken from the infested trees should be immediately burned.

REAEDY NO. 49.

The best season for destroying scale insects on citrus and evergreen trees is when the roung larve are just hatehed, and are creeping over the fruit, foliage, ete. Then apply No. 5 or 7 , four pounds of the mixture to every five gallons of water used, excepting for red scalc, when one pound of the mixture to each gallon of watel used will be more effective. The sulphur is necessary for destroying the black smut or fungus. The application should be repeated when the second brosd of larve appears. Effective results have been obtained by using No. 4. Care should be taken not to spray the trees in rery warm weather, or in the heat of the day, as it may cautesome of the foliage and fruit to fill ofl. But to get rid of the pests some inconveniener must be experted. Aplyty the above solutions at a temperature of $1300^{\circ}$ Fahr.

See liemedy No. To. 


\section{RENEDY NO. 50.}

In January or February, make a strong brine of salt and water, and spray the trees thoroughly; repeat in two weeks. This will denude the trees of foliage, but will effectually destroy the red scale, etc. I have tried this, and found it an excellent remedy, and the tree threw ont a new growth of leaves. To every six gallons of brine add one gallon of No. 13. This is the only effectual remedy for mealy-bugs on citrus trees. As soon as the leaves have fallen, spray thoroughly with No. 4, 5 or 7 .

Read Remedy No. 52.

\section{REMEDY NO. 51.}

To thirty gallons of No. 9, add twenty pounds of No. 5 or $\bar{\tau}$, dissolved in twenty gallons of water. If convenient, add one half pound of buhach by stirring it in the solution immediately before application. If whale oil soap is not at hand, or cannot be had, strong home made soft soap will do. See Remedy No. 3. Spray thoroughly.

The application should be made and repeated when the young larve are moving. This remedy can be used to good effect in Winter, on the vine-hopper. See Remedy No. 33.

Note.-In any case where this remedy should fail, use No. 44 , or 77 , or 8 .

\section{REMEDY NO. 52.}

After spraying as directed in No. 51, a small trench should be dug around the tree and filled with fresh slacked lime, mixed with strong wood ashes, and allowed to remain uncovered to prevent the insects falling on the ground, and those under the surface of the ground from ascending the tree (the lime and ashes will also be useful as a fertilizer). 


\section{RlillED) NO. . .}

When the trees are dormant, spray thoroughly with No. 11 or 12, one pound of the mixture to each gallon of water used; or No. 13, one pound of the mixture to each five yuarts of water used.

Rearl Remerdy No. 12:3 carefully.

\section{RENIEIY NO. it.}

When the tree is in leaf use No. 6, four pounds of the mixture to ach five gallons of water used: spray thoroughly. This solution will not injure the foliage or fruit and will eflectmally lestroy mildew and young scale insects, and prevent the females of the codlin moth, curculios, etc. from depositing their eggs on the fruit. The spraying should be repeated in about two weeks. No.5 or 7 may be used, one pound to ach gallon of water.

Note-Pears on trees sprayed twice matured ten days earliur than the pears that were not sprayed in the same orchard.

see Remedy No. 69, E.

\section{REMEIOY N(), 5.).}

Varions remedies have been recommended for destroying wire worms. The following I consider the most pratctical, at least on farm lands in California:

A.-In cases where garden flowers and plants, regetable or grass-plots are infested, eut potatoes in two or more pieces. accorting to size, and cut wut the eyes to prevent them from growing. In each piece of potate stick a piece of lod or pointed stick; bury one or more pieces of protato near the roots of the infested plants, one or two inches below the surface of the ground. Examine every second day and destroy the larve or grubs eating the potato. This has been tried in this vicinity (Sacramento), and proved an exeellent remenly. A pateh of ground that was so badly infested hy wire-worms 
that lettuce could not be grown upon it, was cleaned in ten lays so that it yielded an exeellent crop this season (188:3).

For the protection of field crops, summer-fallow and clean out the weeds. Applications of salt, soot, etc., have been recommended, but probably the most praetieable for large tracts is as follows:

Dr. Fitch quoted an article from an English paper reporting the suceess of white mustard, which concluded as follows:

"I am therefore under strong persuasion that the wireworms may he sucessfully repelled and erudieated by carefully destroying all weeds and roots, and drilling white mustard seed, and keeping the ground clean by hoeing."

The writer also adds that after the mustard crop he raised the best crop of wheat he had in twenty-one years.

Some of our California farmers express a doubt in regard to sowing mustard, and stating their fears that the remedy would be as troublesome to get rid of as the disease. I am credibly informerl that sueh is not the fact.

The following is taken from the Special Report on WireWrorms, 1883, by Miss Eleanor A. Ormerod, F. M. S., Consulting Entomologist of the Royal Agricultural Society of England:

1. "It has been found by practical experience that the growing and plowing of white mustard will get rid of the wireworm."

The following recommendations are reported by Miss Ormerod :

"The use of mustard as a growing manure crop is not sufficiently resorted to.

"Charles Casweit, Peterborough."

2. "Mustard sown thickly and allowed to grow to a considerable height, and then plowed in, has been found to be a good preventive, and at the same time adding eonsiderably to the fertility of the land.

Right Hon. Earl of Porvis,

$$
\text { "Pel ADAM LEE." }
$$

3. "Found mustard a good preventive, and sometimes the only safe erop to sow where wire-worms prevailed.

"Right Hox. Yiscount Portulan, "Pel J. Forester." 
4. "For tillow after clearing. sow rape or mustard seed, about the end of July, and plow it under when about a foot or eighteen inches high.

Jn C'RAIfi."

5. " The wire-worm has been known to disappear after a crop' of white mustarl. of which ome lalf was eaten on the ground by sheep. Josel'h Pariet."

6. "I have no rloubt of mustard being a good remedy" where it can be applied so as to plowed under for the erop.

"F. R. Hulbert."

7. "White mustarl sown and allowed to stand until it comes into flower, is a very useful preparation-where plowed in and pressed-for all corn, and I think prevents the wireworm doing so much mischief. Josepil ADDisox."

S. "I have never known wire-worms troublesome after" mustard or retches.

II. LOCK BLAKE."

The following remedies are also discussed in this valuable report of Miss Omerod's :

Rolling and treading the land with sheep.

Salt and kainite.

Kainite.

Gas lime and alkali waste.

Gas tarwater.

Rape cake meal etc.

Hand-picking.

Application of sca-weed.

Rooks, etc.

The weight of testimony is in faror of mustard as a remedy, and it is probably the most practical for California.

REMEDY NO. 56 .

Burn the stubble and loose straw, and all the weeds and grasses in and aromel fields that were infested, and also the surrounding fields. The burning should be tone early in Autumn. This will apply to the joint-worm, wheat aphis, ete.

See Remedies Nos. 20 and 106, A. 


\section{REMEII No. T.}

Fifty pounds of serap iron thrown into a barrel eontaining thirty gallons of water, twenty-five pounels of No. 11, 12 or $1:$, and two pounds of sulphur, makes an excellent solution for application to trees that are not healthy from the presence of the scale inseets, gum disease, ete. This mixture should be allowed to stand fonrteen days, and be applied when the tree is dormant. When the barrel is emptied of the liquid, fill again with water, and ardd one half the amount of No. 11, 12 or 13 ; also of the sulphur. In fourteen days it will be ready for use. Lye leached from wood ashes is exeellent, but care should be taken that it is not applied too strong; test with the egg, carrying one and a half. See Remedy No. 2.

\section{REMEDY NO. .S.}

Dig the earth from around the roots of the vine or bush, and apply No. $4 \mathrm{or} 3$, four pounds of the mixture to each five gallons of water used; then fill the earth around the roots. This should be applied in May, when the eggs of the scale insects are hatching. If for woolly aphis, early in April.

See Remedy No. 59.

\section{REMEDT NO. 59.}

In Summer dig the earth from around the eollar of the tree, and apply No. 5 or 7 , one pound of the mixture to each gallon of water used; repeat every four days, until the bark begins to heal. If the tree is dormant, use No. 1:3, one pound of the mixture to each five quarts of water used. This will destroy any insect attacking the tree under the surface of the ground, and also heal the bark destroyed by insects, alkali, or from any other eause.

See Remedies Nos. 3.5, 123 and 124.. 


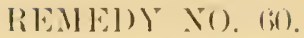

As soon at the stems are notioed hegrimning to wither, ent them out and destroy by burning. The currant bushes should be sprayed thoroughly in the spring. using No. is or 7 , one pound to each gallon of water wsed. The top of the roots should be thoroughly saturated. The spraying is to prevent the females from depositing their exgers on the woerl.

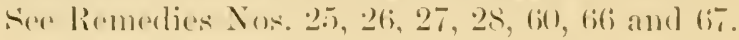

\section{REMLET)Y No. (i1.}

As soon as the larve appear on the leaves spray or thoronghly drench the foliage with No. 5 or 7 , four pounds of the mixture to each five gallons of water used ; add one pound of No. 11 or 12, dissolved in onc gallon of water, to each eight gallons of the former. The object is to destroy the caterpillars and the mhatehed exges. Or use No.t, one pound to earli five quarts of water used. See Nos. (ii:, (i2 and (6.5. Repeat the spraying as often as the larvar alperar.

Read Nos. 35, 123 and 124.

\section{RENETI NO (i.).}

If solutions eammot be realily prosured when the larve or caterpillats appear on the leaves, huild momels of sand or fine earth aromed the tree. Early in the morning shake the branches and the caterpillars will fall oft on the ground and atumot get to the tree over the momd. If material to make proper mounds is not convenient, fut on bands as recommendert in Remerly No. 2:?. ('This will not apply to the pearslug as regards the shaking.)

sire Remedy No. (ii). Read liemerly No, as.

REMENT NO. (6i:.

In case solutions camnot be hat when the slugs appear, finc dust of any kimb thown on them will perent their maturing. 
Sulphur and lime, mixed in the proportion of two pounds of slacked lime to one pound of sulphur, dusted on the foliage, is an excellent remerly, but disagreeable for application.

\section{REMEISY NO. (it.}

Use No. 5 or $\bar{\tau}$, one pound to each two gallons of water userl; or one pound of No. :3 or 4 to each one and one half gallons of water used. Mix in solution, when ready to use. one quarter of a pound of buhach to each ten gallons; application should be made in the cool of the evening; drench thoroughly. This is especially applicable to plant-lice (Aphis) on flowers and plants.

\section{REMEDY NO. 65.}

Use mixture No. 5 or 7 , one pound to each gallon of water used, and then add an equal quantity of No. 9; mix together and spray thoroughly. Apply at a temperature of $130^{\circ}$ Fahr.

See Remedy No. 61.

Note.-No. 6 may be used instead of No. 5 or 7 .

\section{REMEDY NO. 66.}

Cut out the infested canes early in the spring and destroy by burning before the beetles escape. Thorough pruning out of infested canes will be necessary to prevent the spread of the beetles, etc.

See Remedies Nos. 25, 26, 27, 28, 60 and 67.

\section{REMEDT NO. 67.}

Early in the Spring all branches of peach and other trees on which the buds are infested by larve or beetles, should be pruned out and immediately burned, and also all new growth showing signs of withering at the outer end, should be cut off 
amel humed. This should he done theroughly as the safety of the erope depenels on the destruction of the "arly bronds.

see liemelies Yos. 25, 26, 27, 25. lit) and riti.

\section{REMIEDY NO. 6R.}

Where the plants are seriously infesterl, dig ont all infested plants and burn them, and replace with plints not infested. (In this case "an ounce of prevention is worth a pound of cure.")

See liemedy No, 104.

\section{REMLET No, (i!)}

1. From observations it is evident that the destruction of this pest must he ansmmmated while it is in the caterpillar state.

It any time between the first day of Sorember and the first elay of March of each seasom, all thr atpjele. pear and yuinee trees, in any orehart infesterl hy coullin moth. should be carefully serapeel and all loose hark removed, as follows:

Fig. 376.

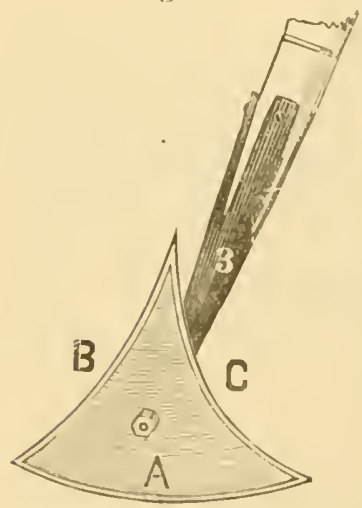

l'rovide sume small ship scralpers and grind two of the edges to al con(ave eurve (Fig. 30 ifi) so that they will fit the trunk of the tree better thath a straight edge can (1) and (', Fig. : 30 (6). forapers having a length of sille of four inches will he latre enough: use hamelles ter-uit. P'rexemere al eloth matele of olel salcks, or any material eonrenient: spreate on the ground aromel the tree as far as the seralpings are likely to fall; then commentere on the tree as far ul at there is any rough loose latrk. and scralpe it carefiully ofl:

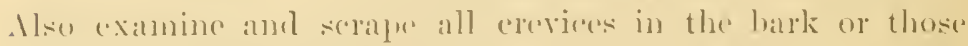
forment in the arotehes of the trees. Contime seraping until 
you reach the gromel. This done, gather the scrapings carefully off the cloth, so that they can bo burned or otherwise destroyed immediately.

Be careful that you do not neglect gathering arefully the scrapings and destroying them, as on this point depends a great deal of your success. By thus burning the debris taken from the trees the larvie hibernating in the debris are destroyed.

B. After having eompleted scraping oft the loose bark, the trunk and limbs should be thoroughly washer or sprayed (providing the tree is only treated against the rorllin moth). If the woolly aphis or scale insects are present, the whole tree should be sprayed with No. 11 or No. 12, one pound of either mixture to each gallon of water used. If properly alplied, this will destroy any larve on the tree, and also produce a new smooth bark. See No. 21 .

(C. Not later than the 10th of May, bands should be placed on the trees as follows:

(ut old grain sacks or cloth in strips from six to eight inches wide, and place a band on each tree near the ground. (It is expected that the rough bark has been scraped off' between the band and the ground). The fastening cord or wire should be as near the upper edge as possible, allowing the lower edge to spread out from the tree, saly a cuarter of an inch or so. Paper will do for bands, but eloth is preferable. Pieces of old sack, or rags, should be placed in the crotrhes. The larve, after leaving the fruit, when looking for a place in which to pass their transformations, will hicle under the bands on the trees, or the rags in the crotches, and make their cocoons or nests. The bands and material in the crotches should be examined every seventh day, without fail, and all the larvar found on them picked off and destroyed.

1). Note.--Notwithstanding the fact that recommendations have been made that it is not necessary to examine the bands, etc., every seventh day, the following fact womld secm to indicate otherwise; a larva which I canght changed to a pupa on the gsth of June, 1883, and the moth emerged from the pupa on July fith; length of time spent in the pupa state, less than eight days. 
E.- Ls son as the apples or pears are formed (say the size of marbles), spray the fruit and foliage with No. 6, four pounds of the mixture to each five gallons of water used; repeat the spraving within twenty days. This will prevent the moth from depositing her eggs on the young fruit, and also destroy mildew and invigorate the tree.

F. Note.-Infested fruit should be picked off of the tree and destroyed by boiling, or otherwise. Fruit falling off the trees should be gathered daily, and all that is infested desitroyed.

G.-The spraring should be repeated at regular intervals to protect late varicties of apples, pears, ete.

H.-By following the above directions in a thorough manner. the codlin moth's ravages need not be feared. Half done work will have but little effect.

See Remedy No. 5t.

\section{RENEDY NO. TO.}

All empty fruit parkages returned from market or used in shipping fruit in any manner, should be thoroughly disinfected before being taken to the orchard, by dipping in boiling water containing one pound of mixture No. 18, or one pound of commereial potash to each twenty gallons of water usedthe packiges to be left remaining in such solution at least two minutes. If only hoiling water is nsed, the prackage should be kept in it at least three minutes.

Note-The neresity for the disinfertion of return parkages is heyourl question. (sore ('happter IV.)

\section{REMEI)Y N(). 71 .}

Empty fruit packages lept in store from the previous year should be thorunghly disinfected before the 1st day of April. as recommencled for return parckinges.

see Renedy No. T(1. 


\section{REMEDY NO. T:2.}

Fruithouses, store-rooms, ete, in which fruit is stored. parcked or sold, should be thoroughly cleaned in the month of llarch of each year. In cases where they camnot be closed up, as described in Chapter XII, page 39, a solution should be made by saturing chloride of lime with eoal oil, all that it will take up, then thinning with water until it can be used with a brush. $A l l$ cracks, crevices, or seams in walls, skirtings, floors, ete., should be thoroughly saturated with this solution. This will penetrate the cocoons or nests, and effectually destroy the larve and pupe of the codlin moth.

see Remerly No. 75.

\section{REMEDY N(). T3.}

A. - A most effectual remedy to prevent cut-worms from ascending a tree is to fasten a piece of tin or zinc around the tree, just above the ground. It should be cut out in a cirenlar form, so that when placed on a tree it will be in the shape of an inverted funnel. The caterpillar annot areep over the smooth surface of the tin. If the tin is not perfectly smooth, it should be made wider.

B.-It is also an excellent trap to dig holes with perpendicular sides in the ground around the trees; the caterpillars falling into the holes cannot get out until captured. Holes made in the ground with a stick are sometimes used. They may also be captured in the manner recommented in Remedy No. 22.

(.-Cabbage leaves spreal around the roots of plants infested hy cut-worms are excellent trajs, as the pests take shelter under the leaves and do not enter the ground. By examing the leaves in the morning the pest ran be found and destroyed.

1).-I have been very suceessful in destroying eut-worms by dusting, or applying in solution, Paris green, or London purple, or arsenic, on the lower side of cabbage leaves placed on grounds infested by cut-worms, invariably finding all that had 
fed on the leaves dead. Where land is thoroughly cultivated, the cablage leaves spread over the ground, prepared as above, is an exeellent remedy; but great rare should be taken that poultry, ete., be kept off of the grounds treated in this manner. Poisons such as Paris green, London purple and arsenic should be used only when all other remedies fail, and then the greatest care should be taken to prevent any accident.

L.-Where plants are infested the eut-worm ean be found close to the plant, three or four inches below the surface of the ground. Early in the Spring, when the buds are opening, the cut-worms can be jarred off of the trees upon a slicet; about mirlnight is the best time for doing this.

see Remedy No. 38.

RENEDY NO. TH.

For destroying aphis (plant-lice) on cabluage plants, ete, rlust the plants with snuff-Geotele snuff is preferable-or dust with No. So, or spray with No. Si) or No. S.; or with No. j or 7 , one pound to each one and one half gallons of water used; or with No. 5 or 7 , as above directed, adrling an erpul pumtity of No. 9; mix well and apply. See No. (i.).

The spraying should be done in the erening, when the sun is near setting.

\section{REMEIY NO. 75.}

For cleaning granaries of weevil before sturing grain in then, use No. Fe freely, and then whitewash.

sie liemedy No. T:2.

\section{REMEI)Y NO. T(\%.}

A.-Grain in storehouses or granaries should be piled so as to allow a free circulation of air around the rows of sacks.

13.-It is erenerally coneeded that the grain weevil camnot breed if the temperature is kept in the building or storehouse lower than $65^{\circ}$ Fahrenheit. 
6.- Thorough ventilation is important, as I have reason to believe that at least part of the wheat is infested before it reaches the granary; therefore the necessity of preventing the eggs from hatching.

D.-Clean thoroughly, as directed in Remedy No. 75, and provide against a high temperature, and good results will follow.

E.-Grain kept in bulk should be turned orer occasionally by shoveling, to prevent becoming heated.

F.-Stored grain should be kept free from damp, and kept perfectly covered, to prevent becoming wet from rains, ete.

\section{REMEDY NO. 77.}

Coal oil or kerosene emulsions. Personally, I am opposed to the nse of mineral oils on trees or foliage, hut deem it proper to give Professor C. V. Riley's remedy for scale insects, known as the "Kerosene Emulsion," which he reports as giving excellent results. It is as follows:

"The process of forming a perfectly stable emulsion of kerosene and milk is comparable to that of ordinary butter-making, and is as follows: The oil and milk in any desired proportions are poured together and violently dashed or churned for a period of time varying with the temperature from fifteen to forty-five minutes. The churning, however, requires to be more violent than ean be effected with an ordinary butter churn.

"The Aquapult foree-pump (the (iregory pump will answer this purpose.-M. C.) niay be used satisfactorily for this purpose where moderate puantities are only required. The pump should be inserted in at tuh or pail containing the liquid, which are then forced into mion by continuous pumping back into the same receptacte through the flexible hose or spray-nozzle. * * * On continual chuming through the pumps, the liquid finally curdles and suddenty thickens, to form a white and glistening butter, perfeetly homogeneous in texture, and stable. This kerosene butter mixes rearlily in water, care being taken to thin it first with a small quantity of the liquid. * * 
At a temperature of $60^{\circ}$ the butter will be made in from thirty to forty-fire minutes. * * At $75^{\circ}$, in about fifteen minutes.

"The following proportions are recommended: 2 quarts of refinet kerosene: 1 (quart of fresh cow's milk (but sour). This will make an emulsion of kerosene $66 \frac{2}{3}$ jer cent, cow's milk 3:: $\frac{1}{3}$ fer eent. Where cow's milk is not readily obtained, eondensed milk cam le used. A cau of milk ats sold in stores contains about twelve fluid omees (three fourths of al pint). Kerosene, 2 puarts epuals + pints-bit per cent: condensed milk, 1 ean erfuals 3 pints, Water (domble the quantity of condenserl milk), 2 cans equals $1 \frac{1}{2}$ pints-36 per cent. In applications for scale insects on ritrus trees it should be userl at the rate of one part of butter to from twelve to sixteen parts of water, or, in other work, one part should be diluted with water fiom twelve to sixteen times."

sie Inited states Agricultural lieport for 1881 and 188:Jages 11:2 to $12 \pi$.

See liemedies Yos. s and 44.

\section{REMEDT No. TS.}

By dusting bonton purple aromed the stems of trees and plants so that eut-worms or caterpillars will have to pass over it; by lieking their feet they are poisoned. I have also found that it has the same eflect on beetles, where it gets upon their feet, antemne, ete.; by cleaning it off their feet, mandibles, ete.. it proisons them. Lumblon purple should not he used, in the summer season on fruts or regetables used for food, at least in California where there are no rains to wash it oft'.

fee Remedies Nos. 79 and $10: 3$.

\section{REMEUT N(). T!.}

Paris green, dusted around the struss of trees and plants, produce the sime eflects upon inserets, and the same oljections are oflered agalinst its nse in the summer season as Nos. Ts and 103 . 


\section{RENEDY NO. SO.}

Buhach is a powder made from the Hower of P'yiethrum cinerurixfolium. (Fig. 37T).

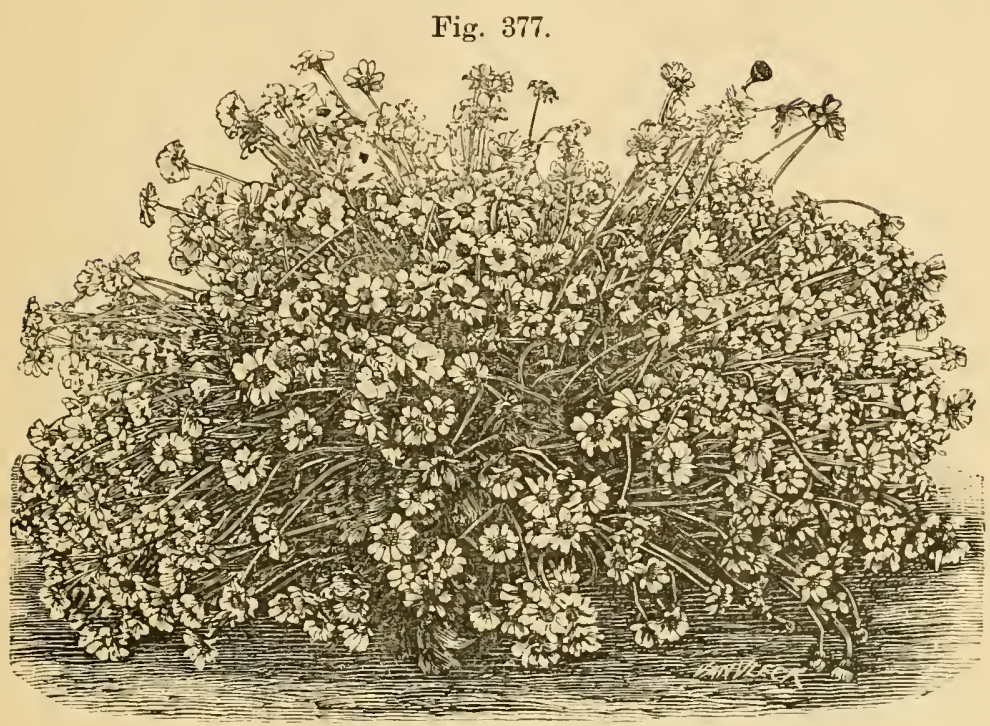

The experiments I have made with this powder, and the results obtained, have warranted me in reeommending its use in many cases, for destroying insect pests of the household, orchard, vineyards, etc., without fear of injury to any person or animal. The plants from which this porder is made are grown on the farm of the Buhach Manufacturing Company, of Stockton, California.

Letters addressed as above will be immediately answered, giving such information as may be required as to prices, ete.

See Remedies Nos. 81, 82, 83, 84, 85, 118 and 123.

\section{REMEDI NO. 81.}

Dry Buhach powder can be dusted around a room to destroy mosquitos, house flies, etc., by a small bellows. (Price, 25 ets.) 
It can also be applieel to plants infested by aphicles in the same mammer. Should it be reguirerl to he used extensively on the arounds, it shruld be thoroughly mixed, one pound of the buhach to five pounds of thour, and dusted as sulphur is applieel on grapes.

See liemerdies Nos. $80,82,8: 3,84,8.5,118$ and 123 .

\section{REMEDY NO. 82.}

For fumigating clothes, ete, infested by mothe, the buhach powder, or tobaceo, or sulphur burns freely. If the former, such as is sold in eans, ly wetting it, it hurns slowly; place the articles infested by moths in a tight box, or in al small. rose room. By fumigating with the buhach, or toluaceo, or sulphur, all insect life will be restroyed. Howerer. thorough application is necessary, as the larvir of heetles are not so easily destroyed as insects of more delicate structure. Place a fel pieces of burning (hareoal in a pau, and on them dust the huhach, tolaceo or sulphur as prepared, place in ajartment to be fumigated, and close up tight. This is also appli(abble to rooms infested hy mosupitoes, house flies. ete.

See Remerlies Yos. s(), s1, si, s4, s.) and $12 \%$.

\section{liEMEDY No. S:}

Mix the powrler in water, one ounce to cach one gallon of water used, and use immediately ; tor caterpillars, plant-lice. ete., intesting trees. plants or llowers, alply in the eroning, or in clouly weatlere. In many rases the solution should he strained through a cloth, so ats not to stain the Howers, ete.

see liemedies Nos. s(), s1, s.2, st. s. a and 12:3.

\section{likillil) N(), S.}

In a gallon of alcohol put six pounds of buhareh, and rork II) tightly; this can be diluted with from ten to twenty parts 
of water to one part of the mixture; apply with spraying nozzle. Strain if necessary. See No. s:'.

See lienedies Nos. $80,81,82,83,85$ and $12: 3$.

\section{REMEDY NO. 8.;.}

Professor Hilgard, of the State Lniversity of California, obtained satisfactory results from a tea, or decoction made by pouring boiling water upon the buhach flowers (not ground), and covering as in making tea, it being fomd that lowling is injurious to the strength of the liquid. For plant-lice, ete., use one pound of the tea to twenty-four gallons of water. For beetles, one pound to every ten gallons. Apply with spray nozzle. The powdered buhach can be used in this manner. Strain if necessary. See No. 83.

See Remedies Nos. $80,81,82,83,84$ and $12: 3$.

\section{REMEDY NO. S6.}

Dig a trench or ditch about twelve inches wide and twelve to fifteen inches deep between the invading army of worms and the fields to be protected, the side of the ditch next to the fields to be perpendicular, or dug under, if possible, to prevent the worms from creeping up. Every fifteen or twenty feet a deep hole should be dug in the bottom of the ditch, where the worms can collect. In these holes they can easily be destroyed by pouring coal oil on them, or dusting them with buhach, or placing straw in the ditch and setting fire to it. A little coal oil sprinkled on the straw will make it burn more readily. This plan proved effectual in this vicinity (Saclanento) in 1879. Effectual results were derived from plowing a furrow eight inches deep, and kept soft by dragging brush in it. But two or three furrows, some two or three feet apart, would be better, and the vegetation on the space between them dusted with Paris areen or London purple, one pound of either (the former is preferable) mixed in twenty pounds of coarse flour and dusted on the vegetation, or one tablespoonful of either 
mixer in a pail of water. 'This solution sprayed or sprinkled on regetation will poison the eaterpillars or worms eating it. These substances should be only used where there is no danger of poisoningstock, poultry, or other animals. On small patches of corm, ete., infested by the army-worm, No. 64 ean be used rffectually, by spraying.

\section{REIEIY NO. 87.}

Spread fresh-slacked lime, mixed with wood ashes, on the floor and around the pots and plants infested by these pestsslugs. They may be trapped by laying fresl eabbage and other leares aromel the roots of Howers and plants; the pests will feed upon them, and renain moler cover until examined early in the morning and destruyed. Plants have been protected from the ravages of snails and slugs, hy spreading fresh woodashe's on the gromel around the roots. No. T2 or 78 , or 79 spread on the gromel around the roots of plants, and also near the hiding places of the pests, will destroythem. Xo. T. is a sure remedy against slugs, ete.

\section{RENEDY NO. SS.}

Extract of buhach applied with a dropping tube or glassone ol two drops will destroy a small colony of insects, also the egrs. The extract should not be used on very tender leaves. This will effectually destroy mealy bugs in conservatories.

\section{RENEDY NO. S9.}

In places where plants, vines or trees are seriously infested, use one pound of arsenic perfeetly dissolved hy hoiling in ten gallons of water; then adel fifteen gallons of water, making twenty-fire gallons of water to each pound: or, see No. 10. Especially in relation to young graperines, one pound of whale oil soap dissolved in one gallon of water, and addesl to every ten gallons of the above will make the latter more effective.

see liemedies Nos. 79, 10:3, 112 and 12!). 


\section{REMEDY NO. 9O.}

As soon as the moths appear, or about the mildle of April, the contents of wardrobes, closets, etc, should be removed, carpets taken up, and tapestry, ete, remover and exposed to the air and sun for several hours, and then be thoroughly brushed and fumigated as directed in No. S2. In infesterl apartments all cracks or crevices in the floors and walls, in the wainscoting and shelving of closets, etc., should be brushed over with spirits of turpentine. Powdered black or careme pepler, or Scotch snuff; strewn uncler the edges of carpets, ete, will repel the moths. Sheets of paper saturated with turpentine, camphor in roarse powler, tobaceo leaves or smuff; are said to be an excellent preventive for placing anong eloths laid away for the summer, or articles not in use. Chests or closets made of cedar wood are said to afford a protection against clothes-moths, ete. Pieces of ceclar wood placed among elothing, ete, is also effective. Carpets that will not be used during the Summer, when taken up and thorough] cleaned, as directed, should be placed in boxes, and all seams or joints in the boxes pasted over with paper, to prevent the moths from entering. Cloth covering will do, if carefully folded, to prevent the moths from getting in through the folds. When carpets that cannot be taken up conveniently are infested, dampen it slightly with turpentine applierl with a sponge. This will leave a disagreeable odor for a short time, but will destroy the larve, ete. Fumigating as recommended in No. 82, will give excellent results.

\section{RENEDY NO. 91.}

In forty gallons of water boil fifty pounds of potash until dissolved; then add one hundred pounds of arsenic, and boil until dissolved; when rool, put in barrel and cork. To one gallon of this mixture add eight gallons of water, and sprinkle the infested hides, ete., with a broom. This will effectually lestroy all insect life upon hirles, ete.

see Remedy No. 12:3. 


\section{REIIEUY NO. 92.}

To each sixty gallons of water userl, artel twenty pounds of sulphur and five pounds of lime, as follows: When the water is boiling, add the resuired proportion of sulpliur ; let it boil for twenty-five minutes, then add the lime, and boil a short time.

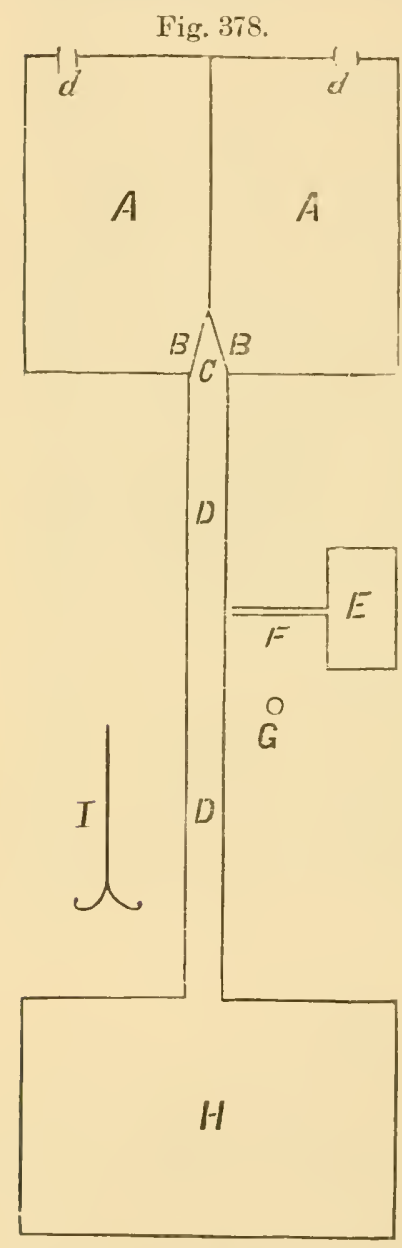

This water is emptied from the boiler or kettle (E, Fig. 37s, ) inte) the tank or trough, until sullicient is preprared to allow the sheep to float.

Fig. 37 is a plan of the arrangements used liy Messis. (iveren do Trainor, of sacramento, at their farm in Placer Comnty.

A 4 are two comals, 10 hy 1 ? feet, floored with tongue and arooved lumler, with fall to deain in center, allowing the wash dripping ofl of the shere alter elippring to drain into the clipping trough.

B b are gates to the corrals.

('. Brielge at encl of dipping trough over which the sheel' ('nter corrals.

1) 1). Dipping trough, is feet long by 2 feet wide and :s feret derel.

E. Boiler, of a capurity of four huncled gallons.

F. Pipe with finced leading to dipping trongh from boiler.

(i. P'ump to supply builer, ete.. with water.

H. Corral, 24 ly 20 feet, into which the shere are gathered before (lipping.

I. Pole, with onter-turned iron prongs, used for forring the sheep under the surface of the lignid when passing thromerh the trough, 1) 1). 
When the sheep are gathered in corral $H$, and the arrangements for dipping are completed, the sleep are forced into the trough, D D, (in which the liquid is twenty-seven inches in (lepth, and kept at at temperature of $80^{\circ} \mathrm{Fahr}$.) ; with the pole I, the animal is foreed under the surface of the licyuid. One of the gates $\mathrm{I}$ is open; the animal reaches the bridge $\mathrm{C}$ and enters the corral through the open gate; when this corral is filled with sheep the gate is closed and the gate of the other opened. During the time the second corral is being filled the sheep placed in the first are sufticiently dripped (or clear of the linuid), and are allowed to go to the pasture; thus the corrals are filled and emptied alternately. I great many sheep, can be dipped in a taly in this way. The supply of liquid and temperature is kept up by the boiler E. Two hundred and seventy-five pounds of sulphur and 70 pounds of lime will make sufficient wash for $4,0(n)$ sheep after the tank is filled at fir'st.

By covering the trough 1) D, the wash can be kept from one season to another.

If the above directions are complied with after each clipping, it is an effectual remedy for the scal.

It is not necessary to boil all the water required to make the solution.

This industry should be protected by legislation, by preventing infested flocks being driven from one section of the State to another, as beyond doubt the scab is spread to all sheep grazing on lands over which infested flocks are driven.

Such laws have been enacted in Australial, and have been of great benefit to sheep-raisers.

\section{REMEIT NO.}

Spirits of turpentine injected into the nostrils with a syringe, will effectually destroy the maggot of the sheep bot-fly; also, maggot in the cars or any part of the body. 


\section{REMEDY NO. 94.}

Placing Storkholn tar on the nose and inside the nostrils, will prevent the bot-fly from deprositing her ege or larva in the nose of the sheep).

\section{REMEIOY NO. 9.5.}

Place Ftockholm tar in the hottom of a trough to the depth of one inch, and cover with salt. In this way the tar gets on the nose and into the nostrils while the sheep is gathering the sitt.

\section{REMEI)Y NO. 9(i.}

Use No. 5 or 7, one pound of the mixture to each gallon of water used, and add one grallon of No.9 to each gallon of the solution used. See Remedy Xo. 5:2.

\section{REMEI) NO. 97.}

In all cases where caterpillars rongregate on a branch an effective remedy is to cut off the luanch and destroy the eaterpillars by hurning or otherwise.

\section{REMEIM NO.}

A.-Dounding. "In the suring, before the moth emerges (April), a bank of dirt about ane foot deep is thrown around the tree and pressed firmly about the trunk. Earch subsequent spring a little more anth is placed on the mound and pressed around the trunk as before. Mr. B. Pullen, of C'entralia, Illinois, states that they should not he momeded till after they are four years old, but examine them in April and September of rach vear previous to that age, and with a knife clestroy all borers that ean he fomnd. This hats been foumd an exeellent mevention, but where the trees are already suffering from 
them, the earth may be removed from the roots and a copious application of hot water male to the tree. This may be applied at any season, and will be very effectual in killing the larva or any eggs that may be present."-I'rofessor G. H. French.

See Remedy No. 41.

B.-Grapevines attacked by Eycria polistiformis may be treated as above, although the mounds need not be so high.

C.-Note- - In the latter end of April or early in May, the moth may be prevented from depositing her egges by covering the stems of the squash plants with earth.

\section{REMEDY NO. 99.}

Hopvines, grapevines, and plants found withering or dying suddenly, should be carefully examined, and if the grub (Fig. 148) of any of the loring beetles or the larva of moths are found, they should be destroyed at once; or if found in hoppoles or rotten wood in the garden or field, they should in every instance be destroyed. (Hop-growers should examine their hop-poles carefully when taken from the ground for grubs, ete.) The beetle (Fig. 150) should be destroyed whenever found. Craperines, or hoprines, or fruit trees, should not be planted upon lands where decaying oak stumps are left in the ground, as there is danger of the trees or vines becoming infested by these grubs.

See Remedy No. 107 .

\section{REMEDI NO. 100.}

Mr. R. B. Blowers, of Woorlland, succeeded in preventing the spread of vine-moths on his premises by capturing the moths that came into his flower garden from the vineyards in the evening, his men eapturing several hundred in one evening.

Also see Remedy No. 14. 


\section{REMEDY N(), 101.}

To rid grounds infester by the pupa of rine-mothe (Figs. 1.5 and 1(it), white grub- (Figs. 109a and 1s1a), cte., early in the sipring inclose an area of wround by portable fence, say from forty stuare rods to one aces in this inclosure place a number of hogs, and on the general prineiples of "root hog or die," the inswets. in any state of their existence, within their leakh, will be gatheresl clean; then move the corral on new gremelnd.

\section{REMEDT NO. 102.}

Make a frame, say three fect square (or any suitable size), leaving an opening to the rentre on one side, so that it will allow the stem or trunk of the vine or plant to enter. the frame to lue covereal with muslin aloth. On one side of the opening talck a piece of cloth wide enough to cover the space not almarly covered. Saturate the cloth with kerosene and place the frame on the ground under the vine or plant; cover the opening with a loose cloth, then jar the vine or plant; any inseret filling upon the saturaterl eloth will dic. This is used at night or in the daytime, aceording to the habits of the insect to tre destroyed; or a frame in the form of a parallelogram,

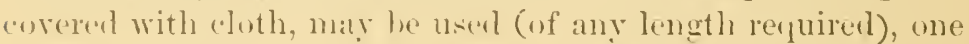
placerl on eiteh sicle of the vine ar vines, ete, provision heing male for eovering the open space. This mode of warfare may alplear ats a tedions operation, hut for destroying the larva of sill-flies, gratle Heatbeetlos, ete., it is a very effective remedy.

ser Remerly No. 3s.

REMEDOY NO. $10 \%$.

l'se l'aris green, one tablespoonful to two gallous of water. The Paris green should be first mixed in two quarts of water, then pour in the balance of two gallons and apply by spraying; or one pound of l'aris green mixed with tifteen pounds of flour. 
The following precautions were suggested hy I)r. Ie Baron in relation to the application of Paris green :

1.- "Always dilute the poison with at least ten times its bulk of flour.

2.-"Apply it to the plants when wet with dew or rain.

3.- "Never entrust its use to young or careless persons.

4.- " Nerer use it near the house where young children resort.

5.- "Apply it with a gauze bag or other sifter attarlied to the end of a pole.

6.- "Let the operator always keep on the side from which the wind is blowing.

7.-- Do not apply it to a plant where it will rome in eontact with the fruit."

Professor Cyrus Thomas writes: "Recent experience appears to give decided preference to the application in liquis solution, especially sinee improver methods of applying it in this form have been invented. This not only aroirls the danger of inhaling the powrler, but it has the advantage of rendering it more certain that the application will reach the insects."

Great care should be taken in keeping such poisomous powders or mixtures where children cannot have access to them.

Note.-When used for cotton worms, mix one onnee to arch gallon of water and spray thoroughly; but mixing ten pound:of No. 4 or 3 to each barrel (say forty gallons) will make the solution more effective.

See Remedies Nos. 79, 112 and 12:?.

\section{RENEDY NO. 104.}

Where strawberries or other plants are infested by the grub or larva of the crown borer, peach moth, exgeria moths, etr.. dig out all infested plants and burn them, and replace with new plants. Better, dig out the whole bed and replant for a sure remedy.

see Remedy No. 6s. 


\section{RIVIEISY No. 10.5.}

Sprinkle the leaves with fresh slacked lime when they are wet with dew or rain; or No. 1! after sunset. These remedies should be applied as soon as the beetles appear.

\section{REMEDY NO. 106.}

1.-1ll graskes, weeds, debris of hoprines, ete., in the hopfields and around the surromeling fenees, roats, ete., should be carefully gathered and lurned as soon as possible after the crop is gathered. There are many species of inserts that feed upon the hopwine and pass the Winter (hilernate as perfect insects), taking shelter among grisses, weeds and hoprine debris that are allowed to remain on the grounds and around fences and roads that are located in or around the field. Therefore the necessity of eleaming and hurning such shelter as they require to pass the Winter mder.

13.-All poles used the previous year in the hopfelds should be thoroughly sealeled before using. (Fee Remedies Nos. 70 and 71, exeepting that one pound of potash should be used for every ten gallons of water.)

C.-The neessity of scalling the poles arises from the fact that I have found the hop allis hibernating in erevices and roughened portions of the proles. I have also found the Winter eggs of a species of plant-lonse, but camnot sal at present that they were the eggs of the hop aphis.

D.-All willow poles should be sealded hefore using. I have found the plant-liee infosting willows at the time the poles vere ant, feeding upon the hoprine.

F.-I have also found the ova of red spiders on the hoppoles, after being taken from the ground in the Fall season.

F.-Cheros.- - have found the hop aphis in several hop ficlds this season (1853). One grower remarked that they were harmless in this state. Do not depend on such statements; prevent them from spreading, by all means in your power; otherwise you may have the same experience of the hop-growers in some of the Eastern States, and also in Europe. 
G.-The presence of the hop aphis, when in great numbers, is noticed by the black smut (Fumago salicina), which appears on the leaves, etc., of the vine. See black scale, Chapter LXXXIV.

H.-Clean cultivation and alkaline solutions properly applied will protect the hop erop; also,

See Remedy No. 94 (root borers).

See Remedy No. 5.), A (wire worms).

See Remedy No. 55, A (cut worms).

See Remedy No. 73.

I.-Should plant-bugs or any species of bectles attack the vines or foliage, use No.19. "Eternal vigilance is the price of"- $\mathrm{a}$ good hop crop. See Remedy No. 99.

\section{REMEDY NO. 107 .}

Flowers, strawberries, plants, and grasses, often suddenly become withered. If the roots are examined it will, in at least a majority of cases, be found that the damage is causer by a grub, commonly called the white grub. It is diflicult to calpture or destroy these pests. Carefully examining the roots of strawberries, flowers, ete, and digging around them, will certainly bring some of the grubs to light; at such times poultry are excellent accessories. In fields they are raided on hy crows, blackbirds, ete. 'The larre of the larger' species of beetles that are leaf-eaters are known under the common name of white grubs. The only remedy that can be recommeneed is hantpicking, as described above, with the assistance of poultry, birds, etc., and by capturing the heetles (perfect insects). See Remedy No. 38.

For excellent illustrations of the so-called white grubs, see Fig. 109a, Fig. 1S1a, and Fig. 290, 2.

See Remedy No. !9. 


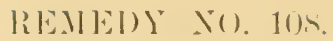

To destroy plant-liee where a large area of corn is infested. in a financial point of view it is questionable if it ean be done profitably. If a ficlel is infesterl, a rotation of (crops may atlord temporary reliet, but small garden lots of sweet corn and other varietice may be saved by spraying with No.:3 or 4 ; one gallom of No. ! adderl to eseryten gallons of the solution used will make the solution more efficient.

After the (a)rn is harvesterl, the stalks and louts should be gathered in heaps and hmoned, and the gromets cleaned, ats recommented in Nos. 20 and 106, 1. Experiunents should he marke with Nos. si() to si.).

\section{REIEDY No, 109.}

Fortunately the fruit oreharels of this state are free from the plum eureulio at the present time. Professor ('. H. Dwinelle has furnisherl the following remedy:

\section{" ВеRKLIEY, August 2:3, $188 \%$.}

"Mu. MATTHEW ConkE-Deut s"i, : In accordance with your request I will give you some netes on tighting the plum rur(ullio or weevil.

"some vears ago I harl charge of a number of plum trees at Rochester, N. Y. They were in their prine, and, als a rule, set full crops of fruit, which were as regularly destroyed by the flum enreulio. The last soason that I had to do with the trees I tried suraying them, when the fruit was alout the size of small green peals, with a wash makle alter a reeipe published in the Ver tork Obserer, as follows:

"To one pround of whate oil soap arlel fomr annees of flour of suphur; mix thoroughly and dissolve in twelve gallons of water. To wme lalf peek of quick lime arle four gallons of water, and stir well together. When fully settled. pour ofl the trans parent lime watere, and add to it the soalp and sulphur mixture ; ached to the same also. say fom gallons of tolerably stromer tolacen water. 
"Apply this mixture, when thus ineorporated, with a garden syringe (or spray pump) to your plum or other fruit trees, so that the foliage shall be well drenched. If no rains succeed for three weeks, one application will be suflicient. Should frequent rains occur, the mixture should be again applied until the stone of the fruit becomes hardened, when the season of the cureulio's ravages is past.

"The mixture is good to destroy the slug, caterpillar, green Hy, thrips, and a host of the enemies of regetation.

"It is my impression that I found the wash stronger than needed or desirable, and diluted it to a considerable extent, but how much I cannot remember. The application was marle by means of a garden engine. As a result, the trees bore a full erop of perfect fruit, while that of my neighbors was destroyed as usual.

"Respectfully yours,

"C. H. DWinelle.

"Unicersity of Californic, August 28, 1889."

REMEDY NO. 110.

In relation to the Remerly No. 109 , which has proved so effective, and is recommended by Professor C. H. Dwinelle, Remedy No. 66 will probably be equally effective should this pest appear in any orchard in this State.

\section{REMEDY NO. 111.}

As soon as the leaves of the cucumber rines appear above the ground, spray thoroughly with No. jor 7 . Should plantlice or the eucumber beetle appear on the foliage, spray thoroughly with No. 4, and cut out and destroy all stems infested by the grub of the heetle; or, use No. 65 ; but if the material is convenient, and the vines seriously infesterl, No. 51 is preferable.

Note.-For aphis, No. 5 or $T$ is sufficient, and will not destroy the natural enemies of these insects. 
REIEIM N(). 11:.

In cares where beetles attalk potato and other vines, grood results have been obtained hy plaring a clish or pan under the rines and hrushing the beetles ofl' of the vines into the pan, dish, or tray; if a little kerosene is placed in the bottom it will make short work of the pests.

See Remedies No. 7!) 103, 112 and 123; also, No. TS.

\section{REMEDT NO. 113.}

Nos. 5 and 7 mixed, one pound to two gallons of water; spray thoronghly at least mee each week, from the time the plants appear above the eround until the latter part of May. If thoroughly surayed, digging a trench along the plants is ummecessary.

REMEI)Y N(). 114.

In many catser good results follow the capturing of hutterflies and moths: atso gathering the putux. Placing pieces of boards, cabloage leaves. ote., under plants. so that the night feeders take shelter umber them, they ean he easily calptured in the moming. This will also apply to the squash bug and other spereses of plant hugs.

\section{REMEDY NO. 115.}

Great care shomld be taken in selecting peas. beans, and other seeds for planting that are liable to be attacked by weevils.

liy careful cxamination, infested seets can be detected by a small bloteh on the skin of the yea or bean a little tarker in color than the rest of the surface. If a pea or bean is broken open, the grul, pupat or beetle will be found under the discolored place. It is claimed by some writers that dipping the seed hefore planting, in boiling water, and letting it remain from thirty to fifty-fire seconds, that it will destroy any insect 
life in the pea or bean. Others elaim that if the peas or beans are put in water the infested ones will float. This is not correct in all cases. A general remedy would be for the farmers in one locality not to plant any peas or heans for one season, but keep the seed from the previons year in closed vessels, so that any infested seed would mature the wervil, and the latter must perish, thus giving clean seed.

\section{REMEDY NO. 116.}

W'hen this species of aphis appears, cut off the infested tops of stalks, and immediately destroy by burning or otherwise. In small garlen patches, use No. 19, or spray with No. 64; or No. 4,5 , or 7 will give good results; but No. 19 or lit are preferable; or use No. 83 or 85.

\section{REMEDY NO. 117.}

By scattering buhach with a small bellows (price twenty-five cents) in a room it will destroy insects, such as mospuitoes, house-flies, gnats, fleas, ete. ; and by dusting in crevices of bedsteads, furniture, and cracks in floors, walls, or ceilings, it will destroy bedhugs and the larve of fleas, ete. Corrosive sublimate will also destroy insect life in joints and cracks in berlsteads, furniture, clothes-chests, and places where clothes, etc., are kept; it should be applied with a brush or feather. (ireat care should be taken if corrosive sublimate is used or kept around the house, especially where there are children, as it is very poisonous.

Ser Remedies Nos. 80, 81, 82, 83, 84, 8.5 and 118.

\section{REMEDY NO. 118.}

By rubling the parts of the body exposed, such as the hands, face, etc., with the oil of pennyroyal, mostpitoes, gnats, ete., will not bite the parts to which it is applied ; a few chrops will be sufficient.

See Remedies Nos. so to 8.5, and 117. 


\section{REMEIIY NO. 11 !}

To destroy wcerils in coffee, rice, cte., fill into an air tight ressel, learing a little space tor a lamp or candle inside; when the candle or lamp is lighted, fasten on the cover tight. If perfectly air tight the lamp will hurn up all the oxygen in the ressel and will then go out, thus reating a racum in the vessel; open in two days and all the beetles (weevils) will be found on top dead. I noticed this in an English authority some time ago, and have tried sereral experiments with wheat, rice, midrlings, etc., and found it rery effective.

Note. $-\Lambda$ shipment of coflece was received in this rity nearly two years ago seriously infested by weril.

\section{REMEDY NO. 120.}

When flour or middlings, in sacks, are infested, place the sack in the sun, and as the bectles gather upon the outside sweep off and destroy.

\section{REIEISY NO, 121.}

Paris green dusted in and around infested places, ete., will effectually destroy cockroaches. No. s1 will also be eflective if applied at intervals of twenty-four hours. Remember, great care should he taken in using Paris green where there are children, as it is a deady poison. This caution also applies to the following: Arsenic mixed in eorn meal and molasses, emengh to form a dough; or arsenie mixed in mashed potatoes. laid in places that the roaches call reach, will effectually destroy them if repeated at intervals. 


\section{REMEI)Y NO, 12.2.}

A.- Various designs of hives have been made to prevent the bee moth from entering, but, so far, all are more or less defective, and the best and surest remedy is to carefully examine the hives that are infesterl once every week, and collect all the nests, cocoons, ete., and destroy by burning; this should be done in the Spring and also in July and August.

B.-Professor C. I. Riley recommends that "a good way to entrap the worms would be to raise the front of the hive on two small wooden blocks, and put a picee of woolen cloth between the botton board and the hack of the hive. The worms (larve) find a cosy place of resort under the rag, where they may be sought and killed from time to time."

C.-Professor G. H. French writes: "With only moderately strong swarms of bees, vigilance, with properly construeted movable frame hives, is the only way to obtain immunity from their ravages."

I have witnessed the successful cleaning of hives seriously infested as described above, but with $\mathrm{C}$ and D the work would probably be still more effective.

D.-A loose band of cloth placed around the top of the hive outside, is an excellent trap for the moths to hide under in the daytime, where they can be easily captured.

\section{REMEDY NO. 123.}

1.-In using whale oil soap and sulphur, the opening in the nozzle should be made a little larger than the opening used for lye, etc.

2.-When buhach is used with any of the solutions recommended, it should be placed in a perfectly tight ressel and hot water poured on it and allowed to soak until the next day, or until ready for use, then strain and mix in solution and apply immediately. Calculation must be made so that only the original quantity of water recommended is used.

3.- In all cases where buhach is applied in liquid form to 
flower:, it should be strained before using, so as not to stain the petals, etc.

4.-If possible, solutions for Summel use on trees, etc., should not le applied on very wam days, as it may injure the foliage: clouly days and after sunset is the best time in hot weather.

5.-By straining through a coarse eloth all liquids or solutions to be used in spraying, will save time in application.

(i.- Tobaceo grown by fruit-growers is erual to so much money saverl, ats it is far superior to any refuse tobacen they "an huy, and will make a solution fifty per eent. stronger; or in other words, one and a half gallons of water can be used to each pound, insteal of one gallon, as recommended.

7.- Vineyarlists should use one pound of buhateh to every twenty pounds of sulphur (or one pound to every ten pounds if the vinc-holpers are numerous) when sulphuring their vines carly in the Spring season; this will be death to the vine-hoppers, etc. The first sulphuring should be lone when the shoots ale from fifteen to twenty inches long.

S.-To those not acquainted with using the lye solutions, at first there will be some ineonvenienee experieneed, but it must be remembered that serious diseases repuire serious treatment.

9.-If the owner of an orehard, vineyard, ete., "annot personally attend to the applieation of the remerlies recommended, it is an imperative necessity that only a reliable persun be intrusted with the charge of the work. Only thorough application will produce satisfactory results.

10.-Be careful in using the remedies that are poisonous, such ats arsenic, Paris green, Lombon purple, corrosive sublimate, re., especially where eliblen are aromed the premises. Lnder no comsiteration are they to be alpllied to fruit, ete. that is to he used as food, as serions results might folluw.

11.-The soaty, and lye solutions recommended are exeellent fertilizers, and produce smooth, healthy hark on the trees washed or sprayed. 
REMEDI NO. 124.

It must be aumitted that proper attention has not been given in the past to the proper treatment of fruit trees, grapevines, ete., as regards the fertilization of the grounds on which they are planted. Chemistry has demonstrated the elements of which the earth is composed, and a list of over sixty is giren; yet strange to say, the vegetable kingdom selects its food from only a few of these elements. That the virgin soil of California abounded with the elements necessary for the fool of plant life, there can be no question; but the growing of continuous erops has deprived the earth of such ingredients as are principally required for the foor of plants. namely: potash, phosphorus, line, ammonia, ete. When the supply of either of these elements falls helow a fixed limit, the plants will not produce as heretofore; and if attacked by insect pests they will soon become worthless. Therefore the necessity of using the best known means of restoring the necessary flantfood to the inpoverished gromel. Is fruit trees and grapevines require a large supply of potash and phosphorus, also some ammonia and lime, these elements can be supplied by using the remedies describur in No. 35.

\section{CONCLUSION}

The measurements throughout this work alove one twentieth of an inch, are given in inches and lines-al line being the twelfth part of an inch. See illustrations in Chapters XXII, XXIII, XLVIII, ete.

The insects are usually figured the natural size, and when enlarged the natural size is generally indicated by a line or by a cross.

The remedies given are mostly the results of personal experience; in cases where remedies are recommended for insects not found in this State, they are given from analogy of insects belonging to closely allied species. 
If new remedies are recommended, do not give up the use of those herein recommended, unless you find by repeated experiments that the new ones are more eflieient. It is to be hoped that fruit-growers and others will carefully experiment with the remedies herein recommended, and give the results of their investigations in some horticultural publication, such as the Pacific lindul Press, Cultivator's Guile, ete., that others may be benefitted by their experience.

In regard to benefieial insects, the reader is referred to my forthcoming work entitled "Ixshets: InJurious AnI Baxefi-

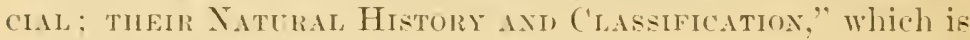
shortly to issule from the press. 


\section{EXPLANATION OF PLATE 1.}

Fig. 32.- Giray Bark-cating IV'eri] -color, gray.

Fig. 40.-Yellow Canker Woms-colors, yellow and black.

Fig. 41.-Female Sellow ('anker IVom Moth-rolors, white and black.

Fig. 42.-Male Yellow Canker Worm Moth-colors, yellowish and brown.

Fig. 51a.--Braeon Fly-colors, blatck and yellow.

Fig. 64.-Red-limmed Caterpillar-color's, yellow, whitr and black.

Fig. 65.-Cocoon of Red-humped Caterpillar-color, whitish.

Fig. 66.--Red-hmmped Caterpillar Moth-colors, light and dark brown.

Fig. 74--Ten-lined Leaf-eater (male)-rolors, grayishbrown and white.

Fig. 75.-Ten-lined Leaf-eater (female)—oolor's, grayishbrown and white.

\section{EXPLANATION OF PLATE 2.}

Fig. 78.-Robust Leaf-beetle-color, brown.

Fig. 82.-Apple Maggot-color, white.

Fig. 83.-Pupa of Apple Maggot-color, brown.

Fig. 84.-Apple Maggot Fly-colors, black and white.

Fig. 92.-Branch bored by the Branch and Twig Burrower.

Fig. 93.- (trape cane bored by the Branch and Twig Burrower.

Fig. 94.-Branch and Twig Burrower entering a branch.

Fig. 95.-Branch and Twig Burrower, enlarged-color, brown.

Fig. 106.-Peach Moth and Larva; upper figure, the moth -colors, gray and black; lower figure, the larra-color: vellowish, tinged with pink.

Fig. 107.-Peach infested by the larva of the Peach Moth.

Fig. 110.-Red-bodied saw-fly, enlarged-colors, redlishbrown and black.

Fig. 111.-Apricot Leaf-roller; upper figure, the motheolors, yellowish and brown; lower figure, the lant-color, green.

Fig. 112.-Striped Bud-beetle-colors, pale yellow and black.

Fig. 115.-Cherry Worm-color. yellowish-white. 
Fig. 32.

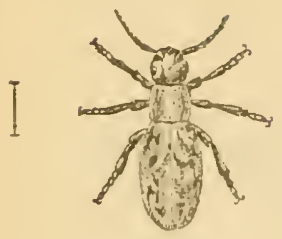

Fig. 51a.

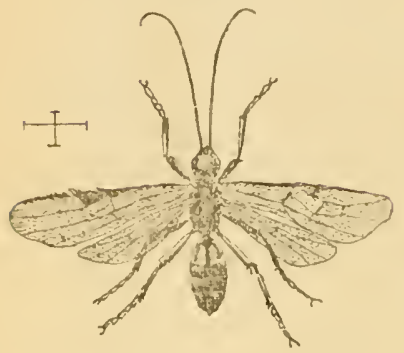

Fig. 74.

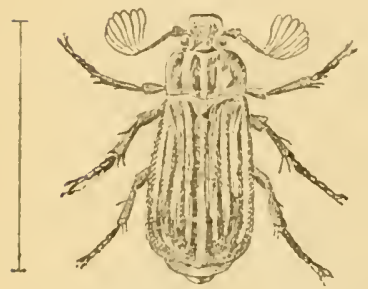

Fig. 65.

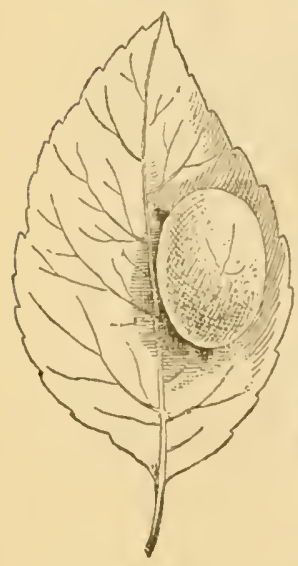

For Figa. $78, \varepsilon 2, \varepsilon 3,84,92,93,94,95,106,107,110,111,112$ and 115, see Plate 2,
Fig. 42 .
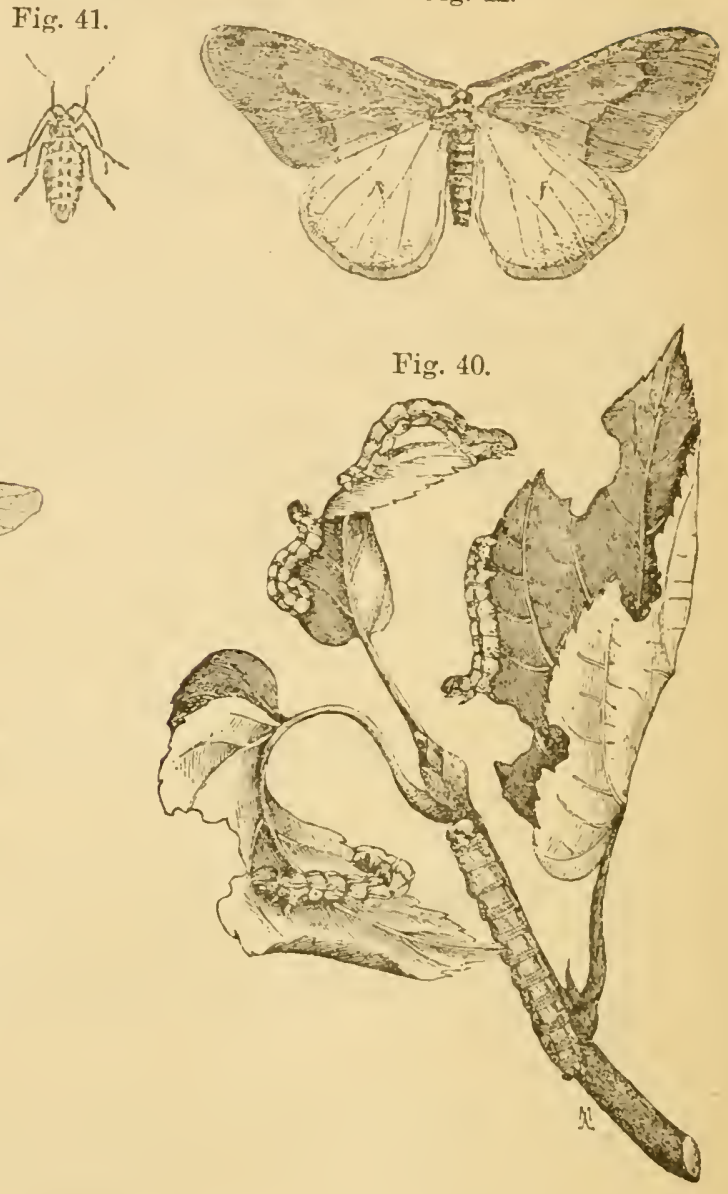

Fig. 61.

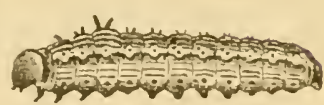

Fig. 66.
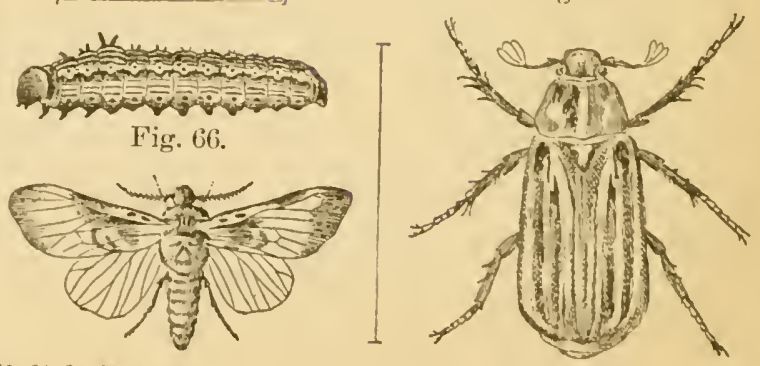

Fig. 75. 


\section{PIATE}

Fig. 78. Fig. 82 . Fig. 83.
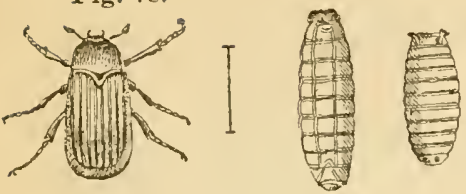

Fig. 94.

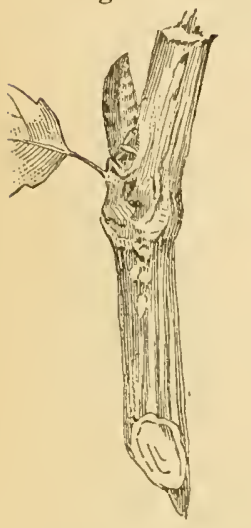

Fig. 95.

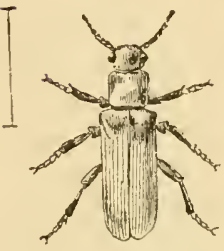

Fig. 84.

Fig. 22. Fig. 93.
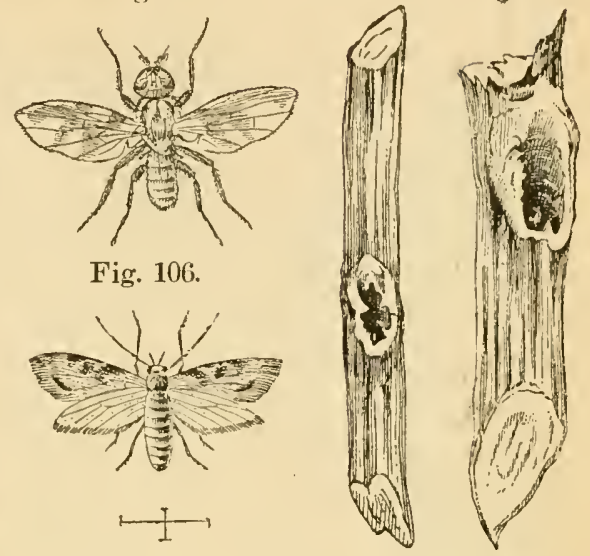

Fig. 111.

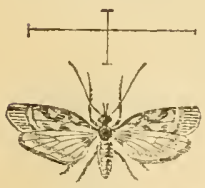

Fig. 106.

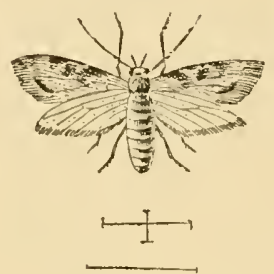

CIIDLDSODO

Fig. 107.

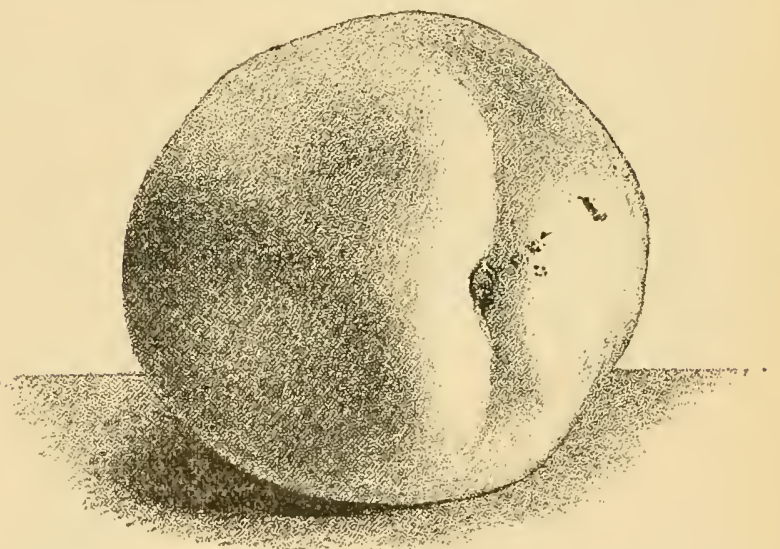

Fig. 112.

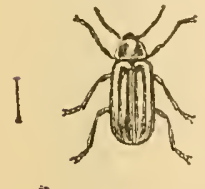

Fig. 110.

Fig. 115.

Suldoro
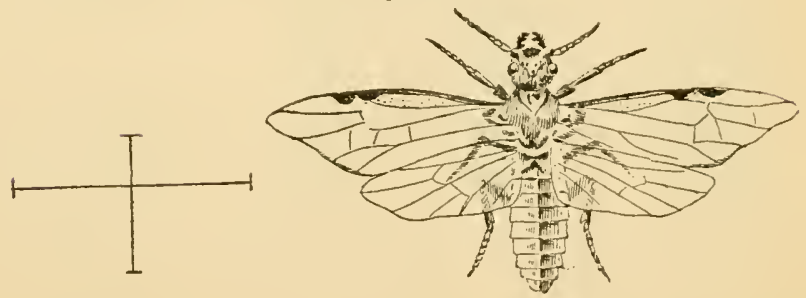


\section{EXPLANATION OF PLATE 3.}

Fig. 127.-Brown Strawhery II eevil-color, brown.

Fig. 146.-Male Cottony Cushion Scale-insect-color. brown.

Fig. 179.-Imported rirape Flea-beetl-color. black.

Fig. 15.-California frape-rine Hopper-colors. pale yollow, orange and black.

Fig. 1St.-Male Yellow Mite. highly magnified-eolor, vellowish.

Fig. 185.-Female Yellow Mite. highly magnified-color, rellowish.

Fir. 2.20.-Branch bored by the Brown C'hestnut-bud Beetle.

Fig. 르.-1.-Brown Chestnut-bud Beetle-color. brown.

Fig. 2:31.-Weeping Willow Borer Moth-colors, black, yellow and brown.

Fig. 2:30.-Weeping Willow Borer-eolur. whitish.

Fig. 246.-Horned Flower Beetle-colors, brownish-yellow and black.

Fig. 27..-Eggs of Clover-stem Burer-color, yellowish.

Fig. 27s-Larva of Clover-stem Borer-eolor. yellow.

Fig. 279-Pupa of Clover-stem Borer-rolor, rellow.

Fig. 2.S().CClover-stem Borer--eolors. blue-blatek and dull red. 


\section{PIAIE 3.}

Fig. 146.

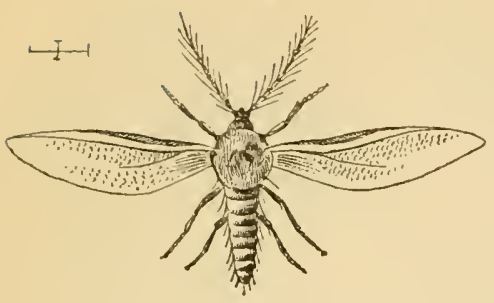

Fig. 184.

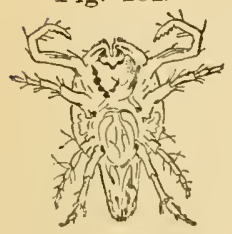

Fig. 230.

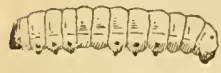

Fig. 220.

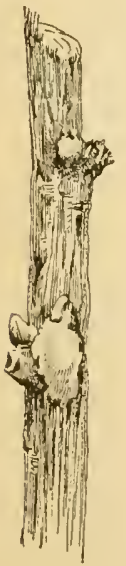

Fig. 246.

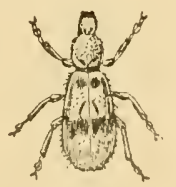

Fig. 277.

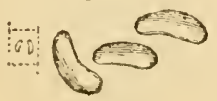

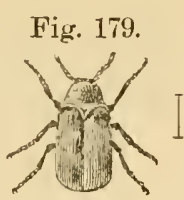

Fig. 185.

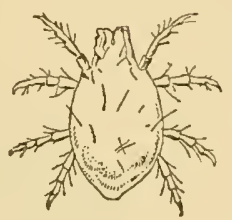

Fig. 221.
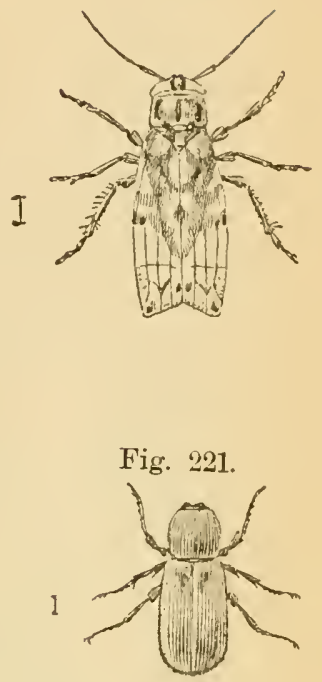

Fig. 182.

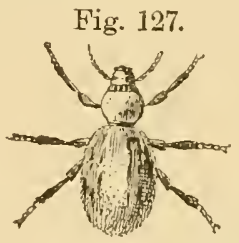

Fig. 278.

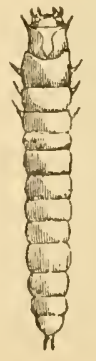

Fig. 280.

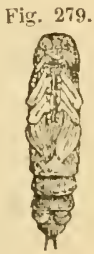

Fig. 231.

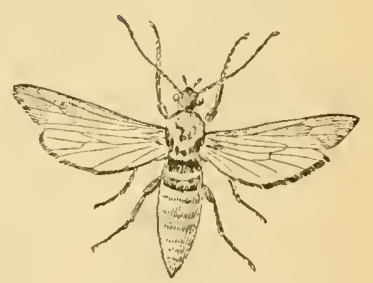




\section{EXPLANATION OF PLATE 4.}

Fig. 297.-Melon Worm; at the left, several of the worms on some leaves-color of worms, ycllowish-green; at the right, a moth-colors, black and white.

Fig. 310.-Small Potato-beetle (No. 1)-color, black.

Fig. 341-Asparagus Beetle-colors, blue-black, rellow and red.

Fig. 342.-Eggs of Asparagus Bectle on a stalk of asparagus -color of eggs, blackish.

Fig. 343.-Larva of Asparagus Bectle-color, grayisl.

Fig. 353.-Dried-fruit Moth--color's, whitish and rusty-brown.

Fig. 354.-Dried-fruit Moth-colors, sray and brown.

Fig. 3.5.).Grain Weevil-color, blackish.

Fig. 35s.-Bran and Flour Bug-color, brown.

Fig. 371.-Wasp- colors, black, the wings reddish.

Fig. 370.-California Lady-bird - colors, reddisl-brown, black and white.

Fig. 372.-Mud nests of a wasp. 


\section{PIATE 4.}

Fig. 297.

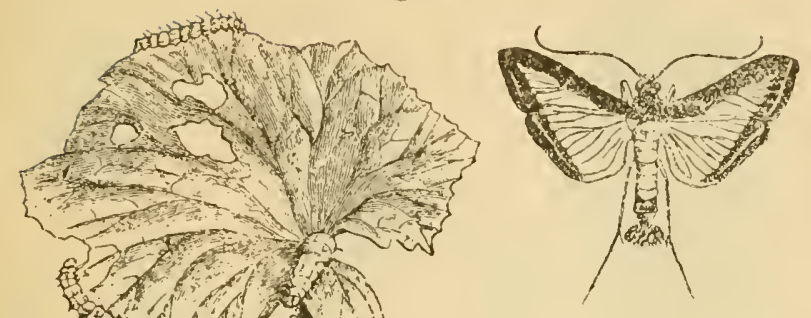

Fig. 310.

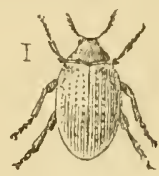

Fig. 358 .

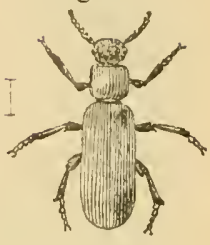

Fig. 341.

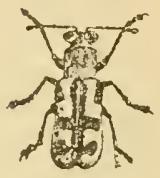

Fig. 370.

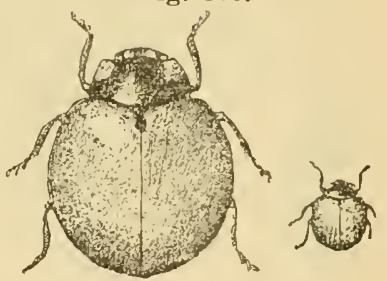

Fig. 371.

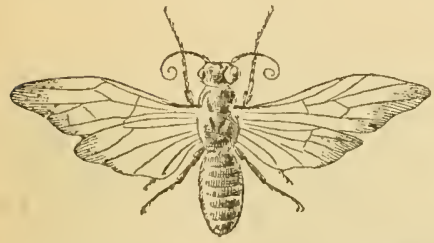

Fig. 3 i3.

Fig. 353.
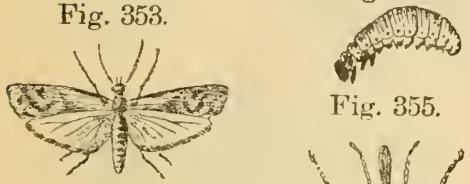

Fig. 355.

Fig. 351.

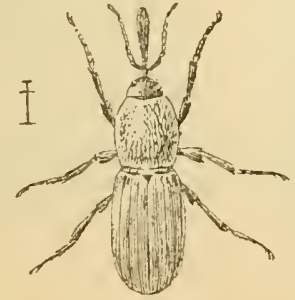

Fig. 342 .

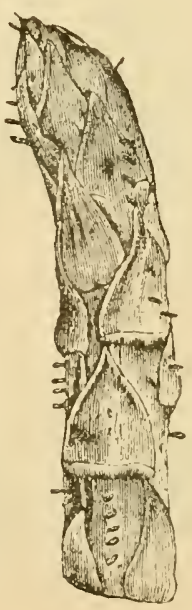

Fig. 372.

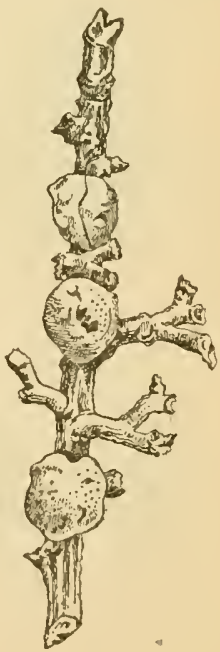




\section{BEETIES.}

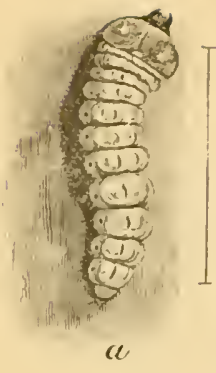

Fig. 31. Fig. 77.
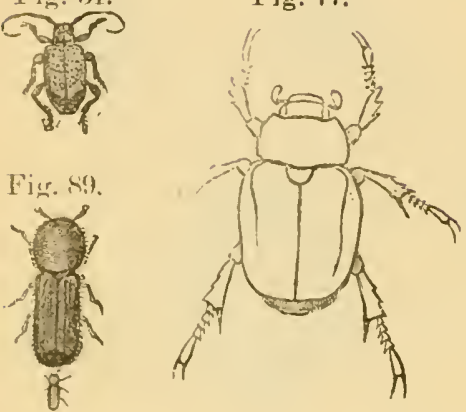

Fig. 109.
Fig. 25.

Fig. 26.
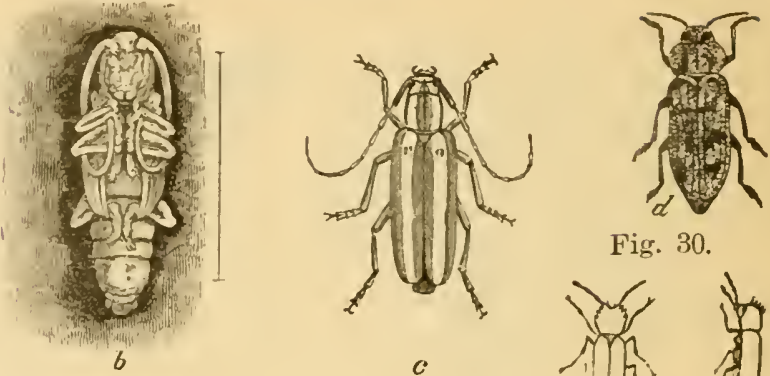

Fig. 30.

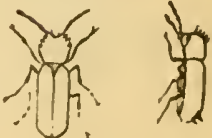

Fig. 86.

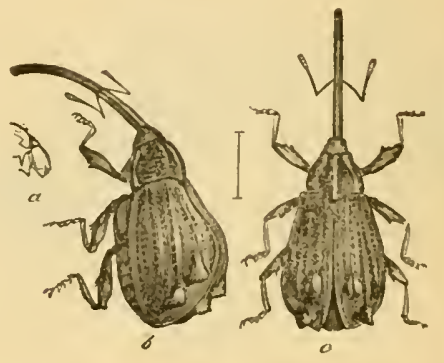

Fig. 108.

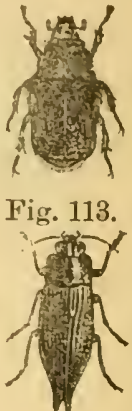

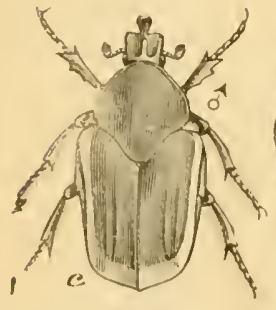

Fig. 10:3.

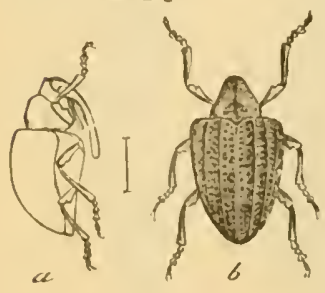

\{\} of fys

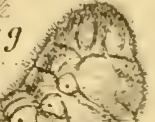
iो के क्ये

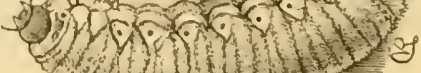
Lo का
Fig. 119.

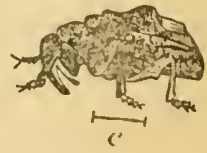

Fig. 197.
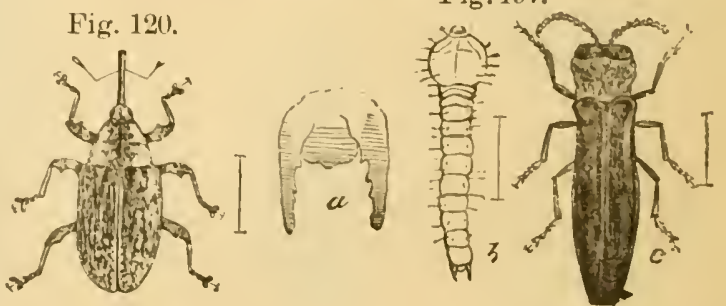
Fig. 156.

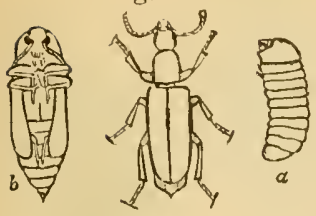

Fig. 201.

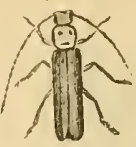

Fig. 180 .

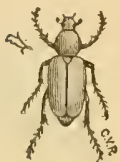

Fig. 178.
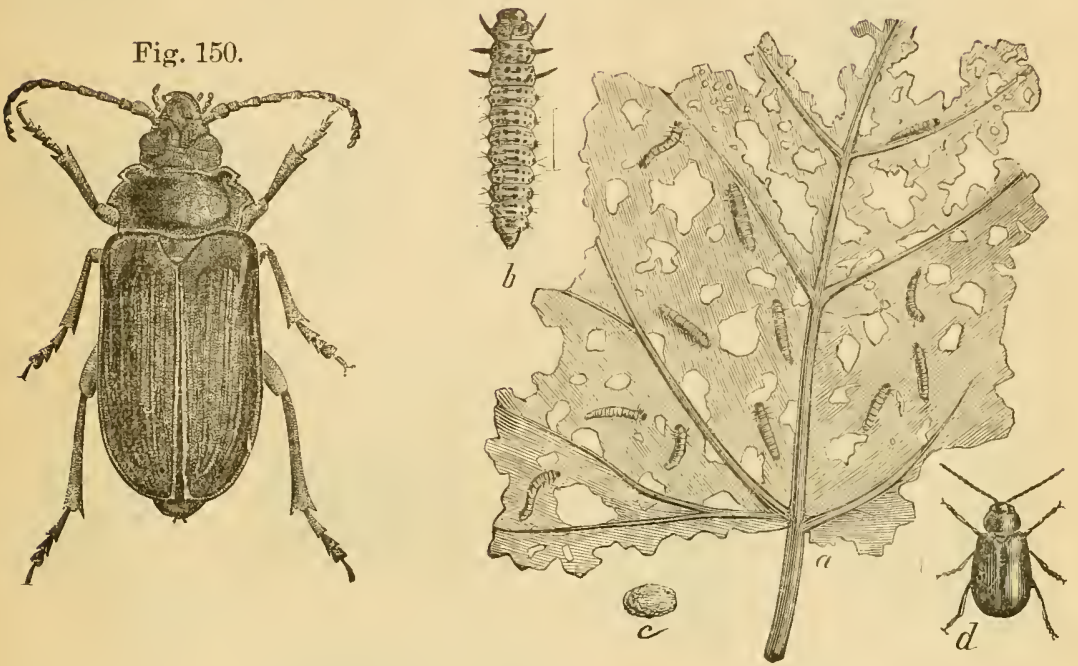

Fig. 181.
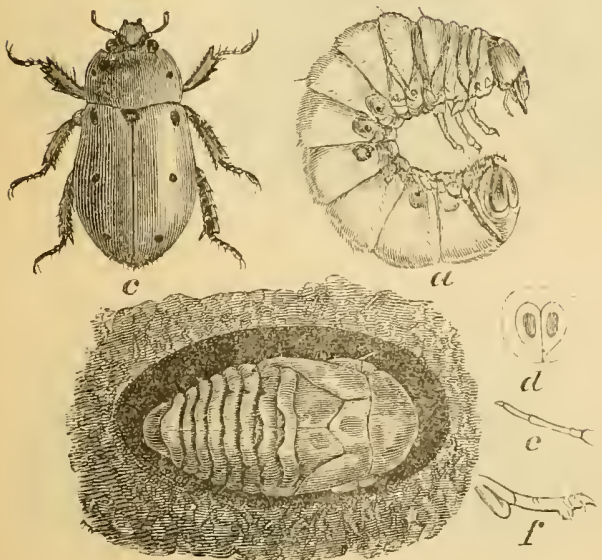

Fig. 204.

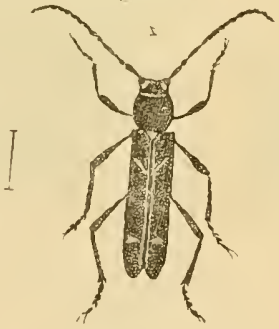

Fig. 229.

Fig. 298.
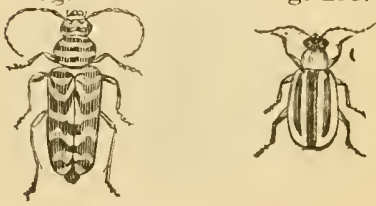
Fig. $195^{1}$

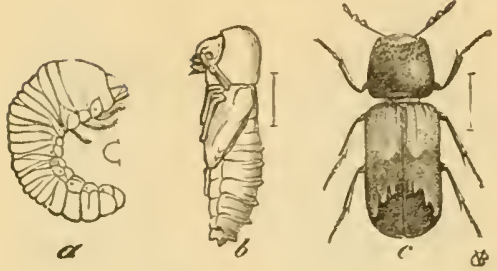

Fig.l 6

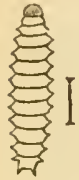

Fig. 234.

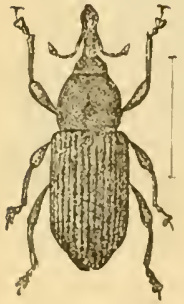

Fig. 306.

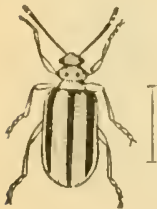

Fig. 191.

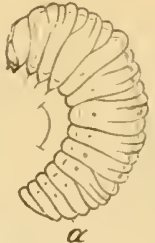

rig.l
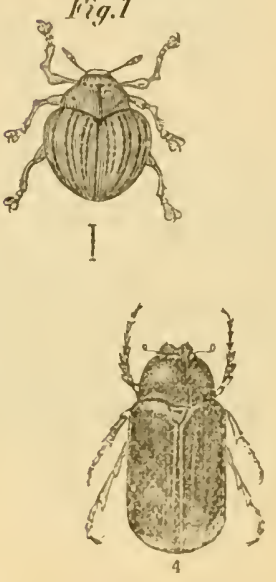

Fig. 290.
Fig. 216.

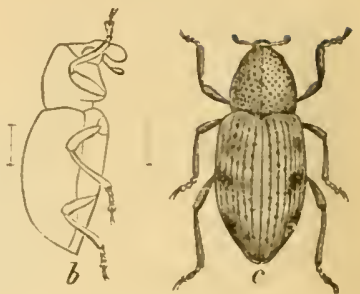

Fig. 312.
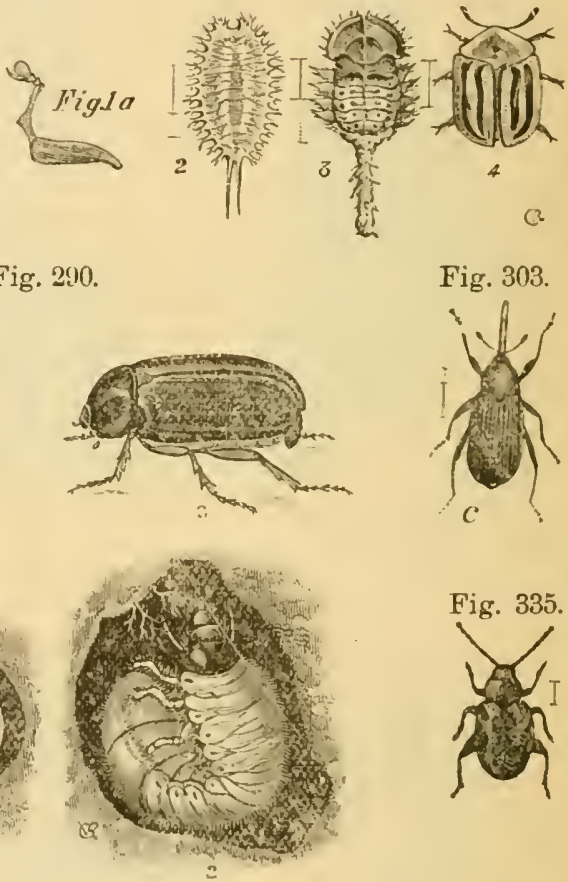

Fig. 335.

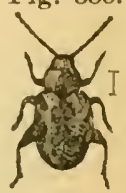

Fig. 308.

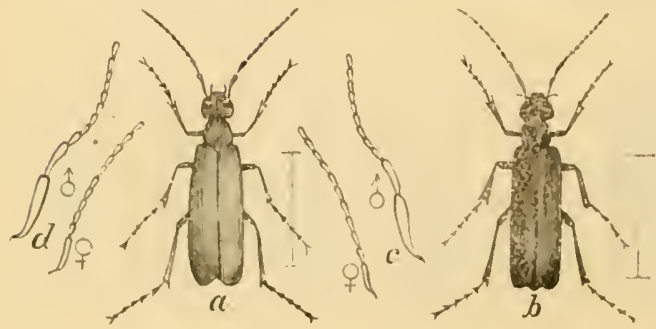

Fig. 314.
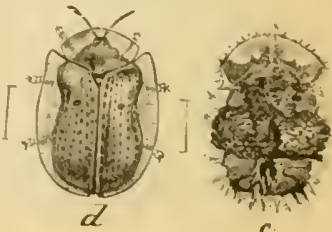
Fig. 282.

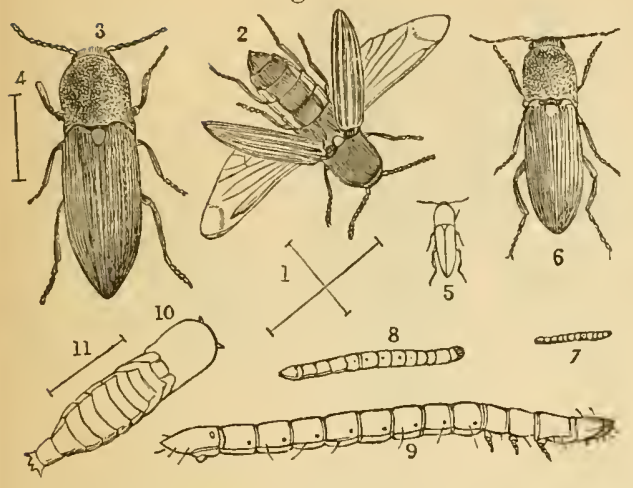

Fig. 359.

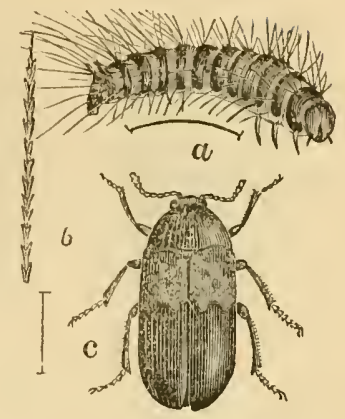

Fig. 305.

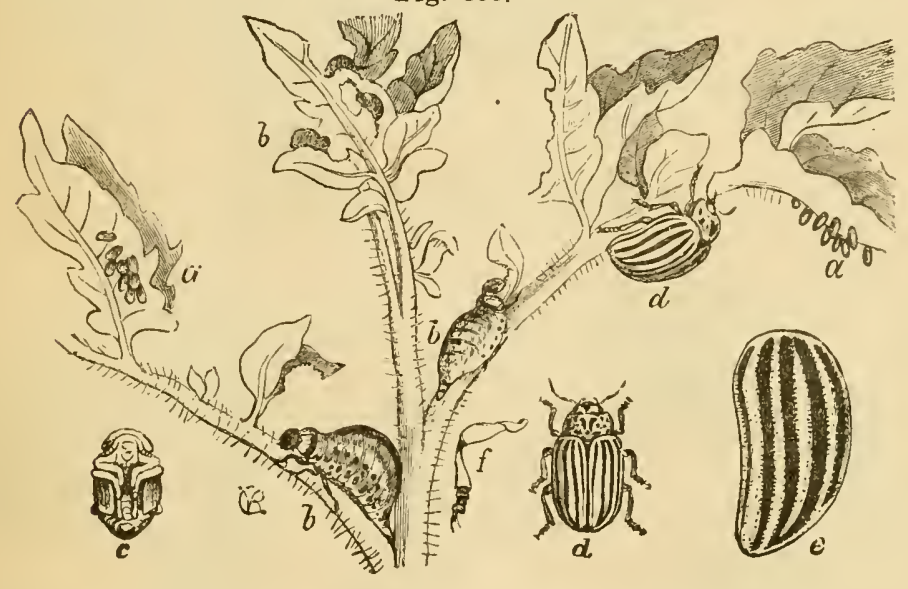

Fig. 309.

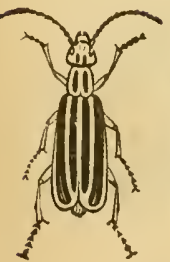

Fig. 313.

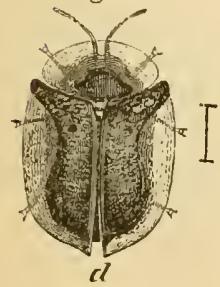

Fig. 316.

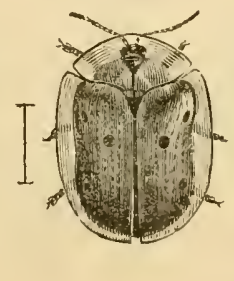

Fig. 339.

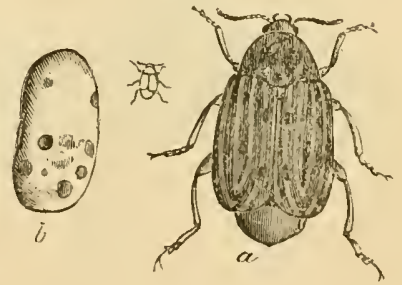


Fig. 350.

Fig. 37 .
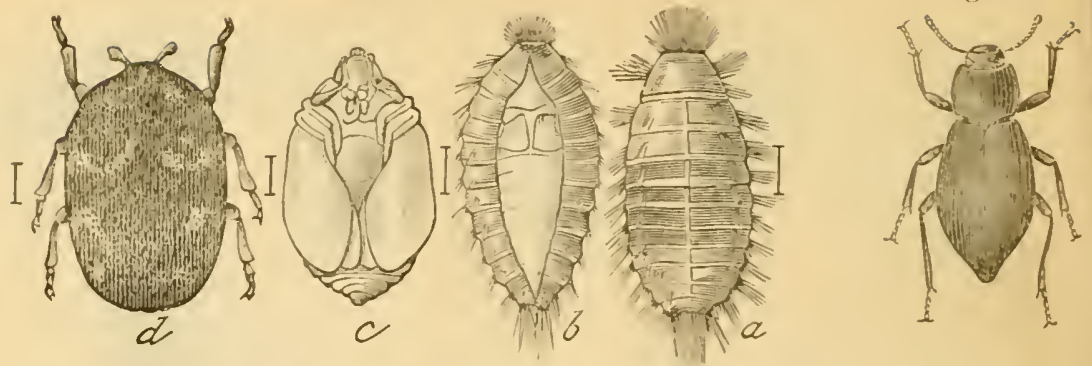

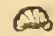

Fig. 338.
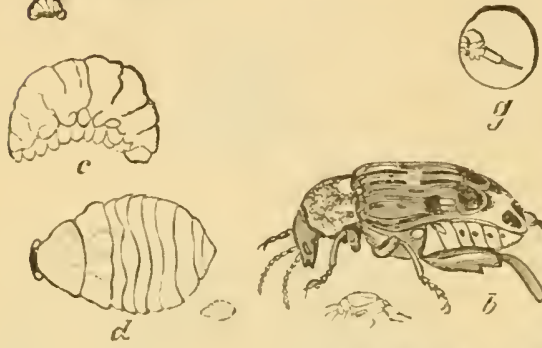

Fig. आ).

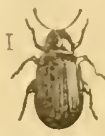

Fig. 373.

हर

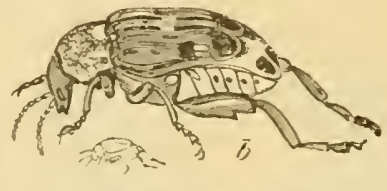

BOT-FIIES.

Fig. 361.

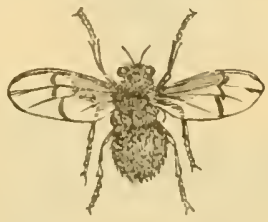

Fig. 364.

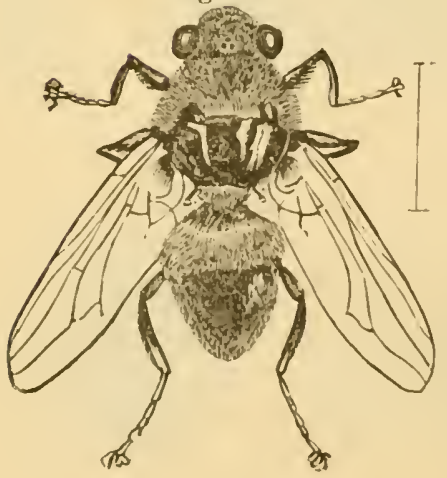

Fig. $36 \%$.

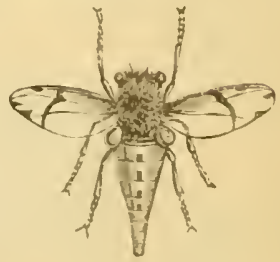

Fig. 365.

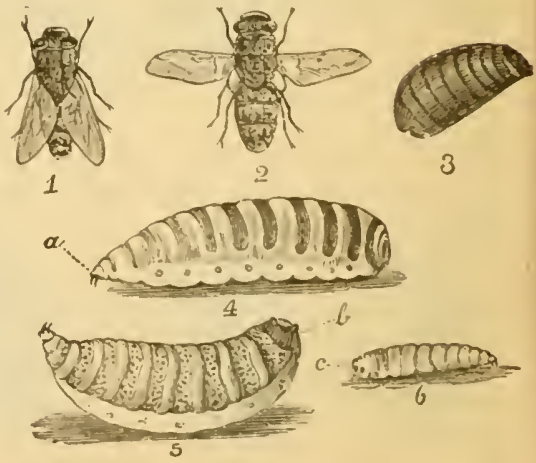




\section{TRUE BUGS.}

Fig. 36 .
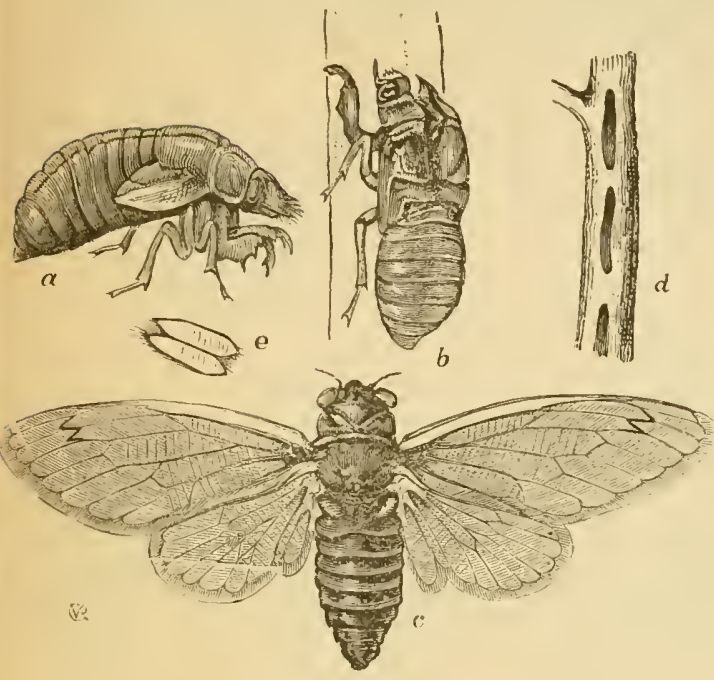

Fig. 266.

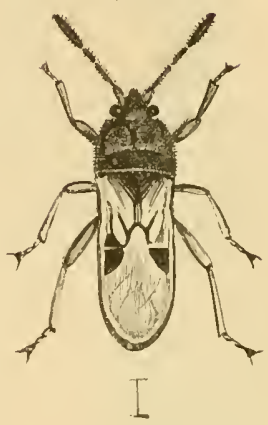

Fig. 183.

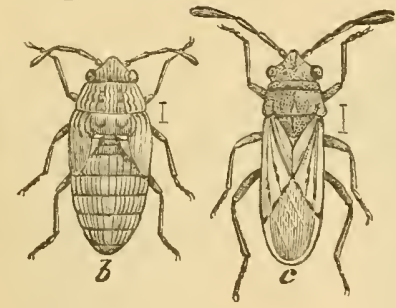

Fig. 296.
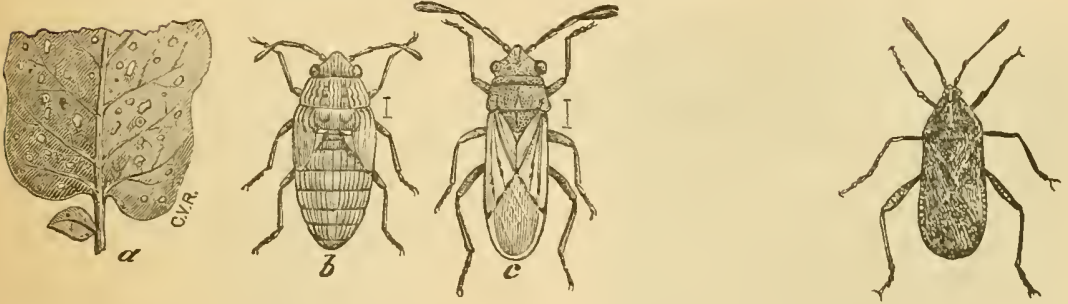

Fig. 200.

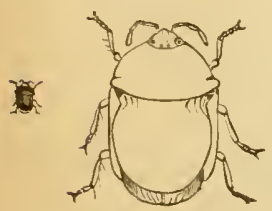

Fig. 333.

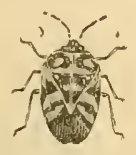

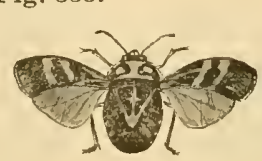

Fig. 33.

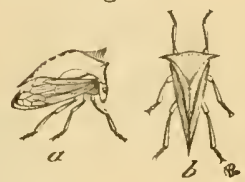




\section{PIANTE-ICICE.}

Fig. 11.

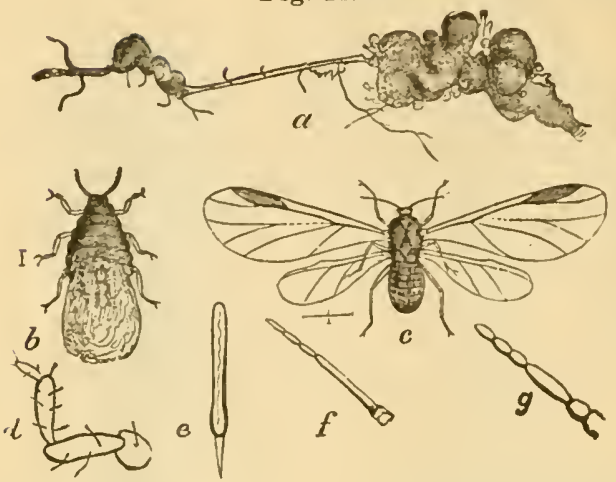

Fig. 74.

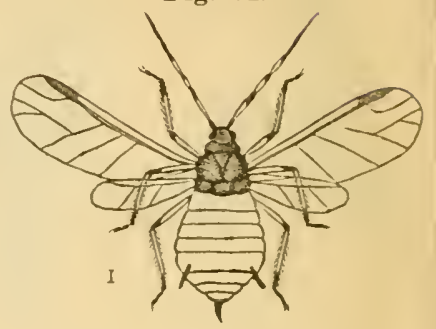

Fig. 73.

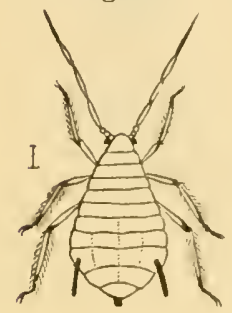

Fig. 212.

Fig. 243.
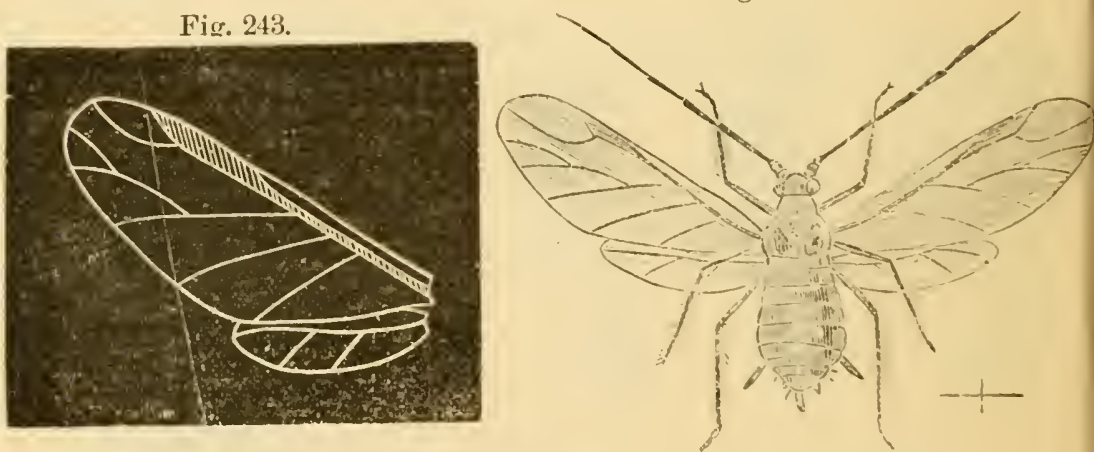

Fig. 256.
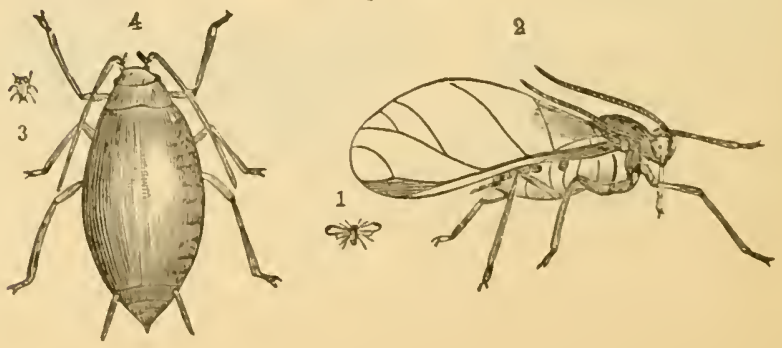
Fig. 152.
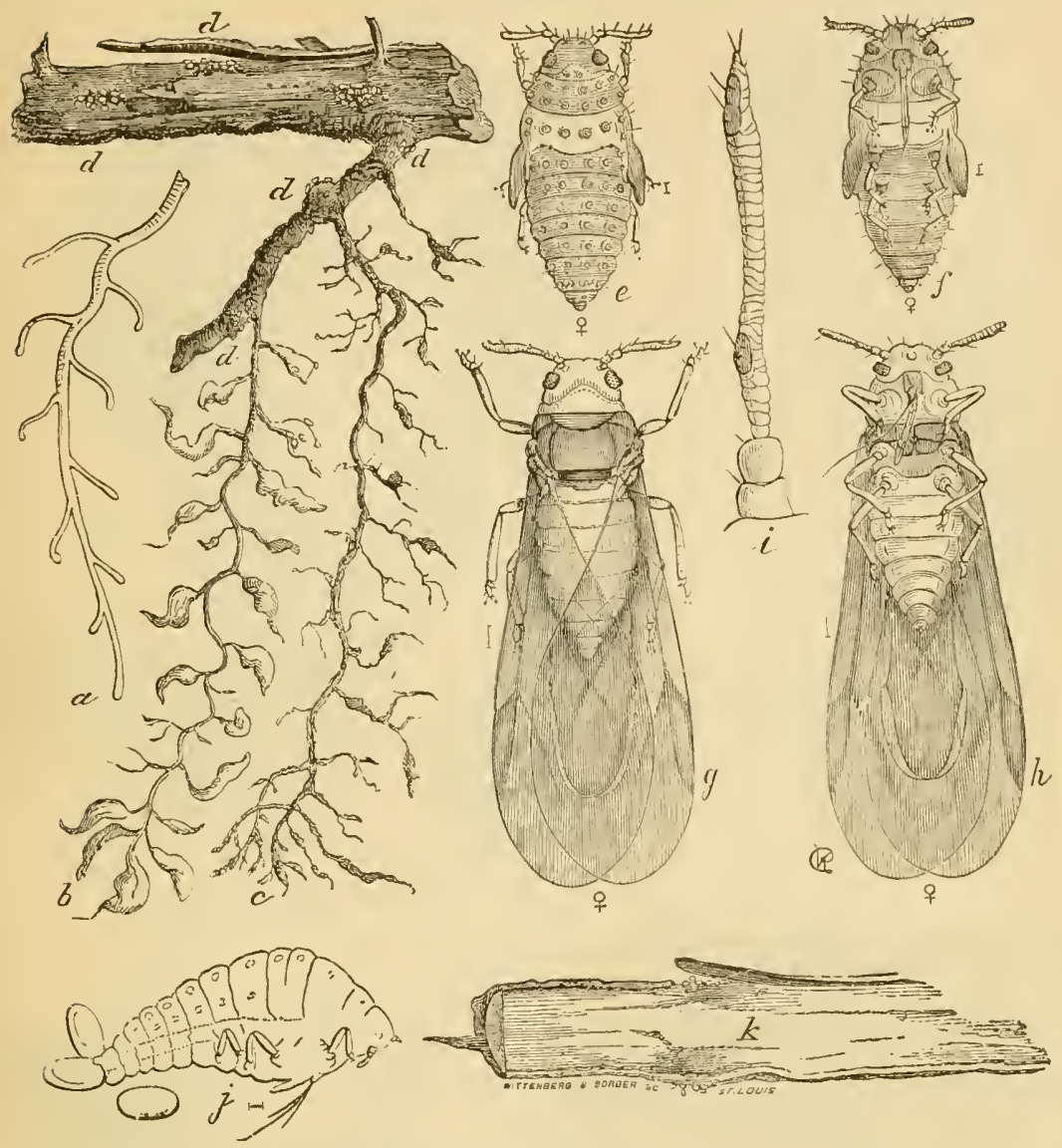

Fig. 225.

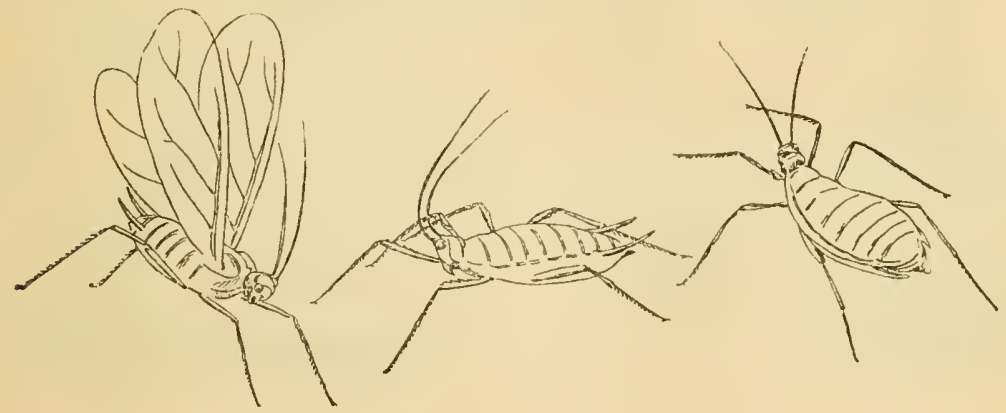


Fig. 3:3t.

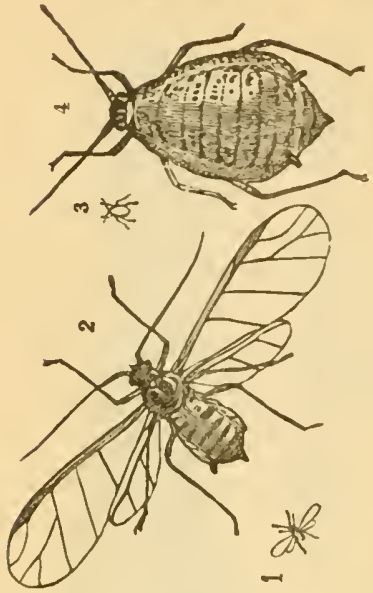

Fig. 207.

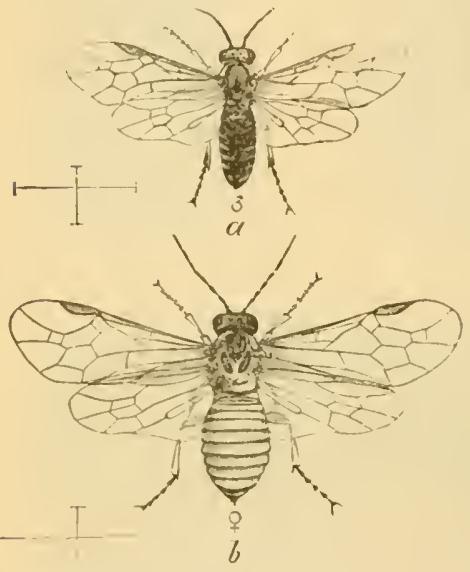

Fig. 97.
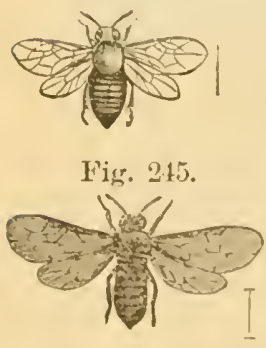

Fig. 99.

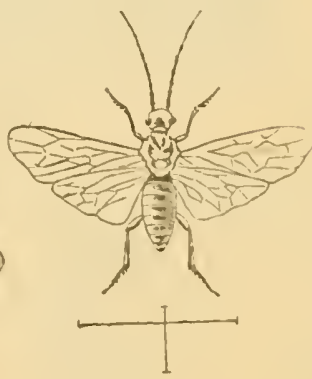

Fig. 340.
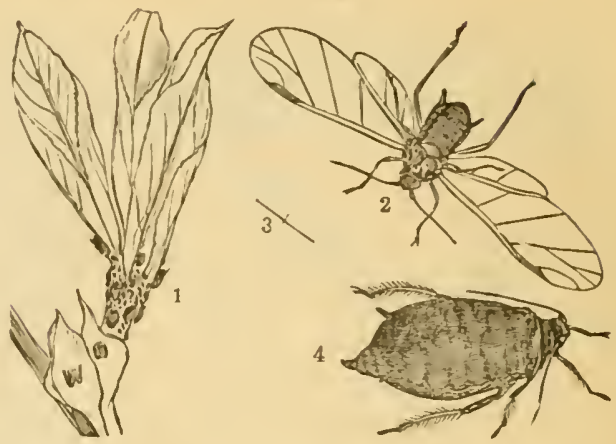

SAW-FIIES.

Fig. 209.
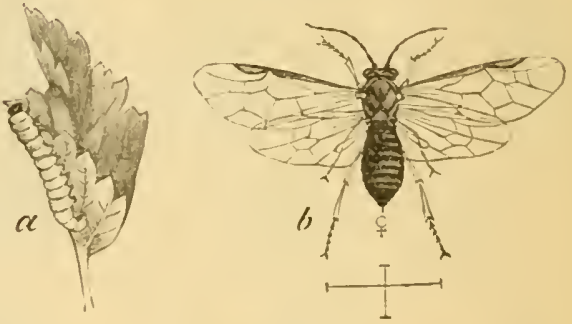

Fig. 218.

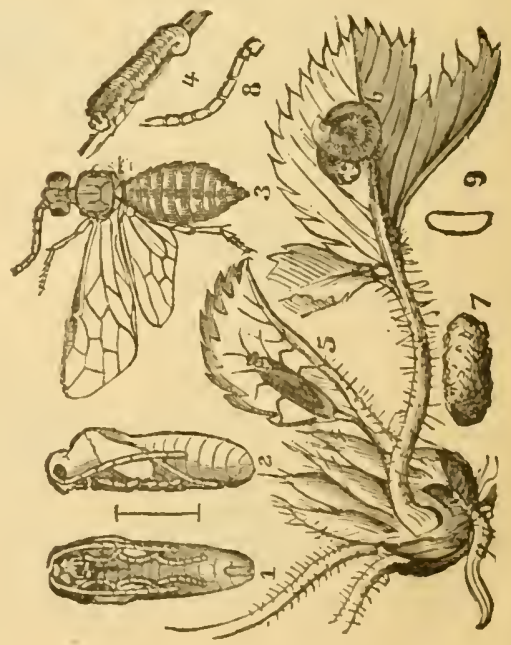


CATERPIIIARS, GRUBS, ETC.

Fig. 52.

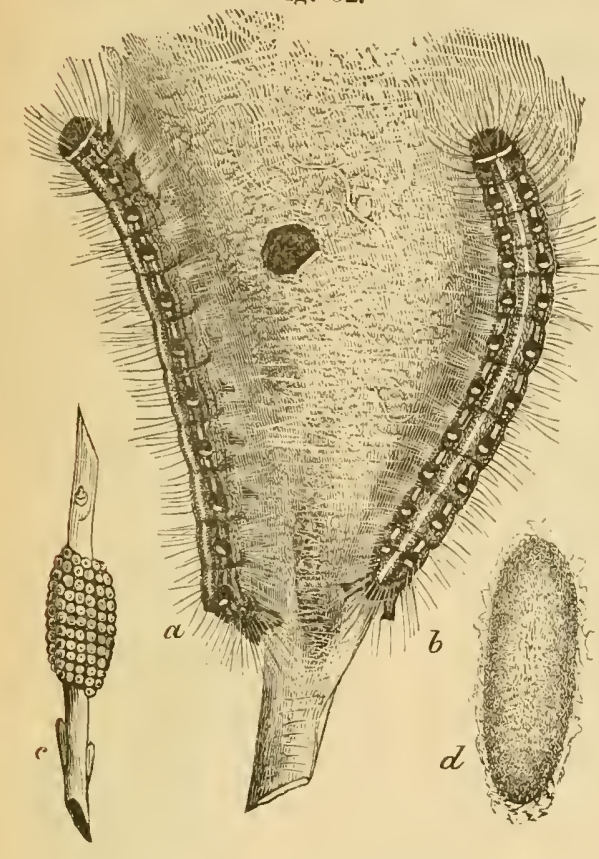

Fig. 55.

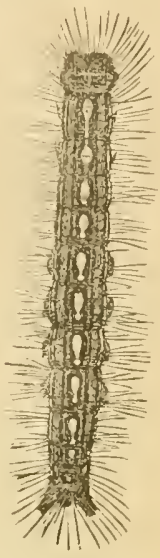

Fig. 27.
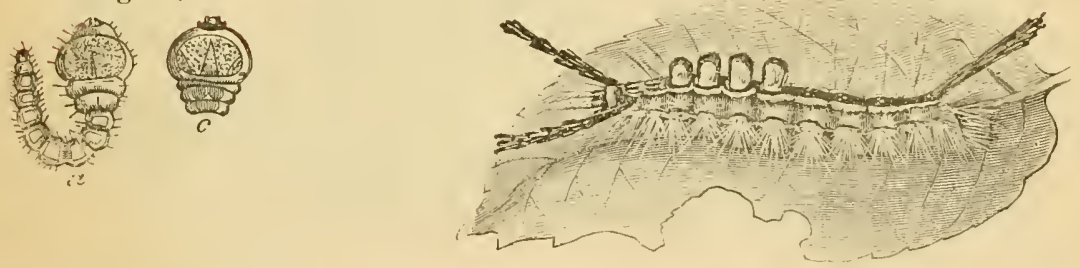

Fig. 37.

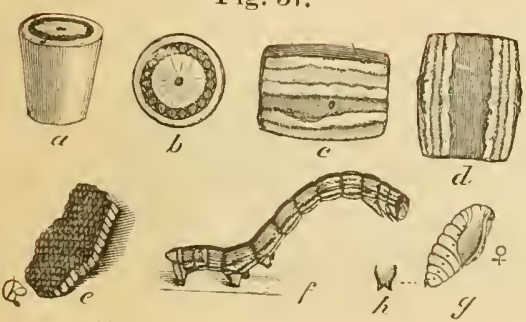

Fig. 43.

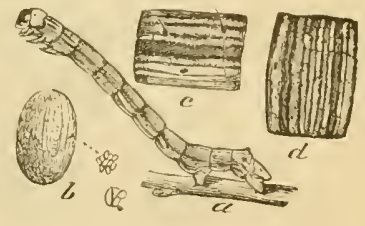



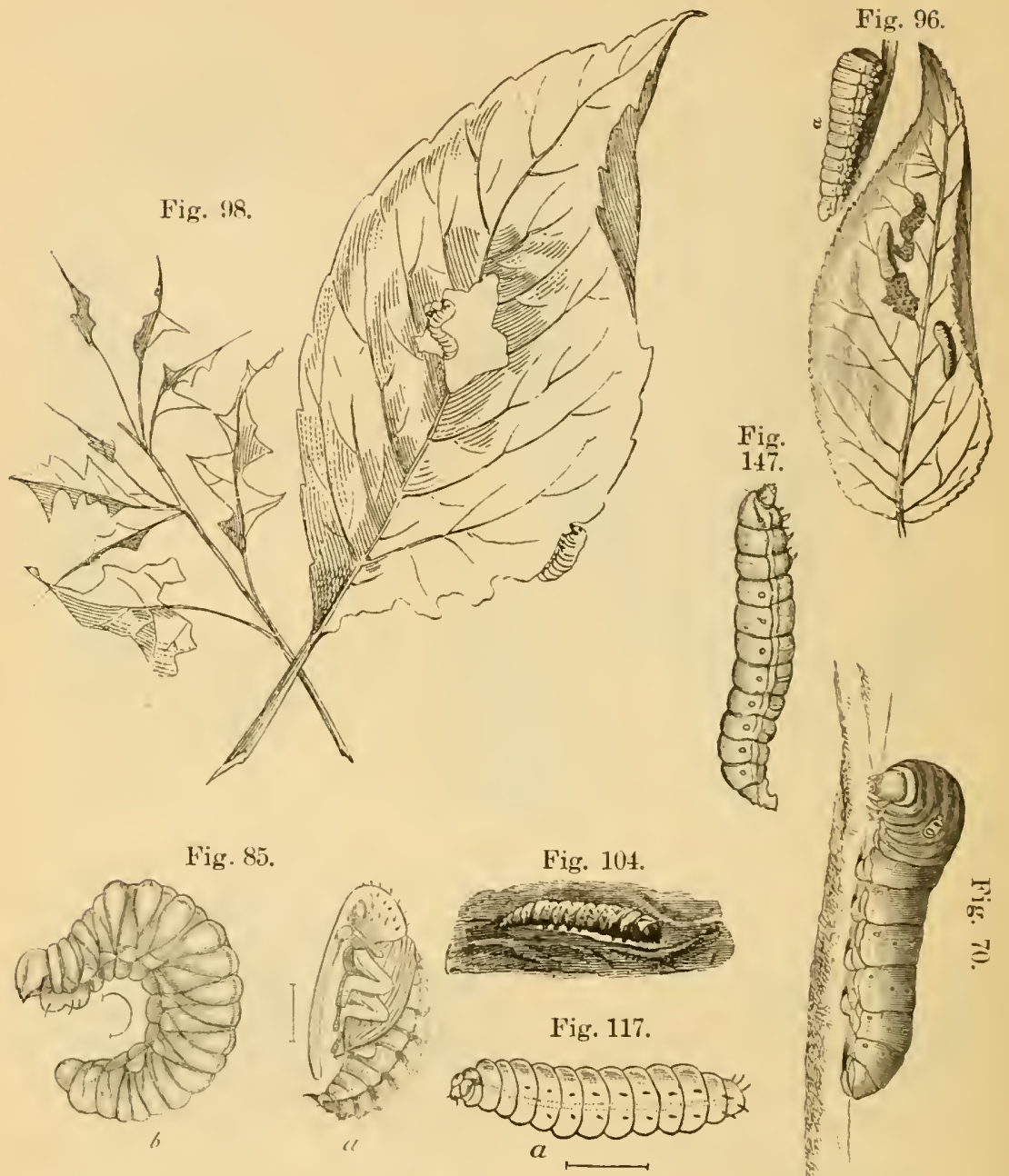

Fig. 148.

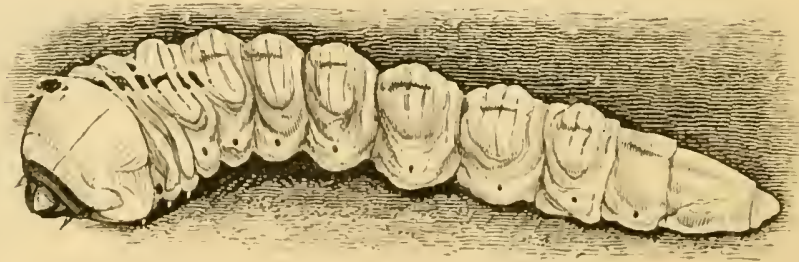




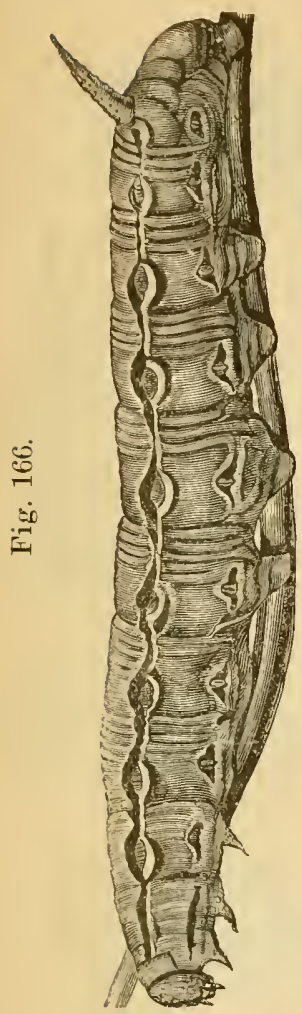

Fig. 157,

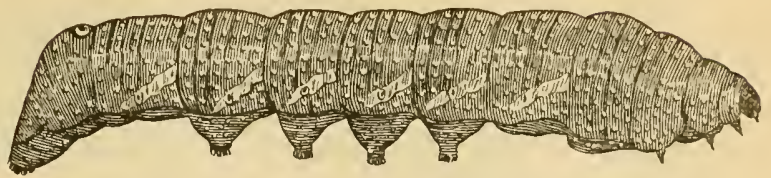

Fig. 163.

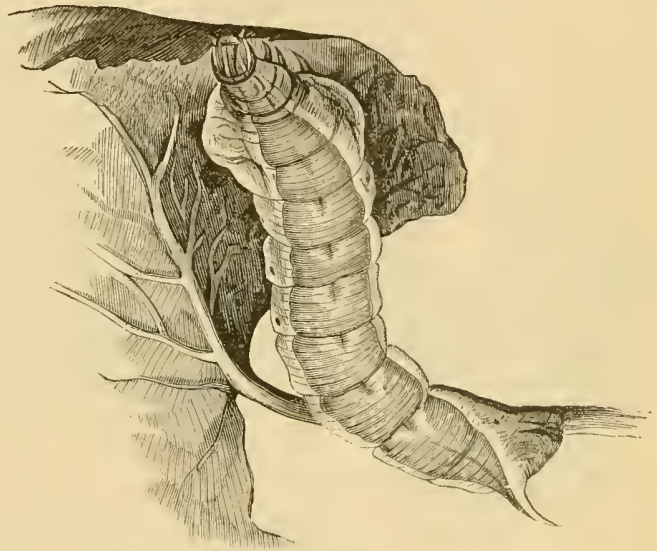

Fig. 160 .

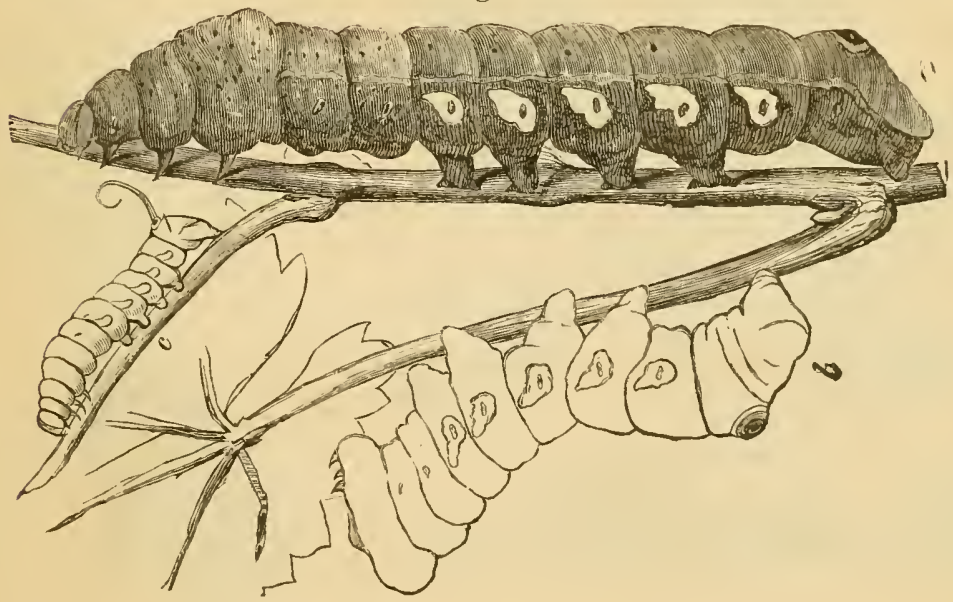



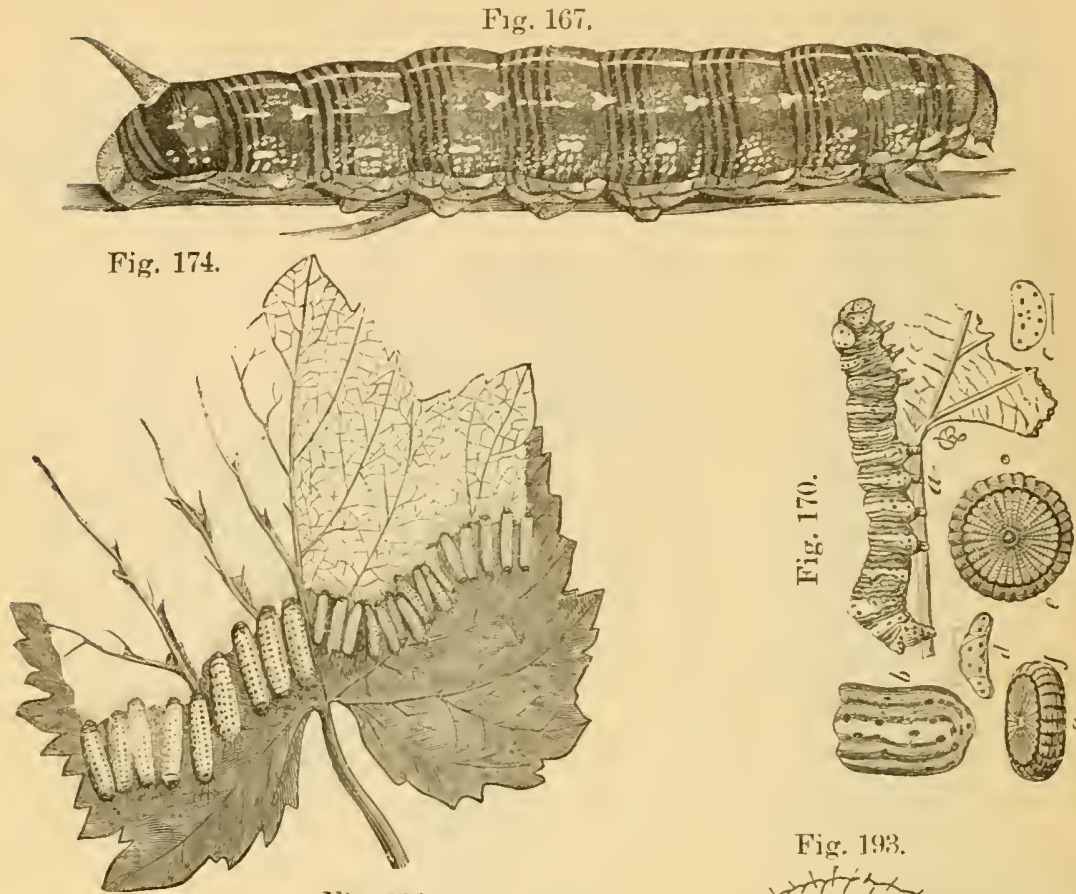

Fig. 198.
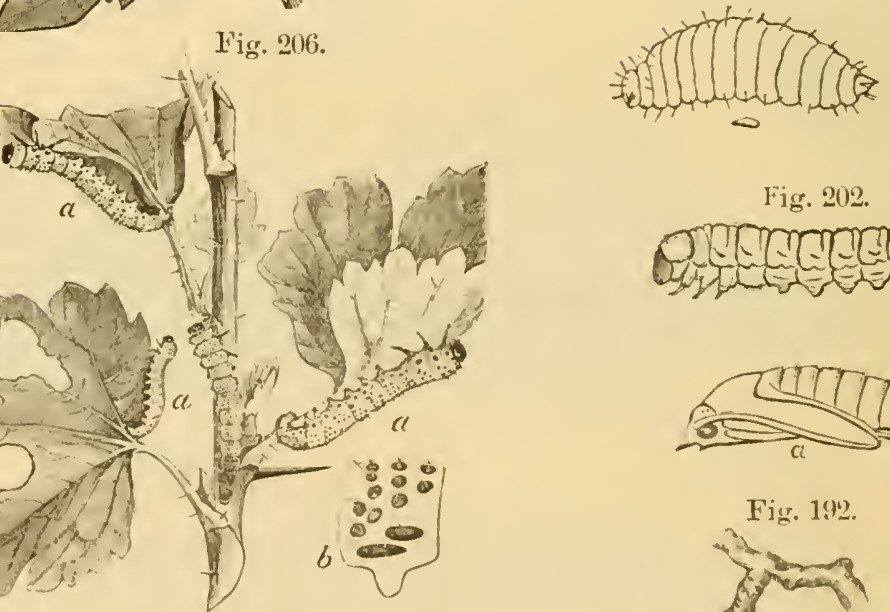

Fig. 202.

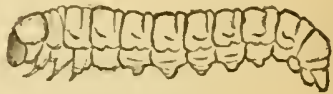

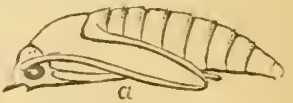

Fig. 192.

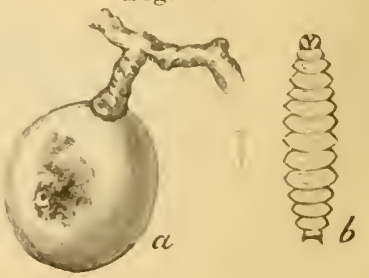


Fig. 210.

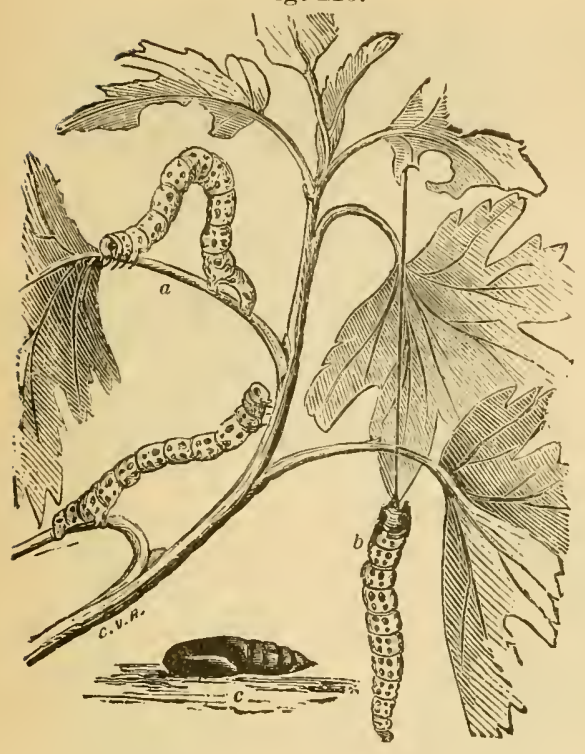

Fig. 227.

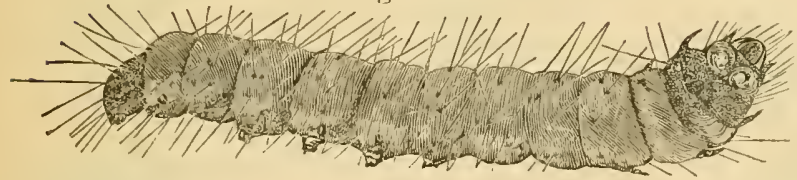

Fig. 214 .

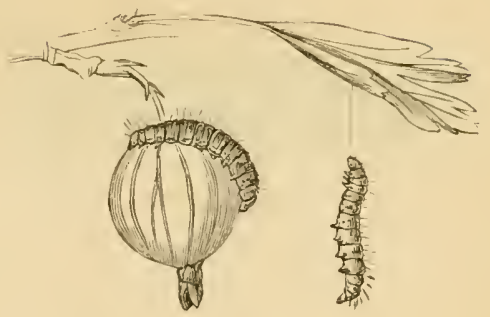

Fig. 224.

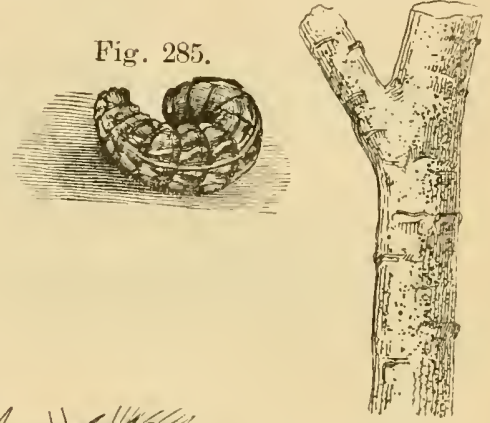

Fig. 269.

Fig. 283.
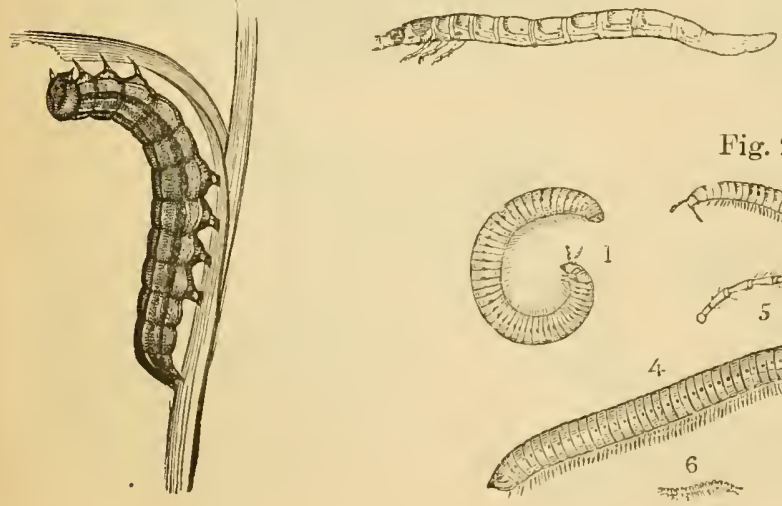

Fig. 284.
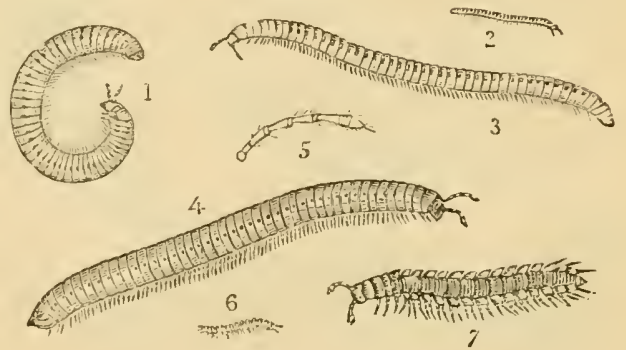
Fig. 286.

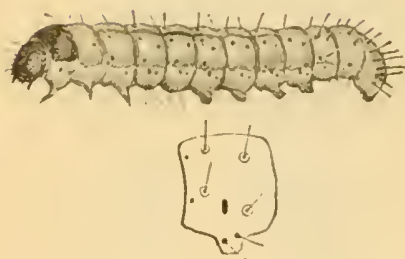

Fig. 299.

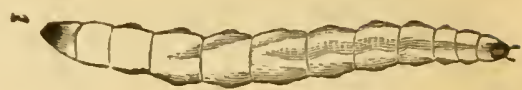

Fig. 292.

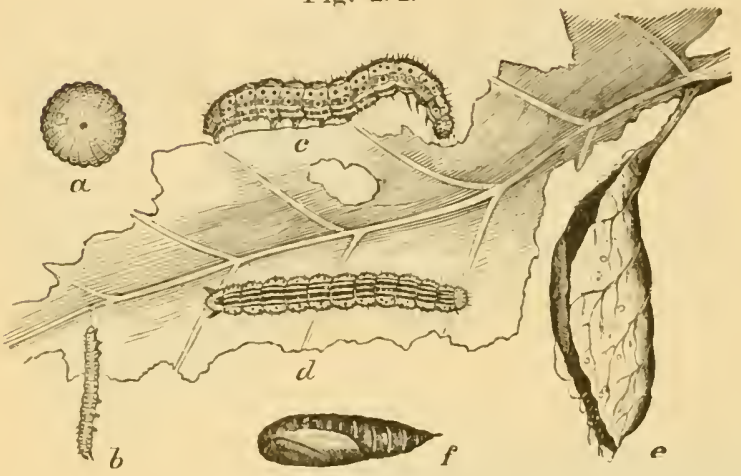

Fin. 327.

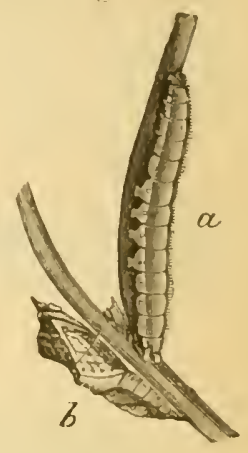

Fig. 302.

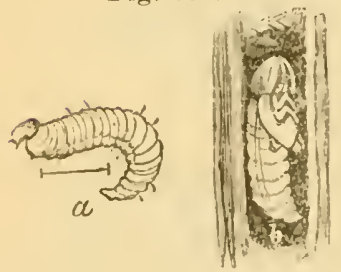

Fig. 321.

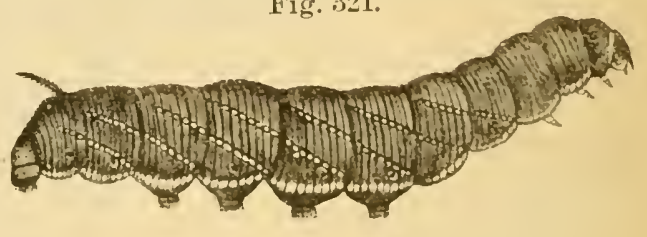

Fig. 324.

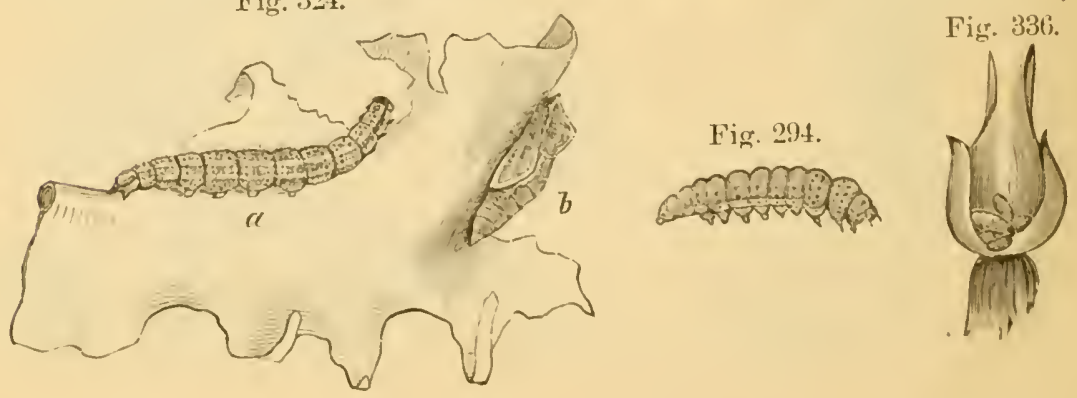


Fig. 318.
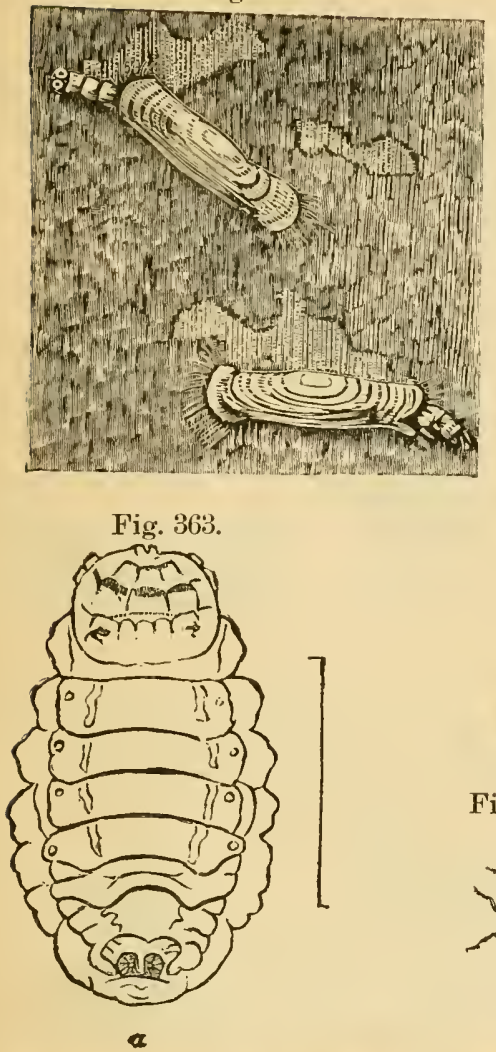

Fig. 351.

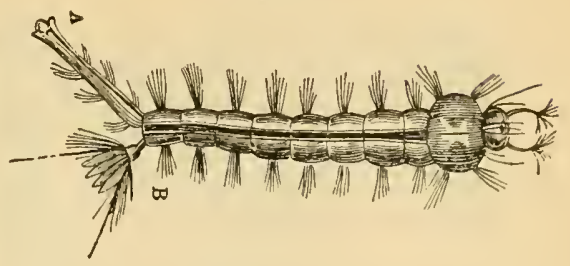

Fig. 347.
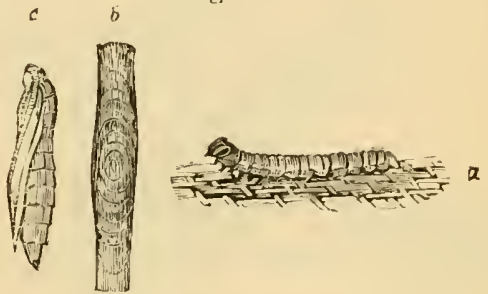

Fig. 34t.

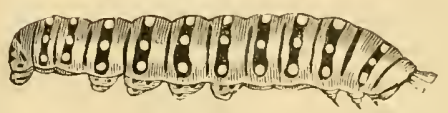

Fig. 369.

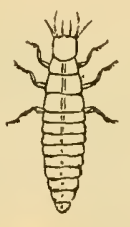

Fig. $35 \pi$.

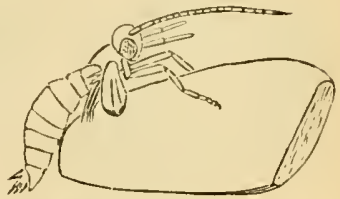

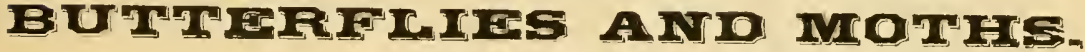

Fig. 39.
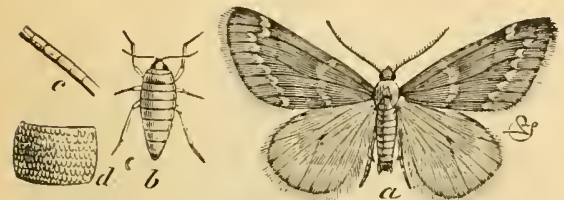

Fig. 49.
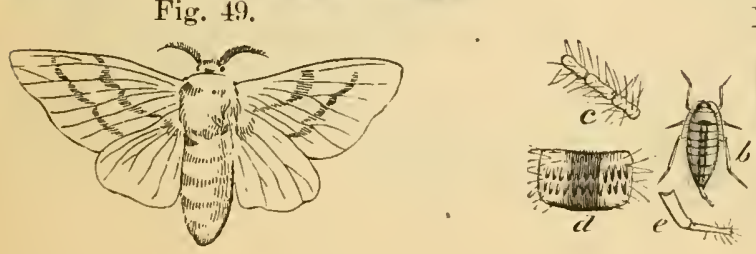

Fig. 48.

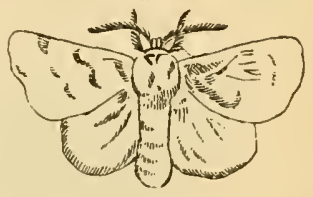

Fig. 45.

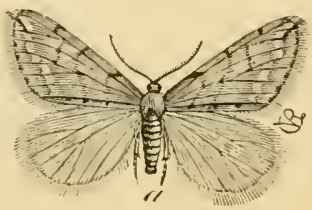


Fig. 68 .
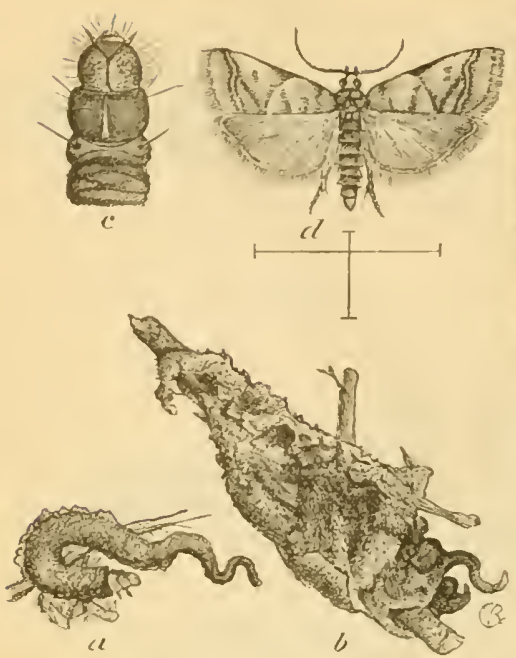

Fig. (i;i).

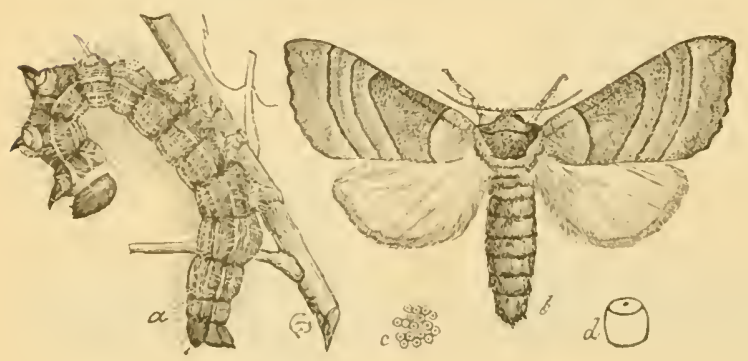

Fig. 57.

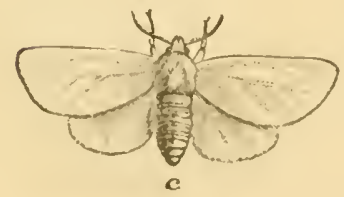

Wetchrerte

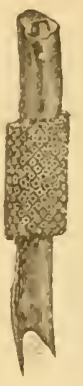

Fig. 5 f.

$a$

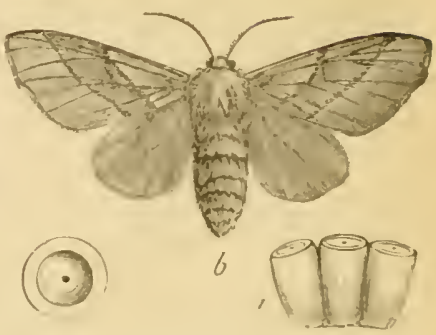

Figr. 69.
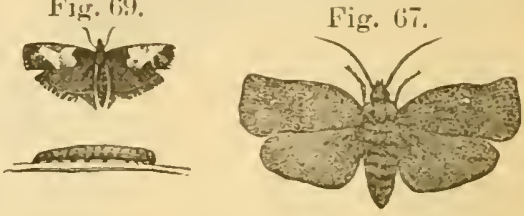

Fig. 60

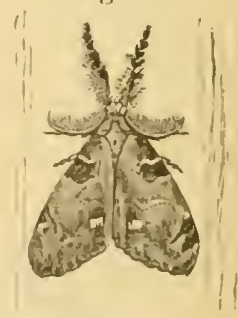

Fig. 73.

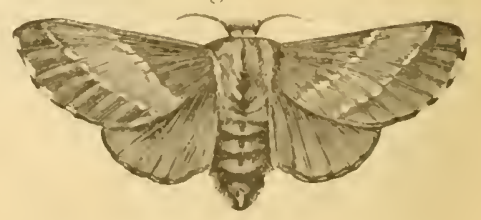


Fig. 71.

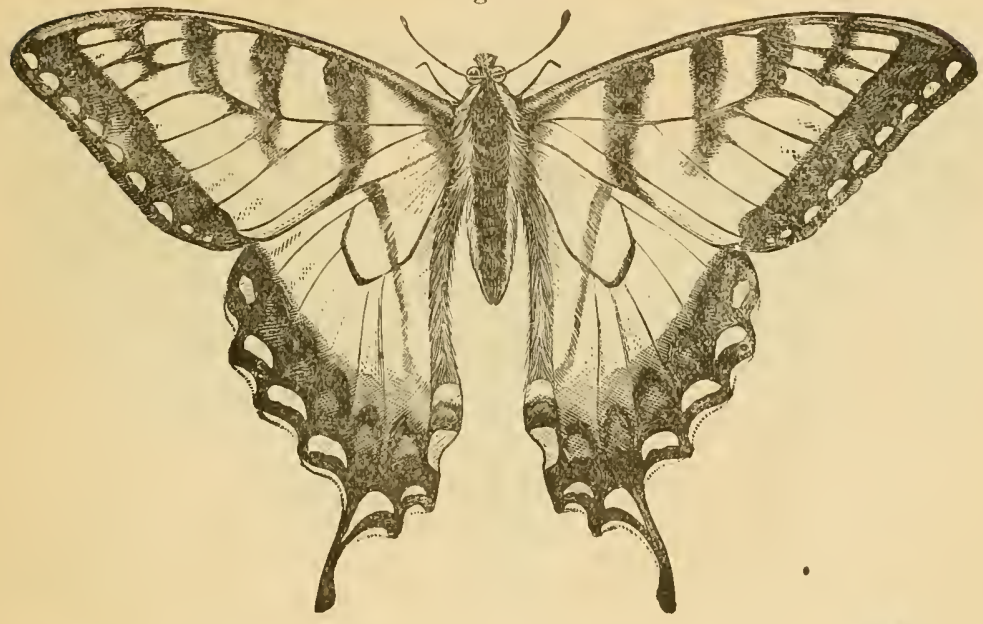

Fig. 72.

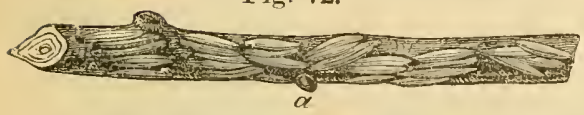

Fig. 88.
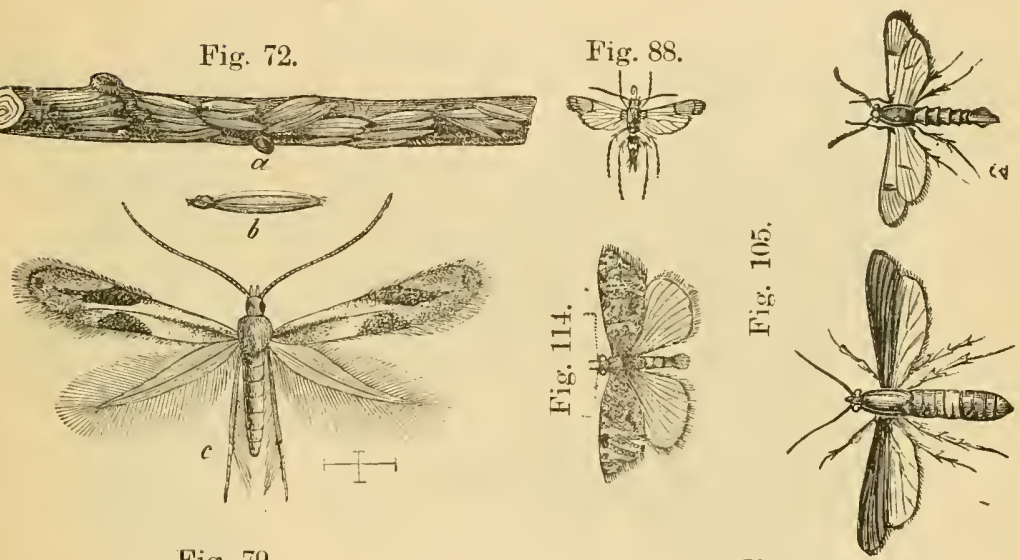

Fig. 79.
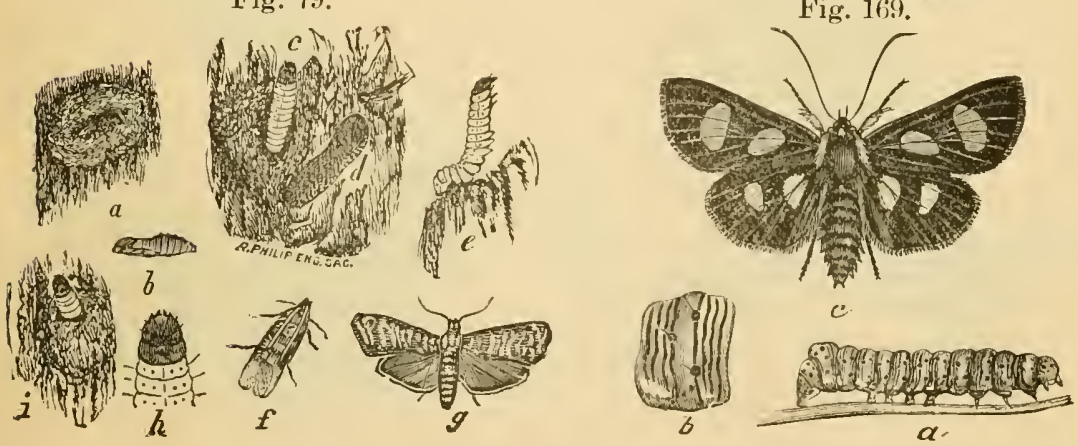
Fig. 161.
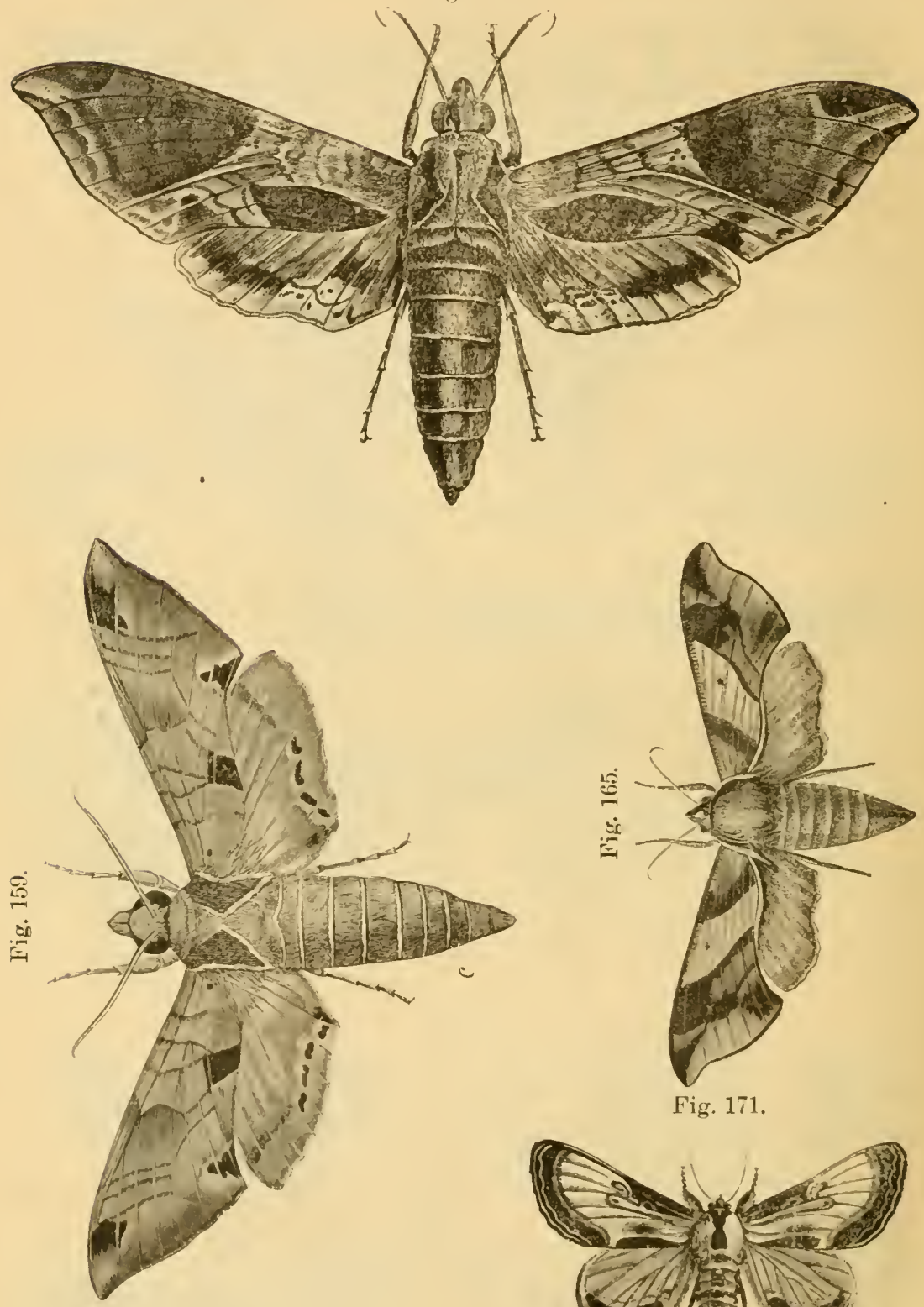

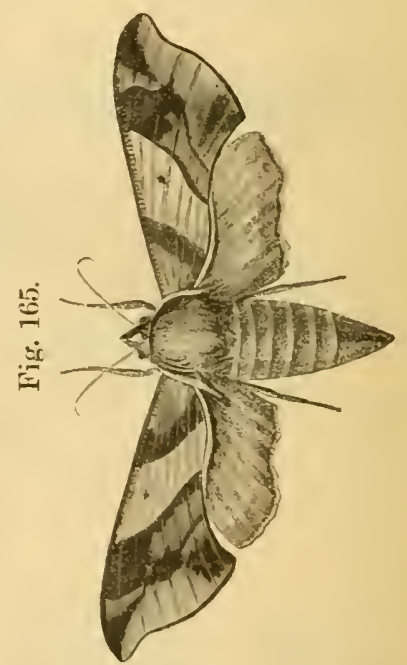

Fig. 171.

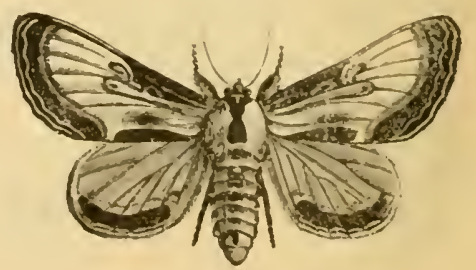


Fig. 162.
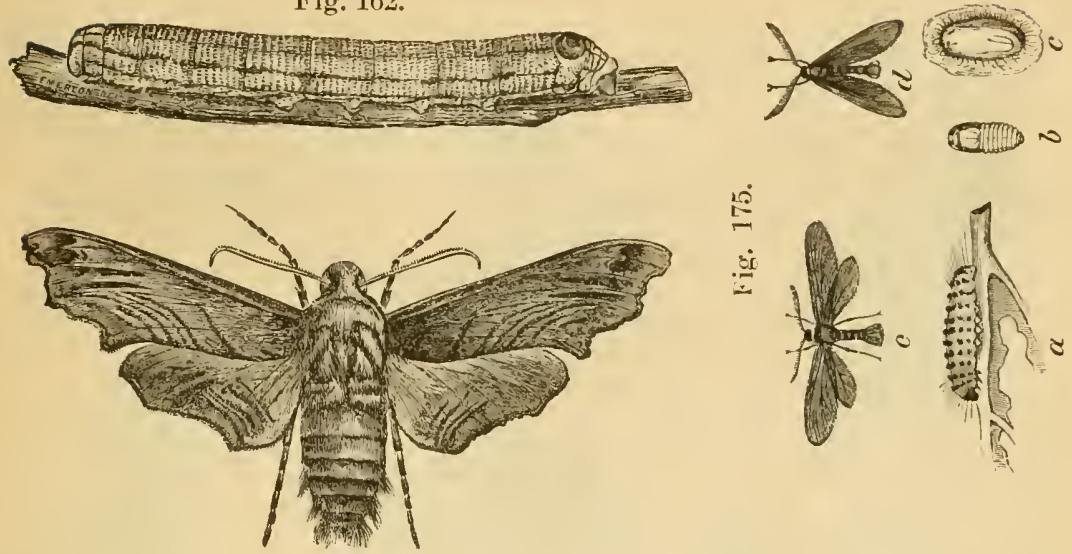

Fig. 168.

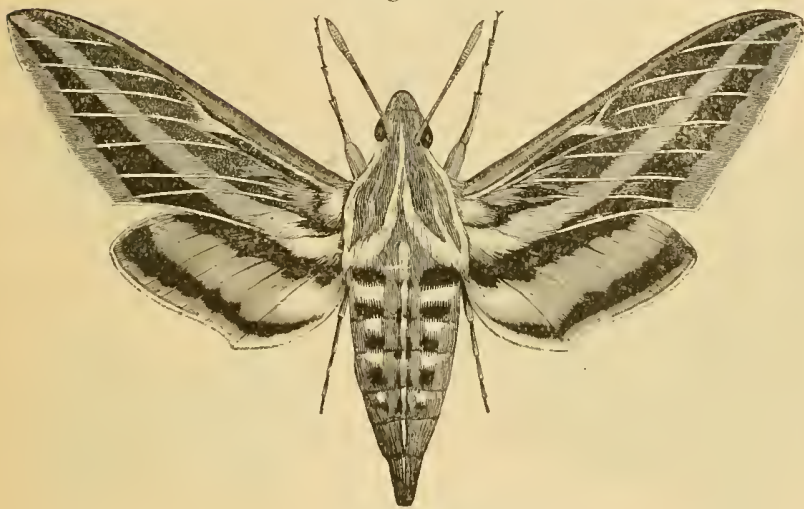

Fig. 173.

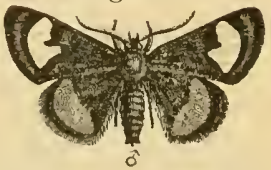

Fig. 203.

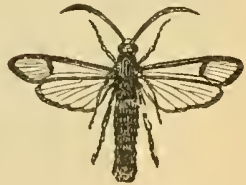

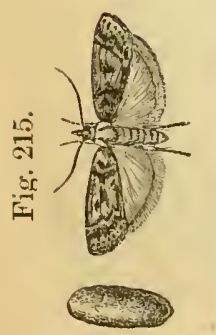
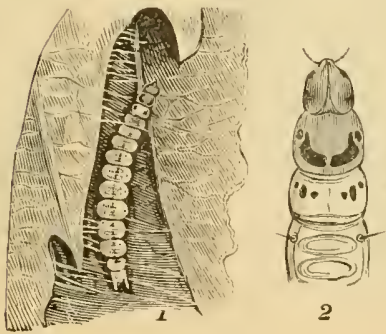

2

Fig. 176.

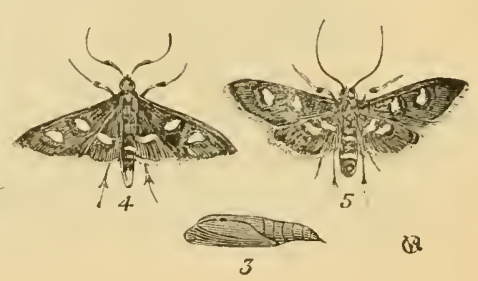


Fig. 177 .

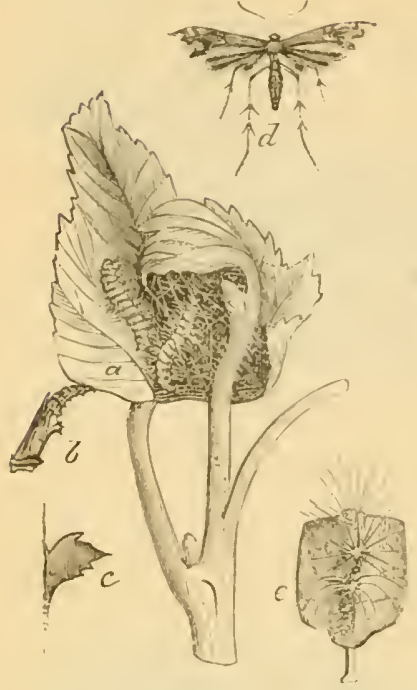

Fig. "228.

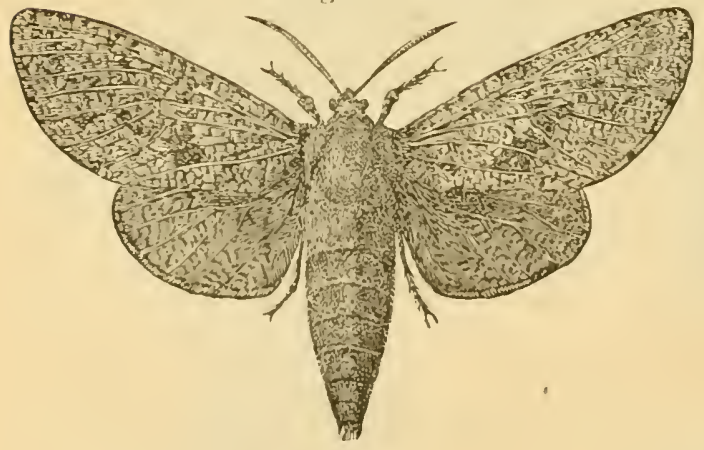

Fig. 254.

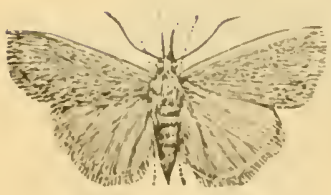

Fig. 196.
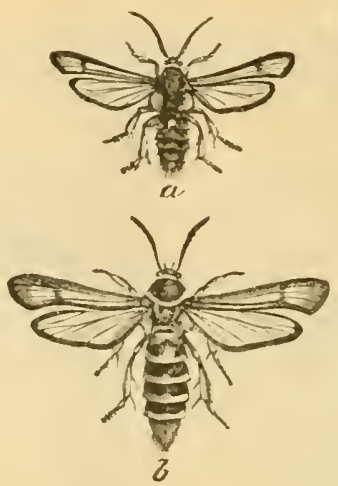

Fig. 211.

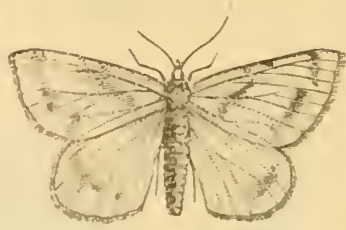

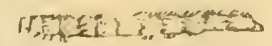

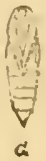

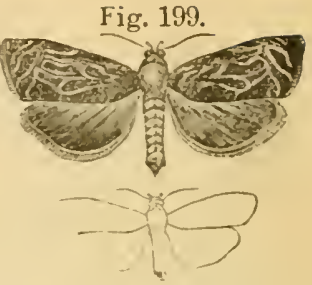
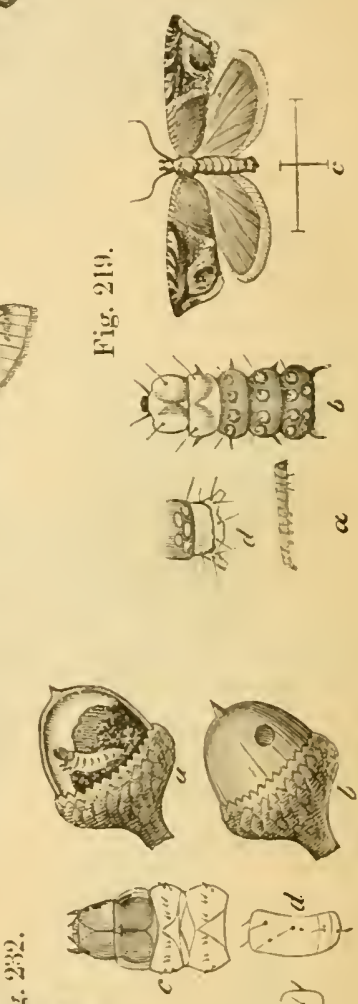

政

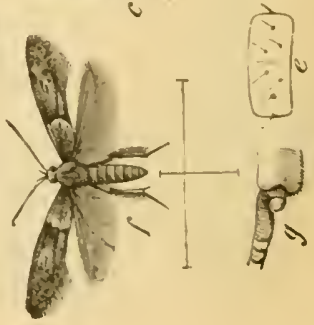


Fig. 291.
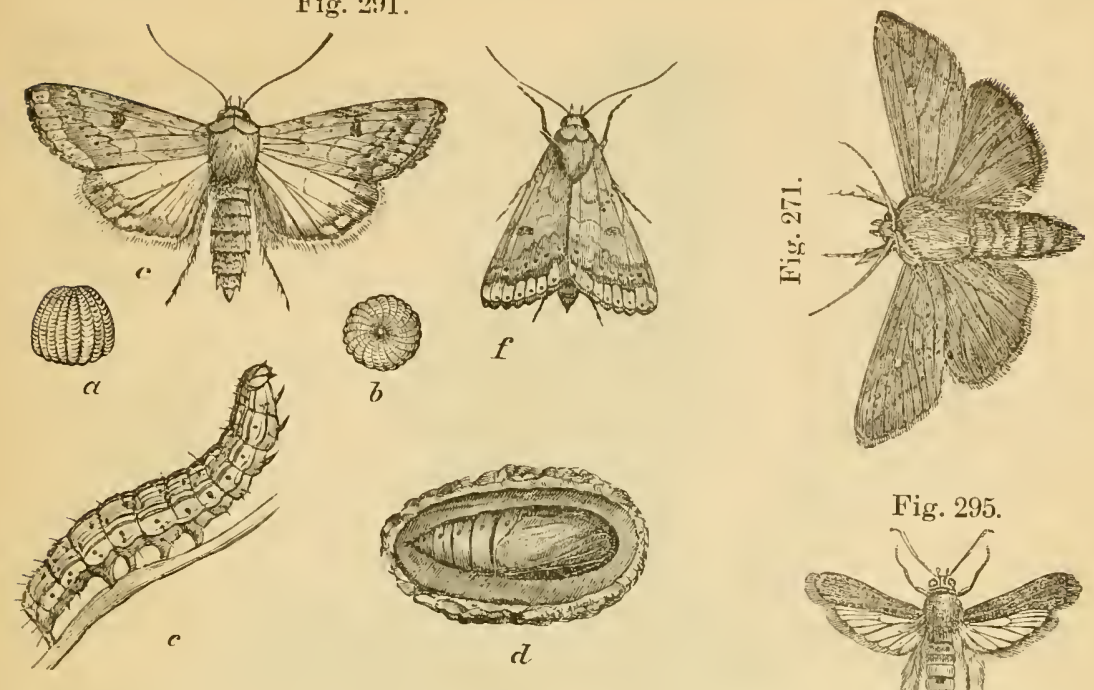

Fig. 287.
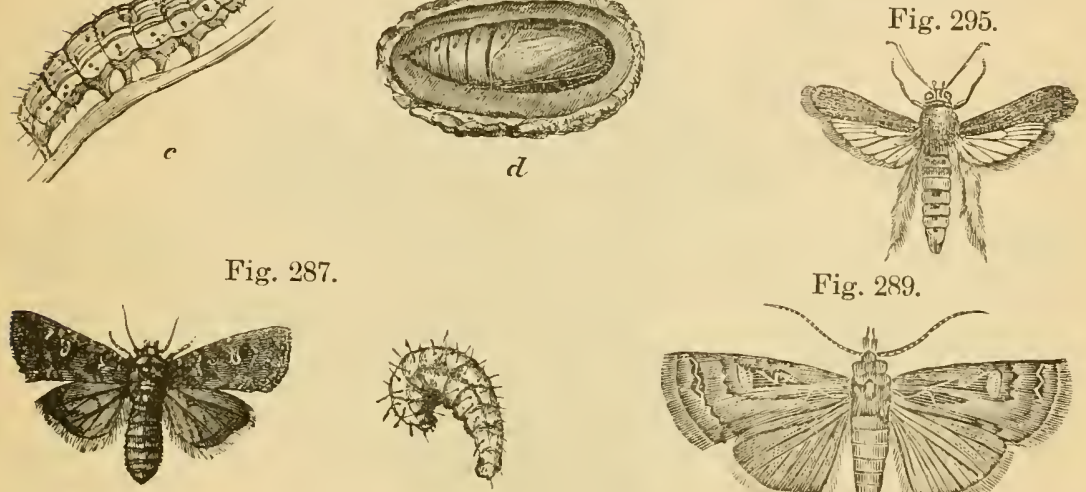

Fig. 289.
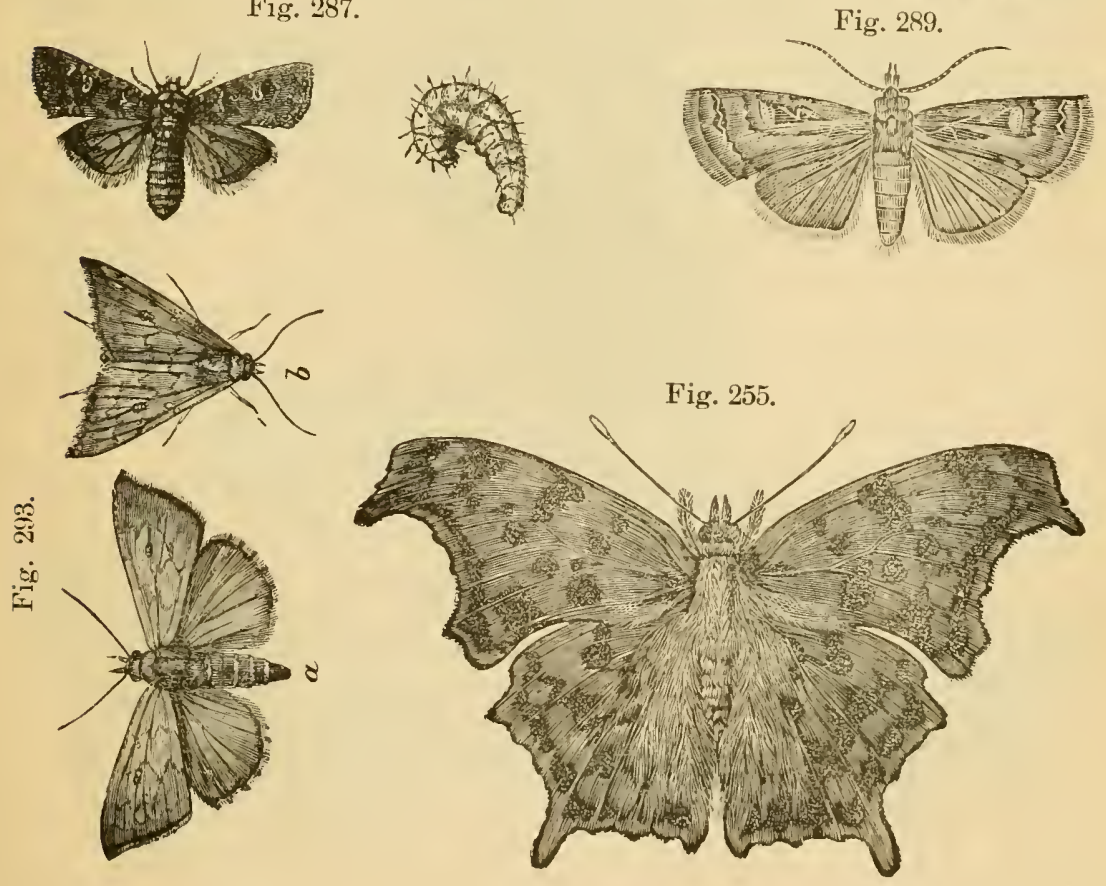


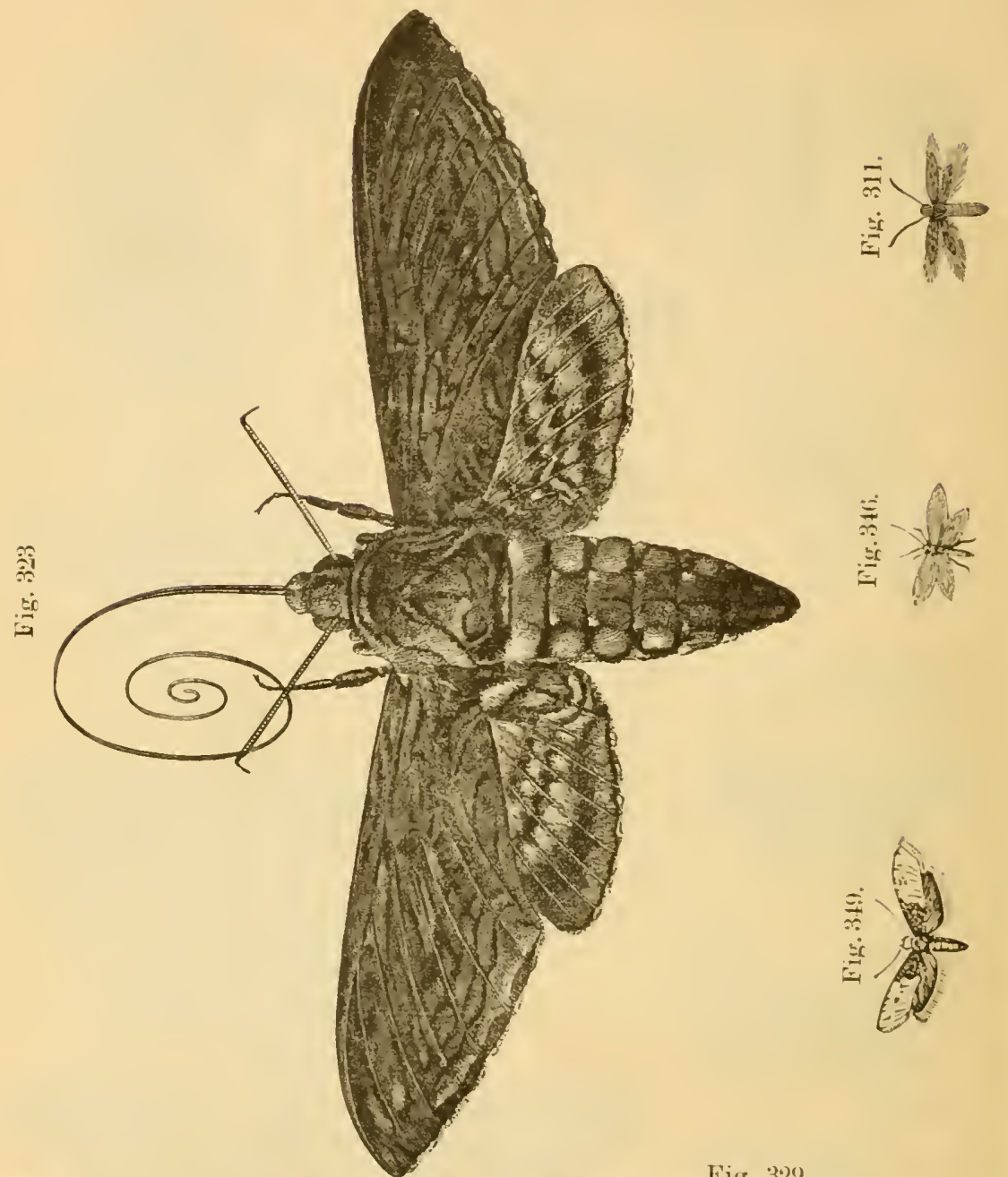

Fig. 304.

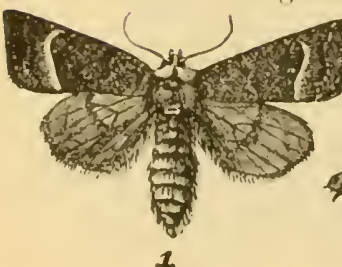

4)

1

2

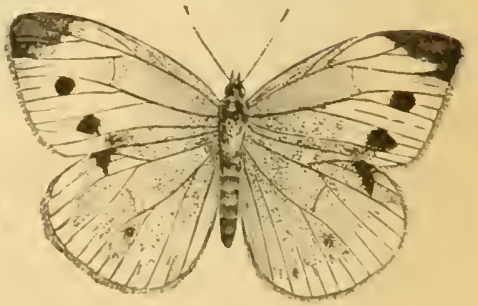


Fig. 301.

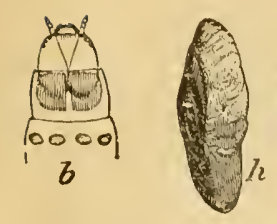

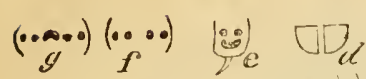

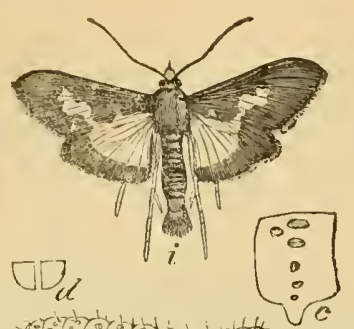

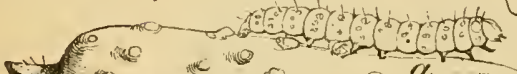

5.

Into mo mo ino

-

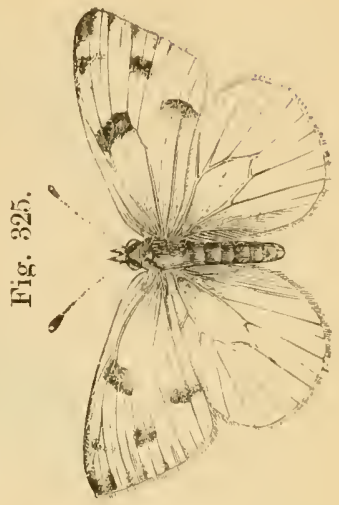

Fig. 326.

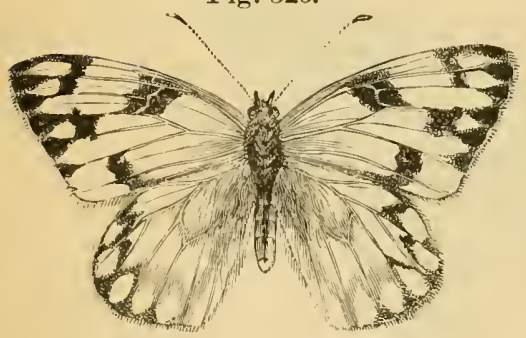

Fig. 330.
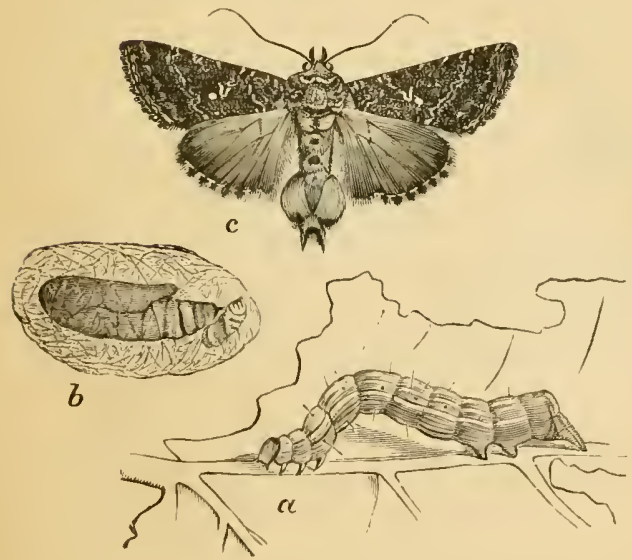

Fig. 328.

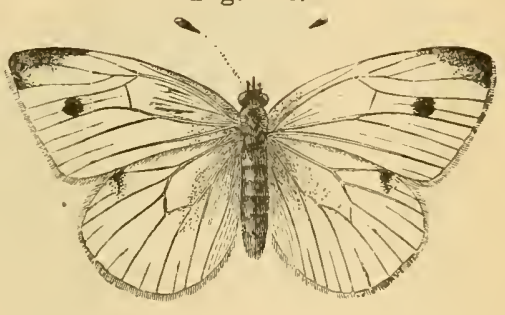

Fig. 356.

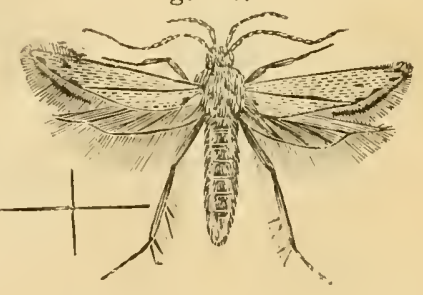


Fig. 331.

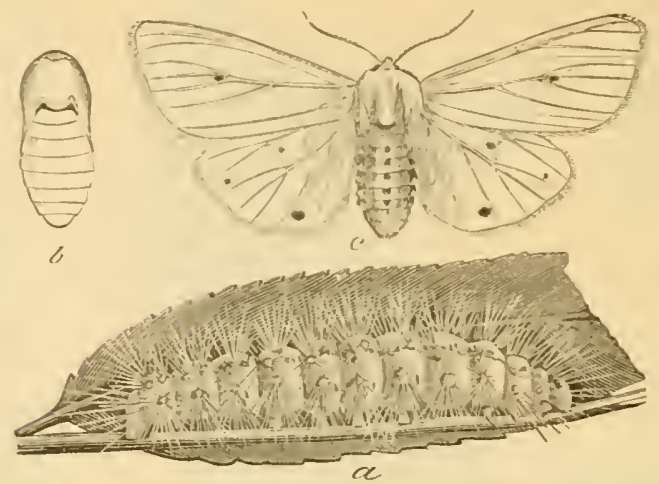

Fig. 345.

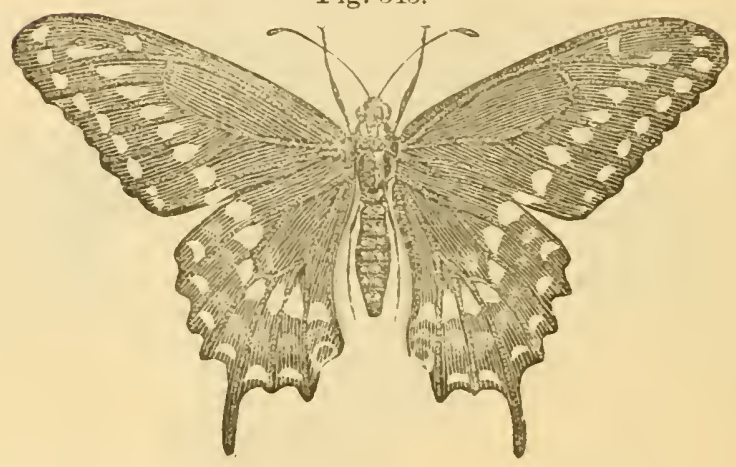

Fig. 368.
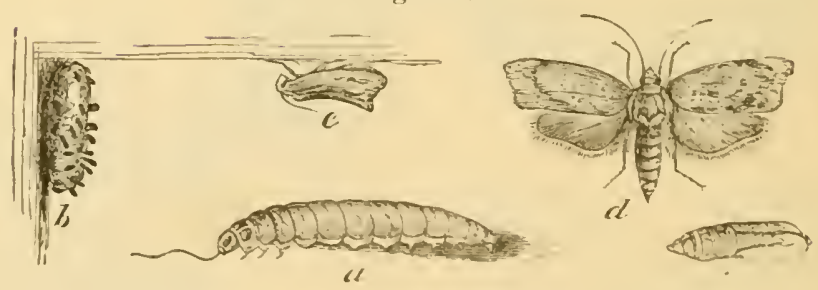


\section{INDEX TO SCIENTIFIC NAMES.}

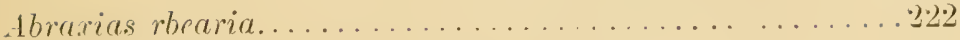

Lerobasis nebulo........................ 93

Adoxus vitis-Tmported Grape Flea-beetle... . . . . . . . . . 19.4

Egeria cueurbitacen-Squash-vine Borer. . . . . . . . . . . . . 2. 29?

. Egeria exitiosa-Peach-tree Borer. . . . . . . . . . . . . . 126

Egeria polistiformi.s-Grape-root Borer . . . . . . . . . . . 16 is

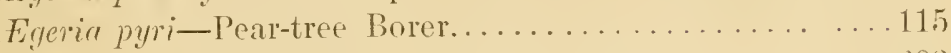

. Egeria rubi-Raspberry-root Borer . . . . . . . . . . . . . . 208

Egeria tipuliformis-Currant Borer. . . . . . . . . . . . .216

Agrilus ruficollis--Raspherry Borer. . . . . . . . . . . . . . . . . 2099

Aletia argillacea-Cotton Worm ...............297

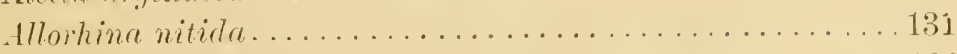

1lypia octomaculata-Eight-spotted Forester. .......... 186

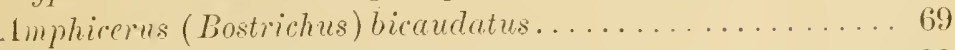

Analsis fragariz-Strawberry Crown-borer . . . . . . . . . . . . 2.28

Anarsia lineatella-Peach Noth. . . . . . . . . . . . . . 128

Inchylopera fragarix-Strawberry Leaf-roller...........28 23

Anisoptery. Autumnata-Fall Canker Worm .......... 75

Anisoptery.r pometaria-Fall Canker Worm............ 75

Anisoptery.r vernata-Spring Canker IVorn............. 78

Anthomyia brassicr-Cabbage Maggot. . . . . . . . . . . . 321

Luthomyia ceparum-Onion Maggot . . . . . . . . . . . . 3930

Anthomyia raphani-Radish Maggot... . . . . . . . . . . . 328

Inthonomus prunicida-Plum Gouger. . . . . . . . . . . . 143

Anthonomus quadrigibbus-Apple Cureulio . . . . . . . . . . 109

Anthrenus seroph!nlarix-Carpet Beetle. . . . . . . . . . . . 340

Lphis amyydali-Almond Aphis................236

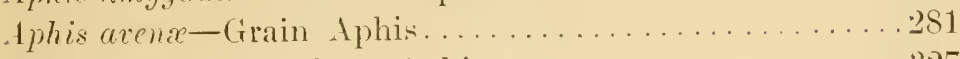

Aphis brassica - Cabbage Aphis...................27

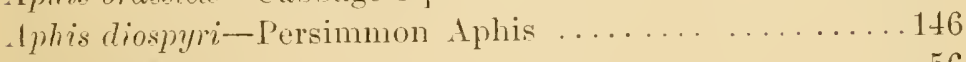

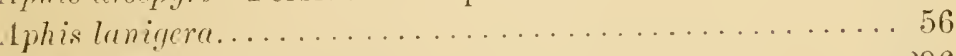

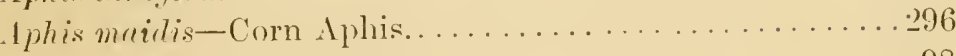

Aphis mali-Apple-tree Iphis.................. 98 


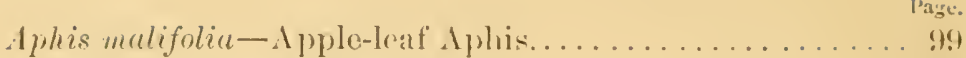

Aphis nerii-Oleander Aphis....................

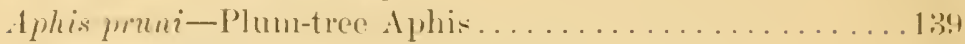

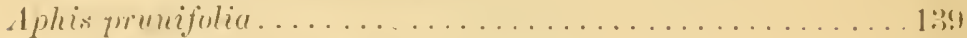

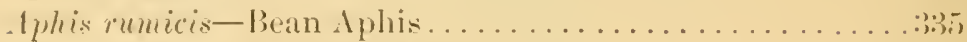

Aphis riburni-snowhall Aphis................

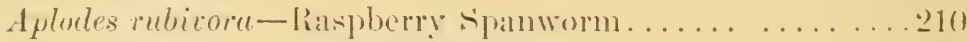

Asopin rostalis-('lover-hay Worm . . . . . . . . . . . . .s'

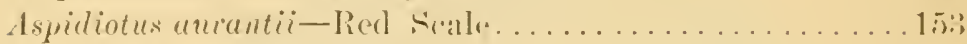

Aspidiotus cimelurix..................... 11.

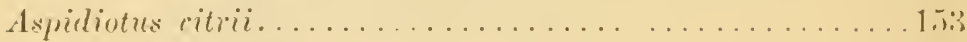

Aspridiotus citricola.........................1li1

Aspidiotus conchiformis-() yster-shell bark-louse........ 5i

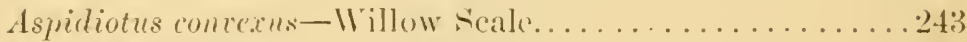

Aspidiotus cydonit - Quince Scale. . . . . . . . . . 1:4

Aspridiotus ficus-lied Scale of Florida............. . . Fti

Aspidiotus juglans-regix-Wahnut Scale...........2:2.

Aspidiotus nerii-Lemon-jeel ścalle.............. $15 \mathrm{~s}$

Aspriliotus ostrexformis.......................

Aspirliotus ortholubus-San Bernardino Willow seale.....244

Aspicliotus peryandi-Pergande's ()range Scale.......... 16(1)

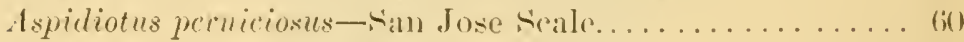

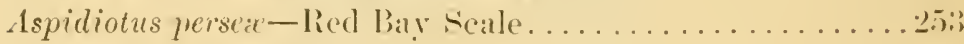

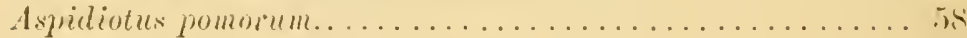

Aspidiotus pyrus-malus...................... is

Aspidiotus rapax-Greedy Scale................ (ii:)

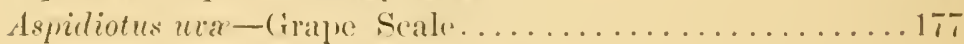

Baridius trinotatus-Potatu-stalk Weevil..............suri

Bitona opaculus-Decaving Wood Borers.............

Blatta Germunicu-Cockronch..................... .

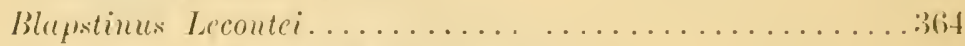

Bestriches bicandatus - Ipple-twig Borer. . . . . . . . 69

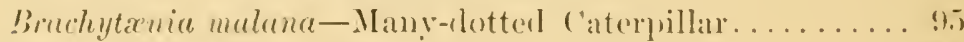

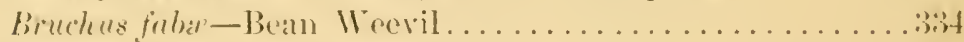

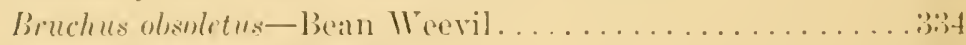

Bruchus prisi-Pea Wrevil....................3:32

Bucculatrix pomifoliella-Apple Bucrulatrix .......... \$7

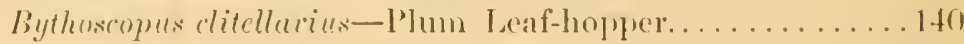


Calamba yranaria-Girain Weevil.................344

Calandra oryza-Rice $\mathbb{T}^{\top}$ eevil. . . . . . . . . . . . . . . .345

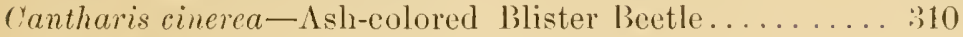

Cantharis vittata-Striped Blister Beetle.... . . . . . . . . 312

('arpocapsa pomonella-Codlin Moth................. 102

Cassida murichalcea-Golden Tortoise Beetle...........316

Crssidlr bivitt uta-Two-striped Tortoise Beetle. . . . . . . . . . \$16

Cassida yuttata-Nottled Tortoise Beetle.............316

Cassida nigripes-Black-legged Tortoise Beetle...........316

Cecidomyia destructor-Hessian Fly ................274

Cecidomyia yrossularix-Goosehery Midge............227

feresc bubalus-Buffalo Tree-hopper............... 71

retonia Inda-Indian Cetonia . . . . . . . . . . . . . . . 1:30)

rharocampa pampinatrix-Hog Caterpillar. . . . . . . . . . . 1s:3

('hionaspis ortholobis-San Bernardino Willow Scale.....24t

chrysobothins femorata-Flat-headed Apple-tree Borer..... 6i7

('hrysomphalus ficus . . . . . . . . . . . . . . . . . 156

('lisiocampa Americana-Orchard Tent Caterpillar....... s.

C'Tisiocampa constricta-Delong's Caterpillar........... T9

Clisiocampu syltatice-Forest Tent Caterpillar......... S5

('ytus Robrinix - Legless Locust Borer . . . . . . . . . . . . . 240

Yoceinella 5-notata var. Califomica-California Lady-hird.:B(i2

Goceotorus scutellaris........................ 14:

roceus mali.......................... 56

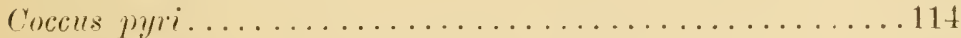

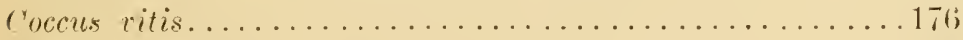

f'uliodes inxqualis-(irape Curculio... . . . . . . . . . . 204

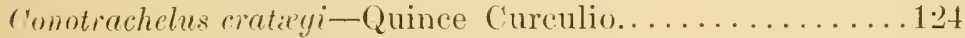

Conotrachelus nemuphar-Plum Curculio............. . . . . . . . .

('oreus tristis-Squash Bug. . . . . . . . . . . . . . . . 300

rorimelana pulicuria-Negro Bug. . . . . . . . . . . . . . . 212

rotalpa lanigera-Goldsmith Beetle................ . 101

(rioceris Asparagi-Asparagus Beetle..............336

('rosia persicana-Peach Leaf-roller. . . . . . . . . . . . . 129)

Ductylopius adonidum-Mealy Bug.................263

Dactylopius destructor-Destructive Mealy Bug..........264

Dactylopius longifilis-Mealy Bug with long threads...... 266

Dacus olea-Olive Wrorm . . . . . . . . . . . . . . . . . 150 
Darapser myron..........................

Datanu ministra-Vellow-necked Caterpillar........... sil

Deile pleila lincata-White-lined Sphinx .... . . . . . . . 184

Dermestes lardurius-Rawhide Beetle..............34t

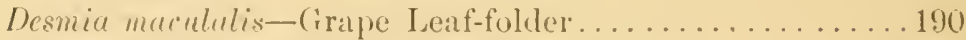

Direbotica rittata-Striped Cur-umber-beetle. . . . . . . . . . : 02

Diahrotica 12-prencta-Twelve-Spotted Dibrotica......... 135

Diespis astrexformis-Oyster-formed seale..........112

Diplosis tritici-Wheat Midge.................2.

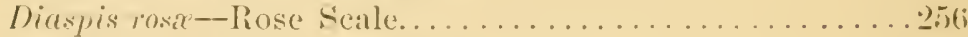

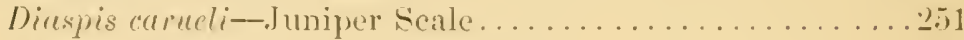

Direren dicaricate-Cherry-tree Borer............. 136t

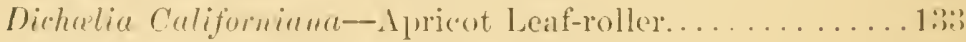

Distoma hepatirum--Liver Fluke..................35i

Disonyche limbirollis-_itriped Bud-beetle............ . . .

Dolerus tejomicus-lieel-bodied saw-fly . . . . . . . . . 13:2

Doryphorn I1)-linerit--C'olorado Potato Beetle..........30s

Ereopsis permundana.......................211

Elendes quadricollis.......................... 365

Ellopia ribraria........................2

Emphytes maculates-Strawherry Worm. ...........280

Epicante itteta-striped Blister-beetle.............312

Epitrix cucumeris..........................303

Epitrix hitigennis-small Potato Beetle, No. 2........313

Épitrie suberinita-Small Potato Beetle, No. 1..........312

Eriococres azelez-Azalea Bark-louse. . . . . . . . . . . 254

Eriosome lenigere........................

Eriosemen mali......................... 56

Erythoneure come -Califormia Grape-vine Hopper. . . . . . 19:

Eudigus gratu-Beatiful Wood Nymph.............

Eufitchia ribedria-Currant sipan-worm ............222

Eurytama flavipes-Yellow-legged barley-fly. . . . . . . . 27?

Eurytoma hordei--Black-legged Barley-fly...........279

Euryomiu Inde . . . . . . . . . . . . . . . . . . 130

Éurytoma secalis-liye Fly. . . . . . . . . . . . . .279

Eurytome tritici-o.Joint Worm..................

E.cuitema permundena-Raspberry Leaf-Roller...........211

Forfiende auviculurie--Earwig..................111 
Galeruca vittata-Striped Cucumber-beetle.

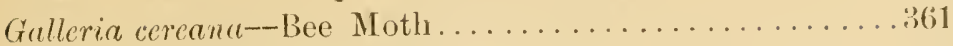

Gelechic cereulella--Angoumois Grain Moth. ..........346

Gortyna nitela--Stalk Borer. . . . . . . . . . . . . . . 307

Giapte interrogutionis--Semicolon Butterfly..........271

Grapte proyne--Progne Buttertly. ................2.23

Gymmetis nitida--Green Fruit-beetle............... . . . . . .

Haltice chalybea-(irape-vine Flea-beetle . . . . . . . . . . 1912

Halticu cucumeris--Cucumber Flea-beetle . . . . . . . . . . . . . . . . . . . . .383

Haltica vittata-Striped Flea-beetle. . . . . . . . . . . . . . 328

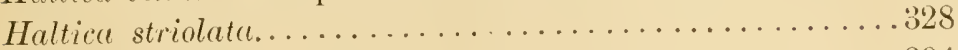

Heliothis armigera-Corn-worm or Boll-worm . . . . . . . . . 294

Hibernia tiliaria-Y Yellow Canker-worm .............. 77

Holocera glandulella-Acorn Noth. . . . . . . . . . . . . . 246

Hylastes trifolii--Clover-root Borer................. . 287

Hylobius pales--Pales Weevil . . . . . . . . . . . . . . 248

Hypewe humuli--Hop-vine Sriout Moth... . . . . . . . . . . 270

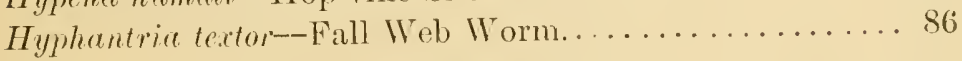

Icerya purchasi--Cottony Cushion Scale............. 165

Isosoma vitis-Grape-seed Maggot.................205

Lachnosterna quercina--White Grub. . . . . . . . . . . . . 293

Languria mozardi-Clover-stem Borer. . . . . . . . . . . . . . . . 288

Lecunium hemisphericum--Filbert seale . . . . . . . . . . . . . . 237

Leconium hesperidum-Soft Olange Sicale.............163

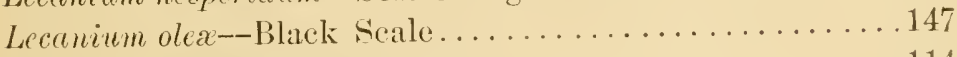

Lecanium pyri--Pear-tree Sicale..................... 114

Lecarium vitis-Cottony Grape Seale . . . . . . . . . . . . . 176

Lema trilineata-Three-lined l'otato Beetle. . . . . . . . . . . . 3099

Leptostylus aculiferus--Prickly Bark-beetle............. 70

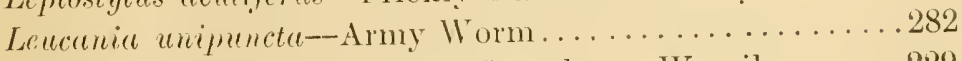

Listronotus Nevadicus--Brown Strawberry Weevil. . . . . . .229

Lo.cotamia cerasicorana-Cherry Tortrix. . . . . . . . . . . . . 137

Loxutienice rosaceuna--Greater Leaf-roller... . . . . . . . . . . 91

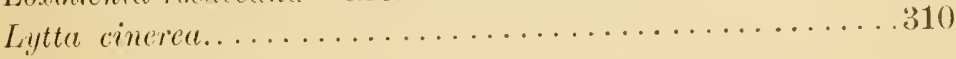

Macrobasis unicolor-Ash-colored Blister Beetle... . . . . . .310

Macrodactylus subspinosus-Rose Chafer............... 195 


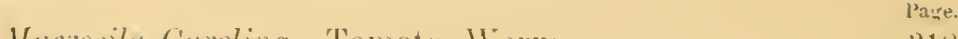

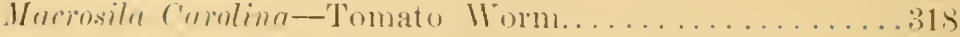

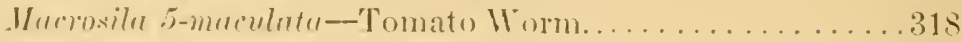

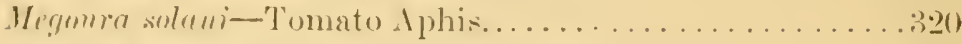

Microcentimm wtimerix-Angular-minged Katvelid . . . . . . 200

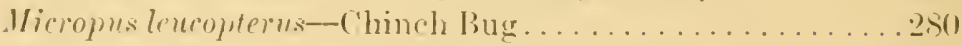

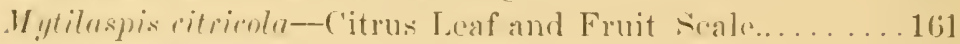

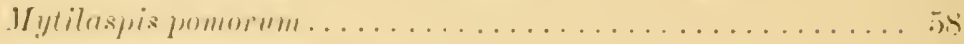

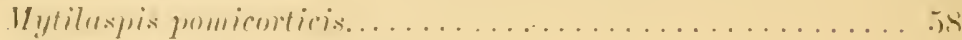

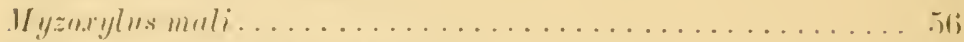

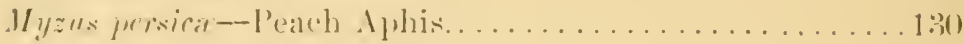

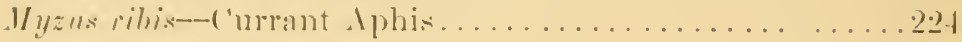

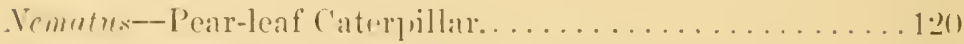

Vrmutus renticosus--1mported ('mant Worm. . . . . . . . 21!)

Volophana mulama......................... !.)

Votorlontu comeimma-liod-lıumped caterpillar......... s)

Voforms monolom-Hornal Flower Beetle. . . . . . . . . . . . . 25)

Vysius destemetor--False ('hinch Bugr. . . . . . . . . . . . 19)

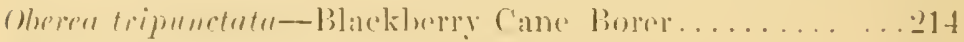

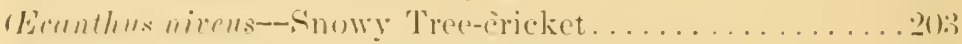

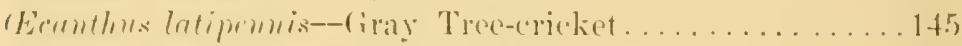

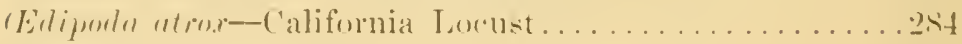

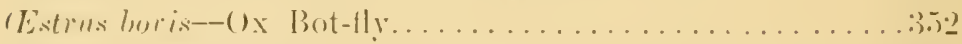

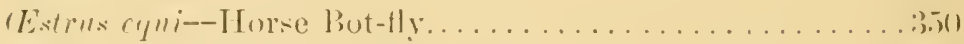

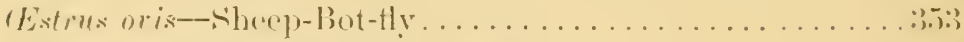

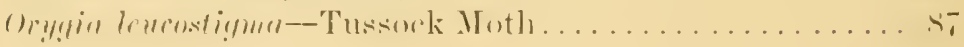

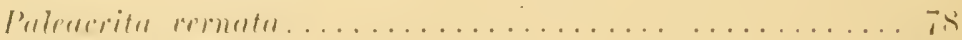

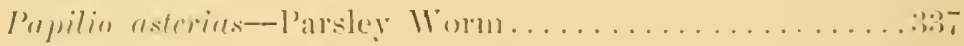

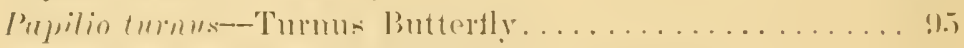

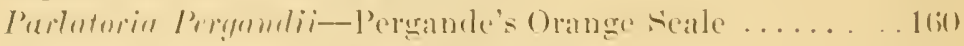

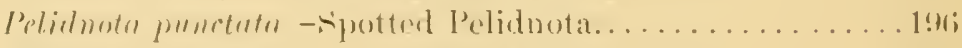

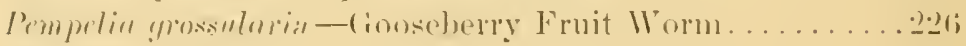

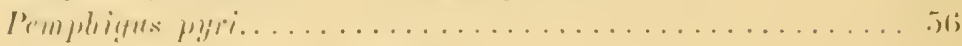

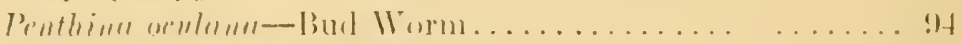

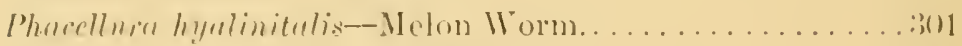

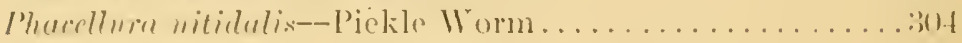

Ihilamplis achemon-. Achemon sphinx ... . . . . . . . . 17!)

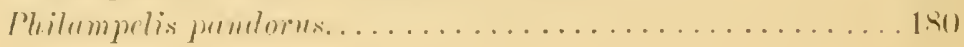




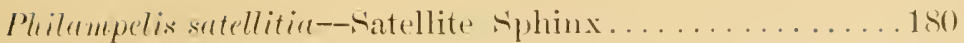

Phorodon humuli--Hop, Aphis...................27.2

Phocopteris froguriap. . . . . . . . . . . . . . . . . . 2:31

Physitr urbulu-. Ipple-leat ('rumpler. . . . . . . . . . . 9:)

Phyllophreye fuser - White (iruh . . . . . . . . . . . . 29?:)

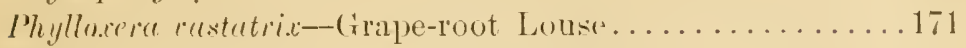

I'ieris protolice - Southern Cabbage Butterfly... . . . . . . . 321

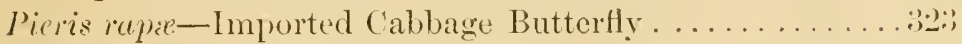

Pissodes strobi-Pine ITeevil................ . . . 247

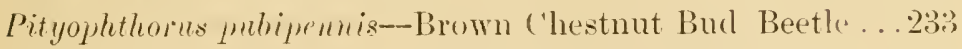

Plusia bulluce-Hop-rine P'usia . . . . . . . . . . . . . . . 269

Plasia brelssicr--Cabbage Plusia. . . . . . . . . . . . . 324

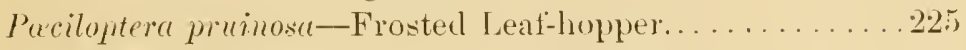

Polycam confertus-Branch and Twig Burrower... . . . . . . 116

Polyphylla 10-lineata--Ten-lined Leat-eater. . . . . . . . . . . . 100

Prioners imbricomis--Tile-horned Prionus . . . . . . . . . . . 171

Prionus laticollis--Broad-neaked Prionus. . . . . . . . . . . . . . 169

Pristophora grossulariac-Native Currant Worm . . . . . . . . 221

Procris Americana- American Procris. . . . . . . . . . . . . . 189

Psenocerus supernotutus--Anerican ( ${ }^{1}$ rrant Borer... . . . . . 217

Psoroptis equi-Scab Mite. . . . . . . . . . . . . . . . 355

Psychomorpha epimenis-Grape-vine Epimenis. . . . . . . . 188

Psylla pyri-Pear-tree Psylla...................... . . . . . . . .

Pterophores periscelidactylus--Grapevine Plume. . . . . . . . . 191

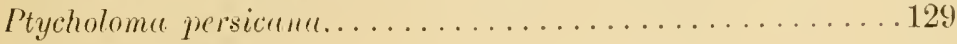

Pygarer ministra........................ $\$$.

Rhodites radicum-- Raspberry-root (iall-Hy . . . . . . . . . 20!)

Rhopalosiphum dianthi-C'arnation Aphis............261

Rhopalosiphum tulipip-Tulip Aphis ..............20.2

Superda bivituta....................... (i5)

Superda cundida-Round-headed Aplole-tree Burer....... (i.)

Schizonenre lamigen-Woolly Aphis ............... 56

Sriapterom robinia- Wreping Willow Borer............ 2t2

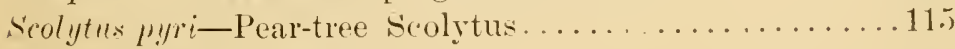

Śclaudria cerasi-Pear Slug. . . . . . . . . . . . . . . . 118

Selandria rosix-Rose slug-worm. . . . . . . . . . . . . . 25!)

Semasia pruniana-Plum Hoth.................. 14t 


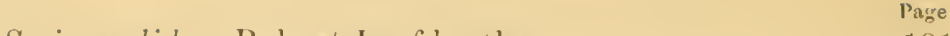

Serice ratidu-Robust Leaf-beotle................. 101

Serira robustr. . . . . . . . . . . . . . . . . . . . 101

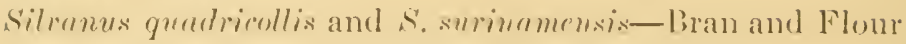

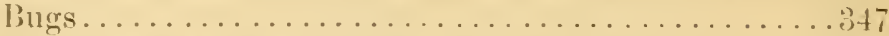

Simorylon hrsillrur-lied-shouldered Grape-vine Borer . . . 207 siplar rubifolii-Blackberry Aphis...............215

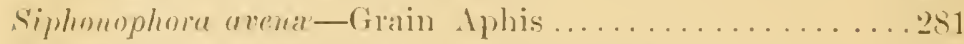

siphonophore cuevilitix-Cueumber Aphis. . . . . . . . . . 304

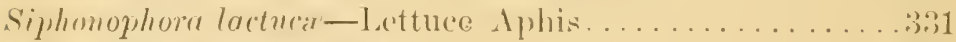

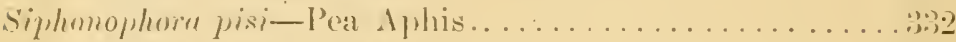

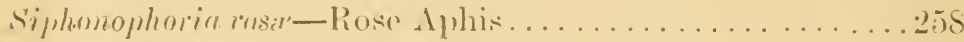

siphomophore mbi-liasploery dphis. .............21"

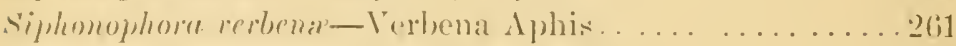

siphonophome viticoln-(irape-vine Iphis . . . . . . . . . . . 19s

Spitmota ocmlama........................ $\$ 4$

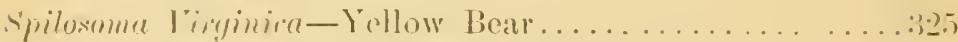

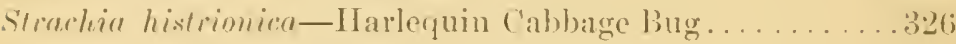

Tubunus atmentu-Black Horse-fly . . . . . . . . . . . . . st9

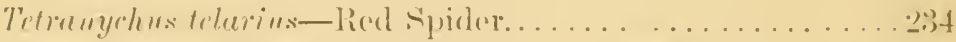

Thricolepis simulator-Craty Bark-eating Weevil ......... .1

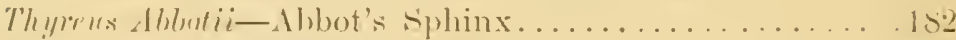

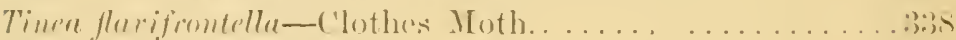

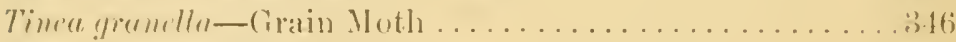

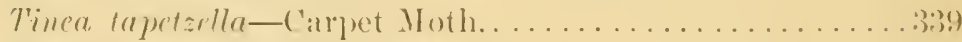

Trypeta pomomelle-1pple Magot. . . . . . . . . . . . . 10s

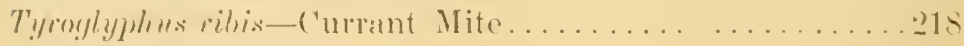

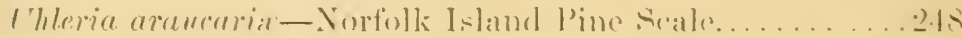

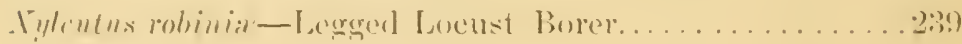




\section{INDEX TO COMMON NAMES.}

Hblot's Sphinx-Thyre.

Aboots sphinx-Thyrews Abbotii................ 1s?

Achemon śphinx-Philumplis achemon... . . . . . . . . . 179

Acorn Moth--Holorera glamdulent. . . . . . . . . . . . . . 246

Alnond Aphis-Aphis amygdali.................2:36

American Curant Borer--Psenocers supernotatus... . . . . 217

American Procris-Procris Lmericana... . . . . . . . . . . 1S?

Angommois Grain Moth--Gelechia cerealella. ............346

Angular-winged Katydid-Mirrocentrum retinerti. . . . . . . 200

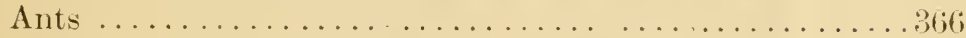

Apple Bucculatrix-Buccul trix pomifoliella........... 97

Apple Cureulio-Inthonomus quadrigiblus. . . . . . . . . . . 109

Apple-leaf Aphis-Aphis malifolia... . . . . . . . . . . . . 99

Apple-leaf Crmpler--Phycitr nebulo............... 9:

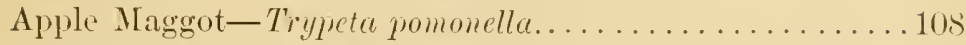

Apple-tree Aplis-1phis mali.................. 9s

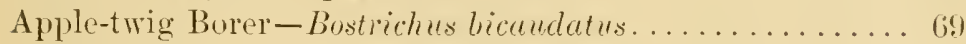

Aprle Worm . . . . . . . . . . . . . . . . . . . . 102

Apricot Leaf-roller-Dichorlia Culiformiana. . . . . . . . . . . 183

Army $\|^{\top}$ orm--Lencunin unijmncta . . . . . . . . . . . . . . . . 2s:

Ash-colored Blister Beetle-Cantharis cinerea.......... : :10

Asparagus Beetle-Crioceris Aspareyi ..............336

Azalea Bark-louse-Eriococeus azalea. . . . . . . . . . . . . s.jt

Bean Aphis-Aphis rmicis................ . .3.5

Bean Meevil-Bruchus fabar . . . . . . . . . . . . . . . 334

Beautiful Wood Xympli--Endryas ymate............. 157

Bee Moth--Galleria cereana...................361

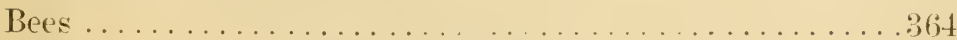

Blackberry Aphis-Siphe rubitolii...............215

Blackberry Cane Borer-OOberen trifunctute............214

Black Horse-fly-Tabrinus atratus . . . . . . . . . . . . . 349

Black-legged Barley-fly--Eurytoma horlei . . . . . . . . . . . . 27?

Black-legged Tortoise Beetle-Cassida nigripus...........\$16 
Black sicale-Lecrnimm ols $x \ldots \ldots \ldots \ldots \ldots \ldots \ldots \ldots .147$

Boll Worm-Hilinthis amigero. . . . . . . . . . . . .294

Bran and Flour Bugs-Sileames quadricollis and S. suri-

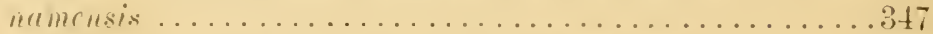

Branch and Twige Burrower-Polycuon confertus.........116

Broat-nerket Prionus-Primus latirollis............. . 169

Brown C'hestnut But Beetle-P'ityophthorus pubiponnis. . 2:33

Brown Strawberry 11 eevil-Listronotus Veraticus. . . . . . . 2.29

Bud IVorn-Penthine oculena................... 94

Buffalo Tree-hopper-Ceresu bubalus..............

Cabhage Aphis-Aphis bressical . . . . . . . . . . . 327

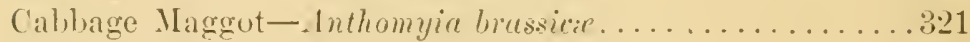

Cabloage P'lusia--I'lusin brassicr . . . . . . . . . . . . 324

C'alifornia (irape-vine Hopper-Erythoneure comes.... . . . 197

California Lady-bird-Coceinella 5-notata var. Californica.362 California Locust-Gidiporla retrox. . . . . . . . . . . . 2.4t

Canker Worms .........................

Carnation Aphis-Rhopalosiphum dianthi..........261

Carpet Beetle-Anthienus serophulariar. . . . . . . . . . . . 340

('arpet Moth-Tinea tapetzella.................;is?

Cherry-tree Borer-Dicerea divaricata.............. 136

Cherry-tree Tortrix-Loxotinia cerasirorena.......... 137

Cherry Worm.............................

C'hineh Bug--1/icropus leucopterus...............2sn

Cicada or Harvest-fly . . . . . . . . . . . . . . . .

Citrus Leaf and Fruit seale-1spidiotus citricolu........161

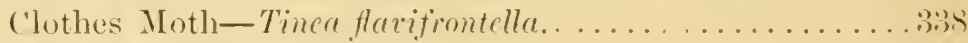

Clover-hay Worm-Asopia rostalis...............2s!

Clover-root Borer--Hylastes trifolii...............287

Clover-stem Borer-Lampurin mozardi............2ss

('ockroach-Blattr Germanica................... 341

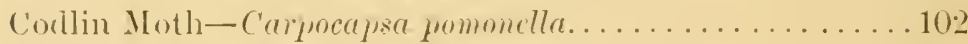

Colorado Potato Beetle-Doryphoia 10-lincata..........30s

Common Mealy Bug-Dectylopius adonidum . . . . . . . . 26:3

Corn Aphis-Aphis maidis. . . . . . . . . . . . . 296

Corn-worm or Boll-worm--Meliothis armigere.......... . 294

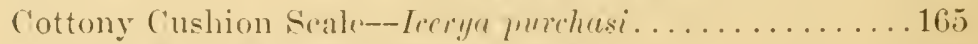

Cottony Cirape Feale-Lecunium ritis.............. 176 
Cotton Worm-Aletia aryillacea................297

Crane Flies..........................273

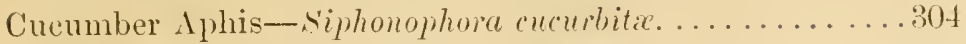

Cucumber Flea-beetle-Hultica cucumeris..............303

Currant Aphis-Hyzus ribis..................224

Currant Borer-Egeria tipuliformis..............216

Currant Mite-Tyroglyphus ribis...............218

Currant Span-worm--Eufitchic ribearia ...........22.2

Cut Worms..........................292

Decaying Wood Borers-Bitoma opaculus............ 17s

Delong's Caterpillar-Clisiocampa constricta......... 79

Destructive Mealy Bug-Dactylopius destructor..........264

Dried Fruit Inoth . . . . . . . . . . . . . . 342

Earwig--Forficula auricularia.................... 111

Eight-spotted Forester-Alypia octomaculata......... 186

Elm and Locust Scale ..................... 45

Fall Canker Worm-Anisoptery.x pometaria.......... 75

Fall Web Worm-Hyphantia textor.............. 86

False Chinch Bug--Nysius destructor................ 198

Filbert Scale--Lecanium hemisphericum .............237

Flat-headed Apple-tree Borer-Chrysobothrus femorata.... 67

Forest Tent Caterpillar-Clisiocampa sylvatica ......... 8.5

Frosted Leaf-hopper--Paciloptera pruinosa...........225

Golden Tortoise Beetle-Cussidu aurichalcea ..........316

Goldsmith Beetle-Cotalpa lanigera............... 101

Gooseberry Fruit Worm-Pempelia grossularix........226

Gooseberry Midge-Cecidomyia grossularix............227

Grain Aphis-Aphis arena...................281

Grain Moth-Tinea grumella . . . . . . . . . . . . . . 346

Grain Weevil-Calandra granaria................. 344

Grape Curculio-Caliodes incqualis . ..............204

Grape Leaf-folder-Desmia muculalis............... 190

Grape-leaf Roller........................206

Grape-root Borer-Egeria polistiformis.............. 168

Grape-root Louse--Phylloxere vertatrix............. 171

Grape Scale - Aspridiotus uva .................. 
(itrape.

Grape-seed Maggot-Isusomure litis. . . . . . . . . . . . 205

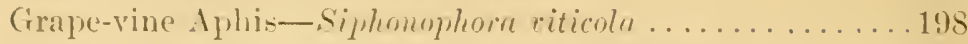

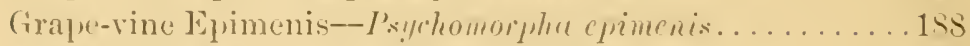

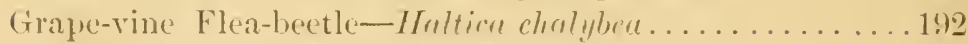

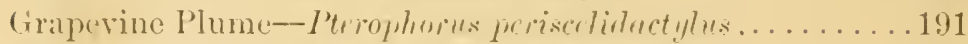

Ciray Burk-eating Wrevil-Thricul pix simulator......... it

Gray Tree-cricket-OEennthus latipemis. . . . . . . . . . . 145

Crreatrr Jeaf-roller-Lomotir nia iostecunu............. 91

Greedy Scalc-Aspieliotus immex................. (ii)

Green Fruit-beetle-- (iymnctis nitidr. . . . . . . . . . . . . 131

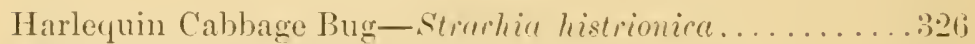

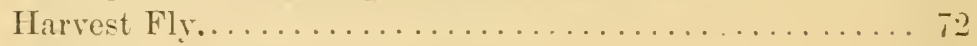

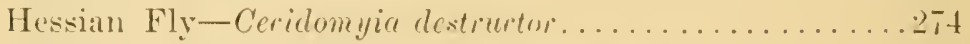

Hog Caterpillan-Charocampe pampinatrix. . . . . . . . . 1\$3

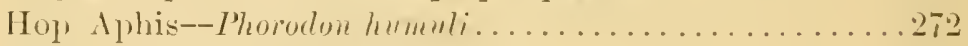

Hop-vine Plusia-Plusin brlluere . . . . . . . . . . . . . . . 2699

Hop-vine Snout Moth-Hypena humuli... . . . . . . . . . . 270

Horned Flower Beetle-_istaxus monodon. . . . . . . . . . . . . 25:9

Horse Bot-fly-tEstrus cymi... . . . . . . . . . . . . . 3500

Imported C'abbage Worm-Picris repie. . . . . . . . . . . 3233

Imported C'urrant Worm-- Vematus ientricosus.... . . . . . 219

Imported Grape Flea-beetle-Adoxus vitis.... . . . . . . . . 194

Indian C'etonia-Cetonia Inda . . . . . . . . . . . . . 130

Joint Worn-Enrytome tritici . . . . . . . . . . . . . . 2Ts

June 13 ug-Larhmosterna quereina . . . . . . . . . . . . . . 2) s);

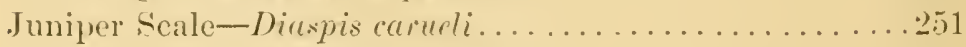

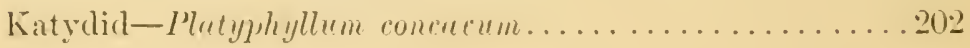

Lace-ringed Fly . . . . . . . . . . . . . . . . . . . . . . . . . .

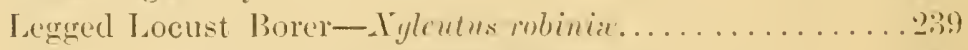

Jeglest Locust Borer-(Yytus Robinix. . . . . . . . . . . . . 240

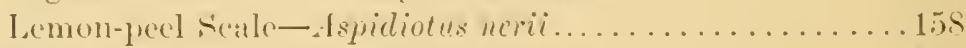

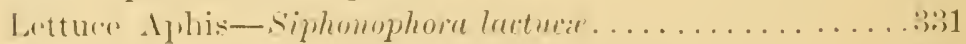

Liver Fluke-Distomu hr pretionm . . . . . . . . . . . . .35)

'Locust Carpenter Moth- Vyleutus robinia . . . . . . . . . . . 239) 
Many-dotted C'aterpillar-Brachytarnia malana......... 9.

Mealy Bug with long threads-Dactylopius. Iongifilis..... . 26ti

Melon ITorm--Phacellurin hyrelintatis.. . . . . . . . . . .301

Millipedes . . . . . . . . . . . . . . . . . . . . . 291

Mosquito...............................

Mottled Tortoise Beetle-Cassida guttatr.............316

Native Currant Worm--Pristophora grosidetiax. . . . . . . 2.21

Negro Bug-Corimelana puliraria ................212

Norfolk Island Pine Scale-Lhteria araucritir.........248

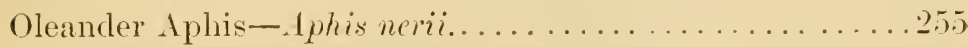

Olive ITorm-Ducus olex . . . . . . . . . . . . . . . . 150

Onion Maggot-1nthompia ceperum..............3:30

Orchard Tent Caterpillar-Clisiocampa Americune....... 8.?

Ox Bot-fly-OEstrus botis.................... 352

Orster-formed Scale-Diespis ostrexformis..... . . . . 112

Oyster-shell Bark-louse-Aspidiotus conchiformis......... .s

Pales Weevil--Hylobius pales ................ 248

Parsley Worm--Papilio asterias.................337

Pea Aphis-Siphonophora pisi................. .392

P'each Aphis--Myzus persicx.................130

Peach Leaf-roller-Ciresia persicana . . . . . . . . . . . . 129

Peach Moth-Anarsia lineutella..................2S

Peach-tree Borer-Egeria exitiosa..............126

Pear-leaf Caterpillar--Ncmatus................. 120

Pear Slug_Selandria crasi.................... 118

Pear-tree Borer-Egeria pyri................. 115

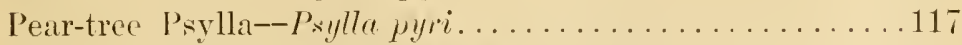

Pear-tree Scale-Lecanium pyri.................. 114

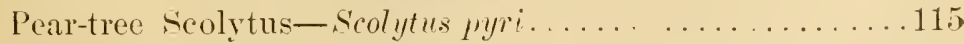

Pea Weevil-Bruchus pisi.................... 332

Pergande's Orange Scale-Aspidiotus pergandi..... . . . 160

Pernicious Scale-Aspidiotus perniciosus............ 60

Persimmon Aphis-Aphis eliospyri................ 146

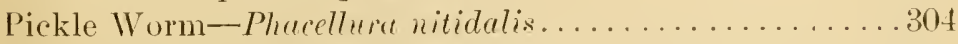

Pine Weevil-Pissoles strobi...................247

Plum Cureulio-Conotrachelus nemuphar.............. 140

Plum Gouger-Anthonomus prunicila............148 


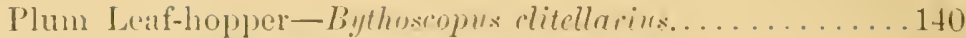

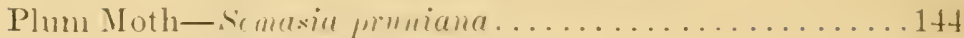

Plum-tree Aphis- lphis jmuni . . . . . . . . . . . . . . 1:3!?

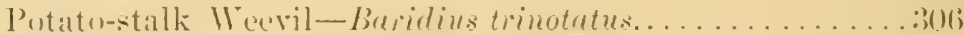

Potato Inoth . . . . . . . . . . . . . . . . . . . . . 313

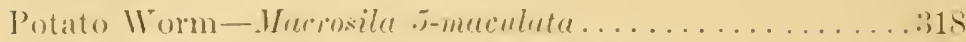

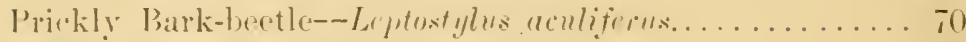

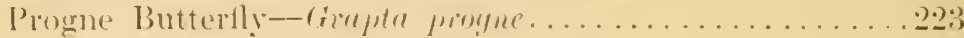

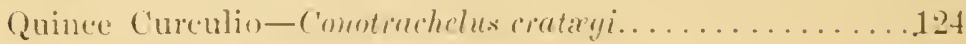

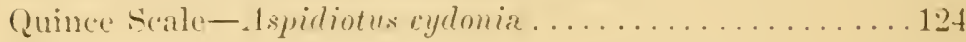

Rarlish Maggot-Aithomyia raphani. . . . . . . . . . . 3.2s

Raspberer Aphis-siphmophore rubi. . . . . . . . . . 212

Raspluery Burer--1yillus inficollis. . . . . . . . . . . . . . . . 209

Raspherry Isat-Roller--Exatema jermundena. . . . . . . . 211

Rasplerry-root Borer- Eyeria rubi.................208

Rasplerey-root Gall-Hy-Rhudites indicum . . . . . . . . . . 20!)

Raspberry spanworm- Iplorles mbivora . . . . . . . . 2111

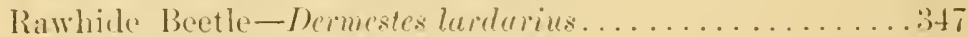

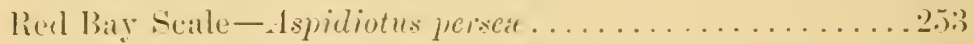

Rerl-lodied saw-tly-Dolrous tejonicus. . . . . . . . . . . 182

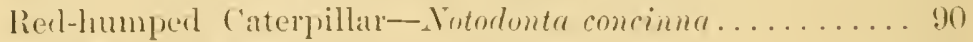

Red sicale- Ispidiotus aurantii. . . . . . . . . . . . . . 15:3

Red sicale of Florida- Aspidiotus ficus . . . . . . . . . . . 156

Red-shouldered Grape-vine Borer-Sinoxylon basilare . . . . 20 T-

Red Finder-Tetramychn. tolarins. . . . . . . . . . . . . 235t

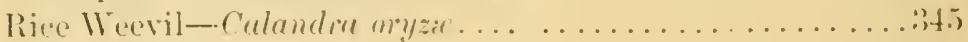

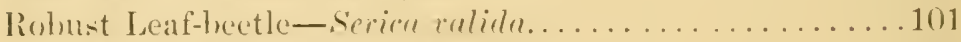

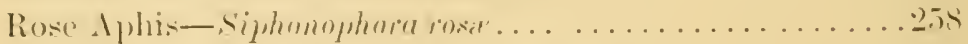

Rose ('hafer-.Maciodurtylus subspinosus. . . . . . . . . . 19)

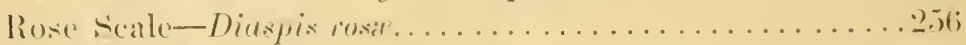

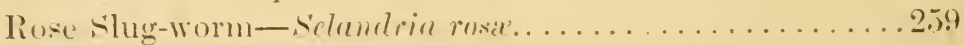

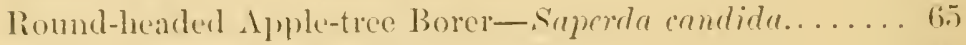

Rye Fly-_Emytoma secalis. . . . . . . . . . . . . . 279

San liernardino Willow Sicale- Ispidiotus ortholobus...... 24t

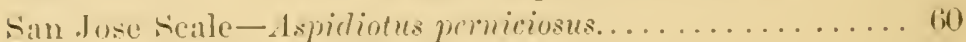

Silnta Cruz sicale - Aspriliotus rapma. . . . . . . . . . . 6:3

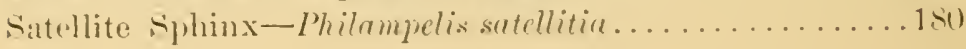


I'age.

Scab Vite-Psoroptis equi.................... 35is

Semicolon Butterfly-Gropte interrogretionis...........

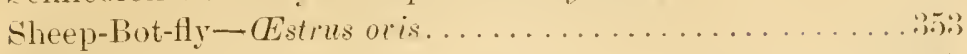

Slugs or Snails . . . . . . . . . . . . . . .

Small Potato Beetle, No. 1--Epitriv subrinitr.......... . 312

Small Potato Beetle, No. - - Epritrix hivipennis. . . . . . . . . 313

Snowball Aphis-Aphis vibumi..............262

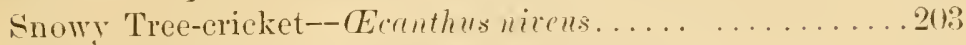

Soft Orange Scale-Lecunium hesperidum . . . . . . . . 16 ?

Southern Cabbage Worm-Pieris protolice............201

Spotted Pelidnota--Pelidnota prenctata............... 196;

Spring Canker Worm-Anisoptery. rernata.......... is

Squash Bug-Coreus tristis. . . . . . . . . . . . . . . . 300

Squash-vine Borer-.Egeria cucubita . . . . . . . . . . 299

Stakk Borer-Gortyna witedn.................... 307

Steel-blue Flea Beetle-Hultica chalybea............. 192

Strawbery Crown-borer-Analcis fragarix...........28

Strawberry Leaf-roller-Inchylopera fiagarix. . . . . . . . 2:31

Strawberry Worm-Emphytu. maculatus. . . . . . . . . . 230

Striped Blister Beetle-Cantharis vittata... . . . . . . . 812

Striped Bud-beetle--Disongche limbicollis.............134

Striped Cucumber-beetle-Diabrotica rittata............302

Striped Flea-beetle-Haltica rittata..................

Ten-lineci Leaf-eater--Polyphyllu 10-lineutu........... . 100

Thousand-legged Worms.....................291

Three-lined Potato Beetle--Lema tritineata... . . . . . . . . 309

Thrips..... . . . . . . . . . . . . . . . . . 12.

Tile-horned Prionus--Prionus imbricornis . . . . . . . . . . 171

Tobaceo Worm-1Frerosiln Carolina..................31s

Tomato Aphis--1Kegoura solani................820

Tomato Worm--Hacrosila Carolina................318

Tortoise Beetles.........................315

Tulip Aphis-Rhopalosiphum tulipx . . . . . . . . 262

Turnus Butterfly--Papilio tumus. . . . . . . . . . 95

Tussock Moth--Orygia leucostigma .............. 87

Twelve-Spotted Diabrotica-Diabrotica 12-punctata...... 135

Two-striped Tortoise Beetle-Cassida birittata..........316 


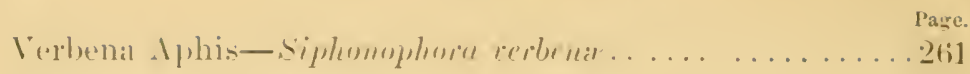

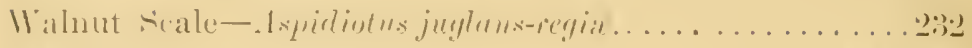

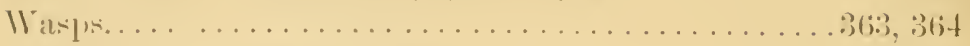

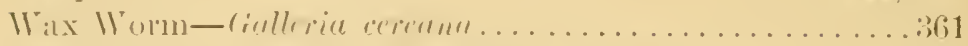

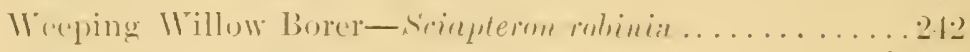

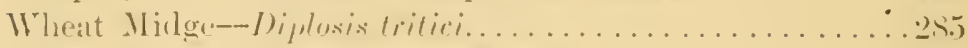

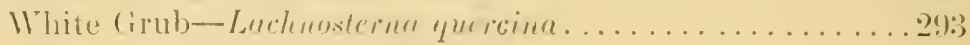

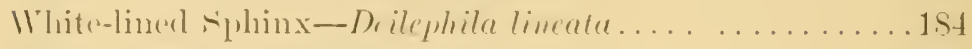

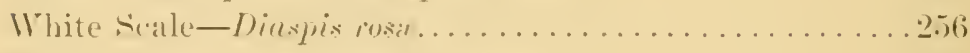

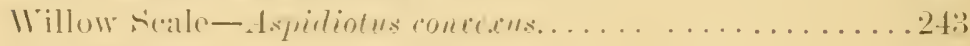

Wire $\|^{*}$ urms . . . . . . . . . . . . . . . . . . . . . . . 290

Woolly Aphis-schizommm lnnigera .............. st;

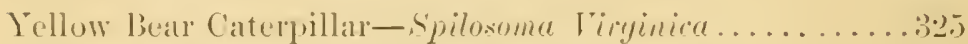

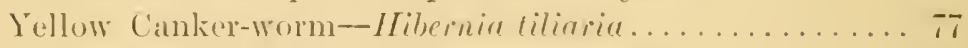

Yellow-legered Barley-Hy-Eurytumn tlaripes. . . . . . . . . . 279

Yelluw Mite. . . . . . . . . . . . . . . . . . . . . . . . . . 199

Jellow-necked ('aterpillar-Dutnure ministia............ s!) 



SMITHSONIAN INSTITUTION LIBRARIES 